DENISE MARTINS MORETTI

\title{
A COMPATIBILIDADE ENTRE A LÓGICA ECONÔMICA E O ENSINO SUPERIOR, APÓS A CONSTITUIÇÃO FEDERAL DE 1988: O CASO DA ANHANGUERA EDUCACIONAL PARTICIPAÇÕES S.A.
}

Dissertação de Mestrado

Orientadora: Professora Associada Nina Beatriz Stocco Ranieri

Faculdade de Direito da Universidade de São Paulo São Paulo

2013 
DENISE MARTINS MORETTI

\section{A COMPATIBILIDADE ENTRE A LÓGICA ECONÔMICA E O ENSINO SUPERIOR, APÓS A CONSTITUIÇÃO FEDERAL DE 1988: O CASO DA ANHANGUERA EDUCACIONAL PARTICIPAÇÕES S.A.}

Dissertação de Mestrado apresentada ao Programa de Pós-Graduação da Faculdade de Direito da Universidade de São Paulo, como exigência parcial para obtenção do título de Mestre em Direito.

Área de Concentração: Direitos Humanos

Orientadora: Professora Associada Nina Beatriz Stocco Ranieri

Faculdade de Direito da Universidade de São Paulo

São Paulo

2013 
Ao meu querido pai, Laercio Moreti, com amor e saudades. 


\section{AGRADECIMENTOS}

A Deus e à Nossa Senhora Desatadora dos Nós.

À minha orientadora, Professora Associada Nina Beatriz Stocco Ranieri, por ter acreditado em meu trabalho e por ter acompanhado minha pesquisa sempre de perto. Sem o seu voto de confiança esta pesquisa não teria sido feita. Muito obrigada por tudo.

Aos Professores Romualdo Portela de Olivera e Gilberto Bercovici pelos preciosos comentários em minha banca de qualificação.

À minha querida mãe, Benedita Moreti, que esteve sempre ao meu lado, compartilhando minhas dificuldades e comemorando minhas conquistas.

Ao meu irmão, Emerson Moreti, sua esposa, Silvia Moreti, e meu sobrinho Enzo; à minha irmã Evelise Moreti Noronha, seu esposo José Ricardo Noronha, e minhas sobrinhas Gegê e Ci; e ao meu irmão Douglas Moreti e sua noiva Tatiana Sibin, por todos os momentos agradáveis que passamos juntos durante este período.

Ao meu querido Bráulio Santos R. de Araújo, pelo companheirismo, pelos conselhos, pelo apoio, pelo amor e pelo carinho. Obrigada pela força, pelo estímulo contínuo e por todas as suas palavras de incentivo durante todos esses anos. Sua presença foi fundamental para tornar este sonho realidade.

Ao meu sogro, Jesus Sebastião Araújo, à minha sogra, Maria Aparecida dos Santos Araújo, e à minha cunhada, Maricy Araújo, pelo apoio, amizade e carinho.

A todos os amigos da Faculdade de Direito do Largo São Francisco, dos tempos de escritório e do interior, Andréa Gonçalves Silva, Carolina Canavarro, Fernanda Barbosa Gonsales, Guilherme Varela, Valeuska de Vassimon, André Roston, Israel Alexandre Souza, Boris Calazans, Fábio Lacaz, Felipe Padin, Carla Tomazella, Geandrei Germano, Renata Cristina Antão, Lara Cortês, Salomão Ximenes, Simone Henriquez, Irinéia Senise, Roberto Viecelli, Erik Arnesen, Neide Novaes dos Santos, Tatiana Waldman, Humberto Bersani, Maria Clara Troncoso, Fernanda Flora Degrava, Eduardo Morais, Mariana Pollini, Luciana Mares, Cristian Seiji Adachi Régis, Beatriz Lancia Noronha e Maira Borges.

A todos os amigos da Faculdade de Educação da USP. Muito obrigada pelas sugestões à pesquisa e por compartilharem experiências e opiniões sobre o tema.

À Fundação de Amparo à Pesquisa do Estado de São Paulo (Fapesp), cujo financiamento foi fundamental para o desenvolvimento desta pesquisa. 
Esta pesquisa foi possível graças ao financiamento da Fundação de Amparo à Pesquisa do Estado de São Paulo (Fapesp) - Processo n ${ }^{0}$ 2010/03236-7 
MORETTI, Denise Martins. A compatibilidade entre a lógica econômica e o ensino superior, após a Constituição Federal de 1988: o caso da Anhanguera Educacional Participações S.A. Dissertação (Mestrado) - Faculdade de Direito, Universidade de São Paulo, São Paulo, 2013.

\section{RESUMO}

A presente Dissertação consiste numa análise teórica e empírica do oferecimento do ensino superior por instituições privadas com fins lucrativos no Brasil, especialmente pelas instituições que fazem parte do grupo Anhanguera, controlado pela Anhanguera Educacional Participações S.A. (Anhanguera ou Companhia), com o objetivo de verificar se o agente privado é capaz de oferecer a educação conforme as normas constitucionais brasileiras e em que medida a lógica econômica é compatível ou não com este direito humano. A análise teórica envolveu o estudo (i) da educação como direito humano, bem público e serviço público, examinando (a) o direito à educação na doutrina dos direitos humanos, (b) a disciplina constitucional do direito à educação no Brasil e (c) as especificidades da educação superior; (ii) da evolução histórica e jurídica da educação superior no Brasil a partir da Constituição de 1988, examinando a evolução da legislação e das políticas públicas nesse período e o impacto dessas medidas para o crescimento do setor privado no ensino superior brasileiro, e abordando o processo de profissionalização e internacionalização do setor na última década, que teve como marco a abertura de capital da Anhanguera em 2007; e (iii) da educação como um serviço prestado mediante o desempenho de uma atividade empresária, examinando as características da atividade empresária, a lógica empresarial e as dificuldades do agente privado em lidar com atividades produtoras de externalidades sociais. A análise empírica envolveu o estudo do caso da Anhanguera, companhia aberta listada no Novo Mercado da BM\&FBOVESPA, controladora de um grupo educacional que atua principalmente no ensino superior. A Anhanguera foi a primeira empresa educacional brasileira a abrir seu capital na BM\&FBOVESPA e, em 31/12/2011, representava o segundo maior grupo educacional do mundo e o maior do Brasil em termos de valor de mercado e em número de alunos. A análise do caso da Anhanguera foi feita a partir do levantamento, triagem e análise da documentação sobre a Companhia disponível para acesso público em sites de órgãos oficiais, e teve por objetivo encontrar respostas para uma série de questões relacionadas direta ou indiretamente aos temas constantes nos itens (i) a (iii) acima e ao objetivo da Dissertação de analisar a compatibilidade entre a lógica econômica e o ensino superior a partir do estudo desse caso concreto. A conclusão da pesquisa foi que a educação quando sujeita à lógica econômica transforma-se numa mercadoria, que será oferecida dentro de uma estrutura empresarial, visando redução de custos e maximização dos lucros para distribuição aos acionistas. No caso da Anhanguera, que se volta para o atendimento das classes média e baixa da população, é oferecido um ensino superior de massa para formação técnica, de baixa qualidade, com valores reduzidos de mensalidade. Nesse contexto, a Anhanguera oferece uma educação limitada, que não atende ao conteúdo normativo do direito à educação.

Palavras-chave: Direito à educação; ensino superior; instituições de ensino superior privadas com fins lucrativos; Anhanguera Educacional; financeirização da educação; externalidades sociais. 
MORETTI, Denise Martins. A compatibilidade entre a lógica econômica e o ensino superior, após a Constituição Federal de 1988: o caso da Anhanguera Educacional Participações S.A. Dissertação (Mestrado) - Faculdade de Direito, Universidade de São Paulo, São Paulo, 2013.

\begin{abstract}
This Dissertation consists of a theoretical and empirical analysis of the offering of higher education by private for-profit institutions in Brazil, especially by institutions that are part of the Anhanguera Group, controlled by Anhanguera Educacional Participações S.A. (Anhanguera or Company), with the purpose of verifying if the private agent is able to offer education in accordance with the Brazilian constitutional rules and to what extent the economic logic is compatible or not with this human right. The theoretical analysis involved the study of (i) education as human right, public good and public service, examining (a) the right to education in human rights doctrine, (b) the constitutional rules concerning the right to education in Brazil and (c) the specificities of higher education, (ii) the historical and legal evolution of higher education in Brazil as from the 1988 Constitution, examining the evolution of legislation and public policies in this period and the impact of these measures for the growth of the private sector in Brazilian higher education, and approaching the process of professionalization and internationalization of the sector in the last decade, which had as landmark the going public of Anhanguera in 2007, and (iii) education as a service rendered through the performance of a corporate activity, examining the characteristics of the corporate activity, the business logic and the difficulties of the private agent in dealing with activities that produce social externalities. The empirical analysis involved the study of Anhanguera's case, a publicly-held company listed on the Novo Mercado of BM\&FBOVESPA, holding of an educational group that operates mainly in higher education. Anhanguera was the first Brazilian educational company to go public in BM\&FBOVESPA and, on 12/31/2011, represented the second largest educational group in the world and largest in Brazil in terms of market value and number of students. The analysis of Anhanguera's case was carried out through survey, selection and analysis of documents regarding the Company that were available for public access on websites of official bodies, and had the purpose of finding answers to a number of questions directly or indirectly related to the topics listed in items (i) to (iii) above and to the purpose of the Dissertation of analyzing the compatibility between economic logic and higher education from the study of this particular case. The research's conclusion was that education, when subjected to economic logic, becomes a commodity that will be offered within a corporate structure, aiming to reduce costs and maximize profits for distribution to shareholders. In the case of Anhanguera, which turns itself to serve the middle and lower classes of the population, the result is a low quality higher education mass service oriented for technical education and rendered against the payment of reduced tuition fees. In this context, Anhanguera offers a limited education, which does not meet the normative content of the right to education.
\end{abstract}

Keywords: Right to education; higher education; private higher education for-profit institutions; Anhanguera Educacional; financialization of education; social externalities. 


\section{LISTA DE TABELAS}

TABELA 1 - Evolução no número de matrículas de instituições privadas - Brasil $1961-1980$

TABELA 2 - Total de Ingressos por Processo Seletivo e Ingressos por meio do Enem nos Cursos Presenciais, por Categoria Administrativa das IES - Brasil 2010 .

TABELA 3 - Evolução do número de instituições e matrículas, segundo a categoria administrativa - Brasil - 1990 a 2010

TABELA 4 - Seis maiores mercados de ensino superior do mundo -2009. 170

TABELA 5 - IES segundo a categoria administrativa e organização acadêmica - 1980 1998.

TABELA 6 - Número de matrículas por organização acadêmica, segundo categoria administrativa - Brasil - 1980-1998.

TABELA 7 - IES segundo a categoria administrativa e organização acadêmica - 2001 2008 .

TABELA 8 - Evolução do $\mathrm{N}^{0}$ de IES por Organização Acadêmica - Brasil - 2001 2010 .

TABELA 9 - Número de matrículas por organização acadêmica, segundo categoria administrativa - Brasil - 2001-2010.

TABELA 10 - Evolução da participação percentual de matrículas de graduação por organização acadêmica - Brasil - 2001 - 2010.

TABELA 11 - Instituições de educação superior segundo unidade federativa e tipo de instituição privada - Brasil - 2009 .

TABELA 12 - Evolução do número de vagas ociosas na graduação presencial, segundo categoria administrativa - Brasil - 2002 a 2008

TABELA 13 - Número de IES conforme o número de cursos de graduação por elas oferecidos - Brasil - 2010

TABELA 14 - Relação das dez maiores IES em número de matrículas na graduação em 2003 e 2008

TABELA 15 - Distribuição do número de matrículas por área geral de conhecimento Brasil - 2010 
TABELA 16 - Matrículas na Educação a Distância - 2004 - 2010

TABELA 17 - Distribuição das matrículas no ensino superior por regiões no Brasil 2001 e 2010

TABELA 18 - Distribuição dos programas reembolsáveis - Brasil - 2009. 186

TABELA 19 - Distribuição dos programas não-reembolsáveis - Brasil - 2009. 186

TABELA 20 - Evolução da participação percentual dos diferentes tipos de regime de trabalho dos docentes por categoria administrativa (pública e privada) - Brasil - 2002 2010 .

TABELA 21 - Evolução da participação percentual da titulação docente por categoria administrativa - $2001-2006-2010$.

TABELA 22 - Atuação Docente por Categoria Administrativa (Pública e Privada) Brasil - 2010 189

TABELA 23 - As dez IES com o número de doutores, pós-doutores e livre-docentes mais elevado - Brasil - 2005 .

TABELA 24 - As dez IES com o número de mestres, doutores, pós-doutores e livredocentes mais elevado - Brasil - 2005

TABELA 25 - Evolução da taxa de escolarização no ensino superior por região - 2001 $2006-2009$.

TABELA 26 - Número médio de anos de estudo para a faixa etária de 18 a 24 anos para as localidades rural e urbana - Brasil e Regiões - 2001 e 2009.

TABELA 27 - Número Médio de Anos de Estudo para a Faixa Etária de 18 a 24 anos, para Alguns Subgrupos Populacionais - Brasil - 2001, 2005 e 2009

TABELA 28 - Perfil do Aluno de Graduação por Modalidade de Ensino - Brasil 2010 .

TABELA 29 - Média de Alunos Matriculados - 2010 - 2011

TABELA 30 - Distribuição da Receita entre os Segmentos Operacionais da Anhanguera $2009-2011$ .235

TABELA 31 - Maiores acionistas da Anhanguera em 31/12/2011. .245

TABELA 32 - Distribuição do capital social do FEBR em 31/12/2011 245

TABELA 33 - Evolução Patrimonial da Anhanguera - 2007 - 2011 246

TABELA 34 - Volume de Negociações, Cotações Valores Mobiliários Anhanguera $2007-2011$ 
TABELA 35 - Informações consolidadas sobre negociações de valores mobiliários da

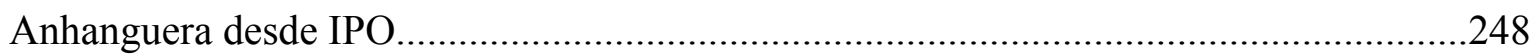

TABELA 36 - Variação do lucro líquido e dividendos Anhanguera - 2007 - 2011.......249

TABELA 37 - Informações sobre Destinação Lucro Líquido e Distribuição de

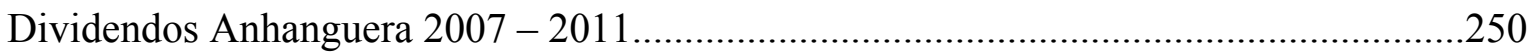

TABELA 38 - Orçamentos de Capital Anhanguera 2008 - 2012 ...................................250

TABELA 39 - Critérios para remuneração variável da administração............................272

TABELA 40 - Quantidade de bolsas ProUni Anhanguera - 2006 - 2010......................277

TABELA 41 - Volume de bolsas de estudos - 2008-2010 _...........................................277

TABELA 42 - $\mathrm{N}^{\mathrm{o}}$ de bolsistas por valor percentual concedido $-2011 \ldots \ldots \ldots \ldots \ldots \ldots \ldots \ldots . . . . .277$

TABELA 43 - Percentual de bolsas ProUni Anhanguera em relação à quantidade total de

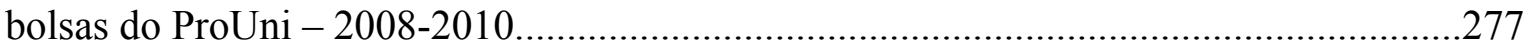

TABELA 44 - Informações sobre o PLT Anhanguera - 2005 - 2011 ..............................280

TABELA 45 - Nível hierárquico do formando Anhanguera - 2010..............................283

TABELA 46 - Setor de atuação do formando Anhanguera - 2010.................................283

TABELA 47 - Faixa salarial do formando Anhanguera - 2010 ......................................283

TABELA 48 - Pesquisa de satisfação dos alunos da Anhanguera....................................284

TABELA 49 - Informações sobre bolsas de iniciação científica Anhanguera - 2008 -

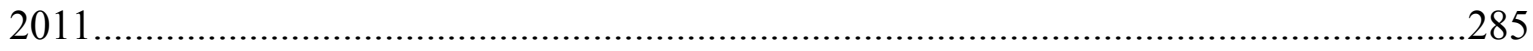

TABELA 50 - Ranking Universitário Folha - RUF - 2012 _.......................................291

TABELA 51 - Ranking Universitário Folha - RUF - Avaliação Mercado - 2012..........292

TABELA 52 - Número de Empregados Anhanguera - 2009 - 2011..............................301

TABELA 53 - Índice de rotatividade docentes/administrativo Anhanguera - 2009-

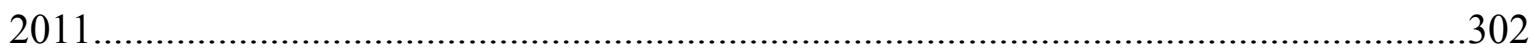

TABELA 54 - Reclamações Trabalhistas contra Anhanguera - 2009 - 2011..................302

TABELA 55 - Fluxo alunos Anhanguera 2010 - 2011 .....................................................307 


\section{LISTA DE QUADROS}

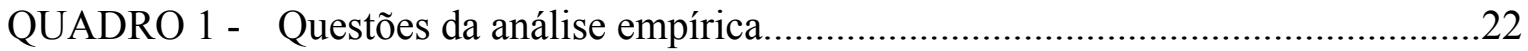

QUADRO 2 - PNE - Objetivos e metas para a educação superior....................................131

QUADRO 3 - Comparativo entre Fies, ProUni e Pravaler................................................161

QUADRO 4 - Questões da Análise Empírica n ${ }^{\text {os }}$ 1, 2, 3 e 4.........................................232

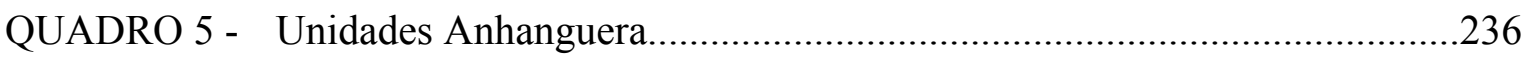

QUADRO 6 - Informações sobre as subsidiárias da Anhanguera, mantenedoras e

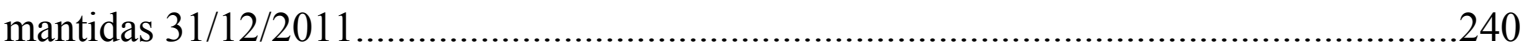

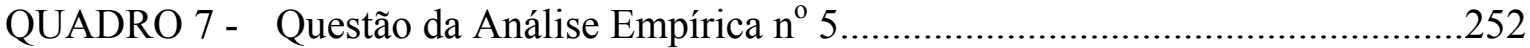

QUADRO 8 - Questão da Análise Empírica n ${ }^{0}$ 6 f...........................................................259

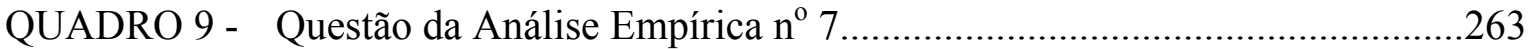

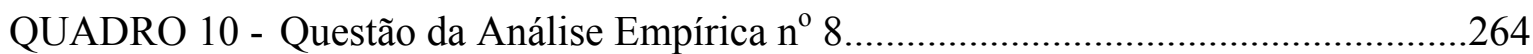

QUADRO 11 - Questões da Análise Empírica $n^{\text {os }} 9$ e 10.................................................268

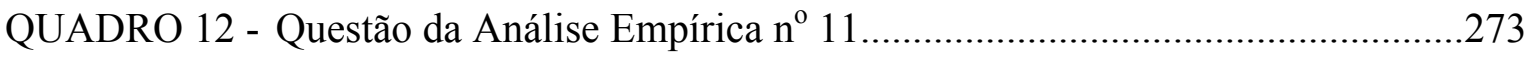

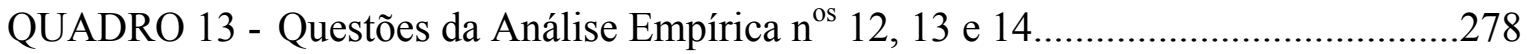

QUADRO 14 - Projetos de responsabilidade social da Anhanguera 2010 e 2011...........286

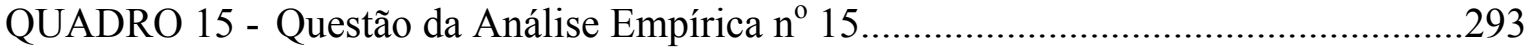

QUADRO 16 - Informações sobre as avaliações das IES integrantes do grupo Anhanguera

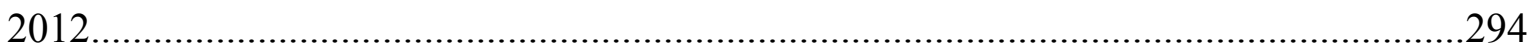

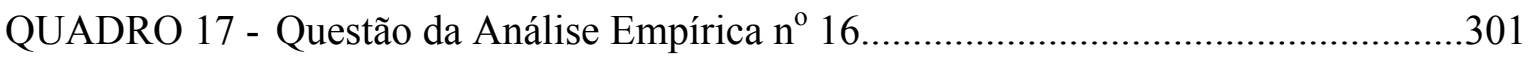

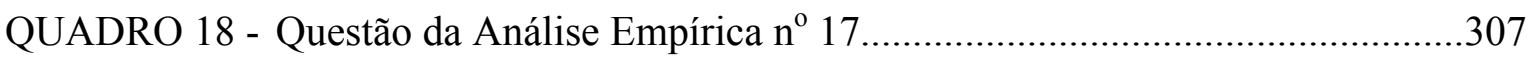

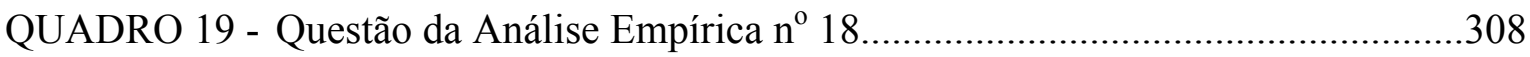




\section{LISTA DE SIGLAS}

ABMES

Abril Educação

ADCT

ADI

ADPF

Aesa

AG

AGE

AGEsp

AGO

AGOE

Anhanguera

AVA

BM\&FBOVESPA

CA

Capes

$\mathrm{CC}$

CF

$\mathrm{CF} / 88$

CI

Conaes

Confenen

$\mathrm{CNE}$

$\mathrm{CPC}$

Cres 2008

Companhia
Associação Brasileira das Mantenedoras de Ensino Superior Abril Educação S.A.

Ato das Disposições Constitucionais Transitórias

Ação Direta de Inconstitucionalidade

Arguição de Descumprimento de Preceito Fundamental

Anhanguera Educacional Ltda.

Assembleia Geral

Assembleia Geral Extraordinária

Assembleia Geral Especial dos Acionistas Preferencialistas

Assembleia Geral Ordinária

Assembleias Gerais Ordinária e Extraordinária

Anhanguera Educacional Participações S.A.

Ambiente Virtual de Aprendizagem

BM\&FBOVESPA S.A. - Bolsa de Valores, Mercadorias e

Futuros

Conselho de Administração

Fundação Coordenação de Aperfeiçoamento de Pessoal de Nível Superior

Conceito de Curso

Conselho Fiscal

Constituição da República Federativa do Brasil de 1988

Conceito Institucional

Comissão Nacional de Avaliação da Educação Superior

Confederação Nacional dos Estabelecimentos de Ensino

Conselho Nacional de Educação

Conceito Preliminar de Curso

Conferência Regional de Educação Superior da América Latina e do Caribe de 2008

Anhanguera Educacional Participações S.A. 


\begin{tabular}{|c|c|}
\hline CVM & Comissão de Valores Mobiliários \\
\hline DEG & Deutsche Investitions Und Entwicklungsgesellschaft Mbh \\
\hline DEM & Partido Democratas \\
\hline DFs & Demonstrações Financeiras \\
\hline DUDH & Declaração Universal dos Direitos Humanos de 1948 \\
\hline $\mathrm{EaD}$ & Ensino a distância \\
\hline $\mathrm{EC}$ & Emenda Constitucional \\
\hline ECA & $\begin{array}{l}\text { Estatuto da Criança e do Adolescente, previsto na Lei } n^{\circ} 8.069 \text {, } \\
\text { de } 13 / 07 / 1990\end{array}$ \\
\hline Enade & Exame Nacional de Desempenho de Estudantes \\
\hline ENC & Exame Nacional de Cursos \\
\hline Enem & Exame Nacional do Ensino Médio \\
\hline $\mathrm{ES}$ & Estatuto Social \\
\hline Estácio & Estácio Participações S.A. \\
\hline FEBR & $\begin{array}{l}\text { Fundo de Educação Para o Brasil - Fundo de Investimento em } \\
\text { Participações }\end{array}$ \\
\hline Fies & $\begin{array}{l}\text { Fundo de Financiamento do Estudante do Ensino Superior, } \\
\text { previsto na Lei } n^{\circ} 10.260 \text {, de } 12 / 07 / 2001\end{array}$ \\
\hline Fundef & $\begin{array}{l}\text { Fundo de Manutenção e Desenvolvimento do Ensino } \\
\text { Fundamental, previsto na Emenda Constitucional } \mathrm{n}^{\mathrm{o}} 14 \text { de } \\
1996\end{array}$ \\
\hline Fundeb & $\begin{array}{l}\text { Fundo de Manutenção e Desenvolvimento da Educação Básica } \\
\text { e de Valorização dos Profissionais da Educação, previsto na } \\
\text { Emenda Constitucional no } 53 \text { de } 2006\end{array}$ \\
\hline GATS (ou AGCS) & Acordo Geral sobre Comércio em Serviços \\
\hline IBGE & Instituto Brasileiro de Geografia e Estatística \\
\hline IDD & $\begin{array}{l}\text { Indicador de Diferença entre os Desempenhos Observado e } \\
\text { Esperado }\end{array}$ \\
\hline IES & Instituição de Ensino Superior \\
\hline IFC & International Finance Corporation \\
\hline IGC & Índice Geral de Cursos \\
\hline Inaf & Indicador de Alfabetismo Funcional \\
\hline
\end{tabular}


Inep

IPO

ISCP

Jucesp

LDB

Lei das S.As.

LFG

MEC

MP

Novo Mercado

ODM

$\mathrm{OMC}$

$\mathrm{ON}$

ONU

Paiub

Paru

Pátria

Pidesc

Pravaler

Procon

Proies

ProUni
Instituto Nacional de Estudos e Pesquisas Educacionais Anísio Teixeira

Initial Public Offering (Oferta Pública Inicial)

Instituto Superior de Comunicação Publicitária

Junta Comercial do Estado de São Paulo

Lei $\mathrm{n}^{\circ}$ 9.394, de 20/12/1996 (Lei de Diretrizes e Bases da Educação Nacional)

Lei ${ }^{\circ}$ 6.404, de 15 de dezembro de 1976 (Lei das Sociedades por Ações)

LFG Business, Edições e Participações Ltda.

Ministério da Educação

Medida Provisória

Segmento especial de negociação de valores mobiliários da BM\&FBOVESPA disciplinado pelo Regulamento de Listagem do Novo Mercado

Objetivos de Desenvolvimento do Milênio

Organização Mundial do Comércio

Ação ordinária nominativa

Organização das Nações Unidas

Programa de Avaliação Institucional das Universidades

Brasileiras

Programa de Avaliação da Reforma Universitária

Pátria Investimentos S.A.

Pacto Internacional dos Direitos Econômicos Sociais e Culturais de 1966

Programa de crédito universitário privado gerido pela Ideal Invest

Fundação de Proteção e Defesa do Consumidor

Programa de Estímulo à Reestruturação e ao Fortalecimento das Instituições de Ensino Superior, previsto na Lei $n^{\circ} 12.688$, de $18 / 07 / 2012$

Programa Universidade para Todos, previsto na Lei $\mathrm{n}^{\mathrm{o}}$ 11.096, 
de 13/01/2005

PN

PNE

Proparco

Saeb

Semesp

RCA

$\mathrm{RCF}$

$\mathrm{RE}$

Reuni

RS

SEB

Sesu

Sinaes

Sisu

STF

STJ

UnB

Unesa

Unesco

Uninove

Unip

Units
Ação preferencial nominativa

Plano Nacional de Educação, previsto na Lei $\mathrm{n}^{\circ} 10.172$, de 09/01/2001

Société de Promotion et de Participation pour la Coopération Économique

Sistema Nacional de Avaliação da Educação Básica

Sindicato das Entidades Mantenedoras de Estabelecimentos de Ensino Superior no Estado de São Paulo

Reunião do Conselho de Administração

Reunião do Conselho Fiscal

Recurso Extraordinário

Programa de Apoio a Planos de Reestruturação e Expansão das Universidades Federais, instituído pelo Decreto ${ }^{0}$ 6.096, de $24 / 04 / 2007$

Reunião de Sócios

SEB - Sistema Educacional Brasileiro S.A.

Secretaria de Educação Superior

Sistema Nacional de Avaliação da Educação Superior

Sistema de Seleção Unificada

Supremo Tribunal Federal

Superior Tribunal de Justiça

Universidade de Brasília

Universidade Estácio de Sá

Organização das Nações Unidas para a Educação, a Ciência e a Cultura

Universidade Nove de Julho

Universidade Paulista

Certificado de depósito de ações que representa, cada um, uma ação ordinária e seis ações preferenciais de emissão da Anhanguera 


\section{SUMÁRIO}

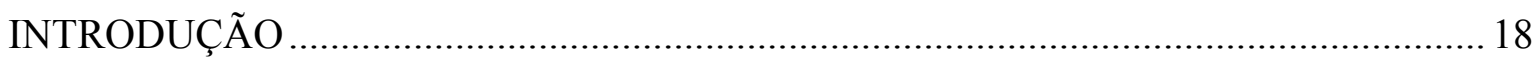

CAPÍTULO 1. A EDUCAÇÃO COMO DIREITO HUMANO, BEM PÚBLICO E

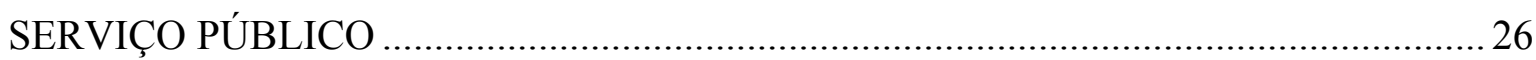

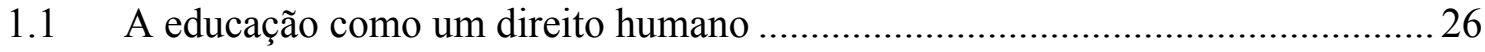

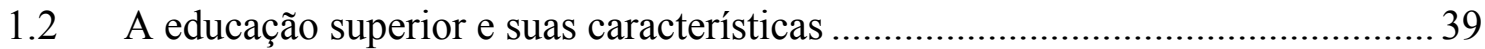

1.3 O direito à educação no ordenamento jurídico brasileiro ................................... 44

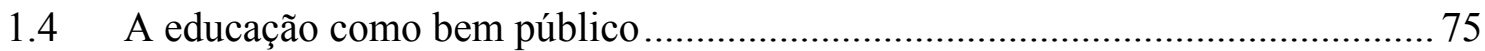

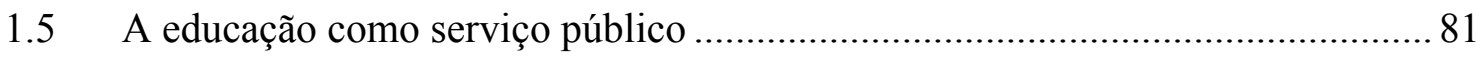

CAPÍTULO 2. A EVOLUÇÃO HISTÓRICA E JURÍDICA DA EDUCAÇÃO SUPERIOR

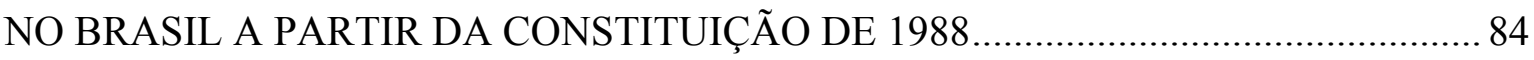

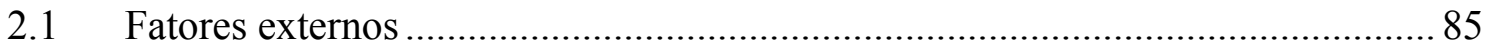

$2.21^{0}$ período - Governos Fernando Collor de Mello (1990-1992) e Itamar Franco

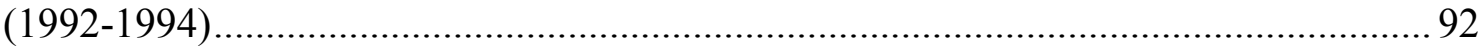

$2.322^{\circ}$ período - Governo Fernando Henrique Cardoso (1995-2002)........................ 98

2.4 Os Governos Luiz Inácio Lula da Silva (2003-2010) e Dilma Roussef (2011) 136

2.5 Análise do setor do ensino superior privado do Brasil ................................... 163

2.6 Dados empíricos sobre o ensino superior no período 1990-2010 …................... 168

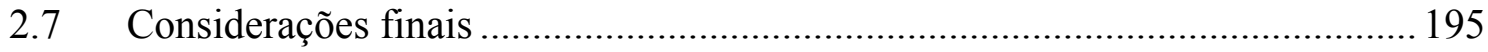

CAPÍTULO 3. EDUCAÇÃO COMO SERVIÇO PRESTADO MEDIANTE O DESEMPENHO DE UMA ATIVIDADE EMPRESÁRIA _............................................. 197

3.1 Atividade empresária, lógica econômica e educação ......................................... 197

3.2 Como construir uma empresa de educação de sucesso..................................... 199

3.3 A relação entre o aluno consumidor e a instituição fornecedora do serviço

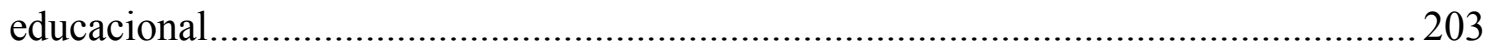

3.4 Motivos para a abertura de capital de uma empresa ...................................... 207

3.5 Sete virtudes do intuito lucrativo para James Tooley (1999) ............................208

3.6 Obrigações e deveres no dia a dia de uma companhia aberta listada no Novo

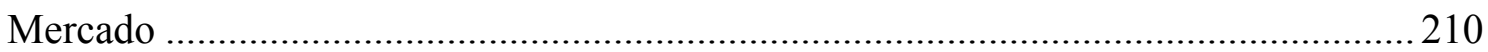

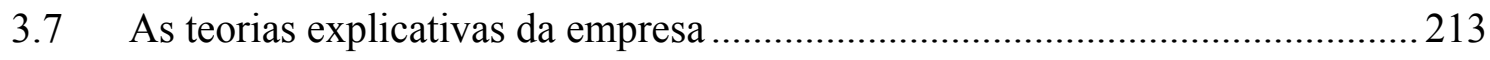


3.8 Função Social da Empresa e suas críticas.......................................................... 216

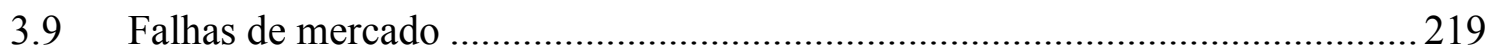

3.10 A educação como bem coletivo e as falhas de mercado ..................................... 220

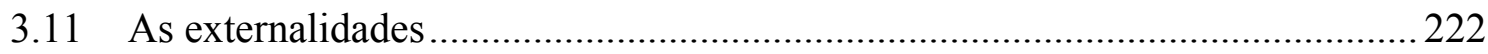

3.12 As externalidades sociais e a sua incompatibilidade com a lógica econômica . 224

3.13 As externalidades sociais da educação e a atuação do setor privado................. 225

CAPÍTULO 4. O CASO DA ANHANGUERA........................................................... 231

4.1 Grupo I - Informações gerais sobre a Anhanguera .......................................... 231

4.2 Grupo II - Educação como serviço prestado mediante o desempenho de uma

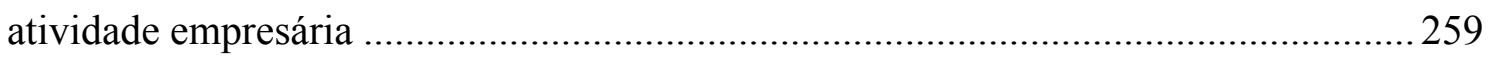

4.3 Grupo III - Educação como Direito Humano, Bem Público e Serviço Público 278

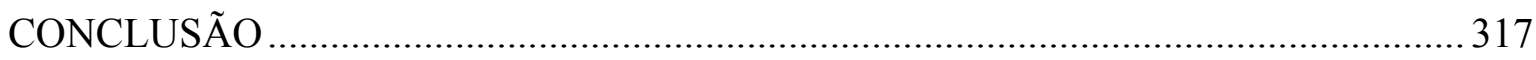

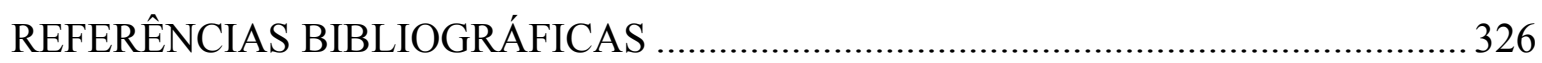

APÊNDICE A - Documentação analisada da Anhanguera................................................ 343

APÊNDICE B - Dispositivos que tratam direta ou indiretamente do direito à educação na

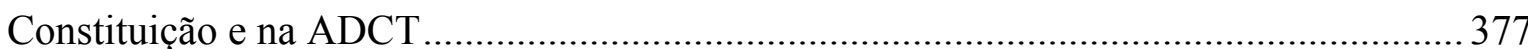

APÊNDICE C - Lista de normas aplicáveis à educação superior vigentes em 05/05/2012 


\section{INTRODUÇÃO}

\section{Tema, limitações e justificativas}

A educação é, tradicionalmente, concebida como um direito humano de segunda dimensão, direito social que pressupõe uma intervenção ativa e material do Estado para sua concretização, em busca de igualdade material entre os indivíduos. Considerando a interdependência e a indivisibilidade dos direitos humanos, o direito à educação possui um papel central para a efetivação dos demais direitos humanos, já que é a base para a cidadania, para o desenvolvimento da pessoa, para a atuação do homem em sociedade e sua emancipação por meio da compreensão de seus direitos e deveres. Nesse contexto, a educação apresenta eminente caráter público, sendo considerada bem público e serviço público.

No entanto, a educação é livre à iniciativa privada, com forte presença do setor privado no Brasil, especialmente no ensino superior. Dentro da lógica econômica, a educação adquire contornos de mercadoria ou serviço oferecido por empresas, mediante o desempenho de uma atividade empresária.

A partir dessas premissas, a presente Dissertação buscará implementar uma análise teórica e empírica do oferecimento do ensino superior por instituições de ensino privadas com fins lucrativos no Brasil, especialmente pelas instituições que fazem parte do grupo Anhanguera, controlado pela Anhanguera Educacional Participações S.A. (Anhanguera ou Companhia), com o objetivo de verificar se o agente privado é capaz de oferecer a educação conforme as normas constitucionais brasileiras, em especial, conforme as regras previstas nos artigos 205 a 214 da Constituição, e em que medida a lógica econômica é compatível ou não com este direito humano.A escolha pelo estudo da educação superior justifica-se: (i) pelo crescimento do ensino superior brasileiro nas últimas décadas, passando de 1.540.080 matrículas e 918 instituições em 1990 para 6.379.299 matrículas e 2.378 instituições em 2010 (INEP, 2012b); (ii) pela adoção pelo Estado Brasileiro, a partir da década de 1990, de políticas públicas, fundadas em alterações constitucionais (ECs $\mathrm{n}^{\circ} \mathrm{s}$ 14/96, 53/06 e 59/09) e legislativas (principalmente, as Leis $\mathrm{n}^{\mathrm{o}} \mathrm{s}$ 9.394/96, 9.131/95, $10.172 / 01,10.219 / 01,10.260 / 01$ e 11.096/06; e os Decretos $n^{\circ}$ s 2.207/97 e 2.306/97) que incentivaram, direta ou indiretamente, o avanço do setor privado na educação superior brasileira; (iii) pelo fato de ser este o nível da educação no qual a atuação privada é 
preponderante no Brasil (74,24\% das matrículas, em 2010 - INEP, 2012b), enquanto na educação básica, o setor público é preponderante (84,5\% das matrículas, em 2011 - INEP, 2012a); e (iv) pela ausência de estudos sistematizados acerca do ensino superior privado com fins lucrativos no Brasil, sobretudo com relação ao seu desenvolvimento nas últimas décadas, com a profissionalização, internacionalização, aumento de concorrência e competição no setor, e com a entrada de seus atores no mercado de valores mobiliários, movimento iniciado com a abertura de capital da Anhanguera em 2007.

Ao longo do século XX, em especial a partir da sua segunda metade, houve um aumento significativo da demanda pela educação superior ao redor do mundo ${ }^{1}$, movimento acompanhado pelo Brasil. Dentro desse período histórico, desenvolveremos, na Dissertação, o período posterior à Constituição de 1988, no qual foram aprovadas as alterações constitucionais e legislativas acima mencionadas que estimularam o crescimento do setor privado no ensino superior brasileiro. Além disso, nesse período, o País alcançou bons resultados em matéria de crescimento econômico, houve a expansão do acesso à educação básica e o aumento dos concluintes do ensino médio, fatos que influenciaram diretamente a ampliação da demanda pela educação superior, com o crescimento da participação de representantes das classes $\mathrm{C}$ e D neste nível de ensino ${ }^{2}$.

Dentre as instituições do setor privado, elegemos como objeto de estudo as instituições de ensino superior privadas, com fins lucrativos, também chamadas de particulares, que são aquelas instituídas e mantidas por uma ou mais pessoas físicas ou jurídicas de direito privado (art. 20, Lei $\mathrm{n}^{0}$ 9.394/96), geralmente, na forma de sociedades simples, limitadas ou por ações. Excluímos, portanto, de nossa análise as instituições privadas comunitárias, cooperativas, confessionais ou filantrópicas, que são regidas por outras finalidades que não a lucrativa. Dentre as instituições de ensino superior privado, a maior parte são particulares, representando 85,98\% delas, em 2009 (INEP, 2010).

Analisando os números do ensino superior brasileiro, verifica-se que entre os anos de 1990 e 2010, o setor privado apresentou um grande crescimento no País, tanto em

\footnotetext{
${ }^{1}$ Segundo dados da Unesco (1998), a segunda metade do século XX entrou para a história do ensino superior como a época de sua maior expansão - em escala mundial, o número de estudantes multiplicou-se por mais de 6 entre 1960 (13 milhões) e 1995 (82 milhões).

${ }^{2}$ A esse respeito, Ryon Braga (2010) destaca que no início dos anos 1990, somente a elite socioeconômica chegava ao ensino superior - as classes A e B representavam 92\% de todo o alunado do setor. Em 2010, a classe A representava 23,3\% do alunado do ensino superior privado no Brasil, tendo estagnado neste percentual por quatro anos. A classe B, com $48,7 \%$ do total, continuava a maior representante do ensino superior privado, mas apresentava crescimento de 29,3\% nos últimos quatro anos, bem inferior ao crescimento da classe C, que evoluíra 53\% no mesmo período. Em 2010, a classe C já representava 22,1\% do alunado do ensino superior privado, e a classe D continuava com uma parcela ainda pequena, de 4,6\%, mas com crescimento de $95,3 \%$ nos últimos quatro anos.
} 
número de instituições - passando de 698 (75,82\% do total) em 1990 para 2.100 (88,3\% do total) em 2010 - como em número de matrículas - passando de 961.455 (62,43\% do total) para 4.736.001 matrículas $(74,24 \%$ do total). Nota-se também que este crescimento foi intenso especialmente no período posterior à promulgação da Lei ${ }^{0}$ 9.394/96 (LDB) e que, a partir do ano 2006, o ritmo de crescimento com relação ao número de instituições do setor privado diminuiu

Uma das possíveis razões para a diminuição do ritmo de crescimento do número de estabelecimentos privados, seria um movimento de concentração do mercado educacional, no qual empresas com maior participação no mercado adquirem suas concorrentes, especialmente, instituições pequenas (em termos de estrutura e número de matrículas) e familiares. Nesse contexto, é importante notar que do total das instituições de ensino superior brasileiras, em 2009, 1.473 (63,8\%) são consideradas de pequeno porte (instituições com, no máximo, 1.000 matrículas) (INEP, 2010). No entanto, o maior número de matrículas está concentrado num pequeno número de instituições de grande porte (instituições com mais de 10.000 matrículas) - em 2009, apenas 117 (5,1\%) das instituições de ensino superior, consideradas de grande porte, detinham 2.505 .670 (48,9\%) matrículas na graduação presencial (INEP, 2010).

Dentre as instituições de ensino superior privadas, particulares e de grande porte, encontra-se o grupo Anhanguera, que atua no setor do ensino superior (graduação e pósgraduação), ensino profissional, educação continuada, cursos na área jurídica e cursos preparatórios para concursos públicos, nas modalidades presencial e a distância. O grupo Anhanguera é controlado pela Anhanguera, uma sociedade por ações de capital aberto, listada no Novo Mercado da BM\&FBOVESPA S.A. - Bolsa de Valores, Mercadorias e Futuros (BM\&FBOVESPA). Escolhemos analisar o caso da Anhanguera porque (i) a Anhanguera atua no ensino superior, nível de ensino que escolhemos analisar na presente pesquisa; (ii) a Anhanguera foi a primeira empresa do setor educacional a abrir o capital na América Latina; (iii) em 31 de dezembro de 2011, o grupo Anhanguera representava o segundo maior grupo educacional do mundo ${ }^{3}$ e o maior do Brasil em termos de valor de mercado que, naquela data, era de $\mathrm{R} \$ 2,93$ bilhões; e em número de alunos que, naquela data, era de mais de 400 mil (ANHANGUERA, 2012d, p. 109); e (iv) até o momento, não existem estudos sistematizados sobre o caso da Anhanguera. Além disso, escolhemos analisar o caso da Anhanguera considerando a possibilidade de acesso a documentos

\footnotetext{
${ }^{3}$ Naquela data, o maior grupo educacional do mundo era o norte-americano Apollo Group. Informações sobre o Apollo Group encontram-se no Capítulo 2 da Dissertação.
} 
relacionados a decisões de seus acionistas e de sua administração ${ }^{4}$, ao funcionamento da Companhia e às práticas empresariais adotadas, que a Anhanguera está obrigada a disponibilizar para acesso público por ser uma companhia aberta e listada no Novo Mercado da BM\&FBOVESPA. Mediante uma análise empírica, pretendemos verificar o tratamento dado por uma empresa de grande porte à educação superior, servindo os resultados dessa pesquisa como parâmetro para o ensino superior privado de massa com fins lucrativos no Brasil.

\section{Objetivos}

A presente Dissertação tem por objetivos analisar:

(i) a educação como direito humano, bem público e serviço público, localizando o direito à educação na doutrina dos direitos humanos, abordando seu conteúdo multidimensional e instrumental, cuidando do tratamento constitucional do direito à educação no Brasil, bem como dos princípios constitucionais da educação e do ensino e das especificidades da educação superior;

(ii) a evolução histórica e jurídica da educação superior no Brasil a partir da Constituição de 1988, seu tratamento legal, as políticas públicas adotadas pelo Estado Brasileiro ao longo desse período com relação à educação superior e o impacto que tais políticas tiveram para o crescimento do setor privado neste nível da educação, bem como verificar os fatores econômicos, sociais e políticos, internos e externos, que podem ter influenciado as posições adotadas pelo Estado Brasileiro, apresentando o contexto atual da educação superior brasileira, com destaque para a profissionalização e internacionalização do setor na última década, que culmina na abertura de capital da Anhanguera em 2007 e num movimento de competição, concorrência e concentração do mercado educacional;

(iii) a educação como serviço prestado mediante o desempenho de uma atividade empresária, as características da atividade empresária, a lógica empresarial, as dificuldades do agente privado em lidar com atividades produtoras de externalidades

\footnotetext{
${ }^{4}$ Como companhia aberta, a Anhanguera está obrigada a disponibilizar no site da Comissão de Valores Mobiliários - CVM (http://www.cvm.gov.br), da BM\&FBOVESPA (http://www.bmfbovespa.com.br) e de Relações com Investidores da Companhia (http://www.anhanguera.com/ri), uma série de documentos societários e econômico-financeiros como Atas de Assembleias Gerais de Acionistas, Atas de Reuniões do Conselho de Administração, Atas de Reuniões do Conselho Fiscal, Atas de Reuniões de Diretoria, Formulário de Referência, Formulário de Informações Anuais - IAN, Formulário de Informações Trimestrais - ITR, Demonstrações Financeiras Anuais, além de prospectos relativos a emissões públicas de valores mobiliários. Referidos documentos constituem a principal fonte de dados na qual baseou-se a análise empírica da Anhanguera.
} 
sociais; e

(iv) analisar o caso da Anhanguera, a partir da documentação sobre a Companhia disponível para acesso público, com o objetivo de encontrar respostas para as questões abaixo (Questões da Análise Empírica), relacionadas direta ou indiretamente aos temas constantes nos itens (i) a (iii) acima e ao objetivo da Dissertação de analisar a compatibilidade entre a lógica econômica e o ensino superior, a partir do estudo desse caso concreto:

\section{Quadro 1 - Questões da análise empírica}

\begin{tabular}{|c|c|}
\hline $\mathbf{N}^{\mathbf{0}}$ & Grupo I - Informações Gerais sobre a Anhanguera \\
\hline 1. & $\begin{array}{l}\text { Qual é o objeto social da Anhanguera? Quais seus direitos e deveres com relação às IESs a ela } \\
\text { subordinadas? Como fica o tratamento da autonomia universitária no relacionamento da } \\
\text { Anhanguera e suas subsidiárias? }\end{array}$ \\
\hline 2. & $\begin{array}{l}\text { Como é a estrutura societária do grupo Anhanguera? Quem detém o controle do grupo? Qual a } \\
\text { posição da Anhanguera dentro do grupo? Quais são as entidades mantenedoras das IESs do grupo? } \\
\text { Quantas IESs fazem parte do grupo? Quais as formas de organização acadêmica dessas } \\
\text { instituições? }\end{array}$ \\
\hline 3. & $\begin{array}{l}\text { Qual a posição da Anhanguera no mercado educacional brasileiro? A quantos alunos seu grupo } \\
\text { atende? Em quais regiões atua? }\end{array}$ \\
\hline 4. & $\begin{array}{l}\text { A Anhanguera é uma empresa atrativa para os investidores? Qual o valor médio de cotação das } \\
\text { ações da Anhanguera? Qual o valor de lucro líquido apurado pela Anhanguera nos últimos anos? }\end{array}$ \\
\hline 5. & $\begin{array}{l}\text { Como foi o histórico de formação da Anhanguera? Em qual contexto da história brasileira ela se } \\
\text { situa? Quando a Anhanguera abriu seu capital? Quantas emissões públicas de valores mobiliários } \\
\text { efetuou e qual o volume de recursos arrecadados em cada uma delas? }\end{array}$ \\
\hline 6. & $\begin{array}{l}\text { Foram encontradas práticas empresariais que evidenciem o tratamento da prestação de serviços } \\
\text { educacionais como atividade empresária? Quais foram as práticas encontradas? Foi encontrada } \\
\text { preocupação com criação de escala e eficiência para diminuição dos custos envolvidos na atividade } \\
\text { e aumento dos lucros para distribuição aos acionistas? }\end{array}$ \\
\hline 7. & $\begin{array}{l}\text { Quais as principais fontes de recurso da Anhanguera? Qual foi a destinação dos recursos captados } \\
\text { no mercado pela Anhanguera? Qual porcentagem foi investida em infraestrutura para os alunos e } \\
\text { qual porcentagem foi destinada para o crescimento da empresa por meio de novas aquisições? Com } \\
\text { relação à infraestrutura, quais foram os investimentos feitos? }\end{array}$ \\
\hline $\mathbf{N}^{\mathbf{0}}$ & $\begin{array}{c}\text { Grupo II - Educação como serviço prestado mediante o desempenho de uma atividade } \\
\text { empresária }\end{array}$ \\
\hline 8. & $\begin{array}{l}\text { Como é o processo seletivo da Anhanguera? Quais são as formas de publicidade e marketing } \\
\text { utilizadas pela Anhanguera para atrair novos alunos? Essas práticas demonstram características } \\
\text { empresariais da atividade? }\end{array}$ \\
\hline 9. & $\begin{array}{l}\text { Como é a administração da Anhanguera? Existem administradores profissionais? Qual o perfil dos } \\
\text { seus administradores? }\end{array}$ \\
\hline 10. & $\begin{array}{l}\text { Foram encontrados mecanismos de estímulo e efetiva participação interna de representantes de } \\
\text { interesses diversos dos acionistas, como de alunos, professores, funcionários etc. nos documentos } \\
\text { analisados? Quais foram os mecanismos encontrados? }\end{array}$ \\
\hline 11. & $\begin{array}{l}\text { Qual o valor médio das mensalidades cobradas pela Anhanguera? Existe um público-alvo? A } \\
\text { Companhia direciona sua atividade para esse público-alvo? }\end{array}$ \\
\hline
\end{tabular}




\section{Quadro 1 - Questões da análise empírica}

\begin{tabular}{|l|l|}
\hline \multicolumn{1}{|l}{ (conclusão) } \\
\hline 12. & $\begin{array}{l}\text { Goi encontrada alguma menção ou preocupação com a observância dos princípios constitucionais } \\
\text { da educação (art. 205) e do ensino (art. 206) pelas IESs do grupo nos documentos analisados? } \\
\text { Existe alguma política interna visando à efetivação desses princípios e que também pode ser } \\
\text { encarada como uma externalidade social oriunda da relação instituição-aluno? }\end{array}$ \\
\hline 13. & $\begin{array}{l}\text { Foi encontrada alguma menção ou preocupação com pesquisa, ensino e extensão nos documentos } \\
\text { analisados? Quais as referências encontradas? Essas referências concretizaram-se em práticas de } \\
\text { pesquisa, ensino e extensão pela Anhanguera? Quais foram as práticas encontradas e quais os } \\
\text { volumes investidos? }\end{array}$ \\
\hline 14. & $\begin{array}{l}\text { Como é a metodologia de ensino da Anhanguera? Pode-se dizer que a formação oferecida pela } \\
\text { Anhanguera é principalmente voltada ao mercado de trabalho? }\end{array}$ \\
\hline 15. & $\begin{array}{l}\text { Como foram as últimas avaliações da qualidade do ensino oferecido pela Anhanguera? Existem } \\
\text { formas de avaliação de qualidade feitas pela própria empresa? Há um caráter empresarial no } \\
\text { controle de qualidade da empresa? }\end{array}$ \\
\hline 16. & $\begin{array}{l}\text { Qual o perfil dos professores da Anhanguera? Qual o regime de trabalho desses professores? Qual a } \\
\text { porcentagem de mestres e doutores? Qual a porcentagem de professores em dedicação integral? }\end{array}$ \\
\hline 17. & $\begin{array}{l}\text { Qual a relação entre alunos ingressantes/concluintes da Anhanguera? Qual a taxa de evasão da } \\
\text { Anhanguera? }\end{array}$ \\
\hline 18. & $\begin{array}{l}\text { Em quantos processos judiciais a Anhanguera é ré? Quais os principais pedidos envolvidos nesses } \\
\text { processos? Quais as principais demandas propostas pelos alunos? Quantos processos coletivos } \\
\text { existem contra a Anhanguera? Como é a jurisprudência dos tribunais superiores sobre a } \\
\text { Anhanguera? }\end{array}$ \\
\hline
\end{tabular}

\section{Metodologia}

Para o desenvolvimento da Dissertação, observamos as seguintes abordagens metodológicas: (i) exposição e confronto de linhas doutrinárias a respeito do tema proposto; (ii) reconstrução histórica dos aspectos econômicos, sociais e políticos que podem ter influenciado a legislação, doutrina, jurisprudência e políticas públicas adotadas sobre o tema no período escolhido para a análise; e (iii) levantamento, triagem e análise dos documentos e dados disponíveis para consulta pública em sites de órgãos oficiais, a respeito do tema proposto, com a elaboração de tabelas e quadros com os dados mais relevantes, com destaque para as informações fornecidas pela própria Anhanguera com relação ao seu modo de funcionamento e suas práticas empresariais.

Em função dessa proposta, utilizamos as seguintes fontes de pesquisa: (i) referências bibliográficas diversas a respeito do tema; (ii) legislação nacional e internacional pertinentes, incluindo declarações, convenções e tratados internacionais para proteção do direito à educação obtidos em sites de legislação e normas internacionais, em especial, os sites do Planalto (http://www.planalto.gov.br/legislacao e http://www4.planalto.gov.br/legislacao/legislacao-por-assunto/educacao-teste\#content ${ }^{5}$ ),

\footnotetext{
${ }^{5}$ Link específico do site de legislação do Planalto para consulta de normas sobre educação.
} 
Senado Federal (http://www.senado.gov.br/legislacao), Câmara dos Deputados (http://www2.camara.leg.br/atividade-legislativa/legislacao); MEC - normas de ensino superior (http://meclegis.mec.gov.br/); Alto Comissariado das Nações Unidas para os Direitos Humanos (http://www2.ohchr.org/english/bodies/ratification/index.htm); e Unesco (http://www.unesco.org); (iii) documentos e dados disponíveis para acesso público obtidos em sites de órgãos oficiais a respeito da educação superior no Brasil e atividades da Anhanguera, em especial, os sites do Inep (http://www.inep.gov.br), MEC (http://www.mec.gov.br e http://emec.mec.gov.br/ ${ }^{6}$ ), Sinaes (http://www.sinaes.gov.br), IBGE (http://www.ibge.gov.br), Comissão de Valores Mobiliários - CVM (http://www.cvm.gov.br),

BM\&FBOVESPA (http://www.bmfbovespa.com.br), Anhanguera - $\quad$ Comercial (http://www.unianhanguera.edu.br $\quad$ ou http://www.anhanguera.com), Anhanguera - Relações com Investidores (http://www.unianhanguera.edu.br/ri ou http://www.anhanguera.com/ri) e Anhanguera Responsabilidade Social (http://rsocial.anhanguera.com); e (iv) jurisprudência pertinente ao tema, especificamente com relação à atuação da Anhanguera, obtida nos sites do Supremo Tribunal Federal (http://www.stf.jus.br) e Superior Tribunal de Justiça (http://www.stj.jus.br).

Foi escolhida como data de corte para as informações incluídas na Dissertação o dia $31 / 12 / 2011^{7}$.

\section{Procedimento de coleta de informações sobre a Anhanguera}

O caso da Anhanguera foi analisado por meio do levantamento, triagem e análise dos principais documentos e dados sobre a Companhia disponíveis para acesso público nos sites acima mencionados, com a elaboração de tabelas e quadros contendo as informações mais importantes. A descrição do material analisado encontra-se no Apêndice A, e no texto

\footnotetext{
${ }^{6}$ Site para consultas sobre instituições de ensino superior e cursos existentes no Brasil, com informações sobre categoria administrativa, organização acadêmica, instituições mantenedoras, localidades dos cursos, avaliações, procedimentos administrativos, entre outras.

${ }^{7}$ Esta data de corte foi utilizada principalmente para a análise da documentação e dados sobre a Anhanguera. Existem, no entanto, algumas informações sobre a Anhanguera com a data de 31/05/2012, que é a data do seu último Estatuto Social consolidado e também a data de entrega do Formulário de Referência de 2012, que tem por base as informações financeiras de 31/12/2011. Há também dados de 30/04/2011, que foi a data de realização da Assembleia Geral Ordinária que aprovou as DFs da Companhia de 31/12/2011. O restante da Dissertação também seguiu esta data de corte (31/12/2011), com exceção de uma listagem de normas sobre ensino superior vigentes em 05/05/2012 presente no Apêndice C, da descrição de decisões do STF sobre as políticas de cotas e o ProUni tomadas no $1^{\circ}$ semestre de 2012 e da descrição da lei do Proies de 18/07/2012, constantes Capítulo 2 da Dissertação.
} 
principal da Dissertação foram incluídas as informações mais relevantes para os objetivos da pesquisa.

Ao final, foram analisados os seguintes documentos e informações: (i) 34 Atas de Assembleias Gerais realizadas desde a constituição da Companhia até 30/04/2012; (ii) 1 Estatuto Social consolidado em 31/05/2012; (iii) 123 Atas de Reuniões do Conselho de Administração realizadas desde a constituição da Companhia até 31/12/2011; (iv) 3 Atas de Reuniões do Conselho Fiscal realizadas desde a constituição da Companhia até 31/12/2011; (v) 4 Prospectos Definitivos de Distribuição Pública de Valores Mobiliários que tratam de todas as ofertas públicas de valores mobiliários realizadas pela Companhia desde sua constituição até 31/12/2011; (vi) 3 Formulários de Referência referentes aos anos de 2010, 2011 e 2012; (vii) 1 Fato Relevante de 18/09/2011; (viii) 1 Formulário de Informações Anuais - IAN relativo ao exercício social findo em 31/12/2008 ; (ix) 1 Formulário de Informações Trimestrais - ITR de 30/09/2010; (x) 1 Relatório Financeiro referente ao $4^{\mathrm{o}}$ trimestre de 2011; (xi) 2 Relatórios de Responsabilidade Social dos anos de 2010 e 2011; e (xii) outros dados e informações sobre a Companhia, principalmente, sobre o seu histórico de formação, instituições de ensino superior integrantes do grupo (formas de organização acadêmica, entidades mantenedoras, cursos, localidades e valores de mensalidade) e ações de responsabilidade social constantes nos sites de relações com investidores da Anhanguera (http://www.unianhanguera.edu.br/ri ou http://www.anhanguera.com/ri), no site comercial da Anhanguera (http://www.unianhanguera.edu.br ou http://www.anhanguera.com) e no site sobre ações de responsabilidade social da Anhanguera (http://rsocial.anhanguera.com).

\footnotetext{
${ }^{8}$ Este é o último IAN preparado pela Anhanguera. A partir da Instrução CVM n ${ }^{\circ} 480$, de 07/12/2009, as companhias abertas substituíram o IAN pelo Formulário de Referência.
} 


\section{CAPÍTULO 1. A EDUCAÇÃO COMO DIREITO HUMANO, BEM PÚBLICO E SERVIÇO PÚBLICO}

O objetivo deste primeiro capítulo é analisar a educação como direito humano, bem público e serviço público. Inicialmente, vamos localizar o direito à educação na doutrina dos direitos humanos, apresentando conceitos e classificações doutrinárias. Em seguida, cuidaremos da educação superior e suas características e do tratamento dado pela Constituição de 1988 ao direito à educação. Ao final, trataremos da educação como bem público e serviço público, apresentando as controvérsias atuais a esse respeito.

\subsection{A educação como um direito humano}

\subsubsection{Terminologia a ser utilizada na dissertação: direitos humanos e direitos fundamentais como instituto jurídico único e direitos em sentido forte}

Utilizaremos nesta Dissertação os termos "direitos humanos" e "direitos fundamentais" de modo indistinto, considerando-os um instituto jurídico único, na forma de um conjunto de direitos que concretizam, a cada momento histórico, as exigências de

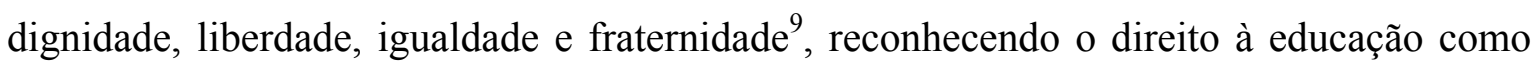
um desses direitos.

Tal escolha segue a doutrina de Sérgio Resende de Barros $(2003)^{10}$, que não vê razão para a dicotomia entre "direitos humanos" e "direitos fundamentais" pregada por doutrinadores como Perez Luño $(1998 ; 2002)^{11}$, que defendem a existência de uma

\footnotetext{
${ }^{9}$ A definição escolhida para o instituto jurídico único é ampla e influenciada pela definição de André de Carvalho Ramos (2005, p. 19) e Norberto Bobbio (1992).

${ }^{10}$ Para Barros (2003, p. 14), não há dicotomia entre "direitos humanos" e "direitos fundamentais", mas sim apenas uma abreviação, dentro do mesmo instituto jurídico. Nessa linha, doutrinadores como Alexandre de Moraes (1997) e Manuel Gonçalves Ferreira Filho (2009) utilizam a expressão "direitos humanos fundamentais"; e José Afonso da Silva (2011, p. 178), "direitos fundamentais do homem”, para se referir a esses direitos, reunindo "direitos humanos" e "direitos fundamentais".

${ }^{11}$ Luño (1998, p. 46) entende que o critério distintivo entre "direitos fundamentais" e "direitos humanos" deve ser o "diferente grau de concreção positiva destas categorias". A esse respeito, afirma que "nos usos linguísticos jurídicos, políticos e mesmo comuns de nosso tempo, o termo 'direitos humanos' aparece como um conceito de contornos mais amplos e imprecisos que a noção dos 'direitos fundamentais"”. Ele, então, define "direitos humanos" como "um conjunto de faculdades e instituições que, em cada momento histórico, concretizam as exigências da dignidade, da liberdade e da igualdade humanas, as quais devem ser reconhecidas positivamente pelos ordenamentos jurídicos em nível nacional e internacional” (LUÑO, 1998, p. 46). E, "direitos fundamentais" como "aqueles direitos humanos garantidos pelo ordenamento jurídico positivo, na maior parte dos casos na sua normativa constitucional, e que, normalmente, desfrutam de uma tutela reforçada (LUÑO, 1998, p. 46). No conceito de Luño (1998, p. 47), os direitos humanos referem-se a
} 
diferença de concreção positiva entre os direitos humanos e os direitos fundamentais para diferenciá-los. Para Barros (2003, p. 39), a tendência dissociativa entre "direitos fundamentais" e "direitos humanos" deve ser repelida por discriminar os direitos humanos, colocando-os como um conceito de contornos mais amplos e imprecisos que a expressão "direitos fundamentais".

$\mathrm{O}$ uso indistinto dos termos considera também a tendência aproximativa entre os planos interno e internacional para a proteção dos direitos humanos no Brasil, em vista (i) do princípio da prevalência dos direitos humanos nas relações internacionais do Brasil (art. $4^{\mathrm{o}}, \mathrm{II}, \mathrm{CF} / 88$ ); (ii) da previsão de que os direitos e garantias previstos na Constituição não excluem outros decorrentes dos tratados internacionais de que o Brasil seja parte (art. $5^{\circ}$, Parágrafo $2^{\circ}, \mathrm{CF} / 88$ ); e (iii) da proteção especial conferida pela Constituição Brasileira aos tratados internacionais de direitos humanos, mediante a previsão de seu status de emenda constitucional desde que aprovados por quórum especial (art. $5^{\circ}$, Parágrafo $3^{\circ}, \mathrm{CF} / 88$ ). A esse respeito, Ramos (2005) afirma que:

\footnotetext{
Essa "união de termos" mostra que a diferenciação entre "direitos humanos", representando os direitos reconhecidos pelo Direito Internacional dos Direitos Humanos, e os "direitos fundamentais", representando os direitos positivados nas Constituições e leis internas, perde a importância, ainda mais na ocorrência [...] de um processo de aproximação e mútua relação entre o Direito Internacional e o Direito Interno na temática dos direitos humanos.
}

O foco de nossa análise será tratar de direitos humanos em sentido forte, que segundo Norberto Bobbio (1992, p. 79-82), são aqueles direitos previstos em sistemas jurídicos dos Estados nacionais (e não apenas em códigos de normas naturais ou morais). Nesse sentido, nossa abordagem do direito à educação como direito humano versará sobre o tratamento constitucional e legal desse direito, bem como sobre os tratados internacionais de direitos humanos ratificados pelo Estado Brasileiro nessa temática. A análise das normas internacionais será feita considerando que o ordenamento jurídico brasileiro acolhe os tratados internacionais de direitos humanos com um status privilegiado, na medida em

direitos e liberdades com uma conotação prescritiva ou deontológica, incluindo, além dos direitos positivados em declarações internacionais, também aquelas exigências mais radicalmente vinculadas ao sistema de necessidades humanas e que, devendo ser objeto de positivação, ainda não o foram. Ingo Sarlet (2008, p. 40), na linha de Luño, destaca que são os direitos fundamentais (direito interno) que, "ao menos em regra atingem (ou, pelo menos, estão em melhores condições para isto) o maior grau de efetivação, particularmente em face da existência de instâncias (especialmente as judiciárias) dotadas do poder de fazer respeitar e realizar estes direitos". Com relação aos direitos humanos, afirma que a efetivação desses direitos depende da boa vontade e da cooperação dos Estados, "salientando-se, neste particular, uma evolução progressiva na eficácia dos mecanismos jurídicos internacionais de controle". 
que complementam o catálogo de direitos constitucionalmente previstos ${ }^{12}$, com a possibilidade de serem invocados judicialmente e de ensejarem responsabilidade interna e internacional do Estado Brasileiro pelo seu descumprimento (por isso, direitos em sentido forte também ${ }^{13}$ ).

\subsubsection{Características dos direitos humanos}

Para os fins da presente Dissertação, é necessário compreender as seguintes características dos direitos humanos: (i) a superioridade normativa; (ii) a universalidade; (iii) a indivisibilidade; (iv) a interdependência; (v) a indisponibilidade; (vi) a aplicabilidade imediata; (vii) a historicidade; (viii) a proibição do retrocesso social; e (ix) a eficácia horizontal.

A superioridade normativa significa que, no plano interno, as normas de direitos humanos são, em geral, de estatura constitucional, possuindo, portanto, hierarquia superior às demais normas do ordenamento jurídico. No Brasil, referidas normas estão inseridas na Constituição e são consideradas cláusulas pétreas. No plano internacional, as normas de direitos humanos são consideradas integrantes do jus cogens internacional, que constitui Direito imperativo para os Estados ${ }^{14}$.

A universalidade dos direitos humanos é considerada em três planos: (i) titularidade - os direitos humanos são universais porque são titularizados por todos os seres humanos, sem distinção de qualquer ordem; (ii) temporal - os direitos humanos são universais porque os homens os possuem em qualquer época da história ${ }^{15}$; e (iii) cultural - os direitos

\footnotetext{
12 Flávia Piovesan (2007, p. 58) afirma que: “a Constituição de 1988 recepciona os direitos enunciados em tratados internacionais de que o Brasil é parte, conferindo-lhes natureza de norma constitucional. Isto é, os direitos constantes nos tratados internacionais integram e complementam o catálogo de direitos constitucionalmente previsto, o que justifica estender a esses direitos o regime constitucional conferido aos demais direitos e garantias fundamentais".

${ }^{13}$ Bobbio (2002) afirma que o sistema internacional é fraco uma vez que os "direitos proclamados são sustentados, quase que exclusivamente, pela pressão social, como ocorre habitualmente no caso dos códigos morais, e são repetidamente violados". Compartilhamos desta visão de Bobbio, no entanto, entendemos que aConstituição Brasileira, após a inclusão das previsões dos artigos $4^{\circ}$, II e $5^{\circ}$, Parágrafos $2^{\circ}$ e $3^{\circ}$, conferiu especial proteção e maior efetividade aos tratados internacionais para proteção dos direitos humanos ratificados pelo Estado Brasileiro. . Uma vez internalizado um determinado tratado de direitos humanos, toda a legislação infraconstitucional deve ser com ele compatível, sujeito a controle judicial, o que confere força e obrigatoriedade às suas disposições. Este fato faz com as normas previstas nestes tratados possam ser consideradas direitos em sentido forte no Brasil.

${ }^{14}$ Para Piovesan (2007, p. 66), "os tratados de direitos humanos apresentam superioridade hierárquica em relação aos demais atos internacionais de caráter mais técnico, formando um universo de princípios que apresentam especial força obrigatória, denominado jus cogens".

${ }^{15}$ Este plano da universalidade é contestado por aqueles que consideram os direitos humanos direitos históricos, como Bobbio (1992).
} 
humanos são universais porque permeiam todas as culturas humanas, em qualquer parte do planeta $^{16}$ (RAMOS, 2005, p. 179).

A indivisibilidade significa que todos os direitos humanos devem ter a mesma proteção jurídica porque todos são essenciais para uma vida digna. Para Ramos (2005, p. 2000), a indivisibilidade possui duas facetas: (i) que o direito protegido possui uma unidade incindível em si; e (ii) que não é possível proteger apenas alguns dos direitos humanos e outros não. Esta segunda faceta impede qualquer privilégio de proteção dos direitos de uma determinada dimensão em detrimento de direitos de outras.

A interdependência é o reconhecimento de que os direitos humanos possuem uma mútua dependência, pois o conteúdo de um determinado direito pode vincular-se ao conteúdo de outro, demonstrando a interação e complementaridade entre eles (RAMOS, 2005, p. 203).

A indisponibilidade significa que os direitos humanos são irrenunciáveis, ou, pelo menos, a vontade de seu titular no sentido de renúncia ou disposição somente pode ser manifestada sob controle, respeitada sempre a dignidade humana (RAMOS, 2005, p. 207).

A aplicabilidade imediata significa que as normas que tratam dos direitos humanos aplicam-se imediatamente às situações fáticas existentes, não dependendo de nenhuma intermediação legislativa. Tal característica foi reconhecida na Constituição Brasileira de 1988 (art. $5^{\circ}$, Parágrafo $1^{\circ}$ ), sem qualquer distinção entre os direitos das diferentes dimensões.

A historicidade é o reconhecimento de que a cada novo contexto histórico, novas demandas são incorporadas ao conteúdo dos direitos humanos, fazendo com que um direito considerado inerente à natureza humana e absoluto num determinado momento possa não ser assim considerado posteriormente ${ }^{17}$ (BOBBIO, 1992, p. 18).

A proibição do retrocesso social é a impossibilidade de que os Estados diminuam a proteção já conferida aos direitos humanos. O Pacto Internacional dos Direitos Econômicos, Sociais e Culturais de 1966 (Pidesc), em seu artigo 2.1, estabelece que os Estados comprometem-se a adotar medidas, conforme os recursos disponíveis, para atingir,

\footnotetext{
${ }^{16}$ Sobre este aspecto são tecidas críticas, sobretudo, pela visão multiculturalista dos direitos. A esse respeito, vide Boaventura de Sousa Santos (2003).

${ }^{17}$ Bobbio (1992, p. 18-19) afirma: "direitos que foram declarados absolutos no final do século XVIII, como a propriedade 'sacré et inviolable', foram submetidos a radicais limitações nas declarações contemporâneas; direitos que as declarações do século XVIII nem sequer mencionavam, como os direitos sociais, são agora proclamados com grande ostentação nas recentes declarações. Não é difícil prever que, no futuro poderão emergir novas pretensões que no momento nem sequer podemos imaginar... o que prova que não existem direitos fundamentais por natureza".
} 
"progressivamente", a plena efetividade dos direitos protegidos. O termo "progressivamente" implica uma ideia de gradualidade e impõe ao Estado o dever de garantir um progresso na efetivação desses direitos, vedando, consequentemente, o regresso (RAMOS, 2005, p. 244).

A eficácia horizontal é a aplicação dos direitos fundamentais nas relações entre particulares (RAMOS, 2005, p. 247). A eficácia horizontal dos direitos fundamentais é um tema que começou a ser discutido em tempos recentes, sobretudo pelo grande poder exercido pelas empresas no capitalismo mundial. Quando os direitos humanos foram inicialmente concebidos representavam basicamente direitos de defesa dos indivíduos frente aos Poderes Públicos. Com o passar dos tempos, verificou-se que a opressão entre os indivíduos não decorria apenas de suas relações com o Estado, mas também de relações com outros indivíduos e entidades privadas. Como na relação com o Estado, o indivíduo encontra-se numa situação de subordinação (vertical), tem-se aqui a eficácia vertical dos direitos fundamentais. Nas relações entre os indivíduos e outros indivíduos ou entidades privadas, a relação é tida como horizontal, e por conta disso, denominou-se de eficácia horizontal dos direitos fundamentais a aplicação dos direitos fundamentais na relação entre os particulares $^{18}$.

Essas características dos direitos humanos serão consideradas na análise do direito à educação, desenvolvida no item 1.1.4 abaixo.

\footnotetext{
18 Segundo Canotilho (2000, p. 400), existem duas teorias sobre a eficácia horizontal dos direitos fundamentais: (i) teoria da eficácia direta ou imediata, segundo a qual "os direitos, liberdades e garantias e direitos de natureza análoga aplicam-se obrigatória e directamente no comércio jurídico entre entidades privadas (individuais ou coletivas)". De acordo com essa teoria, referidos direitos teriam eficácia absoluta, podendo os indivíduos, sem qualquer mediação, exigir a concretização desses direitos; (ii) teoria da eficácia indireta ou mediata, segundo a qual "os direitos, liberdades e garantias teriam uma eficácia indirecta nas relações privadas, pois a sua vinculatividade exercer-se-ia prima facie sobre o legislador, que seria obrigado a conformar as referidas relações obedecendo aos princípios materiais positivados nas normas de direito, liberdades e garantias". Para esta teoria, os direitos fundamentais irradiam seus efeitos nas relações entre particulares por intermédio de atividade legislativa. O Direito Privado, através da lei, sobretudo por meio de cláusulas gerais introduziria os direitos fundamentais nas relações entre particulares (trata-se do chamado efeito irradiador). Observando alguns precedentes do Supremo Tribunal Federal nota-se uma tendência do judiciário brasileiro em admitir a aplicação da teoria da eficácia direta dos direitos fundamentais às relações privadas no Brasil. No RE 160.222-8, o STF entendeu como "constrangimento ilegal" a revista íntima em mulheres em fábrica de lingerie. No RE 158.215-4, o STF entendeu como violado o princípio do devido processo legal e ampla defesa na hipótese de exclusão de sócio de cooperativa sem direito à defesa. No RE 161.243-6, o STF entendeu que houve, na empresa "Air France", discriminação no tratamento a empregado brasileiro em relação ao francês, os quais desempenhavam atividades idênticas, violando o princípio da isonomia.
} 


\subsubsection{As dimensões dos direitos humanos e suas críticas}

Considerando que os direitos humanos são historicamente variáveis e heterogêneos, a doutrina costuma dividi-los em gerações ou dimensões de direitos. O jurista Karel Vasak é considerado o pioneiro na formulação da expressão "gerações de direitos do homem", com a divisão desses direitos em três gerações relacionadas aos lemas da Revolução Francesa - liberdade (primeira geração), igualdade (segunda geração) e fraternidade (terceira geração). Paulo Bonavides (2006) fala também em uma quarta geração de direitos que corresponderia a valores da sociedade aberta do futuro, que protegem a democracia, a informação e o pluralismo.

Bonavides (2006, p. 571-2) e Ingo Sarlet (2008, p. 52) preferem utilizar o termo “dimensões" de direitos em vez de "gerações" para se referir à divisão acima, porque, segundo tais autores, o termo "gerações" levaria ao entendimento de que os direitos humanos se sucederam no tempo, com a caducidade das gerações passadas quando do início das gerações seguintes, o que não ocorreu. Dividir os direitos em "dimensões" e não em "gerações" destacaria o fato de que os direitos humanos são interdependentes e indivisíveis, e que direitos de uma determinada dimensão permanecem válidos enquanto outra é concebida, num processo de acumulação e não de sucessão ou de substituição.

Os direitos de primeira dimensão, que consagram o valor liberdade, são direitos que nasceram influenciados pelos ideais iluministas e jusnaturalistas dos séculos XVII e XVIII (entre eles, Hobbes ${ }^{19}$, Locke $^{20}$ e Rousseau ${ }^{21}$ ), como resultado, de um lado, das lutas que cidadãos europeus travaram para a limitação do poder absoluto dos monarcas, fim dos privilégios hereditários dos estamentos superiores da sociedade e concessão de direitos políticos aos detentores do poder econômico (burguesia); e, de outro, das lutas de cidadãos americanos pela independência das colônias britânicas na América do Norte. Os direitos de primeira dimensão constaram das primeiras declarações de direitos ${ }^{22}$ e das primeiras Constituições $^{23}$ escritas do mundo ocidental, na forma de direitos civis e políticos, que valorizam o homem individual e que apresentam um status negativo de limitação da

\footnotetext{
${ }^{19}$ Hobbes consagrou o direito à vida como o primeiro e essencial direito do homem em sua obra O Leviatã.

${ }^{20}$ Locke influenciou esses movimentos com sua ideia de direitos naturais do homem (liberdade, segurança e propriedade) e direitos de resistência, constante na obra Dois Tratados sobre o Governo Civil.

${ }_{21}$ Rousseau trouxe, sobretudo, a ideia do povo como o soberano e detentor do Poder Legislativo, principalmente na obra $O$ Contrato Social.

${ }^{22}$ Entre elas, Declaração de Direitos do Bom Povo da Virgínia de 1776, Declaração de Independência dos EUA de 1776, Declaração de Direitos do Homem e do Cidadão de 1789.

${ }^{23}$ Entre elas, Constituição Americana de 1787 e Constituições Francesas de 1791 e 1793.
} 
atuação do Estado na esfera privada dos indivíduos, indicando a autonomia do indivíduo contra o Estado. Nesse sentido, são classificados como "direitos de cunho negativo" (uma vez que dirigidos a uma abstenção do Estado) e de "resistência ou de oposição perante o Estado" (SARLET, 2008, p. 54). São considerados direitos de primeira dimensão o direito à vida, o direito à propriedade, o direito à liberdade de locomoção, o direito à liberdade de expressão, o direito de participar do processo eleitoral (direito de votar e ser votado), o direito à igualdade perante a lei (igualdade formal) e algumas garantias processuais (devido processo legal, habeas corpus, direito de petição), entre outros.

Os direitos de segunda geração, que consagram o valor igualdade, passaram a ser reivindicados, principalmente nos séculos XIX e XX, e em especial pelas classes trabalhadoras, que lutaram por melhores condições de trabalho e de vida, num momento em que o liberalismo econômico gerou concentração de rendas e a pauperização das camadas populares. Nesse período histórico, pós-Revolução Industrial, a classe trabalhadora encontrava-se na miséria, com condições de trabalho precárias e sem participação política ${ }^{24}$. A consagração formal da igualdade e da liberdade nas Constituições mostrava-se insuficiente para garantir mínimas condições de vida para essa população. Nesse sentido, novos direitos fundamentais - estes de caráter econômico, social e cultural - foram reconhecidos, sobretudo, na Constituição Mexicana de 1917, na Declaração Russa dos Direitos do Povo Trabalhador e Explorado de 1918 e na Constituição de Weimar de 1919. Os direitos de segunda dimensão implicam uma atuação positiva do Estado para sua efetivação em busca de igualdade material entre os indivíduos, numa transição das liberdades formais e abstratas para as liberdades materiais concretas. Sarlet (2008, p. 55) afirma: "não se cuida mais, portanto, de liberdade do e perante o Estado, e sim de liberdade por intermédio do Estado". Para Bonavides (2006, p. 564), estes direitos nasceram “abraçados ao princípio da igualdade”, entendida num sentido material.

Salienta-se, conforme Sarlet (2008, p. 55), que, a exemplo dos direitos da primeira dimensão, os direitos de segunda dimensão "se reportam à pessoa individual, não podendo ser confundidos com os direitos coletivos e/ou difusos de terceira dimensão".

São considerados direitos de segunda dimensão, dentre outros, o direito à educação, $\mathrm{o}$ direito à cultura, o direito à saúde, o direito ao trabalho, o direito à assistência social, $\mathrm{o}$

\footnotetext{
${ }^{24}$ Para Barros (2003, p. 465): “A história não demorou a mostrar que não se realizaria a liberdade individual projetada na primeira geração dos direitos humanos, se não se realizasse a igualdade social projetada na segunda geração. É por isso que aquela abriu as portas para esta. A geração dos direitos individuais não só permitiu formalmente, como forçou realmente que fossem gerados os direitos sociais que os complementariam no sentido da eficácia social do Direito".
} 
direito ao lazer, o direito à seguridade social, o direito à moradia e direitos dos trabalhadores - como o direito ao salário-mínimo e ao repouso semanal remunerado.

Os direitos de terceira dimensão, que consagram o valor fraternidade (ou solidariedade), são direitos que visam à proteção do gênero humano. Referidos direitos foram concebidos no pós-Segunda Guerra Mundial mediante a percepção de que a comunidade humana como um todo enfrentava sérias ameaças à sua existência e de que existiam bens e objetivos comuns a serem perseguidos pelos povos, como a proteção da paz, do meio ambiente, da comunicação e do patrimônio comum da humanidade. Sarlet (2008, p. 56) destaca que esses direitos diferem dos demais pelo fato de "se desprenderem, em princípio, da figura do homem-indivíduo como seu titular, destinando-se à proteção de grupos humanos (família, povo, nação), e caracterizando-se, consequentemente, como direitos de titularidade coletiva ou difusa".

São considerados direitos de terceira dimensão, dentre outros, o direito ao desenvolvimento, o direito à paz, o direito ao meio ambiente, o direito à comunicação e o direito à autodeterminação dos povos. Com relação à positivação desses direitos, nota-se que, ressalvadas algumas exceções, a maior parte dos direitos de terceira dimensão ainda não foi positivada no direito constitucional, estando, por outro lado, em fase de consagração no direito internacional, mediante diversos tratados e convenções (SARLET, 2008, p. 57 $)^{25}$.

Os direitos de quarta dimensão, segundo Bonavides (2006, p. 571), são resultado do processo de globalização dos direitos fundamentais, no sentido de uma universalização no plano institucional, que corresponde, na sua opinião, à derradeira fase de institucionalização do Estado Social. Para Bonavides (2006), são direitos que ainda aguardam sua consagração nas esferas dos direitos interno e internacional. Sarlet (2008, p. 58) questiona a possibilidade de se sustentar uma nova dimensão de direito frente às incertezas que o futuro nos reserva.

São direitos de quarta dimensão, para Bonavides (2006, p. 571), o direito à democracia (na forma da democracia direta), o direito à informação e o direito ao pluralismo.

Não obstante ser muito utilizada, a divisão dos direitos humanos em dimensões é objeto de críticas.

\footnotetext{
${ }^{25}$ Para Sarlet (2008, p. 58), por apresentarem uma estrutura jurídica de direito de cunho excludente e negativo, de caráter preponderantemente defensivo, estes direitos poderiam enquadrar-se na primeira dimensão, demonstrando a atualidade dos direitos de liberdade, "ainda que com nova roupagem e adaptados às exigências do homem contemporâneo".
} 
Critica-se a tríade liberdade, igualdade, fraternidade considerando-a uma invenção, sem fundamento histórico, uma vez que a evolução dos direitos humanos nos diversos países e no plano internacional não observou necessariamente essa linha de evolução. No Brasil, por exemplo, direitos de segunda dimensão foram garantidos antes da efetivação de direitos de primeira dimensão durante o Estado Novo - período em que foram reconhecidos inúmeros direitos sociais, em especial, trabalhistas e previdenciários, enquanto o país vivia uma ditadura sem direitos de liberdade (de imprensa, de reunião, de associação etc.) e sem direitos políticos ${ }^{26}$. No plano internacional, verifica-se que direitos de segunda dimensão foram consagrados antes que direitos de primeira dimensão, uma vez que a Convenção da OIT, que assegura direitos dos trabalhadores (segunda dimensão), foi assinada em 1919, enquanto o Pacto Internacional dos Direitos Civis e Políticos (primeira dimensão), apenas em 1966.

Critica-se a divisão de direitos em si dizendo que esta técnica pode justificar a adoção de políticas públicas que não reconheçam a indivisibilidade e interdependência dos direitos humanos, levando-se ao privilégio dos direitos de primeira dimensão em detrimento de direitos de outras dimensões. Sobre a indivisibilidade dos direitos humanos, Flávia Piovesan (2003, p. 108) destaca que a violacão dos direitos econômicos, sociais e culturais propicia a violacão de direitos civis e políticos: "eis que a vulnerabilidade econômico-social leva à vulnerabilidade dos direitos civis e políticos".

Piovesan (2003, p. 99) critica também o discurso daqueles que defendem que enquanto os direitos civis e políticos devem ser assegurados pelo Estado, sem escusa ou demora, sendo, portanto, autoaplicáveis, os direitos sociais, econômicos e culturais implicam uma realização progressiva. Para a autora, ambas categorias de direitos demandam prestações positivas e negativas e custos:

\begin{abstract}
A título de exemplo, cabe indagar qual o custo do aparato de segurança, mediante o qual se assegura direitos civis clássicos, como os direitos à liberdade e à propriedade, ou ainda qual o custo do aparato eleitoral, que viabiliza os direitos políticos, ou, do aparato da justiça, que garante o direito ao acesso ao Judiciário. Isto é, os direitos civis e políticos não se restringem a demandar a mera omissão estatal, já que a sua implementação requer políticas públicas direcionadas, que contemplam também um custo. (PIOVESAN, 2003, p. 99)
\end{abstract}

Ademais, é importante salientar que direitos humanos classificados como de uma determinada dimensão podem apresentar características de direitos de outras dimensões, o

\footnotetext{
${ }^{26}$ José Murilo de Carvalho (2009) desenvolve esta temática, comparando o desenvolvimento dos direitos fundamentais no Brasil com o modelo proposto por T. H. Marshall (1967) para o caso inglês.
} 
que realça a indivisibilidade e interdependência desses direitos.

Nesse sentido, não obstante o direito à educação seja tradicionalmente concebido como um direito de segunda dimensão, é importante notar que ele apresenta características de direitos de primeira e terceira dimensões. Além disso, é um direito essencial para a efetivação de direitos de outras dimensões, como veremos no item 1.1.4 abaixo.

Conclui-se assim que a divisão dos direitos humanos em dimensões deve ser utilizada apenas como uma técnica para a compreensão desses direitos, com a relativização dessa doutrina tendo em vista a indivisibilidade e interdependência dos direitos humanos.

\subsubsection{O direito à educação na doutrina dos direitos humanos}

Como direito humano, o direito à educação está intimamente ligado à dignidade humana e aos valores liberdade, igualdade e fraternidade. É direito em sentido forte, pois está previsto na Constituição de 1988 e em diversos tratados internacionais ratificados pelo Estado Brasileiro ${ }^{27}$.

Nas dimensões de direitos, o direito à educação é tradicionalmente considerado um direito de segunda dimensão, na forma de um direito social. Essa foi a classificação adotada no âmbito internacional mediante a previsão do direito à educação no Pacto Internacional dos Direitos Econômicos, Sociais e Culturais de 1966 (Pidesc) e também no âmbito interno, pela Constituição de 1988, que incluiu o direito à educação entre os direitos sociais previstos no seu artigo $6^{\circ}$.

No entanto, o direito à educação é um exemplo da interdependência e indivisibilidade dos direitos humanos, pois apresenta características de direitos de primeira dimensão, dada sua conexão com a liberdade e com os direitos civis e políticos; e também características de direitos de terceira dimensão, dada a sua ligação com a fraternidade e com o direito ao desenvolvimento. Tal fato foi reconhecido pela Organização das Nações

${ }^{27} \mathrm{O}$ direito à educação foi positivado em todas as Constituições Brasileiras e encontra-se previsto nos seguintes tratados internacionais ratificados pelo Estado Brasileiro e atualmente em vigor: (i) Convenção Relativa à Luta Contra a Discriminação no Campo do Ensino, adotada em 14 de dezembro de 1960, pela Conferência Geral da UNESCO e ratificada pelo Estado Brasileiro em 19 de abril de 1968; (ii) Convenção Internacional para a Eliminação de todas as Formas de Discriminação Racial, adotada pela Assembleia Geral da ONU em 21 de dezembro de 1965 e ratificada pelo Estado Brasileiro em 27 de março de 1968; (iii) Pidesc adotado pela Assembleia Geral da ONU em 16 de dezembro de 1966 e ratificado pelo Estado Brasileiro em 24 de janeiro de 1992; (iv) Convenção sobre a Eliminação de todas as Formas de Discriminação contra a Mulher, adotada pela Assembleia Geral da ONU em 18 de dezembro de 1979 e ratificada pelo Estado Brasileiro em $1^{\circ}$ de Fevereiro de 1984; (v) Convenção sobre os Direitos da Criança, adotada pela Assembleia Geral da ONU em 20 de novembro de 1989 e ratificada pelo Estado Brasileiro em 24 de setembro de 1990; e (vi) Convenção sobre os Direitos dos Deficientes, adotada pela Assembleia Geral da ONU em 13 de dezembro de 2006 e ratificada pelo Estado Brasileiro em 1 de agosto de 2008. 
Unidas (ONU) no Comentário Geral 11 de 1999, sobre o artigo 14 do Pidesc:

2. O direito à educação, reconhecido nos artigos 13 e 14 do Pacto, assim como em uma variedade de outros tratados internacionais, tais como a Convenção dos Direitos da Criança e a Convenção para a Eliminação de Todas as Formas de Discriminação contra a Mulher, é de vital importância. Tem sido classificado como direito econômico, direito social e direito cultural. É tudo isso. É também, de várias maneiras, direito civil e direito político, dado que é central para a completa e efetiva realização daqueles direitos também. Nesse sentido, o direito à educação simboliza a indivisibilidade e interdependência de todos os direitos humanos $^{28}$.

Em resumo, o direito à educação envolve: (i) o direito a uma política educacional pelo Estado que promova a igualdade entre os indivíduos (direito de segunda dimensão); (ii) o direito a um processo individual de conhecimento, visando ao pleno desenvolvimento da pessoa (que inclui sua emancipação ${ }^{29}$, pelo conhecimento de seus direitos e deveres em sociedade), seu preparo para o exercício da cidadania ${ }^{30}$ (o que contribui para a democracia) e sua qualificação para o trabalho, promovendo a liberdade e direitos civis e políticos (direitos de primeira dimensão); e (iii) a formação da qualificação necessária dos indivíduos para que estes contribuam para o desenvolvimento econômico e social ${ }^{31}$ e para

${ }^{28}$ Tradução livre de: "2. The right to education, recognized in articles 13 and 14 of the Covenant, as well as in a variety of other international treaties, such as the Convention on the Rights of the Child and the Convention on the Elimination of All Forms of Discrimination against Women, is of vital importance. It has been variously classified as an economic right, a social right and a cultural right. It is all of these. It is also, in many ways, a civil right and a political right, since it is central to the full and effective realization of those rights as well. In this respect, the right to education epitomizes the indivisibility and interdependence of all human rights". Disponível em: $<$ http://www.unhchr.ch/tbs/doc.nsf/0/59c6f685a5a919b8802567a50049d460?Opendocument>. Acesso em: $15 / 05 / 2012$.

${ }^{29}$ A esse respeito, Canotilho (2000, p. 343) nos ensina que: "Igualdade de oportunidades, participação, individualização e emancipação, são componentes do direito à educação e à cultura, e dimensões concretas implícitas no princípio da democracia cultural. Por último, as instituições democráticas do ensino e da cultura transformam-se, no quadro constitucional, em mecanismo de direção, conformadores de novas estruturas sociais: progresso social e participação democrática (art. 73. ${ }^{\circ} / 2$ ), ligação do ensino com as actividades económicas, sociais e culturais (art. 74. '/3-f)".

${ }^{30}$ Para Marshall (1967, p. 73), a "educação das crianças está diretamente relacionada com a cidadania, e, quando o Estado garante que todas as crianças serão educadas, este tem em mente, sem sombra de dúvida, as exigências e a natureza da cidadania. Está tentando estimular o desenvolvimento de cidadãos em formação. $\mathrm{O}$ direito à educação é um direito social de cidadania genuíno porque o objetivo da educação durante a infância é moldar o adulto em perspectiva. Basicamente, deveria ser considerado não como o direito da criança frequentar a escola, mas como o direito do cidadão adulto ser educado".

${ }^{31}$ Joseph Stiglitz (2007, p. 100) destaca a importância que a educação teve no desenvolvimento dos países do Leste Asiático, ressaltando que o que separa os países entre os mais e menos desenvolvidos hoje não é apenas uma distância de recursos mas também um abismo de conhecimento, "motivo pelo qual os investimentos em educação e tecnologia - em larga medida, do governo - são tão importantes" (STIGLITZ, 2007, p. 95). Stiglitz (2007, p. 100) também destaca que os governos destes países expandiram a educação primária e a superior ao mesmo tempo, reconhecendo que o sucesso exigia tanto a alfabetização universal quanto quadros altamente habilitados, capazes de absorver a tecnologia avançada. No Leste Asiático, os governos desempenharam um grande papel também no planejamento e progresso da tecnologia, escolhendo quais setores seus países iriam desenvolver, em vez de deixar essa decisão apenas para o mercado. O investimento no setor de alta tecnologia ajudou Taiwan, Coreia e Malásia a se tornarem produtores importantes de bens 
a promoção dos direitos humanos e da paz (direitos de terceira dimensão) ${ }^{32}$.

Nina Ranieri (2009, p. 288) destaca que, no plano individual, o direito à educação prende-se à realização pessoal e, nesse sentido, é corolário da dignidade humana e dos princípios da liberdade (primeira dimensão) e da igualdade (segunda dimensão). No plano coletivo, o direito à educação conecta-se com a vida em sociedade, com a participação política, com o desenvolvimento nacional, com a promoção dos direitos humanos e da paz (terceira dimensão). Mediante essas considerações, a referida autora (2009, p. 287) entende que o direito à educação é um direito individual e coletivo ao mesmo tempo. Segundo Ranieri (2009, p. 288):

$\mathrm{O}$ direito à educação permite a adultos e crianças marginalizados a integração na comunidade, a promoção da emancipação feminina e a proteção das crianças contra a exploração sexual ou a de seu trabalho. Possibilita, ademais, a difusão da democracia, dos direitos humanos e da proteção do meio ambiente, valores cruciais no mundo contemporâneo. Desse ponto de vista, convém lembrar que a efetividade do direito à educação e suas repercussões beneficiam reciprocamente o indivíduo e a coletividade. Interesse particular e interesse público, assim, se fundem, da mesma forma que os interesses locais, regionais e nacionais.

$\mathrm{O}$ direito à educação pode ser considerado um direito multidimensional e instrumental, por apresentar características de direitos de todas as três dimensões e por contribuir para a efetivação de diferentes direitos humanos.

Com relação à indivisibilidade, destaca-se que o direito à educação deve ser concebido como um direito à educação ao longo da vida ${ }^{33}$. Assim sendo, este direito não pode ser fracionado, nem deve ser restringido à educação básica e obrigatória. O direito à educação inclui necessariamente o direito à educação superior, como prevê a Constituição de 1988 (art. 208, V). O que diferencia o direito ao ensino superior da educação básica é que o ensino superior não é obrigatório e que o acesso a este nível de ensino está sujeito à comprovação da capacidade individual do postulante, em conformidade com o princípio da meritocracia. Uma vez preenchida essa exigência, o acesso a esse nível de ensino deve ser garantido pelo Estado.

$\mathrm{O}$ direito à educação, além das características de interdependência e

eletrônicos, como computadores e chips. No entanto, conforme Bittar (2009, p. 377), deve ser desmistificada a ideia tradicional de que a educação necessariamente implica progresso, desenvolvimento e melhoria pois educar pode significar também uma preparação direcionada para o desenvolvimento de determinadas qualidades, habilidades e competências, que podem atrofiar dados importantes da personalidade humana. Nesse sentido, é necessária uma crítica constante da educação oferecida aos indivíduos.

${ }^{32}$ As características do direito à educação descritas neste parágrado encontram respaldo no artigo 205 da CF/88, no artigo XXVI da DUDH e no artigo V da Convenção contra a Discriminação no Ensino de 1960.

${ }^{33}$ Sobre o conceito de educação ao longo da vida vide Delors (2010). 
indivisibilidade, apresenta também supremacia normativa, universalidade, indisponibilidade, historicidade, vedação ao retrocesso social e eficácia horizontal.

Com relação à supremacia normativa, o direito à educação recebe da ordem jurídica interna brasileira o mais elevado grau de segurança e garantia. Sua previsão como direito social no artigo $6^{\circ}$ da Constituição é cláusula pétrea, e os demais dispositivos constitucionais que tratam do direito à educação são de mudança dificultada, pois alteráveis apenas mediante emendas à Constituição.

O direito à educação pode ser considerado um direito universal em seus três planos - com relação aos seus titulares é universal, pois foi consagrado em documentos internacionais e na Constituição de 1988 como um direito de todos ${ }^{34}$ (art. 205, CF/88); no plano temporal é universal, porque foi reconhecido em todas as Constituições Brasileiras; e no plano cultural é também universal, pois o direito à educação foi consagrado por diferentes culturas ao redor do mundo ${ }^{35}$.

A indisponibilidade do direito à educação é observável na educação básica brasileira, cujo acesso e permanência é direito público subjetivo, além de ser gratuita e obrigatória. O Poder Público pode ser acionado para garantir o direito de acesso à educação básica ${ }^{36}$, e a omissão ou negligência no atendimento desse direito importa responsabilização da autoridade competente. Além disso, a família tem a obrigação de efetuar a matrícula dos menores, a partir de 6 anos de idade, sob pena de responsabilidade civil e penal ${ }^{37}$.

A respeito da vedação ao retrocesso social, a Constituição Brasileira de 1988 utiliza a expressão "progressiva" para referência à universalização do nível médio da educação (art. 208, II, CF/88), seguindo a linha de gradualidade e progresso na efetivação deste direito. No caso brasileiro, primeiro buscou-se a universalização do ensino fundamental. Agora que ela está prestes a ser obtida, busca-se a universalização do ensino médio e da

\footnotetext{
${ }^{34}$ Observada a restrição e dificuldade do exercício do direito à educação em alguns países, sobretudo para indivíduos estrangeiros (legais ou em situação ilegal).

${ }^{35}$ Observada a possibilidade de alguma cultura não ter consagrado o direito à educação.

${ }^{36}$ Observado o prazo para a efetivação das mudanças previstas na EC no 59/2009.

${ }^{37}$ Ranieri (2009, p. 349) destaca também os deveres da família com relação a este direito subjetivo. A família tem a obrigação de efetuar a matrícula dos menores, a partir de 6 anos de idade, nos termos dos artigos 208, Parágrafo $3^{\circ}$ e 227 da CF/88, artigo $6^{\circ}$ da LDB e artigos 4, 22 e 98 do ECA. Está prevista também a possibilidade de ação civil pública contra os próprios pais ou responsáveis, nos termos do artigo 129, III, CF/88 e artigos 129, 155 e 156 da Lei $\mathrm{n}^{\circ} 7.347 / 85$, na hipótese de descumprimento da norma constitucional e de ações privadas por conta do descumprimento de obrigações decorrentes do poder parental, conforme artigo 1.634 do Código Civil ou em virtude de questões econômicas, como no caso da proibição do estabelecimento particular de ensino desligar o aluno em caso de inadimplemento de mensalidades escolares. Além disso, nos termos do artigo 246 do Código Penal, é crime "deixar, sem justa causa, de prover à instrução primária de filho em idade escolar", cuja pena é de detenção, de quinze dias a um mês, ou multa.
} 
educação infantil. Por consequência, em decorrência do aumento dos concluintes do ensino médio, ocorre um aumento da demanda pelo ensino superior, o que faz com que o Poder Público tenha que tomar medidas para aumentar o acesso a esse nível de ensino.

O direito à educação como direito humano vincula também as instituições privadas de ensino de acordo com a teoria da eficácia horizontal dos direitos humanos. Nesse sentido, todos os preceitos constitucionais e princípios aplicáveis à educação e ensino devem ser observados pelas instituições privadas de ensino como parte do conteúdo normativo do direito à educação.

\subsection{A educação superior e suas características}

A educação superior, conforme o artigo $1^{\circ}$ da Declaração Mundial sobre Educação Superior no Século XXI: Visão e Ação (UNESCO, 1998), tem a missão de (i) contribuir para o desenvolvimento sustentável e melhoria do conjunto da sociedade, mediante a formação de diplomados qualificados; (ii) construir um espaço aberto para a formação superior que propicie o aprendizado permanente, dentro de uma concepção de educação ao longo da vida, com o fim de formar cidadãos que participem ativamente da sociedade; (iii) promover e difundir conhecimentos por meio da pesquisa, como parte dos serviços a serem prestados à comunidade; (iv) compreender e difundir as culturas nacionais e regionais, internacionais e históricas, num contexto de pluralismo e diversidade cultural; (v) contribuir para proteger e consolidar os valores da sociedade e contribuir para o desenvolvimento e melhora da educação em todos os níveis, em particular, mediante a capacitação do pessoal docente.

Na mesma linha, o artigo 43 da LDB estabelece que a educação superior tem por finalidade:

I - estimular a criação cultural e o desenvolvimento do espírito científico e do pensamento reflexivo;

II - formar diplomados nas diferentes áreas de conhecimento, aptos para a inserção em setores profissionais e para a participação no desenvolvimento da sociedade brasileira, e colaborar na sua formação contínua;

III - incentivar o trabalho de pesquisa e investigação científica, visando o desenvolvimento da ciência e da tecnologia e da criação e difusão da cultura, e, desse modo, desenvolver o entendimento do homem e do meio em que vive;

IV - promover a divulgação de conhecimentos culturais, científicos e técnicos que constituem patrimônio da humanidade e comunicar o saber através do ensino, de publicações ou de outras formas de comunicação;

$\mathrm{V}$ - suscitar o desejo permanente de aperfeiçoamento cultural e profissional e possibilitar a correspondente concretização, integrando os conhecimentos que vão sendo adquiridos numa estrutura intelectual sistematizadora do conhecimento de cada geração; 
VI - estimular o conhecimento dos problemas do mundo presente, em particular os nacionais e regionais, prestar serviços especializados à comunidade e estabelecer com esta uma relação de reciprocidade;

VII - promover a extensão, aberta à participação da população, visando à difusão das conquistas e benefícios resultantes da criação cultural e da pesquisa científica e tecnológica geradas na instituição.

As primeiras universidades foram criadas no século XIII. Segundo Drèze e Debelle (1983 ${ }^{38}$ apud RANIERI, 2000), duas concepções nortearam a criação das universidades: a idealista e a funcional.

Segundo a concepção idealista, a universidade fundamenta-se no postulado da busca da verdade, em toda parte e sem constrangimentos, como direito da humanidade. A partir desta concepção, é missão da universidade ser locus da busca da verdade. Segundo Boaventura de Sousa Santos (2000, p. 188), de acordo com o idealismo alemão, a missão eterna da universidade é ser o "lugar onde por concessão do Estado e da sociedade uma determinada época pode cultivar a mais lúcida consciência de si própria. Os seus membros congregam-se nela com o único objectivo de procurar, incondicionalmente, a verdade e apenas por amor à verdade". De acordo com essa doutrina (SANTOS, 2000, p. 188), por ordem descrescente de importância, os três grandes objetivos da universidade são: (i) a investigação "porque a verdade só é acessível a quem a procura sistematicamente"; (ii) ser um centro de cultura para a educação do homem no seu todo "porque o âmbito da verdade é muito maior que o da ciência"; (iii) o ensino, orientado para a formação integral "porque a verdade deve ser transmitida".

Segundo a concepção funcional, a universidade deve atender às necessidades sociais e culturais da sociedade. Instituições de caráter funcional voltaram-se à pesquisa científica, como unidades de pesquisa e ensino. Este é o modelo da Universidade de Berlim, criada por Wilhelm Von Humbolt, em 1810 (RANIERI, 2000, p. 40). De acordo com Santos (2000, p. 193), o modelo da universidade de Humbolt é um fenômeno do século XIX e representa a universidade como "lugar privilegiado da produção de alta cultura e conhecimento científico". São características desse modelo a "exigência posta no trabalho universitário, a excelência dos seus produtos culturais e científicos, a criatividade da actividade intelectual, a liberdade de discussão, o espírito crítico, a autonomia e o universalismo dos objectivos". Segundo o autor (2000, p. 193), essa universidade era uma “instituição única, relativamente isolada das restantes instituições sociais, dotada de grande

${ }^{38}$ DRÈZE, Jacques; DEBELLE, Jean. Concepções da universidade. Fortaleza: Ed. Universidade Federal do Ceará, 1983. 
prestígio social e considerada imprescindível para a formação das elites". Segundo Santos (2000, p. 193), esse modelo de universidade entra em declínio no pós-guerra.

Segundo Ranieri (2000, p. 40), algumas instituições de ensino superior assumiram a condição de agentes do progresso, aproximando-se da sociedade, como as instituições desenvolvidas nos Estados Unidos da América, dentro do programa Land Grant Colleges and Universities de 1962. Outras instituições assumiram o caráter de universidades nacionalizadas, integradas ao serviço público e subordinadas ao poder público, em benefício da estabilidade política do Estado, num modelo conhecido como universidade napoleônica (RANIERI, 2000, p. 41). Segundo Drèze e Debelle (1983, p. $96^{39}$ apud RANIERI, 2000), o modelo napoleônico possuía as seguintes características: (i) uniformidade do desenvolvimento material; (ii) fragmentação do conjunto em escolas estanques, que não se congregam no ideal do progresso científico; (iii) imobilismo; e (iv) orientação primordialmente credencialista, que alimenta sonhos de ascensão social. Este modelo foi adotado por países de tradição administrativa francesa, dentre eles, pelo Brasil.

Segundo Santos (2000, p. 193-194), a partir da década de 1960, a universidade sofreu pressões e transformações, decorrentes sobretudo de novas "exigências sociais", da explosão da população universitária, da alteração significativa da composição de classe dessa população estudantil e da ampliação dos quadros de docentes. Com isso houve massificação da universidade e diferenciação das instituições entre as de elite e as de $\operatorname{massa}^{40}$. Segundo Santos (2000, p. 194):

Tal como teve lugar, a democratização da universidade traduziu-se na diferenciaçãohierarquização entre universidades e entre estas e outras instituições de ensino superior. A produção de alta cultura permaneceu em grande medida controlada pelas universidades mais prestigiadas, enquanto as universidades de massa se limitaram à distribuição da altacultura ou, quando a produziam, baixaram o nível de exigência e degradaram a qualidade.

Considerando as novas classes sociais que ingressaram no ensino superior, Santos (2000, p. 212) aponta para uma crise de hegemonia e legitimidade no interior das universidades. Segundo ele (2000, p. 212):

\footnotetext{
${ }^{39}$ DRÈZE, Jacques; DEBELLE, Jean. Concepções da universidade. Fortaleza: Ed. Universidade Federal do Ceará, 1983.

${ }^{40}$ Segundo Santos (2000, p. 198), "por um lado, é hoje evidente que a universidade não consegue manter sob o seu controle a educação profissional. A seu lado, multiplicam-se instituições de menores dimensões, maior flexibilidade e maior proximidade ao espaço da produção com oferta maleável de formação profissional cada vez mais volátil. Aliás, o próprio espaço da produção transforma-se por vezes numa "comunidade educativa" onde as necessidades de formação, sempre em mutação, são satisfeitas no interior do processo produtivo".
} 
Quando a procura de educação deixa de ser uma reivindicação utópica e passa a ser uma aspiração socialmente legitimada, a universidade só pode legitimar-se, satisfazendo-a. Por isso, a sua função tradicional de produzir conhecimentos e de os transmitir a um grupo social restrito e homogêneo, quer em termos das suas origens sociais, quer em termos dos seus destinos profissionais e de modo a impedir a sua queda de status, passa a ser duplicada por estoutra de produzir conhecimentos a camadas sociais muito amplas e heterogêneas e com vista a promover a sua ascensão social. Daí, a implicação mútua da crise de hegemonia e da crise da legitimidade: o tipo de conhecimentos produzidos (questão hegemonia) tende a alterar-se com a alteração do grupo social a que se destina (questão de legitimidade). Por isso, as respostas da universidade à crise de hegemonia analisada acima - incorporação limitada da cultura de massas, da formação profissional, da investigação aplicada e da extensão à comunidade - só são plenamente compreensíveis se tivermos em mente que com elas a universidade pretende incorporar, de modo igualmente limitado, grupos sociais até então excluídos (filhos da classe operária, da pequena burguesia, e de imigrantes, mulheres, minorias étnicas). [...]

Posta perante tais questões, a universidade mais uma vez se prestou a soluções de compromisso que lhe permitiram continuar a reclamar a sua legitimidade sem abrir mão, no essencial do seu elitismo [...] Isto foi possível sobrepondo à diferenciação e estratificação da universidade segundo o tipo de conhecimentos produzidos, analisadas acima, a diferenciação e estratificação segundo a origem social do corpo estudantil. Os múltiplos dualismos referidos, entre ensino superior universitário e não universitário, entre universidades de elite e universidades de massas, entre cursos de grande prestígio e cursos desvalorizados, entre estudos sérios e cultura geral, definiram-se, entre outras coisas, segundo a composição social da população escolar.

Com o desenvolvimento da sociedade capitalista, Santos (2000, p. 196) entende que a educação, que fora inicialmente transmissão de alta cultura, formação do caráter, modo de socialização adequado ao desempenho da direção da sociedade, passou a ser também “educação para o trabalho, ensino de conhecimentos utilitários, de aptidões técnicas especializadas capazes de responder aos desafios do desenvolvimento tecnológico no espaço da produção". O autor (2000, p. 196) destaca também que "o trabalho, que fora inicialmente desempenho de força física no manuseio dos meios de produção, passou a ser também trabalho intelectual, qualificado, produto de uma formação profissional mais ou menos prolongada. A educação cindiu-se entre a cultura geral e a formação profissional e o trabalho, entre o trabalho não qualificado e o trabalho qualificado".

Nesse sentido, a universidade passou a ser entendida como o locus da formação de profissionais. Nesse contexto, compete à universidade formar profissionais e gerar tecnologias e inovações que sejam colocadas a serviço do capital produtivo. Segundo Dourado, Oliveira e Catani (2003, p. 19):

nessa ótica capitalista, só é produtiva a universidade que vincula sua produção às necessidades do mercado, das empresas e do mundo do trabalho em mutação, ou seja, subordina sua produção acadêmica formal e concretamente às demandas e necessidades do mercado e do capital.

Assim sendo, ao lado de universidades "tradicionais" desenvolveram-se outras 
instituições especificamente orientadas para a formação profissional, como as Community and Junior Colleges nos EUA, Fachhochschule na Alemanha, Institutes Universitaires de Technologie na França, Polytechnics na Inglaterra (SANTOS, 2000, p. 196). De acordo com Santos (2000, p. 196), as universidades se multiplicaram e passaram a conhecer novas formas de diferenciação e de estratificação, como, entre as faculdades profissionais tradicionais (Direito e Medicina), as novas ou ampliadas faculdades de especialização profissional (Engenharias, Ciências e Tecnologia, Economia, Administração), e as faculdades "culturais" (Letras e Ciências Sociais).

Para lidar com esse problema, Winch (1996, p. 27) propõe classificar as formas de preparação que têm como foco o desenvolvimento de bons cidadãos e a criação de coesão social como "educação escolar" (schooling) e a educaçao profissional como "treinamento" (training). Para Winch (1996, p. 28), “o training não é apenas uma forma diferente de preparação, é uma forma diferente, embora relacionada, de conceito". O "training está focado no desenvolvimento da técnica, ao invés da preparação do adulto para a vida". O autor destaca que a educação envolve também o desenvolvimento da técnica, por isso esses conceitos não podem ser totalmente dissociados. No entanto, o training como uma educação profissionalizante (vocational education) envolve a formação para uma ocupação específica, que envolve uma técnica específica, a qual não é necessariamente parte da educação embora possa ser, no caso da formação profissional, apenas uma parte de um processo de educação mais amplo.

A educação profissionalizante (vocational education), segundo Winch (1996, p. 38) “está preocupada com o desenvolvimento de conhecimentos, habilidades e entendimentos necessários para a colocação de pessoas num tipo particular de emprego ou numa variedade de empregos". O autor (1996, p. 38) critica a visão tradicional de que a educação profissional é apenas um treinamento de emprego (job training), segundo ele:

Esta é uma visão muito distorcida do que a educação profissional pode ser ou realmente é.
Ela não leva em conta uma grande variedade de ocupações que estão disponíveis. Que
incluem profissões como medicina e advocacia ... carpintaria... Todas essas profissões
requerem conhecimento técnico e habilidades, capacidade social e compromisso ético se
eles estão comprometidos com uma maneira efetiva de trabalhar... Ademais, há valores
associados ao exercício de uma profissão, como diligência, persistência, honestidade,
orgulho no ofício e suas tradições, que são valores intrínsecos a serem escolhidos junto
com a ocupação em $\mathrm{si}^{41}$.

${ }^{41}$ Tradução livre de: "This is a very distorced view of what vocational education might be or actually is. It fails to take account of the wide variety of occupations that are available. These include vocations properly ... professions such as medicine or law... carpentry... All of these require technical knowledge and skill, social ability and ethical commitment if they are to be pursued in an effective and worthwhile manner... Furthermore, there are values associated with the pursuit of an occupation such as diligence, persistence, 
Entre os críticos da educação reduzida ao treinamento, encontra-se Bittar (2008, p. 176), que afirma:

Educação não é mero treinamento e não está somente vocacionada para incluir no mercado de trabalho; educação também serve como forma de humanização, especialmente considerado um mundo onde o humano, incalculavelmente, vem sendo expulso por relações onde a aferição econômica e a 'utilidade do outro' se medem a partir do valor do ter do outro. Na empreitada da educação está a tarefa de formar para evitar uma plena e completa de-formação da personalidade humana pelas formas instrumentais e instrumentalizantes de relacionamento condicionadas pela lógica da rapidez, do excesso de informação, da concorrência e da domesticação de tudo pelas relações de troca".

Bittar (2009, p. 391) ressalta que raciocínios técnicos-operativos não contribuem para a formação de habilidades libertadoras, fornecendo sim instrumentos para operar dentro de uma sociedade competitiva, consumista, individualista e capitalista selvagem ${ }^{42}$.

O processo de massificação e diferenciação entre as instituições de ensino superior, bem como o desenvolvimento de cursos voltados para uma formação profissionalizante também ocorreram no Brasil, como veremos no Capítulo 2 dessa Dissertação.

\subsection{O direito à educação no ordenamento jurídico brasileiro}

A Constituição de 1988 estabeleceu que as normas definidoras de direitos e garantias fundamentais têm aplicabilidade imediata (art. $5^{\circ}$, Parágrafo $1^{\circ}$ ) e previu que os direitos e garantias nela expressos não excluem outros decorrentes do regime e dos princípios por ela adotados, bem como dos tratados internacionais dos quais o Estado Brasileiro seja parte (art. $5^{\circ}$, Parágrafo $\left.2^{\circ}\right)^{43}$.

A Constituição Brasileira e o Ato das Disposições Constitucionais Transitórias (ADCT) apresentam cinqüenta e cinco artigos que tratam direta ou indiretamente sobre o direito à educação. No Apêndice $\mathrm{B}$ da Dissertação consta uma lista contendo esses dispositivos. Dentre eles, destacam-se o artigo $6^{\circ}$, os artigos 205 a 214, o artigo 227 e o artigo 60 da ADCT.

honesty, pride in the craft and its traditions, which themselves are intrinsic values to be chosen along with the occupation itself'(WINCH, 1996, p. 38).

42 A esse repeito, vide Adorno (2010) sobre as diferenças entre formação (Bildung) e semiformação (Halbbildung).

${ }^{43}$ Com a Emenda Constitucional $n^{\circ} 45$ de 2004, os tratados internacionais de direitos humanos passaram a contar com uma especial proteção, mediante a previsão de seu status de emenda constitucional desde que aprovados por quórum especial (art. $5^{\circ}$, Parágrafo $3^{\circ}$ ). $\mathrm{O}$ primeiro tratado a passar por esse procedimento especial e a contar com o status de emenda constitucional no Brasil foi a Convenção sobre os Direitos dos Deficientes, que contém dispositivos sobre o direito à educação. 
Na legislação infraconstitucional é a Lei de Diretrizes e Bases de 1996 (Lei no 9.394, de 20/12/1996) (LDB) o principal ato normativo disciplinador do direito à educação no Brasil.

As normas que estruturam a educação superior no Brasil encontram-se na Constituição Brasileira (tratamento específico nos artigos 207, 208, 213, Parágrafo $2^{\circ}$ e 219), na LDB (Capítulo IV - artigos 43 a 57), nas Leis $n^{\circ}$ s 9.131/95 e 9.192/95 e em diversos decretos, resoluções, portarias e deliberações emanadas dos órgãos executivos dos sistemas de ensino. No Apêndice C da Dissertação encontra-se uma lista contendo as principais normas aplicáveis ao ensino superior, vigentes em 05 de maio de 2012.

Nos itens a seguir trataremos dos principais dispositivos relativos ao direito à educação constantes na Constituição e na LDB. Esclarecemos que a análise implementada considerou as seguintes premissas:

(i) que educação e ensino não se confundem, sendo a educação uma expressão de conteúdo mais amplo que o ensino. Consideramos, em nossa análise, o ensino como um serviço de transmissão de conhecimentos e informações feito nas diferentes instituições de ensino (escolas, institutos, faculdades, universidades etc.), públicas ou privadas, de diferentes formas (presencial ou a distância, com diferentes metodologias), cujas principais características estão previstas na Constituição e na legislação aplicável à matéria; e a educação como um processo de formação do indivíduo (física, intelectual e moral), que visa o desenvolvimento de habilidades e capacidades para a emancipação do ser humano e sua integração social ${ }^{44}$ (RANIERI, 2009, p. 168)

${ }^{44}$ Para Winch (1996, p. 36), “a educação está preocupada principalmente com a preparação de jovens para a vida adulta". Para o autor isso implica preparar os jovens para que tenham autonomia e sejam capazes de viver uma vida independente e produtiva e assumir responsabilidade por suas próprias decisões (WINCH, 1996, p. 37).

${ }^{45}$ Analisando a Constituição e a LDB nota-se essa diferenciação. No artigo 205 da Constituição, a educação é definida como um "direito de todos e dever do Estado e da família", "promovida e incentivada com a colaboração da sociedade, visando ao pleno desenvolvimento da pessoa, seu preparo para o exercício da cidadania e sua qualificação para o trabalho". No artigo $1^{\circ}$ da LDB, o substantivo educação aparece com o sentido de educar, como um processo formativo que envolve a família, o ambiente de trabalho, convivência social, instituições de ensino, entre outros agentes: “Art. $1^{\circ}$, LDB - A educação abrange os processos formativos que se desenvolvem na vida familiar, na convivência humana, no trabalho, nas instituições de ensino e pesquisa, nos movimentos sociais e organizações da sociedade civil e nas manifestações culturais". Referidos processos formativos podem ser oferecidos em diferentes modalidades e formas, de acordo com o nível, natureza da instituição e outras características. Na educação básica, o processo formativo compreende a educação infantil, o ensino fundamental e o ensino médio (arts. 21e 32 da LDB). Na educação superior compreende os cursos sequenciais, os de graduação e os de pós-graduação (art. 44 da LDB). Essas modalidades de ensino podem ser oferecidas de diferentes maneiras - pela educação regular, para as crianças e adolescentes em idade apropriada ou para os jovens e adultos que não tiveram a oportunidade de frequentar o ensino fundamental; por via da educação especial, para aqueles que dela necessitem, sejam crianças, jovens ou adultos; de forma presencial ou a distância (RANIERI, 2009, p. 286). Essa diferenciação entre educação e ensino é também encontrada em dicionários de língua portuguesa, a exemplo do dicionário Houaiss que 
Seguindo o conceito de Adorno (2010, p. 141), a educação não é a "modelagem de pessoas", nem a "mera transmissão de conhecimento", mas sim a "produção de uma consciência verdadeira", que permita a formação de pessoas emancipadas, o que tem uma importância essencial para a democracia, já que essa representa a formação da vontade dos membros da sociedade ${ }^{46}$. Emancipação, para Adorno (2010, p. 141), conecta-se com autonomia, com um poder para reflexão, autodeterminação; e não com heteronomia, com algo que é imposto do exterior, com caráter usurpatório.

Bittar (2009, p. 379) esclarece que "a tarefa da educação para a democracia é a de conceder capacidade de expansão da autonomia individual. Educação e emancipação estão conceitual e umbilicalmente comprometidas". Nesse contexto, uma educação que prepara para a emancipação não deve apenas formular em nível abstrato problemas mas sim conscientizar sobre o passado histórico, tornando-o presente para a análise da responsabilidade individual sobre os destinos coletivos futuros (BITTAR, 2009, p. 379) ${ }^{47}$.

Quando falamos em direito à educação nosso sentido é amplo incluindo o direito ao ensino (como o direito a um serviço de transmissão de conhecimento que possui características estabelecidas pela Constituição e legislação aplicável) e o direito à educação (como processo de formação do indivíduo para sua emancipação).

(ii) que todos os dispositivos constantes na Constituição e na LDB com relação à educação, ao ensino e atividades correlatas fazem parte do conteúdo normativo do direito à educação e são de observância obrigatória por todos os agentes envolvidos no processo (Estado, instituições públicas de ensino, instituições privadas de ensino, estudantes, pais e responsáveis). Assim, consideramos que qualquer violação desses dispositivos representa violação do direito à educação; e

estabelece que a educação corresponde ao "ato ou processo de educar-se, bem como qualquer estágio deste processo; aplicação dos métodos próprios para assegurar a formação e o desenvolvimento físico, intelectual e moral de um ser humano; pedagogia, didática, ensino; conhecimento e observação dos costumes da vida social; civilidade, delicadeza, polidez, cortesia”. O ensino, por sua vez, segundo o mesmo dicionário, corresponde ao "ato ou efeito de ensinar; ensinamento, ensinança; transferência de conhecimento, de informação, na maioria das vezes em local destinado a esse fim (escola, oficina etc.); instrução". Extraído de $<$ http://houaiss.uol.com.br/>. Acesso em 26/09/2010.

${ }^{46}$ Para Adorno (2010, p. 169): “A exigência de emancipação parecer ser evidente numa democracia. [...] "A democracia repousa na formação da vontade de cada um em particular, tal como ela se sintetiza na instituição das eleições representativas. Para evitar um resultado irracional é preciso pressupor a aptidão e a coragem de cada um em se servir do seu próprio entendimento".

47 Interessante o conceito exposto por Bittar (2009, p. 378) para educação, que retoma a concepção de Adorno: "educar só tem sentido como preparação para o desafiar. Uma educação que não seja desafiadora, que não se proponha formar iniciativas, que não prepare para a mobilização, que não instrumente a mudança, que não seja emancipatória, é mera fábrica de repetição das formas de ação já conhecidas. Educação é, por essência, incitação à formulação de experiência, em prol da diferenciação, da recriação, do colorido da diversidade criativa. A partir da educação deve-se ser capaz de ousar”. 
(iii) que os princípios da educação e do ensino previstos nos artigos 205 e 206 da Constituição são: (a) externalidades sociais da educação, na medida em que os preceitos nele previstos proporcionam benefícios e malefícios não apenas aos alunos e às instituições de ensino envolvidas no oferecimento do ensino mas também à coletividade - tema que será desenvolvido no Capítulo 3 da Dissertação; e (b) direitos "na" educação, pois envolvem direitos de natureza instrumental que se realizam por intermédio de abstenções, e submetidos ao regime das liberdades e garantias, de eficácia plena e aplicabilidade imediata, conforme propõe Ranieri (2009, p. 291).

De acordo com Ranieri (2009, p. 291), o direito à educação se desdobra em diversos direitos e faculdade de conteúdo específico e autônomo, distinguindo-se nesse conjunto o direito à educação e os direitos “na” educação. Dessa maneira, Ranieri (2009, p. 290-1) considera o direito à educação como o gênero do qual os direitos "na" educação são desdobramentos (direitos de natureza instrumental):

O direito à educação (gênero) é, fundamentalmente, um direito a prestações positivas materiais, de custo social. Ou seja, a igualdade de condições para o acesso e permanência na escola; a gratuidade do ensino público em estabelecimentos oficiais; o ensino fundamental na língua materna das diversas comunidades indígenas; atendimento educacional especializado aos portadores de deficiências; oferta de ensino noturno; atendimento ao educando no ensino fundamental, dentre outros previstos na legislação brasileira. São essencialmente direitos de promoção e proteção, realizados mediante ações positivas.

Os direitos na educação (os desdobramentos) têm a função primária de defesa das liberdades no campo da educação, tais como a liberdade de aprender, ensinar, pesquisar e divulgar o pensamento, a arte e o saber; o pluralismo de ideias e de concepções pedagógicas, e coexistência de instituições públicas e privadas de ensino; a gestão democrática do ensino público; o ensino religioso facultativo; a autonomia universitária etc. São direitos de natureza instrumental, que se realizam por intermédio de abstenções, e submetidos ao regime das liberdades e garantias, de eficácia plena e aplicabilidade imediata.

\subsubsection{Artigo 205 da Constituição de 1988}

O artigo 205 da Constituição de 1988 estabelece que:

A educação, direito de todos e dever do Estado e da família, será promovida e incentivada com a colaboração da sociedade, visando ao pleno desenvolvimento da pessoa, seu preparo para o exercício da cidadania e sua qualificação para o trabalho.

Deste dispositivo extrai-se que (i) a educação é um direito de todos e dever do 
Estado e da família ${ }^{48}$; (ii) que a educação será promovida e incentivada com a colaboração da sociedade; e (iii) que são objetivos da educação - o pleno desenvolvimento da pessoa, seu preparo para o exercício da cidadania e sua qualificação para o trabalho.

Ao enunciar a educação como um direito de todos, a Constituição reafirma a característica de universalidade dos direitos humanos que se destinam a todos os seres humanos, independentemente de origem, raça, sexo, cor, idade ou quaisquer outros critérios.

Além disso, a Constituição não faz distinção entre os níveis de ensino para a garantia do direito à educação. Do que se conclui que o direito à educação envolve todos os níveis, numa concepção de educação ao longo da vida, que deve ser garantida pelo Estado.

Ao estabelecer que a educação é um dever do Estado e da família e que a sociedade tem um papel importante como incentivadora e colaborada da educação, o artigo 205 coaduna-se com o ideal de sociedade fraterna previsto no preâmbulo da Constituição e com o objetivo fundamental da República Federativa do Brasil de construção de uma sociedade solidária previsto no artigo $3^{\circ}$, I (SILVA, 2009, p. 27). O ideal de solidariedade humana na educação é reafirmado no artigo $2^{\circ}$ da $\mathrm{LDB}^{49}$.

Ranieri (2000, p. 74) afirma que o artigo $3^{\circ}$ da Constituição é o princípio informador do dever do Estado com relação à educação no Brasil. Nesse sentido, a educação brasileira está ligada aos objetivos fundamentais da República Federativa do Brasil: (i) construir uma sociedade livre, justa e solidária; (ii) garantir o desenvolvimento nacional; (iii) erradicar a pobreza e a marginalização e reduzir as desigualdades sociais e regionais; e (iv) promover o bem de todos, sem preconceitos de origem, raça, sexo, cor, idade e quaisquer outras formas de discriminação.

A colaboração da sociedade em matéria de educação é também incentivada pelo Estado por meio do repasse de recursos públicos para instituições privadas de ensino. O artigo 213 da Constituição prevê que os recursos públicos em matéria de educação serão destinados às escolas públicas, podendo ser dirigidos a escolas comunitárias, confessionais ou filantrópicas, definidas em lei, que: "I - comprovem finalidade não-lucrativa e apliquem seus excedentes financeiros em educação; II - assegurem a destinação de seu patrimônio a

\footnotetext{
${ }^{48}$ A Emenda Constitucional n ${ }^{\circ}$ 1, de 1969, que alterou a Constituição de 1967, foi a primeira a declarar que a "educação é direito de todos e dever do Estado" (art. 176).

${ }^{49}$ Art. $2^{\circ}$, LDB. A educação, dever da família e do Estado, inspirada nos princípios de liberdade e nos ideais de solidariedade humana, tem por finalidade o pleno desenvolvimento do educando, seu preparo para o exercício da cidadania e sua qualificação para o trabalho.
} 
outra escola comunitária, filantrópica ou confessional, ou ao Poder Público, no caso de encerramento de suas atividades”. Este dispositivo consagrou a prática brasileira de transferir recursos e conceder benefícios públicos apenas a instituições de ensino sem fins lucrativos. Isso mudou com o ProUni, que transfere benefícios também para instituições com fins lucrativos, conforme será desenvolvido no Capítulo 2 desta Dissertação.

O artigo 208 da Constituição estabelece os deveres do Estado com relação à educação, dentre os quais destacam-se: (i) a obrigatoriedade do oferecimento da educação básica; (ii) a progressiva universalização do ensino médio; (iii) o atendimento aos portadores de deficiência; (iv) a oferta de ensino noturno regular; (v) o atendimento ao educando em todas as etapas da educação básica por meio de programas suplementares de material didático, transporte, alimentação e assistência à saúde; e (vi) declara, em seu Parágrafo $1^{\circ}$, que o acesso ao ensino obrigatório e gratuito é direito público subjetivo ${ }^{50}$.

Por conta da Emenda Constitucional $n^{\circ} 59$ de 2009, que alterou o inciso I do artigo 208, o ensino obrigatório passou a representar a "I - educação básica obrigatória e gratuita dos 4 (quatro) aos 17 (dezessete) anos de idade, assegurada inclusive sua oferta gratuita para todos os que a ela não tiveram acesso na idade própria”. Trata-se de mudança importante para a educação brasileira cuja implementação será progressiva até 2016, nos termos do artigo $6^{\circ}$ da mencionada Emenda e que, certamente, terá impactos no ensino superior, por conta de um aumento do número de jovens formados no ensino médio que desejam continuar os estudos.

\subsubsection{Artigo 206 da Constituição de 1988}

O artigo 206 da Constituição de 1988 estabelece que:

Art. 206. O ensino será ministrado com base nos seguintes princípios:

I - igualdade de condições para o acesso e permanência na escola;

II - liberdade de aprender, ensinar, pesquisar e divulgar o pensamento, a arte e o saber;

III - pluralismo de ideias e de concepções pedagógicas, e coexistência de instituições públicas e privadas de ensino;

\footnotetext{
${ }^{50}$ Como direito público subjetivo, qualquer cidadão, grupo de cidadãos, associações, organização sindical, entidade de classe ou outra legalmente constituída e o Ministério Público, poderão acionar o Poder Público para exigir o direito de acesso à educação básica, sendo gratuita e de rito sumário a ação judicial correspondente, nos termos do artigo $5^{\circ}$ da LDB e artigos 54 e 208 do ECA. Ranieri $(2009$, p. 348) ressalta ainda que "sendo interesse social e individual indisponível, sua defesa poderá, ainda, ser objeto de mandado de segurança ou de injunção, em qualquer juízo, instância ou tribunal, estando o Ministério Público legitimado para tanto", nos termos dos artigos 98, I e 201, IX do ECA. Destaca-se ainda que a omissão ou a negligência no atendimento do direito de acesso à educação básica importa a responsabilização da autoridade competente, nos termos do artigo 208, Parágrafo $2^{\circ}$ da Constituição e artigos 98, I e 208, I do ECA.
} 
IV - gratuidade do ensino público em estabelecimentos oficiais;

V - valorização dos profissionais da educação escolar, garantidos, na forma da lei, planos de carreira, com ingresso exclusivamente por concurso público de provas e títulos, aos das redes públicas;

VI - gestão democrática do ensino público, na forma da lei;

VII - garantia de padrão de qualidade;

VIII - piso salarial profissional nacional para os profissionais da educação escolar pública, nos termos de lei federal.

Parágrafo único. A lei disporá sobre as categorias de trabalhadores considerados profissionais da educação básica e sobre a fixação de prazo para a elaboração ou adequação de seus planos de carreira, no âmbito da União, dos Estados, do Distrito Federal e dos Municípios.

O artigo 206 prevê princípios para o ensino. Considerando que educação e ensino não se confundem, entendemos que nesse dispositivo, ao se referir aos princípios do ensino, a Constituição está disciplinando o serviço de transmissão de conhecimentos mencionado no item 1.3 acima.

Para fins metodológicos vamos tratar dos princípios do ensino a partir de seus núcleos essenciais, discorrendo conjuntamente sobre princípios que envolvem valores semelhantes, da seguinte maneira: (i) igualdade - englobando os princípios da igualdade de condições de acesso e permanência (inciso I), gratuidade (inciso IV) e garantia de padrão de qualidade (inciso VII); (ii) liberdade - englobando a liberdade de aprender e ensinar (inciso II), a coexistência de instituições públicas e privadas, pluralismo (inciso III) e a gestão democrática do ensino (inciso VI); e por fim, (iii) profissionais da educação englobando o princípio da valorização dos profissionais (inciso V) e a previsão do piso salarial profissional nacional (inciso VIII).

Com relação aos princípios que envolvem a liberdade, vamos também considerá-los como direitos "na" educação, conforme classificação de Ranieri (2009) descrita no item 1.3 acima.

\subsubsection{Princípios relacionados à igualdade}

A igualdade pode assumir pelo menos três acepções, conforme Flávia Piovesan (2006, p. 179): (i) igualdade formal, reduzida à fórmula "todos são iguais perante a lei"; (ii) igualdade material, correspondente ao ideal de justiça social e distributiva (igualdade orientada pelo critério socioeconômico); e (iii) igualdade material, correspondente ao ideal de justiça enquanto reconhecimento de identidades (igualdade orientada pelos critérios de gênero, orientação sexual, idade, raça, etnia e demais critérios).

A Constituição de 1988 reconheceu a igualdade formal de todos perante a lei (art. 
$5^{\circ}$ ) e vedou a discriminação por origem, raça, sexo, cor, idade e quaisquer outras formas, colocando como objetivos fundamentais da República Federativa do Brasil construir uma sociedade livre, justa e solidária, garantir o desenvolvimento social, erradicar a pobreza e a marginalização e reduzir as desigualdades sociais e regionais (art. $3^{\circ}$ ). Em busca da realização da igualdade material e da justiça enquanto reconhecimento de identidades, o constituinte brasileiro não se limitou a proibir práticas discriminatórias, prevendo também um conjunto de medidas de discriminação positiva, para promover a inserção e integração social dos injustamente discriminados, como as previstas nos artigos 37, VIII; 208, III; 227, Parágrafo $2^{\mathrm{o}} ; 7^{\mathrm{o}}, \mathrm{XX}$ e XXX; 230, Parágrafo $2^{\mathrm{o}}$; e 203, $\mathrm{V}^{51}$. Além disso, o artigo 22, X previu como competência comum da União, dos Estados, do Distrito Federal e dos Municípios, combater as causas da pobreza e os fatores de marginalização, promovendo a integração social dos setores desfavorecidos, em busca de justiça social.

O artigo 206, I reconhece o princípio da igualdade, na forma de igualdade formal de todos para acesso e permanência nos diferentes níveis de ensino. No entanto, com relação à igualdade material para o acesso e permanência no ensino, a partir do critério socioeconômico e racial, nota-se que o Brasil apresenta grandes desigualdades raciais e de renda que se refletem no seus sistemas de ensino ${ }^{52}$.

No ensino superior, de acordo com dados de 2009, mais da metade dos estudantes que frequentavam a rede pública $(50,9 \%)$ e particular $(53,3 \%)$ pertenciam às famílias situadas entre os 20\% mais ricos (IBGE, 2010, p. 69) ${ }^{53}$. A taxa de escolarização líquida, analisada pelos quintos do rendimento mensal familiar per capita, também revela fortes desigualdades entre os mais pobres e os mais ricos no Brasil: em 2009, no primeiro quinto (os 20\% mais pobres), somente $32 \%$ dos adolescentes de 15 a 17 anos de idade estavam no ensino médio, enquanto no último quinto ( $20 \%$ mais ricos), essa oportunidade atingia

\footnotetext{
${ }^{51}$ Estes dispositivos estabelecem um tratamento diferenciado para (i) os deficientes físicos com relação ao mercado de trabalho, educação, acesso a locais públicos, transporte coletivo e assistência social (art. 37, VIII, art. 208, III, art. 227, $\S 2^{\circ}$ e art. 203, V); (ii) as mulheres no acesso ao mercado de trabalho (art. $7^{\circ}, \mathrm{XX}$ ); e (iii) os idosos no acesso ao transporte coletivo urbano e assistência social (art. $230, \S 2^{\circ}$ e art. 203, V).

52 Sobre a discriminação de renda no ensino superior brasileiro, vide o seguinte artigo de minha autoria: MORETTI, Denise Martins. A discriminação econômica no ensino superior brasileiro. Uma abordagem a partir da Convenção da Unesco contra a Discriminação no Ensino. In: RANIERI, Nina Beatriz Stocco (Org.). Direito à Educação: Igualdade e Discriminação no Ensino. São Paulo: Editora da Universidade de São Paulo, 2010, p. 107-127.

53 A esse respeito, destaca-se que, embora o Brasil tenha experimentado um importante crescimento econômico nas últimas décadas, houve também um aumento da concentração de renda entre a população. Segundo dados do IBGE, em 1960, a parcela mais rica da população (os 10\% mais ricos) detinha uma renda 34 vezes superior à da parcela mais pobre (10\% mais pobres), em 1990, essa taxa alcançou o o patamar de 78 vezes (IBGE, 2006, p. 480). Há uma diferença regional também - no Nordeste, a média de anos de estudo, em 2007, para as pessoas pertencentes ao primeiro quinto era extremamente baixa - 3,2 anos, contra 5,1, no Sudeste; 8,5 anos para aqueles situados nos $20 \%$ mais ricos, contra 10,7, no Sudeste (IBGE, 2008, p. 64).
} 
quase $78 \%$ deste grupo, revelando que a renda familiar exerce grande influência na adequação idade/série frequentada (IBGE, 2010, p. 47).

Com relação à igualdade material a partir dos critérios de gênero, orientação sexual, idade, raça, etnia, o país também apresenta distorções relevantes. Dados apontam para uma diferença de dois anos de estudo na média de escolaridade entre brancos, negros e pardos no Brasil - em 2009, enquanto a população branca de 15 anos ou mais de idade tinha, em média, 8,4 anos de estudo, pretos e pardos tinham, 6,7 anos. A população de cor preta e de cor parda tinha também o dobro da incidência de analfabetismo comparada à população branca brasileira, em 2009: 13,3\% dos pretos e 13,4\% dos pardos, contra 5,9\% dos brancos, eram analfabetos. No ensino superior permanece a desigualdade - a proporção de estudantes de 18 a 24 anos de idade brancos que cursavam o ensino superior, em 2009, foi de $62,6 \%$, ante $28,2 \%$ dos pretos e $31,8 \%$ dos pardos (IBGE, 2010, p. 227).

Tais dados evidenciam uma clara situação de desigualdade de oportunidades no ensino brasileiro, mostrando a necessidade de políticas públicas mais efetivas para proporcionar melhores oportunidades educacionais à população de baixa renda, bem como para a população negra e parda, buscando igualdade real entre os indivíduos.

Para tratar de situações em que a igualdade material não é atingida, surgem as ações afirmativas. Para Flávia Piovesan (2006, p. 179) as ações afirmativas constituem medidas especiais e temporárias que, buscando remediar um passado discriminatório, objetivam acelerar o processo de igualdade, com o alcance da igualdade substantiva por parte de grupos socialmente vulneráveis, como as minorias étnicas e raciais, dentre outros grupos. Enquanto políticas compensatórias adotadas para aliviar e remediar as condições resultantes de um passado discriminatório, as ações afirmativas objetivam transformar a igualdade formal em igualdade material e substantiva, assegurando a diversidade e pluralidade social. As ações afirmativas correspondem à chamada discriminação positiva, tendo como fundamento tratar os iguais de forma igual e os desiguais de forma desigual na proporção de sua desigualdade, estando o tratamento desigual a serviço de um fim constitucionalmente protegido, pautado em uma justificativa racional, mediante a utilização de um critério razoável, proporcional e objetivo ${ }^{54}$.

As ações afirmativas podem ser adotadas pelo Estado, bem como pela iniciativa privada considerando a eficácia horizontal dos direitos humanos.

Importante destacar que referidas políticas no campo da educação encontram

\footnotetext{
${ }^{54}$ Texto construído a partir dos critérios estabelecidos por Celso Antonio Bandeira de Mello (2003, p. 24).
} 
respaldo na Convenção Internacional para a Eliminação de todas as Formas de Discriminação Racial, adotada pela Assembleia Geral da ONU em 21 de dezembro de 1965 e ratificada pelo Estado Brasileiro em 27 de março de $1968^{55}$. Referida Convenção em seu artigo $2^{\circ}$, item 2 , estabelece que ${ }^{56}$ :

\begin{abstract}
Artigo $2^{\circ}$
2. Os Estados Partes adotarão, se as circunstâncias assim o exigirem, nos campos social, econômico, cultural e outros, medidas especiais e concretas para assegurar adequadamente o desenvolvimento ou a proteção de certos grupos raciais ou de indivíduos pertencentes a esses grupos com o propósito de garantir-lhes, em igualdade de condições, o pleno exercício dos direitos humanos e das liberdades fundamentais. Essas medidas não poderão, em hipótese alguma, ter o escopo de conservar direitos desiguais ou diferenciados para os diversos grupos raciais depois de alcançados os objetivos perseguidos.
\end{abstract}

Na mesma linha, a Declaração Mundial sobre Educação Superior no Século XXI: Visão e Ação (UNESCO, 1998), estabelece em seu artigo 3, d, a obrigação de facilitar o acesso à educação superior de alguns grupos específicos:

Artigo 3 - Igualdade de Acesso

d) Deve-se facilitar ativamente o acesso à educação superior dos membros de alguns grupos específicos, como os povos indígenas, as minorias culturais e linguísticas, de grupos desfavorecidos, de povos que vivem em situação de dominação estrangeira e pessoas portadoras de deficiências, pois estes grupos, tanto individualmente como coletivamente, podem possuir experiências e talentos que são de grande valor para o desenvolvimento das sociedades e nações. Uma assistência material especial e soluções educacionais podem contribuir para superar os obstáculos com os quais estes grupos se defrontam, tanto para o acesso como para a continuidade dos estudos na educação superior.

Com base na ideia de justiça compensatória e na forma de ações afirmativas no campo do ensino, foram promulgadas leis, e adotadas pelas instituições públicas de ensino superior políticas de ação afirmativa para o acesso ao ensino superior brasileiro. Referidas leis e políticas serão desenvolvidas no Capítulo 2 desta Dissertação.

A desigualdade no acesso ao ensino superior público envolve também a discussão sobre a qualidade da educação básica brasileira. Nesse ensejo, vamos tratar do princípio da garantia do padrão de qualidade.

Para Maliska (2001, p. 185):

55 A data de ratificação refere-se à data em que o instrumento de ratificação foi depositado na ONU. No Brasil, esta Convenção foi consubstanciada no Decreto-Lei n ${ }^{\circ} 65.810$, de 08/12/1969.

${ }^{56} \mathrm{Na}$ mesma linha, o Estatuto da Igualdade Racial (Lei $\mathrm{n}^{\circ} 12.288$, de 20/07/2010) previu em seus dispositivos ações afirmativas destinadas a garantir à população negra a efetivação da igualdade de oportunidades, a defesa dos direitos étnicos individuais, coletivos e difusos e o combate à discriminação e às demais formas de intolerância étnica. 
[...] a qualidade, em princípio, é um valor intrínseco a qualquer atividade, pois a realização de algo pressupõe a sua realização bem feita. Ainda que tendo presente esta premissa, a garantia de qualidade de ensino apresenta-se como um mecanismo de obrigação jurídica, ou seja, é possível exigir-se qualidade do estabelecimento de ensino por ser uma obrigação jurídica do estabelecimento escolar prestá-la.

Nos termos do artigo 9, incisos V a IX, artigo 10, IV e artigo 11, IV da LDB, compete ao Estado, nas suas três esferas, fiscalizar a qualidade do ensino. É dever da escola prestar o ensino com qualidade e é dever do Estado fiscalizar a prestação do ensino nos seus variados níveis. A efetivação do princípio da garantia do padrão de qualidade ocupa papel central para o direito à educação na atualidade.

O Brasil logrou alcançar a quase universalização do ensino fundamental, reduziu as taxas de analfabetismo, aumentou consideravelmente o número de matrículas no ensino médio, aumentou também o número de matrículas e instituições no ensino superior ${ }^{57}$; contudo, a qualidade do ensino ofertado é insuficiente. Prova disso são os dados sobre o analfabetismo funcional que apontam para uma taxa de analfabetismo funcional de $27 \%$ em 2011-2012, para a população de 15 a $64 \operatorname{anos}^{58}$ e que classificam somente $62 \%$ das pessoas com ensino superior e $35 \%$ das pessoas com ensino médio completo como plenamente alfabetizadas ${ }^{59}$.

Segundo Romualdo Portela de Oliveira (2006, p. 55), do ponto de vista histórico, três significados distintos para qualidade foram construídos na educação brasileira. $\mathrm{O}$

\footnotetext{
${ }^{57}$ Dados a respeito de cada um dos níveis de ensino aqui mencionados e seus avanços nos últimos anos encontram-se no Capítulo 2 da Dissertação.

${ }^{58}$ Dados obtidos do Indicador de Alfabetismo Funcional (Inaf) organizado pelo Instituto Paulo Montenegro e pela ONG Ação Educativa. O Inaf avalia habilidades de leitura, escrita e matemática, classificando os respondentes em quatro níveis de alfabetismo: analfabetos, alfabetizados em nível rudimentar, alfabetizados em nível básico e alfabetizados em nível pleno, sendo os dois primeiros níveis considerados como analfabetismo funcional. Segundo o Inaf são analfabetos aqueles que "não conseguem realizar nem mesmo tarefas simples que envolvem a leitura de palavras e frases ainda que uma parcela destes consiga ler números familiares (números de telefone, preços etc.). São alfabetizados em nível rudimentar aqueles que "localizam uma informação explícita em textos curtos e familiares (como, por exemplo, um anúncio ou pequena carta), leem e escrevem números usuais e realizam operações simples, como manusear dinheiro para o pagamento de pequenas quantias". São alfabetizados em nível básico aqueles que "leem e compreendem textos de média extensão, localizam informações mesmo com pequenas inferências, leem números na casa dos milhões, resolvem problemas envolvendo uma sequência simples de operações e têm noção de proporcionalidade". São alfabetizados em nível pleno "pessoas cujas habilidades não mais impõem restrições para compreender e interpretar textos usuais: leem textos mais longos, analisam e relacionam suas partes, comparam e avaliam informações, distinguem fato de opinião, realizam inferências e sínteses. Quanto à matemática, resolvem problemas que exigem maior planejamento e controle, envolvendo percentuais, proporções e cálculo de área, além de interpretar tabelas de dupla entrada, mapas e gráficos”. Segundo o Inaf, no ano de 2011-2012, o Brasil apresentava $6 \%$ de analfabetos, $21 \%$ de alfabetizados em nível rudimentar, $47 \%$ de alfabetizados em nível básico e $26 \%$ de alfabetizados em nível pleno (o que corresponde a $27 \%$ de analfabetos funcionais e $73 \%$ de alfabetizados funcionalmente). $<$ http://www.ipm.org.br/ipmb_pagina.php?mpg=4.03.00.00.00\&ver=por>. Acesso em 17/07/2012. 59 Conforme dados do Inaf 2011-2012. Disponível em: $<$ http://www.ipm.org.br/ipmb_pagina.php?mpg=4.03.00.00.00\&ver=por>. Acesso em 17/07/2012.
} 
primeiro foi condicionado pela oferta limitada, com isso a qualidade era associada ao acesso à educação. Nesse momento histórico, a escola não era para todos e o acesso era para uma pequena elite. Segundo o autor (2006, p. 56):

[...] o ensino era organizado para atender aos interesses e expectativas de uma minoria privilegiada. Portanto, a definição de qualidade estava dada pela possibilidade ou impossibilidade de acesso. As estatísticas educacionais brasileiras evidenciam, por exemplo, que na década de 1920 mais de $60 \%$ da população brasileira era de não alfabetizados.

O segundo significado foi construído num momento histórico marcado por uma maior democratização das oportunidades de acesso ao ensino, no qual houve uma expansão da rede de escolas. Assim, contingentes maiores da população tiveram acesso ao ensino e houve um rompimento dessa noção de qualidade vinculada a uma escola de elite. Nesse contexto, a política educacional girava em torno da construção de prédios escolares para a ampliação das oportunidades educacionais. Segundo o autor (2006, p. 57):

[...] a partir de 1940 a política de ampliação das oportunidades de escolarização concentrou-se, basicamente, na construção de prédios escolares, na compra de material escolar, muitas vezes de segunda categoria, e na precarização do trabalho docente pelo aviltamento dos salários e das condições de trabalho e por sua oferta qualificada ser insuficiente.

Com isso, nunca houve, de fato, um debate público consistente sobre a melhoria da qualidade do ensino oferecido pela escola pública brasileira. Os nossos políticos primaram pela construção de escolas para toda a população, sem que fosse dada a ênfase necessária na questão da qualidade do ensino a ser oferecido por essas escolas...

Os obstáculos à democratização do ensino foram, então, se transferindo do acesso para a permanência com sucesso no interior do sistema escolar. Primeiramente, na forma de obstáculos formais como o exame de Admissão ao Ginásio. Posteriormente, quando este exame foi eliminado (Lei $\mathrm{n}^{\circ} 5.692 / 71$ ), surgiu um novo tipo de seletividade que deu origem ao segundo conceito de qualidade, agora relacionado à ideia de fluxo, definido como número de alunos que progridem dentro de determinado sistema de ensino (OLIVEIRA, 2006, p. 57). Assim, conforme Oliveira (2006, p. 57):

[...] no final dos anos 1970 e nos anos 1980, um segundo indicador de qualidade foi incorporado ao debate educacional. A partir da comparação entre a entrada e a saída de alunos do sistema de ensino, era medida a "qualidade" da escola. Se a saída se mostrasse muito pequena em relação à entrada, a escola ou o sistema como um todo teria baixa qualidade.

No final da década de 1980, um novo problema é incorporado ao sistema de ensino: 
a expressiva taxa de repetência. Segundo Oliveira (2006, p. 58), nesse período, de cada cem crianças que ingressavam na $1^{\mathrm{a}}$ série, 48 eram reprovadas e duas evadiam, o que evidenciava a baixa qualidade da educação oferecida à população brasileira.

Para lidar com o problema da repetência e da evasão, foram adotados ciclos, promoção automática e programas de aceleração da aprendizagem. Com a redução do problema de fluxo dos alunos, surgiu um terceiro conceito de qualidade que passou a ser medida por meio de testes padronizados em larga escala (OLIVEIRA, 2006, p. 59). É nesse contexto que estamos atualmente. Esses testes mostram as deficiências do nosso sistema e, segundo Oliveira (2006, p. 62):

\begin{abstract}
Assim, diante da quase universalização do acesso à etapa obrigatória de escolarização, dos resultados insatisfatórios alcançados pelos estudantes brasileiros em diferentes testagens em larga escala, como dos reiterados episódios trazidos pela imprensa e vividos no cotidiano escolar quanto aos alunos que estão na escola, mas não se apropriam do mínimo indispensável para viver em sociedade, parece que o grande desafio do atual momento histórico, no que diz respeito ao direito à educação, é fazer com que ele seja, além de garantido e efetivado por meio de medidas de universalização do acesso, da permanência e da conclusão, uma experiência enriquecedora do ponto de vista humano, político e social. Portanto, que o direito à educação tenha como pressuposto um ensino básico de qualidade para todos e que não (re)produza mecanismos de diferenciação e de exclusão social.
\end{abstract}

A qualidade medida por testes tem por base indicadores. Para Oliveira (2006, p. 64), esses indicadores devem ser dinâmicos e constantemente debatidos e reformulados, sendo esta uma tarefa política pois envolve a definição de insumos e parâmetros (o que requer uma análise de custos, condições reais, objetivos e expectativas sociais em torno do processo de escolarização). Na mesma linha, Christopher Winch (1996, p. 19) também entende que a escolha dos mecanismos de controle de qualidade é uma escolha política, direcionada por prioridades políticas, que podem não ser as mesmas escolhas de uma empresa, cujo principal objetivo é o aumento da posição no mercado (market share) ou a lucratividade. Nesse sentido, o envolvimento do Estado em matéria de qualidade de educação é, para Winch (1996, p. 19), a prova de que as instituições educacionais nunca serão completamente livres para escolher como monitorar o sistema ou mesmo como operar internamente a instituição.

A partir dos indicadores usualmente aceitos em países europeus, Oliveira (2006, p. 64) estabelece uma classificação em três categorias: indicadores de investimento, indicadores de desempenho dentro da realidade educativa $e$ indicadores de 
sucesso/fracasso escolar ${ }^{60}$.

Para Oliveira (2006, p. 64), indicadores de investimento "são aqueles relacionados à remuneração docente, proporção de alunos por professor, custo-aluno etc". Indicadores de desempenho na realidade educativa "são aqueles que dizem respeito ao clima e à cultura organizacional da escola". E indicadores de sucesso/fracasso escolar "estão associados ao desenvolvimento de competências e habilidades para determinado nível ou etapa de escolarização".

De acordo com Oliveira (2006, p. 64), no Brasil, “dos vários indicadores de investimento, apenas o gasto-aluno, erroneamente entendido como custo-aluno, foi estabelecido, ainda que não tenhamos chegado a um consenso sobre seu cálculo ${ }^{61}$ ".

Oliveira (2006, p. 64) destaca que os indicadores de desempenho são praticamente inexplorados na realidade brasileira, "pois os sistemas de ensino não possuem metodologias para avaliá-los, apesar de experiências localizadas e estudos internacionais indicarem a relevância do clima e da cultura organizacional para amenizar o peso das desvantagens socioeconômicas e culturais dos alunos no processo de ensinoaprendizagem".

Os indicadores de sucesso/fracasso escolar são utilizados mediante as políticas de

${ }^{60}$ Santos (2000, p. 216) ressalta a dificuldade em se estabelecer medidas para a avaliação da qualidade e da eficácia da educação. Segundo o autor (2000, p. 216), "mesmo aceitando que a universidade produz 'produtos', é reconhecido que muitos deles não são susceptíveis de mensuração directa. Como medir a formação do carácter ou mesmo o progresso científico? Não há medidas directas, e mesmo o recurso a medidas indirectas não deixa de levantar alguns problemas. Mencionarei dois, o quantitativismo e o economicismo". Segundo Santos (2000, p. 217) tende-se a privilegiar medidas quantitativas ao invés das qualitativas - "tomemos um exemplo. Perante a verificação de que a França produz mais diplomas universitários que a Alemanha, apesar de possuir uma taxa de enquadramento (número de alunos por docente) muito inferior (23 na França; 9 na Alemanha) (Bienaymé, 1986: 317), fácil será concluir que o sistema universitário francês é mais eficaz que o alemão. No entanto, tal conclusão nada diz sobre a qualidade dos diplomas, o nível de excelência exigido, ou o impacto do tipo de formação no desempenho profissional dos diplomados". "O problema do quantitativismo não se põe apenas ao nível da falibilidade dos indicadores... Por exemplo, por essa razão, pode fazer-se incidir a avaliação na produção de conhecimentos científicos (medida pelo número de publicações) em detrimento da formação do carácter dos estudantes. Por outro lado, a interiorização, no seio da comunidade universitária, da avaliação quantitativa pode distorcer as prioridades científicas dos docentes e investigadores. Como afirma Giannotti, se Frederico o Grande tivesse exigido quarenta 'papers' para recontratar Kant para a cadeira de Filosofia, em Königsberg, Kant não teria tipo tempo para escrever a Crítica da Razão Pura (Chauí e Giannotti, 1987: A 21). O quantitativismo está intimamente ligado com o economicismo. Na sociedade contemporânea, o arquético do produto social definido quantitativamente é o produto industrial. $\mathrm{O}$ economicismo consiste em conceber o produto universitário como um produto industrial, ainda que de tipo especial, e consequentemente em conceber a universidade como uma organização empresarial. Este viés está hoje muito difundido e a sua vigência incontrolada representa um perigo importante para a autonomia institucional da universidade".

${ }^{61}$ Oliveira (2006, p. 65) destaca que "essa definição não foi antecedida da explicitação de metas a serem atingidas em termos de melhoria de infraestrutura, equipamentos, instalações, salário, de formação inicial e continuada e dos programas de assistência ao estudante. Sendo assim, a definição do gasto-aluno correspondeu a uma lógica que partiu do rateio do montante dos recursos existentes, e não dos insumos necessários e da definição de padrões de qualidade mínimos para o conjunto da população". 
avaliação com testes padronizados como o Saeb (Sistema Nacional de Avaliação da Educação Básica). Segundo Oliveira (2006, p. 66), esses testes:

[...] se, por um lado, aferem competências e habilidades requeridas para um ensino de qualidade, por outro não possuem efetividade, visto que pouca ou nenhuma medida política ou administrativa é tomada a partir de seus resultados, ou seja, não possuem validade consequencial. Dessa forma, os testes padronizados são instrumentos necessários mas insuficientes para a melhoria da qualidade de ensino.

O tema da qualidade no ensino superior e as formas de avaliação de qualidade adotadas pelo Estado Brasileiro a partir da década de 1990 para esse nível de ensino serão desenvolvidas no Capítulo 2 da Dissertação.

Passamos agora à discussão da regra da gratuidade do ensino público em estabelecimentos oficiais. É função primordial do Estado fornecer ensino público e gratuito a seus cidadãos, tendo em vista a natureza do direito à educação e sua ligação à dignidade humana. Além disso, esta regra busca a igualdade material entre os indivíduos, uma vez que nem todos têm condições financeiras para pagar pelo ensino privado. Conforme José Afonso da Silva (2011, p. 846), “compete ao Poder Público, desde a pré-escola, ou até antes, proporcionar, aos alunos carentes, condições de igualização, para que possam concorrer com os abastados em igualdade de situação".

A gratuidade nas instituições de ensino superior oficiais é uma reivindicação antiga dos movimentos estudantis (SAMPAIO, 2000, p. 127). No entanto, a previsão constitucional de sua gratuidade foi reconhecida apenas na Constituição de 1988.

No sistema internacional esta regra também está prevista no artigo 13, 2 do Pidesc:

13, 2. Os Estados Partes no presente Pacto reconhecem que, a fim de assegurar o pleno exercício deste direito:

a) O ensino primário deve ser obrigatório e acessível gratuitamente a todos;

b) O ensino secundário, nas suas diferentes formas, incluindo o ensino secundário técnico e profissional, deve ser generalizado e tornado acessível a todos por todos os meios apropriados e nomeadamente pela instauração progressiva da educação gratuita;

c) $\mathrm{O}$ ensino superior deve ser tornado acessível a todos em plena igualdade, em função das capacidades de cada um, por todos os meios apropriados e nomeadamente pela instauração progressiva da educação gratuita; [...] (grifos nossos)

A gratuidade em sentido amplo deve ser entendida como a abstenção de pagamento de mensalidades e quaisquer outras despesas, bem como na forma de uma prestação por parte do Estado. No primeiro caso está incluso o não pagamento de mensalidades, taxas de 
expedição de diplomas e de matrícula como decidiu o $\mathrm{STF}^{62}$, e de quaisquer outras despesas relacionadas ao serviço de ensino prestado pelos estabelecimentos oficiais ${ }^{63}$. Referindo-se aos estabelecimentos oficiais, entendemos que esta regra deve ser observada por todos os estabelecimentos de ensino oficiais, sejam creches, escolas de ensino infantil, fundamental, médio e superior, cursos de graduação ou pós-graduação, lato sensu ou stricto sensu, ensino regular, especial ou profissionalizante, uma vez que não cabe ao intérprete fazer distinção onde o constituinte não fez (SILVA, 2009, p. 116) ${ }^{64}$.

Como prestação do Estado, temos um exemplo no artigo 208, VII da Constituição que estabelece como dever do Estado garantir o atendimento ao educando, em todas as etapas da educação básica, por meio de programas suplementares, de material didáticoescolar, transporte, alimentação e assistência à saúde. Dessa forma, a Constituição lida com a dificuldade enfrentada pelos alunos carentes para permanecer nos diferentes níveis de ensino ${ }^{65}$. Com relação ao ensino superior, gastos com moradia, alimentação, material didático, transporte, entre outros, também tornam a permanência no sistema inviável para muitos. Nesse sentido, entendemos que a responsabilidade do Estado nesta temática também deve abranger o ensino superior, com medidas que busquem garantir a permanência do estudante também nesse nível de ensino mediante a concessão de bolsas de estudo, auxílio alimentação, residência estudantil, subsídios para a compra de material escolar, entre outras, sob pena de violação da cláusula de vedação do retrocesso social, já

62 Súmula Vinculante $\mathrm{n}^{\mathrm{o}} 12$ do STF: “a cobrança de taxa de matrícula nas universidades públicas viola o disposto no art. 206, IV, da Constituição Federal".

63 Neste contexto destacamos que o art. 5, XXXIV, b, Constituição Brasileira prevê a gratuidade das certidões expedidas pelas instituições públicas.

${ }^{64}$ Maliska (2001, p. 212) trata dos convênios entre instituições públicas de ensino superior, através de suas fundações de apoio e instituições particulares, para a oferta de cursos de especialização em que os alunos pagam mensalidades, dizendo que: "trata-se de um verdadeiro absurdo em termos de gratuidade do ensino público pois a participação da instituição não se dá como forma de diminuir a desigualdade de acesso mas em razão de sua credibilidade e além disso, somente terão acesso a curso aqueles que puderem desembolsar os valores das mensalidades, sendo flagrantemente violados os art. 206, IV e art. 208, V". No entanto, existem posicionamentos contrários - Ranieri (2000, p. 240) é a favor da cobrança de mensalidade em pós lato sensu e cursos de extensão - "posiciono-me no sentido de que também a formulação adotada no artigo 206, IV, deve ser interpretada restritivamente. É dizer: gratuidade para o ensino superior stricto sensu graduação, pósgraduação mestrado e doutorado, formador dos quadros docentes de nível superior (cf. artigo 52, II, da LDB), o que exclui do âmbito do financiamento público, nos estabelecimentos oficiais de ensino superior, os cursos de pós-graduação lato sensu (mestrado profissionalizante, especialização, aperfeiçoamento e outros), bem como os cursos de extensão, exceção feita aos programas de pós-graduação lato sensu que se destinem à formação dos profissionais de educação para planejamento, inspeção, supervisão e orientação educacional para a educação básica, observada nestes casos a base comum nacional (cf. artigo 64, da LDB).

${ }^{65}$ A esse respeito, Maliska destaca que "é indiscutível que a ausência de qualquer um dos deveres do Estado para com a educação pode vir a caracterizar um tratamento desigual, um tratamento que deve ser compreendido no seu devido alcance, pois em se tratando de cidadãos na linha de pobreza e abaixo dela, o não fornecimento das condições básicas (alimentação, por exemplo) pode propiciar o abandono escolar pela impossibilidade de permanecer na escola (MALISKA, 2001, p. 173). 
que tais garantias não podem deixar de ser prestadas, visto que já alcançaram um nível de concretização ${ }^{66}$.

\subsubsection{Princípios relacionados à liberdade}

Para Jorge Miranda (2000, p. 435), a liberdade de educação surge, ao mesmo tempo, como direito autônomo e como exigência ou decorrência de outros direitos e princípios, valendo para os que recebem e ministram a educação. Este princípio está ligado aos direitos e deveres dos pais, à liberdade de consciência e de religião, à liberdade de criação cultural, à liberdade de expressão e informação e à liberdade de associação.

A liberdade de ensino pode, então, ser analisada sob três aspectos fundamentais: (i) direito de escolha da escola; (ii) direito de criação de escolas distintas das do Estado, sem prejuízo do direito à existência de escola pública; e (iii) direito de liberdade de professores e alunos na escola. Esta última liberdade tem como garantia a não programação do ensino nas escolas públicas, segundo quaisquer diretrizes filosóficas, estéticas, políticas, ideológicas ou religiosas (MIRANDA, 2000, p. 435). Dessa maneira, o aluno tem a liberdade de aprender, com a possibilidade de indagar ao professor para esclarecer dúvidas em sala de aula, desenvolver e expor seu pensamento crítico, e o professor tem liberdade de ensinar de acordo com suas concepções mas limitado à proposta pedagógica da unidade escolar (arts. 12 e 13 LDB). Destaca-se que a liberdade de aprender e a de ensinar são complementares, uma só existindo em função da outra. Dessa maneira, havendo abuso de uma haverá violação do direito alheio. Por exemplo, se a pretexto do exercício da liberdade de ensinar, um professor de ensino fundamental fizer uso de um método de alfabetização reconhecidamente inapropriado para crianças, o direito de aprender será violado em prejuízo dos educandos (SILVA, 2009, p. 97).

Conectado à temática das liberdades públicas, está o princípio da gestão democrática. Para José Afonso da Silva (2011, p. 131) são princípios fundamentais da democracia: (i) a soberania popular, segundo o qual o povo é a única fonte do poder; e (ii) a participação, direta ou indireta, do povo no poder, para que este seja a efetiva expressão da vontade popular.

\footnotetext{
${ }^{66}$ A Constituição de 1934 apresentava um dispositivo que tratava desta temática sem diferenciar o nível de ensino: Art 157 - A União, os Estados e o Distrito Federal reservarão uma parte dos seus patrimônios territoriais para a formação dos respectivos fundos de educação. $\S 2^{\circ}$ - Parte dos mesmos fundos se aplicará em auxílios a alunos necessitados, mediante fornecimento gratuito de material escolar, bolsas de estudo, assistência alimentar, dentária e médica, e para villegiaturas.
} 
Além disso, referido autor (2011, p. 126) vê a democracia como um processo de afirmação do povo e da garantia dos direitos fundamentais que este mesmo povo vai conquistando no correr da história. Para ele (2011, p. 132):

[...] a democracia - governo do povo, pelo povo e para o povo - aponta para a realização dos direitos políticos, que apontam para a realização dos direitos econômicos e sociais, que garantem a realização dos direitos individuais, de que a liberdade é a expressão mais importante. Os direitos econômicos e sociais são de natureza igualitária, sem os quais os outros não se efetivam realmente. É nesse sentido que também se pode dizer que os direitos humanos fundamentais são valores da democracia. Vale dizer: ela deve existir para realizálos, com o que estará concretizando a justiça social.

Para Maliska (2001, p. 216), a democratização pretendida pela Constituição não se resume ao Parlamento, sendo extensiva aos mais variados campos, entre eles à educação, uma vez que a democracia é um exercício que deve ser cultivado pelos cidadãos no seu dia a dia.

Assim, a gestão democrática deve ser compreendida em seu sentido amplo, incluindo a gestão da instituição e a política de ensino. Nesse sentido, é a previsão dos artigos 14 e 56 da LDB:

Art. 14. Os sistemas de ensino definirão as normas da gestão democrática do ensino
público na educação básica, de acordo com as suas peculiaridades e conforme os
seguintes princípios: (grifo nosso)
I - participação dos profissionais da educação na elaboração do projeto pedagógico da
escola;
II - participação das comunidades escolar e local em conselhos escolares ou equivalentes.

Art. 56. As instituições públicas de educação superior obedecerão ao princípio da gestão democrática, assegurada a existência de órgãos colegiados deliberativos, de que participarão os segmentos da comunidade institucional, local e regional. (grifo nosso)

A gestão democrática na educação está relacionada à previsão do artigo 205 da Constituição Brasileira, no sentido de que a educação é direito de todos e dever do Estado e família, sendo promovida e incentivada com a colaboração da sociedade. É de fundamental importância a participação da comunidade escolar (dirigentes, docentes, funcionários e alunos), bem como da comunidade local (pais e responsáveis), nos conselhos escolares para a discussão de assuntos relacionados ao ensino a ser ministrado nos estabelecimentos. Nesse contexto, é direito dos pais ou responsáveis ter ciência do processo pedagógico e participar da definição das propostas educacionais, nos termos do artigo 53, Parágrafo Único da Lei $n^{\circ} 8.069 / 90$ (ECA).

Ranieri (2000, p. 115) entende que a gestão democrática é aquela que "congrega 
segmentos da comunidade institucional, local e regional, permite, portanto, a incidência do princípio constitucional, obrigando a todas as instituições de educação superior”.

Como órgão importante nesta temática há o Conselho Nacional de Educação (CNE), composto pelas Câmaras de Educação Básica e de Educação Superior ${ }^{67}$, cada uma formada por 12 conselheiros, nomeados pelo Presidente da República. O CNE, nos termos do artigo $7^{\circ}$ da Lei $\mathrm{n}^{0} 4.024 / 61$, tem atribuições normativas, deliberativas e de assessoramento ao Ministro da Educação, de forma a assegurar a participação da sociedade no aperfeiçoamento da educação nacional ${ }^{68}$. A metade das nomeações é feita, obrigatoriamente, dentre os indicados em listas elaboradas especialmente para cada Câmara, mediante a consulta a entidades da sociedade civil, relacionadas às áreas de atuação dos respectivos colegiados (art. $8^{\circ}$, Parágrafo $1^{\circ}$, Lei $n^{\circ} 4.024 / 61$ ). Para a Câmara de Educação Superior esta consulta envolve, necessariamente, indicações formuladas por entidades nacionais públicas e privadas, que congreguem reitores de universidades, diretores de instituições isoladas, docentes, estudantes e segmentos representativos da comunidade científica (art. $8^{\circ}$, Parágrafo $3^{\circ}$, Lei $n^{\circ} 4.024 / 61$ ). Em todo o caso, a indicação deverá incidir sobre brasileiros de reputação ilibada, que tenham prestado serviços

${ }^{67}$ São atribuições da Câmara de Educação Superior, nos termos do artigo $9^{\circ}$, Parágrafo $2^{\circ}$ da Lei $n^{\circ}$ 4.024/1961: (i) oferecer sugestões para a elaboração do Plano Nacional de Educação e acompanhar sua execução, no âmbito de sua atuação; (ii) deliberar sobre as diretrizes curriculares propostas pelo Ministério da Educação e do Desporto, para os cursos de graduação; (iii) deliberar sobre as normas a serem seguidas pelo Poder Executivo para a autorização, o reconhecimento, a renovação e a suspensão do reconhecimento de cursos e habilitações oferecidos por instituições de ensino superior; (iv) deliberar sobre as normas a serem seguidas pelo Poder Executivo para o credenciamento, o recredenciamento periódico e o descredenciamento de instituições de ensino superior integrantes do Sistema Federal de Ensino, bem assim a suspensão de prerrogativas de autonomia das instituições que dessas gozem, no caso de desempenho insuficiente de seus cursos no Exame Nacional de Cursos e nas demais avaliações conduzidas pelo Ministério da Educação; (v) deliberar sobre o credenciamento e o recredenciamento periódico de universidades e centros universitários, com base em relatórios e avaliações apresentados pelo Ministério da Educação, bem assim sobre seus respectivos estatutos; (vii) deliberar sobre os relatórios para reconhecimento periódico de cursos de mestrado e doutorado, elaborados pelo Ministério da Educação e do Desporto, com base na avaliação dos cursos; (viii) analisar questões relativas à aplicação da legislação referente à educação superior; (ix) assessorar o Ministro de Estado da Educação e do Desporto nos assuntos relativos à educação superior; (x) deliberar sobre processos de reconhecimento de cursos e habilitações oferecidos por instituições de ensino superior, assim como sobre autorização prévia daqueles oferecidos por instituições não universitárias, por iniciativa do Ministério da Educação em caráter excepcional, na forma do regulamento a ser editado pelo Poder Executivo.

${ }^{68}$ Além disso, o CNE é competente para (i) subsidiar a elaboração e acompanhar a execução do Plano Nacional de Educação; (ii) manifestar-se sobre questões que abranjam mais de um nível ou modalidade de ensino; (iii) assessorar o Ministério da Educação e do Desporto no diagnóstico dos problemas e deliberar sobre medidas para aperfeiçoar os sistemas de ensino, especialmente no que diz respeito à integração dos seus diferentes níveis e modalidades; (iv) emitir parecer sobre assuntos da área educacional, por iniciativa de seus conselheiros ou quando solicitado pelo Ministro da Educação e do Desporto; (v) manter intercâmbio com os sistemas de ensino dos estados e do Distrito Federal; (vi) analisar e emitir parecer sobre questões relativas à aplicação da legislação educacional, no que diz respeito à integração entre os diferentes níveis e modalidades de ensino; e (vii) elaborar o seu regimento, a ser aprovado pelo Ministro de Estado da Educação e do Desporto (artigo $7^{\circ}$, Parágrafo $1^{\circ}$, Lei n ${ }^{\circ} 4.024 / 1961$ ). 
relevantes à educação, à ciência e à cultura (art. $8^{\circ}$, Parágrafo $4^{\circ}$, Lei $n^{\circ} 4.024 / 61$ ). O Presidente da República deve ainda levar em conta na sua escolha a necessidade de estarem representadas todas as regiões do País e as diversas modalidades de ensino, de acordo com a especificidade de cada colegiado (art. $8^{\circ}$, Parágrafos $4^{\circ}$ e $5^{\circ}$, Lei $n^{\circ}$ $4.024 / 61)$.

Para Ranieri (2000, p. 162), no entanto, é preciso relativizar as atribuições normativas e deliberativas do CNE e com isso relativizar a "participação da sociedade no aperfeiçoamento da educação superior”. Segundo a referida autora (2000, p. 162), "o que ocorre, em verdade, é a subordinação do CNE ao MEC, especialmente em matéria de avaliação e controle na educação superior, podendo-se deduzir que o Conselho nada mais é senão um órgão de assessoramento do Ministério".

Além disso, verifica-se na composição da Câmara de Educação Superior uma setorização, com a representação de interesses dos principais agentes envolvidos no setor ${ }^{69}$. A esse respeito, Sampaio (2000, p. 137) afirma:

Embora o processo de escolha dos conselheiros não se baseie em uma representação corporativa, conforme previam os dispositivos do substitutivo da LDB elaborado pela Comissão de Educação da Câmara, a composição do Conselho não fugiu à setorização constitutiva do sistema nacional de ensino superior: de um lado, conselheiros cuja trajetória profissional prende-se a universidades públicas e, de outro, conselheiros vinculados a instituições particulares de ensino superior.

Em maio de 2012, eram membros da Câmara de Ensino Superior ${ }^{70}$, representantes ligados às seguintes instituições: universidades federais (cinco membros); Universidade de São Paulo - USP (um membro); instituições de ensino superior privadas com fins lucrativos (três membros); instituições de ensino superior privadas sem fins lucrativos (três

69 Tratando do Conselho Federal de Educação, órgão anterior ao CNE, Cunha (2003, p. 47) já notava o problema da captura do órgão por interesses privados: "o poder do Conselho Federal de Educação, instituído pela primeira LDB (1961), transformou-o num órgão cobiçado pelos empresários do ensino. Como dele dependiam as autorizações, reconhecimento e credenciamento, de cursos e de instituições, os empresários do ensino e seus prepostos, amparados pelas composições políticas da ditadura militar, lograram constituir a maioria, quando não a totalidade desse Conselho. As denúncias de corrupção atingiram o auge no governo interino de Itamar Franco, que dissolveu o Conselho e enviou ao Congresso projeto de lei que criou outro órgão colegiado no seu lugar".

${ }^{70}$ Sobre a Câmara de Educação Superior no governo do Presidente Fernando Henrique Cardoso, Cunha (2003, p. 48) afirmou: "a Câmara de Educação Superior do CNE, na qual se debatem hoje os grandes interesses privados, acabou virando arena de disputa entre os próprios grupos privados, na luta pelo controle do mercado. A guinada privatista na Câmara de Educação Superior do CNE tem uma explicação: a necessidade de manter uma base parlamentar garantidora dos votos capazes de aprovar os projetos do governo levou o presidente a trocar votos no Congresso por nomeaçõees para postos no Poder Executivo, inclusive no CNE - e foram os grupos privatistas que se beneficiaram nessa barganha. Ao termo do longo Governo FHC, a Câmara de Educação Superior do CNE tornou-se tão desmoralizada quanto todo o CFE ao fim do curto mandato de Itamar Franco". 
membros $)^{71}$.

A Constituição previu gestão democrática apenas para os estabelecimentos de ensino público. A esse respeito, entendemos ser necessária a gestão democrática também nos estabelecimentos privados, uma vez que a educação é um serviço de interesse público, e sua orientação não deve ser deixada apenas ao arbítrio dos dirigentes da instituição. Como a educação envolve muitos interesses (dos estudantes, dos seus pais, do Estado, dos proprietários das instituições etc.), a gestão de uma instituição de ensino deve ser democrática, proporcionando a manifestação de todos. Neste caso, prevalece o princípio democrático e a previsão do artigo 205 da Constituição sobre a liberdade de iniciativa.

Além disso, o Estado Democrático de Direito Brasileiro também assegura os valores de uma sociedade pluralista (preâmbulo) e fundamenta-se no pluralismo político (art. $\left.1^{\mathrm{o}}, \mathrm{V}\right)(\mathrm{SILVA}, 2011$, p. 143).

Conforme José Afonso da Silva (2011, p. 143), o pluralismo é uma realidade da sociedade, que se compõe de uma pluralidade de categorias sociais, de classes, grupos sociais, econômicos, culturais e ideológicos, com interesses contraditórios e antinômicos. O desafio está em construir o equilíbrio entre as tensões múltiplas, conciliando a sociabilidade e o particularismo.

O princípio do pluralismo de ideias e de concepções pedagógicas está ligado à liberdade de ensinar e divulgar o pensamento. A partir deste princípio, respeitado um padrão mínimo nacional, cada escola pode desenvolver seu plano pedagógico, sendo livre para escolher a melhor maneira de desenvolver seu projeto (art. 12, LDB) tendo em conta a realidade e peculiaridades locais, transformando a educação em algo que tenha sentido para o aluno, em algo que consiga fazê-lo compreender os ensinamentos e que lhe seja útil (art. 28, LDB) (MALISKA, 2001, p. 180).

O pluralismo é também importante no ambiente escolar para desenvolver nos alunos o respeito às diferenças e ao direito do outro, a tolerância e a amizade (art. $3^{\circ}$, IV, LDB). Este foi um dos argumentos utilizados pelos ministros do STF para julgar constitucional a política de cotas raciais nas universidades brasileiras, conforme tratado no Capítulo 2 da Dissertação.

O pluralismo de ideias também se coaduna com a previsão do artigo 210, Parágrafo $1^{\mathrm{o}}$ e $2^{\mathrm{o}}$ da Constituição, que trata do respeito aos valores culturais e artísticos, nacionais e

\footnotetext{
71 Lista de membros da Câmara de Educação Superior. Disponível em: $<$ http://portal.mec.gov.br/index.php?option=com_content\&view=article\&id=14305\%3Acnecomposicao\&catid=323\%3Aorgaos-vinculados\&Itemid=754> . Acesso em: 16/05/2012.
} 
regionais, permitindo o ensino religioso de matrícula facultativa e a utilização, nas comunidades indígenas, de suas línguas maternas e processos próprios de aprendizagem.

Ainda numa perspectiva plural e conectado ao princípio da liberdade, a Constituição permite a coexistência de instituições públicas e privadas de ensino. .

\subsubsection{Princípios relacionados aos profissionais da educação}

Conforme Maliska (2001, p. 183), valorizar significa prestigiar, incentivar, motivar os profissionais do ensino para que desempenhem da melhor maneira possível suas atividades docentes. Nesse sentido, a Constituição "procurou dar ao professor o status que lhe é de direito, enquanto pessoa respeitada e valorizada na comunidade por exercer tão importante papel na formação dos cidadãos" (MALISKA, 2001, p. 183).

O artigo 67 da LDB concretizou o princípio constitucional de valorização dos profissionais da educação, estabelecendo que:

\footnotetext{
Art. 67. Os sistemas de ensino promoverão a valorização dos profissionais da educação, assegurando-lhes, inclusive nos termos dos estatutos e dos planos de carreira do magistério público:

I - ingresso exclusivamente por concurso público de provas e títulos;

II - aperfeiçoamento profissional continuado, inclusive com licenciamento periódico remunerado para esse fim;

III - piso salarial profissional;

IV - progressão funcional baseada na titulação ou habilitação, e na avaliação do desempenho;

V - período reservado a estudos, planejamento e avaliação, incluído na carga de trabalho;

VI - condições adequadas de trabalho.
}

Para Marcos Wanderley da Silva (2009, p. 123), a valorização dos profissionais da educação é medida fundamental para a melhoria da qualidade do ensino, devendo o Estado, nas suas três esferas, efetivar este princípio, mediante planos de carreira, melhores salários, além de condições satisfatórias de trabalho. Nessa temática, temos o Fundeb incluído pela EC $\mathrm{n}^{0} 53 / 06$, cujo objetivo é financiar o desenvolvimento e a manutenção da educação básica, proporcionando meio de valorizar os respectivos profissionais (Lei $\mathrm{n}^{\mathrm{o}}$ 11.494/07). Além disso, os professores contam com regras de aposentadoria mais benéficas (art. 201, Parágrafo $8^{\circ}$ e art. 40, Parágrafo $5^{\circ}, \mathrm{CF} / 88$ ) e a atividade de magistério é exceção à regra de proibição de acumulação de cargos públicos (art. 37, XVI, a e b, $\mathrm{CF} / 88)$.

Com relação a esse princípio destaca-se que a Constituição falou em profissionais da "educação", conceito mais amplo do que os profissionais do "ensino", que seriam 
apenas os docentes. Os profissionais da educação são todos aqueles que apoiam e oferecem suporte pedagógico ao exercício do magistério, na direção ou administração escolar, no planejamento, na inspeção, na supervisão, na orientação educacional e na coordenação pedagógica (SILVA, 2009, p. 124).

A previsão de piso salarial profissional nacional é uma regra que concretiza o princípio da valorização dos profissionais de educação. A esse respeito, destacamos que a Lei $\mathrm{n}^{0} 11.738 / 08$ regulamentou este dispositivo estabelecendo o piso do magistério público da educação básica e que o STF, no julgamento da ADI $n^{0} 4167$, declarou constitucional referida $l \mathrm{i}^{72}$.

No entanto, a referida lei foi omissa quanto à fixação do piso salarial dos profissionais da educação superior da rede pública, o que pode levar ao ajuizamento de uma ação direta de inconstitucionalidade por omissão ou um mandado de injunção, uma vez que se trata de norma constitucional de eficácia limitada, exigindo norma regulamentadora (SILVA, 2009, p. 145).

\subsubsection{Artigo 207 da Constituição de 1988}

O artigo 207 da Constituição de 1988 estabelece que:

As universidades gozam de autonomia didático-científica, administrativa e de gestão financeira e patrimonial, e obedecerão ao princípio de indissociabilidade entre ensino, pesquisa e extensão.

Referido dispositivo estabelece duas características das universidades brasileiras, que serão tratadas separadamente nos itens a seguir: (i) a autonomia universitária; e (ii) a

72 Ementa da ADI $\mathrm{n}^{\circ}$ 4167: CONSTITUCIONAL. FINANCEIRO. PACTO FEDERATIVO E REPARTIÇÃO DE COMPETÊNCIA. PISO NACIONAL PARA OS PROFESSORES DA EDUCAÇÃO BÁSICA. CONCEITO DE PISO: VENCIMENTO OU REMUNERAÇÃO GLOBAL. RISCOS FINANCEIRO E ORÇAMENTÁRIO. JORNADA DE TRABALHO: FIXAÇÃO DO TEMPO MÍNIMO

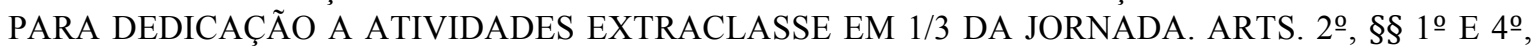
$3^{\circ}$, CAPUT, II E III E 8oㅜ TODOS DA LEI 11.738/2008. CONSTITUCIONALIDADE. PERDA PARCIAL DE OBJETO. 1. Perda parcial do objeto desta ação direta de inconstitucionalidade, na medida em que o cronograma de aplicação escalonada do piso de vencimento dos professores da educação básica se exauriu (arts. $3^{\circ}$ e $8^{\circ}$ da Lei 11.738/2008). 2. É constitucional a norma geral federal que fixou o piso salarial dos professores do ensino médio com base no vencimento, e não na remuneração global. Competência da União para dispor sobre normas gerais relativas ao piso de vencimento dos professores da educação básica, de modo a utilizá-lo como mecanismo de fomento ao sistema educacional e de valorização profissional, e não apenas como instrumento de proteção mínima ao trabalhador. 3. É constitucional a norma geral federal que reserva o percentual mínimo de $1 / 3$ da carga horária dos docentes da educação básica para dedicação às atividades extraclasse. Ação direta de inconstitucionalidade julgada improcedente. Perda de objeto declarada em relação aos arts. $3^{\circ}$ e $8^{\circ}$ da Lei $11.738 / 2008$. 
indissociabilidade entre ensino, pesquisa e extensão.

\subsubsection{A autonomia universitária}

Para Ranieri (1994, p. 61), a autonomia é um "poder derivado funcional circunscrito pelo ordenamento que lhe deu causa - é condição inerente à existência da universidade enquanto instituição social voltada ao ensino, à pesquisa e à extensão de serviços à comunidade".

A autonomia universitária se dá em face do Estado, mas não significa independência ${ }^{73}$, pois é o Estado quem outorga a autonomia e ao mesmo tempo é ele quem autoriza e avalia o funcionamento da instituição. Nesse sentido, caso uma instituição tenha uma avaliação negativa pelo Poder Público é possível a suspensão temporária de prerrogativas de autonomia (art. 46, Parágrafo $1^{\circ}$, LDB).

O primeiro documento legal a reconhecer a autonomia a instituições de ensino superior no Brasil foi o Decreto $\mathrm{n}^{\mathrm{o}}$ 8.659, de 5 de abril de 1911, resultado da "Reforma Rivadávia”. No entanto, foi apenas a Constituição de 1988 que assegurou em nível constitucional a autonomia universitária, e a LDB de 1996 que trouxe contornos mais precisos ao conceito.

A autonomia universitária engloba (i) a autonomia didático-científica; (ii) a autonomia administrativa; e (iii) a autonomia de gestão financeira e patrimonial.

A autonomia didático-científica reafirma o princípio da "liberdade de aprender, ensinar, pesquisar, e divulgar o pensamento, a arte e o saber", previsto no artigo 206, II da Constituição. Para Ranieri (1994, p. 117), a autonomia didática implica o "reconhecimento da competência da universidade para definir a relevância do conhecimento a ser transmitido, bem como sua forma de transmissão".

Considerando as atribuições de autonomia conferidas pelo artigo 53 da LDB às universidades, podem ser consideradas formas de autonomia didático-científica: (i) criar, organizar e extinguir, em sua sede, cursos e programas de educação superior previstos na LDB, obedecendo às normas gerais da União e, quando for o caso, do respectivo sistema de ensino; (ii) fixar os currículos dos seus cursos e programas, observadas as diretrizes

\footnotetext{
${ }^{73}$ Conforme Ranieri (1994, p. 115), “o conceito, tal como posto, designa a possibilidade de direção própria traduzida na capacidade de estabelecer normas internas e de escolher dirigentes - e revela caráter instrumental desse poder, destinado a operacionalizar o cometimento ideal de tarefas públicas. [...] Não pressupõe, portanto, soberania (é poder derivado), nem independência (a autonomia é restrita ao peculiar interesse da entidade)".
} 
gerais pertinentes; (iii) estabelecer planos, programas e projetos de pesquisa científica, produção artística e atividades de extensão; (iv) fixar o número de vagas de acordo com a capacidade institucional e as exigências do seu meio; (v) elaborar e reformar os seus estatutos e regimentos em consonância com as normas gerais atinentes; e (vi) conferir graus, diplomas e outros títulos.

Ademais, a autonomia didático-científica é garantida também pela atuação dos colegiados de ensino e pesquisa das universidades, que nos termos do Parágrafo Único do artigo 53 da LDB devem decidir, dentro dos recursos orçamentários disponíveis, sobre: (i) criação, expansão, modificação e extinção de cursos; (ii) ampliação e diminuição de vagas; (iii) elaboração da programação dos cursos; (iv) programação das pesquisas e das atividades de extensão; (v) contratação e dispensa de professores; e (vi) planos de carreira docente.

A autonomia administrativa é a possibilidade de auto-organização das universidades, que têm o direito de elaborar normas próprias de organização interna, incluindo a administração de recursos humanos e materiais e a escolha de seus dirigentes (RANIERI, 1994, p. 123-124).

Considerando as atribuições de autonomia conferidas pelo artigo 53 da LDB às universidades, podem ser consideradas formas de autonomia administrativa: (i) firmar contratos, acordos e convênios; e (ii) aprovar e executar planos, programas e projetos de investimentos referentes a obras, serviços e aquisições em geral, bem como administrar rendimentos conforme dispositivos institucionais.

A autonomia de gestão financeira e patrimonial implica a capacidade de administrar o patrimônio próprio, que pode ser público ou privado. No estado de São Paulo, há um sistema de alocação de recursos de impostos para as universidades estaduais ${ }^{74}$, o que não existe para as universidades federais. No sistema privado, o patrimônio é formado principalmente pela receita decorrente das mensalidades e demais serviços prestados aos alunos.

Considerando as atribuições de autonomia conferidas pelo artigo 53 da LDB às universidades, podem ser consideradas formas de autonomia de gestão financeira e

\footnotetext{
${ }^{74}$ É atribuído orçamento global às universidades estaduais paulistas, com base em percentual do ICMS fixado anualmente na Lei de Diretrizes Orçamentárias Estadual, que é repassado em duodécimos mensais às instituições. A distribuição do percentual entre as três universidades estaduais paulistas (USP, Unesp e Unicamp) é decidida pelo Conselho de Reitores das Universidades Estaduais (Cruesp), que também cuida da política salarial das instituições (Decreto ${ }^{0}$ 29.582/89). A disposição sobre a utilização do orçamento é feita individual e autonomamente, considerando os preceitos do artigo 207 da Constituição de 1988 e artigo 254 da Constituição do Estado de São Paulo.
} 
patrimonial: (i) administrar os rendimentos e deles dispor na forma prevista no ato de constituição, nas leis e nos respectivos estatutos; e (ii) receber subvenções, doações, heranças, legados e cooperação financeira resultante de convênios com entidades públicas e privadas.

\subsubsection{A indissociabilidade entre ensino, pesquisa e extensão}

A indissociabilidade entre ensino, pesquisa e extensão remonta ao artigo $2^{\circ}$ da Lei $n^{0} 5.540 / 68$, que estabelecia que: “o ensino superior, indissociável da pesquisa, será ministrado em universidades e, excepcionalmente, em estabelecimentos isolados, organizados como instituições de direito público ou privado"75.

Para Ranieri (1994, p. 134), ensino e pesquisa decorrem da própria essência da universidade, enquanto a extensão decorre da "natureza social do trabalho universitário (geração, organização e difusão de conhecimentos) que, financiado por recursos públicos (em se tratando de escolas estatais), deve visar aos interesses mediatos e imediatos da população”. Para a referida autora (1994, p. 134), o princípio da indissociabilidade reafirma a "sociedade como patrocinadora e beneficiária da universidade".

As atividades de ensino estão relacionadas aos quatro pilares da educação proclamados pela Unesco em 2001: (i) aprender a conhecer ${ }^{76}$; (ii) aprender a fazer ${ }^{77}$; (iii) aprender a conviver ${ }^{78}$; e (iv) aprender a $\operatorname{ser}^{79}$. Com relação ao primeiro pilar da Unesco (aprender a conhecer), Calderón (2011, p. 26) destaca que o ensino superior deve

\footnotetext{
75 Há referência à indissociabilidade também no Artigo 11, c da Lei $n^{\circ}$ 5.540/68: “As universidades organizar-se-ão com as seguintes características: c) unidade de funções de ensino e pesquisa, vedada a duplicação de meios para fins idênticos ou equivalentes".

76 Segundo a Unesco (DELORS, 2010, p. 31), "aprender a conhecer, combinando uma cultura geral, suficientemente ampla, com a possibilidade de estudar, em profundidade, um número reduzido de assuntos, ou seja: aprender a aprender, para beneficiar-se das oportunidades oferecidas pela educação ao longo da vida".

${ }^{77}$ Segundo a Unesco (DELORS, 2010, p. 31), “aprender a fazer, a fim de adquirir não só uma qualificação profissional, mas, de uma maneira mais abrangente, a competência que torna a pessoa apta a enfrentar numerosas situações e a trabalhar em equipe. Além disso, aprender a fazer no âmbito das diversas experiências sociais ou de trabalho, oferecidas aos jovens e adolescentes, seja espontaneamente na sequência do contexto local ou nacional, seja formalmente, graças ao desenvolvimento do ensino alternado com o trabalho".

${ }^{78}$ Segundo a Unesco (DELORS, 2010, p. 31), "aprender a conviver, desenvolvendo a compreensão do outro e a percepção das interdependências - realizar projetos comuns e preparar-se para gerenciar conflitos - no respeito pelos valores do pluralismo, da compreensão mútua e da paz".

79 Segundo a Unesco (DELORS, 2010, p. 31), “aprender a ser, para desenvolver, o melhor possível, a personalidade e estar em condições de agir com uma capacidade cada vez maior de autonomia, discernimento e responsabilidade pessoal. Com essa finalidade, a educação deve levar em consideração todas as potencialidades de cada indivíduo: memória, raciocínio, sentido estético, capacidades físicas, aptidão para comunicar-se".
} 
proporcionar aos estudantes os meios para "aprender a procurar informações válidas e confiáveis que, tendo como base a ciência e as metodologias científicas, possibilitem enfrentar as diversas situações desconhecidas que surgem na vida profissional, pessoal e/ou social".

Para Calderón (2011, p. 25), a pesquisa é uma atividade inerente ao ensino e que"diz respeito ao desenvolvimento de aptidões orientadas à procura do conhecimento, de forma metódica e sistemática”.

O artigo 218 da Constituição trata do desenvolvimento científico, da pesquisa e da capacidade tecnológicas, colocando o Estado como promotor e incentivador dessas atividades. Nesse contexto, estabelece que a pesquisa científica básica receberá tratamento prioritário do Estado, tendo em vista o bem público e o progresso das ciências (Parágrafo $1^{\circ}$ ); prevê que a pesquisa tecnológica deverá voltar-se preponderantemente para a solução dos problemas brasileiros e para o desenvolvimento do sistema produtivo nacional e regional (Parágrafo $2^{\circ}$ ); estabelece que o Estado apoiará a formação de recursos humanos nas áreas de ciências, pesquisa e tecnologia e concederá aos que delas se ocupem meios e condições especiais de trabalho (Parágrafo $3^{\circ}$ ); prevê que lei apoiará e estimulará as empresas que invistam em pesquisa e criação de tecnologia adequada ao País (Parágrafo $4^{\circ}$ ); e estabelece que os Estados e o Distrito Federal poderão vincular parcela de sua receita orçamentária a entidades públicas de fomento à pesquisa científica e tecnológica (Parágrafo $5^{\circ}$ ).

A extensão universitária, isoladamente, foi incluída no ordenamento jurídico brasileiro, pela primeira vez, no Primeiro Estatuto das Universidades Brasileiras (Decreto $\mathrm{n}^{\mathrm{o}} 19.851$, de $11 / 04 / 1931^{80}$ ). Na década de 1970, a extensão universitária foi impulsionada

\footnotetext{
${ }^{80}$ Decreto $\mathrm{n}^{\mathrm{o}}$ 19.851, de 11 de abril de 1931: “Art. 35. Nos institutos de ensino profisseonal superior serão realizados os seguintes cursos: [...] f) cursos de extensão universetária, destinados a prolongar, em benefício collectivo, a actividade téchnica e scientifica dos institutos universetarios".

“Art. 42. A extensão universetária será effectivada por meio de cursos e conferências de caracter educacional ou utilitário, uns e outras organizados pelos diversos institutos da Universidade, com prévia autorizacção do Conselho Universetário. $\S 1^{\circ}$ Os cursos e conferências, de que trata este artigo, destinam-se principalmente à diffusão de conhecimento uteis à vida individual ou collectiva, à solução de problemas sociaes ou à propagacção de idéias e princípios que salvaguardem os altos interesses nacionaes. $\S 2^{\circ}$ Estes cursos e conferências poderão ser realizados por qualquer instituto universetário em outros institutos de ensino technico ou superior, de ensino secundario ou primário ou em condições que os façam accesseveis ao grande público".

"Art. 109. A extensão universetária destina-se à diffusão de conhecimentos philosophicos, artísticos, litterarios e scientificos, em benefício do aperfeiçoamento individual e collectivo. $\S 1^{\circ}$ De accôrdo com os fins acima referidos, a extensão universetária será realizada por meio de cursos intra e extra-universetarios, de conferências de propaganda e ainda de demonstrações práticas que se façam indicadas. $\S 2^{\circ}$ Caberá ao Conselho Universetário, em entendimento com os Conselhos technico-administrativos dos diversos institutos, effectivar pelos meios convenientes a extensão universetária".
} 
pelo governo federal com Projeto Rondon, que visava o fortalecimento da relação universidade/comunidade ${ }^{81}$.

Segundo o Ministério da Educação, entende-se como extensão "o processo interdisciplinar, educativo, cultural, científico e político que promove a interação transformadora entre a universidade e outros setores da sociedade orientado pelo princípio constitucional da indissociabilidade com o ensino e a pesquisa".

O artigo 43, VII da LDB prevê como finalidade da educação superior "promover a extensão, aberta à participação da população, visando à difusão das conquistas e benefícios resultantes da criação cultural e da pesquisa científica e tecnológica geradas na instituição".

$\mathrm{O}$ artigo 213, Parágrafo $2^{\circ}$ da Constituição prevê que as atividades universitárias (públicas ou privadas) de pesquisa e extensão poderão receber apoio financeiro do Poder Público $^{82}$.

Nesse sentido, a previsão de indissociabilidade entre ensino, pesquisa e extensão foi considerada no passado um empecilho para o desenvolvimento do ensino superior no Brasil, já que universidades de pesquisa como as concebidas pelo artigo $2^{\circ}$ da Lei $n^{\circ}$ 5.540/68 (e posteriomente, art. 207, CF/88) exigiam grandes investimentos, sem garantia de retorno, sendo assim pouco atrativas ao setor privado. Nesse sentido, o setor privado brasileiro foi construído em torno de estabelecimentos isolados que não observavam o modelo universitário. A esse respeito, Roberto Leher (2003, p. 84) afirma:

Por trinta anos, desde a reforma universitária de 1968, a legislação para o ensino superior instituiu no modelo único de ensino superior oferecido por estabelecimentos universitários que procuram concretizar a indissociabilidade do ensino e da pesquisa. Não obstante a existência desse "modelo", na prática o sistema de ensino superior expandiu-se mediante a proliferação de estabelecimentos isolados e bem poucas foram as universidades que conseguiram instituir a pesquisa e institucionalizar a produção científica.

Esse fato é comprovado pelos números apresentados no Capítulo 2 da Dissertação.

Críticos da exigência de indissociabilidade entre ensino, pesquisa e extensão, como Eunice Durham (1998), entendem que a indissociabilidade manteve-se mais como bandeira ideológica do que como realização concreta na maioria das universidades. Sobre esse tema,

81 Em 2005, o Projeto Rondon foi relançado. Para informações sobre o Projeto vide: $<$ http://projetorondon.pagina-oficial.com/portal/>. Acesso em: 12/07/2012.

82 Em 2003, o MEC, por meio da Secretaria de Educação Superior (Sesu) e do Departamento de Modernização e Programas da Educação Superior (Depem), lançou o Programa de Apoio à Extensão Universitária (Proext) para "fortalecer a institucionalização da extensão no âmbito das instituições federais de ensino superior". 
Ranieri (2000, p. 184) afirma:

[...] embora os programas de mestrado e doutorado se concentrem nas universidades públicas (o que indica o desenvolvimento de atividades de pesquisa), o modelo universitário não garante a associação entre ensino e pesquisa, exigida pelo artigo 207 da Constituição Federal. A fórmula idealizada pela Lei $\mathrm{n}^{\circ}$ 5.540/68, em verdade, mostrou-se irreal na grande maioria das instituições.

Sobre a indissociabilidade de ensino, pesquisa e extensão nas instituições privadas, Calderón (2011, p. 30) destaca que a maioria das universidades particulares é vocacionada para o ensino, sendo a pesquisa científica "uma atividade pontual que na maioria das vezes se atém às exigências legais", e a extensão uma atividade "relegada a segundo plano" e na forma de um “departamento de assistência social”. Segundo Calderón (2011, p. 30):

Acreditamos que ainda predomina, no setor particular, a visão da extensão como mero balcão de negócios ou como mero departamento de assistência social. Com isto, não estamos afirmando que as IES particulares não desenvolvam ações voltadas ao desenvolvimento social de seu entorno territorial, mas acreditamos que exista a urgência de qualificar essas ações dentro dos princípios conceituais mencionados neste artigo, visando a potencialização de seu status acadêmico, distante das meras práticas assistencialistas.

\subsubsection{Artigo 208, V da Constituição de 1988}

O artigo 208, V da Constituição de 1988 prevê que:

Art. 208. O dever do Estado com a educação será efetivado mediante a garantia de: $\mathrm{V}$ - acesso aos níveis mais elevados do ensino, da pesquisa e da criação artística, segundo a capacidade de cada um;

Trata-se do princípio da meritocracia constante também no Artigo XXVI da DUDH. Para Ranieri (2000, p. 241):

A garantia de acesso (entrada, ingresso), condicionada ao mérito, supõe seleção e, por via de consequência, classificação diante de um número finito de vagas. $\mathrm{O}$ ensino superior, diversamente do que ocorre em relação aos níveis fundamental e médio, não se destina a todos, ainda que este último deva ser progressivamente universalizado, a título gratuito (CF, artigo 208, I e II).

O princípio da meritocracia deve ser entendido a partir da previsão de que o direito à educação é um direito de todos e que deve ser garantido ao longo da vida, sendo um direito indivisível.

O ensino superior não faz parte da educação obrigatória e compulsória. Nesse 
sentido, o acesso a esse nível de ensino depende do interesse do estudante. Além disso, diferentemente dos demais níveis de ensino, o ensino superior é, por exigência constitucional, marcado pela seletividade - apenas aqueles que têm "capacidade" podem acessar esse nível. Considerando a realidade brasileira, essa regra implica processos seletivos muito concorridos e com um nível de exigência elevado nas instituições públicas, as quais apresentam vagas insuficientes para atender a demanda brasileira, fatores que resultam na exclusão de muitos estudantes no acesso ao ensino superior público. Nesse contexto, muitos grupos privados de educação superior atendem à população brasileira.

No setor privado, a meritocracia é flexibilizada, uma vez que em muitas instituições e em determinados cursos existem mais vagas do que candidatos, o que torna o processo seletivo dessas instituições de fácil aprovação. Trataremos dessa questão no Capítulo 2 da Dissertação.

O problema para o acesso ao ensino superior privado é o valor das mensalidades, pois muitos estudantes não têm condições financeiras de arcar com os custos dos cursos. Para lidar com essa barreira, o Governo Federal criou programas de financiamento estudantil e de bolsas de estudo (o Fies e o ProUni), que serão tratados no Capítulo 2 da Dissertação.

Analisando a meritocracia e o princípio da igualdade de condições de acesso e permanência na escola (artigo 206, I, CF), Ranieri (2000, p. 241) afirma:

É evidente que a atribuição formal do direito de acesso não significa a possibilidade de exercê-lo em igualdade de condições. A dicotomia igualdade formal e igualdade material revela que os direitos são os mesmos para todos, mas que nem todos se acham em condições de exercê-los. Necessário se faz, portanto, criar condições para que se alcance uma igualdade real de acesso e permanência para todos aqueles que possam vir a atender ao ensino superior, sendo certo que a igualdade jurídica é a condição preliminar desta garantia.

Para a Ministra Carmem Lúcia, o termo "capacidade de cada um”, expresso no artigo 208, V, significa:

A capacidade de cada um, para fins do disposto no dispositivo acima mencionado, haverá que ser entendida como a habilitação intelectual comprovada mediante condições avaliadas em igualdade de condições com todos os postulantes às vagas dos cursos superiores oferecidos. Esta habilitação comprova ser o candidato capaz para os fins de aproveitamento do curso escolhido e para uma vaga no qual disputa com outros interessados ${ }^{83}$.

83 Extraído do parecer emitido pela Ministra Carmem Lúcia, anexado à petição inicial da ADI 3330 (CONFENEN, 2004, p. 270). 
Nesse contexto, estão inseridas as políticas de ações afirmativas para reserva de vagas em instituições de ensino superior segundo critérios étnicos e/ou sociais. Tema discutido pelo STF e desenvolvido no Capítulo 2 da Dissertação.

\title{
1.3.5 Artigo 209 da Constituição de 1988
}

O artigo 209 da Constituição estabelece que:

Art. 209. O ensino é livre à iniciativa privada, atendidas as seguintes condições:

I - cumprimento das normas gerais da educação nacional;

II - autorização e avaliação de qualidade pelo Poder Público.

O artigo 209 da Constituição proclama que o ensino é livre à iniciativa privada, mas o submete ao cumprimento de normas gerais de educação e à autorização e à avaliação de qualidade pelo Poder Público. Nesse sentido, a atividade de ensino não se enquadra na previsão do artigo 170, Parágrafo Único da Constituição, que assegura a todos o livre exercício de qualquer atividade econômica, independentemente de autorização de órgãos públicos, salvo nos casos previstos em lei.

Mônica Sifuentes (2001, p. 73) destaca que o ensino, apesar de livre à iniciativa privada, não poderá ser organizado com a liberdade de iniciativa que caracteriza o exercício das atividades econômicas. Muito pelo contrário, pois se trata de atividade fiscalizada pelo Poder Público e por ele avaliada, devendo observar as normas constitucionais relativas à educação, a LDB e demais normas aplicáveis. Para Ranieri (2000, p. 135):

\begin{abstract}
se na iniciativa privada há amplo espaço para o exercício da atividade econômica, isto não se verifica na área educacional. Ainda que o inciso III, do artigo 206, da própria Constituição, garanta o pluralismo de ideias e concepções pedagógicas, e a coexistência de instituições públicas e privadas de ensino, meios e fins na atividade educacional privada são controlados pelo governo federal, inclusive no que diz respeito às mensalidades escolares.
\end{abstract}

O ensino superior é fiscalizado e avaliado pelo Poder Executivo Federal ${ }^{84}$, por meio

${ }^{84} \mathrm{O}$ artigo 211 da Constituição trata da distribuição de competências em matéria de educação no Brasil. Referido dispositivo estabelece que todos os entes federativos devem atuar de forma colaborativa e em regime de colaboração devem organizar seus sistemas de ensino para assegurar a universalização do ensino obrigatório. As competências específicas de cada ente são as seguintes: (i) os Municípios atuam prioritariamente no ensino fundamental e na educação infantil (art. 211, Parágrafo $2^{\circ}$ ); (ii) Estados e o Distrito Federal atuam prioritariamente no ensino fundamental e médio (art. 211, Parágrafo $3^{\circ}$ ); (iii) a União (a) organiza o sistema federal de ensino e o dos Territórios e financia as instituições de ensino públicas 
do Ministério da Educação e por órgãos e autarquias a ele ligadas (Inep, Capes, CNE etc.).

Outro exemplo de limitação na atuação da iniciativa privada nas atividades de ensino é a regra constante na Lei $n^{\circ}$ 9.870/99, que proíbe a instituição de ensino, por conta de uma situação de inadimplência, de adotar quaisquer medidas disciplinares ou penalidades pedagógicas contra o aluno, como a suspensão de provas escolares e a retenção de documentos escolares que possam constranger o aluno e prejudicá-lo em seus estudos ${ }^{85}$.

Considerando a regra prevista no artigo 209, discute-se a classificação da educação como serviço público. Este tema será desenvolvimento do item 1.5 abaixo.

\subsection{A educação como bem público}

Em documentos emanados por organismos internacionais encontramos a definição da educação como um bem público.

federais (art. 211, Parágrafo $1^{\circ}$ ); (b) tem função redistributiva e supletiva de forma a garantir a equalização de oportunidades educacionais e padrão mínimo de qualidade do ensino, mediante assistência técnica e financeira aos Estados, Distrito Federal e Municípios; (c) pode intervir nos Estados e no Distrito Federal, em hipótese de não aplicação, na educação, do mínimo exigido da receita resultante de impostos estaduais, na forma do artigo 34, VII, "e" da Constituição; (d) deve coordenar a política nacional de educação, articulando os diferentes níveis e sistemas e exercendo função normativa, redistributiva e supletiva em relação às demais instâncias educacionais (art. $\left.8^{\circ}, \mathrm{LDB}\right)$; (e) autoriza e avalia os estabelecimentos de ensino de seu sistema (art. 206, VII), inclusive os particulares (art. 209, II). A Constituição não indicou nenhum nível de ensino para atuação prioritária da União. Considerando sua função supletiva e redistributiva, compete à União oferecer ensino superior na ausência de seu oferecimento pelos demais entes federativos. Para Ranieri (2000, p. 99), como os demais entes ocupam-se prioritariamente com a educação básica, a competência da União, em relação ao ensino superior, é residual e supletiva, lembrando que no Brasil, tradicionalmente, o governo federal se ocupou do oferecimento do ensino superior.

${ }^{85} \mathrm{O}$ controle das mensalidades faz-se ao abrigo do artigo 173, Parágrafo $4^{\circ}$, da Constituição (“a lei reprimirá o abuso do poder econômico que vise à dominação dos mercados, à eliminação da concorrência e ao aumento arbitrário dos lucros"), sendo pacífica a jurisprudência do STF neste sentido: “Ato jurídico perfeito - direito adquirido - Constituição Federal. A existência de ato jurídico perfeito, a desaguar em direito adquirido, pressupõe a formalização em harmonia com a ordem jurídica constitucional. Isto não ocorre quando a Corte soberana no exame dos elementos probatórios dos autos decidiu considerada a possibilidade de o Estado coartar abusos econômicos perpetrados na fixação dos preços das mensalidades escolares. É que o Parágrafo $4^{\circ}$, do artigo 173 da Constituição Federal, reserva à lei a repressão ao abuso do poder econômico, no que vise à dominação dos mercados, à eliminação da concorrência e ao aumento arbitrário dos lucros. Assim, não se pode ter a Lei $n^{\circ} 8.039 / 90$, no particular, como conflitante com a autonomia assegurada no artigo 209, nem com princípio estabelecido no inciso XXXVI, do artigo 5, ambos da Carta Federal de 1988" (STF, AGRAG - 155.772/SP, 2 ${ }^{\text {a }}$ Turma; v.u.; Rel. Min. Marco Aurélio; DJ de 27/05/1994). Ementa: Ação direta de inconstitucionalidade - Lei 8.039, de 30 de maio de 1990, que dispõe sobre critérios de reajuste das mensalidades escolares e dá outras providências. Em face da atual Constituição, para conciliar o fundamento da livre iniciativa e do princípio da livre concorrência com os da defesa do consumidor e da redução das desigualdade sociais, em conformidade com os ditames da justiça social, pode o Estado, por via legislativa, regular a política de preços de bens e de serviços, abusivo que é o poder econômico que visa ao aumento arbitrário dos lucros. Não é, pois, inconstitucional a Lei n. 8.039, de 30 de maio de 1990, pelo só fato de ela dispor sobre critérios de reajuste de mensalidades das escolas particulares (STF; ADI-319/DF; Tribunal Pleno; v.u.; Rel. Min. Moreira Alves; DJ de 30/04/1993). 
Exemplo disso é o Relatório Final da Conferência Internacional da Educação de 2008, organizada pela Unesco, que afirma em seu Anexo VIIIb (UNESCO, 2008, p. 58):

Muitos participantes expressaram insatisfação com a atual tendência para a comercialização de serviços educacionais, e ressaltaram que a educação é um bem público e, portanto, não deve ser considerado como qualquer outro setor da economia. Também foi observado que a educação tem um papel cultural fundamental que ajuda a moldar identidades nacionais e locais, e, portanto, não pode ser considerada como um bem meramente negocial ${ }^{86}$ (grifo nosso).

Especificamente com relação à educação superior, a Declaração da Conferência Regional de Educação Superior da América Latina e do Caribe de $2008^{87}$ também afirmou que a educação superior é um bem público:

A Educação Superior é um bem público social, um direito humano e universal e um dever do Estado. Esta é a convicção e a base para o papel estratégico que deve assumir nos processos de desenvolvimento sustentável dos países da região. [...]

B - A Educação Superior como direito humano e bem público social

1 - A Educação Superior é um direito humano e um bem público social. Os Estados têm o dever fundamental de garantir este direito. Os Estados, as sociedades nacionais e as comunidades acadêmicas devem ser os atores que definem os princípios básicos nos quais se fundamenta a formação dos cidadãos e cidadãs, cuidando para que ela seja pertinente e de qualidade.

2 - O caráter de bem público social da Educação Superior se reafirma à medida que o acesso à mesma seja um direito real de todos os cidadãos e cidadãs. As políticas educacionais nacionais constituem a condição necessária para favorecer o acesso a uma Educação Superior de qualidade, mediante estratégias e ações consequentes. [...]

6 - A Educação Superior como bem público social enfrenta correntes que promovem sua mercantilização e privatização, assim como a redução do apoio e financiamento do Estado. É fundamental reverter esta tendência, de tal forma que os governos da América Latina e do Caribe garantam o financiamento adequado das instituições de Educação Superior pública e que estas respondam com uma gestão transparente. A Educação não pode, de modo algum, reger-se por regulamentos e instituições com fins comerciais, nem pela lógica do mercado. $\mathrm{O}$ deslocamento do nacional e do regional em direção ao global (bem público global) tem como consequência o fortalecimento de hegemonias que existem de fato. (grifo nosso)

Na mesma linha, o Comunicado da Conferência Mundial sobre Ensino Superior de 2009, organizada pela Unesco ${ }^{88}$ (UNESCO, 2009):

${ }^{86}$ Tradução livre de: "Many participants expressed dissatisfaction over the current trend to commercialise educational services, and stressed that education is a public good and therefore should not be considered as any other sector of the economy. It was also noted that education has a fundamental cultural role that helps shape national and local identities, and thus cannot be regarded as a mere transactional good'. (UNESCO, 2008, p. 58)

${ }^{87}$ A Conferência Regional de Educação Superior na América Latina e no Caribe (Cres) ocorreu de 4 a 6 de junho de 2008, na cidade de Cartagena de Índias, Colômbia, com o apoio do Instituto Internacional da Unesco para a Educação Superior na América Latina e no Caribe (Iesalc-Unesco) e do Ministério de Educação Nacional da Colômbia, com a colaboração dos governos do Brasil, Espanha, México e da República Bolivariana da Venezuela.

${ }^{88}$ No documento "Higher Education in a Globalized Society" de 2004, a Unesco também debate a 
1. A Educação Superior como um bem público é responsabilidade de todos os investidores, especialmente dos governantes. [...]

47. Financiamento: A educação é um bem público, porém financiamento privado deve ser estimulado. Enquanto todos os esforços devem ser tomados para aumentar o financiamento público do ensino superior, é necessário reconhecer que os financiamentos públicos são limitados e podem não ser suficientes para desenvolver o setor rapidamente. Outras fórmulas e fontes de financiamento devem ser encontradas, especialmente as baseadas no modelo de parceria público-privado. (grifo nosso)

Referidos documentos proclamam a educação como um bem público, mas não definem bem público. De acordo com os trechos analisados, pode-se concluir que: (i) bens públicos não podem ser negociados no mercado e não se sujeitam às leis, nem se submetem à lógica do mercado; e (ii) o Estado tem um papel importante no fornecimento de bens públicos. Como um bem público, a educação apresenta essas características, que se reforçam com a sua condição de direito humano universal e dever do Estado.

Investigando autores da área educacional, encontramos Gerald Grace, que num texto de 1989 debateu a natureza da educação como bem público ou mercadoria, considerando a realidade da Nova Zelândia na época e um documento do Tesouro Nacional daquele país sobre esse assunto. Neste texto, Grace (1989, p. 213) afirmou que, no sentido técnico dos economistas, a educação não é um bem público, por não preencher as características desses bens (não exclusão, não competição e pelo valor do bem não estar ligado a sua oferta restrita $\left.{ }^{89}\right)$.

Grace (1989, p. 213), então, propôs um conceito alternativo de bem público, que não considere a tecnicidade dos economistas mas sim o fato de a educação ser fundamental para o "desenvolvimento da personalidade dos cidadãos e de suas habilidades artísticas, criativas e intelectuais, independentemente da sua classe social, raça ou gênero e independentemente de sua região" e também porque a educação "busca desenvolver em todos os cidadãos um senso moral, um senso de responsabilidade social e fraternal para os outros, e uma disposição para agir de forma racional e cooperativa ${ }^{90,}$.

classificação da educação superior como bem público.

89 Segundo Grace (1989, p. 213 - tradução livre): “a oferta de educação formal e de qualificações educacionais associadas não se enquadram nessas categorias. Os indivíduos podem ser excluídos da oferta e pessoas fora da idade escolar compulsória são excluídos. $\mathrm{O}$ custo marginal da oferta não é zero. $\mathrm{O}$ valor das qualificações educacionais, pelo menos em parte, reside na sua escassez. Por isso, a educação compartilha das principais características de outras mercadorias negociadas no mercado".

${ }^{90}$ Tradução livre de afirmações constantes no seguinte trecho: "Might not education be regarded as a public good because one of its fundamental aims is to facilitate the development of the personality and the artistic, creative and intellectual abilities of all citizens regardless of their class, race or gender status and regardless of their regional location? Might not education be regarded as a public good because it seeks to develop in all citizens a moral sense, a sense of social and fraternal responsibility for others, and a 


\section{Dessa maneira, Grace (1989, p. 216) define bem público como:}

Bens públicos são serviços intrinsecamente desejáveis, prestados de forma pública, que melhorem a qualidade de vida de todos os cidadãos e que facilitem a aquisição por esses cidadãos de competências morais, intelectuais, criativas, econômicas e políticas, independentemente da capacidade individual desses cidadãos de pagar pelos serviços ${ }^{91}$.

Grace (1989, p. 216-217), então, define a educação como um bem público:

Sugiro, portanto, por todas essas razões, que devemos encarar a questão colocada por este trabalho e que temos que afirmar, contra o Tesouro, que a educação é um bem público na Nova Zelândia e deve continuar a ser um bem público. É um bem público porque, na Nova Zelândia, de qualquer forma, ela coloca alta prioridade na justiça social, equidade e na tentativa de estabelecer uma sociedade justa, na medida em que a educação pode ajudar nesses fins. É um bem público porque tem o potencial de reforçar as características democráticas e igualitárias da sociedade sobre e contra qualquer tendência para o autoritarismo. É um bem público, porque nos dá os recursos intelectuais para enxergar através de argumentos do Tesouro ${ }^{92}$.

Analisando autores da doutrina econômica para verificar se a afirmação de Grace (1989) (de que no sentido técnico, educação não é um bem público) se sustentava, encontramos a seguinte distinção entre bens privados e bens públicos em Joseph Stiglitz (1999, p. 127-128):

[...] bens privados têm as propriedades de consumo rival e excludente; bens públicos são caracterizados pelo consumo não rival e não excludente. Bens para os quais não há rivalidade no consumo e para os quais é impossível a exclusão são bem públicos puros [...] Consumo rival significa que se o bem é usado por uma pessoa, ele não pode ser usado por outra. [...] Por outro lado, consumo não-rival refere-se aos casos em que o consumo de uma pessoa não diminui nem impede o consumo de outra [...] Bens privados sempre têm a propriedade de exclusão: indivíduos podem ser excluídos de desfrutar do bem a não ser que

disposition to act in rational and cooperative ways?" (GRACE, 1989, p. 213).

${ }^{91}$ Tradução livre de: "Public goods are intrinsically desirable publicly provided services which enhance the quality of life of all citizens and which facilitate the acquisition by those citizens of moral, intellectual, creative, economic and political competencies, regardless of the individual ability of those citizens to pay for services." (GRACE, 1989, p. 216). O autor também afirma (1989, p. 213): “in other words, a public good can be seen to be: - that which potentially enhances the person (regardless of the social status of that person) for the full realisation of all their abilities and competencies that which potentially develops in that person a sense of moral, social, economic and political responsibility as a citizen that which potentially assists the effective operation of democratic government and the emergence of more equitable conditions in society and which, in its operation, is not affected by the differential market capacity of individuals and of families to pay for a privileged share of these benefits".

92 Tradução livre de: "I suggest therefore, for all these reasons, that we must come face to face with the question posed for this paper and that we must assert, contra the Treasury, that education is a public good in New Zealand and ought to remain a public good. It is a public good because, in New Zealand at any rate, it places a high priority upon social justice, equity and the attempt to establish a fair society insofar as education can assist these ends. It is a public good because it has the potential to strengthen the democratic and egalitarian features of the society over and against any tendencies towards authoritarianism. It is a public good because it gives us the intellectual resources to see through the Treasury's arguments". (GRACE, 1989, p. 216-217) 
paguem por ele.

Joseph Stiglitz (1999, p. 136) define a educação como um bem privado prestado de forma pública (publicly provided private goods):

\begin{abstract}
Bens prestados de forma pública para os quais existe um grande custo marginal associado com o seu fornecimento para indivíduos adicionais são referidos como bens privados prestados de forma pública. Não obstante os custos de funcionamento de um mercado para o fornecimento do bem sejam uma das justificativas para o fornecimento público de alguns desses bens, ela não é razão mais importante. Educação é um bem privado prestado de forma pública, no sentido definido acima - se o número de alunos matriculados duplica, os custos aproximadamente dobram (assumindo que a qualidade, refletida no tamanho da classe, as despesas com professores e livros didáticos, e assim por diante, são mantidos aproximadamente da mesma maneira). Uma das explicações habitualmente dadas para a provisão pública de educação é a preocupação com as considerações de distribuição; sensação de que as oportunidades dos jovens não devem depender da riqueza de seus pais $^{93}$
\end{abstract}

Encontramos também Fábio Nusdeo (2008), que possui um entendimento que possibilita a caracterização da educação como bem público.

Inicialmente, cabe esclarecer que Nusdeo (2008, p. 41), em vez de "bem público", utiliza o termo "bem coletivo", para evitar o sentido dúbio da expressão no direito brasileiro ${ }^{94}$. A expressão "bem coletivo" também foi utilizada em Relatório da Unesco do ano de 1998 para se referir à educação ${ }^{95}$.

Em seu conceito de bem coletivo, Nusdeo (2008, p. 39) ressalta a não exclusão,

93 Tradução livre de: "Publicly provided goods for which there is a large marginal cost associated with supplying additional individuals are referred to as publicly provided private goods. Though the costs of running a market provide one of the rationales for the public supply of some of these goods, it is not the only or even the most important rationale. Education is a publicly provided private good in the sense defined above - if the number of students enrolled doubles, costs will roughly double (assuming that quality, as reflected in class size, expenditures on teachers and textbooks, and so on, are kept roughly the same). One of the usual explanations given for public provision of education is concerned with distributive considerations; many feel that the opportunities of the young should not depend on the wealth of their parents". (STIGLITZ, 1999, p. 136)

${ }^{94}$ Segundo Nusdeo (2008, p. 41), "os bens coletivos são também chamados na literatura econômica de bens públicos, sobretudo por autores ingleses e americanos. No entanto, em Direito, a palavra pode ter sentido dúbio, pois públicos são os de uso comum como as águas dos rios, ruas e praças, ou os de uso especial, como prédios que abriguem serviços do Estado e também os chamados dominicais, por pertencerem a uma pessoa jurídica de direito público. E aí pode surgir a confusão porque o automóvel que serve o presidente da República ou o governador do Estado é, sob o ponto de vista legal, público, mas tem a natureza econômica de bem exclusivo, pois utilizado apenas por aquelas autoridades, com exclusão dos demais. Por essa razão, tais bens serão sempre chamados aqui de coletivos e não públicos, a fim de evitar qualquer confusão".

95 Segundo a Unesco (DELORS, 2010, p. 22): "É evidente que, nesse âmbito, todas as decisões têm consequências financeiras. A Comissão não minimiza essa condicionante; sem entrar na complexa diversidade dos sistemas, ela pensa que a educação é um bem coletivo que deve ser acessível a todos. Uma vez admitido esse princípio, é possível combinar os recursos financeiros do setor público e privado, de acordo com diferentes fórmulas que levem em consideração as tradições de cada país, seu estágio de desenvolvimento, os estilos de vida e a distribuição de recursos". No mesmo documento, segundo a UNESCO (DELORS, 2010, p. 36): "De fato, a educação constitui um bem coletivo que não pode ser regulado pelo simples jogo do mercado". 
afirmando que os "bens coletivos não estão sujeitos ao princípio da exclusão, ou seja, eles podem atender concomitantemente à necessidade de um grupo mais ou menos amplo de pessoas e, até mesmo, dos cidadãos de um país como um todo ${ }^{96, "}$

Em oposição aos bens coletivos estão os bens exclusivos, que atendem à necessidade de um único indivíduo. Nusdeo (2008, p. 39) destaca que alguns bens podem ser coletivos e exclusivos ao mesmo tempo e coloca como exemplo as escolas -para os alunos que nela estão inscritos, a escola é um bem coletivo porque todos podem dela usufruir. Para os demais indivíduos que não frequentam a escola, ela é um bem exclusivo, pois dela eles estão excluídos.

Nusdeo (2008, p. 40) destaca então que "todo o bem coletivo pode comportar alguns aspectos ou características de exclusividade, em maior ou menor grau". Assim sendo, deve-se analisar a finalidade do bem para concluir qual caráter prevalece, se o de coletividade ou de exclusividade.

Serviços públicos, como o abastecimento de água ou luz, segundo Nusdeo (2008, p. 40), são bens coletivos, "pois, ainda que o consumo de cada unidade atendida possa variar ou até não existir num dado período, o acesso aos mesmos está assegurado, em princípio, a todos dentro de uma determinada área geográfica".

Com base no entendimento de Nusdeo (2008), a educação pode ser considerada um bem público ou coletivo, pois é um direito de todos, e todos dela deveriam usufruir. Segundo Nusdeo (2008), o sistema de mercado falha no abastecimento de bens coletivos e com base nisso podem ser feitas críticas à submissão da educação a regras de mercado. Esse tema será desenvolvido no Capítulo 3 da Dissertação.

A posição de Grace (1989) e de autores como Nusdeo (2008) pode ter influenciado os documentos internacionais mencionados, que definem a educação como um bem público ou coletivo. Essa classificação ressalta o caráter coletivo e o interesse público que envolvem a atividade, bem como os benefícios que ela deve proporcionar a todos, independentemente da condição financeira para pagamento pelo serviço. Além disso, ressalta que a educação não deve ser tratada como qualquer outro bem negociável, pois ela não se rege pela lógica do mercado.

\footnotetext{
${ }^{96}$ Para Nusdeo (2008, p. 161), “o exemplo mais absoluto de um bem coletivo, como já apontado, é a defesa nacional. Com efeito, a proteção que ela traz a um cidadão é exatamente igual àquela proporcionada a qualquer outro membro da coletividade".
} 


\subsection{A educação como serviço público}

Considerando a previsão do artigo 205 da Constituição, que coloca a educação como um dever do Estado, e do artigo 209, que estabelece que o ensino é livre à iniciativa privada, atendidas as condições previstas nos seus incisos, discute-se a classificação da educação como serviço público no Brasil.

Os diferentes conceitos de serviço público levam em consideração três elementos:

(i) subjetivo (com relação à pessoa) - de acordo com essa classificação, serviço público é aquele prestado pelo Estado ou por seus delegados. O serviço público incumbe ao Estado, que pode fazê-lo direta ou indiretamente por meio de concessão ou permissão;

(ii) material (leva em consideração o objeto) - serviço público é uma atividade de satisfação de necessidades individuais ou coletivas essenciais;

(iii) formal - serviço público é aquele exercido em regime de direito público, derrogatório e exorbitante do direito comum. É a submissão de uma atividade a um regime de Direito Público.

Considerando esses três elementos, Di Pietro (2006, p. 114) define serviço público como:

[...] toda atividade material que a lei atribui ao Estado para que a exerça diretamente ou por meio de seus delegados (elemento subjetivo ${ }^{97}$ ), com o objetivo de satisfazer concretamente às necessidades coletivas (elemento material ${ }^{98}$ ), sob regime jurídico total ou parcialmente público (elemento formal ${ }^{99}$ ).

Eros Grau (2007, p. 136) valoriza o elemento material em sua definição, considerando serviço público "a atividade explícita ou supostamente definida pela Constituição como indispensável, em determinado momento histórico, à realização e ao desenvolvimento da coesão e da interdependência social".

Marçal Justen Filho (2006, p. 482), comentando essas opiniões, entende que o elemento material ou objetivo é mais relevante que os outros dois, do ponto de vista lógico, uma vez que os elementos subjetivo e formal dão identidade ao serviço público, mas são decorrentes do aspecto material. Para ele, uma "atividade é um serviço público em virtude de dirigir-se à satisfação direta e imediata de direitos fundamentais. Como consequência

\footnotetext{
${ }^{97}$ Comentário nosso.

${ }^{98}$ Comentário nosso.

${ }^{99}$ Comentário nosso.
} 
disso, essa atividade é submetida ao regime de direito público e, na maior parte dos casos, sua titularidade é atribuída ao Estado".

Nesse contexto, a educação, quando oferecida pelo Estado, é considerada serviço público. No entanto, quando prestada por particulares, é questão jurídica controversa. Parte da doutrina e jurisprudência (MELLO, 2011, p. 695; DI PIETRO, 2006, p. 119; GRAU, 2010, p. 123; STF, ADI 1.266/BA, ADI 1.007/PE) entende ser serviço público não privativo ou não exclusivo do Estado, uma vez que se trata de serviço que o Estado deve desempenhar, sob regime de Direito Público, sem, entretanto, impedir o exercício desta atividade pela iniciativa privada, independentemente de concessão ou permissão (MELLO, 2011, p. 695, DI PIETRO, 2006, p. 119; STF, ADI 1.266/BA). Outros doutrinadores (MEIRELLES, 2006, p. 230; MEDAUAR, 2006, p. 315, 317; JUSTEN, 2006, p. 495, 497), no entanto, entendem tratar-se de serviço privado, por não preencher adequadamente os elementos subjetivo e formal dos serviços públicos ${ }^{100}$.

Embora não considere a educação como um serviço público em sentido estrito ${ }^{101}$, Ranieri (2000, p. 129 e 252) entende que o regime jurídico da educação é de Direito Público, o que resulta numa disciplina normativa peculiar, "que se delineia em função da natureza pública da educação superior e da supremacia do interesse público sobre o particular, e que alcança as instituições de ensino públicas e privadas, bem como os particulares envolvidos na atividade educacional". A referida autora (2000, p. 42) destaca que a educação superior tem natureza pública em razão de seus fins, e não por ser oferecida ou não pelo Estado.

Para Ranieri (2000, p. 252), são consequências do regime de Direito Público da educação:

$[\ldots]$

a) na esfera pública, a especificidade dos princípios constitucionais que informam o desenvolvimento das atividades educacionais permite tratamento jurídico menos rígido das formas e processos (exemplo marcante é o da autonomia das universidades públicas);

b) da mesma forma, no plano individual, o regime legal pode ser flexibilizado, na medida em que o permitam os valores educacionais: a letra da lei cede ao interesse público, em situações nas quais o processo de aprendizagem se complete, em benefício do aluno, ainda que ao arrepio da forma legal;

\footnotetext{
${ }^{100}$ O Código de Educação do Estado de São Paulo (Lei no 10.125, de 04/06/1968) proclamou a educação como serviço público estabelecendo em seu artigo $3^{\circ}$ - "A educação é função de eminente interesse social, e as pessoas naturais e jurídicas de direito privado, que mantenham estabelecimentos de qualquer grau ou nível de ensino, são consideradas como investidas em função de caráter público, cabendo-lhes, em matéria educativa, os deveres e responsabilidades inerentes ao serviço público".

${ }^{101}$ Para Ranieri (2000, p. 129), a educação não é serviço público em sentido estrito, isto é, "não constitui atividade material que a lei considere como tal (embora seja tarefa que corresponda a necessidades coletivas), não há que se falar em delegação para o particular".
} 
c) diversamente, na esfera privada, a natureza pública da atividade educacional determina a derrogação parcial de prerrogativas inerente ao regime privatístico por normas de Direito Público, dada a prevalência da finalidade pública sobre o interesse particular (como ocorre em relação às instituições privadas de ensino superior, submetidas que estão às normas gerais de educação).

Nesse sentido, a liberdade de iniciativa em matéria de educação é limitada pela ação controladora do Estado. O regime privado deve observar todas as normas constitucionais, com destaque para os princípios da educação e do ensino, as finalidades da educação previstas no artigo 205 da Constituição, as normas relativas à autorização e reconhecimento de cursos, avaliação e credenciamento de instituições, bem como as demais normas infraconstitucionais que disciplinam a matéria, e sempre proteger o direito à educação dos indivíduos que contratam os serviços privados de educação.

Para Ranieri (2000, p. 131):

[...] a prestação sob o regime do Direito Privado não elide a incidência dos princípios constitucionais especiais (CF, artigo 206); a natureza pública da atividade educacional, na esfera privada, determina a derrogação parcial de prerrogativas inerentes ao regime privatístico por normas de direito público, dada a prevalência da finalidade pública sobre o interesse particular, muito embora, em tese, o interesse público e interesse particular se confundam em face dos fins da atividade educacional.

José Afonso da Silva (2011, p. 841) entende que, ainda que privada, a educação tem essencial caráter público, sendo elevada à condição de serviço público essencial do Estado. O mesmo autor ainda ressalta a preferência constitucional pelo ensino público, ocupando a iniciativa privada um papel subsidiário.

Em vista do acima exposto, concluímos que a educação, mesmo quando oferecida por prestadores privados, pode ser considerada um serviço público, o que realça o interesse público e a relevância social desta atividade, bem como a necessidade de constante atuação do Estado para sua efetivação.

Destacamos, contudo, na linha de Medauar (2006, p. 314) e Justen (2006, p. 492) que a definição sobre o que é ou não serviço público envolve também a concepção política dominante e os limites da atuação do Estado e da iniciativa privada numa determinada atividade. Nesse sentido, conforme veremos no Capítulo 2 abaixo, em especial com relação à educação superior, é forte a presença da iniciativa privada e a pressão para a aquisição, cada vez maior, de características de serviço privado por essa atividade. 


\section{CAPÍTUlO 2. A EVOLUÇÃO HISTÓRICA E JURÍDICA DA EDUCAÇÃO SUPERIOR NO BRASIL A PARTIR DA CONSTITUIÇÃO DE 1988}

O objetivo deste Capítulo é tratar da evolução histórica e jurídica da educação superior no Brasil, a partir da Constituição de 1988, apresentando as principais alterações constitucionais e legislativas, as políticas públicas adotadas, os principais agentes e fatores sociais, econômicos e políticos que podem ter influenciado a configuração deste nível de ensino nesse período histórico.

A partir da década de 1990, o Estado Brasileiro passou por mudanças políticas, econômicas e sociais. Nesse contexto, o ensino superior brasileiro passou por uma série de transformações, que envolveram um processo acelerado de crescimento do setor privado o número de estabelecimentos privados de ensino superior passou de $696(75,82 \%$ do total), em 1990, para 2.100 (88,3\% do total), em 2010; ao mesmo tempo em que o número de alunos matriculados em instituições de ensino superior privadas cresceu de 961.455 , em 1990 (62,43\% do total), para 4.736 .0001 (74,24\% do total), em 2010 (INEP, 2012b).

Foi nesse período que o ensino privado com fins lucrativos se desenvolveu no Brasil, com a edição de Decretos no ano de 1997 que aprovaram essa forma de oferecimento do ensino superior. Após essa abertura do setor de ensino para instituições com fins lucrativos, veio a profissionalização e a emergência de grandes empresas de educação, algumas de capital aberto, como é o caso da Anhanguera.

Com isso, o ensino superior no Brasil, que tradicionalmente atendia apenas a elite brasileira, passou a ganhar contornos de um sistema de massa, atingindo um grande número de estudantes, muitos oriundos de classes sociais que não tinham acesso ao ensino superior anteriormente. Segundo Sampaio (2000, p. 104), “a passagem de sistemas de elite para sistemas de massa, capazes de absorver um contingente maior de estudantes foi, sem dúvida, a maior transformação do ensino superior neste século".

Conforme destaca Sampaio (2000, p. 105), junto com a expansão do sistema ocorreram mudanças nos currículos e nas formas de instrução - aulas expositivas passaram a substituir seminários para atender a um número maior de alunos; desenvolveu-se o ensino a distância; houve um aumentou no número de alunos em tempo parcial, que conciliam estudo e trabalho. Essas características são notadas na Anhanguera, que é uma 
instituição de massa, cujo público alvo são os jovens trabalhadores, que trabalham durante o dia e estudam à noite e que possui uma das maiores plataformas de ensino à distância do país, conforme será desenvolvido no Capítulo 4 da Dissertação.

Ao longo do período que vamos analisar, selecionamos alguns marcos normativos e também fatores externos que podem ter influenciado as políticas adotadas pelo Estado Brasileiro. Para tratar das questões acima, este Capítulo inicialmente apresenta os fatores externos e, posteriormente, trata dos principais acontecimentos internos, divididos em três períodos: (i) $1^{\circ}$ período - Governos Fernando Collor de Mello (1990-1992) e Itamar Franco (1992-1994); (ii) $2^{\circ}$ período - Governo Fernando Henrique Cardoso (1995-2002); e (iii) $3^{\circ}$ período - Governos Luiz Inácio Lula da Silva (2003-2010) e Dilma Roussef (2011).

Ao final deste Capítulo, apresentamos um quadro geral do ensino superior no Brasil atualmente.

\subsection{Fatores externos}

\subsubsection{Recomendações do Banco Mundial e da Unesco e debates na OMC}

Desde a década de 1980, o Banco Mundial defende a ideia de que a privatização generalizada do ensino propiciaria maior controle da qualidade e também permitiria adaptações regionais e locais, favorecendo a integração entre pais, alunos, professores, administradores, além de estimular o desenvolvimento de novas fontes de financiamento para a educação (RANIERI, 2000, p. 29) ${ }^{102}$.

Em 1995, o Banco Mundial divulgou um documento contendo recomendações sobre educação para os países em desenvolvimento, denominado "La enseñanza superior. Las lecciones derivadas de la experiencia”, elaborado pelo seu Departamento de Educação e Política Social. Com relação aos aspectos econômicos, as recomendações apresentaram postura reducionista com relação ao papel do Estado, propondo uma redefinição de sua atuação na educação superior. Referido documento incentivou modelos de desenvolvimento universitário que visassem à vinculação das instituições com as empresas, à diminuição da atuação do Estado no financiamento das universidades públicas e ao aumento da atuação das instituições privadas na educação superior. Além disso, propôs aos Estados que: (i) fomentassem a maior diferenciação organizacional das

\footnotetext{
${ }^{102}$ Nesse sentido é o documento do Banco Mundial denominado Financing Education in Developing
} Countries: An Exploration of Police Option, publicado em 1986. 
instituições, incluindo o desenvolvimento de instituições privadas; (ii) proporcionassem incentivos para que as instituições públicas diversificassem suas fontes de financiamento; (iii) redefinissem a função do governo em relação ao ensino superior; e (iv) adotassem políticas destinadas a priorizar os objetivos de qualidade e de equidade (BANCO MUNDIAL, 1995, p. 4). O Banco Mundial também recomendou nesse período que os investimentos nacionais fossem direcionados para a educação fundamental.

Sobre a oferta da educação superior privada, o mesmo documento (BANCO MUNDIAL, 1995) afirma que:

As instituições privadas constituem um elemento importante de alguns dos sistemas de educação pos-secundária mais eficazes que existem atualmente no mundo em desenvolvimento. Podem reagir de forma eficiente e flexível diante das transformações da demanda, e ampliam as oportunidades educacionais com pouco ou nenhum custo adicional para o Estado. Os governos podem fomentar o desenvolvimento da educação superior privada a fim de complementar as instituições estatais como meio de controlar os custos do aumento da matrícula na educação superior, incrementar a diversidade dos programas de educação e ampliar a participação social no nível superior ${ }^{103}$.

Em 1995, ocorreram debates entre os países membros da Organização Mundial do Comércio (OMC), acerca da inclusão da educação no Acordo Geral sobre Comércio em Serviços (GATS ou AGCS), assinado em janeiro daquele ano. A aprovação desse acordo possibilitaria a liberalização do mercado de serviços educacionais, o que permitiria a livre circulação da oferta de educação sem limitações nas legislações nacionais, sujeita apenas às regras relativas ao comércio internacional de serviços em geral, incrementando a mercantilização da área e a internacionalização da oferta, com a penetração de grandes grupos multinacionais (OLIVEIRA, 2009, p. 740). A liberalização permitiria superar as barreiras internas para o exercício da educação no País, tanto com relação ao livrecomércio (tributação sobre remessa de lucro e importação de material escolar, por exemplo), como com relação à atividade de ensino propriamente dita e sua regulação no Brasil (necessidade de reconhecimento e revalidação de diplomas, autorização para funcionamento de instituições e avaliação de qualidade de cursos etc. ${ }^{104}$ ) (RANIERI, 2005,

\footnotetext{
103 Tradução livre de: "Las instituciones privadas constituyen un elemento importante de algunos de los sistemas de ensenãnza postsecundaria más eficaces que existen actualmente en el mundo en desarrollo. Pueden reaccionar en forma eficiente y flexible al cambio de la demanda, y amplian las oportunidades educacionales con poco o ningún costo adicional para el Estado. Los gobiernos pueden fomentar el desarrollo de la educación terciaria privada a fin de complementar las instituciones estatales como medio de controlar los costos del aumento de la matrícula de la educación superior, incrementar la diversidad de los programas de ensenãnza y ampliar la participación social en el nivel terciario" (BANCO MUNDIAL, 1995, p. 6).

${ }^{104}$ No entanto, essa liberalização deveria ser incorporada na legislação nacional para poder valer no Brasil,
} 
p. 58).

Para Paulo Speller (2010, p. 21), em termos práticos, isso significaria que:

[...] uma instituição de ensino superior poderia oferecer livremente seus cursos onde bem entendesse como já ocorre através da internet, com plena aceitação da certificação emitida nos países membros da OMC. A regulação e o reconhecimento desses cursos se fariam através de mecanismos de mercado ou de acordos internacionais abrangentes sob a supervisão da própria OMC ou organismos congêneres.

Para Ranieri (2005, p. 61-2), considerar a educação como mercadoria poderia ser danoso para o alcance dos objetivos educacionais do País. Nesse sentido, a autora (2005, p. 61-2) questiona:

Desvinculada a educação do dever de garantir a promoção do indivíduo e do desenvolvimento nacionais, quais são os valores que a informam? Em que medida pode ser garantida, por seu intermédio, a identidade e a cultura nacional? Se no capitalismo contemporâneo o conhecimento e a inovação tecnológicos requerem competitividade e inserção global, como garantir esses fatores com a indiscriminada abertura do "mercado" do ensino superior? Quem produz e detém o conhecimento? Como serão distribuídos os seus benefícios?

Além disso, a a autora (2005, p. 62) destaca que a educação ficaria submetida ao "investimento especulativo e aos interesses mercantis que orientam as iniciativas dos investidores". Com isso, "compromete-se a qualidade da educação (pautada pela relação custo/benefício), a segurança do aluno e dos profissionais de educação (considerando a possibilidade de se encerrarem as atividades da instituição de ensino, devido à falta de rentabilidade do capital) e das próprias instituições de ensino nacionais, diante da competitividade externa”. O que para ela $(2005$, p. 62) não seriam problemas triviais, tanto do ponto de vista do desenvolvimento, como do direito à educação e da proteção aos profissionais do setor.

Dentro das regras do GATS, a liberalização de um determinado mercado nacional de serviços depende da aprovação expressa do Estado-Membro da OMC. Nesse contexto, os países dividiram-se. Um bloco formado por Estados Unidos, Japão, Austrália e Nova Zelândia apresentou propostas a favor da liberalização, e outro, formado sobretudo por países europeus e latino-americanos (entre eles o Brasil) mostrou-se contra (ABREU,

via emenda constitucional ou pela incorporação de um tratado internacional. A esse respeito Ranieri (2000, p. 65) afirma: "a prevalência das normas constitucionais sobre os tratados garante que os serviços educacionais que venham a ser oferecidos no Brasil, por meio de negociações na OMC ou no MERCOSUL, submetam-se à legislação interna e também à autorização e avaliação de qualidade pelo Poder Público, com a ressalva de que as suas regulamentações legal e administrativa estão sujeitas a alteração através de tratados". 
2008, p. 92).

Nesse sentido, a educação não foi incluída no setor de serviços, dentro das regras do GATS para o Brasil. No entanto, na prática, como veremos abaixo, a educação adquiriu contornos de serviço privado no Brasil.

A Unesco, em sua publicação "Higher Education in a Globalized Society", de 2004, afirmou que a inclusão do comércio de serviços de educação nos moldes do GATS era uma realidade que não se modificaria, cabendo a cada Estado determinar em que medida permitiria que provedores estrangeiros de serviços de educação teriam acesso ao seu mercado interno.

Destaca-se também que, a partir de 1997, a International Finance Corporation (IFC), maior agência de desenvolvimento do mundo, braço do Banco Mundial para estímulo do setor privado em países em desenvolvimento, fez estudos sobre a educação privada em países em desenvolvimento (v.g. Investment Opportunities in Private Schools and Universities in Developing Countries). Segundo James Tooley (2001, p. 32), a IFC "ficou interessada em se tornar ativa na infraestrutura social de áreas como saúde e educação, baseada na sua percepção dos benefícios muito importantes que seriam obtidos desses setores ${ }^{105}$ ". Em estudo financiado pela IFC, Tooley (2001, p. 41) sugeriu que essa agência investivesse em grandes empresas de educação em países em desenvolvimento, que não atendessem apenas a elite, mas também uma grande variedade de grupos sociais.

De acordo com Tooley (2001, p. 43), a IFC tinha interesse em investir em companhias que preenchessem as seguintes características: (i) que fossem lucrativas; (ii) que fossem financiadas totalmente (ou na sua grande parte) pelas mensalidades pagas pelos estudantes; (iii) que cobrassem comparativamente mensalidades modestas e que, por isso, fossem acessíveis para muitos grupos socioeconômicos e não apenas para a elite.

Nesse sentido, a IFC passou a financiar empresas privadas de educação superior de massa, como a Anhanguera, conforme será descrito no Capítulo 4 desta Dissertação.

Romualdo Portela de Oliveira (2006, p. 4) entende que a agenda internacional não determinou as políticas educacionais brasileiras das últimas décadas. Segundo o autor (2006, p. 4-5):

Ainda que as reformas empreendidas ao longo dos anos 1990, adentrando aos dias atuais, pautem-se por uma agenda mundializada, em cada país sua concretização se dá com

${ }^{105}$ Tradução livre de "It had become interested in becoming active in social infrastructure areas such as health and education, based on its perception of the very important developmental benefits to be had from these sectors" (TOOLEY, 2001, p. 32). 
diferenças, em ênfase e amplitude, decorrentes de história e trajetória específicas. Dessa forma, pela natureza e expressão da economia brasileira, ainda que as agências internacionais sejam um agente importante, longe estão de serem os determinantes dos resultados das políticas efetivamente implementadas.

Nesse sentido, Oliveira (2006, p. 4-5), cita o exemplo do ensino superior - segundo o autor, há mais de quatro décadas, agências internacionais recomendam a cobrança de anuidades em universidades públicas. Nem por isso, o Brasil instituiu essa cobrança. Outros países, vários da América Latina, no entanto, instituíram a cobrança de anuidades no ensino superior público.

Para Oliveira (2006, p. 89), combater algumas propostas de organismos internacionais como o Banco Mundial, como a priorização no ensino fundamental, pode colocar seus críticos numa posição conservadora:

\footnotetext{
Um exemplo disso é a crítica à proposição do Banco Mundial de priorização do Ensino Fundamental. Opor-se a ela significaria desconsiderar a luta de gerações de brasileiros pela universalização dessa etapa da Educação Básica. Não basta ser contra as "novas" propostas sem enfrentar os problemas que lhes deram origem, caso contrário, seus críticos podem vir a ser identificados com a situação anteriormente vigente, de modo algum defensável.
}

No Brasil, o que se verificou nas últimas décadas foi a priorização da universalização do ensino fundamental, o aumento do acesso ao ensino médio e superior, o aumento da participação privada no ensino superior e a diferenciação organizacional das instituições que o compõem. Houve também a internacionalização do setor educacional, com o ingresso de investidores estrangeiros via aquisição de participação societária em grupos de educação brasileiros (como é o caso da Anhanguera) abertos ou fechados. Nesse contexto, o mercado educacional brasileiro tornou-se um dos mais atrativos do mundo, com a movimentação de um grande volume de recursos. Esses temas serão desenvolvidos neste Capítulo.

\subsubsection{Compromissos internacionais para a universalização da educação básica}

No plano internacional, a partir da década de 1960 teve início um movimento de especialização e diferenciação da proteção internacional dos direitos humanos. Nesse contexto, os seguintes tratados internacionais para a proteção do direito à educação foram assinados e ratificados pelo Estado Brasileiro ${ }^{106}$ : (i) Convenção Relativa à Luta Contra a

${ }^{106}$ Observe-se que a maioria desses instrumentos apenas foi ratificada pelo Estado Brasileiro na década de 
Discriminação no Campo do Ensino, adotada em 14 de dezembro de 1960 pela Conferência Geral da Unesco, e ratificada pelo Estado Brasileiro em 19 de abril de 1968; (ii) Convenção Internacional para a Eliminação de todas as Formas de Discriminação Racial, adotada pela Assembleia Geral da ONU em 21 de dezembro de 1965 e ratificada pelo Estado Brasileiro em 27 de março de 1968; (iii) Pidesc adotado pela Assembleia Geral da ONU em 16 de dezembro de 1966 e ratificado pelo Estado Brasileiro em 24 de janeiro de 1992; (iv) Convenção sobre a Eliminação de todas as Formas de Discriminação contra a Mulher, adotada pela Assembleia Geral da ONU em 18 de dezembro de 1979 e ratificada pelo Estado Brasileiro em $1^{\circ}$ de Fevereiro 1984; (v) Convenção sobre os Direitos da Criança, adotada pela Assembleia Geral da ONU em 20 de novembro de 1989 e ratificada pelo Estado Brasileiro em 24 de setembro de $1990^{107}$; e (vi) Convenção sobre os Direitos dos Deficientes, adotada pela Assembleia Geral da ONU em 13 de dezembro de 2006 e ratificada pelo Estado Brasileiro em 01 de agosto de 2008.

Os instrumentos acima mencionados contribuíram para o desenvolvimento do direito à educação no Brasil e, nesse sentido, muitas de suas disposições foram incorporadas ao direito pátrio, seja na Constituição de 1988, seja no Estatuto da Criança e do Adolescente de 1990 (ECA) e na Lei de Diretrizes e Bases de 1996 (LDB). O controle do cumprimento das obrigações assumidas por meio desses tratados é feito, principalmente, pelo sistema convencional (na modalidade não-contenciosa, na forma de relatórios periódicos) e pelo sistema extraconvencional ${ }^{108}$.

Nesse período, o Brasil assinou também alguns compromissos internacionais para a efetivação do direito à educação, em especial, buscando a universalização da educação básica. No ano de 1998, Estados-membros da ONU assinaram o programa Educação para Todos - EPT (Resolução A/RES/52/84 da Assembleia Geral da ONU). Este programa é resultado da Conferência Mundial Educação para Todos, realizada pela Unesco, em Jomtien, no ano de $1990^{109}$, na qual os Estados assumiram o compromisso de expandir as oportunidades educacionais para crianças, jovens e adultos, com o estabelecimento de

1990, no período de redemocratização.

${ }^{107}$ O Brasil ratificou também os seguintes documentos adicionais a esta Convenção: (i) Emenda ao artigo 43 (2) da Convenção sobre os Direitos da Criança - o Brasil aceitou a emenda em 26/02/1998; (ii) Protocolo Opcional à Convenção sobre os Direitos da Criança sobre o envolvimento das crianças em conflitos armados - ratificado pelo Brasil em 27/01/2004; (iii) Protocolo Opcional à Convenção dos Direitos da Criança sobre a Venda de Crianças, Prostituição e Pornografia Infantil - aprovado pelo Decreto $n^{\circ}$ 5.007, de 03/2004.

${ }^{108}$ Sobre este tema, vide o seguinte artigo de minha autoria: MORETTI, Denise Martins. A responsabilidade internacional do Estado Brasileiro por violações do direito à educação a partir do sistema global de proteção dos direitos humanos. Revista Digital de Direito Público, Ribeirão Preto, v. 1, n. 1, 2012, p. 30-59. Disponível em: <www.direitorp.usp.br/periodicos $>$.

${ }^{109}$ Nessa ocasião foi assinada a Declaração Educação para Todos de 1990. 
objetivos e metas para o ano 2000. Passados dez anos dessa Conferência, realizou-se em Dacar, Senegal, em abril de 2000, o Fórum de Educação para Todos, com a presença de representantes de 164 países, para a discussão dos progressos realizados desde 1990. Verificou-se nessa ocasião que a agenda do EPT havia sido negligenciada por muitos países e, então, novo compromisso foi firmado (Compromisso de Dacar), com o estabelecimento de seis metas a serem cumpridas pelos países signatários: (i) "ampliar e aperfeiçoar os cuidados e a educação para a primeira infância, especialmente no caso das crianças mais vulneráveis e em situação de maior carência"; (ii) "assegurar que, até 2015, todas as crianças, particularmente as meninas, vivendo em circunstâncias difíceis e as pertencentes a minorias étnicas, tenham acesso ao ensino primário gratuito, obrigatório e de boa qualidade"; (iii) "assegurar que sejam atendidas as necessidades de aprendizado de todos os jovens e adultos através de acesso equitativo a programas apropriados de aprendizagem e de treinamento para a vida"; (iv) "alcançar, até 2015, uma melhoria de $50 \%$ nos níveis de alfabetização de adultos, especialmente no que se refere às mulheres, bem como acesso equitativo à educação básica e contínua para todos os adultos"; (v) “eliminar, até 2005, as disparidades de gênero no ensino primário e secundário, alcançando, em 2015, igualdade de gêneros na educação, visando principalmente garantir que as meninas tenham acesso pleno e igualitário, bem como bom desempenho, no ensino primário de boa qualidade"; e (vi) "melhorar todos os aspectos da qualidade da educação e assegurar a excelência de todos, de forma que resultados de aprendizagem reconhecidos e mensuráveis sejam alcançados por todos, especialmente em alfabetização linguística e matemática e na capacitação essencial para a vida" (UNESCO, 2008, p. 7-10).

O Relatório de Monitoramento Global EPT de 2010 destacou que (i) a qualidade da educação no Brasil é baixa, principalmente no ensino básico; (ii) apesar da melhora apresentada entre 1999 e 2007, o índice de repetência no ensino fundamental brasileiro $(18,7 \%)$ era o mais elevado na América Latina e ficava expressivamente acima da média mundial (2,9\%); (iii) o alto índice de abandono nos primeiros anos de educação alimenta a fragilidade do sistema educacional do Brasil (cerca de 13,8\% dos brasileiros largam os estudos já no primeiro ano no ensino básico). Na avaliação da Unesco, o Brasil poderia estar em uma situação melhor se não fosse a baixa qualidade do seu ensino, pois das quatro metas quantificáveis ${ }^{110}$ usadas pela organização, o País registra altos índices em três

\footnotetext{
${ }^{110} \mathrm{O}$ acompanhamento do cumprimento das metas do EPT é feito a partir de parâmetros comuns, que compõem o Índice de Desenvolvimento da Educação para Todos (IDE). Referido índice é formado por quatro indicadores quantitativos: (i) universalização da educação primária; (ii) alfabetização de adultos; (iii)
} 
(atendimento universal, igualdade de gênero e analfabetismo), mas um indicador muito baixo no percentual de crianças que ultrapassa o $5^{\circ}$ ano ${ }^{111}$.

No ano 2000, o Brasil e mais 189 países, reunidos durante a Cúpula do Milênio promovida pela ONU, assinaram a Declaração do Milênio, que estabeleceu uma série de compromissos visando eliminar a extrema pobreza e a fome do planeta até 2015. Para tanto, foram acordados oito objetivos, chamados de Objetivos de Desenvolvimento do Milênio $(\mathrm{ODM})^{112}$, dentre os quais dois se referem ao tema da educação: (i) ODM 2 universalização da educação primária (garantir que todas as crianças, de ambos os sexos, de todas as regiões do País, independentemente da cor, raça e sexo, terminem o ensino fundamental); e (ii) ODM 3 - paridade de gênero (eliminar a disparidade de gênero na educação primária e secundária, preferencialmente até 2005, e em todos os níveis de ensino até 2015).

Tanto o programa EPT como os ODM demonstram a preocupação da comunidade internacional com a efetivação do direito à educação, e que avanços nessa área dependem da atuação dos Estados. Nesse sentido, o estabelecimento de metas e o monitoramento dos Estados por órgãos internacionais podem auxiliar as políticas internas desses países, sinalizando as áreas em que os esforços devem se concentrar, contribuindo, assim, para a efetivação desses direitos.

\section{$2.2 \quad 1^{0}$ período - Governos Fernando Collor de Mello (1990-1992) e Itamar Franco (1992-1994)}

Antes de tratarmos dos Governos Fernando Collor de Mello e Itamar Franco, vamos apresentar um breve panorama do desenvolvimento da educação superior no

paridade de gêneros; e (iv) qualidade da educação. De acordo com o Relatório de Monitoramento EPT Brasil de 2008, com relação à meta da universalização da educação primária, encontra-se no Quadrante I (alta chance de atingir as metas até 2015) (UNESCO, 2008, p. 20); com relação à alfabetização de adultos, situa-se no Quadrante III (em risco de não alcançar o objetivo até 2015) (UNESCO, 2008, p. 21); com relação à paridade de gênero, o Brasil está em risco de não alcançar até 2015, com probabilidade de alcançar até 2025 (UNESCO, 2008, p. 23); e por fim, com relação à qualidade, o relatório esclarece que, sobre algumas de suas dimensões (resultados em avaliações nacionais e internacionais, condições para o ensino e aprendizagem, quantidade e qualidade dos professores), é difícil fazer projeções, e que as melhoras nesse campo dependem do crescimento econômico e dos recursos governamentais (UNESCO, 2008, p. 24).

${ }^{111}$ Disponível em: $<$ http://www.estadao.com.br/noticias/suplementos,qualidade-da-educacao-no-brasil-aindae-baixa-aponta-unesco,498175,0.shtm>. Acesso em 14/12/2010.

${ }^{112}$ Para cada um dos objetivos foram estabelecidas metas, sendo 18 no total. Os demais ODMs são: (i) ODM 1 - erradicar a pobreza extrema e a fome; (ii) ODM 4 - reduzir a mortalidade na infância; (iii) ODM 5 melhorar a saúde materna; (iv) ODM 6 - combater o HIV/Aids, Malária e outras doenças; (v) ODM 7 garantir a sustentabilidade ambiental; (vi) ODM 8 - estabelecer uma parceria mundial para o desenvolvimento. Disponível em: <http://www.pnud.org.br/odm/>. Acesso em: 14/12/2010. 
período que os antecedeu.

\subsubsection{Antecedentes históricos: breve panorama da educação superior durante a ditadura militar}

Até as reformas ocorridas na década de 1990, o eixo normativo que tratava da educação superior no Brasil girava em torno da Constituição de 1967 e da Emenda Constitucional $n^{0} 1$ de 1969, da Lei de Diretrizes e Bases da Educação de 1961 (Lei no 4.024, de 20/12/1961) e da Lei de Reforma Universitária de 1968 (Lei $\mathrm{n}^{\circ}$ 5.540, de 28/11/1968). Esses referenciais normativos estabeleceram as bases que permitiram que o ensino superior brasileiro alcançasse sua estrutura atual, fortemente concentrada no setor privado, que predomina em número de vagas, matrículas e instituições.

A Constituição de 1967, de cunho autoritário, ampliou os anos de ensino primário nos estabelecimentos oficiais (que passou a ser dos 7 aos 14 anos), estabeleceu a gratuidade do ensino oficial posterior ao primário, para os que não tivessem recursos e demonstrassem aproveitamento e previu que, sempre que possível, o Poder Público deveria substituir o regime de gratuidade pelo de concessão de bolsas de estudo, exigido o posterior reembolso no caso de ensino de grau superior (art. 168, Parágrafo $3^{\circ}$, II e IIII). Um retrocesso desta Constituição foi não estabelecer percentuais mínimos de aplicação da renda dos impostos da União, Estados, Distrito Federal e Municípios na educação, previsão constante nas Constituições de 1934 e $1946^{113}$. A referida Constituição limitou-se a prever, genericamente, que a União deveria "prestar assistência técnica e financeira para o desenvolvimento dos sistemas de ensino dos Estados e do Distrito Federal" (art. 169, Parágrafo $1^{\circ}$ ).

A Lei $\mathrm{n}^{\mathrm{o}} 5.540 / 68$ propôs uma reforma profunda do ensino superior brasileiro, e entre outras medidas: (i) aboliu a cátedra e instituiu os departamentos como unidades mínimas de ensino e pesquisa (art. 33); (ii) previu cursos de formação profissional (art. $1^{\circ}$, art. 23); (iii) fixou a indissociabilidade entre pesquisa e ensino e o seu oferecimento preferencial por universidades (art. $2^{\circ}$ ); (iv) estabeleceu que as universidades e escolas isoladas, quando oficiais, seriam constituídas sob a forma de autarquias de regime especial

\footnotetext{
113 Artigo 156, Constituição de 1934 - A União e os Municipios applicarão nunca menos de dez por cento, e os Estados e o Districto Federal nunca menos de vinte por cento, da renda resultante dos impostos na manutenção e no desenvolvimento dos systemas educativos. Artigo 169, Constituição de 1946 - Anualmente, a União aplicará nunca menos de dez por cento, e os Estados, o Distrito Federal e os Municípios nunca menos de vinte por cento da renda resultante dos impostos na manutenção e desenvolvimento do ensino.
} 
ou fundações de direito público e, quando particulares, na forma de fundações ou associações (art. $\left.4^{\circ}\right)$.

Nesse sentido, a referida lei estruturou o sistema em torno das universidades de pesquisa e não permitiu a prestação do ensino superior privado por instituições com fins lucrativos. Em vista dessa restrição, as instituições privadas gozavam de subsídios e isenções de impostos que lhes permitiam condições favoráveis de funcionamento (OLIVEIRA, 2005, p. 155).

Os anos 60 podem ser resumidos como anos de repressão e expansão do sistema de ensino superior. Para atender a demanda por ensino superior no período, o governo militar atuou de duas maneiras: (i) com a ampliação das vagas do ensino público; e (ii) com o estímulo à expansão do setor privado (SAMPAIO, 1991, p. 16).

Para Ranieri (2000, p. 52), a estratégia foi de ampliação de vagas sem o ônus dos investimentos públicos substanciais, e com isso:

Tal política permitiu o acesso de vastas camadas da classe média ao ensino universitário, atendendo-se às suas expectativas e demandas, ao mesmo tempo em que se desonerava o Estado de oferecê-lo diretamente. O caráter empresarial de muitas escolas particulares (à exceção das confessionais), entretanto, determinou um perfil de ensino menos exigente do que o oferecido nas escolas públicas, que à época absorvia docentes em regime de dedicação exclusiva.

Para Ranieri (2000, p. 53), as consequências desse ciclo foram: falta de qualidade, desajuste em relação ao setor produtivo, rigidez curricular e financiamento escasso, que criaram pontos de estrangulamento no ensino superior, que permaneceram presentes nas décadas de 1980 e 1990.

Em cerca de 30 anos, o número de matrículas no ensino superior cresceu de 98.892, em 1961, para 1.540.080, em 1990, e o ensino privado passou de 44\% das matrículas em 1961 para $62,42 \%$ em 1990, conforme dados abaixo: 
Tabela 1 - Evolução no número de matrículas de instituições privadas - Brasil 1961-1980

\begin{tabular}{c|c|c|c}
\hline Ano & Total de matrículas & $\begin{array}{c}\text { Matrículas instituições } \\
\text { privadas }\end{array}$ & $\begin{array}{c}\text { Matrículas privadas } \\
(\%)\end{array}$ \\
\hline 1961 & 98.892 & 43.560 & $44 \%$ \\
1964 & 142.386 & 54.721 & $38,4 \%$ \\
1968 & 278.205 & 124.496 & $44,7 \%$ \\
1970 & 425.478 & 214.865 & $50,5 \%$ \\
1971 & 561.397 & 309.134 & $55,1 \%$ \\
1975 & 1.072 .548 & 662.323 & $61,8 \%$ \\
1980 & 1.377 .286 & 885.054 & $64,26 \%$ \\
1985 & 1.367 .609 & 810.929 & $59,29 \%$ \\
1990 & 1.540 .080 & 961.455 & $62,42 \%$ \\
\hline Fonte: Levy $^{114}(1990$, apud SAMPAIO, 1991, p. 16); Inep (1999) e IBGE (2006)
\end{tabular}

Pelos dados da tabela, nota-se que o número de matrículas no ensino superior, em toda a década de 1960, aumentou quatro vezes. Durante a década de 1970, esse número triplicou. Na década de 1980, o ritmo de crescimento diminuiu. No ano de 1990 é alcançado o patamar de mais de 1,5 milhão de matrículas.

\subsubsection{Governos Fernando Collor de Mello e Itamar Franco}

O principal marco normativo do governo de Fernando Collor de Mello e dos demais períodos a serem tratados nesta Dissertação é a Constituição de 1988.

Não repetiremos aqui o tratamento constitucional do direito à educação desenvolvido no Capítulo 1 desta Dissertação. No entanto, cabe aqui resgatar alguns aspectos da Constituição de 1988, que influenciaram as políticas para o ensino superior adotadas a partir da década de 1990:

(i) o reconhecimento constitucional da autonomia universitária (art. 207) estimulou, no período imediatamente posterior a Constituição de 1988, um crescimento significativo no número de universidades privadas. Muitas instituições isoladas foram transformadas em universidades visando os benefícios da autonomia universitária, o que favoreceu também a iniciativa privada pela possibilidade de abrir e fechar cursos de acordo com a demanda ${ }^{116}$. Posteriormente, com a aprovação da LDB em 1996, foi também

\footnotetext{
${ }^{114}$ LEVY, Daniel. Higher Education and the State in Latin America. Chicago: The University of Chicago Press, 1990.

${ }^{115}$ Dados sobre o número total de matrículas em 1968 e 1970 extraídos de IBGE (2006). Os dados de 1980, 1985 e 1990 extraídos de Inep (1999). Os demais dados são de Levy (1990, apud SAMPAIO, 1991). Não localizamos dados consolidados de uma única fonte.

${ }^{116}$ Para Sampaio (2000, p. 77), "ao disciplinar o princípio da autonomia para as universidades, tanto públicas
} 
conferida autonomia universitária aos centros universitários, nova forma de organização acadêmica, que surgiu como uma boa alternativa de atuação para o setor privado. Estes assuntos serão desenvolvidos nos itens 2.3 .1 e 2.6 a seguir;

(ii) a manutenção da indissociabilidade entre ensino, pesquisa e extensão como exigência apenas para as universidades (art. 207) atendeu aos interesses do setor privado que poderia continuar a manter estabelecimentos isolados que não precisam cumprir com essa determinação constitucional, que requer altos altos investimentos, com retorno não previsível;

(iii) a previsão do estabelecimento de um Plano Nacional de Educação, de duração decenal (art. 214), foi muito positivo para o desenvolvimento da educação no País. O primeiro Plano Nacional de Educação foi aprovado em 2001 e, atualmente, encontra-se em fase de elaboração um novo plano, conforme será tratado no item 2.3.5 a seguir;

(iv) a Constituição de 1988 estimulou o debate para a elaboração de uma nova lei de diretrizes e bases para a educação nacional, que foi promulgada em 1996 e cujas principais disposições serão apresentadas no item 2.3.1 a seguir; e

(v) a Constituição de 1988 previu deveres do Estado com relação à obrigatoriedade, gratuidade e universalização da educação (art. 208), tornando o ensino obrigatório e gratuito um direito público subjetivo (art. 208, Parágrafo $1^{\circ}$ ). Emendas Constitucionais posteriores aumentaram progressivamente as obrigações do Estado com relação à educação, culminando na obrigação de "progressiva universalização do ensino médio gratuito" (art. 208, II, redação dada pela EC n 14/1996) e de "educação básica obrigatória e gratuita dos 4 (quatro) aos 17 (dezessete) anos de idade, assegurada inclusive sua oferta gratuita para todos os que a ela não tiveram acesso na idade própria” (art. 208, I, redação dada pela $\mathrm{EC} \mathrm{n}^{\circ}$ 59/2009). Com base nesses dispositivos constitucionais, houve um esforço nacional para a universalização do ensino fundamental e, posteriormente, para a universalização do ensino médio. O aumento do acesso à educação nos níveis inferiores

quanto particulares, a Constituição criou instrumento que abriu ao setor privado a possibilidade de se libertar do controle burocrático do Conselho Federal de Educação. Com a LDB de 1996, a autonomia atribuiu às universidades a competência para criar e extinguir cursos na própria sede e remanejar o número de vagas dos cursos que oferecem. Dispondo dessa prerrogativa da autonomia, os estabelecimentos particulares podem responder, de forma mais ágil, ao atendimento da demanda de massa por ensino superior. Na prática significa fechar cursos menos procurados, abrir outros com maior capacidade de atrair a clientela, alterar o número de vagas oferecidas de acordo com as oscilações das matrículas e da evasão, entre outras providências; decisões dessa natureza de ajuste ao mercado podem ser aplicadas sem serem submetidas à tramitação burocrática por que passam os pleitos de autorização de cursos encaminhados pelas instituições não universitárias. Nesse sentido, ao outorgar autonomia às universidades, a Constituição Federal de 1988 e, posteriormente, a LDB de 1996, forneceram um instrumento que vem ao encontro do caráter dinâmico, característico de um setor privado de massa em se amoldar à demanda, e intensificou o movimento dos estabelecimentos privados em se transformarem em universidades". 
teve reflexos no ensino superior, que apresentou um número muito maior de ingressantes e concluintes.

O governo do Presidente Fernando Collor de Mello, primeiro civil eleito diretamente depois de 20 anos de ditadura militar, teve duração breve. Após denúncias de corrupção, foi destituído de seu cargo em 1992 por um processo de impeachment, por decisão do Congresso Nacional, apoiada pela população brasileira.

No seu pequeno período de governo, foi aprovado o Programa Nacional de Desestatização (Lei $n^{\circ} 8.031$, de 12/04/1990), que tinha como objetivos fundamentais (art. $1^{\circ}$ ): (i) "reordenar a posição estratégica do Estado na economia, transferindo à iniciativa privada atividades indevidamente exploradas pelo setor público" (inciso I); (ii) "contribuir para a redução da dívida pública, concorrendo para o saneamento das finanças do setor público" (inciso II); (iii) "permitir a retomada de investimentos nas empresas e atividades que vierem a ser transferidas à iniciativa privada" (inciso III); (iv) "contribuir para modernização do parque industrial do País, ampliando sua competitividade e reforçando a capacidade empresarial nos diversos setores da economia" (inciso IV); (v) "permitir que a administração pública concentre seus esforços nas atividades em que a presença do Estado seja fundamental para a consecução das prioridades nacionais" (inciso V); e (vi) “contribuir para o fortalecimento do mercado de capitais, através do acréscimo da oferta de valores mobiliários e da democratização da propriedade do capital das empresas que integrarem o Programa" (inciso VI).

Com base nesse Programa, o Estado Brasileiro diminuiu sua esfera de atuação, e muitas empresas estatais foram privatizadas, mediante a transferência de seu controle para a iniciativa privada.

Após o processo de impeachment, o governo foi assumido, a partir de 1992, pelo vice de Fernando Collor de Melo, Itamar Franco, que encampou uma política de estabilização financeira por meio do Plano Real, articulado pelo Ministro da Fazenda na época, Fernando Henrique Cardoso.

Com relação ao ensino superior, o governo Itamar Franco lançou em 1993 o Programa de Avaliação Institucional das Universidades Brasileiras (Paiub). O Paiub sustentava-se no princípio da adesão voluntária das universidades e concebia a autoavaliação como etapa inicial de um processo que se estendia a toda a instituição e se completava com a avaliação externa (INEP, 2004, p. 19). O Paiub iniciou a prática de avaliação das instituições de ensino superior, com relação à graduação, o que foi desenvolvido no governo Fernando Henrique Cardoso, conforme descrito abaixo. 


\section{$2.3 \quad 2^{0}$ período - Governo Fernando Henrique Cardoso (1995-2002)}

Fernando Henrique Cardoso, ex-ministro da Fazenda do Presidente Itamar Franco, impulsionado pelo sucesso do Plano Real, foi eleito Presidente da República em 1995, reeleito em 1998, permanecendo no poder até 2002.

No seu primeiro ano de governo (1995), o Presidente Fernando Henrique Cardoso aprovou o Plano Diretor da Reforma do Aparelho do Estado Brasileiro. O referido plano, entre outras medidas visando a redefinição do papel do Estado Brasileiro ${ }^{117}$, previa:

(ii) a transferência para o setor privado das atividades que podem ser controladas pelo mercado ${ }^{119}$;

(iii) a transferência para o setor público não-estatal dos serviços de educação, com a transformação das universidades públicas em organizações sociais, que celebram contratos de gestão com o poder público ${ }^{120}$;

${ }^{117}$ O referido plano previa a reforma do Estado e do aparelho do Estado brasileiro, afirmando que "a reforma do Estado é um projeto amplo que diz respeito às varias áreas do governo e, ainda, ao conjunto da sociedade brasileira, enquanto que a reforma do aparelho do Estado tem um escopo mais restrito: está orientada para tornar a administração pública mais eficiente e mais voltada para a cidadania (BRASIL, 1995, p. 12). Sobre a reforma do Estado dizia: "a reforma do Estado deve ser entendida dentro do contexto da redefinição do papel do Estado, que deixa de ser o responsável direto pelo desenvolvimento econômico e social pela via da produção de bens e serviços, para fortalecer-se na função de promotor e regulador desse desenvolvimento" (BRASIL, 1995, p. 12).

118 "SERVIÇOS NÃO EXCLUSIVOS. Corresponde ao setor onde o Estado atua simultaneamente com outras organizações públicas não-estatais e privadas. As instituições desse setor não possuem o poder de Estado. Este, entretanto, está presente porque os serviços envolvem direitos humanos fundamentais, como os da educação e da saúde, ou porque possuem "economias externas" relevantes, na medida que produzem ganhos que não podem ser apropriados por esses serviços através do mercado. As economias produzidas imediatamente se espalham para o resto da sociedade, não podendo ser transformadas em lucros. São exemplos deste setor: as universidades, os hospitais, os centros de pesquisa e os museus". (BRASIL, 1995, p. 41-42). Sobre a inclusão da educação no setor de serviços não exclusivos do Estado, Ranieri (2000, p. 237) afirma: "por essas razões, acompanhando a nomenclatura adotada no Plano Diretor da Reforma do Aparelho do Estado (BRASIL, 1995), as universidades públicas devem integrar o 'núcleo estratégico' do Estado, e não o setor de 'serviços não-exclusivos', como ali proposto. Como poderia um país em desenvolvimento ter fora de seu núcleo estratégico as instituições às quais delegou a missão de produzir e transmitir conhecimentos”.

119 “(...) reformar o Estado significa transferir para o setor privado as atividades que podem ser controladas pelo mercado. Daí a generalização dos processos de privatização de empresas estatais." (BRASIL, 1995, p. 12).

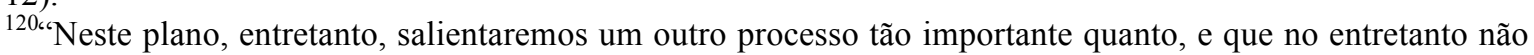
está tão claro: a descentralização para o setor público não-estatal da execução de serviços que não envolvem o exercício do poder de Estado, mas devem ser subsidiados pelo Estado, como é o caso dos serviços de educação, saúde, cultura e pesquisa científica. Chamaremos a esse processo de "publicização" (BRASIL, 1995, p. 12-13). "Transferir para o setor publico não-estatal estes serviços, através de um programa de "publicização", transformando as atuais fundações públicas em organizações sociais, ou seja, em entidades de direito privado, sem fins lucrativos, que tenham autorização específica do poder legislativo para celebrar contrato de gestão com o poder executivo e assim ter direito a dotação orçamentária" (BRASIL, 2995, p. 4647). 
(iv) a redução do papel do Estado como executor ou prestador direto de serviços de educação e outros serviços sociais, mantendo sua atuação como regulador, provedor ou promotor desses serviços ${ }^{121}$; e

(v) o atendimento do cidadão-cliente com eficiência, qualidade e custo menor $^{122}$.

O Plano previa que essas medidas deveriam ser implementadas mediante a atuação do governo em três dimensões: (i) institucional-legal, mediante a reforma do sistema jurídico e das relações de propriedade; (ii) cultural, mediante a transição de uma cultura burocrática para uma cultura gerencial; e (iii) gestão pública, por meio da introdução de uma administração gerencial, com a modernização da estrutura organizacional e os métodos de gestão (BRASIL, 1995, p. 48).

Com relação à primeira dimensão (institucional-legal), durante o governo Fernando Henrique Cardoso, foram aprovadas leis e emendas constitucionais que implicaram alterações significativas na educação brasileira, entre elas, (i) a LDB e os Decretos $\mathrm{n}^{\mathrm{o}} \mathrm{s}$ 2.207, de 15/04/1997 e 2.306, de 19/08/1997; (ii) a Emenda Constitucional no 14 de 1996, que criou o Fundo de Manutenção e Desenvolvimento do Ensino Fundamental (Fundef); (iii) a Lei $n^{\circ}$ 9.131, de 24/11/1995, que tratou da avaliação de cursos e instituições de ensino superior; (iv) o Plano Nacional de Educação (Lei no 10.172, de 09/01/2001) (PNE); (v) a Lei do Bolsa Escola (Lei ${ }^{\circ} 10.219$, de 11/04/2001); e (vi) a Lei do Fundo de Financiamento do Estudante do Ensino Superior (Lei no 10.260, de 12/07/2001) (Fies), que serão desenvolvidos nos itens a seguir. Referidas leis e emendas constitucionais buscaram também a diversificação do sistema de ensino superior brasileiro para o atendimento de um maior número de estudantes, o que foi obtido pela atuação do setor privado, principalmente. Com isso, construiu-se um sistema de massa. A esse respeito, Dourado,

121 "Deste modo o Estado reduz seu papel de executor ou prestador direto de serviços, mantendo-se entretanto no papel de regulador e provedor ou promotor destes, principalmente dos serviços sociais como educação e saúde, que são essenciais para o desenvolvimento, na medida em que envolvem investimento em capital humano; para a democracia, na medida em que promovem cidadãos; e para uma distribuição de renda mais justa, que o mercado é incapaz de garantir, dada a oferta muito superior à demanda de mão-de-obra nãoespecializada. Como promotor desses serviços o Estado continuará a subsidiá-los, buscando, ao mesmo tempo, o controle social direto e a participação da sociedade. Nesta nova perspectiva, busca-se o fortalecimento das funções de regulação e de coordenação do Estado, particularmente no nível federal, e a progressiva descentralização vertical, para os níveis estadual e municipal, das funções executivas no campo da prestação de serviços sociais e de infra-estrutura". (BRASIL, 1995, p. 13).

122 "Aumentar, assim, a eficiência e a qualidade dos serviços, atendendo melhor o cidadão-cliente a um custo menor" (BRASIL, 1995, p. 47). Para Ranieri (2000, p. 157), a "inserção constitucional de novas atribuições regulamentares para o Poder Executivo, claramente vinculadas ao princípio da eficiência (artigo 37, caput), promove a emergência de um Estado regulador forte, que tende a atuar mediante padrões gerenciais, baseados na economia de mercado, e que se volta mais ao controle de resultados que ao controle dos processos". 
Oliveira e Catani (2003, p. 22) afirmam:

[...] particularmente no governo $\mathrm{FHC}$, a diversificação e a diferenciação do sistema de educação superior foi adotada como política visando à expansão da educação superior em função da demanda crescente de vagas, por meio de mecanismos que objetivam a massificação desse nível de ensino. A expansão do sistema, bem como a integração dos diferentes procedimentos de avaliação, credenciamento e recredenciamento, visando a produzir um sistema baseado na flexibilidade, competitividade, diferenciação e avaliação, balizam as políticas adotadas pelo Ministério da Educação (MEC) no campo da educação superior.

As alterações constitucionais e legislativas tiveram como consequência a focalização dos gastos públicos na universalização do ensino fundamental, a expansão gradativa do ensino médio e do ensino superior e o aumento da participação privada no ensino superior - ao final dos oito anos de governo de Fernando Henrique Cardoso, o setor privado aumentou sua participação nas matrículas de 970.584 (58,43\%) em 1994 para 2.428.258 (69,78\%) em 2002. Esses assuntos serão desenvolvidos abaixo.

\subsubsection{A LDB e os Decretos $n^{o s} 2.207 / 97$ e 2.306/97}

A LDB, Lei $\mathrm{n}^{\mathrm{o}}$ 9.394, de 20/12/1996, também conhecida como Lei Darcy Ribeiro $^{123}$, é a principal lei regulamentadora do direito à educação no Brasil.

Referida lei revogou (i) a Lei $n^{0} 4.024 / 61$ (antiga Lei de Diretrizes e Bases Nacional), com exceção dos artigos $6^{\circ}$ ao $9^{\circ}$, alterados pela Lei $n^{\circ} 9.131 / 95$; e (ii) a Lei $n^{\circ}$ 5.540/68 (Lei da Reforma Universitária), com exceção do artigo 16, alterado pela Lei $\mathrm{n}^{\circ}$ 9.192/95.

Para Ranieri (2000, p. 25), a LDB é:

[...] "inovadora e modernizadora", rompendo com prescrições rígidas da legislação anterior e buscando descentralização e controle das atividades, financiamento da educação pública, competências normativas e executivas nos diversos sistemas de ensino, regime jurídico das instituições públicas e sua autonomia frente aos governos mantenedores.

Após a sanção da LDB, o setor privado do ensino superior ganhou um impulso no seu crescimento. Nesse sentido, a LDB é vista como uma lei que favoreceu o crescimento do setor privado no Brasil. A própria Anhanguera (2012d) reconhece este fato:

${ }^{123}$ A LDB foi votada em 17 de dezembro de 1996, na Câmara de Deputados, e alcançou em sua votação 349 votos a favor, 73 contra e 4 abstenções. O texto aprovado foi o do substitutivo apresentado pelo senador Darcy Ribeiro, após sofrer modificações na Câmara (SAMPAIO, 2000, p. 138). 


\begin{abstract}
Um dos fatores para esse crescimento foi a mudança na regulamentação do setor na década de 1990. Anteriormente a 1996, o setor de educação superior no Brasil enfrentava restrições regulatórias que dificultavam a entrada de novos concorrentes e a expansão das instituições privadas então existentes, além da insuficiência dos investimentos públicos nos diversos níveis do setor. A partir da promulgação da Lei $n^{0}$ 9.394, de 20 de dezembro de 1996, diversas medidas foram lançadas para incentivar o investimento privado no setor de educação superior brasileiro. Dentre as principais iniciativas adotadas incluem-se a flexibilização das restrições regulatórias para a abertura de cursos e instituições e a regulamentação da lei que permitiu que instituições de ensino superior fossem constituídas como empresas com fins lucrativos (ANHANGUERA, 2012d, p. 117).
\end{abstract}

Segundo a Lei ${ }^{\circ}$ 9.394, de 20 de dezembro de 1996, o Brasil deve priorizar investimentos públicos no ensino fundamental e médio e estimular investimentos no ensino superior por entidades privadas. Historicamente, o apoio do governo ao ensino superior concentra-se em determinadas universidades que atuam como centros de excelência e pesquisa. $\mathrm{O}$ número limitado de vagas e processos de admissão altamente competitivos restringem significativamente o acesso a essas universidades. Em razão dessas restrições orçamentárias, os recursos públicos disponíveis para oferecer oportunidades de ensino superior a adultos já inseridos no mercado de trabalho são limitados (ANHANGUERA, 2012d, p. 24).

$\mathrm{Na}$ descrição a seguir vamos apresentar previsões da LDB que estimularam o crescimento do setor privado no ensino superior brasileiro.

Para Ranieri (2000, p. 108), na área da educação, diretriz diz respeito "às metas de promoção do indivíduo como pessoa, cidadão e trabalhador", cuja execução volta-se ao cumprimento dos objetivos do artigo $3^{\circ}$ da Constituição Brasileira e requer condições de exequibilidade (órgãos, autoridades e meios de concretização), que constituem a "base", a que se refere a Constituição. Além disso, para Ranieri (2000, p. 108), na "base" da educação nacional estão as garantias do direito à educação indicadas pela Constituição e a preeminência do Ministério da Educação e do Conselho Nacional de Educação como órgãos definidores das políticas públicas para os diversos graus de ensino (conforme Lei $\mathrm{n}^{\mathrm{o}}$ 9.131 de $24 / 11 / 1995)$.

Para Ranieri (2000, p. 109), "diretrizes e bases" designam "fundamentos (razão justificativa); organização; condições de exequibilidade. Logo, quando se fala em diretrizes e bases, fala-se em estrutura, em arcabouço da educação nacional”.

Apesar de buscar "diretrizes e bases" para a educação nacional, Cunha (2003, p. 40) afirma que a LDB aprovada foi minimalista e não apresentou todas as diretrizes nem todas as bases da educação nacional, as quais devem ser procuradas dentro e fora da LDB. Nesse sentido, verifica-se que uma série de leis e decretos cuidaram de assuntos que foram deixados de fora da LDB. Alguns deles são tratados abaixo e nas seções a seguir.

A LDB possui dois eixos de orientação: (i) o da descentralização - expresso na discriminação de competências das entidades federativas e dos sistemas de ensino; e (ii) o 
do estímulo à inovação - expresso pela margem de liberdade de processos que concede aos sistemas e às instituições de ensino (RANIERI, 2000, p. 255).

Com relação à descentralização, a LDB repete as competências constitucionais da União em matéria de educação (arts. 22, XXIV; 24, IX; e 211, Parágrafo 1º, CF/88), destacando que cabe "à União a coordenação da política nacional de educação, articulando os diferentes níveis e sistemas e exercendo função normativa, redistributiva e supletiva, em relação às demais instâncias educacionais" (art. $8^{\circ}$, Parágrafo $1^{\circ}$, LDB). Nesse contexto, o MEC é o responsável por exercer as atribuições do poder público federal em matéria de educação, "cabendo-lhe formular e avaliar a política nacional de educação, zelar pela qualidade do ensino e velar pelo cumprimento das leis que o regem" (artigo $6^{\circ}$, Lei $\mathrm{n}^{\circ}$ 4.024/61, conforme alterada), tarefa que desempenhará com a colaboração do Conselho Nacional de Educação e das Câmaras que o compõem (Câmara de Educação Básica e Câmara de Educação Superior) (art. $6^{\circ}$, Lei n ${ }^{\circ} 4.024 / 61$, conforme alterada).

Nos termos do artigo 16 da LDB, compõem o sistema federal de ensino: (i) as instituições de ensino mantidas pela União; (ii) as instituições de educação superior criadas e mantidas pela iniciativa privada; e (iii) órgãos federais de educação. Nos termos do artigo 17 da LDB, compõem os sistemas de ensino dos Estados e do Distrito Federal: (i) as instituições de ensino mantidas, respectivamente, pelo Poder Público estadual e pelo Distrito Federal; (ii) as instituições de educação superior mantidas pelo Poder Público municipal; (iii) as instituições de ensino fundamental e médio criadas e mantidas pela iniciativa privada; (iv) os órgãos de educação estaduais e do Distrito Federal; e (v) no Distrito Federal, as instituições de educação infantil, criadas e mantidas pela iniciativa privada. Nos termos do artigo 18 da LDB, os sistemas municipais de ensino compreendem: (i) as instituições de ensino fundamental, médio e de educação infantil mantidas pelo Poder Público municipal; (ii) as instituições de educação infantil criadas e mantidas pela iniciativa privada; e (iii) os órgãos municipais de educação.

Com relação à inovação, a LDB, em seu artigo 45, "quebrou" o modelo preferencialmente universitário do ensino superior brasileiro, permitindo sua oferta em "instituições de ensino superior, públicas ou privadas, com variados graus de abrangência ou especialização". Referido dispositivo também excluiu o termo "excepcionalmente" presente no artigo $2^{\circ}$ da Lei $n^{0} 5.540 / 68^{124}$, que tratava dessa matéria. Para Sampaio (2000,

\footnotetext{
${ }^{124}$ Art. $2^{\circ}$, Lei $\mathrm{n}^{\circ} 5.540 / 68$ - O ensino superior, indissociável da pesquisa, será ministrado em universidades e, excepcionalmente, em estabelecimentos isolados, organizados como instituições de direito público ou privado.
} 
p. 140), "isso significa, no plano formal, que as instituições isoladas deixam de ser um desvio no sistema de ensino superior até então disciplinado preferencialmente como constituído por universidades e 'excepcionalmente' por estabelecimentos isolados".

Com essa mudança, autorizou-se a criação de novas formas de organização acadêmica, o que ocorreu com o Decreto $\mathrm{n}^{\circ} 2.207$, de 15 de abril de 1997, que incluiu entre as universidades e faculdades, como formas de organização acadêmica, os centros universitários, faculdades integradas, institutos superiores e escolas superiores ${ }^{125}$. Posteriormente, o Decreto $\mathrm{n}^{\mathrm{o}} 5.773$, de 09 de maio de $2006^{126}$, reduziu as formas de organização acadêmica para três categorias: (i) universidades; (ii) centros universitários; e (iii) faculdades, com a equiparação, para fins de organização e prerrogativas, das faculdades integradas, institutos superiores e escolas superiores às faculdades ${ }^{127}$.

A Portaria Normativa $\mathrm{n}^{\mathrm{o}}$ 40, de 12 de dezembro de 2007, do MEC aumentou as formas de organização acadêmica para: (i) universidades; (ii) faculdades; (iii) centros universitários; (iv) institutos federais de educação, ciência e tecnologia, que para efeitos regulatórios, equiparam-se às universidades tecnológicas; e (v) centros federais de educação tecnológica (Cefets), que para efeitos regulatórios, equiparam-se aos centros universitários. Considerando as equiparações, permanecemos com três formas de organização acadêmica (universidade, faculdade e centro universitário).

Os centros universitários e as faculdades (nas suas variadas formas) podem atuar sem desenvolver as funções indissociáveis de ensino, pesquisa e extensão que as universidades devem cumprir, conforme artigo 207 da Constituição e, nesse contexto, as

\footnotetext{
${ }^{125}$ Art. $4^{\mathrm{o}}$, Decreto n ${ }^{\circ} 2.207 / 97$ - "Quanto à sua organização acadêmica, as instituições de ensino superior do Sistema Federal de Ensino classificam-se em: I - universidades; II - centros universitários; III - faculdades integradas; IV - faculdades; V - institutos superiores ou escolas superiores".

126 Art. 12, Decreto $n^{0} 5.773$ de 09/05/2006 - "As instituições de educação superior, de acordo com sua organização e respectivas prerrogativas acadêmicas, serão credenciadas como: I - faculdades; II - centros universitários; e III - universidades".

${ }^{127}$ Nos termos do Parecer $n^{\circ}$ 218/2006 da Câmara de Educação Superior, aprovado pelo Ministro da Educação, Fernando Haddad, em 13/09/2006, que trata de consulta sobre a possibilidade de credenciamento de Faculdades Integradas, Escolas Superiores e Institutos Superiores de Educação, ante o disposto no art. 12 do Decreto $n^{0} 5.773$ de 09/05/2006, “a classificação expressa no art. 12 do Decreto $n^{0}$ 5.773/2006 é feita para fins de organização e prerrogativas acadêmicas; as Instituições credenciadas como Faculdades Integradas, Instituto Superior de Educação, Faculdades de Tecnologia, Faculdades Associadas, Escolas Superiores ou denominação semelhante são consideradas para fins de organização e prerrogativas acadêmicas como faculdades e a elas são equiparadas para os fins do que dispõe o Decreto $n^{\circ}$ 5773/2006; independentemente da denominação da instituição credenciada todas estão formalmente aptas as solicitar autorização de novos cursos de graduação sem que haja necessidade de novo processo de credenciamento; não se pode admitir, no entanto, que o nome da Instituição de ensino induza a sociedade a interpretações equivocadas de classificação. Os órgãos próprios do MEC não podem aceitar denominações 'Faculdades' que incluam expressões como 'Universidade', 'Uni', 'Centro', 'Autônomas', etc, porque estas comumente gozam de autonomia universitária”. Disponível em: <http://www2.mec.gov.br/sapiens/portarias/res2006_218.html>. Acesso em: 17/07/2012.
} 
faculdades predominam no Brasil, representando 85,2\% dos estabelecimentos, em 2010 (INEP, 2012b), como veremos no item 2.6 abaixo.

As universidades apresentam o maior grau de abrangência e especialização do sistema, sendo definidas pela LDB (art. 52) como "instituições pluridisciplinares de formação dos quadros profissionais de nível superior, de pesquisa, de extensão e de domínio e cultivo do saber humano", com "produção intelectual institucionalizada mediante o estudo sistemático dos temas e problemas mais relevantes, tanto do ponto de vista científico e cultural, quanto regional e nacional" (art. 52, I, LDB). Considerando a as previsões da LDB e da Constituição de 1988, são características das universidades: (i) indissociabilidade entre ensino, pesquisa e extensão (art. 207, CF/88); (ii) autonomia universitária (art. 207); (iii) um terço do corpo docente, pelo menos, com titulação acadêmica de mestrado ou doutorado (art. 52, II, LDB); e (iv) um terço do corpo docente em regime de tempo integral ${ }^{128}$ (art. 52, III, LDB).

Para Ranieri (2000, p. 186), a definição de universidade constante no artigo 52 da LDB associa traços funcionais e idealistas, expressos no controle qualitativo referente ao corpo docente e na indissociabilidade entre ensino, pesquisa e extensão, consoante a previsão do artigo 207 da Constituição.

Os centros universitários, regulados inicialmente pelo Decreto $\mathrm{n}^{\circ} 2.207 / 97$ e atualmente pelo Decreto $n^{0} 5.786$, de 24/05/2006, ficam numa situação intermediária de grau de abrangência e especialização e são definidos como "instituições de ensino superior pluricurriculares, que se caracterizam pela excelência do ensino oferecido, pela qualificação do seu corpo docente e pelas condições de trabalho acadêmico oferecidas à comunidade escolar" (art. $1^{\circ}$, Decreto $n^{\circ} 5.786 / 06$ ) e que atendem aos seguintes requisitos: (i) um quinto do corpo docente em regime de tempo integral (art. $1^{\circ}$, Parágrafo Único, inciso I, Decreto ${ }^{0}$ 5.786/06); e (ii) um terço do corpo docente, pelo menos, com titulação acadêmica de mestrado ou doutorado (art. $1^{\circ}$, Parágrafo Único, inciso II, Decreto $\mathrm{n}^{\mathrm{o}}$ 5.786/06).

A LDB permitiu que as atribuições de autonomia universitária, até então exclusivas das universidades, fossem estendidas às instituições que comprovassem "alta qualificação para o ensino ou para a pesquisa, com base em avaliação realizada pelo Poder Público" (art. 54, Parágrafo $2^{\circ}$ ).

Nesse sentido, aos centros universitários foi conferida autonomia para "criar,

${ }^{128} \mathrm{O}$ regime de dedicação integral corresponde a 40 horas semanais de trabalho na mesma instituição, devendo 20 horas serem dedicadas a estudos, atividades de extensão e avaliação. 
organizar e extinguir, em sua sede, cursos e programas de educação superior, assim como remanejar ou ampliar vagas nos cursos existentes" (art. $2^{\circ}$, Decreto $\left.n^{\circ} 5.786 / 06\right)^{129}$.

Os centros universitários apresentaram-se, portanto, como instituições com prerrogativas de autonomia universitária, mas que não precisam cumprir com a indissociabilidade entre ensino, pesquisa e extensão. Para Cunha (2003, p. 54), os centros universitários passaram a ocupar o lugar das universidades de ensino, em oposição às universidades de pesquisa ${ }^{130}$. Essas características atraíram o setor privado para esta forma de organização - os centros universitários desde sua criação são preponderantamente privados, conforme descrito no item 2.6 abaixo.

A esse respeito, Sampaio (2000, p. 143) afirma:

\begin{abstract}
Apesar de os centros não desfrutarem do mesmo status e de outras prerrogativas das universidades, a autonomia da qual dispõem para responder à demanda de mercado (em oferta de cursos e vagas), sem dúvida, é um fator que contribui para tornar essa forma de organização mais atrativa do que, por exemplo, a figura da federação de escolas. [...] Da perspectiva do setor privado, é fundamental que as instituições tenham flexibilidade em sua interação com o mercado, dirigindo sua oferta de cursos e moldando o número de vagas oferecidas nos diferentes cursos de acordo com a demanda. Ao conferir aos centros universitários essas mesmas prerrogativas dispensadas às universidades, a nova legislação procura deslocar a pressão dos estabelecimentos do setor privado para se transformarem em universidades oferecendo outra alternativa de organização institucional.
\end{abstract}

A Resolução CNE/CES n ${ }^{\circ} 1$, de 20/01/2010, definiu, em seu artigo $2^{\circ}$, critérios mais precisos para a criação de centros universitários, estabelecendo que a criação deles se dá pelo credenciamento de faculdades já credenciadas e em funcionamento regular há, no mínimo, seis anos e que tenham obtido conceito igual ou superior a quatro na avaliação institucional do ciclo avaliativo do Sistema Nacional de Avaliação da Educação Superior (Sinaes) imediatamente anterior. Referida resolução previu também outras exigências, envolvendo avaliação e atividades de extensão, para o credenciamento de faculdades como centros universitários ${ }^{131}$.

\footnotetext{
129 A extensão da autonomia universitária a outras formas de organização acadêmica que não as universidades estava prevista no artigo $54, \S 2^{\circ}$ da LDB. Esse dispositivo foi regulamentado, inicialmente, pelo Decreto $\mathrm{n}^{\circ} 2.207 / 97$ para os centros universitários, com uma redação mais ampla que a atualmente vigente: Art. $6^{\circ}, \S 1^{\circ}$ - "Serão estendidas aos centros universitários credenciados autonomia para criar, organizar e extinguir, em sua sede, cursos e programas de educação superior, previstos na Lei ${ }^{\circ}$ 9.394, de 1996." $§ 2^{\circ}$ - "Os centros universitários poderão usufruir de outras atribuições da autonomia universitária, além da que se refere o parágrafo anterior, devidamente definidas no ato de seu credenciamento, nos termos do $\S 2^{\circ}$ do art. 54, da Lei ${ }^{\circ} 9.394$, de 1996".

130 Sobre os centros universitários, Cunha (2003, p. 54) afirma: "quase autônomos ou detentores de quase toda a autonomia universitária, os centros universitários ocupam o lugar, no discurso reformista oficial, da universidade de ensino, definida por oposição à universidade de pesquisa, esta sim, a universidade plenamente constituída".

131 Art. $3^{\circ}$, Resolução CNE/CES n $n^{0} 1 / 2010$ - "São condicões necessárias para a Faculdade solicitar
} 
Não existe definição expressa na legislação para as faculdades, o que as torna uma categoria residual. O que não é centro universitário, nem universidade é faculdade. São, portanto, instituições de ensino superior, sem prerrogativas de autonomia, que não estão sujeitas à indissociabilidade de ensino, pesquisa e extensão, submetidas à autorização e avaliação de qualidade pelo Poder Público. As faculdades apresentam assim o menor grau de abrangência e especialização do sistema.

As exigências de titulação do corpo docente previstas na LDB foram objeto de disputa entre os participantes do setor. Instituições privadas com fins lucrativos levantaram essa questão no passado visando sua flexibilização. Houve um Projeto de Lei (PL $\mathrm{n}^{\mathrm{o}}$ 220/2010) que, sob forte pressão das instituições privadas, visava alterar o artigo 66 da $\mathrm{LDB}^{132}$ para retirar a exigência de formação em nível de pós-graduação para o exercício do magistério superior, de forma a permitir a admissão de docentes, portadores de diploma de graduação apenas, para atuação nas áreas de tecnologia e de infraestrutura, desde que comprovassem relevante experiência profissional ${ }^{133}$. A justificativa para o projeto de lei foi a falta de profissionais com esse nível de formação no Brasil e o fato de que profissionais sem titulação mas com experiência prática poderiam lecionar em nível superior de forma satisfatória. Argumentos contrários destacaram que o Brasil possui um grande número de pós-graduados e que o objetivo principal do projeto de lei era a redução de custos para os grupos educacionais privados do País, que querem pagar salários mais baixos para profissionais com titulação menor. A mídia tratou do assunto da seguinte maneira:

credenciamento como Centro Universitário: I - mínimo de 20\% (vinte por cento) do corpo docente contratado em regime de tempo integral; II - mínimo de 33\% (trinta e três por cento) do corpo docente com titulação acadêmica de mestrado ou doutorado; III - mínimo de 8 (oito) cursos de graduação reconhecidos e com conceito satisfatório obtido na avaliação realizada pelo Ministério da Educação; IV - plano de desenvolvimento institucional e proposta de estatuto compatíveis com a solicitacão de transformacão em Centro Universitário; V - programa de extensão institucionalizado nas áreas do conhecimento abrangidas por seus cursos de graduacão; VI - programa de iniciação científica com projeto orientado por professores doutores ou mestres, podendo também oferecer programas de iniciacão profissional ou tecnológica e de iniciacão à docência; VII - plano de carreira e política de capacitacão docente implantados; VIII - biblioteca com integracão efetiva na vida acadêmica da Instituicão e que atenda às exigê ncias dos cursos em funcionamento, com planos fundamentados de expansão física e de acervo; IX - não ter firmado, nos últimos 3 (três) anos, termo de saneamento de deficiências ou protocolo de compromisso com o Ministério da Educação, relativamente à própria Instituição ou qualquer de seus cursos; X - não ter sofrido qualquer das penalidades de que trata o $\S 1^{\circ}$ do art. 46 da Lei $\mathrm{n}^{\circ} 9.394 / 1996$, regulamentado pelo art. 52 do Decreto $\mathrm{n}^{\circ}$ 5.773/2006. Parágrafo único. Na hipótese da ocorrência das situações previstas nos incisos IX e X durante qualquer fase da tramitação do processo, este será arquivado".

${ }^{132}$ Art. 66, LDB. "A preparação para o exercício do magistério superior far-se-á em nível de pós-graduação, prioritariamente em programas de mestrado e doutorado. Parágrafo único. O notório saber, reconhecido por universidade com curso de doutorado em área afim, poderá suprir a exigência de título acadêmico".
133 Informações sobre o projeto de lei disponíveis em:

$<$ http://www.senado.gov.br/atividade/materia/detalhes.asp?p_cod_mate=97871 >. Acesso em: 25/09/2012. 
Alegando que não há mestres e doutores em número suficiente para lecionar nessas universidades, o relator do projeto, senador Álvaro Dias (PSDB-PR), deu-lhe parecer favorável. O argumento usado é o mesmo dos dirigentes de várias escolas particulares. Segundo eles, haveria déficit de docentes titulados em várias áreas. "Um profissional com experiência tem muito a ensinar, mesmo que não tenha pós-graduação. Por outro lado, há aqueles que terminam a graduação e emendam com o mestrado. Que experiência têm eles para passar?", diz Ana Maria Souza, da Anhanguera Educacional ${ }^{134}$. [...]

O projeto defende que há déficit de profissionais. No entanto, o Brasil forma todo ano 50 mil novos mestres e doutores. Hoje, $56 \%$ dos professores universitários são pós-graduados e a meta do Plano Nacional de Educação (PNE) é que esse número chegue a 75\%. Setores críticos ao projeto, como sindicatos de professores, alegam que a medida precarizaria as relações de trabalho e empobreceria a formação do graduando ${ }^{135}$. [...]

Para os dirigentes de universidades públicas, se as universidades privadas enfrentam problemas para contratar docentes com mestrado e doutorado, o motivo não estaria na falta de pós-graduados em número suficiente, mas nos baixos salários. "O gargalo está nas más condições de empregabilidade que as instituições particulares oferecem", diz o professor Roberto Piqueira, da Escola Politécnica da USP.

A polêmica em torno da exigência de um mínimo de titulação dos professores universitários começou quando grandes grupos nacionais e internacionais - inclusive fundos de investimento - começaram a investir no ensino superior, adquirindo instituições de pequeno e médio portes. Além de desprezar as atividades de pesquisa e extensão, que são fortemente enfatizadas pela LDB, esses grupos - muitos dos quais com ações cotadas em bolsas de valores - demitiram os docentes mais experientes e contrataram bacharéis recém-formados, com o objetivo de reduzir custos.

Para esses grupos empresariais, a educação é apenas negócio - e o projeto que o Senado vai votar parece ter sido feito para atender a seus interesses. É por isso que as universidades confessionais e as universidades privadas mais tradicionais não estão apoiando esse projeto. Para elas, sua aprovação seria um perigoso retrocesso ${ }^{136}$.

\section{No entanto, referido projeto de lei restou arquivado após receber parecer}

desfavorável do Senador Aloysio Nunes Ferreira, que rejeitou o projeto de lei e afirmou ${ }^{137}$ :

Precisamos nos precaver a respeito da qualificação docente, que pode estar ameaçada pela vigorosa expansão dos cursos superiores, incluindo os tecnológicos. Será necessário, em algum momento, que julgamos estar próximo, exigir que a formação se dê exclusivamente em cursos de mestrado e doutorado, o que depende não somente de resoluções do Conselho Nacional de Educação (CNE) como de dispositivos da LDB e de políticas de oferta qualificada de pós-graduação stricto sensu.

Além dessas ponderações, somos da opinião que a abertura da exceção para graduados das áreas de tecnologia e infraestrutura terem acesso à docência na educação superior pode dar início a uma enxurrada de pedidos ao MEC e ao CNE para a inclusão, na excepcionalidade, de outros setores do trabalho carentes de profissionais.

Finalmente, o recente incremento dos cursos de tecnologia (em todos os setores da economia) poderia dar oportunidade a uma distorção de interpretação do presente projeto, como se fosse guarida para diminuir a exigência acadêmica para os docentes formadores de tecnólogos, o que seria lamentável.

134

Disponível em: $\quad<$ http://www.estadao.com.br/noticias/impresso,retrocesso-no-ensinosuperior, $743708,0 . h t m>$. Acesso em: 25/09/2012.

${ }^{135}$ Disponível em: <http://www.redebrasilatual.com.br/temas/educacao/2011/07/mec-e-contra-projeto-de-leique-dispensa-pos-graduacao-na-formacao-de-professores-universitarios $>$. Acesso em: 05/12/2012.

${ }^{136}$ Disponível em: <http://www.redebrasilatual.com.br/temas/educacao/2011/07/mec-e-contra-projeto-de-leique-dispensa-pos-graduacao-na-formacao-de-professores-universitarios $>$. Acesso em: 05/12/2012.

${ }_{137}$ Disponível em: < http://www6.senado.gov.br/mate-pdf/99756.pdf $>$. Acesso em: 25/09/2012. 
A LDB também diferenciou as instituições de ensino dos diversos níveis entre públicas e privadas, estabelecendo, em seu artigo 19, que são públicas as instituições “criadas ou incorporadas, mantidas e administradas pelo Poder Público" (art. 19, I) e que são privadas "as mantidas e administradas por pessoas físicas ou jurídicas de direito privado" (art. 19, II).

Como se nota da redação do dispositivo, o critério de distinção é a natureza jurídica do ente ou órgão mantenedor: se de direito público - a instituição de ensino é pública; se de direito privado - a instituição de ensino é privada.

Não há forma prévia prevista em lei para as instituições públicas, que, geralmente, assumem a forma de fundações ou autarquias de regime especial. Para as instituições privadas, a LDB, em seu artigo 20, estabeleceu formas específicas, que seguem categorias previstas no artigo 213 da Constituição de $1988^{138}$ : (i) particulares em sentido estrito, assim entendidas as que são instituídas e mantidas por uma ou mais pessoas físicas ou jurídicas de direito privado que não apresentem as características dos itens a seguir (inciso I) - essas são as instituições com fins lucrativos, geralmente constituídas na forma de sociedades simples, limitadas ou por ações; (ii) comunitárias ${ }^{139}$, assim entendidas as que são instituídas por grupos de pessoas físicas ou por uma ou mais pessoas jurídicas, inclusive cooperativas educacionais, sem fins lucrativos, que incluam na sua entidade mantenedora representantes da comunidade (inciso II); (iii) confessionais, "assim entendidas as que são instituídas por grupos de pessoas físicas ou por uma ou mais pessoas jurídicas que atendem a orientação confessional e ideologia específicas e ao disposto no item anterior (inciso III); e (iv) filantrópicas, na forma da lei (inciso IV). No artigo 20 da LDB, o critério de distinção também se refere à pessoa que mantém a instituição e não à instituição propriamente dita.

Os artigos 19 e 20 da LDB, para Ranieri (2000, p. 194):

[...] revelam a preocupação da LDB com a atividade econômica na área educacional, exercida, no geral, de forma complementar, por dois entes distintos: uma pessoa física ou jurídica, com capacidade econômico-financeira, titular do patrimônio (a mantenedora), e

\footnotetext{
138 Art. 213, CF/88. "Os recursos públicos serão destinados às escolas públicas, podendo ser dirigidos a escolas comunitárias, confessionais ou filantrópicas, definidas em lei, que: I - comprovem finalidade nãolucrativa e apliquem seus excedentes financeiros em educação; II - assegurem a destinação de seu patrimônio a outra escola comunitária, filantrópica ou confessional, ou ao Poder Público, no caso de encerramento de suas atividades".

${ }^{139}$ A noção de instituição comunitária foi uma novidade da Constituição de 1988, a qual foi incluída também na LDB. Dentro dessa definição foram incluídas instituições laicas sem fins lucrativos, que tenham participação da comunidade em sua organização e que podem pleitear recursos públicos, nos termos do artigo 213 da $\mathrm{CF} / 88$.
} 
outra pessoa jurídica, prestadora de serviços, que congrega a capacidade física instalada e os recursos humanos disponíveis (a mantida).

A cisão das atividades de ensino (exercida pela instituição de ensino - mantida) das de administração institucional (exercida pela instituição mantenedora ${ }^{140}$ ) remonta à Lei $\mathrm{n}^{\mathrm{o}}$ 4.024/61 $1^{141}$. A Lei $\mathrm{n}^{\mathrm{0}}$ 5.540/68 abandonou essa estrutura dual, mas segundo Ranieri (2000), na prática isso não ocorreu. A atual LDB retomou o modelo dual (mantenedora - mantida) e preocupou-se com as implicações fiscais e previdenciárias que decorrem da existência ou não de finalidade lucrativa nas instituições de ensino. O objetivo final, para Ranieri (2000, p. 195), é “delimitar o alcance da imunidade tributária prevista no artigo 150, VI, 'c', e da isenção previdenciária do artigo 195, Parágrafo $7^{\circ}$, da Constituição Federal”.

Nesse contexto, primeiro o Decreto $\mathrm{n}^{\mathrm{o}} 2.207$, de 15 de abril de $1997^{142}$, e posteriormente o Decreto ${ }^{\mathrm{o}} 2.306$, de 19 de agosto de 1997, autorizaram que as entidades mantenedoras de instituições de ensino superior assumissem a forma de sociedades

\footnotetext{
${ }^{140}$ Encontra-se uma definição de mantenedora e mantida na Lei $\mathrm{n}^{\mathrm{o}} 12.688 / 12$. Nos termos do artigo $3^{\circ}$, § $2^{\mathrm{o}}$, da referida Lei - "Para os efeitos desta Lei, considera-se: I - mantenedora: a instituição de direito público ou privado que se responsabiliza pelo provimento dos fundos necessários para a manutenção de ensino superior; e II - mantida: a instituição de ensino superior, integrante dos sistemas de ensino a que se referem os incisos I e II do caput, que realiza a oferta da educação superior".

141 Artigo 21, Lei $n^{\circ} 4.024 / 61$ - "O ensino, em todos os graus, pode ser ministrado em escolas públicas, mantidas por fundações cujo patrimônio e dotações sejam provenientes do Poder Público, ficando o pessoal que nelas servir sujeito, exclusivamente, às leis trabalhistas".

${ }^{142}$ Art $1^{\circ}$, Decreto n ${ }^{\circ} 2.207 / 97$ - "As instituições de ensino superior do Sistema Federal de Ensino, nos termos do art. 16 da Lei $n^{\circ}$ 9.394, de 20 de dezembro de 1996, classificam-se, quanto a sua natureza jurídica, em: I públicas, quando criadas ou incorporadas, mantidas e administradas pelo Governo Federal; II - privadas, quando mantidas e administradas por pessoas físicas ou jurídicas de direito privado; Parágrafo único. As entidades mantenedoras das instituições privadas de ensino superior poderão se constituir sob qualquer das formas de pessoa jurídica, de direito privado previstas nos incisos I e II do art. 16 do Código Civil Brasileiro". (grifo nosso).

Art. 16, CC/16. - "São pessoas jurídicas de direito privado: I. As sociedades civis, religiosas, pias, morais, científicas ou literárias, as associações de utilidade pública e as fundações. II. As sociedades mercantis"

Art $2^{\circ}$, Decreto $n^{\circ} 2.207 / 97$ - "As entidades mantenedoras das instituições privadas de ensino superior que se revestirem de finalidade não lucrativa deverão observar o seguinte: I - contar com um conselho fiscal, com representação acadêmica; II - publicar anualmente seu balanço, certificado por auditores independentes; III submeter-se, a qualquer tempo, a auditoria pelo poder público; IV - comprovar a aplicação dos seus excedentes financeiros para os fins da instituição mantida; V - comprovar a não-remuneração ou concessão de vantagens ou benefícios, por qualquer forma ou título, a seus instituidores, dirigentes, sócios, conselheiros, ou equivalentes; VI - comprovar a destinação de seu patrimônio a outra instituição congênere ou ao Poder Público no caso de encerramento de suas atividades; VII - comprovar a destinação de pelo menos dois terços de sua receita operacional à remuneração do corpo docente e a técnico administrativo. Parágrafo único. As atuais mantenedoras das instituições privadas de ensino superior a que se refere este artigo que desejarem alterar sua natureza jurídica, observado o disposto no parágrafo único do art. $1^{\circ}$ deste Decreto, revestindo umas das formas estabelecidas nas leis comerciais, poderão fazê-lo no prazo de 120 dias, a contar da data de publicação, deste Decreto, submetendo a correspondente alteração estatutária, devidamente averbada pelos órgãos competentes, ao Ministério da Educação e do Desporto, para fins de recredenciamento, ouvido o Conselho Nacional de Educação". (grifo nosso)

Em 08/08/1997, foi também editada a MP $n^{\circ} 1.477-39$, que em seu artigo 10 aprovou alterações na Lei $n^{\circ}$ 9.131/95 para refletir a autorização de adoção da forma de sociedades mercantis pelas mantenedoras de instituições de ensino superior.
} 
mercantis, portanto, de pessoas jurídicas de direito privado com fins lucrativos, submetidas à legislação que rege este tipo de pessoa jurídica, especialmente com relação aos encargos fiscais, parafiscais e trabalhistas ${ }^{143}$ e também estabeleceu que as instituições de ensino (mantidas) deveriam se classificar de acordo com o regime jurídico que as mantenedoras assumissem $^{144}$.

Antes desses decretos, as instituições de ensino superior apenas podiam assumir a forma de entidades sem fins lucrativos (autarquias ou fundações para o setor público e associações ou fundações para o setor privado ${ }^{145}$ ), e suas mantenedoras, em geral $^{146}$, adotavam apenas essa forma de organização para o cumprimento das leis aplicáveis.

Em contrapartida da impossibilidade de distribuir aos participantes da atividade parcela de seu patrimônio ou renda a qualquer título, a legislação brasileira concedia benefícios fiscais às entidades de educação, que eram imunes do pagamento de qualquer imposto sobre patrimônio, renda e serviços ${ }^{147}$. Considerando esse fato e a necessidade de

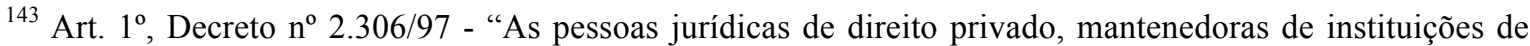
ensino superior, previstas no inciso II do art. 19 da Lei ${ }^{\circ}$ 9.394, de 20 de dezembro de 1996, poderão assumir qualquer das formas admitidas em direito, de natureza civil ou comercial e, quando constituídas como fundações, serão regidas pelo disposto no art. 24 do Código Civil Brasileiro".

${ }^{144}$ Art. $6^{\circ}$, Decreto n ${ }^{\circ}$ 2.306/97 - "As instituições de ensino superior do Sistema Federal de Ensino, criadas e mantidas pela iniciativa privada, classificam-se pelo regime jurídico a que se submetem as pessoas físicas ou jurídicas de direito privado que as mantêm e administram".

${ }^{145}$ Art. 81, Lei $\mathrm{n}^{\mathrm{o}}$ 4.024/61 - "As universidades serão constituídas sob a forma de autarquias, fundações ou associações. A inscrição do ato constitutivo no registro civil das pessoas jurídicas será precedido de autorização por decreto do govêrno federal ou estadual".

Art. 85, Lei $\mathrm{n}^{\circ} 4.024 / 61$ - "Os estabelecimentos isolados serão constituídos sob a forma de autarquias, de fundações, ou associações".

Art. $4^{\circ}$, Lei $\mathrm{n}^{\circ} 5.540 / 68$ - "As universidades e os estabelecimentos de ensino superior isolados constituir-seão, quando oficiais, em autarquias de regime especial ou em fundações de direito público e, quando particulares, sob a forma de fundações ou associações".

146 - Pesquisa do Observatório Universitário afirma, com base em dados do Inep/MEC, que antes da edição dos decretos de 1997, existiram mantenedoras de instituições de ensino superior com fins lucrativos no Brasil, segundo a pesquisa durante a década de 1910 houve 1 mantenedora constituída sob a forma de pessoa jurídica com fins lucrativos; na década de 1950 eram 2; na década de 1960 eram 13; na década de 1970 eram 24; e na década de 80 eram 10. (FERNANDES, 2007, p. 51).

${ }^{147}$ Benefícios que existem até hoje, aplicáveis às instituições de educação sem fins lucrativos. Nos termos do artigo 150, VI, c, da Constituição de 1988, é vedado à União, aos Estados, ao Distrito Federal e aos Municípios instituir impostos sobre: "patrimônio, renda ou serviços dos partidos políticos, inclusive suas fundações, das entidades sindicais dos trabalhadores, das instituições de educação e de assistência social, sem fins lucrativos, atendidos os requisitos da lei". Este dispositivo também constava no artigo 19, III, c da Constituição de 1967, conforme alterada pela EC n 01/69, sem a referência a instituições "sem fins lucrativos", o que era desnecessário, já que todas eram sem fins lucrativos. Essa previsão era repetida na redação original do artigo 9 , IV, c do Código Tributário Nacional, também sem a referência à finalidade não lucrativa, que apenas foi incluída em alteração pela Lei Complementar 104/2001. O CTN prevê alguns requisitos para a fruição da imunidade tributária por essas entidades, em seu artigo 14, estabelecendo que: "o disposto na alínea $\mathrm{c}$ do inciso IV do artigo $9^{\circ}$ é subordinado à observância dos seguintes requisitos pelas entidades nele referidas: I - não distribuírem qualquer parcela de seu patrimônio ou de suas rendas, a qualquer título; (Redação dada pela LC n 104/2001); II - aplicarem integralmente, no País, os seus recursos na manutenção dos seus objetivos institucionais; III - manterem escrituração de suas receitas e despesas em livros revestidos de formalidades capazes de assegurar sua exatidão". 
contraprestação pelos investimentos feitos e atividades exercidas por seus sócios ou associados, as entidades praticavam várias formas de manobra para remunerá-los, sem com isso perder os benefícios fisciais recebidos do governo. A esse respeito, destacamos que a Anhanguera possui alguns processos discutindo práticas remuneratórias do período em que era uma instituição sem fins lucrativos, conforme descrito no Capítulo 4 da Dissertação.

A nova regra, ao permitir oficialmente a adoção do regime mercantil (hoje, denominado empresarial) pelas instituições mantenedoras, pôs fim a esse problema organizacional e às fraudes dele decorrentes. A esse respeito, Sampaio (2000, p. 146) afirma:

O fato de a nova legislação reconhecer a possibilidade de existência de instituições com finalidade lucrativa, e torná-las sujeitas à legislação mercantil, rompe com a tradição legal que só previa o serviço educacional sem finalidade lucrativa, dando origem a uma série de subterfúgios no sentido de burlar as restrições legais.

Essa mudança impulsionou o crescimento do ensino superior com fins lucrativos no Brasil, com a organização das instituições na forma de empresas que buscam lucro para distribuição aos seus sócios.

As instituições que preferiram manter a estrutura sem fins lucrativos passaram a ter que cumprir exigências adicionais, como elaborar e publicar demonstrações financeiras certificadas por auditores independentes, a obrigatoriedade de não remunerar seus instituidores, dirigentes, sócios, conselheiros ou equivalentes e de destinarem, pelo menos, $60 \%$ da receita das mensalidades da instituição mantida para o pagamento de professores e funcionários (art. $2^{\circ}$, Decreto $\mathrm{n}^{\mathrm{o}} 2.306 / 97$ ), sob pena de pagarem impostos como qualquer sociedade empresária.

Regras constantes no Decreto $\mathrm{n}^{\circ} 2.306 / 97$ foram incluídas na Lei $\mathrm{n}^{\circ}$ 9.131/95, por meio de alteração aprovada em 1999 (Lei $n^{\circ}$ 9.879). Nesse sentido, o artigo $7^{\circ}$-A da Lei $n^{\circ}$ 9.131/95, conforme alterado e vigente, prevê que:

Art. $7^{\circ}$-A. As pessoas jurídicas de direito privado, mantenedoras de instituições de ensino superior, previstas no inciso II do art. 19 da Lei n ${ }^{\circ}$ 9.394, de 20 de dezembro de 1996, poderão assumir qualquer das formas admitidas em direito, de natureza civil ou comercial e, quando constituídas como fundações, serão regidas pelo disposto no art. 24 do Código Civil Brasileiro.

Com relação às entidades mantenedoras de instituições de ensino superior com finalidade lucrativa, estabeleceu que: 
Art. $7^{\circ}$-D. As entidades mantenedoras de instituições de ensino superior, com finalidade lucrativa, ainda que de natureza civil, deverão elaborar, em cada exercício social, demonstrações financeiras atestadas por profissionais competentes.

E, com relação às entidades mantenedoras de instituições de ensino superior sem fins lucrativos, previu que ${ }^{148}$ :

Art. $7^{\circ}$-B. As entidades mantenedoras de instituições de ensino superior, sem finalidade lucrativa, deverão:

I - elaborar e publicar em cada exercício social demonstrações financeiras, com o parecer do conselho fiscal, ou órgão similar;

II - manter escrituração completa e regular de todos os livros fiscais, na forma da legislação pertinente, bem como de quaisquer outros atos ou operações que venham a modificar sua situação patrimonial, em livros revestidos de formalidades que assegurem a respectiva exatidão;

III - conservar em boa ordem, pelo prazo de cinco anos, contado da data de emissão, os documentos que comprovem a origem de suas receitas e a efetivação de suas despesas, bem como a realização de quaisquer outros atos ou operações que venham a modificar sua situação patrimonial;

IV - submeter-se, a qualquer tempo, a auditoria pelo Poder Público;

V - destinar seu patrimônio a outra instituição congênere ou ao Poder Público, no caso de encerramento de suas atividades, promovendo, se necessário, a alteração estatutária correspondente;

VI - comprovar, sempre que solicitada pelo órgão competente:

a) a aplicação dos seus excedentes financeiros para os fins da instituição de ensino;

b) a não-remuneração ou concessão de vantagens ou benefícios, por qualquer forma ou título, a seus instituidores, dirigentes, sócios, conselheiros ou equivalentes.

Parágrafo único. A comprovação do disposto neste artigo é indispensável, para fins de credenciamento e recredenciamento da instituição de ensino superior.

O credenciamento e recredenciamento das instituições está condicionado à definição preliminar do intuito lucrativo, conforme artigo $7^{\circ}-\mathrm{B}$, Parágrafo Único, Lei $\mathrm{n}^{\mathrm{o}}$ 9.131/95, conforme alterada.

A LDB, em seu artigo 44, ampliou os cursos que compõem o ensino superior no Brasil $^{149}$, que passou a abranger: (i) "cursos sequenciais por campo de saber, de diferentes níveis de abrangência, abertos a candidatos que atendam aos requisitos estabelecidos pelas instituições de ensino, desde que tenham concluído o ensino médio ou equivalente" (inciso I, redação dada pela Lei n $\left.{ }^{0} 11.632 / 07\right)$; (ii) “de graduação, abertos a candidatos que tenham

\footnotetext{
${ }^{148}$ A exigência de que as demonstrações financeiras fossem certificadas por auditores independentes e de destinar, pelo menos, $60 \%$ da receita com o pagamento da folha de salários não foi incluída na Lei $\mathrm{n}^{\mathrm{o}}$ 9.131/95.

${ }^{149} \mathrm{O}$ artigo 17 da Lei $\mathrm{n}^{0}$ 5.540/68 estabelecia que: "Nas universidades e nos estabelecimentos isolados de ensino superior poderão ser ministradas as seguintes modalidades de cursos: a) de graduação, abertos à matrícula de candidatos que hajam concluído o ciclo colegial ou equivalente e tenham sido classificados em concurso vestibular; b) de pós-graduação, abertos à matrícula de candidatos diplomados em curso de graduação que preencham as condições prescritas em cada caso; c) de especialização e aperfeiçoamento, abertos à matrícula de candidatos diplomados em cursos de graduação ou que apresentem títulos equivalentes; d) de extensão e outros, abertos a candidatos que satisfaçam os requisitos exigidos".
} 
concluído o ensino médio ou equivalente e tenham sido classificados em processo seletivo" (inciso II); (iii) “de pós-graduação, compreendendo programas de mestrado e doutorado, cursos de especialização, aperfeiçoamento e outros, abertos a candidatos diplomados em cursos de graduação e que atendam às exigências das instituições de ensino" (inciso III); (iv) "de extensão, abertos a candidatos que atendam aos requisitos estabelecidos em cada caso pelas instituições de ensino". O Capítulo III da LDB cuidou também da educação profissional tecnológica, integrada aos diferentes níveis de ensino. Esta forma de ensino foi regulada pelo Decreto $n^{0} 2.208$ de 17/04/1997 e atualmente é regulada pelo Decreto $n^{0} 5.154$ de 23/07/2004, que expressamente prevê os cursos de educação profissional tecnológica de graduação e pós-graduação. Posteriormente, o Capítulo III da LDB foi alterado pela Lei $\mathrm{n}^{\mathrm{o}} 11.741$, de 2008, que atualizou este tema considerando o grande crescimento desse tipo de curso no Brasil.

São novidades da LDB os cursos sequenciais por campo de saber, a abertura da pós-graduação para "outros" tipos de cursos e a menção a "processo seletivo" para o ingresso no ensino superior.

Os cursos sequenciais por campo de saber não foram definidos na LDB. São cursos que se destinam aos indivíduos que concluíram o ensino médio ou superior mas que não se sujeitam às diretrizes gerais fixadas pelo MEC para os cursos de graduação. A Portaria MEC n ${ }^{\circ} 4.363$, de 29/12/2004, fixou duas modalidades de cursos sequenciais: (i) os cursos superiores de formação específica; e (ii) os cursos superiores de complementação de estudos com destinação coletiva ou individual (art. $1^{\circ}$ ). Nos termos da mesma portaria, os “cursos superiores de formação específica reconhecidos conduzem à obtenção de diploma de curso superior que terá validade nacional quando registrado de acordo com a legislação em vigor" (art. $2^{\circ}$ ), enquanto que os cursos de complementação de estudos com destinação coletiva ou individual "conduzem a certificado expedido pela instituição que o ministrou" (art. $\left.3^{\circ}\right)$ e "não dependem de prévia autorização e não estão sujeitos a reconhecimento" (art. $3^{\circ}$, Parágrafo Único).

Segundo Cunha (2003, p. 42), em sua concepção original, os cursos sequenciais por campo de saber deveriam ser uma alternativa à rigidez dos cursos de graduação, em especial quando eles estavam submetidos a currículos mínimos, que eram muito exigentes e não permitiam a "indispensável flexibilidade diante das mudanças no mundo do trabalho". Contudo, conforme Cunha (2003, p. 42): 
vagas dos cursos de graduação, mesmo no processo seletivo mais aligeirado que a legislação permite, as que demonstraram preferência por esse tipo de curso. Os alunos que não conseguiam ingressar nos cursos de graduação eram chamados aos sequenciais, com o objetivo de acumular créditos que poderiam ser aceitos, posteriormente, pelos cursos de graduação.

Com relação aos "outros" cursos de pós-graduação, essa mudança na LDB também foi no sentido de liberalização, permitindo a criação de novas modalidades de cursos de pós-graduação, como os mestrados profissionalizantes, regulados pela Portaria Capes $\mathrm{n}^{\mathrm{o}}$ 80 , de 16/12/1998.

Rompendo com uma tradição do ensino superior brasileiro ${ }^{150}$, a LDB não menciona exames ou concursos vestibulares, fazendo referência apenas a "processos seletivos". Como requisito dos processos seletivos, a LDB passou a exigir, a partir de 2006, que seus resultados "serão tornados públicos pelas instituições de ensino superior, sendo obrigatória a divulgação da relação nominal dos classificados, a respectiva ordem de classificação, bem como do cronograma das chamadas para matrícula, de acordo com os critérios para preenchimento das vagas constantes do respectivo edital" (Parágrafo Único do artigo 44, incluído pela Lei $\left.\mathrm{n}^{\mathrm{o}} 11.331 / 06\right)$.

Em vista dessa nova sistemática, as instituições de ensino superior ampliaram as possibilidades de processo de admissão de estudantes. Simplificaram todo o processo e seu nível de exigência. Nesse contexto, passaram a aplicar provas agendadas, com questões de múltipla escolha, em diferentes épocas do ano. Essa prática foi alvo de críticas e denúncias sobre sua insuficiência para avaliar a capacidade dos candidatos para o ingresso ao ensino superior (conforme requer o princípio da meritocracia previsto no art. 208, V, CF/88).

No ano de 2001, foi noticiado no programa Fantástico da Rede Globo a aprovação de um semianalfabeto, em nono lugar no vestibular de direito da Universidade Estácio de Sá, no Rio de Janeiro ${ }^{151}$. O candidato não fez a prova de redação e apenas marcou respostas A e B na prova de múltipla escolha. Nessa época, a Universidade Estácio de Sá fazia vestibulares de 15 em 15 dias, ofertava muitas vagas, e a nota final do candidato era obtida por uma média aritmética entre a nota da prova de múltipla escolha e a da redação.

\footnotetext{
150 Segundo Cunha (2003, p. 43), “desde 1911, os candidatos a todos os cursos de graduação deveriam submeter-se a processos seletivos denominados exames (ou concursos) vestibulares. No início, os candidatos deveriam ser aprovados nos exames; desde os anos de 1970, bastava obter nota diferente de zero, desde que a classificação os situasse no número prefixado de vagas. Mas os exames (ou concursos) eram obrigatórios. Sua razão explícita era selecionar os candidatos intelectualmente habilitados aos cursos superiores, já que não havia um processo institucionalizado de fazê-lo no próprio ensino secundário, ao longo dele nem ao seu fim (exame de Estado)".

${ }^{151}$ Esta reportagem está disponível em: <http://www.youtube.com/watch?v=A2ykCr9jg5Q $>$. Acesso em: $25 / 09 / 2012$.
} 
A reportagem destacou as falhas no processo de seleção da instituição, que permitiram a aprovação de um candidato absolutamente inabilitado e levantou debates sobre o crescimento das instituições privadas no Brasil na época e a falta de critério nos processos seletivos. O diretor da universidade defendeu-se dizendo que o fator sorte teria sido essencial para a aprovação do candidato ${ }^{152}$ :

Para o diretor, Silva foi beneficiado também na hora em que optou por prestar vestibular para direito, no turno da tarde do campus do Méier (bairro da zona norte carioca). "Tínhamos 20 vagas disponíveis e nove candidatos. Ele ficou em nono lugar, que, nesse caso, equivale à última colocação", afirmou Campos.

Quanto ao fato de Silva ter sido aprovado mesmo sem ter feito a prova de redação, Campos disse que a nota final é obtida por meio de uma média aritmética entre a nota da prova de múltipla escolha e a redação. "E ele foi muito bem na prova", afirmou.

A polêmica prosseguiu e, uma semana depois dessa reportagem, o programa fez um novo teste: inscreveram o mesmo candidato e mais uma jovem analfabeta no vestibular da Universidade Gama Filho para a Faculdade de Letras. As provas foram todas de múltipla escolha e sem redação, e os dois candidatos foram aprovados ${ }^{153}$.

Esses casos tiveram muita repercussão, e o Ministério da Educação, pouco tempo depois das reportagens, aprovou uma portaria ${ }^{154}$ mudando as regras dos processos

152 Disponível em: <http://www1.folha.uol.com.br/folha/educacao/ult305u7470.shtml>. Acesso em: 25/09/2012.

${ }^{153}$ Esta reportagem está disponível em: $<\mathrm{http}: / /$ www.youtube.com/watch? $\mathrm{v}=\mathrm{Vy} 7 \mathrm{faOi}$ 6os\&feature $=\mathrm{relmfu}>$. Acesso em: 25/09/2012. Reportagem no portal UOL disponível em: $<$ http://www2.uol.com.br/aprendiz/n_noticias/ensino_superior/id171201.htm>. Acesso em: 25/09/2012.

154 Trata-se da Portaria MEC n $n^{\circ} .941$, de 17/12/2001, que continha a seguinte redação: “Art. $1^{\circ}$ - Os Processos Seletivos para ingresso nas Instituições Públicas e Privadas pertencentes ao Sistema Federal de Ensino Superior, a que se refere o Inciso II do Art 44 da Lei de Diretrizes e Bases da Educação Nacional, deverão seguir as determinações do Parecer no 98/99 de 6 julho de 1999 do Conselho Nacional de Educação e as disposições da presente Portaria. Art. $2^{\circ}$ Todos os Processos Seletivos a que se refere o artigo anterior incluirão necessariamente uma prova de redação em língua portuguesa, de caráter eliminatório, segundo normas explicitadas no edital de convocação do processo seletivo. $\S 1^{\circ} \mathrm{Em}$ qualquer caso será eliminado o aluno que obtiver nota zero na prova de redação. $\S 2^{\circ}$ Cada instituição de ensino deverá fixar no edital do processo seletivo a nota mínima exigida na prova de redação. Art. $3^{\circ}$ Somente serão aceitas inscrições nos processos seletivos a que se refere o Art. $2^{\circ}$ de candidatos que estejam cursando o Ensino Médio ou que possuam o Certificado de Conclusão deste nível de ensino obtido pela via regular ou da suplência. Art. $4^{\circ}$. Somente poderão ser realizados um máximo de dois processos seletivos para cada período de ingresso, seja anual ou semestral. Art. $5^{\circ} \mathrm{O}$ resultado obtido pelo candidato no Exame Nacional do Ensino Médio - ENEM realizado pelo Ministério da Educação deverá fazer parte necessariamente do conjunto de requisitos ou provas dos Processos Seletivos das Faculdades Isoladas, das Faculdades Integradas e dos Centros Universitários. $\S 1^{\circ}$ Serão considerados apenas resultados do ENEM obtidos pelos candidatos nos três anos anteriores à realização do processo seletivo. $\S 2^{\circ} \mathrm{O}$ resultado obtido pelo candidato na prova de redação do ENEM poderá ser considerado para fins de dar cumprimento ao disposto no Art. $2^{\circ}$ da presente portaria. $\S 3^{\circ}$ $\mathrm{O}$ disposto no presente artigo entrará em vigor a partir dos processos seletivos realizados para ingresso no ano 2003. $\S 4^{\circ}$ Para as universidades que adotarem o ENEM como parte do processo seletivo aplica-se o disposto no parágrafo $2^{\circ}$. Art. $6^{\circ}$ Esta Portaria entra em vigor no dia $1^{\circ}$ de janeiro de 2002 , devendo suas disposições serem observadas para todos os processos seletivos realizados para ingresso a partir do segundo semestre do mesmo ano, revogadas as disposições em contrário". 
seletivos, passando a exigir a aplicação de uma prova de redação de caráter eliminatório, com nota mínima. O Enem também passou a fazer parte dos requisitos ou provas dos processos seletivos. Instituições privadas, no entanto, reclamaram da mudança e dos custos envolvidos para aplicação da prova de redação nos processos seletivos ${ }^{155}$.

Apesar das mudanças, os processos seletivos das instituições privadas de ensino superior continuaram sendo alvo de críticas e denúncias. No ano de 2008, um menino de apenas 8 anos foi aprovado em processo seletivo para o curso de direito da Universidade Paulista (Unip). Segundo notícia da época ${ }^{156}$, a criança fez uma prova agendada no final de fevereiro, sua aprovação saiu na segunda-feira (dia 03/03) e a matrícula no curso foi efetivada na quarta-feira (05/03). No primeiro dia de aula, o jovem universitário foi barrado na entrada da Unip e terminou por desistir de fazer o curso. Esse caso teve grande repercussão interna e internacional, com investigações pelo Ministério Público Federal e Ministério da Educação. Preocupou especialmente às autoridades a aprovação de uma criança no exame de redação, já que ele ainda cursava a $5^{\text {a }}$ série do ensino fundamental. Diversas entidades se manifestaram, entre elas, a OAB de Goiás, que afirmou ${ }^{157}$ :

\begin{abstract}
A Ordem dos Advogados do Brasil - Seção de Goiás considera preocupante a informação de que uma criança de apenas oito anos passou no vestibular da Faculdade Unip para o curso de Direito. O fato materializa o alerta que a OAB-GO vem fazendo há tempos sobre a mercantilização do ensino jurídico, que não está sendo tratada pelas autoridades com a devida urgência que requer. A OAB-GO defende maior rigor na fiscalização das Instituições de Ensino Superior por parte do Ministério da Educação e luta para que sejam punidas aquelas que tratam o curso de Direito com interesse meramente mercantil, desrespeitando a relevância da boa formação do bacharel para a sociedade.

O referido fato, por si só, caso seja comprovado, merece que a instituição de ensino sofra imediata intervenção do MEC para que seja verificado se casos semelhantes ocorrem com frequência e em que circunstância o episódio ocorreu.
\end{abstract}

Tais fatos evidenciam que algumas instituições privadas não fazem na verdade um processo seletivo, mas sim um processo de ingresso, em que bastam notas mínimas, muito baixas, para a aprovação. Nesse sentido, o princípio da meritocracia (art. 208, V, CF/88) é claramente ignorado por tais instituições, o que prejudica todo o sistema, que passa a absorver um grande número de alunos que não possuem as habilidades necessárias para o

\footnotetext{
155 Notícia da época destacou este fato: “Quanto à reclamação de algumas faculdades de que é caro incluir a redação no processo seletivo, Paulo Renato disse que elas poderão utilizar a redação do Enem como critério de aprovação em seus vestibulares. Diponível em: $<$ http://www2.uol.com.br/aprendiz/n_noticias/cbn/id181201.htm>. Acesso em: 25/09/2012.

${ }_{156}$ Disponível em: < $\quad$ http://educacao.uol.com.br/ultnot/2008/03/05/ult105u6285.jhtm> e $<$ http://educacao.uol.com.br/ultnot/2008/03/08/ult105u6301.jhtm>. Acesso em: 25/09/2012.

157 Disponível em: <http://educacao.uol.com.br/ultnot/2008/03/05/ult105u6285.jhtm>. Acesso em: 25/09/2012.
} 
ensino superior. Isso levanta debates sobre a necessidade das instituições de ensino superior oferecerem aulas de reforço com matérias do ensino médio; e faz com que o mercado de trabalho passe a questionar a qualidade de determinados diplomas.

Outra mudança importante da LDB foi a eliminação da exigência de "currículos mínimos" para os cursos de graduação das profisssões reguladas em lei e outros necessários ao desenvolvimento nacional, conforme previa o artigo 26 da Lei $n^{0} 5.540 / 1968$. A LDB apenas garantiu uma "base comum nacional" para os cursos de graduação ou pósgraduação em pedagogia (art. 64). Com isso, a LDB conferiu maior flexibilidade de conteúdo para esses cursos, o que atendeu a interesses do setor privado, que passou a organizar tais cursos conforme sua estrutura e as necessidades de sua clientela.

A LDB previu, em seu artigo 80, que o Poder Público deveria "incentivar o desenvolvimento e a veiculação de programas de ensino a distância, em todos os níveis ${ }^{158} \mathrm{e}$ modalidades de ensino, e de educação continuada". A LDB concedeu tratamento diferenciado à educação a distância, o que se evidencia pelas seguintes previsões (art. 80, Parágrafo $4^{\circ}$ ): (i) “custos de transmissão reduzidos em canais comerciais de radiodifusão sonora e de sons e imagens e em outros meios de comunicação que sejam explorados mediante autorização, concessão ou permissão do poder público"; (inciso I, com a redação dada pela Lei $\mathrm{n}^{\mathrm{o}}$ 12.603/21); (ii) “concessão de canais com finalidades exclusivamente educativas" (inciso II); e (iii) "reserva de tempo mínimo, sem ônus para o Poder Público, pelos concessionários de canais comerciais" (inciso III).

As previsões constantes na LDB estimularam o desenvolvimento da educação a distância no Brasil, a qual foi, primeiramente, regulamentada pelo Decreto $\mathrm{n}^{0} 2.494$ de 10/02/1998 e posteriormente pelo Decreto $\mathrm{n}^{\mathrm{o}} 5.622$ de 19/12/2005 (atualmente, em vigor ${ }^{159}$ ). Segundo o artigo $1^{\circ}$ do Decreto $\mathrm{n}^{\mathrm{o}} 5.622 / 05$, a educação a distância é "modalidade educacional na qual a mediação didático-pedagógica nos processos de ensino e aprendizagem ocorre com a utilização de meios e tecnologias de informação e comunicação, com estudantes e professores desenvolvendo atividades educativas em lugares ou tempos diversos" (art. $1^{\circ}$, Decreto $\left.n^{0} 5.622 / 05\right)$. Apesar de caracterizado pela

\footnotetext{
${ }^{158}$ Nos termos do artigo $2^{\circ}$ do Decreto $n^{\circ} 5.622 / 05$, “a educação a distância poderá ser ofertada nos seguintes níveis e modalidades educacionais: I - educação básica, nos termos do art. 30 deste Decreto; II - educação de jovens e adultos, nos termos do art. 37 da Lei n ${ }^{\circ}$ 9.394, de 20 de dezembro de 1996; III - educação especial, respeitadas as especificidades legais pertinentes; IV - educação profissional, abrangendo os seguintes cursos e programas: a) técnicos, de nível médio; e b) tecnológicos, de nível superior; $\mathrm{V}$ - educação superior, abrangendo os seguintes cursos e programas: a) sequenciais; b) de graduação; c) de especialização; d) de mestrado; e e) de doutorado".

${ }^{159}$ Este decreto foi alterado em 2007, pelo Decreto $n^{\circ} 6.303$, de 12/12/2007.
} 
redução do contato direto entre alunos e professores, o Decreto $\mathrm{n}^{\mathrm{o}}$ 5.622/05 (art. $1^{\mathrm{o}}$, Parágrafo $1^{\circ}$ ) exige que os cursos a distância desenvolvam as seguintes atividades em momentos presenciais ${ }^{160}$ : (i) avaliações de estudantes; (ii) estágios obrigatórios; (iii) defesa de trabalhos de conclusão de curso; e (iv) atividades relacionadas a laboratórios de ensino.

A educação a distância é considerada uma resposta para as dificuldades de estudar em decorrência de (i) problemas de distância física do local de ensino - para muitas pessoas o ensino superior encontra-se em locais muito distantes de suas residências, o que dificulta o acesso; (ii) falta de tempo - muitos estudantes têm obrigações que envolvem família e trabalho que conflitam com os horários escolares tradicionais; e (iii) custos - a educação a distância é uma modalidade de ensino mais barata tanto para o fornecedor como para o aluno (DIRR, 1990, p. 398).

Seguindo a orientação de um Estado regulador e avaliador, a LDB limitou o prazo de autorização e reconhecimento de cursos, bem como de credenciamento e recredenciamento das instituições. Com isso, as instituições passaram a se sujeitar a processos periódicos de avaliação. Esse assunto será desenvolvido no item 2.3.4 abaixo.

\subsubsection{Fundef/Fundeb}

Nos termos do artigo 212 da Constituição de 1988, a União aplicará, anualmente, nunca menos de 18\%; e os Estados, o Distrito Federal e os Municípios, no mínimo, 25\% da receita resultante de impostos, compreendida a proveniente de transferências, na manutenção e desenvolvimento do ensino ${ }^{161}$.

De acordo com o Parágrafo $3^{\circ}$ do artigo 212 da Constituição, a distribuição dos recursos públicos assegurará prioridade ao atendimento das necessidades do ensino obrigatório, no que se refere a universalização, garantia de padrão de qualidade e equidade, nos termos do Plano Nacional de Educação ${ }^{162}$.

Para a distribuição dos recursos da educação entre os entes federados, por meio da

\footnotetext{
${ }^{160}$ Nos termos do artigo 10, $2^{\circ}$, do Decreto $n^{\circ} 5.622 / 05$ (Incluído pelo Decreto $\mathrm{n}^{\mathrm{o}}$ 6.303, de 2007) - “As atividades presenciais obrigatórias, compreendendo avaliação, estágios, defesa de trabalhos ou prática em laboratório, conforme o art. $1^{\circ}, \S 1^{\circ}$, serão realizados na sede da instituição ou nos pólos de apoio presencial, devidamente credenciados".

${ }^{161}$ Os parâmetros previstos no art. 212 da Constiuição de 1988 são mínimos. Nesse sentido, o Estado de São Paulo, por exemplo, nos termos do artigo 225 de sua Constituição Estadual, deve aplicar 30\% da receita resultante de impostos, incluindo recursos provenientes de transferências na manutenção e desenvolvimento do ensino no estado.

${ }^{162}$ Redação dada pela $\mathrm{EC} \mathrm{n}{ }^{\circ} 59 / 2009$, que incluiu no texto: "no que se refere a universalização, garantia de padrão de qualidade e equidade".
} 
Emenda Constitucional $\mathrm{n}^{\mathrm{o}} 14$ de 1996, que alterou o artigo 60 da ADCT, foi incluída a previsão de criação, no âmbito de cada Estado e do Distrito Federal de um Fundo de Manutenção e Desenvolvimento do Ensino Fundamental e Valorização do Magistério (Fundef), de natureza contábil, para gerir parte dos recursos destinados à educação, visando assegurar a universalização do atendimento do ensino fundamental e a remuneração condigna do magistério. Com isso criou-se o Fundef, que passou a ser regido pela Lei $n^{0}$ 9.424, de 24/12/1996.

Oliveira (2006, p. 90) destaca que o Fundef foi uma forma de descentralização da gestão e do financiamento da educação, que impulsionou a municipalização do ensino fundamental no País. Segundo o autor (2006, p. 98):

\begin{abstract}
Este fundo, de natureza contábil, foi instituído pela EC-14 e regulamentado pela Lei $\mathrm{n}^{\circ}$ 9.242/96. A Emenda 14 é uma reformulação de alguns artigos da Constituição Federal que incide sobre o conjunto dos sistemas de maneira acentuada. Esta emenda foi originada, em termos jurídicos, tanto pela necessidade de se precisar a distribuição de competências quanto a de permitir que a União se desvencilhasse do 'imbróglio' em que se encontrava por não cumprir, até aquele momento, o artigo 60 do Ato das Disposições Constitucionais Transitórias (ADCT).
\end{abstract}

Em 2006, o Fundef foi aprofundado e, por meio da Emenda Constitucional n ${ }^{0} 53$ de 2006, previu-se a criação do Fundo de Manutenção e Desenvolvimento da Educação Básica e de Valorização dos Profíssionais da Educação (Fundeb), que ampliou a abrangência do fundo para toda a educação básica e para a remuneração dos trabalhadores da educação (art. 60, ADCT), com o aumento do percentual dos impostos incluídos no fundo. A Lei n ${ }^{\circ} 11.494$, de 20/06/2007, passou a regular o Fundeb.

O Fundeb é um mecanismo criado pelo legislador constitucional para separar e organizar os recursos destinados à manutenção dos sistemas de ensino, com o objetivo de auxiliar a universalização da educação básica, promover a igualdade, melhorar a qualidade do ensino e valorizar os profissionais da educação - a esse respeito, o artigo 22 da Lei $n^{\circ}$ $11.494 / 07$ prevê que, pelo menos, $60 \%$ dos recursos anuais totais dos fundos ${ }^{163}$ serão destinados ao pagamento da remuneração dos profissionais do magistério da educação básica em efetivo exercício na rede pública.

O Fundeb também foi instituído no âmbito de cada Estado e Distrito Federal, com

\footnotetext{
${ }^{163}$ Fala-se em fundos, no plural, porque cada Estado e o Distrito Federal possui um fundo específico para os recursos na respectiva unidade da federação. Nos termos do artigo $1^{\circ}$ da Lei 11.494/07, "é instituído, no âmbito de cada Estado e do Distrito Federal, um Fundo de Manutenção e Desenvolvimento da Educação Básica e de Valorização dos Profissionais da Educação - Fundeb, de natureza contábil, nos termos do art. 60 do Ato das Disposições Constitucionais Transitórias - ADCT”.
} 
natureza contábil, composto de recursos financeiros dos próprios estados e municípios, complementados pela União, quando for o caso. A retirada dos recursos é feita de acordo com o número de alunos matriculados e proporcionalmente à modalidade de ensino (cada série da educação básica tem um determinado valor por aluno). Tendo natureza contábil, os recursos são repassados automaticamente, por meio de conta única e específica de cada Estado e Município, mensalmente, de acordo com coeficientes de distribuição estabelecidos e publicados previamente (art. 17, Lei $\mathrm{n}^{0}$ 11.494/07). As receitas e despesas, por sua vez, deverão estar previstas no orçamento, e a execução, contabilizada de forma específica.

O interessante da sistemática do Fundeb é que todos os entes contribuem, conforme sua arrecadação, mas os valores são divididos igualmente de acordo com o número de alunos (assim entes que arrecadam mais auxiliam entes que arrecadam menos). Este sistema permite uma melhoria da qualidade do ensino do sistema como um todo, diminuindo as diferenças regionais, em linha com os princípios de igualdade de condição de acesso e permanência na escola e garantia de padrão de qualidade previstos no artigo 206 da Constituição.

Ademais, com o objetivo de disciplinar o artigo 60, III, “e”, do ADCT, para instituir o piso salarial profissional nacional aos profissionais do magistério público da educação básica, foi publicada a Lei $\mathrm{n}^{0} 11.738 / 08$, comentada no Capítulo 1 desta Dissertação.

O Fundef e o Fundeb permitiram a transferência de recursos para a educação, o que favoreceu a busca pela universalização da educação básica e, consequentemente, o aumento do acesso ao ensino superior.

Para Oliveira (2006), a quase universalização do acesso ${ }^{164}$ e permanência no ensino fundamental foi o eixo propulsor de um novo panorama no ensino brasileiro, que teve como consequência uma demanda por expansão de todo o sistema ${ }^{165}$ e trouxe como

\footnotetext{
164 Segundo Oliveira (2006, p. 14): "números evidenciam que nessas últimas três décadas, praticamente universalizou-se o atendimento de toda a população no Ensino Fundamental. Além disso, durante os anos da década de 1990, foram reincorporados ao sistema educacional parcela substantiva de alunos anteriormente excluídos ou que não haviam, ainda, ingressado no sistema escolar".

${ }^{165}$ Segundo Oliveira (2006, p. 43), "a ampliação dos índices de conclusão do Ensino Fundamental fez com que populações historicamente excluídas do sistema de ensino, ou por não conseguirem ingressar ou por serem expelidas de seu interior nas etapas iniciais de seu processo de escolarização, pela primeira vez, passaram a ter condições de avançar para as etapas posteriores. Vencida a primeira barreira, o Ensino Fundamental, a expansão do Ensino Médio na década de 90 foi notável. Ainda que a matrícula esteja hoje na casa dos nove milhões, abaixo até mesmo, da coorte etária de 15 a 17 anos e com uma matrícula líquida acentuadamente menor do que a bruta, já se pode perceber que a pressão por expansão se transferiu nos primeiros anos desta década, para o ensino superior".
} 
problema central a qualidade. Segundo o autor (2006, p. 40-1):

\begin{abstract}
A universalização do Ensino Fundamental gerou duas novas demandas populares por acesso à educação. Uma materializada na matrícula no Ensino Médio e mesmo no Ensino Superior, implodindo, ironicamente, a vertente da economia de recursos que originou parte das políticas de correção de fluxo. A vertente que prosperou foi a democratizadora, por mais educação, para maior número de pessoas, por mais tempo.

A segunda demanda [...] refere-se à questão da qualidade [...]. Ainda que não se possa arguir com tranquilidade que a escola que foi deixada para trás nesse processo, a idílica escola de privilégios de alguns, como menciona Mariana Enguita, tivesse de fato qualidade, posto que a maioria dela se encontrava excluída. Entretanto, é ela "que oprime o cérebro dos vivos" e ocupa o centro da crítica ao processo presente de expansão.
\end{abstract}

Dados sobre a quase universalização do ensino fundamental e o crescimento do ensino médio no Brasil encontram-se no item 2.6 abaixo.

\title{
2.3.4 Lei $n^{\circ}$ 9.131/95 - Avaliação
}

A mais antiga experiência brasileira de avaliação da educação superior é a dos cursos e programas de pós-graduação, desenvolvida desde 1976 pela Fundação Coordenação de Aperfeiçoamento de Pessoal de Nível Superior (Capes).

No entanto, com relação à graduação, o tema da avaliação apenas começou a ser debatido no País a partir da década de 1980, por conta do crescimento do ensino superior (em número de instituições e matrículas) (INEP, 2004, p. 18). Nesse contexto, a avaliação era concebida como uma forma de as instituições de ensino superior prestarem contas à sociedade dos investimentos efetuados pelo Poder Público. Assim, surgiu o Programa de Avaliação da Reforma Universitária (Paru) em $1983^{166}$ e, posteriormente, em 1993, foi lançado o Programa de Avaliação Institucional das Universidades Brasileiras (Paiub).

Em 1994, as políticas de avaliação do ensino superior começam a ser implantadas por meio de medidas provisórias (MP n ${ }^{0} 661$, de 18/10/1994; MP n ${ }^{0} 711$, de 17/11/1994; MP no 765, de 16/12/1994; MP nº 830, de 13/01/1995; MP n 891, de 14/02/1995), que previam atribuições genéricas ao Ministério da Educação e do Desporto de "zelar pela qualidade do ensino e observância das leis que o regem" e ao CNE de emitir pareceres, propor procedimentos para o funcionamento das instituições de ensino superior, promover sindicâncias e inquéritos. Em 16 de março de 1995, com a MP nº 938, foi introduzido no

\footnotetext{
${ }^{166}$ O Paru envolvia basicamente dois temas: gestão e produção/disseminação de conhecimentos, utilizandose de levantamento e análises de dados institucionais colhidos através de roteiros e questionários preenchidos por estudantes, professores e administradores (INEP, 2004, p. 18).
} 
sistema de ensino brasileiro os "Exames Nacionais de Cursos" (ENC), conhecidos como "provões"167. Esses exames foram confirmados por sucessivas medidas provisórias (MP $\mathrm{n}^{\mathrm{o}}$

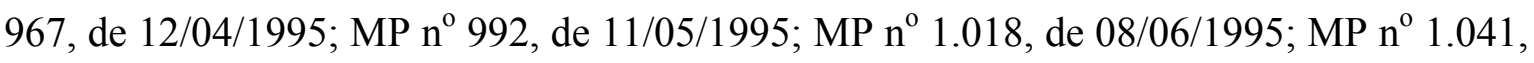
29/06/1995; MP n ${ }^{0} 1.064$, de 28/07/1995, MP n 1.094, de 28/08/1995; MP n ${ }^{0} 1.126$, de 26/09/1995; MP $n^{0} 1.159$, de 26/10/1996) até a edição da Lei $n^{0} 9.131$ de 24/11/1995 (conversão da $\left.M P n^{\circ} 1.159 / 96\right)$, que previu em seu artigo $3^{\circ}$ que:

Art. $3^{\circ}$ - Com vistas ao disposto na letra e do $\S 2^{\circ}$ do art. $9^{\circ}$ da Lei $n^{\circ} 4.024$, de 1961 , com a redação dada pela presente Lei, o Ministério da Educação e do Desporto fará realizar avaliações periódicas das instituições e dos cursos de nível superior, fazendo uso de procedimentos e critérios abrangentes dos diversos fatores que determinam a qualidade e a eficiência das atividades de ensino, pesquisa e extensão.

$\S 1^{\circ}$ - Os procedimentos a serem adotados para as avaliações a que se refere o caput incluirão, necessariamente, a realização, a cada ano, de exames nacionais com base nos conteúdos mínimos estabelecidos para cada curso, previamente divulgados e destinados a aferir os conhecimentos e competências adquiridos pelos alunos em fase de conclusão dos cursos de graduação. (grifo nosso)

$\S 2^{\circ}$ - O Ministério da Educação e do Desporto divulgará, anualmente, o resultado das avaliações referidas no caput deste artigo, inclusive dos exames previstos no parágrafo anterior, informando o desempenho de cada curso, sem identificar nominalmente os alunos avaliados.

$\S 3^{\circ}$ - A realização de exame referido no $\S 1^{\circ}$ deste artigo é condição prévia para obtenção do diploma, mas constará do histórico escolar de cada aluno apenas o registro da data em que a ele se submeteu.

$\S 4^{\circ}$ - Os resultados individuais obtidos pelos alunos examinados não serão computados para sua aprovação, mas constarão de documento específico, emitido pelo Ministério da Educação e do Desporto, a ser fornecido exclusivamente a cada aluno.

$\S 5^{\circ}$ - A divulgação dos resultados dos exames, para fins diversos do instituído neste artigo, implicará responsabilidade para o agente, na forma da legislação pertinente.

$\S 6^{\circ}$ - O aluno poderá, sempre que julgar conveniente, submeter-se a novo exame, nos anos subsequentes, fazendo jus a novo documento específico.

$\S 7^{\circ}$ - A introdução dos exames nacionais, como um dos procedimentos para avaliação dos cursos de graduação, será efetuada gradativamente, a partir do ano seguinte à publicação da presente Lei, cabendo ao Ministro de Estado da Educação e do Desporto determinar os cursos a serem avaliados.

As sistemáticas do Paiub e do ENC eram diferentes - o primeiro tinha foco na instituição em sua globalidade e o segundo, foco nos resultados e na avaliação dos cursos e dos alunos. Segundo o Inep (2004, p. 20):

${ }^{167}$ Art. 3, MP nº 938/95 - “O Ministério da Educação e do Desporto fará realizar exames de avaliação dos conhecimentos adquiridos pelos alunos das últimas séries dos cursos de graduação das instituições de ensino superior. $\S 1^{\circ}$ - No primeiro ano de aplicação dos exames referidos no caput deste artigo, serão avaliados os alunos dos cursos das áreas da saúde física e mental, da engenharia e do direito, estendendo-se gradativamente o mesmo procedimento aos cursos das demais áreas. $\S 2^{\circ}$ - O resultado da avaliação constará do histórico escolar do aluno, não importando em qualquer restrição para a emissão do diploma de conclusão do curso respectivo. $\S 3^{\circ}$ - O Ministério da Educação e do Desporto divulgará, anualmente, o resultado das avaliações, informando o desempenho de cada curso, sem identificar nominalmente os alunos avaliados. $\S 4^{\circ}$ - Os resultados das avaliações serão considerados quando do processo de recredenciamento da respectiva instituição de ensino superior". 
enquanto no Paiub a preocupação estava com a totalidade, com o processo e com a missão da instituição na sociedade, no ENC a ênfase recai sobre os resultados, com a produtividade, a eficiência, com o controle do desempenho frente a um padrão estabelecido e com a prestação de contas. O Paiub tem como referência a globalidade institucional, aí compreendidas todas as dimensões e funções das IES. O ENC tem como foco o Curso, em sua dimensão de ensino, e tem função classificatória, com vistas a construir bases para uma possível fiscalização, regulação e controle, por parte do Estado, baseada na lógica de que a qualidade de um curso é igual à qualidade de seus alunos.

A esse respeito, Cunha (2003, p. 49) afirma:

contrariando a proposta de governo do candidato Fernando Henrique Cardoso, o foco da avaliação do ensino superior deslocou-se da dimensão institucional para a dimensão individual. Ao passo que o Programa de Avaliação Institucional das Universidades Brasileiras (PAIUB) era sensivelmente desacelerado, e a Lei $\mathrm{n}^{\circ}$ 9.131/95 dizia que o MEC procederia a "avaliações periódicas das instituições e dos cursos de ensino superior, fazendo uso de procedimentos e critérios abrangentes, dos diversos fatores que determinam a qualidade e a eficiência das atividades de ensino, pesquisa e extensão", o que se instituiu mesmo foram os Exames Nacionais de Cursos, os quais seriam obrigatórios para todos os estudantes do último ano dos cursos superiores de graduação do País.

Junto com o ENC, foi instituída, em 1997, a Avaliação das Condições de Oferta de Cursos de Graduação, que se baseava na verificação em campo de três dimensões: corpo docente, organização didática e pedagógica e instalações físicas.

Uma importante inovação da LDB em matéria de avaliação foi a previsão de que a “autorização e o reconhecimento de cursos, bem como o credenciamento de instituições de educação superior, terão prazos limitados, sendo renovados, periodicamente, após processo regular de avaliação" (art. 46). Previu também que os resultados dos processos de avaliação podem gerar sanções - constatadas deficiências será aberto um prazo para saneamento, que gerará uma reavaliação, que poderá resultar, em “desativação de cursos e habilitações, em intervenção na instituição, em suspensão temporária de prerrogativas da autonomia, ou em descredenciamento" (art. 46, Parágrafo $1^{\circ}$ ).

Nesse contexto, primeiro o Decreto $n^{0} 2.026$ de 10/10/1996, depois o Decreto $n^{\circ}$ 3.860 de 09/07/2001 e finalmente o Decreto $n^{0} 5.773$ de 09/05/2006 (em vigor), regularam os processos de avaliação das instituições e cursos de ensino superior no Brasil. Nos termos do artigo $3^{\circ}$ do Decreto $\mathrm{n}^{0} 5.773 / 06$, as funções de regulação, supervisão e avaliação serão exercidas pelo Ministério da Educação ${ }^{168}$, pelo $\mathrm{CNE}^{169}$, pelo Instituto

168 Art. $4^{\circ}$, Decreto $n^{\circ}$ 5.773/06 - "Ao Ministro de Estado da Educação, como autoridade máxima da educação superior no sistema federal de ensino, compete, no que respeita às funções disciplinadas por este Decreto: I - homologar deliberações do CNE em pedidos de credenciamento e recredenciamento de instituições de educação superior; II - homologar os instrumentos de avaliação elaborados pelo INEP; III homologar os pareceres da CONAES; IV - homologar pareceres e propostas de atos normativos aprovadas pelo CNE; e V - expedir normas e instruções para a execução de leis, decretos e regulamentos. Art. $5^{\circ}$ - No 
Nacional de Estudos e Pesquisas Educacionais Anísio Teixeira - Inep ${ }^{170}$, e pela Comissão Nacional de Avaliação da Educação Superior - Conaes ${ }^{171}$.

$\mathrm{Na}$ estrutura atual do MEC, três secretarias exercem competências de avaliação e regulação da educação superior: (i) Secretaria de Educação Superior (Sesu); (ii) Secretaria de Educação Profissional e Tecnológica; e (iii) Secretaria de Educação a Distância.

O controle da atividade de educação superior envolve a atuação dos órgãos reguladores na entrada, permanência e saída do sistema. O processo de entrada se dá por meio da autorização e do credenciamentoO primeiro passo da autorização é a análise da proposta e avaliação preliminar, com verificação in loco das condições institucionais para o funcionamento do curso proposto, com isso se faz a autorização do curso e

que diz respeito à matéria objeto deste Decreto, compete ao Ministério da Educação, por intermédio de suas Secretarias, exercer as funções de regulação e supervisão da educação superior, em suas respectivas áreas de atuação".

${ }^{169}$ Art. $6^{\circ}$, Decreto $n^{0} 5.773 / 06$ - "No que diz respeito à matéria objeto deste Decreto, compete ao CNE: I exercer atribuições normativas, deliberativas e de assessoramento do Ministro de Estado da Educação; II deliberar, com base no parecer da Secretaria competente, observado o disposto no art. $4^{\mathrm{o}}$, inciso I, sobre pedidos de credenciamento e recredenciamento de instituições de educação superior e específico para a oferta de cursos de educação superior a distância; III - recomendar, por sua Câmara de Educação Superior, providências das Secretarias, entre as quais a celebração de protocolo de compromisso, quando não satisfeito o padrão de qualidade específico para credenciamento e recredenciamento de universidades, centros universitários e faculdades; IV - deliberar sobre as diretrizes propostas pelas Secretarias para a elaboração, pelo INEP, dos instrumentos de avaliação para credenciamento de instituições; V - aprovar os instrumentos de avaliação para credenciamento de instituições, elaborados pelo INEP; VI - deliberar, por sua Câmara de Educação Superior, sobre a exclusão de denominação de curso superior de tecnologia do catálogo de que trata o art. $5^{\circ}, \S 3^{\circ}$, inciso VII; VII - aplicar as penalidades previstas no Capítulo IV deste Decreto; VIII julgar recursos, nas hipóteses previstas neste Decreto; IX - analisar questões relativas à aplicação da legislação da educação superior; e X - orientar sobre os casos omissos na aplicação deste Decreto, ouvido o órgão de consultoria jurídica do Ministério da Educação".

${ }^{170}$ Art. $7^{\circ}$, Decreto $n^{\circ} 5.773 / 06$ - "No que diz respeito à matéria objeto deste Decreto, compete ao INEP: I realizar visitas para avaliação in loco nos processos de credenciamento e recredenciamento de instituições de educação superior e nos processos de autorização, reconhecimento e renovação de reconhecimento de cursos de graduação e sequenciais; II - realizar as diligências necessárias à verificação das condições de funcionamento de instituições e cursos, como subsídio para o parecer da Secretaria competente, quando solicitado; III - realizar a avaliação das instituições, dos cursos e do desempenho dos estudantes; IV elaborar os instrumentos de avaliação conforme as diretrizes da CONAES; V - elaborar os instrumentos de avaliação para credenciamento de instituições e autorização de cursos, conforme as diretrizes do CNE e das Secretarias, conforme o caso; e VI - constituir e manter banco público de avaliadores especializados, conforme diretrizes da CONAES".

${ }^{171}$ Art. $8^{\circ}$, Decreto ${ }^{\circ}{ }^{5}$.773/06 - "No que diz respeito à matéria objeto deste Decreto, compete à CONAES: I - coordenar e supervisionar o SINAES; II - estabelecer diretrizes para a elaboração, pelo INEP, dos instrumentos de avaliação de cursos de graduação e de avaliação interna e externa de instituições; III estabelecer diretrizes para a constituição e manutenção do banco público de avaliadores especializados; IV aprovar os instrumentos de avaliação referidos no inciso II e submetê-los à homologação pelo Ministro de Estado da Educação; V - submeter à aprovação do Ministro de Estado da Educação a relação dos cursos para aplicação do Exame Nacional de Desempenho dos Estudantes - ENADE; VI - avaliar anualmente as dinâmicas, procedimentos e mecanismos da avaliação institucional, de cursos e de desempenho dos estudantes do SINAES; VII - estabelecer diretrizes para organização e designação de comissões de avaliação, analisar relatórios, elaborar pareceres e encaminhar recomendações às instâncias competentes; VIII - ter acesso a dados, processos e resultados da avaliação; e IX - submeter anualmente, para fins de publicação pelo Ministério da Educação, relatório com os resultados globais da avaliação do SINAES". 
posteriormente a autorização da instituição. Uma vez autorizada a funcionar, a instituição de ensino superior deve preparar-se para, no prazo de três anos, em efetivo funcionamento, realizar o processo de avaliação para reconhecimento dos seus cursos iniciais e credenciamento como instituição de ensino superior (INEP, 2004, p. 127).

Concluído o ato de reconhecimento dos cursos e realizado o credenciamento da instituição, ela passará a integrar o sistema de avaliações periódicas de acreditação, a primeira a ser concluída por volta do oitavo ano, desde o início das atividades, ou a partir de três anos após o credenciamento inicial da instituição (INEP, 2004, p. 127).

Essa estrutura possui quatro características principais: (i) a autorização passa a ser um processo temporário que antecede o reconhecimento de cursos e o credenciamento da instituição e durante o processo de autorização, a instituição de ensino superior funcionará a título experimental, precário, sob supervisão da Sesu; (ii) o foco para a avaliação e para a a supervisão passa a ser a instituição; (iii) o plano de desenvolvimento institucional ganha força ao ser revisto no terceiro ano de funcionamento, deixando de ser uma carta de intenções; e (iv) o prazo para a primeira avaliação periódica, a contar do início do funcionamento, passa a ser de até oito anos (INEP, 2004, p. 130).

Em 14 de abril de 2004, por meio da Lei $\mathrm{n}^{\mathrm{o}} 10.861$ (em vigor), foi instituído o Sistema Nacional de Avaliação da Educação Superior (Sinaes), que é hoje o principal instrumento de avaliação do ensino superior no Brasil. O Sinaes tem o objetivo de “assegurar processo nacional de avaliação das instituições de educação superior, dos cursos de graduação e do desempenho acadêmico de seus estudantes, nos termos do art. $9^{\circ}$, VI, VIII e IX”, da LDB (art. $1^{\circ}$, Lei n $\left.{ }^{\circ} 10.861 / 04\right)$. O criação do Sinaes estava prevista no PNE de $2001^{172}$.

De acordo com o Inep ${ }^{173}$ :

o Sinaes é formado por três componentes principais: a avaliação das instituições, dos cursos e do desempenho dos estudantes. O Sinaes avalia todos os aspectos que giram em torno desses três eixos: o ensino, a pesquisa, a extensão, a responsabilidade social, o desempenho dos alunos, a gestão da instituição, o corpo docente, as instalações e vários outros aspectos.

O Sinaes utiliza uma série de instrumentos complementares: autoavaliação,

\footnotetext{
${ }^{172}$ Art. $4^{\circ}$, Lei $\mathrm{n}^{\mathrm{o}}$ 10.172/01 - “A União instituirá o Sistema Nacional de Avaliação e estabelecerá os mecanismos necessários ao acompanhamento das metas constantes do Plano Nacional de Educação". Art. $3^{\circ}$, Lei $n^{\circ}$ 10.172/01 - “A União, em articulação com os Estados, o Distrito Federal, os municípios e a sociedade civil, procederá a avaliações periódicas da implementação do Plano Nacional de Educação".

${ }^{173}$ Disponível em: <http://portal.inep.gov.br/superior-sinaes $>$. Acesso em: 28/07/2012.
} 
avaliação externa ${ }^{174}$, o Exame Nacional de Desempenho de Estudantes (Enade), avaliação dos cursos de graduação ${ }^{175}$ e instrumentos de informação (censo e cadastro) ${ }^{176}$. Os processos avaliativos são coordenados e supervisionados pela Comissão Nacional de Avaliação da Educação Superior (Conaes), e a operacionalização do processo é de responsabilidade do Inep ${ }^{177}$.

O Enade é uma prova nacional aplicada pelo MEC para os alunos de graduação do primeiro e do último ano de cada curso. A cada ano, é avaliado um grupo de cursos, completando a avaliação de todos os principais cursos a cada ciclo de três anos. O primeiro Enade ocorreu em 2004, quando foi instituído o Sinaes, e substituiu o ENC - Provão, que era aplicado apenas aos alunos matriculados no último ano de cada curso. De acordo com informações do Inep, “a avaliação dos estudantes, através do Enade, será aplicada periodicamente aos alunos de todos os cursos de graduação, ao final do primeiro e do último ano de curso. A avaliação será expressa por meio de conceitos, tomando por base padrões mínimos estabelecidos por especialistas das diferentes áreas do conhecimento" ${ }^{178}$.

\footnotetext{
${ }^{174}$ Segundo informações do Inep, a Avaliação Institucional, interna e externa, considera dez dimensões: 1. Missão e PDI; 2. Política para o ensino, a pesquisa, a pós-graduação e a extensão; 3. Responsabilidade social da IES; 4. Comunicação com a sociedade; 5 . As políticas de pessoal, as carreiras do corpo docente e técnicoadministrativo; 6. Organização de gestão da IES; 7. Infraestrutura física; 8. Planejamento de avaliação; 9. Políticas de atendimento aos estudantes; 10. Sustentabilidade financeira. Disponível em: $<$ http://portal.inep.gov.br/superior-sinaes-componentes>. Acesso em: 28/07/2012.

${ }^{175}$ Segundo informações do Inep, a avaliação dos cursos considera três dimensões: 1. Organização didáticopedagógica; 2. Perfil do corpo docente; 3. Instalações físicas. Disponível em: $<$ http://portal.inep.gov.br/superior-sinaes-componentes>. Acesso em: 28/07/2012.

${ }^{176}$ Segundo dados do Inep, os instrumentos de informação são: (i) Censo da Educação Superior (integrado ao Sinaes e incluindo informações sobre atividades de extensão); (ii) Cadastro de Cursos e Instituições (integrado ao Sinaes); e (iii) CPA: Comissão Própria de Avaliação (criadas nas IES com a atribuição de conduzir os processos de avaliação interna da instituição, de sistematização e de coleta de informações). Disponível em: <http://portal.inep.gov.br/superior-sinaes-componentes>. Acesso em: 28/07/2012.

${ }^{177}$ Disponível em: $<$ http://portal.inep.gov.br/superior-sinaes $>$. Acesso em: 28/07/2012.

${ }^{178} \mathrm{O}$ Enade é uma prova nacional aplicada pelo MEC para os alunos de graduação do $1^{\circ}$ primeiro e do último ano de cada curso. A cada ano, é avaliado um grupo de cursos, completando a avaliação de todos os principais cursos a cada ciclo de três anos. O primeiro Enade ocorreu em 2004, quando foi instituído o Sinaes, e substituiu o ENC - Provão, que era aplicado apenas aos alunos matriculados no último ano de cada curso. De acordo com informações do Inep, “a avaliação dos estudantes, através do Enade, será aplicada periodicamente aos alunos de todos os cursos de graduação, ao final do primeiro e do último ano de curso. A avaliação será expressa por meio de conceitos, tomando por base padrões mínimos estabelecidos por especialistas das diferentes áreas do conhecimento". Disponível em: <http://portal.inep.gov.br/superiorsinaes-componentes $>$. Acesso em: 28/07/2012. A imprensa noticiou a influência de instituições de ensino superior no questionário do Enade a ser respondido pelos alunos sobre a estrutura do curso. Segundo o jornal O Estado de São Paulo, alunos da Universidade Paulista (Unip) relataram que a instituição ofereceu um pen drive em troca de avaliação positiva no questionário socioeconômico do Enade, que seria aplicado na instituição. No questionário, o aluno dá opinião sobre infraestrutura, professores e métodos pedagógicos - informações usadas pelo Ministério da Educação para compor a avaliação final do curso. Estudantes ouvidos pelo jornal afirmaram que, "na semana passada, professores informaram que quem preenchesse o questionário de maneira favorável à universidade seria premiado com um pen drive". A Unip, por sua vez, afirmou que "presenteou todos os selecionados para fazer o Enade com o equipamento, como uma maneira de estimulá-los a fazer a prova". Alguns estudantes contaram também que chegaram a participar de uma reunião para receber orientações sobre como preencher o questionário. Disponível em:
} 
A integração de todos os instrumentos (autoavaliação, avaliação externa, avaliação das condições de ensino, Enade, censo e cadastro) permite a atribuição de conceitos às instituições e cursos, ordenados numa escala com cinco níveis (de 1 a $5^{179}$ ). Dentro dessa sistemática, são elaborados os seguintes indicadores:

(i) Conceito Preliminar de Curso (CPC) - composto pela nota do Enade, pelo Indicador de Diferença entre os Desempenhos Observado e Esperado $\left(\right.$ IDD $^{180}$ ) e variáveis de insumo - corpo docente (titulação e regime de trabalho), organização didáticopedagógica $^{181}$ e infraestrutura. Este conceito, que varia de 1 a 5, segundo o MEC (s/d), "é um indicador prévio da situação dos cursos de graduação no país". Cursos com CPC 1 e 2 são automaticamente incluídos no cronograma de visitas dos avaliadores do Inep para verificação in loco das condições de ensino. Cursos com conceito igual ou superior a 3 podem optar por não receber a visita dos avaliadores e, assim, transformar o CPC em conceito permanente (o Conceito de Curso - CC). O CPC é divulgado a cada três anos para cada grupo de cursos, juntamente com os resultados do Enade;

(ii) Índice Geral de Cursos (IGC) - indicador de qualidade dos cursos de gradução e pós-graduação stricto sensu (mestrado e doutorado) das instituições de ensino superior, que considera, em sua composição ${ }^{182}$, para a graduação, o CPC dos cursos; e, para a pós-graduação, a nota Capes. O resultado final é expresso em valores contínuos (que vão de 0 a 500) e em faixas (de 1 a 5). O IGC é critério nos processos de credenciamento e recredenciamento de instituições e também no processo de autorização para novos cursos instituições com IGC inferior a 3 podem ter seus pedidos de abertura de novo curso indeferidos pelo MEC; ao mesmo tempo, instituições com bom desempenho ficam dispensadas da autorização do MEC para abertura de novos cursos (MEC, s/d); e

$<$ http://www.estadao.com.br/noticias/impresso,unip-da-brinde-a-aluno-que-fara-enade,462577,0.htm>. Acesso em: 25/09/2012.

${ }^{179}$ Os resultados 1 e 2 expressam condições insatisfatórias, o 3 expressa condição satisfatória, e o 4 e o 5 expressam condições acima das satisfatórias. Vide Portaria Normativa do Ministério da Educação $n^{0} 4$, de 05/08/2008.

${ }^{180}$ Segundo o MEC (s/d), o IDD mede a "diferença entre o desempenho médio do concluinte de um curso e o desempenho médio estimado para os concluintes desse mesmo curso. Representa, portanto, quanto cada curso se destaca da média, podendo ficar acima ou abaixo do que seria esperado, baseando-se no perfil de seus estudantes. O indicador tem escala de 1 a 5 , sendo 5 o melhor resultado.

Segundo Paiva, "Índice de Desenvolvimento Discente - Avalia o conjunto dos alunos do curso em comparação com o conjunto dos alunos que fizeram o ENADE, permitindo avaliar a capacidade do curso em agregar conhecimento aos alunos ingressantes em comparação com o desempenho dos formandos. O IDD mostra a capacidade da IES transferir conhecimento ao seu aluno ao longo do curso", disponível em: http://professorpaiva.blogspot.com.br/2011/01/esclarecendo-as-avaliacoes-do-mec-para.html.

${ }_{181}$ Avaliadas por meio do Censo da Educação Superior e de respostas ao questionário socioeconômico do ENADE.

182 Disponível em: http://www.inep.gov.br/imprensa/noticias/edusuperior/institucional/news09_06.htm. Acesso em: 03/12/2012. 
(iii) Conceito Institucional (CI) e Avaliação Institucional - a cada ciclo avaliativo, a instituição de ensino superior é avaliada in loco. Os avaliadores, orientados pelos IGCs das instituições, atribuem um Conceito Institucional, considerando os elementos da visita. A Avaliação Institucional é composta pela autoavaliação ou avaliação interna (coordenada por comissão própria de avaliação de cada instituição) e pela avaliação externa, realizada pelas comissões designadas pelo Inep (MEC, s/d).

Os resultados da avaliação do Sinaes são públicos. Com base neles são elaborados rankings das instituições.

Segundo Oliveira (2006, p. 100), a "difusão de uma cultura avaliativa" baseou-se na expectativa de que a "simples divulgação dos resultados obtidos por sistemas e por escolas induziria a melhoria de qualidade, tanto por meio de iniciativas autônomas dos próprios sistemas e escolas quanto como resultado de uma maior pressão da comunidade de usuários". Por essa sistemática, as instituições de ensino superior que não tivessem bom desempenho na prova deveriam melhorar seus resultados, caso contrário, perderiam alunos para outras mais bem colocadas nos rankings (BARREYRO, 2008, p. 22).

Para Dourado, Oliveira e Catani (2003, p. 25), a avaliação nesses moldes é utilizada como instrumento de regulação e de controle pelo mercado, e ao mesmo tempo:

[...] garante a implementação efetiva da reforma da educação superior, com a aquiescência da opinião pública, que passa a ser alimentada com informações sobre a qualidade das instituições e dos cursos ofertados. [...] O parâmetro do controle de qualidade no mercado acadêmico é, portanto, o consumidor dos serviços e produtos universitários. É o consumidor, bem informado, quem decide e faz a escolha, em função do que pode consumir.

A esse respeito, Sampaio (2000, p. 148) afirma:

O princípio é que consumidores bem informados realizam melhores escolhas. Com base no elenco de informações, que o MEC exige que as instituições tornem públicas, o candidato poderá proceder à escolha do curso no estabelecimento de ensino superior que lhe pareça mais adequado, sério, idôneo ou de preço mais acessível.

No entanto, Sampaio (2000, p. 149) destaca os problemas e a insuficiência dessa regulação pelo mercado, pois os interesses que levam o aluno à escolha da instiuição podem não estar relacionados à qualidade do curso, mas sim a outros interesses privados, como preço e relação candidato/vaga:

Todavia, essa norma pode ter outra leitura. A melhor escolha, da perspectiva do consumidor, nem sempre é a do estabelecimento de ensino superior que apresenta o quadro 
de docentes com melhor titulação ou ainda o estabelecimento mais bem equipado em laboratórios e bibliotecas. É fato que a obrigatoriedade do fornecimento dessas informações pelos estabelecimentos instala uma dinâmica de competição entre eles tendo em vista atrair maior número de alunos. Todavia, deve ser notado que essa competição não promove, por si, a melhoria da qualidade do ensino oferecido. A natureza das informações divulgadas pelas instituições é muito diversa. A clientela, por sua vez, é muito heterogênea, com interesses muito distintos quando busca a formação de nível superior. Um valor de anuidade para determinado curso que seja inferior ao valor cobrado pelo mesmo curso em outra instituição pode influir na escolha do candidato pela primeira instituição. Também a relação candidato/vaga pode ser outro fator decisivo na escolha. Outros fatores, que não constam do catálogo de informações do estabelecimento, podem ser ponderados pelos consumidores no momento da escolha do curso. Em suma, escolhas dessa natureza são legítimas do ponto de vista da racionalidade do consumidor considerado individualmente; porém, em seu conjunto, elas não convergem necessariamente para os estabelecimentos que apresentam a melhor performance do ponto de vista acadêmico.

Oliveira (2006, p. 103-4), por outro lado, destaca que o processo avaliativo pode auxiliar na melhoria da qualidade do ensino superior mas, ao mesmo tempo, ressalta que essa prática decorre das exigências legais. Segundo o autor:

É inegável o estímulo em busca de melhoria que a divulgação dos resultados das avaliações gera nas mais diversas instituições. No caso do Ensino Superior, um importante indicador é $\mathrm{o}$ efeito que o Provão e o seu sucedâneo, o Enade, têm induzido em inúmeras instituições a buscar contratar profissionais mais capacitados com maiores certificações, até mesmo por exigência da legislação.

É tão evidente que o indutor desse comportamento foram as exigências legais, pois muitas instituições privadas, ao atingirem os patamares mínimos de titulados exigidos pela legislação, demitem eventuais docentes que estejam em processo de titulação, ou demitem os mais antigos e absorvem os novos com salários mais baixos.

\subsubsection{O Plano Nacional de Educação}

O Plano Nacional de Educação de 2001 (Lei n 10.172, de 09/01/2001 - PNE), previsto no artigo 214 da Constituição e nos artigos $9^{\circ}$, I e 87, Parágrafo $1^{\circ}$ da LDB, estabeleceu para cada nível educacional "diagnóstico", "diretrizes”, “objetivos e metas".

O diagnóstico da educação superior (item 4.1) naquele período previu: (i) um provável aumento da demanda por esse nível de ensino nos anos seguintes em decorrência do aumento das exigências do mercado de trabalho, além das políticas de melhoria do ensino médio; (ii) que a manutenção das atividades típicas da universidades - ensino, pesquisa e extensão - dependiam do fortalecimento do setor público, mas que em paralelo, a expansão do setor privado deveria continuar, desde que garantida a qualidade; (iii) que a distribuição de vagas era muito desigual entre as regiões brasileiras, com a concentração das matrículas nas instituições particulares das regiões mais desenvolvidas, destacando-se que o setor público apresentava uma distribuição mais homogênea entre as regiões, 
desempenhando uma função importante de diminuição das desigualdades regionais; (iv) que no conjunto da América Latina, o Brasil apresentava um dos índices mais baixos de acesso ao ensino superior (menos de $12 \%$ da população entre 18 e 24 anos, ante $40 \%$ dos jovens argentinos na mesma faixa etária, 20,6\% dos jovens chilenos, $26 \%$ dos jovens venezuelanos e $20,6 \%$ dos jovens bolivianos); e (v) o custo por aluno no ensino superior brasileiro, indicando como estratégia de diversificação do sistema a expansão do ensino pós-secundário, com o investimento na formação de qualificação em áreas técnicas e profissionais.

Nas diretrizes da educação superior, destacou que "nenhum país pode aspirar a ser desenvolvido e independente sem um forte sistema de educação superior”. Além disso, colocou a autonomia universtária como diretriz básica para o bom funcionamento do sistema e afirmou que "deve-se planejar a expansão com qualidade, evitando-se o fácil caminho da massificação". Ademais, reconheceu que é "importante a contribuição do setor privado, que já oferece a maior parte das vagas na educação superior e tem um relevante papel a cumprir, desde que respeitados os parâmetros de qualidade estabelecidos pelos sistemas de ensino", mas que havia necessidade de "expansão das universidades públicas para atender à demanda crescente dos alunos, sobretudo os carentes, bem como ao desenvolvimento da pesquisa necessária ao País, que depende dessas instituições, uma vez que realizam mais de $90 \%$ da pesquisa e da pós-graduação nacionais - em sintonia com o papel constitucional a elas reservado", devendo assegurar que o setor público "tenha uma expansão de vagas tal que, no mínimo, mantenha uma proporção nunca inferior a $40 \%$ do total". Tratou da importância da expansão das vagas no período noturno, sobretudo nas instituições federais. Por fim, destacou ser "indispensável melhorar a qualidade do ensino oferecido, para o que constitui instrumento adequado a institucionalização de um amplo sistema de avaliação associada à ampliação dos programas de pós-graduação, cujo objetivo é qualificar os docentes que atuam na educação superior”. 
O PNE estabeleceu $22^{183}$ objetivos e metas para a educação superior:

\section{Quadro 2 - PNE - Objetivos e metas para a educação superior}

(continua)

\begin{tabular}{|c|c|}
\hline & Objetivos e metas para a educação superior \\
\hline 1. & $\begin{array}{l}\text { Prover, até o final da década, a oferta de educação superior para, pelo menos, } 30 \% \text { da faixa etária de } \\
18 \text { a } 24 \text { anos. }\end{array}$ \\
\hline 2. & VETADO \\
\hline 3. & $\begin{array}{l}\text { Estabelecer uma política de expansão que diminua as desigualdades de oferta existentes entre as } \\
\text { diferentes regiões do País. }\end{array}$ \\
\hline 4. & $\begin{array}{l}\text { Estabelecer um amplo sistema interativo de educação a distância, utilizando-o, inclusive, para } \\
\text { ampliar as possibilidades de atendimento nos cursos presenciais, regulares ou de educação } \\
\text { continuada. }\end{array}$ \\
\hline 5. & $\begin{array}{l}\text { Assegurar efetiva autonomia didática, científica, administrativa e de gestão financeira para as } \\
\text { universidades públicas. }\end{array}$ \\
\hline 6. & $\begin{array}{l}\text { Institucionalizar um amplo e diversificado sistema de avaliação interna e externa que englobe os } \\
\text { setores público e privado, e promova a melhoria da qualidade do ensino, da pesquisa, da extensão e } \\
\text { da gestão acadêmica. }\end{array}$ \\
\hline 7. & $\begin{array}{l}\text { Instituir programas de fomento para que as instituições de educação superior constituam sistemas } \\
\text { próprios e sempre que possível nacionalmente articulados, de avaliação institucional e de cursos, } \\
\text { capazes de possibilitar a elevação dos padrões de qualidade do ensino, de extensão e, no caso das } \\
\text { universidades, também de pesquisa. }\end{array}$ \\
\hline 8. & $\begin{array}{l}\text { Estender, com base no sistema de avaliação, diferentes prerrogativas de autonomia às instituições } \\
\text { não-universitárias públicas e privadas. }\end{array}$ \\
\hline 9. & $\begin{array}{l}\text { Estabelecer sistema de recredenciamento periódico das instituições e reconhecimento periódico dos } \\
\text { cursos superiores, apoiado no sistema nacional de avaliação. }\end{array}$ \\
\hline 10. & $\begin{array}{l}\text { Diversificar o sistema superior de ensino, favorecendo e valorizando estabelecimentos não- } \\
\text { universitários que ofereçam ensino de qualidade e que atendam clientelas com demandas específicas } \\
\text { de formação: tecnológica, profissional liberal, em novas profissões, para exercício do magistério ou } \\
\text { de formação geral. }\end{array}$ \\
\hline 11. & $\begin{array}{l}\text { Estabelecer, em nível nacional, diretrizes curriculares que assegurem a necessária flexibilidade e } \\
\text { diversidade nos programas de estudos oferecidos pelas diferentes instituições de educação superior, } \\
\text { de forma a melhor atender às necessidades diferenciais de suas clientelas e às peculiaridades das } \\
\text { regiões nas quais se inserem. }\end{array}$ \\
\hline 12. & $\begin{array}{l}\text { Incluir nas diretrizes curriculares dos cursos de formação de docentes temas relacionados às } \\
\text { problemáticas tratadas nos temas transversais, especialmente no que se refere à abordagem, tais } \\
\text { como: gênero, educação sexual, ética (justiça, diálogo, respeito mútuo, solidariedade e tolerância), } \\
\text { pluralidade cultural, meio ambiente, saúde e temas locais. }\end{array}$ \\
\hline 13. & $\begin{array}{l}\text { Diversificar a oferta de ensino, incentivando a criação de cursos noturnos com propostas inovadoras, } \\
\text { de cursos sequenciais e de cursos modulares, com a certificação, permitindo maior flexibilidade na } \\
\text { formação e ampliação da oferta de ensino. }\end{array}$ \\
\hline 14. & $\begin{array}{l}\text { A partir de padrões mínimos fixados pelo Poder Público, exigir melhoria progressiva da } \\
\text { infraestrutura de laboratórios, equipamentos e bibliotecas, como condição para o recredenciamento } \\
\text { das instituições de educação superior e renovação do reconhecimento de cursos. }\end{array}$ \\
\hline 15. & $\begin{array}{l}\text { Estimular a consolidação e o desenvolvimento da pós-graduação e da pesquisa das universidades, } \\
\text { dobrando, em dez anos, o número de pesquisadores qualificados. }\end{array}$ \\
\hline 16. & $\begin{array}{l}\text { Promover o aumento anual do número de mestres e de doutores formados no sistema nacional } \\
\text { pós-graduação em, pelo menos, } 5 \% \text {. }\end{array}$ \\
\hline
\end{tabular}

${ }^{183}$ Inicialmente, eram 23 objetivos, o objetivo $\mathrm{n}^{\mathrm{o}} 2$, contudo, foi vetado. 


\section{Quadro 2 - PNE - Objetivos e metas para a educação superior}

\begin{tabular}{|c|c|}
\hline & Objetivos e metas para a educação superior \\
\hline 17. & $\begin{array}{l}\text { Promover levantamentos periódicos do êxodo de pesquisadores brasileiros formados, para outros } \\
\text { países, investigar suas causas, desenvolver ações imediatas no sentido de impedir que o êxodo } \\
\text { continue e planejar estratégias de atração desses pesquisadores, bem como de talentos provenientes } \\
\text { de outros países. }\end{array}$ \\
\hline 18. & $\begin{array}{l}\text { centivar a generalização da prática da pesquisa como elemento integrante e modernizador dos } \\
\text { ocessos de ensino-aprendizagem em toda a educação superior, inclusive com a participação de } \\
\text { inos no desenvolvimento da pesquisa. }\end{array}$ \\
\hline 19. & $\begin{array}{l}\text { Criar políticas que facilitem às minorias, vítimas de discriminação, o acesso à educação superior, } \\
\text { através de programas de compensação de deficiências de sua formação escolar anterior, permitindo- } \\
\text { lhes, desta forma, competir em igualdade de condições nos processos de seleção e admissão a esse } \\
\text { nível de ensino. }\end{array}$ \\
\hline 20. & $\begin{array}{l}\text { plantar planos de capacitação dos servidores técnico-administrativos das instituições públicas de } \\
\text { ucação superior, sendo de competência da IES definir a forma de utilização dos recursos previstos } \\
\text { aa esta finalidade. }\end{array}$ \\
\hline 21. & $\begin{array}{l}\text { rantir, nas instituições de educação superior, a oferta de cursos de extensão, para atender as } \\
\text { cessidades da educação continuada de adultos, com ou sem formação superior, na perspectiva de } \\
\text { egrar o necessário esforço nacional de resgate da dívida social e educacional. }\end{array}$ \\
\hline 22. & $\begin{array}{l}\text { Garantir a criação de conselhos com a participação da comunidade e de entidades da sociedade civil } \\
\text { organizada, para acompanhamento e controle social das atividades universitárias, com o objetivo de } \\
\text { assegurar o retorno à sociedade dos resultados das pesquisas, do ensino e da extensão. }\end{array}$ \\
\hline 23. & $\begin{array}{l}\text { Implantar o Programa de Desenvolvimento da Extensão Universitária em todas as Instituições } \\
\text { Federais de Ensino Superior no quadriênio 2001-2004 e assegurar que, no mínimo, } 10 \% \text { do total de } \\
\text { créditos exigidos para a graduação no ensino superior no País será reservado para a atuação dos } \\
\text { alunos em ações extensionistas. }\end{array}$ \\
\hline
\end{tabular}

Fonte: PNE

Para atingir algumas dessas metas, o Estado Brasileiro contou com o auxílio do setor privado. No entanto, ao final da década, muitas das metas estabelecidas não foram alcançadas, e um novo Plano Nacional de Educação encontra-se em discussão no Congresso Nacional (Projeto de Lei $n^{\circ} 8.035 / 10$ ).

\subsubsection{O Programa Bolsa Escola}

Em 2001, foi instituído o Programa Bolsa Escola (Lei nº 10.219, de 11/04/2001), programa de transferência de renda vinculado à freqüência escolar. Nos termos do artigo $2^{\circ}$, II, da Lei $n^{\circ} 10.219 / 01$, os beneficiários do programa eram famílias com renda familiar per capita inferior a um valor fixado nacionalmente pelo Poder Executivo para cada exercício e que possuíssem, sob sua responsabilidade, crianças com idade entre 6 e 15 anos, matriculadas em estabelecimentos de ensino fundamental regular, com frequência escolar igual ou superior a $85 \%$.

Por meio da $\mathrm{MP}^{\mathrm{o}} 132$, de 20/10/2003, posteriormente convertida na Lei $\mathrm{n}^{\mathrm{o}} 10.836$, de 09/01/2004, foi instituído o Programa Bolsa Família, novo programa de transferência de 
renda com condicionalidades, que unificou os seguintes programas: Bolsa Escola, Programa Nacional de Acesso à Alimentação - PNAA (Lei n ${ }^{0}$ 10.689, de 13/06/2003), Programa Nacional de Renda Mínima vinculado à Saúde - Bolsa Alimentação (MP n ${ }^{\circ}$ 2.206-1, de 06/09/2001), Programa Auxílio-Gás (Decreto no 4.102, de 24/01/2002) e o Cadastramento Único do Governo Federal (Decreto $n^{\circ} 3.877$, de 24/07/2001). O Programa Bolsa Família manteve a condicionalidade de frequência escolar de $85 \%{ }^{184}$.

Esses programas reforçaram o foco do Estado Brasileiro na universalização do ensino fundamental e, especialmente, o Bolsa Família tornou-se um dos principais programas do governo federal para o combate à extrema pobreza no País.

\subsubsection{O Fies}

A partir de 1999, inicia-se a implantação do Fundo de Financiamento ao Estudante do Ensino Superior no Brasil (Fies) - em 27 de maio de 1999, foi editada a MP n 1.827 que o criou. MPs posteriores (MP n ${ }^{0} 1.827-1$, de 24/06/1999; MP $n^{0} 1.865-2,29 / 06 / 1999$, MP $n^{0} 1.865-3$, de 27/07/1999; MP $n^{0} 1.865-4$, de 26/08/1999; MP $n^{\circ} 1.865-5$, de 22/09/1999; $\mathrm{MP} \mathrm{n}^{\mathrm{o}}$ 1.865-6, de 21/10/1999; MP n ${ }^{\mathrm{o}}$ 1.865-7, de 18/11/1999; $\mathrm{MP} \mathrm{n}^{\mathrm{o}}$ 1.972-8, 10/12/1999; MP n 1.972-9, de 11/01/2000; MP n 1.972-10, de 10/02/2000; MP n ${ }^{\circ} 1.972-$ 11, de 09/03/2000; MP n ${ }^{\circ} 1.972-12$, de 06/04/2000; MP n ${ }^{\circ} 1.972-13$, de 04/05/2000; MP ${ }^{\circ}$ 1.972-14, de 01/06/2000; MP nº 1.972-15, de 29/06/2000; MP n ${ }^{0} 1.972-16$, de 28/07/2000; MP n 1.972-17, de 28/08/2000; MP n 1.972-18, de 27/09/2000; MP n 1.972-19, de 26/10/2000; MP n 1.972-20, de 23/11/2000; MP nº 1.972-21, de 21/12/2000; MP nº 2.09422, de 27/12/2000; $\mathrm{MP} \mathrm{n}^{\mathrm{o}} 2.094-23$, de 25/01/2001; $\mathrm{MP} \mathrm{n}^{\mathrm{o}} 2.094-24$, de 22/02/2001; $\mathrm{MP} \mathrm{n}^{\mathrm{o}}$ 2.094-25, de 22/03/2001; MP nº 2.094-26, de 19/04/2001; MP nº 2.094-27, de 17/05/2001; MP $n^{0} 2.094-28$, de 13/06/2001), confirmaram o Fies até a edição da Lei $n^{\circ} 10.260$, de 12/07/2001 (conversão da MP n ${ }^{0} 2.094-28 / 01$ ).

O programa foi ampliado em 2010, por meio da Lei $n^{\circ} 12.202$, de 2010, e em 2011, pela Lei $\mathrm{n}^{0}$ 12.513, que alteraram a lei inicial do Fies. O Fies é um programa de financiamento estudantil que permite aos estudantes de instituições de ensino superior

\footnotetext{
${ }^{184}$ Art. $3^{\circ}$, Lei n ${ }^{\circ} 10.836$, de 09/01/2004 - “A concessão dos benefícios dependerá do cumprimento, no que couber, de condicionalidades relativas ao exame pré-natal, ao acompanhamento nutricional, ao acompanhamento de saúde, à frequência escolar de $85 \%$ (oitenta e cinco por cento) em estabelecimento de ensino regular, sem prejuízo de outras previstas em regulamento. Parágrafo único. O acompanhamento da frequência escolar relacionada ao benefício previsto no inciso III do caput do art. $2^{\circ}$ desta Lei considerará $75 \%$ (setenta e cinco por cento) de frequência, em conformidade com o previsto no inciso VI do caput do art. 24 da Lei no 9.394, de 20 de dezembro de 1996”. (Incluído pela Lei nº 11.692, de 2008)
} 
privadas em nível de graduação, mestrado, doutorado ou de cursos de educação profissional e tecnológica, presenciais ${ }^{185}$ e com avaliação positiva ${ }^{186}$, financiar de $50 \%$ a $100 \%$ do curso ${ }^{187}$ e efetuar o pagamento do débito em até três vezes o período financiado do curso, acrescido de 12 meses, pagando juros de 3,4\% ao ano ${ }^{188}$. O programa prevê um período de carência de um ano e meio após o término do curso para o início dos pagamentos principais (durante o curso e o período de carência, o estudante efetua apenas pagamentos trimestrais de valores correspondentes aos juros do financiamento, no valor máximo de $\left.\mathrm{R} \$ 50,00^{189}\right)$.

Estão excluídos do programa estudantes (i) cuja matrícula acadêmica esteja em situação de trancamento geral de disciplinas no momento da inscrição; (ii) que já tenham sido beneficiados com outro financiamento do Fies; (iii) inadimplentes com o Programa de Crédito Educativo (PCE/Creduc); (iv) cujo percentual de comprometimento da renda familiar mensal bruta per capita seja inferior a 20\%; (v) cuja renda familiar mensal bruta seja superior a 20 salários mínimos ${ }^{190}$.

A partir do ano letivo de 2010, passou a ser exigência para o pedido do Fies que o estudante realizasse o Exame Nacional do Ensino Médio (Enem). Ficaram isentos da exigência do Enem os professores da rede pública de ensino, no efetivo exercício do magistério da educação básica, integrantes do quadro de pessoal permanente de instituição pública, regularmente matriculados em cursos de licenciatura, normal superior ou pedagogia $^{191}$.

185 O Projeto de Lei 325/11, do deputado Rubens Bueno (PPS-PR), visa incluir os cursos a distância no âmbito do FIES. Informações sobre o projeto de lei disponíveis em: http://www2.camara.leg.br/camaranoticias/noticias/EDUCACAO-E-CULTURA/200280-FIES-PODERAFINANCIAR-CURSO-DE-EDUCACAO-A-DISTANCIA.html. Acesso em: 14/01/2013.

${ }^{186}$ Nos termos do Artigo $1^{\circ}, \S 2^{\circ}$, da Lei n ${ }^{\circ} 10.260 / 01$, conforme alterada - "São considerados cursos de graduação com avaliação positiva, aqueles que obtiverem conceito maior ou igual a 3 (três) no Sistema Nacional de Avaliação da Educação Superior - Sinaes, de que trata a Lei n ${ }^{\circ} 10.861$, de 14 de abril de 2004". Artigo $1^{\circ}, \S 4^{\circ}$ - "São considerados cursos de mestrado e doutorado, com avaliação positiva, aqueles que, nos processos conduzidos pela Coordenação de Aperfeiçoamento de Pessoal de Nível Superior - Capes, nos termos da Lei $n^{0} 8.405$, de 9 de janeiro de 1992, obedecerem aos padrões de qualidade por ela propostos".

$187 \mathrm{O}$ percentual de financiamento varia conforme o percentual do comprometimento da renda familiar mensal bruta per capita com os encargos educacionais. Para informações a esse respeito, vide: http://sisfiesportal.mec.gov.br/faq.html. Acesso em: 23/07/2012.

${ }^{188}$ Fonte: http://sisfiesportal.mec.gov.br/condicoes.html. Acesso em: 23/07/2012.

${ }^{189}$ Fonte: <http://sisfiesportal.mec.gov.br/condicoes.html $>$. Acesso em: 23/07/2012.

${ }^{190}$ Fonte: <http://sisfiesportal.mec.gov.br/faq.html>. Acesso em: 23/07/2012.

${ }^{191}$ Art. 19, Portaria Normativa MEC n ${ }^{\circ} 10$, de 30/04/2010, conforme alterada pela Portaria Normativa MEC $n^{0} 12$, de 06/06/2011 - "Para fins de solicitação de financiamento ao Fies será exigido do estudante concluinte do ensino médio a partir do ano letivo de 2010, participação no Exame Nacional do Ensino Médio (Enem) de 2010 ou posterior, ou que possua a condição de professor da rede pública de ensino, no efetivo exercício do magistério da educação básica integrante do quadro de pessoal permanente da instituição pública, regularmente matriculado em cursos de licenciatura, normal superior ou pedagogia". Fonte: $<$ http://sisfiesportal.mec.gov.br/faq.html $>$. Acesso em: 23/07/2012. 
Para a contratação do financiamento é exigida fiança (convencional ou solidária) ${ }^{192}$. Bolsistas parciais do ProUni também podem participar do Fies.

Estudantes financiados pelo Fies em cursos de licenciatura, pedagogia ou normal superior, em efetivo exercício na rede pública de educação básica, e estudantes graduados em medicina, integrantes de equipe de saúde da família oficialmente cadastrada, podem trocar o trabalho na rede pública por abatimentos da dívida com o Fies ${ }^{193}$.

O Fies foi uma das respostas do governo federal para o aumento da demanda por ensino superior no País. Um dos problemas para o acesso dos estudantes ao ensino superior privado era o valor das mensalidades. Por meio do Fies, estudantes que antes tinham dificuldades para acessar e permanecer no ensino privado puderam financiar seus estudos.

Apesar de importante para o crescimento do ensino superior no Brasil, o Fies ainda enfrenta algumas dificuldades. Primeiro porque ainda não se formou uma cultura de tomada de crédito para o custeio de estudos de nível superior no Brasil, como há em outros países. Segundo os gestores do fundo de financiamento estudantil privado Pravaler, no Brasil, entre $5 \%$ e $10 \%$ da população utilizam algum tipo de crédito para a universidade, enquanto nos Estados Unidos, $70 \%$ aderem ao financiamento ${ }^{194}$.

192 Ficam dispensados da exigência de fiador os alunos bolsistas parciais do ProUni, os alunos matriculados em cursos de licenciatura e os alunos que tenham renda familiar per capita de até um salário mínimo e meio e que tenham optado pelo Fundo de Garantia de Operações de Crédito Educativo (FGEDUC). Fonte: $<$ http://sisfiesportal.mec.gov.br/faq.html>. Acesso em: 23/07/2012.

193 Art. $6^{\circ}$-B, Lei 10.260/01 - "O Fies poderá abater, na forma do regulamento, mensalmente, 1,00\% (um inteiro por cento) do saldo devedor consolidado, incluídos os juros devidos no período e independentemente da data de contratação do financiamento, dos estudantes que exercerem as seguintes profissões: (Incluído pela Lei $\mathrm{n}^{\circ} 12.202$, de 2010) I - professor em efetivo exercício na rede pública de educação básica com jornada de, no mínimo, 20 (vinte) horas semanais, graduado em licenciatura; e (Incluído pela Lei $\mathrm{n}^{\circ}$ 12.202, de 2010) II - médico integrante de equipe de saúde da família oficialmente cadastrada, com atuação em áreas e regiões com carência e dificuldade de retenção desse profissional, definidas como prioritárias pelo Ministério da Saúde, na forma do regulamento. (Incluído pela Lei $n^{\circ} 12.202$, de 2010) $\S 2^{\circ} \mathrm{O}$ estudante que já estiver em efetivo exercício na rede pública de educação básica com jornada de, no mínimo, 20 (vinte) horas semanais, por ocasião da matrícula no curso de licenciatura, terá direito ao abatimento de que trata o caput desde o início do curso. (Incluído pela Lei $n^{\circ} 12.202$, de 2010) $\S 3^{\circ} \mathrm{O}$ estudante graduado em Medicina que optar por ingressar em programa credenciado Medicina pela Comissão Nacional de Residência Médica, de que trata a Lei $\mathrm{n}^{\mathrm{o}}$ 6.932, de 7 de julho de 1981, e em especialidades prioritárias definidas em ato do Ministro de Estado da Saúde terá o período de carência estendido por todo o período de duração da residência médica. (Incluído pela Lei $\mathrm{n}^{\circ} 12.202$, de 2010$) \S 4^{\circ} \mathrm{O}$ abatimento mensal referido no caput será operacionalizado anualmente pelo agente operador do Fies, vedado o primeiro abatimento em prazo inferior a 1 (um) ano de trabalho. (Incluído pela Lei $n^{\circ} 12.202$, de 2010) $\S 5^{\circ}$ No período em que obtiverem o abatimento do saldo devedor, na forma do caput, os estudantes ficam desobrigados da amortização de que trata o inciso $\mathrm{V}$ do caput do art. $5^{\circ}$.(Incluído pela Lei $\mathrm{n}^{\circ} 12.202$, de 2010) $\S 6^{\circ} \mathrm{O}$ estudante financiado que deixar de atender às condições previstas neste artigo deverá amortizar a parcela remanescente do saldo devedor regularmente, na forma do inciso V do art. $5^{\circ}$ (Incluído pela Lei $\mathrm{n}^{\circ} 12.202$, de 2010).

${ }^{194}$ Segundo informações da empresa, "no Brasil, especialistas da área de educação estimam que existam 6 milhões de pessoas, acima de 18 anos, que poderiam se matricular no ensino superior, mas não o fazem por razões financeiras ou outras de cunho pessoal. A parcela que se forma anualmente está longe dessa estatística. De acordo com o Censo da Educação 2010, cerca de 960 mil estudantes concluíram a graduação em 2010. Os dados do governo ainda revelam que, de cada dez alunos de universidades privadas, três 
Segundo, porque os critérios de renda e as porcentagens de comprometimento da renda familiar dos beneficiários deixam de fora do programa uma parcela significativa de estudantes.

De acordo com o Ministério da Educação, entre 2010 e 2012 foram firmados 535,8 mil contratos do Fies ${ }^{195}$.

\subsection{Os Governos Luiz Inácio Lula da Silva (2003-2010) e Dilma Roussef (2011)}

Durante os oito anos do governo Luiz Inácio Lula da Silva, nota-se que houve uma continuidade da busca da universalização do ensino fundamental e da política de incentivo ao crescimento do setor privado no ensino superior como uma forma de resposta ao aumento da demanda por esse nível de ensino. Nesse contexto, o governo Lula criou o Bolsa Família e ampliou o Fies, conforme descrito acima, e além disso, criou o ProUni, que discutiremos a seguir.

Para lidar com o problema do acesso ao ensino superior e da pressão dos grupos excluídos, foi intenso durante os governos Lula e Dilma Roussef o debate em torno da constitucionalidade das políticas de ações afirmativas para o acesso a instituições públicas de ensino superior.

Nesse período houve também investimentos no sistema público de ensino superior, com a criação de novas universidades federais e ampliação das vagas nas universidades existentes.

O governo Lula alterou também o Enem, buscando torná-lo uma forma de seleção unificada para o ingresso no ensino superior.

No pouco tempo analisado do governo Dilma Roussef, nota-se a manutenção das políticas do Presidente Lula. Além disso, houve a aprovação da abertura de novas universidades federais e a aprovação de uma lei que permite a compensação de dívidas de instituições de ensino superior privadas por bolsas de estudo.

Um dos traços dos governos de Luiz Inácio Lula da Silva e de Dilma Roussef foi a intensificação da financeirização, da profissionalização e do empresariamento do ensino superior privado.

\footnotetext{
recorrem a alguma forma de auxílio mensal". Disponível em: $<$ http://www.creditouniversitario.com.br/noticia/30.11.2011---Credito-facilita-acesso-ao-ensino-superior>. Acesso em: 26/03/2012.

195 Disponível em: http://www2.planalto.gov.br/imprensa/noticias-de-governo/alunos-beneficiarios-do-fiesja-podem-antecipar-quitacao-do-credito-estudantil. Acesso em: 14/01/2013.
} 
Os temas acima serão desenvolvidos na sequência.

\subsubsection{Políticas de ação afirmativa para acesso ao ensino superior}

Nos últimos anos, foram promulgadas leis e adotadas, pelas instituições públicas de ensino, políticas de ação afirmativa para o acesso ao ensino superior.

Nesse contexto, houve a Lei $n^{0} 10.558$, de 13 de novembro de $2002^{196}$, que criou o Programa Diversidade na Universidade, no âmbito do Ministério da Educação, com a finalidade de implementar e avaliar estratégias para a promoção do acesso ao ensino superior de pessoas pertencentes a grupos socialmente desfavorecidos, especialmente afrodescendentes e indígenas.

Posteriormente, foi promulgada a Lei $\mathrm{n}^{\mathrm{o}} 11.096$, de 13 de janeiro de $2005^{197}$, que instituiu, sob gestão do Ministério da Educação, o Programa Universidade para Todos (ProUni), destinado à concessão de bolsas de estudo integrais e bolsas de estudo parciais de $50 \%$ ou de $25 \%$ para estudantes de cursos de graduação e sequenciais de formação específica, em instituições privadas de ensino superior, com ou sem fins lucrativos. A referida lei foi um marco das políticas de ações afirmativas e será discutida abaixo.

Entre $2002^{198}$ e 2012, instituições públicas de ensino superior brasileiras, com base na deliberação de seus órgãos colegiados, adotaram ações afirmativas para a reserva de vagas em seus cursos que envolveram critérios de renda, histórico escolar (tempo na rede pública de ensino), raça/etnia/cor de pele e território.

A constitucionalidade dessas ações afirmativas foram objeto de questionamento no Supremo Tribunal Federal (STF). Com relação à política de reserva de vagas nas universidades públicas, foi ajuizada a Arguição de Descumprimento de Preceito Fundamental (ADPF) n $n^{\circ} 186$ e o Recurso Extraordinário (RE) n $n^{0} 597.285 / R S$; e com relação ao ProUni, a Ação Direta de Inconstitucionalidade (ADI) n ${ }^{\circ} 3330$, a ADI n 3314 e a ADI n ${ }^{\circ} 3379$.

A ADPF n 186 foi ajuizada pelo Partido Democratas (DEM) em 2009 para questionar atos administrativos do Conselho de Ensino, Pesquisa e Extensão da Universidade de Brasília (Cepe/UnB) que resultaram na instituição, por um período de dez anos, da reserva de $20 \%$ das vagas oferecidas pela Universidade a candidatos negros

\footnotetext{
${ }^{196}$ Conversão da Medida Provisória no 63, de 26 de agosto de 2002.

${ }^{197}$ Conversão da Medida Provisória no 213, de 10 de setembro de 2004.

${ }^{198}$ A Universidade Estadual do Rio de Janeiro (UERJ) foi a primeira instituição pública a adotar o sistema de reserva de vagas em seu exame de ingresso no ano de 2002.
} 
(dentre pretos e pardos) e de um pequeno número de vagas para candidatos indígenas de todos os estados brasileiros. Referidas cotas foram instituídas pela primeira vez no vestibular de 2004 na UnB.

O partido alegou que a política de cotas adotada na UnB feria vários preceitos fundamentais da Constituição, como os princípios da dignidade da pessoa humana (art. $1^{\circ}$, III), de vedação ao preconceito de cor e discriminação (art. $3^{\circ}$, IV), de repúdio ao racismo (art. $4^{\circ}$, VIII), da igualdade (art. $5^{\circ}$, I), da legalidade, da impessoalidade, da razoabilidade, da publicidade e da moralidade (art. 37, caput), corolários do princípio republicano, do direito universal à educação (art. 205), do direito de igualdade nas condições de acesso ao ensino (art. 206, caput e I) e o princípio meritocrático (art. 208, V) (DEM, 2009).

Em sua argumentação, o DEM (2009) afirmou que: (i) no Brasil, ninguém é excluído do sistema de ensino pelo simples fato de ser negro, mas sim por diferenças de renda e pela péssima qualidade das escolas que os pobres brasileiros (brancos, pretos ou pardos) conseguem frequentar (DEM, 2009, p. 27 e 56); (ii) geneticamente, não existem raças, sendo raça um conceito social e não científico (DEM, 2009, p. 37); (iii) pesquisas científicas apontam que a população brasileira tem um nível muito elevado de miscigenação e que a esmagadora maioria dos brasileiros tem algum grau de ancestralidade africana, o que gera grande dificuldade de se mensurar qual o grau necessário para que alguém seja considerado negro (DEM, 2009, p. 32); (iii) existe um relativo equilíbrio entre as raças no Brasil, nesse sentido, tentar implementar ações afirmativas em que a raça seja o único critério levado em consideração poderia, de alguma forma, afetar esse equilíbrio e, em vez de promover a inserção dos afrodescendentes, "criar esferas sociais apartadas, daqueles que são beneficiados pelas medidas e dos que não são" (DEM, 2009, p. 68), instituindo também a consciência estatal da raça, o que promove ofensa ao princípio da igualdade, gerando discriminação reversa em relação aos brancos pobres, além de favorecer a classe média negra (DEM, 2009, p. 29); (iii) a inconstitucionalidade da instituição de um Tribunal Racial para definir quem é negro no Brasil, conforme modelo da UnB; (v) com relação ao argumento da justiça compensatória, defendeu a impossibilidade de se responsabilizar, no presente, os brancos por atos cometidos no passado (DEM, 2009, p. 34); (vi) a autonomia universitária não pode ser entendida como um direito absoluto, "de maneira que não pode significar que os dirigentes e professores possam fazer o que bem entenderem na instituição", pois eles devem observar os princípios constitucionais da proporcionalidade, da razoabilidade, da legalidade, da publicidade, da impessoalidade, da moralidade, do mérito e do acesso 
universal em seus atos (DEM, 2009, p. 36).

O plenário do STF, em 26 de abril de 2012, considerou, por unanimidade, constitucional a política de cotas étnico-raciais da UnB e julgou totalmente improcedente a ADPF $\mathrm{n}^{\circ}$ 186. Os ministros seguiram o voto do relator do caso, Ministro Ricardo Lewandowski, que afirmou que as políticas de ação afirmativa adotadas pela UnB: "(i) têm como objetivo estabelecer um ambiente acadêmico plural e diversificado, superando distorções sociais historicamente consolidadas, (ii) revelam proporcionalidade e a razoabilidade no concernente aos meios empregados e aos fins perseguidos, (iii) são transitórias e preveem a revisão periódica de seus resultados, e (iv) empregam métodos seletivos eficazes e compatíveis com o princípio da dignidade humana"; e isto posto julgou improcedente a ADPF (STF, 2012, p. 47).

Em seu voto, o Ministro Relator destacou: (i) o direito à igualdade material entre os indivíduos (STF, 2012, p. 5) e a aplicação da justiça distributiva, para a "transformação do direito à isonomia em igualdade de possibilidades, sobretudo no tocante a uma participação equitativa nos bens sociais" e com o objetivo de "promover a inclusão social de grupos excluídos ou marginalizados, especialmente daqueles que, historicamente, foram compelidos a viver na periferia da sociedade" (STF, 2012, p. 7); (iii) incluiu precedentes da Corte em que as políticas de ação afirmativa foram consideradas constitucionais (STF, 2012, p. 11); (iv) destacou o pluralismo de ideias que a política proporciona (STF, 2012, p. 13); (v) a persistência do racismo enquanto categoria histórico-cultural (STF, 2012, p. 20) e dados demonstrando as diferenças entre brancos e negros em indicadores de educação no Brasil (STF, 2012, p. 23-5); (vi) a política de ação afirmativa como uma política de reconhecimento e valorização do grupo étnico e cultural (STF, 2012, p. 27); (vii) que a utilização exclusiva do critério social ou de baixa renda é insuficiente para promover a integração social de grupos excluídos por questões étnicas e raciais" (STF, 2012, p. 28); (viii) que as políticas de ação afirmativa contribuem para o papel integrador da universidade $^{199}$; (ix) que a política de reserva de vagas no Brasil, ao contrário dos EUA, encontra amparo na constituição (STF, 2012, p. 41); (x) a natureza transitória da política de ação afirmativa da $\mathrm{UnB}^{200}$;e (xi) que há proporcionalidade e razoabilidade entre os meios

\footnotetext{
199 Segundo Lewandowski: “o grande beneficiado pelas políticas de ação afirmativa não é aquele estudante que ingressou na universidade por meio das políticas de reservas de vagas, mas todo o meio acadêmico que terá a oportunidade de conviver com o diferente, ou nas palavras de Jürgen Habermas, conviver com o outro" (STF, 2012, p. 31).

${ }^{200}$ Segundo Lewandowski: "na medida em que essas distorções históricas forem corrigidas e a representação dos negros e demais excluídos nas esferas públicas e privadas de poder atenda ao que se contém no princípio constitucional da isonomia, não haverá mais qualquer razão para a subsistência dos programas de reservas de
} 
empregados e os fins colimados ${ }^{201}$.

O RE $n^{\circ} 597285 / R S$ foi ajuizado por um candidato não aprovado no vestibular da Universidade Federal do Rio Grande do Sul (UFRGS), que se sentiu prejudicado pela política de cotas da instituição, que previa a reserva de vagas para alunos oriundos de escolas públicas. Segundo o edital do vestibular na UFRGS, 30\% das vagas são destinadas a egressos de escola pública e negros que também tenham estudado em escolas públicas (sendo 15\% para cada), além de dez vagas para candidatos indígenas. Referido RE foi julgado em 09 de maio de 2012, ocasião em que, por maioria de votos, o Plenário do STF reafirmou os fundamentos da decisão da ADPF $\mathrm{n}^{0} 186$, pela constitucionalidade das políticas de ação afirmativa, e negou provimento ao recurso. O único voto divergente foi o do Ministro Marco Aurélio, que julgou inconstitucional a previsão da UFRGS, por entender que não há motivo para haver cotas de acesso à universidade para alunos oriundos da escola pública, segundo ele, "uma coisa é a busca do tratamento igualitário levando em conta a raça e o gênero. Outra coisa é fazer uma distinção pela escola de origem”. Além disso, segundo o ministro, o critério econômico não pode ser aventado no caso, pois não estudam em colégios públicos apenas os "menos afortunados ${ }^{202}$ ".

Após as decisões do STF e da pacificação do entendimento sobre a constitucionalidade das políticas de reserva de vagas em universidades, foi promulgada em 29 de agosto de 2012 a Lei $n^{0}$ 12.711, que instituiu, para as instituições federais de educação superior, vinculadas ao Ministério da Educação e para as instituições federais de ensino técnico de nível médio, a reserva, em cada concurso seletivo para ingresso nos cursos de graduação ou técnico de nível médio, por curso e turno, de no mínimo de $50 \%$ de suas vagas para estudantes que tenham cursado integralmente o ensino médio ou fundamental, conforme o caso, em escolas públicas, sendo que destas vagas, $50 \%$ deverão ser reservadas aos estudantes oriundos de famílias com renda igual ou inferior a um salário-mínimo e meio per capita (arts. $1^{\circ}$ e $4^{\circ}$ ).

A referida lei previu também que as vagas reservadas deverão ser preenchidas, por

vagas nas universidades públicas, pois o seu objetivo já terá sido alcançado" (STF, 2012, p. 44).

${ }^{201}$ Segundo o Ministro Lewandowski: "as experiências submetidas ao crivo desta Suprema Corte têm como propósito a correção de desigualdades sociais, historicamente determinadas, bem como a promoção da diversidade cultural na comunidade acadêmica e científica. No caso da Universidade de Brasília, a reserva de $20 \%$ de suas vagas para estudantes negros e de "um pequeno número" delas para "índios de todos os Estados brasileiros", pelo prazo de 10 anos, constitui providência adequada e proporcional ao atingimento dos mencionados desideratos. Dito de outro modo, a política de ação afirmativa adotada pela UnB não se mostra desproporcional ou irrazoável, afigurando-se, também sob esse ângulo, compatível com os valores e princípios da Constituição" (STF, 2012, p. 46-47).

${ }_{202}$ Disponível em: <http://www.stf.jus.br/portal/cms/verNoticiaDetalhe.asp?idConteudo=207003>. Acesso em: 08/05/2012. 
“autodeclarados pretos, pardos e indígenas, em proporção no mínimo igual à de pretos, pardos e indígenas na população da unidade da Federação onde está instalada a instituição, segundo o último censo do Instituto Brasileiro de Geografia e Estatística (IBGE)”. No caso de não preenchimento das vagas segundo o critério de raça, previu que as vagas remanescentes devem ser completadas pelos estudantes que tenham cursado integralmente o ensino médio em escolas públicas (arts. $3^{\circ}$ e $5^{\circ}$ ).

Observando um dos elementos destacados pelos ministros do STF nos julgamentos acima descritos - sobre a transitoriedade dessas políticas - o artigo $7^{\circ}$ da Lei $n^{\circ} 12.711 / 12$ estabeleceu que “o Poder Executivo promoverá, no prazo de 10 (dez) anos, a contar da publicação desta Lei, a revisão do programa especial para o acesso de estudantes pretos, pardos e indígenas, bem como daqueles que tenham cursado integralmente o ensino médio em escolas públicas, às instituições de educação superior"203.

O programa começou a ser instituído já nos processos seletivos do ano de 2012, para ingresso nas instituições federais de ensino superior no ano de 2013, com a observância da proporção prevista no artigo $8^{\circ}$ da lei, que prevê a implementação do programa num prazo máximo de quatro anos, com a reserva de $25 \%$ do total das vagas previstas na lei a cada ano $^{204}$.

\subsubsection{O ProUni}

Em 2005, foi criado o Programa Universidade Para Todos (ProUni) (Lei n ${ }^{0} 11.096$, de 13/01/2005 - conversão da MP n ${ }^{0} 213$, de 10/09/2004), que alterou uma política antiga brasileira. Historicamente, apenas instituições de ensino privadas sem fins lucrativos desfrutavam de benefícios fiscais no Brasil - com o ProUni, essa regra mudou. O ProUni nivelou o tratamento fiscal entre instituições de ensino com e sem fins lucrativos, mediante a previsão de troca de cerca de $10 \%$ das vagas das instituições privadas ou de $8,5 \%$ da sua receita bruta $^{205}$, na forma de bolsas integrais ou parciais (de $50 \%$ ou de $25 \%$ ) aos

\footnotetext{
${ }^{203}$ Interessante notar que a lei nada falou sobre a revisão do programa com relação às instituições federais de ensino técnico de nível médio.

${ }^{204}$ Art. $8^{\circ}$, Lei $\mathrm{n}^{\mathrm{o}} 12.711 / 12$ - "As instituições de que trata o art. $1^{\circ}$ desta Lei deverão implementar, no mínimo, 25\% (vinte e cinco por cento) da reserva de vagas prevista nesta Lei, a cada ano, e terão o prazo máximo de 4 (quatro) anos, a partir da data de sua publicação, para o cumprimento integral do disposto nesta Lei". Nota-se outra lacuna aqui também com relação ao prazo e a forma de efetivação da lei para as instituições federais de ensino técnico de nível médio.

${ }^{205}$ Art. $5^{\circ}$, Lei $\mathrm{n}^{\mathrm{O}} 11.096 / 05$ - A instituição privada de ensino superior, com fins lucrativos ou sem fins lucrativos não beneficente, poderá aderir ao Prouni mediante assinatura de termo de adesão, cumprindo-lhe oferecer, no mínimo, 1 (uma) bolsa integral para o equivalente a 10,7 (dez inteiros e sete décimos) estudantes
} 
destinatários do programa, pela isenção, para as instituições participantes, de um conjunto de impostos ${ }^{206}$.

Os destinatários das bolsas são alunos provenientes de famílias de baixa renda, que cursaram o ensino médio completo em escola da rede pública ou em instituições privadas na qualidade de bolsistas integrais, portadores de deficiência e professores da rede pública de ensino, para os cursos de licenciatura, normal superior e pedagogia, destinados à formação do magistério da educação básica, independentemente da renda (art. $2^{\circ}$ ).

A seleção dos bolsistas leva em conta os resultados e perfis socioeconômicos do Enem (art. $3^{\circ}$ ) e também considera parâmetros de política afirmativa de acesso aos portadores de deficiência e autodeclarados "negros" e "indígenas" (art. $7^{\circ}$ ).

As bolsas de estudo integrais são concedidas a brasileiros não portadores de diploma de curso superior, cuja renda familiar mensal per capita não exceda o valor de até 1 (um) salário-mínimo e 1/2 (meio) (art. $1^{\circ}$, Parágrafo $1^{\circ}$ ). As bolsas de estudo parciais de $50 \%$ ou de $25 \%$, cujos critérios de distribuição são definidos em regulamento pelo Ministério da Educação, são concedidas a brasileiros não-portadores de diploma de curso superior, cuja renda familiar mensal per capita não exceda o valor de até 3 (três) saláriosmínimos, mediante critérios definidos pelo Ministério da Educação (art. $1^{\circ}$, Parágrafo $2^{\circ}$ ).

Segundo dados do $\mathrm{MEC}^{207}$, o Prouni já atendeu, desde sua criação até o processo seletivo do primeiro semestre de 2011, 863 mil estudantes, sendo 67\% com bolsas integrais.

Segundo o jornal Folha de São Paulo, no ano de 2011, estimou-se que o ProUni

regularmente pagantes e devidamente matriculados ao final do correspondente período letivo anterior, conforme regulamento a ser estabelecido pelo Ministério da Educação, excluído o número correspondente a bolsas integrais concedidas pelo Prouni ou pela própria instituição, em cursos efetivamente nela instalados. [...] $\S 4^{\circ} \mathrm{A}$ instituição privada de ensino superior com fins lucrativos ou sem fins lucrativos não beneficente poderá, alternativamente, em substituição ao requisito previsto no caput deste artigo, oferecer 1 (uma) bolsa integral para cada 22 (vinte e dois) estudantes regularmente pagantes e devidamente matriculados em cursos efetivamente nela instalados, conforme regulamento a ser estabelecido pelo Ministério da Educação, desde que ofereça, adicionalmente, quantidade de bolsas parciais de $50 \%$ (cinqüenta por cento) ou de $25 \%$ (vinte e cinco por cento) na proporção necessária para que a soma dos benefícios concedidos na forma desta Lei atinja o equivalente a $8,5 \%$ (oito inteiros e cinco décimos por cento) da receita anual dos períodos letivos que já têm bolsistas do Prouni, efetivamente recebida nos termos da Lei no 9.870, de 23 de novembro de 1999, em cursos de graduação ou seqüencial de formação específica.

${ }^{206}$ Art. $8^{\circ}$, Lei $\mathrm{n}^{\circ} 11.096 / 05$ - A instituição que aderir ao Prouni ficará isenta dos seguintes impostos e contribuições no período de vigência do termo de adesão: I - Imposto de Renda das Pessoas Jurídicas; II Contribuição Social sobre o Lucro Líquido, instituída pela Lei $\mathrm{n}^{0} 7.689$, de 15 de dezembro de 1988; III Contribuição Social para Financiamento da Seguridade Social, instituída pela Lei Complementar n ${ }^{\circ} 70$, de 30 de dezembro de 1991; e IV - Contribuição para o Programa de Integração Social, instituída pela Lei Complementar $\mathrm{n}^{\mathrm{o}} 7$, de 7 de setembro de 1970 . 207

Disponível

em:

$<$ http://prouniportal.mec.gov.br/index.php?option=com_content\&view=article\&id=124\&Itemid=140>.

Acesso em 28/06/2011. 
custaria R \$ 500 milhões em isenções, valor que, segundo o jornal, poderia manter cerca de 30 mil estudantes em uma universidade pública. No entanto, o programa, só no ano de 2009, teria oferecido mais de 240 mil bolsas, o que o torna, segundo o jornal, um "multiplicador de acesso ao ensino superior que pode e deve ser aperfeiçoado ${ }^{208}$ ".

O ProUni contribuiu também para minimizar um dos problemas da educação superior privada do Brasil, que são as vagas ociosas, e com isso favoreceu o crescimento do setor. Conforme o Censo da Educação Superior de 2008, verificou-se, em todo o Brasil, 1.479.318 vagas ociosas em relação ao número total de ingressos, a maior parte delas na rede privada (1.442.593 vagas ociosas). As razões para esse fato envolvem questões econômicas, já que muitos estudantes não conseguem arcar com os custos das mensalidades na rede privada. Por meio do ProUni e do Fies, parte dessas vagas ociosas é preenchida.

Destaca-se, no entanto, que a ociosidade permanece em parte das bolsas oferecidas pelo ProUni. Segundo reportagem do jornal Folha de São Paulo, nos dois processos seletivos realizados em 2010, respectivamente $30 \%$ e $40 \%$ das bolsas oferecidas pelo ProUni ficaram sem utilização, a maior parte delas na modalidade bolsa parcial. Esse fato leva à discussão da necessidade de aumento das bolsas integrais ou de aumento do teto da renda dos beneficiários para as bolsas parciais, de modo a atingir um público maior.

Sobre a importância do ProUni para o setor privado com fins lucrativos, a Anhanguera (2012d, p. 118) afirma:

Ao fornecer isenções fiscais às instituições com fins lucrativos, o Programa Universidade para Todos também desempenhou o importante papel de estimular o crescimento e o investimento privado no setor de educação superior, possibilitando que as instituições com fins lucrativos oferecessem cursos a preços competitivos comparados àqueles praticados por instituições filantrópicas e sem fins lucrativos.

Em 02 de abril de 2008, iniciou-se o julgamento da ADI $n^{\circ} 3033$, ajuizada pela Confederação Nacional dos Estabelecimentos de Ensino (Confenen), anexada à ADI ${ }^{\circ}$ 3314, proposta pelo DEM, por possuírem o mesmo objeto: questionar a constitucionalidade da Medida Provisória $n^{\circ}$ 213/04, convertida na Lei $n^{\circ} 11.096 / 2005$, que instituiu o ProUni. A ADI n ${ }^{\circ} 3379$, que tratava da mesma matéria, não foi julgada pelo STF, pois o Plenário, por unanimidade, não reconheceu a legitimidade ativa da Federação Nacional dos Auditores Fiscais da Previdência Social (Fenafisp), autora dessa ADI, para

${ }^{208}$ Disponível em: <http://www1.folha.uol.com.br/fsp/opiniao/fz0405201102.htm>. Acesso em: 25/09/2012. 
propor a ação. Naquela ocasião, o Ministro Relator do caso, Ayres Britto, pronunciou-se pela improcedência do pedido constante nas ADIs 3033 e 3312, mas o julgamento foi suspenso em virtude do pedido de vista feito pelo Ministro Joaquim Barbosa.

O julgamento foi retomado em 03 de maio de 2012, poucos dias após o julgamento das cotas da UnB, com a apresentação do voto-vista do ministro Joaquim Barbosa e dos demais ministros.

Em suas petições, a Confenen (2004) e o DEM (2004) sustentaram que: (i) a Medida Provisória (MP) e a Lei em que foi convertida violavam o artigo 62 da Constituição, que prevê a necessidade de urgência e relevância para a edição de medidas provisórias pelo Presidente da República, o que não foi observado no caso, com a consequente violação do artigo $2^{\circ}$ da Constituição, que consagra do princípio da separação de poderes; (ii) a MP e a Lei estabeleceram requisitos para o gozo de imunidades tributárias, matéria que deve ser disciplinada por lei complementar ${ }^{209}$; (iii) que a invalidade da MP contamina a lei de conversão; (iv) que a sujeição do estudante ao cumprimento de requisitos de desempenho acadêmico, estabelecidos pelo Ministério da Educação, sob pena de interrupção da bolsa, representa indevida delegação legislativa ao Ministério, violação da autonomia universitária e do princípio do pluralismo de ideias e concepções pedagógicas previsto no artigo 206, III, da Constituição; (v) houve carência de razoabilidade nos critérios previstos no artigo $2^{\circ}$ da Lei para estabelecer os destinatários do programa $^{210}$; (vi) houve violação da autonomia universitária (art. 207, CF/88) por se tratar de uma interferência indevida do Estado na iniciativa privada das atividades de ensino; (vii) houve violação do artigo $5^{\circ}$, II e XXXIX da Constituição ao estabelecer penalidades pelo descumprimento das normas do ProUni, ou seja, institui normas de natureza penal, por meio de MP (art. $9^{\circ}$ da MP) e não por lei; e (viii) houve violação da isonomia, autonomia universitária (art. 207, CF/88) e livre iniciativa (arts. 209 e 170, Parágrafo Único, $\mathrm{CF} / 88$ ) ao estabelecer prioridade na distribuição dos Fies às instituições que aderirem ao ProUni; (ix) era necessária interpretação conforme do artigo $8^{\circ}$ da $\mathrm{MP}$, no sentido de que a norma dele contida não se aplica à entidade beneficente de assistência

\footnotetext{
${ }^{209}$ Segundo a petição da Confenem, os artigos 10 e 11 da Lei impugnada violam os artigos 146, II e 195, Parágrafo $7^{\circ}$ da Constituição por invadirem competência de Lei Complementar para regular imunidades tributárias, nos termos do artigo 146, II, Constituição, ao pretenderem conceituar entidade beneficente de assistência social", e ao estabelecerem "requisitos para que tais instituições gozem de desoneração de contribuições sociais" (CONFENEM, 2004, p. 14).

${ }^{210}$ Afirma o Confenem (2012, p. 21): "não há coerência em impedir que tenham acesso aos benefícios, os alunos que tenham cursado o ensino médio em instituições privadas, beneficiados por bolsas parciais, desde que atendam aos parâmetros do art. $1^{\text {o" }}$ (CONFENEM, 2004, p. 21).
} 
social, nem às filantrópicas, que gozam de imunidades de impostos e contribuições sociais.

O Ministro Relator destacou em seu voto: (i) o direito à igualdade material; (ii) que não há inconstitucionalidade com relação à matéria tributária incluída na lei, pois no conceito de entidades beneficentes de assistência social estão as entidades de assistência educacional, e que a lei do ProUni tão somente criou um "critério objetivo de registro contábil compensatório da aplicação financeira em gratuidade por parte das instituições educacionais"; (iii) sobre a inclusão de matéria penal na lei, na forma das penalidades a serem aplicadas pelo MEC, afirmou que as determinações da lei não trataram de matéria penal e sim de matéria administrativa, e que a eventual sanção a uma entidade somente poderá ser feita após a instauração de procedimento administrativo, assegurado o contraditório e o direito de defesa ${ }^{211}$.

O julgamento foi retomado em 03 de maio de 2012, ocasião em que o Plenário do $\mathrm{STF}$, por maioria de votos, julgou improcedente o pedido feito na ADI.

Em seu voto-vista, o Ministro Joaquim Barbosa acompanhou o relator e (i) sustentou que o ProUni é coerente com diversos dispositivos constitucionais que pregam a redução das desigualdades sociais; (ii) citou dados mostrando o grande número de vagas ociosas no ensino superior brasileiro, sobretudo nas instituições privadas, afirmando que a causa disso era a dificuldade financeira das famílias para pagar o ensino superior de seus filhos; (iii) ao financiar a bolsa total para alunos de famílias com renda até 1,5 salário mínimo e parcial para aqueles egressos de famílias com renda de até 3 salários mínimos, o ProUni representa um importante fator de inserção social, afirmação confirmada por pesquisa feita em março de 2009 pelo Ibope, segundo a qual 56\% dos alunos apoiados pelo ProUni já trabalhavam quando iniciaram seu curso superior, mas seu nível de emprego aumentou para $80 \%$ após esse patrocínio, contribuindo para melhorar a renda de suas famílias. Além disso, argumentou que o custo de cada bolsa do programa é inferior ao custo por aluno em universidades públicas e, também, privadas; (iv) refutou a alegação de que o ProUni ofenderia o princípio da autonomia universitária, pois a adesão das universidades ao programa é facultativa, além disso, a autonomia universitária não é um objetivo que se esgota em si próprio. Ela existe para que se atinjam outros objetivos, de natureza educacional, social, cultural; (v) refutou a alegação de ofensa ao princípio da igualdade, uma vez que somente podem candidatar-se ao ProUni candidatos aprovados em

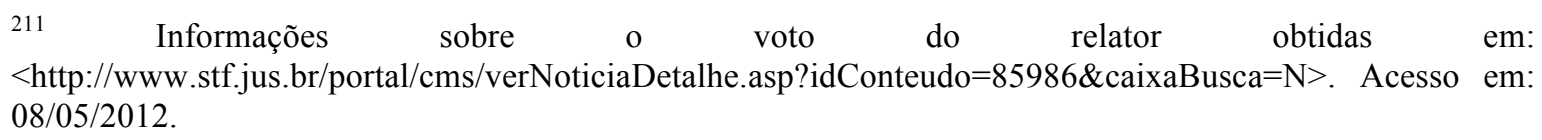


processo de seleção regular, disputado com os demais alunos; (vi) rebateu o argumento de que o ProUni ofenderia o princípio da livre iniciativa (art. 170, parágrafo único), pois as universidades que aderem ao ProUni não sofrem qualquer restrição. E, considerando a ociosidade de vagas nessas instituições, a lei pode até favorecer a manutenção de suas atividades, em razão dos benefícios tributários que passarão a usufruir; (vii) destacou que a educação não é uma mercadoria ou serviço sujeito às leis do mercado e sob a regência do princípio da livre iniciativa. "Se a legislação franqueia a educação à exploração pela iniciativa privada, essa só pode ocorrer se atendidos requisitos do artigo 209 da CF”, sustentou. Segundo ele, "não se trata, propriamente, de incidência pura do princípio da livre iniciativa" ${ }^{212}$.

O único Ministro a divergir do voto do relator foi Marco Aurélio. Segundo ele, o projeto de lei originalmente apresentado pelo Executivo ao Congresso Nacional com o intuito de criar o ProUni foi atropelado pela MP, que contém diversos vícios, como, por exemplo, não respeitar os requisitos de urgência e relevância previstos na Constituição, e regular matéria tributária, o que somente pode ser feito por meio de lei complementar. Nesse sentido, pouco importa que a MP tenha sido convertida em lei, pois "o vício originário quanto à edição da medida provisória contamina a lei de conversão. A lei de conversão, em síntese, é válida se válida se mostrar a medida provisória" ${ }^{213}$. Além disso, o ministro Marco Aurélio também questionou o fato de a lei prever sanções, a serem aplicadas pelo Ministério da Educação, para instituições que descumprirem as obrigações assumidas no termo de adesão ao ProUni, o que feriria a autonomia universitária. Ao final de seu voto, o ministro defendeu que o Estado deveria investir em universidades públicas, ao invés de "compelir a iniciativa privada fazer o que o próprio Estado deveria fazer" 214.

\subsubsection{O Reuni}

Durante o governo Luiz Inácio Lula da Silva, especialmente, a partir de 2004, foram estabelecidas medidas para a expansão do sistema público na educação superior, dentro de um programa de expansão das universidades federais, que incluiu o aumento das

\footnotetext{
${ }^{212}$ Também acompanharam o relator: a Ministra Rosa Weber, os Ministros Luiz Fux, Cezar Peluso e Gilmar Mendes. Informações sobre o julgamento disponíveis em: $<$ http://www.stf.jus.br/portal/cms/verNoticiaDetalhe.asp?idConteudo=206553>. Acesso em: 08/05/2012. 213 Informações $\quad$ sobre $\quad$ o $\quad$ julgamento $\quad$ obtidas $<$ http://www.stf.jus.br/portal/cms/verNoticiaDetalhe.asp?idConteudo=206553>. Acesso em: 08/05/2012.

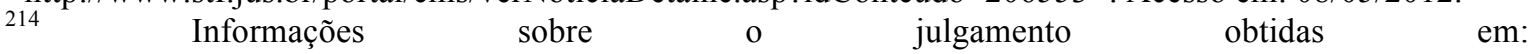
$<$ http://www.stf.jus.br/portal/cms/verNoticiaDetalhe.asp?idConteudo=206553>. Acesso em: 08/05/2012.
} 
vagas em instituições federais já existentes e a abertura de novas universidades federais. Dentro desse programa, foram criadas as Universidades Federais do ABC (UFABC), da Fronteira Sul (UFFS), da Integração Latino-Americana (Unila), da Integração Luso-AfroBrasileira (Unilab) e da Integração Amazônica (Uniam).

A Presidente Dilma Roussef aprovou a abertura, até 2012, de mais quatro novas universidades - Universidades Federais do Sul e Sudeste do Pará (Unifesspa), da Região do Cariri no Ceará (UFRC); do Oeste da Bahia (Ufoba) e do Sul da Bahia (Ufesba) ${ }^{215}$.

Em 2007, esse programa foi intensificado por meio do Reuni (Programa de Apoio a Planos de Reestruturação e Expansão das Universidades Federais, Decreto $n^{0}$ 6.096, de 24/04/2007), que busca a redução das taxas de evasão, aumento de vagas de ingresso, especialmente no período noturno, reforma e reestruturação das instituições existentes e criação de novas instituições federais.

Como as mudanças acima descritas são recentes, elas ainda não tiveram um impacto significativo na estrutura da educação superior brasileira, descrita no item 2.6 abaixo, mas apontam para um cenário de possível crescimento do setor público, nos próximos anos.

\subsubsection{O novo Enem e o Sisu}

No ano de 2009, foram aprovadas mudanças no Exame Nacional do Ensino Médio (Enem), que foram progressivamente implementadas a partir de 2010. O objetivo principal dessas mudanças foi substituir os exames vestibulares das universidades federais pelo Enem e, com isso, unificar os processos seletivos dessas instituições. Além disso, o "novo Enem" permitiu que estudantes de diferentes partes do País, que antes tinham dificuldades para se locomover pelo território nacional para prestar os exames vestibulares, pudessem participar de processos seletivos de diferentes instituições, em diferentes regiões do País, por meio de uma prova unificada, aumentando sua chance de aprovação.

Nesse contexto, foi desenvolvido o Sisu - Sistema de Seleção Unificada. O Sisu, desenvolvido pelo MEC, seleciona os candidatos às vagas das instituições de ensino superior públicas que utilizam a nota do Enem como única fase do seu processo seletivo.

As instituições privadas logo incorporaram o resultado do Enem como parte ou como toda a sua forma de seleção de candidatos. As instituições públicas resistiram um

215 Fonte: http://portal.mec.gov.br/index.php?option=com_content\&view=article\&id=16972. Acesso em: $23 / 07 / 2012$. 
pouco ao exame, mas no decorrer do tempo passaram também a incorporar o resultado do Enem em sua seleção, algumas substituindo a sua primeira fase pelo exame. Com isso a procura pelo Enem aumentou consideravelmente, o que gerou algumas crises e denúncias de fraudes ${ }^{216}$.

De acordo com o Censo da Educação Superior de 2010, do total de 1.590.212 ingressos por processo seletivo em cursos superiores de graduação presencial, 244.362 (ou 15,4\%) entraram por meio do Enem em instituições que o utilizaram, total ou parcialmente, em seus processos seletivos.

Abaixo a utilização do Enem por categoria administrativa:

Tabela 2 - Total de Ingressos por Processo Seletivo e Ingressos por meio do Enem nos Cursos Presenciais, por Categoria Administrativa das IES - Brasil $-2010$

\begin{tabular}{c|c|c|c|c|c}
\hline $\begin{array}{c}\text { Ingressos } \\
\text { por } \\
\text { processo } \\
\text { seletivo }\end{array}$ & Total & Federal & Estadual & Municipal & Privada \\
\hline Total & 1.590 .212 & 251.059 & 130.035 & 27.468 & 1.181 .650 \\
Enem & 244.362 & 79.506 & 2.454 & 652 & 161.750 \\
\% Enem & 15,4 & 31,7 & 1,9 & 2,4 & 13,7 \\
\hline
\end{tabular}

Fonte: Inep (2012b)

\subsubsection{Ensino a distância}

O governo Luiz Inácio Lula da Silva estimulou também o desenvolvimento do ensino a distância no Brasil. Uma das principais iniciativas nesse sentido foi a criação da Universidade Aberta do Brasil (UAB), regulamentada pelo Decreto $n^{0} 5.800$ de 08/06/2006. A UAB não é uma nova instituição de ensino, mas sim a articulação entre instituições de ensino superior públicas existentes, com a "finalidade de expandir e interiorizar a oferta de cursos e programas de educação superior no País" (art. $1^{\circ}$ ), levando o ensino superior público a locais em que ele não esteja presente fisicamente. A prioridade da UAB é a formação de professores para a educação básica. O ensino se dá “em regime de colaboração da União com entes federativos, mediante a oferta de cursos e programas de educação superior a distância por instituições públicas de ensino superior, em articulação com polos de apoio presencial" (art. $2^{\circ}$ ), que possuem a infraestrutura e os

${ }^{216}$ Em 2009, houve vazamento da prova do Enem, e o MEC foi obrigado a cancelar a prova e remarcá-la. Em 2010, houve problemas em algumas versões da prova, que apresentavam questões repetidas. Em 2011, o exame teve 14 questões anuladas, que constaram de um simulado de um colégio e curso pré-vestibular. Fonte: <http://www.enem2012.com.br/sobre-enem/os-problemas-enem.html>. Acesso em: 23/07/2012. 
recursos humanos necessários para as fases presenciais dos cursos (art. $2^{\circ}$, Parágrafo $2^{\circ}$ ).

O ensino a distância registrou aumento nos últimos anos, como será desenvolvido no item 2.6 a seguir.

Rodrigo Ximenes Sécca e Rodrigo Mendes Leal (2009, p. 43) acreditam que o ensino a distância $(\mathrm{EaD})$ aumentará ainda mais sua participação no ensino superior brasileiro e destacam que a $\mathrm{EaD}$ é interessante para o setor privado porque é capaz de reduzir custos e aumentar a capilaridade das instituições de ensino superior, fazendo o ensino superior chegar a regiões em que não há instituições de ensino físicas. Segundo os autores (2009, p. 43):

[...] pode-se inferir que a EAD é capaz de proporcionar redução de custos e aumento de capilaridade para as IES, por permitir atingir um número maior de estudantes por docente via utilização de recursos tecnológicos. Diminui também a necessidade de ocupação de salas de aula e chega a estudantes que estão em regiões em que não há IES físicas.

\subsubsection{Proies}

Em 18 de julho de 2012, foi aprovada a Lei $n^{0} 12.688$, que estabeleceu o Programa de Estímulo à Reestruturação e ao Fortalecimento das Instituições de Ensino Superior (Proies), que tem por objetivo "assegurar condições para a continuidade das atividades de entidades mantenedoras de instituições integrantes do sistema de ensino federal" $\left(\operatorname{art.} 1^{\circ}\right)$. A referida lei permitiu que instituições em grave situação econômica ${ }^{217}$ possam pedir a moratória de suas dívidas tributárias federais pelo prazo de 12 meses, sendo pagos em 180 prestações sucessivas, a partir do $13^{\circ}$ mês de adesão ao programa (arts. $6^{\circ}$ e 10). Para o pagamento das dívidas, autorizou a utilização de títulos do Tesouro Nacional, emitidos em contrapartida a bolsas de estudos oferecidas por essas instituições, nos seguintes termos:

Art. 13. É facultado o pagamento de até $90 \%$ (noventa por cento) do valor das prestações mensais de que trata o art. 10 mediante a utilização de certificados de emissão do Tesouro Nacional, emitidos pela União, na forma de títulos da dívida pública, em contrapartida às bolsas Proies concedidas pelas mantenedoras das IES para estudantes de cursos superiores

\footnotetext{
${ }^{217}$ Nos termos do artigo $4^{\circ}$, Parágrafo Único da Lei $n^{\circ} 12.688 / 12$ - “Considera-se em estado de grave situação econômico-financeira a mantenedora de IES que, em 31 de maio de 2012, apresentava montante de dívidas tributárias federais vencidas que, dividido pelo número de matrículas total, resulte em valor igual ou superior a $\mathrm{R} \$ 1.500,00$ (mil e quinhentos reais), observadas as seguintes regras: I - o montante de dívidas tributárias federais vencidas engloba as inscritas ou não em Dívida Ativa da União (DAU), as ajuizadas ou não e as com exigibilidade suspensa ou não, em 31 de maio de 2012; e II - o número de matrículas total da mantenedora corresponderá ao número de alunos matriculados nas IES vinculadas à mantenedora, de acordo com os dados disponíveis do Censo da Educação Superior, em 31 de maio de 2012". Esse dado significa que, para uma instituição com 300 alunos, por exemplo, a dívida mínima a ser parcelada será de R\$450 mil.
} 
não gratuitos e com avaliação positiva nos processos conduzidos pelos órgãos referidos no parágrafo único do art. $5^{\circ}$, condicionada à observância das seguintes condições por ocasião da adesão:

I - adesão ao Programa Universidade para Todos (Prouni), instituído pela Lei ${ }^{\circ} 11.096$, de 13 de janeiro de 2005, com oferta exclusiva de bolsas obrigatórias integrais;

II - adesão ao Fundo de Financiamento Estudantil (Fies), sem limitação do valor financeiro destinado à concessão de financiamentos, nos termos e condições estabelecidos pela Lei $\mathrm{n}^{\mathrm{o}}$ 10.260 , de 12 de julho de 2001;

III - adesão ao Fundo de Garantia de Operações de Crédito Educativo (FGEDUC), criado a partir da Lei $\mathrm{n}^{0}$ 12.087, de 11 de novembro de 2009, nos termos e condições que regulamentam aquele Fundo.

$\S 1^{\circ}$ - As bolsas de estudo de que trata o caput atenderão ao requisito previsto no art. $3^{\circ}$ da Lei $\mathrm{n}^{\circ}$ 11.096, de 13 de janeiro de 2005, e demais condições estabelecidas pelo MEC, eliminada a etapa final de seleção pelos critérios da IES.

$\S 2^{\circ}$ - As bolsas concedidas no âmbito do Programa Universidade para Todos (ProUni), instituído pela Lei $\mathrm{n}^{\circ} 11.096$, de 13 de janeiro de 2005 , não poderão ser utilizadas para pagamento das prestações de que trata o art. 10 da presente Lei.

$\S 3^{\circ}$ - O valor de cada bolsa de estudo corresponderá ao encargo educacional mensalmente cobrado dos estudantes sem direito a bolsa, mesmo que parcial, por parte da IES, considerando todos os descontos regulares e de caráter coletivo oferecidos pela instituição, inclusive aqueles concedidos em virtude de seu pagamento pontual.

$\S 4^{\circ}$ (VETADO).

$\S 5^{\circ}$ - O valor do certificado será mensalmente apurado e corresponderá ao total de bolsas de estudo concedidas no mês imediatamente anterior multiplicado pelo valor da bolsa de estudo definido no $\S 3^{\circ}$.

$\S 6^{\circ}$ - O valor mensal da prestação não liquidada com o certificado deverá ser liquidado em moeda corrente.

$\S 7^{0}-\mathrm{O}$ certificado, que será nominativo e não poderá ser transferido para terceiros, terá sua característica definida em ato do Ministro de Estado da Fazenda, não podendo ser utilizado para outra finalidade que não seja a liquidação de parcela das prestações de que trata $\mathrm{o}$ art. 10.

$\S 8^{\circ}$ - Nos casos em que o valor do certificado exceder ao percentual máximo estabelecido no caput, as mantenedoras poderão utilizar o saldo remanescente para pagamento das prestações vincendas, desde que respeitado o pagamento mínimo em moeda corrente.

$\S 9^{\circ}$ - As IES que já participavam do ProUni ou do Fies por ocasião da adesão ao Proies dever-se-ão adaptar para cumprimento integral das condições fixadas nos incisos I e II do caput.

Por meio deste Programa, o Governo Federal trocou dívidas de instituições de ensino superior privadas por novas bolsas de estudo, incentivando, por meio da transferência indireta de recursos, a atuação do setor privado no ensino superior do País. 


\subsubsection{Financeirização e internacionalização da educação}

\subsubsection{Participação estrangeira em empresas educacionais brasileiras}

Antes mesmo do ingresso de empresas educacionais brasileiras no mercado de capitais, investidores estrangeiros e fundos de investimento nacionais e internacionais passaram a atuar no setor.

A esse respeito, nota-se que na legislação nacional não há qualquer vedação ao oferecimento da educação, em qualquer nível, por instituições estrangeiras, nem à participação estrangeira em empresas de educação, o que torna esse tipo de operação absolutamente legal. Conforme destaca Ranieri (2005, p. 63), "não há monopólio estatal sobre o setor de ensino, nem reserva de mercado para as instituições ou empresas nacionais desta área".

Contudo, a participação estrangeira em empresas de educação é objeto de discussão no Brasil. Tramita no Congresso Nacional um projeto de lei visando a Reforma Universitária, que prevê a limitação da participação estrangeira no capital votante das empresas educacionais a $30 \%{ }^{218}$. Temendo a aprovação dessa lei, a Anhanguera, em sua abertura de capital em 2007, emitiu ações com direito de voto (ordinárias) e sem direito de voto (preferenciais), já pensando nos investidores estrangeiros. Anos depois, em 2010, sem a aprovação dessa lei, a empresa encorajou-se e aderiu ao Novo Mercado, segmento especial de governança corporativa que admite apenas a negociação de ações com direito de voto. Segundo a Revista Capital Aberto (2010), a participação de estrangeiros nas ofertas da Anhanguera foi significativa: $76 \%$ do IPO de 2007, 96\% da oferta primária de 2008 e $79 \%$ da oferta secundária de 2009.

Sobre a participação de fundos no setor educacional brasileiro, Oliveira (2009, p. 743) entende que:

Esses fundos têm condições de injetar altas quantias em empresas educacionais, ao mesmo tempo em que empreendem ou induzem processos de reestruturação das escolas nas quais investem, por meio da redução de custos, da racionalização administrativa, em suma, da

\footnotetext{
${ }^{218}$ Art. $7^{\circ}$, PL 7200/2006 - "Poderá manter instituição de ensino superior: I - o Poder Público; e II - pessoa física, sociedade, associação ou fundação, com personalidade jurídica de direito privado, cuja finalidade principal seja a formação de recursos humanos ou a produção de conhecimento. $\S 4^{\circ}$ - Em qualquer caso, pelo menos setenta por cento do capital votante das entidades mantenedoras de instituição de ensino superior, quando constituídas sob a forma de sociedade com finalidades lucrativas, deverá pertencer, direta ou indiretamente, a brasileiros natos ou naturalizados".
} 
"profissionalização" da gestão das instituições de ensino, numa perspectiva claramente empresarial. Essa perspectiva racionalizadora é fundamentalmente orientada para a maximização de lucros, chegando ao paroxismo em algumas situações.

A primeira operação relevante envolvendo investidores estrangeiros no setor educacional brasileiro ocorreu no ano de 2001, quando o norte-americano Apollo Group, considerado o maior grupo educacional do mundo ${ }^{219}$, listado na bolsa eletrônica Nasdaq, adquiriu participação societária na Kroton ${ }^{220}$. Segundo informações da Kroton, o ingresso do Apollo Group trouxe "capital e experiência internacional em gestão educacional para o seu projeto de Ensino Superior". Por questões internas do grupo, que decidiu limitar suas atividades fora dos Estados Unidas, em 2006, o Apollo Group alineou sua participação na Kroton $^{221}$.

Em dezembro de 2005, o grupo norte-americano Laureate International Universities adquiriu 51\% da Universidade Anhembi Morumbi, de São Paulo, numa operação de R\$165 milhões ${ }^{222}$ (REVISTA CAPITAL ABERTO, 2007, p. 54; OLIVEIRA, 2009, p. 739-60).

No mesmo ano, o Fundo de Educação Para o Brasil - Fundo de Investimento em Participações (FEBR), criado, administrado e gerido pelo Pátria Investimentos S.A. (Pátria), adquiriu 70\% do capital social da Anhanguera, numa operação que contou com aporte de US\$12 milhões da IFC. Após o ingresso do FEBR e de outros investidores, a Anhanguera expandiu-se, adquiriu diversas mantenedoras de instituições de ensino superior e abriu seu capital no bolsa de valores no ano de 2007, conforme mais bem descrito no Capítulo 4.

No ano seguinte (2006), a Whitney International University System, outra empresa do ramo educacional internacional, capitalizada por um fundo de investimentos

\footnotetext{
${ }^{219}$ O Apollo Group é considerado o maior grupo educacional do mundo, em número de alunos. Este grupo atua no setor educacional há de mais de 35 anos, com atividades nos Estados Unidos (cuja principal instituição é a University of Phoenix, maior universidade com fins lucrativos do mundo, em número de alunos, com mais de 406 mil em fevereiro de 2012), Porto Rico, América Latina e Europa; e também por meio da metodologia de ensino a distância oferece cursos para todo o mundo. Disponível em: http://www.marketingnasies.com.br/2012/12/17/grupo-apollo-global/;

http://www.wikinvest.com/stock/Apollo_Group_(APOL);

http://www.apollogrp.edu/sites/default/files/files/Apollo-Group-Fact-Sheet.pdf. Acessos em: 14/01/2013.

${ }^{220}$ Segundo informações da Kroton, a participação foi adquirida pelo fundo particular de investimentos em educação denominado Apollo International. Disponível em: $<$ http://www.faculdadepitagoras.com.br/BeloHorizonte/afaculdade/Paginas/historico.aspx>. Acesso em: 08/12/2012.

$221 \quad$ Fonte: $\quad<$ http://www.faculdadepitagoras.com.br/BeloHorizonte/afaculdade/Paginas/historico.aspx $>$. Acesso em: 08/12/2012.

${ }^{222}$ Segundo o jornal Folha de São Paulo, em 2010, o grupo Laureate participava de nove instituições no Brasil, incluindo Anhembi Morumbi, e só não atuava na Região Centro-Oeste. Fonte: $<$ http://www1.folha.uol.com.br/fsp/mercado/me1708201013.htm>. Acesso em: 05/06/2012.
} 
denominado Best Associates, adquiriu participação societária na Faculdade Jorge Amado, de Salvador, numa operação de R\$23 milhões ${ }^{223}$ (REVISTA CAPITAL ABERTO, 2007, p. 54).

Em maio de 2008, o GP Investments, maior fundo de private equity ${ }^{224}$ da América Latina, adquiriu 20\% do capital social da Estácio Participações S.A., companhia aberta do setor educacional brasileiro; e estabeleceu com os fundadores da empresa uma aliança estratégica, com gestão compartilhada, visando o crescimento da empresa ${ }^{225}$.

Em 2009, o grupo educacional norte-americano, DeVry University ${ }^{226}$, adquiriu instituições de ensino superior em Salvador e Fortaleza, iniciando suas atividades no Brasil. Atualmente, o grupo possui cinco instituições de ensino superior no Brasil, todas na região Nordeste ${ }^{227}$. Neste mesmo ano, o fundo de private equity norte-americano, Advent International, adquiriu participação societária na Kroton Educacional S.A. (Kroton), numa operação de R $\$ 280$ milhões ${ }^{228}$.

No ano de 2010, uma das principais empresas do setor educacional brasileiro, a SEB - Sistema Educacional Brasileiro S.A., foi adquirida (90,46\% do capital social votante e 69,04\% do capital social total) pela Pearson Education do Brasil Ltda., subsidiária do grupo inglês Pearson ${ }^{229}$. Essa operação envolveu a venda para a Pearson das marcas de ensino COC, Dom Bosco, Pueri Domus e Name, juntamente com a editora do grupo, o material didático e todo o sistema educacional, desde o desenvolvimento das apostilas até o treinamento de professores. Os antigos acionistas da SEB ficaram apenas com as escolas físicas ${ }^{230}$. Pouco tempo depois dessa aquisição, a SEB fechou seu capital e deixou de negociar ações na BM\&FBOVESPA.

\footnotetext{
${ }^{223}$ Disponível em: http://revistaensinosuperior.uol.com.br/textos.asp?codigo=11892. Acesso em: 30/06/2012.

${ }^{224}$ Fundos de private equity são "fundos que investem diretamente em empresas (listadas ou não), com o intuito de geri-las, e realizar o desinvestimento em um período de longo prazo. No mundo, destacam-se KKR e Blackstone Group como as maiores gestoras de fundos de Private Equity. Já no Brasil, as gestoras com maior volume de investimento no mercado de Private Equity são Advent e GP Investments". Fonte: http://pt.wikipedia.org/wiki/Fundos_de_Private_Equity. Acesso em: 14/01/2013.

${ }^{225}$ Disponível em: http://www.mzweb.com.br/gp2012/web/arquivos/GP_Press_Release_20080511_eng.pdf e http://oglobo.globo.com/economia/fundador-da-estacio-de-sa-vai-se-desfazer-de-participacao-nauniversidade-2967430\#ixzz2I4zye14U. Acessos em: 14/01/2013.

${ }^{226}$ A DeVry University foi a primeira empresa de educação a abrir o capital no mundo (REVISTA CAPITAL ABERTO, 2007, p. 56).

${ }^{227}$ São elas: (i) Área 1, que oferece cursos de engenharia e tecnologia, em Salvador/BA; (ii) Fanor de Fortaleza/CE; (iii) Faculdade do Valor do Ipojuca de Caruaru/PE; (iv) Faculdade Boa Viagem, que possui três campi no estado de Pernambuco; e (v) Faculdade Ruy Barbosa de Salvador/BA. Fonte: $<$ http://www.devrybrasil.com.br/devry-no-brasil/faculdades-no-brasil/>. Acesso em: 08/12/2012.

${ }^{228}$ Disponível em: http://exame.abril.com.br/negocios/empresas/noticias/fundo-advent-compra-parte-krotonr-280-milhoes-479807. Acesso em: 14/01/2013.

${ }^{229}$ O grupo Pearson é uma das maiores companhias de educação do mundo, dona do Financial Times e da revista The Economist.

${ }^{230}$ Fonte: O Estado de São Paulo, caderno Negócio, edição de 01/10/2012.
} 
Em dezembro de 2011, a Pearson investiu também no setor de editoras, por meio da compra, realizada por sua editora Penguin, de 45\% da Companhia das Letras.

Em movimento contrário, a Estácio Participações S.A. (Estácio), outra grande empresa do setor educacional brasileiro, adquiriu operações no exterior - em 2007, adquiriu $100 \%$ da Asociación de Estudios Superiores de Las Américas, no Paraguai, que possuía uma unidade, 12 cursos e 1.524 alunos; e 80\% da Escuela de Informática SRL, no Uruguai, que possuía uma unidade, dois cursos de graduação e sete cursos técnicos, totalizando 361 alunos em 2007 (SÉCCA; LEAL, 2009, p. 40).

Agências de desenvolvimento também efetuaram empréstimos e investiram em empresas de educação no Brasil. A IFC efetuou empréstimos para a Anhanguera e investiu na Ideal Invest, conforme descrito no Capítulo 4 desta Dissertação e no item 2.4.6.3 abaixo.

\subsubsection{Companhias abertas do setor de educação}

Em março de 2007, a Anhanguera foi a primeira empresa brasileira de educação a abrir o capital na BM\&FBOVESPA. Este fato marcou um novo movimento do setor privado do ensino, que partiu para o mercado de capitais em busca de novos recursos para o seu crescimento.

No mesmo ano, aproveitando os cenários nacional e internacional favoráveis, as empresas Estácio, Kroton Educacional S.A. (Kroton) e SEB também realizaram ofertas públicas iniciais (IPOs, na sigla em inglês). Os IPOs da Anhanguera e dessas três empresas educacionais, realizados entre março de 2007 e abril de 2008, levantaram R $\$ 1,9$ bilhões ${ }^{231}$ na BM\&FBOVESPA (REVISTA CAPITAL ABERTO, 2009, p. 21). A Anhanguera foi a empresa que conseguiu o maior volume de recursos - em seu IPO e na segunda oferta pública realizada em 2008, obteve mais de R\$910 milhões.

Atualmente, existem quatro empresas que atuam no setor educacional listadas na BM\&FBOVESPA: (i) Anhanguera; (ii) Estácio; (iii) Kroton; e (iv) Abril Educação ${ }^{232}$. A

\footnotetext{
${ }^{231}$ Segundo a Revista Capital Aberto (2009, p. 21), esse valor equivale a 3,16\% dos R\$60,2 bilhões gastos pelo Ministério da Educação em 2007.

${ }^{232}$ De acordo com a classificação da BM\&FBOVESPA no setor de atuação - "serviços educacionais" estão listadas apenas Anhanguera, Estácio e Kroton. A Abril Educação, que detém o Grupo Anglo e atua na educação básica, segundo a classificação da BM\&FBOVESPA atua no setor de "jornais, livros e revistas". Considerando o ramo de atuação da Abril, optamos por incluí-la como empresa educacional. Disponível em: No setor de "livros, jornais e revistas" Neste setor também está listada a Saraiva S.A. Livreiros e Editores. Fonte: 
$\mathrm{SEB}^{233}$, conforme mencionamos acima, fechou seu capital no ano de 2010 e a Abril Educação abriu seu capital e efetuou seu IPO em julho de 2011.

O grupo Anhanguera atua no setor do ensino superior, ensino profissional, educação continuada, cursos na área jurídica e cursos preparatórios para concursos públicos, nas modalidades presencial e a distância. Em 31/12/2011, era o maior grupo de educação do Brasil e o segundo maior grupo do mundo, em número de alunos e valor de mercado. Informações sobre a Anhanguera encontram-se no Capítulo 4 da Dissertação.

As instituições integrantes do grupo Kroton atuam na educação básica (por meio da rede Pitágoras e com a marca Projecta na rede pública) há mais de 45 anos e no ensino superior $^{234}$ (com inúmeras instituições de ensino superior, entre elas a Unopar) há mais de 10 anos, nas modalidades presencial e a distância. Desde 2009, a Kroton possui participação do fundo de investimentos Advent e apresentou um grande crescimento nos últimos anos, encostando na líder Anhanguera.

O grupo Estácio atua no ensino superior há mais de 40 anos (possuindo atualmente inúmeras instituições de ensino superior), oferecendo cursos de graduação (bacharelado e licenciatura), graduação tecnológica e pós-graduação, nas modalidades presencial, a distância e flex $x^{235}$. A Estácio, a partir do ano de 2008, passou a ter como acionista o fundo de investimentos GP Investments e apresentou também um grande crescimento nos últimos anos.

A Abril Educação atua na educação básica, pré-universitária e na área de cursos preparatórios para concurso público (por meio da rede Siga). Na educação básica e préuniversitária, atua por meio de sistemas de ensino (com as marcas Anglo e SER); de

listadas/BuscaEmpresaListada.aspx?Idioma=pt-brhttp://www.bmfbovespa.com.br/cias-listadas/empresaslistadas/BuscaEmpresaListada.aspx?Idioma=pt-br>. Acesso em: 08/06/2012.

${ }^{233}$ O SEB atuava na graduação presencial e a distância, cursos de pós-graduação lato sensu, cursos para concursos públicos e sistema de ensino (material didático e apoio pedagógico) para escolas do ensino fundamental da rede privada e pública. No ano de 2010, a SEB foi dividida, e a parte referente aos sistemas de ensino (COC, Dom Bosco, Pueri Domus e Name) foi adquirida pelo Grupo Pearson (HOPER, 2011, p. 82).

${ }^{234}$ Segundo informações da empresa, "a Kroton possui 53 unidades de Ensino Superior, presentes em 10 estados e 39 cidades brasileiras e 447 Polos de Graduação EAD credenciados pelo MEC. A Companhia ainda conta com mais de 810 escolas associadas em todo o território nacional, além de cinco no Japão e uma no Canadá, por meio da Rede Pitágoras. Na área pública, a instituição está presente com a marca Projecta, que tem o objetivo de levar educação de qualidade aos municípios brasileiros por meio de programas de gestão, materiais didáticos e avaliações educacionais". Disponível em: http://www.mzweb.com.br/kroton2010/web/conteudo_pt.asp?idioma=0\&conta=28\&tipo=32816. Acesso em: $14 / 01 / 2013$.

${ }^{235}$ Segundo informações da empresa: “com 40 anos de atuação em ensino, a Estácio é uma das maiores e melhores redes de ensino superior do Brasil, integrando Universidade, Centros Universitários e Faculdades, atualmente com mais de 270 mil alunos e presente em 20 estados do Brasil com mais de 70 unidades". Disponível em: http://portal.estacio.br/. Acesso em: 14/01/2013. 
editoras de livros didáticos (Ática e Scipione); de escolas próprias (Anglo Vestibulares e pH Colégio e Vestibulares); além disso, atua no ensino técnico (rede de Escolas Técnicas do Brasil) ${ }^{236}$.

Por meio da captação de recursos no mercado de capitais, essas empresas participaram de diversos processos de fusões e aquisições ocorridos nos últimos anos, aumentando sua rede de ensino e sua dispersão pelo território nacional, consolidando sua posição no mercado ${ }^{237}$. Com o crescimento em número de instituições e de alunos, essas instituições obtiveram ganhos em escala, que permitiram a cobrança de mensalidades mais baixas de seus alunos. A esse respeito, a Revista Veja ${ }^{238}$ fez a seguinte afirmação sobre os grandes grupos de educação de massa do Brasil:

O ingresso das faculdades no mercado de capitais não provoca apenas uma mudança fundamental na condução desse tipo de negócio no país. Pode representar, também, um avanço para os alunos. Foi o que se viu nos Estados Unidos, onde as universidades começaram a aventurar-se na bolsa quinze anos atrás. A breve experiência brasileira aponta para o mesmo tipo de ganho: mensalidades mais baixas, avanços na infra-estrutura e, por vezes, até a melhora do ensino. Ao abrirem o capital, as universidades juntam dinheiro para esparramar-se por vários endereços e logo se transformam em redes de ensino, nas quais tudo é pensado em grande escala. Na prática, nenhum funcionário vai mais à loja vizinha comprar papel e tinta ou uma impressora nova. Esses artigos são encomendados aos milhares, o que reduz os custos. Torna-se possível, por exemplo, a compra de equipamentos para um laboratório pela metade do preço - daí as chances de a infraestrutura melhorar. Com esse tipo de economia, a margem de lucro de uma faculdade, que normalmente beira os $7 \%$, chega a $20 \%$. É por isso que grupos que entraram na bolsa, como Anhanguera e Estácio de Sá, conseguem cobrar mensalidades até 50\% mais baixas.

Para certas faculdades, a entrada na bolsa acaba tendo ainda impacto positivo no nível do ensino (o que não faz mal às universidades brasileiras). Uma das razões remete, de novo, aos ganhos de escala. Numa rede, os custos com a confecção de currículos e material didático (parte do negócio que sai caro para as universidades) caem drasticamente. $\mathrm{O}$ mesmo material é adotado em dezenas de faculdades. Foi justamente por isso que o Kroton (grupo já tradicional no ensino básico, como o SEB, outro que entrou na bolsa) investiu alto na contratação de uma equipe de especialistas em diversas áreas, com a missão de elaborar um plano pedagógico. "Não conseguiríamos isso fora de uma rede de ensino", diz Alicia Figueiró, vice-presidente do grupo. Outro fator que pode impulsionar a melhora do ensino diz respeito à simples lógica do mercado: faculdades muito ruins espantam os investidores e, por isso, aquelas que vão à bolsa têm de se preocupar mais com o lado

236 Disponível em: http://www.abrileducacao.com.br/doc/anunVEJA_AbrilEducacao.pdf. Acesso em: $14 / 01 / 2013$.

${ }^{237}$ Como resultado dos seus IPOs, essas empresas aumentaram consideravelmente o número de unidades de ensino - de dezembro de 2006 para dezembro de 2008, a Anhanguera passou de 13 campi operacionais para 52, e a quantidade de alunos mais que sextuplicou no período, passando de 24,5 mil para 157,2 mil; a quantidade de alunos da Kroton quase triplicou entre 2007 e 2008, passando de 15 mil para 42 mil; e o SEB passou de 21 mil alunos em dezembro de 2007 para 51 mil alunos em dezembro de 2008 (REVISTA CAPITAL ABERTO, 2009, p. 23). O crescimento da Anhanguera será tratado com detalhes no Capítulo 4 da Dissertação.

238

Disponível

em:

$<$

http://v<<eja.abril.com.br/020708/p_080.shtmlhttp://veja.abril.com.br/020708/p_080.shtml>. Acesso em: $25 / 09 / 2012$. 
acadêmico. Diante de notas baixas em alguns de seus cursos em provas aplicadas pelo Ministério da Educação, a Anhanguera decidiu enviar professores para um curso de reciclagem. "Trata-se de uma questão de sobrevivência no longo prazo", afirma o especialista Ryon Braga.

Segundo levantamento da Fator Corretora, apenas no ano 2008, Anhanguera, Kroton, SEB e Estácio realizaram 34 operações de fusões e aquisições, movimentando $\mathrm{R} \$ 652,4$ milhões e atingindo mais de 146 mil alunos (REVISTA CAPITAL ABERTO, 2009, p. 21). Em julho de 2010, a Abril Educação S.A. (Abril Educação) adquiriu o Grupo Anglo por R\$ 717 milhões. Um ano depois (em julho de 2011), realizou seu IPO e captou no mercado R\$317 milhões ${ }^{239}$. Com dinheiro em caixa, a Abril Educação fechou quatro aquisições em 2011, que somaram R 279 milhões.

Nos anos seguintes, o crescimento dessas empresas continuou intenso - segundo levantamento do jornal Valor Econômico ${ }^{240}$, no ano de 2011, Anhanguera, Abril Educação, Estácio e Kroton movimentaram cerca de R \$ 2,4 bilhões em cerca de 20 aquisições.

Dentre as aquisições ocorridas em 2011, destacaram-se: (i) a aquisição do grupo Uniban pela Anhanguera ${ }^{241}$, realizada em 16 de setembro de 2011. Por meio dessa aquisição, que envolveu mais de R\$510 milhões, o grupo Anhanguera tornou-se o segundo maior grupo educacional do mundo, atrás apenas do Apollo Group ${ }^{242}$; e (ii) a aquisição da Universidade do Norte do Paraná (Unopar) pela Kroton, realizada em 15 de dezembro de 2011, pelo valor de $\mathrm{R} \$ 1,3$ bilhão $^{243}$. A Unopar era líder no segmento de ensino a distância no País. Segundo informações do jornal Valor Econômico, essa operação foi a maior já fechada na história do setor de educação do Brasil. Com essa aquisição, a Kroton passou a ocupar a segunda posição no mercado educacional brasileiro, em 31/12/2011, com 264 mil estudantes $^{244}$.

A título de comparação, verificamos que, na bolsa eletrônica Nasdaq, em 28 de novembro de 2012, havia 27 empresas no setor de serviços educacionais (educational services), dentre elas, o Apollo Group e a DeVry ${ }^{245}$.

\footnotetext{
${ }^{239}$ Disponível em: http://www.abrileducacao.com.br/not_int_16.html. Acesso em: 30/06/2012.

${ }^{240}$ Reportagem de 09/01/2012. Disponível em: http://www.valor.com.br. Acesso em: 30/06/2012.

${ }^{241}$ Informações sobre essa operação encontram-se no Capítulo 4 da Dissertação.

${ }^{242}$ Essa operação é mais bem descrita no Capítulo 4 da Dissertação.

${ }^{243}$ Disponível também em: <http://www.mzcenter.com.br/Arquivos/401383.pdf>. Acesso em: 08/12/2012.

${ }^{244}$ Reportagem de 09/01/2012. Disponível em: http://www.valor.com.br. Acesso em: 30/06/2012.

${ }^{245}$ São elas: (i) Gp Strategies C; (ii) Grand Canyon Ed; (iii) China Distance; (iv) New Oriental Ed; (v) Ambassadors Gro; (vi) Chinaedu Corp.; (vii) Washington Post; (viii) Universal Techn; (ix) Tal Education G; (x) Learning Tree; (xi) Devry Inc.; (xii) American Public; (xiii) Capella Educati; (xiv) Bridgepoint Edu; (xv) Xueda Education; (xvi) K12 Inc.; (xvii) Smartpros Ltd; (xviii) Corinthian Coll; (xix) Ata Inc.; (xx) Ambow Education; (xxi) National Americ; (xxii) Lincoln Educati; (xxiii) Career Educatio; (xxiv) Strayer Educati; (xv) Apollo Group; (xxvi) Itt Educational; (xxvii) Education Manag. Fonte:
} 
Encontramos também empresas do setor de educação listadas em bolsas de valores em outros países em desenvolvimento. Na Índia, existe a empresa NIIT, fundada em 1979, que atua principalmente nas áreas de ensino de informática e formação técnica, produção de softwares educativos, treinamento e consultoria de software para empresas (TOOLEY, 2001, p. 54-5). Segundo Tooley (2001, p. 54-5), essa empresa possuía em 1999 um market share de 37\%, lucros de US\$ 13 milhões, 500.000 alunos, 400 centros na Índia e atuação fora do país. Segundo Tooley (2001, p. 55), a expansão dessa empresa intensificou-se em 1993, com a abertura de seu capital na Bolsa de Valores de Bombaim e Délhi.

$\mathrm{Na}$ África do Sul existe a Education Investment Corporation Limited (Educor), que era, em 2001, segundo Tooley (2001, p. 57), o maior grupo privado de educação do sul da África, com 300.000 estudantes, mais de 40 campi, atuação na educação a distância e lucros de US\$ 6 milhões em 1997. A Educor atua na educação básica de adultos, formação profissional, ensino superior e pós-graduação ${ }^{246}$. Em 1996, A Educor listou-se na Bolsa de Valores de Johannesburg.

\subsubsection{Outros investimentos no setor de educação: o financiamento} estudantil privado

No setor de educação, além do investimento em empresas que oferecem educação, encontram-se também fundos que investem em crédito universitário. Um exemplo é a atuação da Ideal Invest, gestora independente de programas de crédito universitário privado realizados por meio de dois Fundos de Investimento em Direitos Creditórios (FIDCs): (i) Ideal Educação FIDC; e (ii) Crédito Universitário FIDC (REVISTA CAPITAL ABERTO, 2009, p. 21).

São acionistas da Ideal Invest, dentre outros: (i) a IFC; (ii) o Banco Itaú Unibanco $^{247}$; (iii) um fundo gerido pela Gávea Investimentos; (iv) o Pragma Patrimônio ${ }^{248}$;

\footnotetext{
$<$ http://www.nasdaq.com/reference/BarChartSectors.stm?page $=$ sectors\&sec $=$ sic8200. sec\&level $=2 \&$ title $=$ SIC $\% 2 \mathrm{~d} 8200+$ Services $\% 2 \mathrm{dEducational+Services}>$. Acesso em: 28/11/2012.

${ }^{246}$ O grupo Educor compreendia, em 1997, o Damelin Education Group ${ }^{246}$, Midrand Campus, Eden College, Graduate Institute of Management and Technology, Intec, Charter Group, e duas divisões de recrutamento e colocação profissional - Renwick Group e a PAG Placements (TOOLEY, 2001, p. 58). A Damelin Education Group é uma das principais empresas do grupo. Ela atua no ensino a distância, tendo iniciado suas atividades nesse ramo em 1955, com uma instituição que oferecia ensino por correspondência para professores da área rural que não tinham diploma de ensino superior (TOOLEY, 2001, p. 57).

247 Disponível em: <http://exame.abril.com.br/negocios/noticias/itau-compra-participacao-na-ideal-invest>. Acesso em: 26/03/2012.

${ }^{248}$ Companhia de participações criada pelos fundadores da Natura.
} 
e (v) um fundo gerido pela EOS Investimentos ${ }^{249}$.

O Ideal Educação FIDC atende às IES. Criado em 2004 e com um patrimônio de R\$ 65 milhões em 2009, esse fundo adianta o recebimento de mensalidades a taxas de desconto variadas conforme o volume, o prazo e as garantias da operação (entre Selic + $3 \%$ e Selic $+20 \%$ ao ano). Segundo a Revista Capital Aberto (2009, p. 22), esse Fundo, até maio de 2009, já havia investido mais de R \$ 300 milhões no setor e, com esse recurso, as IES haviam construído novos campi e quitado dívidas.

O Crédito Universitário FIDC, criado em janeiro de 2007, aplica seus recursos em direitos decorrentes de contratos de Crédito Direto ao Consumidor (CDC) celebrados em razão da prestação de serviços educacionais - um banco empresta ao estudante os recursos necessários para custear os estudos e, em seguida, passa ao fundo os seus direitos creditórios. Com isso, o fundo assume a condição de credor do estudante. Segundo informações da empresa ${ }^{250}$, os bancos envolvidos nesse projeto são Banco ABC Brasil S.A. e Banco Paulista S.A. O nome comercial do projeto é crédito universitário Pravaler.

O crédito universitário Pravaler, em 26 de março de 2012, era o maior programa de financiamento estudantil privado do País. Trata-se de alternativa ao Fies, que permite o financiamento de mensalidades da graduação, pós-graduação (especialização, mestrado, doutorado, MBA) e cursos técnicos, presenciais ou a distância em instituições de ensino parceiras.

O crédito universitário Pravaler é parceiro de mais de 260 instituições de ensino, atendendo mais de 12.500 cursos em todo o País, exceto nos estados de Rondônia, Tocantis, Piauí e Paraíba ${ }^{251}$. Até agosto de 2011, 17 mil universitários brasileiros haviam sido beneficiados por esse financiamento. Desde 2006, R\$ 590 milhões haviam sido repassados às instituições ${ }^{252}$. A Anhanguera é uma das parceiras do Pravaler.

O Pravaler funciona da seguinte maneira: cada mensalidade do curso é dividida em duas parcelas de financiamento, com a incidência de juros. Assim, um semestre é pago em um ano, e o estudante pode parcelar o valor total do curso tendo o dobro de tempo para pagá-1o ${ }^{253}$. Os juros do financiamento variam de $0 \%$ a $1,99 \%$ ao mês, dependendo da faculdade e do curso. Alunos da graduação que possuem mensalidades atrasadas na

\footnotetext{
${ }^{249}$ Disponível em: <http://www.creditouniversitario.com.br/quem-somos/>. Acesso em 26/03/2012.

${ }^{250}$ Disponível em: < http://www.creditouniversitario.com.br/quem-somos/>. Acesso em 26/03/2012.

${ }^{251}$ Disponível em: < http://www.creditouniversitario.com.br/quem-somos/>. Acesso em 26/03/2012.

252 Disponível em: <http://www.creditouniversitario.com.br/noticia/30.09.2011---Ideal-Invest-pretendefinanciar-20-mil-universitarios $>$. Acesso em 26/03/2012.

${ }_{253}$ Disponível em: <http://www.creditouniversitario.com.br/conheca-mais/pravaler/>. Acesso em 26/03/2012.
} 
faculdade também podem parcelar seu débito com o Pravaler - neste caso, os juros variam de $1,99 \%$ a $3,49 \%$ ao mês.

Considerando essas características, nota-se que esse financiamento funciona segundo o mesmo raciocínio dos financiamentos para as demais mercadorias presentes em nosso mercado - compra-se um produto e paga-se num prazo maior com a incidência de juros. Esse intuito é inclusive reconhecido pela empresa na seguinte declaração: “o número de faculdades que ofertam essa vantagem aos alunos só tem aumentado. Isso porque os próprios estudantes percebem que, além de financiarem a casa, o carro e a geladeira, é possível fazer o mesmo com a educação. Por que haveria de ser diferente ${ }^{254}$ ?".

Segundo informações da empresa, o Pravaler apresenta as seguintes características que o fazem suprir uma lacuna não preenchida pelo Fies e pelo ProUni: (i) não exige que o aluno tenha cursado o ensino médio em escola pública ou em escola privada na qualidade de bolsista integral; (ii) não exige que o aluno tenha feito o Enem; (iii) não há número de vagas limitado; (iv) pode ser solicitado o ano todo; e (v) a resposta sobre a pré-aprovação do crédito é rápida - três dias úteis ${ }^{255}$.

São requisitos para solicitar o financiamento: (i) ter um garantidor com renda de, pelo menos, um salário mínimo; (ii) não ter restrições de crédito no SPC, Serasa e estar com o CPF regular, tanto o estudante quanto o garantidor; (iii) não financiar ao mesmo tempo graduação e pós-graduação; (iv) comprovar renda mínima de duas vezes o valor da mensalidade (a renda mínima pode ser composta pela renda do garantidor mais a do estudante $)^{256}$.

Segundo dados da empresa, a renda média geral dos alunos recém-formados com o apoio do Pravaler aumenta 51\% após a conclusão do curso; 77\% dos alunos saem da faculdade empregados; e 56\% empregados e trabalhando na área de atuação ${ }^{257}$. Além disso, segundo informações da empresa, 64\% dos alunos que contratam o Pravaler trabalham e possuem renda média mensal de $\mathrm{R} \$ 1.050,00^{258}$.

Abaixo um quadro comparativo entre o Fies, o ProUni e o Pravaler:

\footnotetext{
254 Declaração de Carlos Furlan, diretor executivo do Pravaler. Disponível em: $<$ http://www.creditouniversitario.com.br/noticia/18.11.2011---Credito-facilita-acesso-ao-ensinosuperior>.Acesso em 26/03/2012.

${ }^{255}$ Disponível em: <http://www.creditouniversitario.com.br/como-contratar/>. Acesso em 26/03/2012.

${ }^{256}$ Disponível em: <http://www.creditouniversitario.com.br/como-contratar/>. Acesso em 26/03/2012.

${ }^{257}$ Disponível em: <http://www.creditouniversitario.com.br/como-contratar/>. Acesso em 26/03/2012.

${ }^{258}$ Disponível em: <http://www.creditouniversitario.com.br/como-contratar/>. Acesso em 26/03/2012.
} 


\section{Quadro 3 - Comparativo entre Fies, ProUni e Pravaler}

\begin{tabular}{|c|c|c|c|}
\hline & Fies & ProUni & Pravaler \\
\hline Ano de criação & 1999 & 2004 & 2006 \\
\hline $\begin{array}{c}\text { Setor } \\
\text { responsável }\end{array}$ & $\begin{array}{l}\text { Público. Parceria entre o } \\
\text { Governo Federal e a Caixa } \\
\text { Econômica Federal }\end{array}$ & $\begin{array}{l}\text { Público. Política } \\
\text { Governo Federal. }\end{array}$ & $\begin{array}{l}\text { Privado. Gerido pela } \\
\text { Ideal Invest. }\end{array}$ \\
\hline Objetivo & $\begin{array}{l}\text { Fornecer financiamento } \\
\text { estudantil a estudantes da } \\
\text { rede privada, para } \\
\text { pagamento de } 50 \% \text { a } 100 \% \\
\text { do curso, em IES em nível } \\
\text { de graduação, mestrado, } \\
\text { doutorado ou de cursos de } \\
\text { educação profissional e } \\
\text { tecnológica, com avaliação } \\
\text { positiva. }\end{array}$ & $\begin{array}{l}\text { Concessão de isenção de } \\
\text { um grupo de impostos às } \\
\text { IES em contrapartida à } \\
\text { concessão de bolsas de } \\
\text { estudo parciais e integrais. } \\
\text { O programa integra-se ao } \\
\text { Fies no caso das bolsas } \\
\text { parciais. }\end{array}$ & $\begin{array}{l}\text { Fornecer } \\
\text { financiamento privado } \\
\text { aos estudantes da rede } \\
\text { privada. }\end{array}$ \\
\hline $\begin{array}{c}\text { IES } \\
\text { Beneficiárias/ } \\
\text { Parceiras e } \\
\text { Cursos }\end{array}$ & $\begin{array}{l}\text { Podem participar do } \\
\text { programa apenas cursos com } \\
\text { conceito maior ou igual a } 3 \\
\text { no Sinaes. } \\
\text { É vedada a concessão de } \\
\text { financiamento a cursos } \\
\text { superiores ministrados na } \\
\text { modalidade a distância. }\end{array}$ & $\begin{array}{l}\text { Podem participar } \\
\text { programa } \\
\text { assinstituições } \\
\text { adesão, o termo de } \\
\text { compromisso de fornecer } \\
\text { um número mínimo de } \\
\text { bolsas. } \\
\text { O MEC desvinculará do } \\
\text { ProUni com } \\
\text { considerados insuficientes } \\
\text { segundo critérios de } \\
\text { desempennho do SINAES, } \\
\text { por duas avaliações } \\
\text { consecutivas. }\end{array}$ & $\begin{array}{l}\text { Participam } \\
\text { parceiras. }\end{array}$ \\
\hline
\end{tabular}




\section{Quadro 3 - Comparativo entre Fies, ProUni e Pravaler}

\begin{tabular}{|c|c|c|c|}
\hline & Fies & ProUni & Pravaler \\
\hline $\begin{array}{c}\text { Estudantes } \\
\text { beneficiários }\end{array}$ & $\begin{array}{l}\text { Estão excluídos do programa } \\
\text { estudantes (i) cuja matrícula } \\
\text { acadêmica esteja em situação } \\
\text { de trancamento geral de } \\
\text { disciplinas no momento da } \\
\text { inscrição; (ii) que já tenham } \\
\text { sido beneficiados com outro } \\
\text { financiamento do Fies; (iii) } \\
\text { inadimplentes com o } \\
\text { Programa de Crédito } \\
\text { Educativo (PCE/Creduc); } \\
\text { (iv) cujo percentual de } \\
\text { comprometimento da renda } \\
\text { familiar mensal bruta per } \\
\text { capita seja inferior a 20\%; } \\
\text { (v) cuja renda familiar } \\
\text { mensal bruta seja superior a } \\
20 \text { salários mínimos. } \\
\text { Exige a participação do } \\
\text { beneficiário no Enem. }\end{array}$ & $\begin{array}{l}\text { Destinado a estudantes } \\
\text { provenientes de famílias } \\
\text { de baixa renda (renda } \\
\text { família mensal per capita } \\
\text { de até } 3 \text { salários mínimos), } \\
\text { que cursaram o ensino } \\
\text { médio completo em escola } \\
\text { da rede pública ou em } \\
\text { instituições privadas na } \\
\text { qualidade de bolsitas } \\
\text { integrais, portadores de } \\
\text { deficiênia e professores da } \\
\text { rede pública para os cursos } \\
\text { de licenciatura, normal } \\
\text { superior e pedagogia, } \\
\text { destinados à formação do } \\
\text { magistério da educação } \\
\text { básica, independentemente } \\
\text { da renda. en } \\
\text { A seleção dos bolsistas } \\
\text { leva em conta os } \\
\text { resultados e perfis } \\
\text { socioeconômicos do Enem } \\
\text { e também parâmetros de } \\
\text { política afirmativa de } \\
\text { acesso aos portadores de } \\
\text { deficiência } \\
\text { autodeclarados "negros" e } \\
\text { "indígenas". } \\
\text { Exige a participação do } \\
\text { beneficiário no Enem. }\end{array}$ & $\begin{array}{l}\text { Destinado a qualquer } \\
\text { interessado que } \\
\text { apresentar as garantias } \\
\text { econômicas exigidas. } \\
\text { Não exige a } \\
\text { participação do } \\
\text { beneficiário no Enem. }\end{array}$ \\
\hline Abrangência & $\begin{array}{l}\text { Entre os anos de } 2010 \text { e } \\
2012 \text { beneficiou cerca de } \\
535 \text { mil estudantes. }\end{array}$ & $\begin{array}{l}\text { Desde sua criação até } 2010 \\
\text { beneficiou cerca de } 863 \\
\text { mil estudantes, dos quais } \\
67 \% \text { com bolsas integrais } \\
\text { (INEP, 2012b). }\end{array}$ & $\begin{array}{l}\text { Desde sua criação até } \\
2011 \text { beneficiou cerca } \\
\text { de } 17 \text { mil estudantes }\end{array}$ \\
\hline
\end{tabular}

Fonte: Lei $\mathrm{n}^{\mathrm{o}}$ 10.260, de 12/07/2001; Lei $\mathrm{n}^{\circ} 11.096$, de 13/01/2005 e site

http://www.creditouniversitario.com.br

259 Disponível em: <http://www.creditouniversitario.com.br/blog/2012/07/31/pravaler-mostra-como-chegara-faculdade-na-6a-feira-guia-do-estudante/> . Acesso em 26/03/2012. 


\subsection{Análise do setor do ensino superior privado do Brasil}

\subsubsection{Principais atores e segmentos de mercado}

De acordo com Maurício Garcia ${ }^{260}$ (2005), a atuação das instituições de ensino superior privadas nos últimos anos pode ser dividida em quatro segmentos de mercado ${ }^{261}$, considerando o preço das mensalidades, a quantidade de alunos e o tipo de cursos oferecidos $^{262}$ :

(i) instituições de elite - neste segmento encontram-se instituições de nicho, que oferecem cursos em torno de uma mesma área e buscam excelência de ensino (GARCIA, 2005, p. 42). Podem ser incluídas nessa categoria, conforme Sécca e Leal (2009, p. 124), Ibmec, FGV e $\operatorname{ESPM}^{263}$, que são instituições com poucos cursos de graduação, com grande reputação e boas avaliações pelo MEC.

Nessas instituições, os alunos são predominantemente das classes mais altas (A e

\footnotetext{
${ }^{260}$ Quando da publicação deste artigo, Mauricio Garcia era Vice-Reitor da Universidade Anhembi Morumbi. Disponível em: <http://www.mgar.com.br/mgPdf/2005_03_EnsSuperior.pdf >. Acesso em: 27/07/2012.

${ }^{261}$ Tooley (2001, p. 104-105) agrupou as instituições de ensino privadas em três grupos: (i) instituições que cobram mensalidades muito baixas, voltadas para a população rural e urbana, com um ensino de qualidade variável, alta proporção de alunos por professor (mais de 90 alunos por professores). Essas instituições podem ser administradas por grupos de caridade ou religiosos; (ii) instituições patrocinadas pela classe média, incluindo grupos reliogiosos sem fins lucrativos e grupos com fins lucrativos; (iii) instituições privadas de elite, com mensalidades em valor elevado, as quais podem oferecer bolsas de estudos para alunos carentes ou em situação financeira ruim durante o período de estudo. Com relação ao ensino superior, Tooley (2001, p. 105) destaca a presença de cursos voltados para o público de renda baixa ou média, que fazem sacrifícios para manter os filhos em cursos profissionalizantes, que proporcionam um retorno rápido. Há também cursos mais acadêmicos, estes voltados para para a classe média e alta. Tooley (2001, p. 105) destaca como um caso interessante o das universidades brasileiras como a Unip, que possuem um perfil que não é de elite e que são mais procuradas pelos grupos de renda mais baixa do que as prestigiadas universidades públicas brasileiras.

${ }^{262}$ Partindo da análise de Garcia (2005), Sécca e Leal (2009) também colocam as avaliações de qualidade feitas pelo MEC e os conceitos obtidos no IGC como forma de diferenciar as instituições das quatro categorias criadas por Garcia (2005). Na linha de Garcia (2005), Sampaio (2000, p. 25) afirma que: "as instituições privadas também se distinguem em função de aspectos referentes à organização acadêmica e aos serviços educacionais que prestam - - escopo dos cursos de graduação e sua vinculação às diferentes áreas de conhecimento, relação candidato/vaga em cursos para uma mesma formação, existência de pesquisa e pósgraduação, titulação do corpo docente, entre outros. Essas variáveis, em geral, mostram o contraste de qualidade que existe entre o setor público e o privado de ensino superior no País, ressalvando, do último, algumas universidades católicas".

${ }^{263}$ Tratando da ESPM, o Jornal Valor Econômico, em reportagem de 02/12/2011 afirmou: "com a onda de consolidação no setor de ensino, a ESPM também quer se posicionar como consolidadora. '"Não haverá espaço para pequenos nessa área de educação. Por isso, pensamos em incorporar outras faculdades'", disse Penteado. "Mas isso não quer dizer que seremos tão grandes como Unip, Anhanguera ou Estácio. Somos uma faculdade de nicho"', complementou o publicitário. A mensalidade média é de R\$ 2 mil em seus cinco cursos: publicidade e propaganda, administração, design, jornalismo e relações internacionais".
} 
B), capazes de pagar mensalidades com valores mais altos ${ }^{264}$. São estudantes que normalmente ingressam na universidade com a idade correspondente ao nível de ensino e que possuem uma boa formação do ensino médio, geralmente em escola particular. Normalmente, são alunos que se dedicam aos estudos até iniciarem estágio em sua área de atuação (SÉCCA; LEAL, 2009, p. 125).

(ii) quadrante dos sonhos - ocupado por instituições de grande tradição ou sem concorrência acirrada com outras instituições. É um segmento difícil de ser alcançado, segundo Garcia (2005, p. 42).

Para Sécca e Leal (2009, p. 125), são exemplos de instituições desse segmento: as Pontifícias Universidades Católicas (PUCs), que são instituições tradicionais, com cursos de reconhecida qualidade e bem avaliados pelo MEC. Diferentemente das "instituições de elite", as instituições do "quadrante dos sonhos" atuam com escala e oferecem cursos de graduação nas mais diversas áreas. Segundo Sécca e Leal (2009, p. 125), o perfil do aluno desse segmento costuma ser o mesmo daquele das "instituições de elite".

(iii) instituições de massa - ocupam este segmento as instituições de ensino superior que oferecem cursos populares, por meio de grandes redes de ensino, com instalações multicampi e ganhos de escala.

Para Sécca e Leal (2009, p. 124), são exemplo de instituições desse segmento: Universidade Paulista (Unip), Universidade Estácio de Sá (Unesa), Universidade Nove de Julho (Uninove) e a Anhanguera.

As "instituições de massa" caracterizam-se por mensalidades mais baixas e um número de alunos muito grande. Segundo Sécca e Leal (2009, p. 125), “normalmente, elas não têm como meta formar as elites do País, mas, sim prover qualificação para o mercado de trabalho e atender às expectativas de ascensão profissional e social de seus alunos". Essas instituições têm uma variedade grande de cursos e adaptam seu portfólio à demanda dos alunos. Foram pioneiras na criação de cursos que não existiam em instituições públicas, como gastronomia, turismo e moda e também investiram na graduação tecnológica e em cursos de curta duração que oferecem diploma de nível superior (SÉCCA; LEAL, 2009, p. 125).

\footnotetext{
${ }^{264}$ Com base em estudos da Gismarket Estudo de Mercado Ltda., a Anhanguera destaca que "jovens entre 18 e 24 anos pertencentes às classes média-alta e alta, estimados em 5,9 milhões de habitantes, são atendidos principalmente por instituições públicas e privadas de elite e são tradicionalmente alunos de período integral. Já os jovens da mesma faixa etária, pertencentes às classes sociais mais baixas, estimados em 20,4 milhões de habitantes, em sua maioria trabalhadores e com foco na colocação e ascensão profissional/salarial, a partir de 1996 passaram a ser servidos por instituições privadas” (ANHANGUERA, 2012d, p. 118).
} 
Segundo Sécca e Leal (2009, p. 126), o perfil do aluno das instituições de massa é o jovem trabalhador, que estuda à noite e tem uma idade média superior à do aluno das "instituições de elite" e do "quadrante dos sonhos, pertence, principalmente, à classe C, com alunos das classes B e D também. Este aluno mora em grandes centros urbanos e busca uma formação voltada para o mercado de trabalho (SÉCCA; LEAL, 2009, p. 126). Este é o perfil do aluno da Anhanguera, como será desenvolvido no Capítulo 4 da Dissertação.

(iv) quadrante do pesadelo - ocupam este segmento instituições com poucos alunos e mensalidades com valor baixo. Segundo Garcia (2005, p. 42), este é o "pior lugar para posicionar uma instituição", pois "não há escala para otimizar os custos e o valor recebido é muito baixo".

Segundo Sécca e Leal (2009, p. 124), estão nesse segmento as instituições de ensino superior pequenas espalhadas pelo País. Para Sécca e Leal (2009, p. 126), o perfil dos alunos desse segmento é semelhante ao das instituições de massa, porém as mensalidades podem ser mais baratas e avançar mais no mercado da classe D. Conforme Sécca e Leal (2009, p. 126), essas instituições são numerosas no interior do País, algumas localizadas em cidades que têm poucas opções de ensino superior. Estão presentes também nos grandes centros urbanos, locais em que enfrentam a difícil competição com as “instituições de massa”, que têm marca e economia de escala.

Muitas dessas instituições estão sendo adquiridas pelas grandes do mercado, como a Anhanguera.

Conforme Sécca e Leal (2009, p. 123), o grande crescimento recente se deu no quadrante das instituições de massa e no "quadrante do pesadelo".

Sobre essa diferenciação entre as instituições de ensino superior brasileiro, Sampaio (2000, p. 110) afirma:

[...] instaurou uma diferenciação e hierarquização entre os estabelecimentos que compõem o sistema; nesse processo, algumas universidades públicas e poucas instituições católicas ou laicas de elite situam-se no topo, porque conseguiram preservar-se dos efeitos da massificação, ao passo que os demais estabelecimentos que se instalaram voltaram-se ao atendimento da demanda de massa.

Segundo reportagem da Folha de São Paulo de junho de 2010, a "concorrência acirrada e a estagnação na entrada de novos alunos derrubaram as mensalidades das universidades particulares ao menor nível em dez anos”. Segundo a mesma reportagem, “de 1999 a 2009, o valor nominal médio caiu 31\% de R\$532 para R \$367” em todo o País. 
De acordo com a Folha de São Paulo, "as instituições que oferecem preços mais baixos são em geral as menores, que investem menos em pesquisa, professores e instalações"265. Para Edson Almeida (2009), nos próximos anos, o mercado do setor do ensino superior privado adotará uma estrutura semelhante ao de uma pirâmide:

No topo, estarão as escolas de nicho, destinadas às classes A e B, como FGV, Ibmec e ESPM. A seguir virão as escolas premium, de grande escala e variedade de cursos, como FAAP, Mackenzie, PUC, Facamp. Abaixo estarão universidades e centros universitários de porte, como Anhembi Morumbi, Unip, seguidos pelas instituições multicampi, com boa localização e mensalidades na faixa de 300 a 400 reais, como é o caso da Anhanguera e Estácio de Sá.

\subsubsection{Possíveis razões para o crescimento do setor do ensino superior privado no Brasil nas últimas duas décadas}

Com base na análise de Sécca e Leal (2009) e na descrição constante neste Capítulo, são hipóteses de fatores condicionantes para o aumento da demanda por ensino superior no Brasil e o consequente crescimento do setor privado ${ }^{266}$ :

(i) o fato de o Brasil possuir uma população jovem - em 2009, 32,8\% do total da população brasileira era composta de crianças e adolescentes até 19 anos de idade, a qual ainda apresenta um baixo acesso ao ensino superior (IBGE, 2010);

(ii) exigências do mercado de trabalho - segundo Sécca e Leal (2009, p. 7), “com o aumento do desemprego nos anos 1990, no Brasil, e a maior inserção do País no mercado global, tendo suas empresas expostas à competição mundial, tornaram-se cada vez mais importantes a qualificação profissional e o ensino voltado para atender as demandas mais imediatas de mão de obra do mercado”. Nesse período, houve um crescimento dos setores intensivos, maior automatização de atividades operacionais e uma intensificação das relações comerciais globais (SÉCCA; LEAL, 2009, p. 7). Com isso, houve um aumento de requisitos de qualificação para os trabalhadores, e a população, especialmente os jovens, partiu em busca dessa qualificação, em cursos técnicos e também no ensino superior. A esse respeito, a Anhanguera (2012d, p. 118) afirma:

$<$ http://www1.folha.uol.com.br/fsp/cotidian/ff2106201001.htmhttp://www1.folha.uol.com.br/fsp/cotidian/ff2 106201001.htm>. Acesso em: 25/09/2012.

${ }^{266}$ Por meio de entrevistas com representantes do governo, agências internacionais e o empresários da educação, Tooley (2001, p. 122), levantou seis fatores que influenciam investimentos no setor privado de educação em doze 12 países, dentre eles o Brasil: (i) o tamanho do mercado potencial e a maturidade do mercado de ensino privado existente; (ii) o ambiente regulatório; (iii) o clima de investimento; (iv) a disponibilidade de recursos; (v) possibilidades de financiamento estudantil; e (vi) tamanho e maturidade do mercado de ensino privado. 
[...] a população de classes média e baixa, que historicamente não tinha acesso ao ensino superior, foi a maior responsável pelo aumento no número de alunos matriculados, sendo representados, na sua maioria, por adultos trabalhadores em busca de melhores salários e oportunidades de emprego. [...]

A perspectiva de ascensão profissional e o aumento salarial significativo para os trabalhadores com diploma superior são dois fatores centrais associados à expansão do setor de ensino superior brasileiro.

(iii) o crescimento do ensino médio no Brasil - considerando que o ensino superior é a continuidade natural dos estudos para os concluintes do ensino médio, conforme aumenta o número de concluintes do ensino médio, aumenta o número de estudantes que ingressam no ensino superior. Dados a esse respeito, encontram-se no item 2.6 abaixo.

(iv) maior disponibilidade de financiamento estudantil e bolsas de estudo nesse contexto, incluem-se o Fies, o ProUni e os financiamentos privados, entre eles o Pravaler, que permitiram o acesso ao ensino superior a populações de menor renda.

(v) desregulamentação - a promulgação da LDB de 1996 incentivou o crescimento do setor privado porque, dentre outras medidas, permitiu a flexibilização do setor com a quebra do modelo universitário e criação de novas formas de organização acadêmica como os centros universitários dotados de autonomia universitária sem a obrigação de indissociabilidade entre ensino, pesquisa e extensão; com a autorização de substituição do vestibular por outros tipos de processos seletivos; e com o fim da obrigatoriedade dos currículos mínimos. Ademais, a autorização para que as mantenedoras de instituições de ensino superior passassem a adotar a forma de entidades com fins lucrativos presente nos Decretos $n^{\circ}$ s 2.207/97 e 2.306/97 também estimulou o setor privado.

Em linhas com as conclusões acima, a Anhanguera (2012d, p. 119) acredita que o número de matrículas em instituições de ensino superior continue a crescer nos próximos anos, por conta: (i) da perspectiva de ascensão profissional; (ii) do aumento significativo na renda individual daqueles que detêm um diploma de ensino superior; (iii) da demanda substancial por trabalhadores qualificados não atendida e em expansão; e (iv) da crescente disponibilidade de alternativas educacionais para a população de classes média e baixa ${ }^{267}$, em função do apoio contínuo do Governo Federal ao ensino superior privado e,

${ }^{267}$ Classes média e baixa que correspondem às classes sociais B, C, D e E conforme classificação feita pelo IBGE para as classes sociais brasileiras, de acordo com a renda familiar, correspondendo ao seguinte: (i) Classe B: acima de 5 até 15 salários mínimos; (ii) Classe C: acima de 3 até 5 salários Mínimos; (iii) Classe D: acima de 1 até 3 salários Mínimos; e (iv) Classe E: até 1 salário Mínimo (ANHANGUERA, 2012d, p. 24). 
especificamente, do investimento privado no ensino superior ${ }^{268}$.

\subsection{Dados empíricos sobre o ensino superior no período 1990-2010}

\subsubsection{Panorama Geral}

Considerando a atuação dos setores público e privado nos diferentes níveis do ensino brasileiro, nas últimas duas décadas, temos como resultado:

(i) a quase universalização do ensino fundamental, com apenas 2,3\% das crianças entre 7 e 14 anos fora da escola, em 2008 (INEP, 2009) ${ }^{269}$;

(ii) a redução das taxas de analfabetismo - para a população de 15 a 24 anos de idade, em 1997, a taxa de analfabetismo era de 12\%, e em 2007 passou para 5,3\% (IBGE, 2008, p. 44);

(iii) taxa de analfabetismo funcional de $27 \%$ em 2011-2012, para a população de 15 a $64 \operatorname{anos}^{270}$, e $62 \%$ das pessoas com ensino superior e $35 \%$ das pessoas com ensino médio completo consideradas plenamente alfabetizadas ${ }^{271}$;

(iv) o crescimento do ensino médio, passando de 3.772 .689 matrículas, em 1991, para 8.400.689, em 2011 (INEP, 2012a);

(v) o crescimento do ensino superior, passando de 1.540 .080 matrículas, em 1990, para 6.379.299, em 2010, e de 918 instituições, em 1990, para 2.378, em 2010 (INEP, 2012b);

(vi) o crescimento da educação profissional, que, em 2011, alcançou aproximadamente 1 milhão de matrículas na educação profissional concomitante e

\footnotetext{
268 Para a Anhanguera (2012d, p. 118): “O aumento das alternativas de financiamento aos alunos e o crescimento do número de instituições e cursos de educação superior destinados à população de classes média e baixa podem ser vistos como oportunidades para o crescimento do número de matrículas do ensino superior no Brasil, além de criar incentivos fiscais e financeiros para as instituições de ensino que tenham alunos matriculados nos programas do governo. A diminuição do valor médio das mensalidades, atualmente em torno de R $\$ 500,00$, segundo dados da Hoper Consultoria, Pesquisa e Editora Ltda., foi um dos principais fatores para o crescimento do setor de ensino superior privado, possibilitando a entrada no mercado de alunos das classes média e baixa".

${ }^{269}$ Este dado do Inep não trata da educação infantil. Pesquisa efetuada pela ONG "Todos pela Educação" apurou que, em 2010,8,5\% da população entre 4 e 17 anos encontrava-se fora da escola, o que representa 3,8 milhões de crianças e jovens nessa faixa etária. Disponível em: $<$ http:/www.todospelaeducacao.org.br/comunicacao-e-midia/educacao-na-midia/21377/brasil-tem-38milhoes-de-criancas-e-jovens-fora-da-escola/>. Acesso em: 25/07/2012.

270 Esclarecimentos sobre este assunto no Capítulo 1 da Dissertação. Fonte: $<271$ http:/www.ipm.org.br/ipmb_pagina.php?mpg=4.03.00.00.00\&ver=por>. Acesso em 17/07/2012. $\begin{array}{lcccc}271 & \text { Conforme dados do } & \text { Inaf } & 2011-2012 . & \text { Disponível } \\ <\text { http://www.ipm.org.br/ipmb_pagina.php?mpg=4.03.00.00.00\&ver=por }>\text {. Acesso em 17/07/2012. }\end{array}$
} 
subsequente ao ensino médio e 1,3 milhões de alunos na educação profissional com ensino médio integral, com uma forte expansão da rede federal, que nos últimos 9 anos apresentou um crescimento de $143 \%$ no número de matrículas (INEP, 2012a);

(vii) a atuação preponderante do setor público na educação básica, responsável por $84,5 \%$ das matrículas, em 2011 (INEP, 2012a); e

(viii) a atuação preponderante do setor privado no ensino superior, responsável por 74,24\% das matrículas e 88,30\% das instituições, em 2010 (INEP, 2012b).

\subsubsection{Instituições, matrículas e cursos}

Entre os anos de 1990 e 2010, o número de instituições e matrículas por categoria administrativa (público e privado) no ensino superior brasileiro evoluiu da seguinte maneira:

Tabela 3 - Evolução do número de instituições e matrículas, segundo a categoria administrativa - Brasil - 1990 a 2010

(continua)

\begin{tabular}{c|c|c|c|c|c|c|c|c|c|c}
\hline & \multicolumn{9}{|c}{ Instituições } & \multicolumn{5}{c}{ Número de matrículas } \\
\hline Ano & Total & Público & $\begin{array}{c}\text { \% } \\
\text { Público }\end{array}$ & Privado & $\begin{array}{c}\text { \% } \\
\text { Privado }\end{array}$ & Total & Público & $\begin{array}{c}\text { \% } \\
\text { Público }\end{array}$ & Privado & $\begin{array}{c}\text { \% } \\
\text { Privado }\end{array}$ \\
\hline 1990 & 918 & 222 & 24,18 & 696 & 75,82 & 1.540 .080 & 578.625 & 37,57 & 961.455 & 62,43 \\
1991 & 893 & 222 & 24,86 & 671 & 75,14 & 1.565 .056 & 605.736 & 38,70 & 959.320 & 61,30 \\
1992 & 893 & 227 & 25,42 & 666 & 74,58 & 1.535 .788 & 629.662 & 41,00 & 906.126 & 59,00 \\
1993 & 873 & 221 & 25,32 & 652 & 74,68 & 1.594 .668 & 653.516 & 40,98 & 941.152 & 59,02 \\
1994 & 851 & 218 & 25,62 & 633 & 74,38 & 1.661 .034 & 690.450 & 41,57 & 970.584 & 58,43 \\
1995 & 894 & 210 & 23,49 & 684 & 76,51 & 1.759 .703 & 700.540 & 39,81 & 1.059 .163 & 60,19 \\
1996 & 922 & 211 & 22,89 & 711 & 77,11 & 1.868 .529 & 735.427 & 39,36 & 1.133 .102 & 60,64 \\
1997 & 900 & 211 & 23,44 & 689 & 76,56 & 1.945 .615 & 759.182 & 39,02 & 1.186 .433 & 60,98 \\
1998 & 973 & 209 & 21,48 & 764 & 78,52 & 2.125 .958 & 804.729 & 37,85 & 1.321 .229 & 62,15 \\
1999 & 1.097 & 192 & 17,50 & 905 & 82,49 & 2.369 .945 & 832.022 & 35,11 & 1.537 .923 & 64,89 \\
2000 & 1.180 & 176 & 14,92 & 1.004 & 85,08 & 2.694 .245 & 887.026 & 32,92 & 1.807 .219 & 67,08 \\
2001 & 1.391 & 183 & 13,16 & 1.208 & 86,84 & 3.030 .754 & 939.225 & 30,99 & 2.091 .529 & 69,01 \\
2002 & 1.637 & 195 & 11,91 & 1.442 & 88,09 & 3.479 .913 & 1.051 .655 & 30,22 & 2.428 .258 & 69,78 \\
2003 & 1.859 & 207 & 11,14 & 1.652 & 88,86 & 3.887 .022 & 1.136 .370 & 29,23 & 2.750 .652 & 70,77 \\
2004 & 2.013 & 224 & 11,13 & 1.789 & 88,87 & 4.163 .733 & 1.178 .328 & 28,30 & 2.985 .405 & 71,70 \\
2005 & 2.165 & 231 & 10.67 & 1.934 & 89,33 & 4.453 .156 & 1.192 .189 & 26,77 & 3.260 .967 & 73,23 \\
2006 & 2.270 & 248 & 10,93 & 2.022 & 89,07 & 4.676 .646 & 1.209 .304 & 25,86 & 3.467 .342 & 74,14
\end{tabular}


Tabela 3 - Evolução do número de instituições e matrículas, segundo a categoria administrativa - Brasil - 1990 a 2010

\begin{tabular}{c|c|c|c|c|c|c|c|c|cc}
\hline & \multicolumn{9}{|c|}{ Instituiç̃os } & \multicolumn{5}{c}{ Número de matrículas } \\
\hline Ano & Total & Público & $\begin{array}{c}\text { \% } \\
\text { Público }\end{array}$ & Privado & $\begin{array}{c}\text { \% } \\
\text { Privado }\end{array}$ & Total & Público & $\begin{array}{c}\text { \% } \\
\text { Público }\end{array}$ & Privado & $\begin{array}{c}\text { \% } \\
\text { Privado }\end{array}$ \\
\hline 2007 & 2.281 & 249 & 10,92 & 2.032 & 89,08 & 4.880 .381 & 1.240 .968 & 25,43 & 3.639 .413 & 74,57 \\
2008 & 2.252 & 236 & 10,48 & 2.016 & 89,52 & 5.080 .056 & 1.273 .965 & 25,08 & 3.806 .091 & 74,92 \\
2009 & 2.314 & 245 & 10,59 & 2.069 & 89,41 & 5.954 .021 & 1.523 .864 & 25,59 & 4.430 .157 & 74,41 \\
2010 & 2.378 & 278 & 11,69 & 2.100 & 88,30 & 6.379 .299 & 1.643 .298 & 25,75 & 4.736 .001 & 74,24 \\
\hline
\end{tabular}

Fonte: MEC/Inep/Sinaes ${ }^{272}$

Tais dados tornaram o Brasil, no ano de 2009, o quinto maior mercado de ensino superior do mundo em número de matrículas, conforme Unesco (2011, p. 180-9):

Tabela 4 - Seis maiores mercados de ensino superior do mundo - 2009

\begin{tabular}{l|c|c}
\hline & País & $\mathbf{N}^{\mathbf{0}}$ de matrículas (em milhões) \\
\hline $\mathbf{1}^{\mathbf{0}}$ & China & 29,296 \\
$\mathbf{2}^{\mathbf{0}}$ & EUA & 19,103 \\
$\mathbf{3}^{\mathbf{o}}$ & Índia & 14,863 \\
$\mathbf{4}^{\mathbf{o}}$ & Rússia & 9,446 \\
$\mathbf{5}^{\mathbf{0}}$ & Brasil & $6,115^{273}$ \\
$\mathbf{6}^{\mathbf{0}}$ & Indonésia & 4,859 \\
\hline
\end{tabular}

Fonte: Unesco (2011)

Pelos dados acima, nota-se que o ensino superior brasileiro comportou-se de maneira diferente antes e depois da LDB (1996):

(i) até o ano de 1996, houve um retrocesso no número de instituições (894 em 1995 ante 918 em 1990), tanto do setor público quanto do setor privado, que permaneceram com uma participação entre $23-25 \%$ para o setor público e $77-75 \%$ para o setor privado. Nesse período houve um crescimento tímido no número de matrículas (1.759.703 em 1995 ante 1.540.080 em 1990), com uma participação que oscilou entre 58$62 \%$ para o setor privado e $42-38 \%$ para o setor público. Este dado aponta para uma possível transformação de estabelecimentos isolados em universidades, incentivados pela previsão de autonomia universitária na Constituição de 1988. Esta informação será

\footnotetext{
272 Dados de 1990 disponíveis em: <http://portal.inep.gov.br/web/censo-da-educacao-superior/evolucao1980-a-2007>. Acesso em 20/06/2009. Informações entre 1991 e 2005 disponíveis em: $<$ http://sinaes.inep.gov.br:8080/sinaes/>. Acesso em 20/06/2009. Os dados relativos aos anos de 2005 e 2010 disponíveis em Inep (2009), Inep (2010) e Inep (2012b).

${ }^{273}$ Note-se que o dado sobre o número de matrículas da Unesco é diferente do dado fornecido pelo Inep, em, aproximadamente $150 \mathrm{mil}$ alunos.
} 
analisada abaixo ${ }^{274}$;

(ii) entre 1996 e 1999 verifica-se um aumento no número de instituições (1.097 em 1999 ante 922 em 1996), com o aumento da participação privada, que alcançou 82,49\% das instituições em 1999 (ante 77,11\% do total em 1996); e um crescimento no número total de matrículas (2.369.945 em 1999 ante 1.868 .529 em 1996), com aumento da participação privada, que alcançou 64,89\% do total das matrículas em 1999 (ante 60,64\% do total em 1996). Com isso, conclui-se que a LDB foi um fator impulsionador do crescimento do setor privado no ensino superior no Brasil;

(iii) na primeira década dos anos 2000, o número de instituições dobrou (2.378 em 2010 ante 1.180 em 2000), com um crescimento maior do setor privado, que dobrou seu número de instituições (2.100 em 2010 ante 1.004 em 2000) e alcançou 88,3\% das instituições em 2010, e o número de matrículas aumentou quase duas vezes e meia (6.379.299 em 2010 ante 2.694.245 em 2000). Desse total, as matrículas privadas aumentaram mais de duas vezes e meia (4.736.001 em 2010 ante 1.807.219), alcançando $72,24 \%$ do total em 2010. Com isso, conclui-se que o crescimento impulsionado pela LDB continuou ocorrendo na década de 2000.

Com relação à organização acadêmica, categoria administrativa e matrículas, encontram-se abaixo os dados da evolução divididos em dois períodos - de 1980 a 1998 e de 2001 a 2008/2010, considerando os dados disponíveis ${ }^{275}$. Sobre tais dados, destaca-se que os centros universitários apenas foram criados com a LDB de 1996 e que, após 2008, o Inep não divulgou mais dados sobre a distribuição entre categoria administrativa e organização acadêmica.

Entre 1980 e 1998, dados do Inep distribuem as instituições entre as seguintes formas de organização acadêmica: (i) universidades; (ii) estabelecimentos isolados; e (iii) faculdades integradas e centros universitários.

Abaixo os dados sobre a proporção de IESs, segundo a categoria administrativa e organização acadêmica nesse período:

\footnotetext{
${ }^{274}$ Sobre o decréscimo no nuúmero de estabelecimentos privados entre 1991-1994, Sampaio (2000, p. 79) afirma: "deve ser notado que o decréscimo no número de estabelecimentos nos períodos considerados não significa que eles estivessem sendo fechados. Essa redução, frequentemente, resulta de um processo de fusão, que envolve dois ou mais estabelecimentos isolados ou, ainda, de incorporação de um ou vários estabelecimentos por uma terceira instituição. Isso ocorre tanto no setor privado como no setor público de ensino superior. Essas oscilações, muitas vezes, constituem a contrapartida do movimento dos estabelecimentos isolados particulares ou públicos em se transformarem em universidades".

${ }^{275}$ Não localizamos dados sobre organização acadêmica e categoria administrativa entre 1999 e 2000.
} 
Tabela 5 - IES segundo a categoria administrativa e organização acadêmica - 19801998

\begin{tabular}{|c|c|c|c|c|c|c|}
\hline \multirow{2}{*}{ Ano } & \multicolumn{3}{|c|}{ Universidades } & \multicolumn{3}{|c|}{ Estabelecimentos Isolados } \\
\hline & Total & Privadas & $\%$ Privadas & Total & Privados & \% Privados \\
\hline 1980 & 65 & 20 & 30,76 & 797 & 643 & 80,67 \\
\hline 1985 & 68 & 20 & 29,41 & 732 & 548 & 74,86 \\
\hline 1990 & 95 & 40 & 42,10 & 749 & 582 & 77,70 \\
\hline 1991 & 99 & 40 & 40,40 & 709 & 549 & 77,43 \\
\hline 1992 & 106 & 46 & 43,39 & 703 & 539 & 76,67 \\
\hline 1993 & 114 & 53 & 46,49 & 671 & 514 & 76,60 \\
\hline 1994 & 127 & 59 & 46,45 & 637 & 490 & 76,92 \\
\hline 1995 & 135 & 63 & 46,66 & 648 & 520 & 80,24 \\
\hline 1996 & 136 & 64 & 47,05 & 643 & 515 & 80,09 \\
\hline 1997 & 150 & 73 & 48,66 & 659 & 526 & 79,81 \\
\hline 1998 & 153 & 76 & 49,67 & 727 & 595 & 81,84 \\
\hline \multirow{2}{*}{ Ano } & \multicolumn{4}{|c|}{ Faculdades Integradas e Centros Universitários } & \multirow{2}{*}{\multicolumn{2}{|c|}{ Total }} \\
\hline & Total & & vados & $\%$ Privados & & \\
\hline 1980 & 20 & \multicolumn{2}{|c|}{19} & 95 & \multicolumn{2}{|r|}{882} \\
\hline 1985 & 59 & \multicolumn{2}{|c|}{58} & 98,30 & \multicolumn{2}{|r|}{859} \\
\hline 1990 & 74 & \multicolumn{2}{|c|}{74} & 100 & \multicolumn{2}{|r|}{918} \\
\hline 1991 & 85 & \multicolumn{2}{|c|}{82} & 96,47 & \multicolumn{2}{|r|}{893} \\
\hline 1992 & 84 & \multicolumn{2}{|c|}{81} & 96,42 & \multicolumn{2}{|r|}{893} \\
\hline 1993 & 88 & \multicolumn{2}{|c|}{85} & 96,59 & \multicolumn{2}{|r|}{873} \\
\hline 1994 & 87 & \multicolumn{2}{|c|}{84} & 96,55 & \multicolumn{2}{|r|}{851} \\
\hline 1995 & 111 & \multicolumn{2}{|c|}{101} & 90,99 & \multicolumn{2}{|r|}{894} \\
\hline 1996 & 143 & \multicolumn{2}{|c|}{132} & 92,30 & \multicolumn{2}{|r|}{922} \\
\hline 1997 & 91 & \multicolumn{2}{|c|}{90} & 98,90 & \multicolumn{2}{|r|}{900} \\
\hline 1998 & 93 & \multicolumn{2}{|c|}{93} & 100 & \multicolumn{2}{|r|}{973} \\
\hline
\end{tabular}

Fonte: Inep ${ }^{276}$

Abaixo dados sobre a distribuição das matrículas de acordo com a organização acadêmica e categoria administrativa no período:

Tabela 6 - Número de matrículas por organização acadêmica, segundo categoria administrativa - Brasil - 1980-1998

(continua)

\begin{tabular}{r|c|r|r|r|r}
\hline \multirow{2}{*}{ Ano } & $\begin{array}{c}\text { Categoria } \\
\text { Administrativa }\end{array}$ & Total & Universidades & $\begin{array}{c}\text { Fac. Integradas } \\
\text { e Centros } \\
\text { Universitários }\end{array}$ & $\begin{array}{c}\text { Estabelecimentos } \\
\text { Isolados }\end{array}$ \\
\hline $\mathbf{1 9 8 0}$ & Total & $\mathbf{1 . 3 7 7 . 2 8 6}$ & $\mathbf{6 5 2 . 2 0 0}$ & $\mathbf{9 6 . 8 9 2}$ & $\mathbf{6 2 8 . 1 9 4}$ \\
& Estadual & 109.252 & 81.723 & 2.622 & 24.907 \\
& Federal & 316.715 & 305.099 & - & 11.616 \\
& Municipal & 66.265 & 17.019 & - & 49.246 \\
& Privada & 885.054 & 248.359 & 94.270 & 542.425
\end{tabular}

\footnotetext{
276 Disponível em: <http://portal.inep.gov.br/web/censo-da-educacao-superior/evolucao-1980-a-2007>.
} Acesso em: 26/07/2012. 
Tabela 6 - Número de matrículas por organização acadêmica, segundo categoria administrativa - Brasil - 1990-1998

\begin{tabular}{|c|c|c|c|c|c|}
\hline Ano & $\begin{array}{c}\text { Categoria } \\
\text { Administrativa }\end{array}$ & Total & Universidades & $\begin{array}{c}\text { Fac. Integradas e } \\
\text { Centros } \\
\text { Universitários }\end{array}$ & $\begin{array}{l}\text { Estabelecimentos } \\
\text { Isolados }\end{array}$ \\
\hline \multirow[t]{5}{*}{1985} & Total & 1.367 .609 & 671.977 & 184.016 & 511.616 \\
\hline & Estadual & 146.816 & 104.441 & - & 42.375 \\
\hline & Federal & 326.522 & 314.102 & - & 12.420 \\
\hline & Municipal & 83.342 & 15.414 & 4.052 & 63.876 \\
\hline & Privada & 810.919 & 238.020 & 179.964 & 392.945 \\
\hline \multirow[t]{5}{*}{1990} & Total & 1.540 .080 & 824.627 & 202.079 & 513.374 \\
\hline & Estadual & 194.417 & 136.257 & - & 58.160 \\
\hline & Federal & 308.867 & 294.626 & - & 14.241 \\
\hline & Municipal & 75.341 & 23.499 & - & 51.842 \\
\hline & Privada & 961.455 & 370.245 & 202.079 & 389.131 \\
\hline \multirow[t]{5}{*}{1991} & Total & 1.565 .056 & 855.258 & 225.700 & 484.098 \\
\hline & Estadual & 202.315 & 153.678 & - & 48.637 \\
\hline & Federal & 320.135 & 305.350 & - & 14.785 \\
\hline & Municipal & 83.286 & 24.390 & 9.266 & 49.630 \\
\hline & Privada & 959.320 & 371.840 & 216.434 & 371.046 \\
\hline \multirow[t]{5}{*}{1992} & Total & 1.535 .788 & 871.729 & 205.465 & 458.594 \\
\hline & Estadual & 210.133 & 159.963 & - & 50.170 \\
\hline & Federal & 325.884 & 310.533 & - & 15.351 \\
\hline & Municipal & 93.645 & 30.353 & 9.445 & 53.847 \\
\hline & Privada & 906.126 & 370.880 & 196.020 & 339.226 \\
\hline \multirow[t]{5}{*}{1993} & Total & 1.594 .668 & 940.921 & 210.117 & 443.630 \\
\hline & Estadual & 216.535 & 167.674 & - & 48.861 \\
\hline & Federal & 344.387 & 328.907 & - & 15.480 \\
\hline & Municipal & 92.594 & 28.623 & 10.362 & 53.609 \\
\hline & Privada & 941.152 & 415.717 & 199.755 & 325.680 \\
\hline \multirow[t]{5}{*}{1994} & Total & 1.661 .034 & 1.034 .726 & 203.471 & 422.837 \\
\hline & Estadual & 231.936 & 190.271 & - & 41.665 \\
\hline & Federal & 363.543 & 349.790 & - & 13.753 \\
\hline & Municipal & 94.971 & 31.547 & 10.344 & 53.080 \\
\hline & Privada & 970.584 & 463.118 & 193.127 & 314.339 \\
\hline \multirow[t]{5}{*}{1995} & Total & 1.759 .703 & 1.127 .932 & 193.814 & 437.957 \\
\hline & Estadual & 239.215 & 201.974 & 1.161 & 36.080 \\
\hline & Federal & 367.531 & 353.235 & - & 14.296 \\
\hline & Municipal & 93.974 & 43.370 & 4.168 & 46.256 \\
\hline & Privada & 1.061 .173 & 529.353 & 188.485 & 341.325 \\
\hline \multirow[t]{5}{*}{1996} & Total & 1.868 .529 & 1.209 .400 & 245.029 & 414.100 \\
\hline & Estadual & 243.101 & 204.819 & 1.592 & 36.690 \\
\hline & Federal & 388.987 & 373.880 & - & 15.107 \\
\hline & Municipal & 103.339 & 47.432 & 7.089 & 48.818 \\
\hline & Privada & 1.133 .102 & 583.269 & 236.348 & 313.485 \\
\hline \multirow[t]{5}{*}{1997} & Total & 1.945.615 & 1.326 .459 & 192.667 & 426.489 \\
\hline & Estadual & 253.678 & 226.149 & - & 27.529 \\
\hline & Federal & 395.833 & 380.980 & - & 14.853 \\
\hline & Municipal & 109.671 & 59.292 & 1.078 & 49.301 \\
\hline & Privada & 1.186 .433 & 660.038 & 191.589 & 334.806 \\
\hline
\end{tabular}


Tabela 6 - Número de matrículas por organização acadêmica, segundo categoria administrativa - Brasil - 1990-1998

(continua)

\begin{tabular}{c|c|r|r|r|r}
\hline \multirow{2}{*}{ Ano } & $\begin{array}{c}\text { Categoria } \\
\text { Administrativa }\end{array}$ & Total & Universidades & $\begin{array}{c}\text { Fac. Integradas e } \\
\text { Centros } \\
\text { Universitários }\end{array}$ & $\begin{array}{c}\text { Estabelecimentos } \\
\text { Isolados }\end{array}$ \\
\hline $\mathbf{1 9 9 8}$ & Total & $\mathbf{2 . 1 2 5 . 9 5 8}$ & $\mathbf{1 . 4 6 7 . 8 8 8}$ & $\mathbf{2 1 6 . 1 3 7}$ & $\mathbf{4 4 1 . 9 3 3}$ \\
& Estadual & 274.934 & 239.908 & - & 35.026 \\
& Federal & 408.640 & 392.873 & - & 15.767 \\
& Municipal & 121.155 & 67.758 & - & 53.397 \\
& Privada & 1.321 .229 & 767.349 & 216.137 & 337.743 \\
\hline
\end{tabular}

Fonte: Inep ${ }^{277}$

Entre 2000 e 2010, os dados do Inep passaram a incluir apenas três formas de organização acadêmica: (i) universidades; (ii) centros universitários; e (iii) faculdades. Dentro das "faculdades" foram incluídas as faculdades integradas, faculdades, escolas e institutos, centros federais de educação tecnológica e faculdades de tecnologia (conforme Decreto $\left.\mathrm{n}^{\mathrm{0}} 5.773 / 06\right)^{278}$.

Tabela 7 - IES segundo a categoria administrativa e organização acadêmica - 2001 2008

\begin{tabular}{|c|c|c|c|c|c|c|}
\hline \multirow[t]{2}{*}{ Ano } & \multicolumn{3}{|c|}{ Universidades } & \multicolumn{3}{|c|}{ Faculdades } \\
\hline & Total & Privadas & $\%$ Privadas & Total & Privados & \% Privados \\
\hline 2001 & 156 & 85 & 54,48 & 1.169 & 1.059 & 90,59 \\
\hline 2002 & 162 & 84 & 51,85 & 1.398 & 1.284 & 91,84 \\
\hline 2003 & 163 & 84 & 51,53 & 1.615 & 1.490 & 92,26 \\
\hline 2004 & 169 & 86 & 50,88 & 1.737 & 1.599 & 92,05 \\
\hline 2005 & 176 & 86 & 48,86 & 1.875 & 1.737 & 92,6 \\
\hline 2006 & 178 & 86 & 48,31 & 1.973 & 1.821 & 92,3 \\
\hline 2007 & 183 & 87 & 47,54 & 1.978 & 1.829 & 92,5 \\
\hline 2008 & 183 & 86 & 46,99 & 1.945 & 1.811 & 93,1 \\
\hline \multirow{2}{*}{ Ano } & \multicolumn{5}{|c|}{ Centros Universitários } & \multirow{2}{*}{ Total } \\
\hline & \multicolumn{2}{|c|}{ Total } & Privados & \multicolumn{2}{|c|}{$\%$ Privados } & \\
\hline 2001 & \multicolumn{2}{|c|}{66} & 64 & \multicolumn{2}{|c|}{96,96} & 1.391 \\
\hline 2002 & \multicolumn{2}{|c|}{77} & 74 & \multicolumn{2}{|c|}{96,10} & 1.637 \\
\hline 2003 & \multicolumn{2}{|c|}{81} & 78 & \multicolumn{2}{|c|}{96,29} & 1.859 \\
\hline 2004 & \multicolumn{2}{|c|}{107} & 104 & \multicolumn{2}{|c|}{97,19} & 2.013 \\
\hline 2005 & \multicolumn{2}{|c|}{114} & 111 & \multicolumn{2}{|c|}{97,36} & 2.165 \\
\hline 2006 & \multicolumn{2}{|c|}{119} & 115 & \multicolumn{2}{|c|}{96,63} & 2.270 \\
\hline 2007 & \multicolumn{2}{|c|}{120} & 116 & \multicolumn{2}{|c|}{96,66} & 2.281 \\
\hline 2008 & \multicolumn{2}{|c|}{124} & 119 & \multicolumn{2}{|c|}{95,96} & 2.252 \\
\hline
\end{tabular}

Fonte: Inep ${ }^{279}$

277 Fonte: Evolução da Educação Superior - Graduação de 1980/1998. Disponível em: $<$ http://portal.inep.gov.br/web/censo-da-educacao-superior/evolucao-1980-a-2007>. Acesso em: 08/12/2012.

${ }^{278}$ Nos censos dos anos 2002 a 2004, o Inep separava os dados dessas categorias de faculdades. A partir de 2004, passou a consolidar os dados na categoria "faculdades". A partir do censo de 2008, passou-se a classificar as instituições em quatro categorias: (i) universidades; (ii) centros universitários; (iii) faculdades; e (iv) institutos federais e centros federais de educação tecnológica (Cefets). A partir do censo de 2008, não há mais informações sobre a distribuição das formas de organização acadêmica de acordo com a categoria administrativa.

279 Disponível em: <http://portal.inep.gov.br/web/censo-da-educacao-superior/evolucao-1980-a-2007>. Acesso em: 26/07/2012. Incluídos dados também do Resumo Técnico do Censo da Educação Superior de 2004 e 2008. 
A partir do Censo da Educação Superior de 2009, as instituições passaram a ser classificadas em: (i) universidades; (ii) centros universitários; (iii) faculdades e institutos federais de educação, ciência e tecnologia (IFs) e centros federais de educação tecnológica (Cefets), sem a distribuição entre as categorias administrativas (público/privado). Em 2010, com relação à organização acadêmica, as faculdades predominam no Brasil - das 2.378 instituições, $85,2 \%$ são faculdades, $8 \%$ são universidades, $5,3 \%$ centros universitários e 1,6\% IFs e Cefets (MEC, 2012).

Tabela 8 - Evolução do $\mathbf{N}^{0}$ de IES por Organização Acadêmica - Brasil - 2001 - 2010

\begin{tabular}{c|c|c|c|c|c|c|c|c|c}
\hline Ano & Total & Universidades & $\mathbf{\%}$ & $\begin{array}{c}\text { Centros } \\
\text { Universitários }\end{array}$ & $\mathbf{\%}$ & Faculdades & $\mathbf{\%}$ & $\begin{array}{c}\text { IFs e } \\
\text { Cefets }\end{array}$ & $\mathbf{\%}$ \\
\hline $\mathbf{2 0 0 1}$ & 1.391 & 156 & 11,2 & 66 & 4,7 & 1.143 & 82,2 & 26 & 1,9 \\
$\mathbf{2 0 0 2}$ & 1.637 & 162 & 9,9 & 77 & 4,7 & 1.367 & 83,5 & 31 & 1,9 \\
$\mathbf{2 0 0 3}$ & 1.859 & 163 & 8,8 & 81 & 4,4 & 1.576 & 84,8 & 39 & 2,1 \\
$\mathbf{2 0 0 4}$ & 2.013 & 169 & 8,4 & 107 & 5,3 & 1.703 & 84,6 & 34 & 1,7 \\
$\mathbf{2 0 0 5}$ & 2.165 & 176 & 8,1 & 114 & 5,3 & 1.842 & 85,1 & 33 & 1,5 \\
$\mathbf{2 0 0 6}$ & 2.270 & 178 & 7,8 & 119 & 5,2 & 1.940 & 85,5 & 33 & 1,5 \\
$\mathbf{2 0 0 7}$ & 2.281 & 183 & 8,0 & 120 & 5,3 & 1.945 & 85,3 & 33 & 1,4 \\
$\mathbf{2 0 0 8}$ & 2.252 & 183 & 8,1 & 124 & 5,5 & 1.911 & 84,9 & 34 & 1,5 \\
$\mathbf{2 0 0 9}$ & 2.314 & 186 & 8,0 & 127 & 5,5 & 1.966 & 85,0 & 35 & 1,5 \\
$\mathbf{2 0 1 0}$ & 2.378 & 190 & 8,0 & 126 & 5,3 & 2.025 & 85,2 & 37 & 1,6 \\
\hline
\end{tabular}

Abaixo dados sobre a distribuição das matrículas de acordo com a organização acadêmica e categoria administrativa entre 2001 e 2010:

Tabela 9 - Número de matrículas por organização acadêmica, segundo categoria administrativa - Brasil - 2001-2010

\begin{tabular}{c|c|r|r|r|r|r}
\hline \multirow{2}{*}{ Ano } & $\begin{array}{c}\text { Categoria } \\
\text { Administrativa }\end{array}$ & \multicolumn{1}{c|}{ Total } & Universidades & $\begin{array}{c}\text { Centros } \\
\text { Universitários }\end{array}$ & Faculdades & $\begin{array}{c}\text { IFs e } \\
\text { Cefets }\end{array}$ \\
\hline \multirow{2}{*}{$\mathbf{2 0 0 1}$} & Total & $\mathbf{3 . 0 3 6 . 1 1 3}$ & $\mathbf{1 . 9 6 1 . 9 0 1}$ & $\mathbf{3 3 8 . 2 7 5}$ & $\mathbf{7 1 5 . 7 0 9}$ & $\mathbf{2 0 . 2 2 8}$ \\
& Estadual & 360.537 & 325.535 & - & 35.002 & - \\
& Federal & 504.797 & 473.826 & 1.012 & 9.731 & 20.228 \\
& Municipal & 79.250 & 22.911 & 4.738 & 51.601 & - \\
& Privada & 2.091 .529 & 1.139 .629 & 332.525 & 619.375 & - \\
$\mathbf{2 0 0 2}$ & & & & & & $\mathbf{2 6 . 2 6 2}$ \\
& Total & $\mathbf{3 . 5 2 0 . 6 2 7}$ & $\mathbf{2 . 1 8 7 . 1 3 3}$ & $\mathbf{4 3 2 . 8 1 8}$ & $\mathbf{8 7 4 . 4 1 4}$ & $\mathbf{2 6 . 2 6}$ \\
& Estadual & 437.927 & 403.315 & - & 34.612 & - \\
& Federal & 543.598 & 512.423 & 1.061 & 3.852 & 26.262 \\
& Municipal & 104.452 & 34.486 & 13.585 & 56.381 & - \\
& Privada & 2.434 .650 & 1.236 .909 & 418.172 & 779.569 & -
\end{tabular}

280 Fonte: Resumo Técnico Censo da Educação Superior 2010, diponível em: $<$ http://download.inep.gov.br/educacao_superior/censo_superior/resumo_tecnico/resumo_tecnico_censo_edu cacao_superior_2010.pdf $>$. Acesso em: 23/07/2012. 
Tabela 9 - Número de matrículas por organização acadêmica e categoria administrativa - Brasil - 2001-2010

\begin{tabular}{|c|c|c|c|c|c|c|}
\hline Ano & $\begin{array}{c}\text { Categoria } \\
\text { Administrativa }\end{array}$ & Total & Universidades & $\begin{array}{c}\text { Centros } \\
\text { Universitários } \\
\end{array}$ & Faculdades & $\begin{array}{c}\text { IFs e } \\
\text { Cefets }\end{array}$ \\
\hline \multirow[t]{5}{*}{2003} & Total & 3.936 .933 & 2.319 .097 & $\mathbf{5 0 3 . 5 7 7}$ & 1.080 .458 & 33.801 \\
\hline & Estadual & 465.978 & 428.093 & - & 37.885 & - \\
\hline & Federal & 583.633 & 544.251 & 1.159 & 4.422 & 33.801 \\
\hline & Municipal & 126.563 & 52.925 & 15.446 & 58.192 & - \\
\hline & Privada & 2.760 .759 & 1.293 .828 & 486.972 & 979.959 & - \\
\hline \multirow[t]{5}{*}{2004} & Total & 4.223.344 & 2.419.280 & 616.396 & 1.151.927 & 35.741 \\
\hline & Estadual & 489.529 & 447.691 & - & 41.838 & - \\
\hline & Federal & 592.705 & 552.013 & 1.205 & 3.746 & 35.741 \\
\hline & Municipal & 132.083 & 59.208 & 12.678 & 60.197 & - \\
\hline & Privada & 3.009 .027 & 1.360 .368 & 602.513 & 1.046 .146 & - \\
\hline \multirow[t]{5}{*}{2005} & Total & 4.567.798 & 2.560 .917 & 679.417 & 1.299.212 & 28.252 \\
\hline & Estadual & 514.726 & 471.069 & - & 43.657 & - \\
\hline & Federal & 595.327 & 564.911 & - & 2.164 & 28.252 \\
\hline & Municipal & 136.651 & 61.351 & 15.757 & 59.543 & - \\
\hline & Privada & 3.321 .094 & 1.463 .586 & 663.660 & 1.193 .848 & - \\
\hline \multirow[t]{5}{*}{2006} & Total & 4.883.852 & 2.646.522 & 743.471 & 1.463 .080 & 30.779 \\
\hline & Estadual & 502.826 & 457.732 & - & 45.094 & - \\
\hline & Federal & 607.180 & 573.590 & - & 2.811 & 30.779 \\
\hline & Municipal & 141.359 & 64.002 & 16.510 & 60.847 & - \\
\hline & Privada & 3.632 .487 & 1.551 .198 & 726.961 & 1.354 .328 & - \\
\hline \multirow[t]{5}{*}{2007} & Total & 5.250 .147 & 2.931.117 & 705.642 & 1.579.251 & 34.137 \\
\hline & Estadual & 550.089 & 506.860 & - & 43.229 & - \\
\hline & Federal & 641.094 & 604.088 & - & 2.869 & 34.137 \\
\hline & Municipal & 143.994 & 65.945 & 17.617 & 60.432 & - \\
\hline & Privada & 3.914 .970 & 1.754 .224 & 688.025 & 1.472 .721 & - \\
\hline \multirow[t]{5}{*}{2008} & Total & 5.808.017 & 3.270 .904 & 755.796 & 1.737 .290 & 44.027 \\
\hline & Estadual & 710.175 & 666.772 & - & 43.403 & 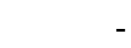 \\
\hline & Federal & 698.319 & 652.898 & - & 1.394 & 44.027 \\
\hline & Municipal & 144.459 & 67.171 & 23.110 & 54.178 & - \\
\hline & Privada & 4.255 .064 & 1.884 .063 & 732.686 & 1.638 .315 & - \\
\hline \multirow[t]{5}{*}{2009} & Total & 5.954 .021 & 3.306 .845 & 795.033 & 1.784 .046 & 68.097 \\
\hline & Estadual & 566.204 & 523.103 & 869 & 42.232 & - \\
\hline & Federal & 839.397 & 769.879 & - & 1.421 & 68.097 \\
\hline & Municipal & 118.263 & 56.946 & 12.980 & 48.337 & - \\
\hline & Privada & 4.430 .157 & 1.956 .917 & 781.184 & 1.692 .056 & - \\
\hline \multirow[t]{5}{*}{2010} & Total & 6.379.299 & 3.464 .711 & 836.680 & 1.990 .402 & 87.506 \\
\hline & Estadual & 601.112 & 547.683 & 1.199 & 52.230 & - \\
\hline & Federal & 938.656 & 849.679 & - & 1.471 & 87.506 \\
\hline & Municipal & 103.530 & 38.277 & 12.967 & 52.286 & - \\
\hline & Privada & 4.736 .001 & 2.029 .072 & 822.514 & 1.884 .415 & . \\
\hline
\end{tabular}

281 Fonte: Resumo Técnico Censo da Educação Superior 2010, disponível em: $<$ http://download.inep.gov.br/educacao_superior/censo_superior/resumo_tecnico/resumo_tecnico_censo_edu cacao_superior_2010.pdf $>$. Acesso em: 23/07/2012. 
Nota-se que o Brasil apresenta um grande número de instituições, sobretudo faculdades, contudo, as matrículas concentram-se em um número reduzido de instituições. Nesse sentido, em 2010, a maior parte das matrículas (54,3\%), estava concentrada nas universidades, seguidas pelas faculdades $(31,2 \%)$, centros universitários $(13,1 \%)$, institutos federais (IFs) e centros federais de educação tecnológica (Cefets) $(1,4 \%)$ :

\begin{tabular}{|c|c|c|c|c|}
\hline Ano & $\begin{array}{c}\text { Universidades } \\
(\%)\end{array}$ & $\begin{array}{c}\text { Centros } \\
\text { Universitários (\%) }\end{array}$ & $\begin{array}{c}\text { Faculdades } \\
(\%)\end{array}$ & IFs e Cefets (\%) \\
\hline 2001 & 64,6 & 11,1 & 23,6 & 0,7 \\
\hline 2002 & 62,1 & 12,3 & 24,8 & 0,7 \\
\hline 2003 & 58,9 & 12,8 & 27,4 & 0,9 \\
\hline 2004 & 57,3 & 14,6 & 27,3 & 0,8 \\
\hline 2005 & 56,1 & 14,9 & 28,4 & 0,6 \\
\hline 2006 & 54,2 & 15,2 & 30,0 & 0,6 \\
\hline 2007 & 55,8 & 13,4 & 30,1 & 0,7 \\
\hline 2008 & 56,3 & 13,0 & 29,9 & 0,8 \\
\hline 2009 & 55,5 & 13,4 & 30,0 & 1,1 \\
\hline 2010 & 54,3 & 13,1 & 31,2 & 1,4 \\
\hline
\end{tabular}

Fonte: Inep (2012) $)^{28}$

Pelos dados acima, nota-se que:

(i) entre os anos 1985 e 1990, o número de universidades privadas dobrou no Brasil (de 20 em 1985 para 40 em 1990), com uma diminuição do número de estabelecimentos isolados (de 643 em 1985 para 582 em 1990) (cf. Tabela 5); ao mesmo tempo o número de matrículas privadas cresceu (de 885.054 em 1985 para 961.455 em 1990) (cf. Tabela 6). Tal fato comprova o argumento de que, com a previsão de autonomia universitária na Constituição de 1988 (reafirmada na LDB), houve um impulso para a transformação das instituições do setor privado em universidades, visando a flexibilidade maior de gestão oferecida pela autonomia ${ }^{283}$;

(ii) as universidades eram, até 1997, em sua maioria públicas (com percentuais acima de 53\%, cf. Tabela 5). A partir de 1998, passam a ter quase a mesma proporção entre o setor público e o setor privado, com destaque para o ano de 2001 em que o número de universidades privadas chegou a $54,48 \%$ do total (cf. Tabelas 5 e 7);

282 Fonte: Resumo Técnico Censo da Educação Superior 2010, disponível em: $<$ http://download.inep.gov.br/educacao_superior/censo_superior/resumo_tecnico/resumo_tecnico_censo_edu cacao_superior_2010.pdf $>$. Acesso em: 23/07/2012.

283 A esse respeito, Barreyro (2008, p. 20) afirma que, a partir da autonomia outorgada pela Constituição de 1988 e reafirmada pela LDB, o setor privado achou conveniente transformar suas instituições em universidades, "pois com autonomia é possível ter mais flexibilidade na gestão, por exemplo, abrindo ou fechando cursos, segundo a demanda do mercado". 
(iii) os centros universitários são historicamente, em sua maioria, privados, em proporções acima de $95 \%$ (cf. Tabela 7$)$;

(iv) as faculdades e estabelecimentos isolados são historicamente, em sua maioria, privados, na faixa de $75 \%$ a $80 \%$ até os anos 2000 , quando passam a ser mais de 90\% privados (cf. Tabelas 5 e 7);

(v) em número de instituições, preponderam no ensino superior brasileiro, no período analisado, as faculdades e os estabelecimentos isolados (cf. Tabelas 5, 7 e 8);

(vi) as matrículas concentram-se, historicamente, nas universidades, tanto públicas quanto privadas (cf. Tabelas 6, 9 e 10);

(vii) as matrículas do setor privado concentravam-se nas universidades, mas a partir dos anos 2000, as matrículas nas faculdades cresceram num ritmo maior, alcançando, no ano de 2010, 2.029.072 matrículas em universidades privadas e 1.884.415 matrículas em faculdades (cf. Tabelas 6 e 9);

(viii) as matrículas no setor público, entre os anos de 1980 e 1998, cresceram num ritmo pequeno na esfera federal (408.640 em 1998 ante 316.715 em 1980), mas com crescimento expressivo na esfera estadual (274.934 em 1998 ante 109.252 em 1980). Na última década, o crescimento tanto da esfera federal quanto estadual foi expressivo, passando de 360.537 (estadual) e 504.797 (federal), em 2001, para 601.112 (estaduais) e 938.656 (federais), em 2010. A esfera municipal tem menor participação no setor público e apresentou crescimento nos dois períodos analisados (121.155 em 1998 ante 66.265 em 1980; e 103.530 em 2010 ante 79.250 em 2001) (cf. Tabelas 6 e 9);

(ix) as matrículas nos centros universitários tiveram um grande crescimento na última década, passando de 338.275, em 2001, para 836.680, em 2010 (cf. Tabela 9); e

(x) as matrículas nos IFs e Cefets mais que quadruplicaram na última década, passando de 20.228, em 2001, para 87.506, em 2010 (cf. Tabela 9).

Dentre as instituições de ensino superior do setor privado, a maior parte são particulares (instituições com fins lucrativos), representando 85,98\% delas, em 2009, conforme tabela 12 abaixo: 
Tabela 11 - Instituições de educação superior segundo unidade federativa e tipo de instituição privada - Brasil - 2009

\begin{tabular}{cc|c|r}
\hline & Unidade Federativa & \multicolumn{1}{c}{ IES } & \% Dentre as Públicas \\
\hline Total Públicas & \multicolumn{2}{c}{$\mathbf{2 4 5}$} & $\mathbf{1 0 0}$ \\
Fúblicas & Esteral & 94 & 38,37 \\
& Municipal & 84 & 34,28 \\
& \multicolumn{2}{c}{67} & 27,35 \\
\hline \multicolumn{2}{c}{ Tipo de Instituição Privada } & \multicolumn{1}{c}{ IES } & \% Dentre as Privadas \\
\hline Privadas & Total Privadas & $\mathbf{2 . 0 6 9}$ & $\mathbf{1 0 0}$ \\
& Particulares & 1.779 & 85,98 \\
& Confessionais, & 290 & 14,02
\end{tabular}

Fonte: Inep (2010)

Esse dado demonstra (i) o predomínio no setor privado de instituições com fins lucrativos no Brasil atualmente; e (ii) que no setor público há um predomínio de instituições federais (38,37\%), seguidas das instituições estaduais (34,28\%).

O setor privado predomina também no número de vagas oferecidas no ensino superior - segundo o Censo da Educação Superior de 2009, foram oferecidas, na graduação presencial e a distância, no ano de 2009, 4.726.394 vagas, das quais 461.694 em instituições públicas e 4.264.700 em instituições privadas. Concorreram para as vagas totais do ensino superior, no mesmo ano, 6.889 .269 candidatos, o que representou uma relação candidato/vaga de 5,92 na rede pública e de 0,97 na rede privada ${ }^{284}$ (INEP, 2010). Este dado demonstra também a baixa relação candidato/vaga no setor privado, o que contribui para a conclusão de que a meritocracia em algumas instituições do setor privado é flexibilizada em razão de processos seletivos em que há mais vagas do que candidatos.

Uma das características do ensino superior brasileiro é a existência de vagas não preenchidas, as quais predominam no setor privado com percentuais acima de $97 \%$ :

Tabela 12 - Evolução do número de vagas ociosas na graduação presencial, segundo categoria administrativa - Brasil - 2002 a 2008

\begin{tabular}{c|c|c|c|c|c}
\hline Ano & Total & Público & \% Público & Privado & \% Privado \\
\hline 2002 & 567.947 & 14.863 & 2,62 & 553.084 & 97,38 \\
2003 & 739.779 & 14.132 & 1,91 & 725.647 & 98,09 \\
2004 & 1.017 .311 & 21.250 & 2,09 & 996.061 & 97,91 \\
2005 & 1.038 .706 & 24.687 & 2,38 & 1.014 .019 & 97,62 \\
2006 & 1.181 .089 & 33.698 & 2,85 & 1.147 .391 & 97,15 \\
2007 & 1.341 .987 & 30.769 & 2,29 & 1.311 .218 & 97,71 \\
2008 & 1.479 .318 & 36.725 & 2,48 & 1.442 .593 & 97,52 \\
\hline
\end{tabular}

Fonte: Inep (2009)

\footnotetext{
${ }^{284}$ Segundo Ryon Braga, diretor da Hoper Educacional, "a taxa de ociosidade de mais de 50\% das vagas no ensino superior privado resultou no fato de que $89 \%$ dos cursos superiores nas IES particulares não preenchem todas as vagas, portanto todos os que fizerem a prova estarão aprovados, uma vez que, na quase totalidade dos casos, não há linha de corte. Ou seja, qualquer um passa no vestibular das instituições privadas, em praticamente todos os cursos". Disponível em: <www.hoper.com.br>.
} 
O ensino superior brasileiro apresenta também taxas de evasão consideráveis. No Brasil, em 2009, a taxa de evasão no ensino superior foi de $17 \%{ }^{285}$. Pesquisa divulgada em 2011 pelo Sindicato das Entidades Mantenedoras de Estabelecimentos de Ensino Superior no Estado de São Paulo (Semesp) mostra que um em cada quatro alunos no ensino superior privado desistiu do curso na região metropolitana de São Paulo no ano de 2009. A taxa de evasão de $27 \%$ é a maior proporção de desistência registrada na década. A pesquisa destaca que, no mesmo período, a evasão nas instituições públicas teve queda ${ }^{286}$.

Segundo reportagem da Folha de São Paulo ${ }^{287}$, para as universidades privadas, o crescimento da desistência está ligado à chegada dos alunos das classes $\mathrm{C}$ e D ao ensino superior: "os estudantes vêm com dificuldades acadêmicas, não acompanham o primeiro semestre e desistem”, afirmou o diretor executivo do Semesp na reportagem, que completou dizendo: "as universidades ainda não sabem como reter esses alunos", "elas precisarão se reorganizar, criar setor que identifique as dificuldades financeiras e pedagógicas deles".

Na mesma reportagem ${ }^{288}$, o pesquisador Oscar Hipólito, ex-diretor do Instituto de Física da USP - São Carlos afirmou: "o estudante desiste ao perceber que o custo com as mensalidades e a manutenção não valem o que a universidade oferece". O problema das vagas ociosas e da evasão de alunos está relacionada à oferta de cursos para os quais não há demanda, nem mercado de trabalho, e a questões econômicas (o aluno não consegue arcar com os custos das mensalidades). Para lidar com as dificuldades econômicas, há o Fies e ProUni (além de financiamentos privados e bolsas de estudos) que contribuem para a ampliação do acesso ao ensino superior privado e para a retenção de alunos.

As outras duas questões (excesso de demanda e falta de mercado de trabalho) podem indicar um excesso de oferta no setor e que ele poderá se concentrar nos próximos anos. Para Helena Sampaio (2000, p. 91), “o aumento no porcentual de vagas não preenchidas no sistema de ensino superior é indicativo de que esse sistema de ensino superior cresceu mais do que a demanda poderia alimentar".

A esse respeito, de acordo com os dados constantes na tabela 3, verifica-se que, entre os anos de 1990 e 2010, o setor privado apresentou um grande crescimento no País, mas que, a partir do ano 2006, o ritmo de crescimento no número de instituições diminuiu,

\footnotetext{
285 Disponível em: $<$ http://revistaensinosuperior.uol.com.br/textos.asp?codigo=12816>. Acesso em: 25/09/2012.

${ }^{286}$ Disponível em: < http://www1.folha.uol.com.br/fsp/cotidian/ff2106201115.htm>. Acesso em: 25/09/2012.

${ }^{287}$ Disponível em: <http://www1.folha.uol.com.br/fsp/cotidian/ff2106201115.htm>. Acesso em: 25/09/2012.

${ }^{288}$ Disponível em: < http://www1.folha.uol.com.br/fsp/cotidian/ff2106201115.htm>. Acesso em: 25/09/2012.
} 
possivelmente influenciado por um movimento de concentração do mercado educacional, em que as empresas com maior participação no mercado adquirem suas concorrentes, especialmente instituições de pequeno porte, pequenas (em termos de estrutura e número de matrículas) e familiares, formando conglomerados maiores.

Esse processo de concentração tende a construir um cenário educacional com um número reduzido de fornecedores atendendo a grande parcela do mercado, oferecendo produtos mais competitivos e abarcando mais consumidores (OLIVEIRA, 2009, p. 754). Nesse contexto, a Anhanguera envolveu-se em muitos processos de aquisição nos últimos anos, contribuindo para esse movimento de concentração do mercado, como veremos no Capítulo 4 da Dissertação. Segundo Sécca e Leal (2009, p. 144), para as IES de massa, a consolidação é uma oportunidade de crescimento, de ganho de escala e aumento da capilaridade. Já para as IES privadas menores, “é uma ameaça, uma vez que, incapazes de competir, podem se ver obrigadas a se associar ou ser adquiridas pelas maiores"289.

Nesse contexto, é importante notar que, do total das instituições de ensino superior brasileiras, em 2009, 1.473 (63,8\%) são consideradas de pequeno porte (instituições com no máximo 1.000 matrículas). No entanto, o maior número de matrículas está concentrado num pequeno número de instituições de grande porte (instituições com mais de 10.000 matrículas). Em 2009, apenas 117 (5,1\%) das instituições de ensino superior detinham 2.505.670 (48,9\%) matrículas na graduação presencial (INEP, 2010).

Nota-se também que a maioria $(73,4 \%)$ das instituições oferece menos que dez cursos, conforme tabela 13 abaixo.

Tabela 13 - Número de IES conforme o número de cursos de graduação por elas oferecidos - Brasil - 2010

\begin{tabular}{l|c|c}
\hline \multicolumn{1}{c}{ Número de Cursos } & Quantidade de IES & \% \\
\hline Menos que 10 & 1.744 & 73,4 \\
Entre $10-20$ & 310 & 13,0 \\
Entre $20-50$ & 191 & 8,0 \\
Entre $50-100$ & 88 & 3,7 \\
100 ou mais & 44 & 1,9 \\
Total & $\mathbf{2 . 3 7 7}$ & $\mathbf{1 0 0}$ \\
\hline
\end{tabular}

Fonte: Inep (2012) 290

\footnotetext{
${ }^{289}$ Para Sécca e Leal (2009, p. 129), a tendência é que as taxas de crescimento experimentadas no passado recente não se repitam no futuro próximo, apesar da ainda baixa penetração do ensino superior no Brasil. Para essa conclusão, referidos autores destacam que o número de concluintes no ensino médio estagnou, que o perfil etário da população brasileira vem se alterando e que o número de jovens em idade de ingressar na universidade tende a se estabilizar, refletindo as menores taxas de natalidade dos anos 1990, comparadas às verificadas na década anterior.

290 Fonte: Resumo Técnico Censo da Educação Superior 2010, disponível em: $<$ http://download.inep.gov.br/educacao_superior/censo_superior/resumo_tecnico/resumo_tecnico_censo_edu cacao_superior_2010.pdf $>$. Acesso em: 23/07/2012.
} 
Abaixo dados sobre as dez maiores instituições de ensino superior do País nos anos de 2003 e $2008^{291}$ :

\section{Tabela 14 - Relação das dez maiores IES em número de matrículas na graduação em 2003 e 2008}

(continua)

\begin{tabular}{|c|c|c|c|c|c|}
\hline \multicolumn{6}{|c|}{2003} \\
\hline & IES & UF & Cat. Adm. & Org. Acad. & $\mathrm{N}^{0}$ de Matrículas \\
\hline 1 & $\begin{array}{c}\text { Universidade Estácio de } \\
\text { Sá - Unesa }\end{array}$ & RJ & Universidade & Privada & 100.617 \\
\hline 2 & $\begin{array}{c}\text { Universidade Paulista - } \\
\text { Unip }\end{array}$ & SP & Universidade & Privada & 92.023 \\
\hline 3 & $\begin{array}{l}\text { Universidade de São } \\
\text { Paulo - USP }\end{array}$ & SP & Universidade & Pública Estad. & 44.281 \\
\hline 4 & $\begin{array}{l}\text { Universidade Luterana } \\
\text { do Brasil -Ulbra }\end{array}$ & RS & Universidade & Privada & 41.450 \\
\hline 5 & $\begin{array}{c}\text { Pontifícia Universidade } \\
\text { Católica de Minas Gerais } \\
\text { - PUC Minas }\end{array}$ & MG & Universidade & Privada & 36.749 \\
\hline 6 & $\begin{array}{l}\text { Universidade Salgado de } \\
\text { Oliveira - Universo }\end{array}$ & RJ & Universidade & Privada & 35.719 \\
\hline 7 & $\begin{array}{l}\text { Universidade Estadual } \\
\text { do Piauí - Uespi }\end{array}$ & PI & Universidade & $\begin{array}{l}\text { Pública } \\
\text { Est. }\end{array}$ & 35.683 \\
\hline 8 & $\begin{array}{l}\text { Universidade Estadual de } \\
\text { Goiás - UEG }\end{array}$ & $\mathrm{GO}$ & Universidade & $\begin{array}{l}\text { Pública } \\
\text { Est. }\end{array}$ & 34.113 \\
\hline 9 & $\begin{array}{c}\text { Universidade } \\
\text { Bandeirante de São } \\
\text { Paulo - Uniban }\end{array}$ & $\mathrm{SP}$ & Universidade & Privada & 32.852 \\
\hline 10 & $\begin{array}{l}\text { Universidade do Vale do } \\
\text { Rio dos Sinos - Unisinos }\end{array}$ & RS & Universidade & Privada & 31.482 \\
\hline & Total de matrícu & is das & maiores IES e & & 484.969 \\
\hline
\end{tabular}

\begin{tabular}{|c|c|c|c|c|c|}
\hline \multicolumn{6}{|c|}{2008} \\
\hline & IES & $\mathbf{U F}$ & Cat. Adm. & Org. Acad. & $\mathrm{N}^{0}$ de Matrículas \\
\hline 1 & $\begin{array}{c}\text { Universidade Paulista - } \\
\text { Unip }\end{array}$ & SP & Universidade & Privada & 166.601 \\
\hline 2 & $\begin{array}{l}\text { Universidade Estácio de } \\
\text { Sá - Unesa }\end{array}$ & RJ & Universidade & Privada & 115.916 \\
\hline 3 & $\begin{array}{l}\text { Universidade Nove de } \\
\text { Julho - Uninove }\end{array}$ & SP & Universidade & Privada & 93.520 \\
\hline 4 & $\begin{array}{l}\text { Universidade Presidente } \\
\text { Antônio Carlos - Unipac }\end{array}$ & $\mathrm{MG}$ & Universidade & Privada & 55.686 \\
\hline 5 & $\begin{array}{c}\text { Universidade } \\
\text { Bandeirante de São Paulo } \\
\text { - Uniban }\end{array}$ & SP & Universidade & Privada & 50.674 \\
\hline 6 & $\begin{array}{l}\text { Universidade de São } \\
\text { Paulo - USP }\end{array}$ & SP & Universidade & $\begin{array}{l}\text { Pública } \\
\text { Est. }\end{array}$ & 50.508 \\
\hline 7 & $\begin{array}{l}\text { Universidade Salgado de } \\
\text { Oliveira - Universo }\end{array}$ & RJ & Universidade & Privada & 43.437 \\
\hline
\end{tabular}

${ }^{291}$ Não localizamos esta informação com relação a outros anos. 
Tabela 14 - Relação das dez maiores IES em número de matrículas na graduação em 2003 e 2008

\begin{tabular}{|c|c|c|c|c|c|}
\hline \multicolumn{6}{|c|}{2008} \\
\hline & IES & UF & Cat. Adm. & Org. Acad. & $\mathrm{N}^{0}$ de Matrículas \\
\hline 8 & $\begin{array}{l}\text { Universidade Luterana } \\
\text { do Brasil - Ulbra }\end{array}$ & RS & Universidade & Privada & 39.305 \\
\hline 9 & $\begin{array}{c}\text { Pontifícia Universidade } \\
\text { Católica de Minas Gerais } \\
\text { - PUC Minas }\end{array}$ & MG & Universidade & Privada & 34.017 \\
\hline 10 & $\begin{array}{l}\text { Universidade Estadual } \\
\text { Paulista Júlio de } \\
\text { Mesquita Filho - Unesp }\end{array}$ & SP & Universidade & $\begin{array}{l}\text { Pública } \\
\text { Est. }\end{array}$ & 31.974 \\
\hline \multicolumn{5}{|c|}{ Total de matrículas das dez maiores IES em 2008} & 681.638 \\
\hline
\end{tabular}

Analisando os dados constantes na tabela acima, nota-se que (i) as dez maiores IES do País, nos anos de 2003 e 2008, possuíam, em conjunto, 484.969 matrículas, em 2003, o que correspondia a $12,47 \%$ do total do País; e 681.638, em 2008, o que correspondia a $13,41 \%$ do total do País; (ii) todas as dez maiores IES detinham mais que 30.000 matrículas no anos analisados; (iii) apenas três das dez maiores IES no ano de 2003 e duas no ano de 2008 eram IES públicas e estaduais; e (iv) não há nenhuma IES federal entre as dez maiores IES nos anos de 2003 e 2008. Com isso, conclui-se que há um predomínio de instituições de ensino do setor privado no oferecimento da educação superior de massa no País.

Ressalta-se que a Anhanguera não apareceu na lista das dez maiores IES do País porque sua atividade é exercida, principalmente, por meio de faculdades isoladas, e não por uma grande universidade. No entanto, considerando todas as instituições integrantes do grupo (inclusive a Uniban, que aparece na lista acima e que foi adquirida pela Anhanguera em 2011), o grupo Anhanguera era o maior grupo de ensino do Brasil, em 31/12/2011, com mais de 400 mil alunos, conforme desenvolvido no Capítulo 4 desta Dissertação.

Segundo dados do Inep (2012b, p. 34), das 1.744 instituições de ensino superior com menos de dez cursos, 771 têm um ou dois cursos, fato este que, segundo o Inep (2012b, p. 34), "parece apontar que essas pequenas IES são polarizadas em torno de um curso ou de uma área do conhecimento". A esse respeito, destaca-se que 800 instituições dedicam-se a uma única área geral do conhecimento (INEP, 2012b, p. 34).

Nesse contexto, as áreas de "Ciências Sociais, Negócios e Direito" e "Educação" representam mais de $60 \%$ de todas as matrículas de graduação no Brasil, em 2010 (INEP, 2012b): 
Tabela 15 - Distribuição do número de matrículas por área geral de conhecimento Brasil - 2010

\begin{tabular}{l|c}
\hline \multicolumn{1}{c|}{ Área Geral do Conhecimento } & $\mathbf{\%}$ \\
\hline Ciências Sociais, Negócios e Direito & 41,5 \\
Educação & 21,1 \\
Saúde e Bem-estar Social & 14,0 \\
Engenharia, Produção e Construção & 9,9 \\
Ciências, Matemática e Computação & 6,5 \\
Humanidades e Artes & 2,3 \\
Agricultura e Veterinária & 2,3 \\
Serviços & 2,2 \\
Total & $\mathbf{1 0 0}$ \\
\hline
\end{tabular}

Fonte: Inep (2012b)

Sobre a concentração dos cursos oferecidos na área de Ciências Humanas e Ciências Sociais Aplicadas, o que também ocorre no setor privado, Sampaio (2000, p. 219) afirma:

\begin{abstract}
Com efeito, trata-se de áreas do conhecimento que não requerem altos investimentos para serem criadas e mantidas e cujos cursos, em média, têm alta demanda no mercado. Tal demanda estaria associada ao fato de esses cursos, em geral mais flexíveis em termos acadêmicos, serem ministrados em só um período, e com anuidades relativamente mais acessíveis, justamente em razão dos poucos insumos necessários para seu funcionamento. Acresce ainda a esses aspectos a suposição de que existe mercado profissional mais amplo para os graduados de cursos menos definidos quanto à área de atuação no mercado ocupacional. Nesse sentido, a relativa facilidade de acesso e de permanência do aluno em cursos de Humanas e de Ciências Sociais Aplicadas, em virtude das próprias características que envolvem a formação acadêmica e profissional nessas áreas, seriam alguns dos fatores que explicariam a alta demanda por esses cursos e o dinamismo do setor privado em atendê-la, muitas vezes, até criando a demanda como uma estratégia de expansão de seus serviços nessas áreas. A abertura e o funcionamento desses cursos também estão menos sujeitos à reserva de mercado de grupos de profissionais. A área da Saúde, em contraste, é ilustrativa do forte controle das associações profissionais sobre a ampliação do número de escolas de formação de médicos e dentistas, por exemplo.
\end{abstract}

Em 2010, os cursos de graduação com maior número de matrículas foram os presenciais - 5.449.120 matrículas ou 85,42\% ante 930.179 matrículas ou 14,6\% para os cursos a distância. Da totalidade dos cursos a distância, $80,5 \%$ são oferecidas pelo setor privado (INEP, 2012b, p. 42). Como vimos, a metodologia de ensino a distancia permite a redução de custos e a criação de escala. Considerando esses benefícios econômicos, o setor privado atua com intensidade nessa modalidade de cursos.

Destaca-que a educação a distância cresceu muito nos últimos anos no Brasil, acumulando uma taxa de aumento de $70 \%$ entre os anos 2004 e 2009: 
Tabela 16 - Matrículas na Educação a Distância - 2004 - 2010

\begin{tabular}{c|c}
\hline Ano & $\mathbf{N}^{\mathbf{0}}$ de matrículas (em milhares) \\
\hline 2004 & 60 \\
2005 & 115 \\
2006 & 207 \\
2007 & 370 \\
2008 & 728 \\
2009 & 838 \\
2010 & 930 \\
\hline
\end{tabular}

Fonte: Anhanguera (2012d)

Com relação ao período dos cursos, destaca-se que seis em cada dez alunos do ensino superior no Brasil estudam à noite. As matrículas nos cursos noturnos cresceram de $56,1 \%$ para $63,5 \%$ entre 2001 e 2010 . Nas instituições federais, predomina o atendimento diurno, oferecido a mais de $70 \%$ dos estudantes. Já as universidades estaduais apresentam um atendimento mais equilibrado, com quase $46 \%$ dos alunos matriculados no turno da noite. Nas instituições privadas, os números indicam um aumento na oferta de vagas noturnas que, em 2010, corresponderam a 72,8\% dos estudantes matriculados ${ }^{292}$.

\subsubsection{Diferenças regionais}

Uma das características do ensino superior brasileiro é a disparidade regional - em 2010, quase metade das matrículas (48,7\%) estavam situadas na Região Sudeste, conforme dados abaixo:

Tabela 17 - Distribuição das matrículas no ensino superior por regiões no Brasil 2001 e 2010

\begin{tabular}{l|r|c|r|r|r|r}
\hline \multirow{2}{*}{ Brasil/Regiões } & \multicolumn{4}{c|}{$\mathbf{2 0 0 1}$} & \multicolumn{3}{c}{$\mathbf{2 0 1 0}$} \\
\cline { 2 - 7 } & $\begin{array}{c}\mathbf{N}^{\mathbf{0}} \\
\text { Matrículas }\end{array}$ & $\begin{array}{c}\mathbf{\%} \\
\text { Matrículas }\end{array}$ & $\begin{array}{c}\mathbf{\%} \\
\text { População }\end{array}$ & $\begin{array}{c}\mathbf{N}^{\mathbf{0}} \\
\text { Matrículas }\end{array}$ & $\begin{array}{c}\mathbf{\%} \\
\text { Matrículas }\end{array}$ & \% População \\
\hline Brasil & 3.030 .754 & 100 & 100 & 5.449 .120 & 100 & 100 \\
Centro-Oeste & 260.349 & 8,6 & 7,1 & 495.240 & 9,1 & 7,4 \\
Nordeste & 460.315 & 15,2 & 28,7 & 1.052 .161 & 19,3 & 27,8 \\
Norte & 141.892 & 4,7 & 5,8 & 352.358 & 6,5 & 8,3 \\
Sudeste & 1.566 .610 & 51,7 & 43,4 & 2.656 .231 & 48,7 & 42,1 \\
Sul & 601.588 & 19,8 & 15 & 893.130 & 16,4 & 14,4 \\
\hline
\end{tabular}

Fonte: Inep (2012b)

A concentração das IES na região Sudeste pode ser explicada pelo tamanho e pela rentabilidade do mercado dessa região (SÉCCA; LEAL, 2009, p. 20).

Grandes instituições do Sudeste ganharam escala e acumularam capital para sua

\footnotetext{
${ }^{292}$ Disponível em: <http://www.estadao.com.br/noticias/vidae,mais-de-60-dos-alunos-do-ensino-superior-nopais-estudam-a-noite, 795683,0.htm>. Acesso em: 08/12/2012.
} 
expansão para outras regiões do País, tanto por crescimento orgânico quanto por aquisições. A Anhanguera, conforme será desenvolvido no Capítulo 4, nasceu na região Sudeste e depois expandiu-se para o Centro-Oeste e Sul do País.

\subsubsection{Fies e ProUni}

De cada dez alunos matriculados nas instituições de ensino superior privadas no Brasil, em 2009, três possuíam bolsas de estudo. Do total de bolsistas, 10.019 .532 (82,5\%) eram de programas reembolsáveis ${ }^{293}$ e 215.777 (17,5\%) de não-reembolsáveis ${ }^{294}$ (INEP, 2010). A participação do Fies e do ProUni dentro desses programas é relevante, conforme tabelas 18 e 19 abaixo:

Tabela 18 - Distribuição dos programas reembolsáveis - Brasil - 2009

\begin{tabular}{lc}
\hline \multicolumn{1}{c}{ Programa } & Participação no Total (\%) \\
\hline Fies & $\mathbf{6 4}$ \\
Própria IES & 18 \\
Governo Estadual & 5 \\
Governo Municipal & 4 \\
Entidades Externas & 4 \\
Outros & 5 \\
Total & 100 \\
\hline
\end{tabular}

Fonte: Inep (2010)

Tabela 19 - Distribuição dos programas não-reembolsáveis - Brasil - 2009

\begin{tabular}{|c|c|}
\hline Programa & Participação no Total (\%) \\
\hline Própria IES & 44 \\
\hline ProUni Integral & 25 \\
\hline ProUni Parcial & 11 \\
\hline Governo Estadual & 4 \\
\hline Governo Municipal & 2 \\
\hline Entidades Externas & 3 \\
\hline Outros & 11 \\
\hline Total & 100 \\
\hline
\end{tabular}

Fonte: Inep (2010)

\subsubsection{Docentes}

Considerando que muitos docentes atuam em mais de uma instituição, é relevante utilizar o conceito de "funções docentes" para definir a participação dos docentes nas

\footnotetext{
293 Como o Fies, que é do Governo Federal, ou programas de financiamento estudantil dos governos estaduais ou municipais, entidades externas ou da própria instituição em que o aluno estuda.

${ }^{294}$ Como o ProUni, que é do Governo Federal, ou programas de bolsa dos governos estaduais ou municipais, de entidades externas ou da própria instituição em que o aluno estuda.
} 
instituições em que desempenham tarefas. No Brasil, em 2010, havia 315.535 docentes no ensino superior brasileiro, correspondentes a 366.882 funções docentes, as quais representam vínculo institucional. Desses totais, encontravam-se em exercício, em 2010, 300.078 docentes ou 345.335 funções docentes (INEP, 2012b).

Para medir as características do corpo docente de uma instituição, é importante verificar o regime de trabalho docente e a titulação. Os regimes de trabalho são: (i) de dedicação exclusiva ou tempo integral; (ii) de dedicação parcial; e (iii) horista.

A LDB estabelece para as universidades que (i) um terço do corpo docente deve possuir o regime de trabalho em tempo integral; e (ii) um terço do corpo docente, pelo menos, deve possuir titulação acadêmica de mestrado ou doutorado. Os centros universitários, nos termos do Decreto $n^{0} 5.786 / 06$, devem possuir (i) um quinto do corpo docente com contrato em tempo integral; e (ii) um terço do corpo docente, pelo menos, com titulação acadêmica de mestrado ou doutorado.

Abaixo a situação do regime de trabalho dos docentes nas instituições públicas e privadas entre 2002 e 2010 :

Tabela 20 - Evolução da participação percentual dos diferentes tipos de regime de trabalho dos docentes por categoria administrativa (pública e privada) Brasil - 2002 - 2010

\begin{tabular}{c|c|c|c|c}
\hline $\begin{array}{c}\text { Categoria } \\
\text { Administrativa }\end{array}$ & Ano & $\begin{array}{c}\text { Tempo Integral } \\
\mathbf{( \% )}\end{array}$ & $\begin{array}{c}\text { Tempo Parcial } \\
\mathbf{( \% )}\end{array}$ & $\begin{array}{c}\text { Horista } \\
\mathbf{( \% )}\end{array}$ \\
\hline \multirow{4}{*}{ Pública } & $\mathbf{2 0 0 2}$ & 75,9 & 18,5 & 5,6 \\
& $\mathbf{2 0 0 4}$ & 73,3 & 18,6 & 8,1 \\
& $\mathbf{2 0 0 6}$ & 74,1 & 16,3 & 9,6 \\
& $\mathbf{2 0 0 8}$ & 76,1 & 16,2 & 7,7 \\
Privada & $\mathbf{2 0 1 0}$ & 80,2 & 12,9 & 6,8 \\
\hline & $\mathbf{2 0 0 2}$ & 16,3 & 27,9 & 55,8 \\
& $\mathbf{2 0 0 4}$ & 14,5 & 23,8 & 61,7 \\
& $\mathbf{2 0 0 6}$ & 16,5 & 23,2 & 60,3 \\
& $\mathbf{2 0 0 8}$ & 18,8 & 23,5 & 57,7 \\
\hline
\end{tabular}

Fonte: Inep (2012b)

De acordo com os dados da tabela acima, nota-se que no setor público predominam as funções docentes em tempo integral (em porcentagens acima de $73 \%$ no período analisado), enquanto no setor privado as funções docentes horistas prevalecem, ainda que tenham diminuído de 55,8\% em 2002 para 48\% em 2010. Nota-se também que os regimes integral e parcial aumentaram seus percentuais de participação no setor privado, sobretudo a partir de 2008, quando os regimes em tempo integral passaram de 18,8\% em 2008 para $24 \%$ em 2010; e os regimes de tempo parcial passaram de $23,5 \%$ em 2008 para $28 \%$ em 
2010

Abaixo dados a respeito da titulação do corpo docente:

Tabela 21 - Evolução da participação percentual da titulação docente por categoria administrativa $-2001-2006-2010$

\begin{tabular}{|c|c|c|c|c|c|c|}
\hline \multirow[b]{2}{*}{ Ano } & \multicolumn{3}{|c|}{ Pública } & \multicolumn{3}{|c|}{ Privada } \\
\hline & $\begin{array}{c}\text { Até } \\
\text { Especialização } \\
(\%) \\
\end{array}$ & $\begin{array}{c}\text { Mestrado } \\
\text { (\%) }\end{array}$ & $\begin{array}{c}\text { Doutorado } \\
\text { (\%) }\end{array}$ & $\begin{array}{c}\text { Até } \\
\text { Especialização } \\
(\%) \\
\end{array}$ & $\begin{array}{c}\text { Mestrado } \\
\text { (\%) }\end{array}$ & $\begin{array}{c}\text { Doutorado } \\
\text { (\%) }\end{array}$ \\
\hline 2001 & 37,2 & 26,9 & 35,9 & 52,5 & 35,4 & 12,1 \\
\hline 2006 & 29,4 & 28,3 & 42,3 & 47,6 & 40 & 12,4 \\
\hline 2010 & 21,2 & 28,9 & 49,9 & 41,5 & 43,1 & 15,4 \\
\hline
\end{tabular}

Fonte: Inep (2012b)

Analisando os dados acima, nota-se que (i) no setor público, a partir de 2006, predominam doutores, com percentuais acima de 42,3\%; e (ii) no setor privado predominam mestres e especialistas com percentuais acima de $85 \%$ nos anos analisados. ${ }^{295}$. As possíveis razões para essa diferença de titulação entre os docentes do setor público e privado, para Gladys Barreyro (2008, p. 49), são: (i) “a contratação de doutores implica maiores custos, então se cumpre a porcentagem da lei com a contratação de mestres com menor custo"; e (ii) "a existência de cursos de pós-graduação, maiormente nas IES públicas, implica maior utilização de doutores, contratados em regime de tempo integral".

O setor privado tem visão crítica sobre os percentuais mínimos de mestres e doutores. A esse respeito, Celso Frauches (2012), colunista do site da ABMES, afirma:

[...] não há nenhum fundamento legal e nem pesquisas científicas que comprovem que o doutor é peça fundamental para a qualidade de um curso de graduação. Eu disse de graduação: tecnólogos, bacharelados e licenciaturas. É puro achismo dos doutores que elaboraram ou conduziram a elaboração das fórmulas do CPC e dos critérios de avaliação dos atuais instrumentos adotados pelo Inep. Por outro lado, não há doutores suficientes no Brasil para o atendimento aos atuais indicadores para os mais de trinta mil cursos de graduação em funcionamento, exceto em pouquíssimas e restritas áreas.

Para lidar com essa questão, houve o Projeto de Lei ${ }^{0} 220 / 2010$, comentado no item 2.3.1 acima.

\footnotetext{
${ }^{295}$ Meta 13 do Projeto de Lei no 8.035/2010, que trata do PNE 2011-2020, estabelece: "elevar a qualidade da educação superior pela ampliação da atuação de mestres e doutores nas instituições de educação superior para setenta e cinco por cento, no mínimo, do corpo docente em efetivo exercício, sendo, do total, trinta e cinco por cento doutores". Considerando os resultados apresentados no Censo de 2010, nota-se que os percentuais projetados, a despeito das disparidades regionais, são atendidos pelo conjunto de instituições púlicas. No entanto, o setor privado ainda não alcançou esses percentuais. Dessa forma, para o Inep (2012), o cumprimento dessa meta tende a estar condicionado preponderantemente ao desempenho da categoria privada.
} 
De acordo com dados do Inep (2012, p. 53), o "típico" docente vinculado às instituições de ensino superior públicas é do sexo masculino, possui 45 anos de idade, título de doutor e atua em regime de trabalho em tempo integral. Nas instituições de ensino superior do setor privado, diferentemente, o "típico" docente é mais jovem, com 33 anos, possui título de mestrado e atua como horista. Assim como nas públicas, predominam docentes do sexo masculino nas instituições privadas.

Abaixo dados sobre a atuação docente, nas categorias pública e privada:

Tabela 22 - Atuação Docente por Categoria Administrativa (Pública e Privada) Brasil - 2010

\begin{tabular}{|c|c|c|c|c|}
\hline \multirow[t]{3}{*}{ Atuação Docente } & \multicolumn{4}{|c|}{ Categoria Administrativa } \\
\hline & \multicolumn{2}{|l|}{ Privada } & \multicolumn{2}{|c|}{ Pública } \\
\hline & $\begin{array}{c}\text { Total de Funções } \\
\text { Docentes }\end{array}$ & $(\%)^{296(1)}$ & $\begin{array}{c}\text { Total de Funções } \\
\text { Docentes }\end{array}$ & $(\%)$ \\
\hline $\begin{array}{l}\text { Graduação a } \\
\text { Distância } 97\end{array}$ & 5.063 & 2,4 & 3.446 & 2,6 \\
\hline Extensão & 29.907 & 13,9 & 30.054 & 23 \\
\hline Gestão & 38.373 & 17,9 & 24.539 & 18,8 \\
\hline Graduação & 208.538 & 97,2 & 121.852 & 93,2 \\
\hline Presencial & & & & \\
\hline $\begin{array}{l}\text { Pós-Graduação a } \\
\text { Distância }\end{array}$ & 78 & 0,0 & 238 & 0,2 \\
\hline $\begin{array}{l}\text { Pós-Graduação } \\
\text { Presencial }\end{array}$ & 7.221 & 3,4 & 28.812 & 22 \\
\hline Sequencial & 1.844 & 0,9 & 37 & 0,0 \\
\hline Pesquisa & 25.101 & 11,7 & 52.204 & 39,9 \\
\hline
\end{tabular}

De acordo com os dados da tabela acima ${ }^{298}$, verifica-se que, nas instituições públicas, os docentes estão envolvidos em mais atividades do que nas instituições privadas. A atuação em atividades de extensão, pós-graduação e pesquisa é maior nas instituições públicas.

É possível comparar as maiores instituições públicas e privadas com relação ao número de docentes. Abaixo a lista das dez IES com maior número de doutores, pósdoutores e livre-docentes, em $2005^{299}$. Destaca-se que nesta lista não aparece nenhuma instituição privada:

\footnotetext{
296 Segundo o Inep (2012b), “Os percentuais foram calculados, por categoria administrativa, em relação ao total de funções docentes em exercício, quais sejam: 214.546 para a categoria privada e 130.789 para a pública".

${ }^{297}$ Segundo o Inep (2012b), não foram coletadas informações relativas à tutoria.

${ }^{298}$ Inep (2012b, p. 54) destaca, com relação aos dados de atuação docente, que o mesmo docente pode atuar em mais de uma atividade (como também em mais de uma categoria administrativa).

${ }^{299}$ Não localizamos este dado consolidado com relação a nenhum outro ano.
} 
Tabela 23 - As dez IES com o número de doutores, pós-doutores e livre-docentes mais elevado - Brasil - 2005

\begin{tabular}{|c|c|c|c|c|c|}
\hline & IES & $\mathbf{U F}$ & $\begin{array}{c}\text { Categoria } \\
\text { Administrativa }\end{array}$ & $\begin{array}{c}\text { Organização } \\
\text { Acadêmica }\end{array}$ & $\begin{array}{l}\mathbf{N}^{0} \text { de doutores } \\
\text { pós-doutores e } \\
\text { livre-docentes }\end{array}$ \\
\hline $1^{\mathrm{a}}$ & Universidade de São Paulo - USP & SP & Universidade & Pública & 2.765 \\
\hline $2^{a}$ & $\begin{array}{l}\text { Universidade Estadual Paulista } \\
\text { Júlio de Mesquita Filho - Unesp }\end{array}$ & SP & Universidade & $\begin{array}{l}\text { Pública } \\
\text { Estadual }\end{array}$ & 2.629 \\
\hline $3^{\mathrm{a}}$ & $\begin{array}{l}\text { Universidade Federal do Rio de } \\
\text { Janeiro-UFRJ }\end{array}$ & RJ & Universidade & $\begin{array}{l}\text { Pública } \\
\text { Federal }\end{array}$ & 2.297 \\
\hline $4^{a}$ & $\begin{array}{l}\text { Universidade do Estado do Rio de } \\
\text { Janeiro - Uerj }\end{array}$ & $\mathrm{RJ}$ & Universidade & $\begin{array}{l}\text { Pública } \\
\text { Estadual }\end{array}$ & 2.237 \\
\hline $5^{\mathrm{a}}$ & $\begin{array}{l}\text { Universidade Estadual de Campinas } \\
\text { - Unicamp }\end{array}$ & $\mathrm{SP}$ & Universidade & $\begin{array}{l}\text { Pública } \\
\text { Estadual }\end{array}$ & 1.790 \\
\hline $6^{\mathbf{a}}$ & $\begin{array}{l}\text { Universidade Federal de Minas } \\
\text { Gerais - UFMG }\end{array}$ & MG & Universidade & $\begin{array}{l}\text { Pública } \\
\text { Federal }\end{array}$ & 1.610 \\
\hline $7^{\mathrm{a}}$ & $\begin{array}{l}\text { Universidade Federal do Rio } \\
\text { Grande do Sul - UFRGS }\end{array}$ & RS & Universidade & $\begin{array}{l}\text { Pública } \\
\text { Federal }\end{array}$ & 1.383 \\
\hline $8^{a}$ & $\begin{array}{l}\text { Universidade Federal de Santa } \\
\text { Catarina-UFSC }\end{array}$ & $\mathrm{SC}$ & Universidade & $\begin{array}{l}\text { Pública } \\
\text { Federal }\end{array}$ & 1.168 \\
\hline $9^{a}$ & $\begin{array}{l}\text { Universidade Federal } \\
\text { Pernambuco - UFPE }\end{array}$ & $\mathrm{PE}$ & Universidade & $\begin{array}{l}\text { Pública } \\
\text { Federal }\end{array}$ & 1.074 \\
\hline 10 & $\begin{array}{l}\text { Universidade Federal da Bahia - } \\
\text { UFBA }\end{array}$ & $\mathrm{BA}$ & Universidade & $\begin{array}{l}\text { Pública } \\
\text { Federal }\end{array}$ & 937 \\
\hline
\end{tabular}

Considerando a titulação de mestre, doutor, pós-doutor e livre-docente, das dez instituições com maior número de docentes, em 2005, oito são públicas:

Tabela 24 - As dez IES com o número de mestres, doutores, pós-doutores e livredocentes mais elevado - Brasil - 2005

\begin{tabular}{|c|c|c|c|c|c|}
\hline & IES & $\mathbf{U F}$ & $\begin{array}{c}\text { Categoria } \\
\text { Administrativa }\end{array}$ & $\begin{array}{l}\text { Organização } \\
\text { Acadêmica }\end{array}$ & $\begin{array}{c}\mathbf{N}^{0} \text { de mestres, } \\
\text { doutores, pos- } \\
\text { doutores e livre- } \\
\text { docentes }\end{array}$ \\
\hline $1^{\mathrm{a}}$ & $\begin{array}{c}\text { Universidade do Estado do Rio } \\
\text { de Janeiro - UERJ }\end{array}$ & $\mathrm{RJ}$ & Universidade & $\begin{array}{l}\text { Pública } \\
\text { Estadual }\end{array}$ & 3.038 \\
\hline $2^{\mathrm{a}}$ & $\begin{array}{l}\text { Universidade Federal do Rio de } \\
\text { Janeiro - UFRJ }\end{array}$ & $\mathrm{RJ}$ & Universidade & $\begin{array}{l}\text { Pública } \\
\text { Federal }\end{array}$ & 3.023 \\
\hline $3^{\mathrm{a}}$ & $\begin{array}{l}\text { Universidade Estadual Paulista } \\
\text { Júlio de Mesquita Filho - Unesp }\end{array}$ & SP & Universidade & $\begin{array}{l}\text { Pública } \\
\text { Estadual }\end{array}$ & 2.958 \\
\hline $4^{a}$ & $\begin{array}{c}\text { Universidade de São Paulo - } \\
\text { USP }\end{array}$ & SP & Universidade & $\begin{array}{l}\text { Pública } \\
\text { Estadual }\end{array}$ & 2.873 \\
\hline $5^{a}$ & Universidade Paulista - Unip & SP & Universidade & Privada & 2.271 \\
\hline $6^{\mathrm{a}}$ & $\begin{array}{c}\text { Universidade Federal de Minas } \\
\text { Gerais - UFMG }\end{array}$ & MG & Universidade & $\begin{array}{l}\text { Pública } \\
\text { Federal }\end{array}$ & 2.249 \\
\hline $7^{\mathrm{a}}$ & $\begin{array}{c}\text { Universidade Federal do Rio } \\
\text { Grande do Sul - UFRGS }\end{array}$ & RS & Universidade & $\begin{array}{l}\text { Pública } \\
\text { Federal }\end{array}$ & 1.965 \\
\hline
\end{tabular}

300 Cadastro Nacional de Docentes da Educação Superior de 2005. Disponível em: $<$ http://download.inep.gov.br/download/superior/2004/censosuperior/Resumo_Tecnico_Cadastro_Docentes2 005_1.pdf>. Acesso em: 08/12/2012. 
Tabela 24 - As dez IES com o número de mestres, doutores, pós-doutores e livredocentes mais elevado - Brasil - 2005

\begin{tabular}{|c|c|c|c|c|c|}
\hline & IES & $\mathbf{U F}$ & $\begin{array}{c}\text { Categoria } \\
\text { Administrativa }\end{array}$ & $\begin{array}{c}\text { Organização } \\
\text { Acadêmica }\end{array}$ & $\begin{array}{c}\mathrm{N}^{0} \text { de mestres, } \\
\text { doutores, pos- } \\
\text { doutores e livre- } \\
\text { docentes }\end{array}$ \\
\hline $8^{\mathrm{a}}$ & $\begin{array}{l}\text { Universidade Estadual de } \\
\text { Campinas - Unicamp }\end{array}$ & SP & Universidade & $\begin{array}{l}\text { Pública } \\
\text { Estadual }\end{array}$ & 1.902 \\
\hline $9^{a}$ & $\begin{array}{l}\text { Pontifícia Universidade Católica } \\
\text { de Minas Gerais - PUC Minas }\end{array}$ & MG & Universidade & Privada & 1.756 \\
\hline 10 & $\begin{array}{c}\text { Universidade Federal de Santa } \\
\text { Catarina - UFSC }\end{array}$ & $\mathrm{SC}$ & Universidade & $\begin{array}{l}\text { Pública } \\
\text { Federal }\end{array}$ & 1.567 \\
\hline
\end{tabular}
Fonte: Inep ${ }^{301}$

\subsubsection{Alunos}

\subsubsection{Taxa de Escolarização}

Entre os anos de 2001 e 2009, verificou-se uma significativa expansão do atendimento no ensino superior - a taxa de escolarização bruta passou de 15,1\%, em 2001, para 26,7\% em 2009; enquanto a taxa líquida passou de 8,9\% em 2001 para 14,4\% em $2009^{302}$.

O PNE de 2001 estabelecia como meta, para o final da década, alcançar o provimento do ensino superior para, pelo menos, $30 \%$ da população de 18 a 24 anos. A Meta 12 do Projeto de Lei $n^{\circ} 8.035$ de 2010, relativo ao PNE 2011-2020, aumenta a taxa bruta para $50 \%$, e a líquida para $33 \%$ da população de 18 a 24 anos.

Abaixo, a evolução da taxa de escolarização bruta e líquida no ensino superior brasileiro entre os anos de 2001, 2006 e 2009, por região:

\footnotetext{
301 Cadastro Nacional de Docentes da Educação Superior de 2005. Disponível em: $<$ http://download.inep.gov.br/download/superior/2004/censosuperior/Resumo_Tecnico_Cadastro_Docentes2 005 1.pdf>. Acesso em: 08/12/2012.

${ }^{302}$ Taxa de escolarização bruta consiste em um indicador que permite comparar o total de matrículas de determinado nível de ensino com a população na faixa etária teoricamente adequada a esse nível. O indicador taxa de escolarização líquida, por sua vez, identifica o percentual da população matriculada em determinado nível de ensino na faixa etária teoricamente adequada em relação à população na faixa etária teoricamente adequada ao mesmo nível de ensino (INEP, 2012, p. 35).
} 
Tabela 25 - Evolução da taxa de escolarização no ensino superior por região $2001-2006-2009$

\begin{tabular}{c|c|c|c|c|c|c}
\hline & \multicolumn{3}{|c|}{ Escolarização Bruta } & \multicolumn{3}{c}{ Escolarização Líquida } \\
\hline $\begin{array}{c}\text { Brasil/ } \\
\text { Reg. }\end{array}$ & $\mathbf{2 0 0 1}$ & $\mathbf{2 0 0 6}$ & $\mathbf{2 0 0 9}$ & $\mathbf{2 0 0 1}$ & $\mathbf{2 0 0 6}$ & $\mathbf{2 0 0 9}$ \\
\hline CO & 18,2 & 27,0 & 32,6 & 9,7 & 14,8 & 17,9 \\
NE & 9,1 & 14,3 & 18,4 & 5,1 & 7,1 & 9,4 \\
NO & 11,3 & 17,0 & 23,7 & 5,2 & 7,6 & 11,0 \\
SE & 17,3 & 26,7 & 30,1 & 10,9 & 15,7 & 16,8 \\
SU & 21,3 & 29,7 & 33,5 & 12,7 & 17,1 & 19,2 \\
Brasil & 15,1 & 22,6 & 26,7 & 8,9 & 12,6 & 14,4 \\
\hline
\end{tabular}

Fonte: Inep (2012b)

De acordo com os resultados da Pesquisa Nacional por Amostra de Domicílios (Pnad)/IBGE, a escolaridade média ${ }^{303}$ da população de 18 a 24 anos apresentou um incremento de 1,6 anos de estudo no período de 2001 a 2009. Em 2009, para essa faixa etária, a média era de 9,4 anos de estudo. Segundo o Inep (2012b, p. 36), “os resultados ora apresentados indicam que, em média, a população de 18 a 24 anos passou a frequentar o ensino médio; regionalmente, essa realidade ainda não havia sido alcançada pelo Norte e Nordeste".

Como se verifica pelos dados abaixo, houve uma diminuição na desigualdade referente à escolaridade média entre as regiões e as localidades urbana e rural no Brasil entre os anos 2001 e 2009:

Tabela 26 - Número médio de anos de estudo para a faixa etária de 18 a 24 anos para as localidades rural e urbana - Brasil e Regiões - 2001 e 2009

\begin{tabular}{|c|c|c|c|}
\hline Brasil/Região & Localizacão & 2001 & 2009 \\
\hline \multirow{3}{*}{ Brasil } & Total & 7,9 & 9,4 \\
\hline & Urbana & 8,3 & 9,8 \\
\hline & Rural & 5,1 & 7,5 \\
\hline \multirow[t]{3}{*}{ Norte } & Total & 7,4 & 8,8 \\
\hline & Urbana & 7,4 & 9,1 \\
\hline & Rural & 5,0 & 7,1 \\
\hline \multirow[t]{3}{*}{ Centro-Oeste } & Total & 7,9 & 9,8 \\
\hline & Urbana & 8,2 & 9,9 \\
\hline & Rural & 6,1 & 8,5 \\
\hline
\end{tabular}

${ }^{303}$ Escolaridade média é sinônimo do número médio de anos de estudo. Tal como definido pelo IBGE, a variável anos de estudo corresponde ao período estabelecido em função da série e do nível ou grau mais elevado alcançado pela pessoa, considerando a última série concluída com aprovação (IBGE, 2010). 
Tabela 26 - Número médio de anos de estudo para a faixa etária de 18 a 24 anos para as localidades rural e urbana - Brasil e Regiões - 2001 e 2009

\begin{tabular}{c|c|c|c}
\hline \multicolumn{2}{c}{} & \multicolumn{2}{c}{ (conclusão) } \\
\hline Brasil/Região & Localização & $\mathbf{2 0 0 1}$ & $\mathbf{2 0 0 9}$ \\
\hline Nordeste & Total & $\mathbf{6 , 3}$ & $\mathbf{8 , 5}$ \\
& Urbana & 7,1 & 9,0 \\
& Rural & 4,1 & 6,9 \\
& & & $\mathbf{1 0 , 1}$ \\
Sudeste & Total & $\mathbf{8 , 8}$ & 10,2 \\
& Urbana & 9,0 & 8,4 \\
& Rural & 6,1 & $\mathbf{9 , 9}$ \\
& Total & $\mathbf{8 , 6}$ & 10,1 \\
& Urbana & 8,9 & 8,9 \\
\hline
\end{tabular}

Fonte: Inep (2012b)

No período analisado, as Regiões Sudeste, Sul e Centro-Oeste mantiveram escolaridade média superior à média nacional.

Segundo Inep (2012b, p. 38), “a elevação da escolaridade média da população de 18 a 24 anos é acompanhada por uma tendência geral de aproximação da escolaridade da população negra da respectiva faixa etária em relação aos jovens brancos. Em 2009, os jovens brancos possuíam 10,2 anos de estudos, e os jovens negros tinham, comparativamente, 1,5 anos a menos, ou seja, 8,7 anos de estudo".

Nesse contexto, a Meta 8 do Projeto de Lei no 8.035 de 2010 (PNE 2011-2010) prevê a elevação da "escolaridade média da população de dezoito a vinte e quatro anos de modo a alcançar mínimo de doze anos de estudo para as populações do campo, da região de menor escolaridade no país e dos vinte e cinco por cento mais pobres, bem como igualar a escolaridade média entre negros e não negros, com vistas à redução da desigualdade educacional".

Abaixo, tabela sobre a escolaridade de subgrupos populacionais, com faixa etária de 18 a 24 anos:

Tabela 27 - Número Médio de Anos de Estudo para a Faixa Etária de 18 a 24 anos, para Alguns Subgrupos Populacionais - Brasil - 2001, 2005 e 2009

\begin{tabular}{l|c|c|c}
\hline \multicolumn{1}{c}{ Subgrupos/Ano } & $\mathbf{2 0 0 1}$ & $\mathbf{2 0 0 5}$ & $\mathbf{2 0 0 9}$ \\
\hline $1^{\text {o }}$ quarto da distribuição de renda & 7,4 & 8,4 & 9,2 \\
Campo & 5,1 & 6,4 & 7,5 \\
Região Nordeste & 6,3 & 7,4 & 8,5 \\
Negros (pretos e pardos) & 6,8 & 8,0 & 8,7 \\
Brancos & 8,8 & 9,6 & 10,2 \\
Média Nacional & 7,9 & 8,8 & 9,4 \\
\hline
\end{tabular}

Fonte: INEP (2012b) 
de número de anos de estudo com base nas regiões brasileiras (com taxas menores nas regiões Norte e Nordeste), entre as populações urbana e rural (com taxas menores para a população rural), racias (com taxas menores para a população negra) e de renda (com maior número de anos de estudo para o $1^{\circ}$ quarto da distribuição de renda brasileira).

\subsubsection{Perfil do aluno}

A respeito do perfil do aluno, a educação superior brasileira, em 2010, era predominantemente formada por pessoas do sexo feminino, vinculadas a uma instituição privada, que quando matriculadas em cursos presenciais, são atendidas no período notuno (INEP, 2012b).

Segundo Inep (2012b, p. 57), o perfil dos alunos de graduação dos cursos presencial e a distância difere sobretudo com relação à idade, com predomínio de pessoas mais velhas nos últimos:

Tabela 28 - Perfil do Aluno de Graduação por Modalidade de Ensino - Brasil - 2010

\begin{tabular}{l|cc}
\hline \multirow{1}{*}{ Atributo } & \multicolumn{2}{c}{ Modalidade de Ensino } \\
\cline { 2 - 3 } & Presencial & A Distância \\
\hline Sexo & Feminino & Feminino \\
Categoria Administrativa & Privada & Privada \\
Grau Acadêmico & Bacharelado & Licenciatura \\
Turno & Noturno & - \\
Idade (Matrícula) & 21 & 29 \\
Idade (Ingresso) & 19 & 28 \\
Idade (Concluinte) & 23 & 31 \\
\hline
\end{tabular}

Fonte: INEP (2012b)

Na graduação presencial, em 2009, as mulheres correspondiam a 55,1\% do total de matrículas e a 58,8\% dos concluintes. Na modalidade de educação a distância, em 2009, as mulheres correspondiam a $69,2 \%$ das matrículas e $76,2 \%$ dos concluintes.

Com relação ao grau acadêmico, nos cursos presenciais predomina o bacharelado e, nos cursos a distância, a licenciatura (INEP, 2012b).

Com relação às áreas de conhecimento, verifica-se predominância feminina nas áreas de Educação, Humanidades e Artes, Ciências Sociais, Negócios e Direito, Saúde e Bem-estar Social e Serviço; e predominância masculina nas áreas de Ciências, Matemática e Computação, Engenharia, Produção e Construção e Agricultura e Veterinária. 


\subsubsection{Ações Afirmativas}

Na graduação presencial das instituições de ensino superior públicas, 51.494 dos ingressos de 2010 ocorreram por meio de programa de reserva de vagas, o que representa um incremento de 41,9\% em relação ao ano anterior (2009). Entre os tipos de programa de reserva (étnico, procedente do ensino público, social/renda familiar, pessoa com deficiência e outros), o que apresentou maior participação foi o destinado a alunos procedentes do ensino público (64\%), seguido do étnico (27\%), social/renda familiar (6\%) e os restantes (3\%) (INEP, 2012b).

\subsection{Considerações finais}

Em vista dos números apresentados acima e da estrutura da educação superior brasileira, fica evidente que uma grande parcela dos estudantes egressos do ensino médio brasileiro seguirá seus estudos no ensino superior privado, o qual, hoje, predomina em número de vagas, matrículas e instituições. Contudo, esse sistema apenas estará aberto àqueles estudantes que possuírem condições econômicas para arcar com seus estudos ou que receberem auxílio governamental ou privado, mediante os programas de financiamento de estudo reembolsáveis ou não, e bolsas de estudo, excluindo os demais.

Dentro do mercado educacional brasileiro, o estudante que busca uma vaga no setor privado procura uma instituição que melhor se enquadra nas suas expectativas. Nesse contexto, muitas vezes, o estudante procura uma instituição que apresenta custo compatível com a sua posição social, deixando a relação de ser regida, primordialmente, pela busca da qualidade do ensino, pela ideia de pleno desenvolvimento do educando e preparo para o exercício da cidadania, para privilegiar o custo-benefício.

Além disso, com um grande número de vagas e um processo seletivo menos concorrido, o setor privado recebe um grande número de alunos oriundos de uma educação básica de baixa qualidade, que apresentam muitas deficiências de formação, que deixam marcas nos profissionais formados ${ }^{304}$.

Em vista desse cenário, trataremos no próximo capítulo da lógica econômica. A

\footnotetext{
${ }^{304}$ A seguir trecho de uma entrevista proferida por um professor de um cursinho pré-vestibular popular destinado a alunos de baixa renda, oriundos do ensino público brasileiro: "Nós temos um número bastante grande de alunos que poderiam ser considerados analfabetos funcionais, que têm uma dificuldade muito grande de compreensão do que é passado. A maioria é representada por alunos que nunca tiveram determinada matéria, porque nunca lhes foi passado na escola pública." (ZAGO, 2009, p. 266).
} 
iniciativa privada rege-se por uma lógica própria, voltada, sobretudo, à busca do lucro para distribuição aos acionistas. Por outro lado, a educação é base para a cidadania, para o desenvolvimento da pessoa, para a atuação do homem em sociedade e sua emancipação por meio da compreensão de seus direitos e deveres e, em especial, a educação superior está ligada ao desenvolvimento do país e promoção e difusão do conhecimento por meio de pesquisas. Trata-se de um cenário em que são possíveis embates entre o interesse público que envolve a educação e o interesse privado ligado à atividade. 


\section{CAPÍtULO 3. EDUCAÇÃO COMO SERVIÇO PRESTADO MEDIANTE O DESEMPENHO DE UMA ATIVIDADE EMPRESÁRIA}

O objetivo deste Capítulo é apresentar a educação como um serviço oferecido por empresas educacionais, mediante o desempenho de uma atividade empresária. $\mathrm{O}$ foco de nossa análise será caracterizar a atividade desempenhada por essas empresas, de modo a entender a lógica econômica que as orienta. Dentro desse contexto, trataremos do conceito de externalidades e da ideia desenvolvida por Calixto Salomão Filho (2008) de que os agentes privados têm dificuldades em lidar com atividades que produzem externalidades sociais, como a educação.

\subsection{Atividade empresária, lógica econômica e educação}

Nos termos do artigo 966 do Código Civil Brasileiro: "considera-se empresário quem exerce profissionalmente atividade econômica organizada para a produção ou a circulação de bens ou de serviços", excetuando-se dessa classificação quem "exerce profissão intelectual, de natureza científica, literária ou artística, ainda com o concurso de auxiliares ou colaboradores, salvo se o exercício da profissão constituir elemento de empresa", nos termos do Parágrafo Único do mesmo dispositivo.

Considerando a previsão legal, são características de toda atividade empresária: (i) ser econômica, isto é, criadora de riqueza e dirigida ao mercado, em busca do lucro; (ii) ser organizada e profissional, o que pressupõe uma série de atos e indivíduos interagindo de forma coordenada; e (iii) ter como produtos bens ou serviços (ASCARELLI, 1998, p. 203).

Nos termos do artigo $3^{\circ}$, Parágrafos $1^{\circ}$ e $2^{\circ}$ do Código de Defesa do Consumidor (CDC), "produto é qualquer bem, móvel ou imóvel, material ou imaterial", e "serviço é qualquer atividade fornecida no mercado de consumo, mediante remuneração, inclusive as de natureza bancária, financeira, de crédito e securitária, salvo as decorrentes das relações de caráter trabalhista".

No setor privado, as relações buscam a menor interferência possível do Estado na atividade $^{305}$ e têm como fundamentos a propriedade privada e a autonomia da vontade.

\footnotetext{
${ }^{305}$ Exceto, quando a interferência do Estado é benéfica, na forma de incentivos fiscais ou de benefícios de qualquer outra ordem. A esse respeito, Tooley (1998, p. 267-8) descreve quatro questionamentos de autores neoliberais sobre a intervenção estatal na educação: (i) que a intervenção estatal é "inimiga da liberdade pessoal e política"; (ii) que a intervenção estatal é suscetível de conduzir o currículo a um viés "profissional",
} 
O agente privado, dentro da lógica econômica, possui como objetivos no desempenho de sua atividade, dentre outros: a busca pelo lucro; a manutenção e o incremento da posição da empresa no mercado (market share); o oferecimento de um produto competitivo; a redução de custos; e a criação de escala na forma de produção buscando eficiência e produtividade.

Em linha com essas características, a educação pode ser oferecida mediante o exercício de uma atividade empresária. Nesse caso, a educação adquire a forma de um serviço prestado pelas instituições de ensino com fins lucrativos aos seus alunos consumidores. Nesse contexto, a instituição de ensino deve constituir-se como uma empresa (profissional, organizada), que oferece educação (serviço) a um determinado mercado consumidor, mediante remuneração, visando lucro para distribuição aos seus sócios.

A esse respeito, Sampaio (2000, p. 88) afirma:

O setor privado de ensino superior, sobretudo seu segmento não-confessional, que é voltado ao atendimento de massa, é financiado, fundamentalmente, com recursos privados. Como qualquer outro setor empresarial, o empreendimento tem custo de manutenção e de investimento e visa à obtenção do lucro para os seu(s) proprietário(s). A prestação desse serviço específico, que é ensino superior, faz-se mediante a cobrança de taxas de matrículas e de anuidades do estudante.

Sobre a transformação da educação num serviço oferecido por empresas, é interessante analisar algumas considerações de Boaventura de Sousa Santos (2000, p. 217 8) sobre as diferenças entre a lógica da universidade e a lógica empresarial. Segundo o autor (2000, p. 217-8):

\begin{abstract}
A lógica da rentabilidade do investimento tende a favorecer o curto prazo em detrimento do longo prazo, e por isso só um número reduzido de empresas faz investimento estratégico, orientado para o médio ou longo prazo. A aplicação desta lógica ao desempenho da universidade tende a favorecer utilidades de curto prazo, sejam elas cursos curtos em detrimento de cursos longos, formações unidireccionadas em detrimento de formações complexas, investigação competitiva em detrimento de investigação précompetitiva, reciclagem profissional em detrimento de elevação do nível cultural, etc.. E isto é tanto mais perigoso quanto é certo que, como referirei adiante, a universidade é uma das poucas instituições da sociedade contemporânea onde é ainda possível pensar a longo prazo e agir em função dele [...]
\end{abstract}

Na mesma linha, Winch (1996, p. 19) ressalta que o sistema educacional busca a

à custa da manutenção de um patrimônio cultural; (iii) que essa intervenção fortalece o poder de ensino dos produtores de educação - professores e funcionários educacionais - permitindo que seus preconceitos dominem a agenda educacional; e (iv) que a intervenção gera burocracias inúteis e dispendiosas que não fornecem um serviço com custo-benefício. 
criação e transmissão de valores, implicando um relacionamento de longo prazo com o aluno, o que seria uma conduta não comum aos empreendimentos privados, que buscam respostas rápidas às suas demandas.

Quando analisamos a atividade desenvolvida por empresas de educação no Brasil, verificamos que as considerações de Santos (2000) se aplicam. A Anhanguera, como veremos no Capítulo 4, oferece diversas utilidades de curto prazo, como cursos com duração reduzida, a distância e de formação tecnológica. Tal fato demonstra que a absorção pelas instituições de ensino superior privadas da lógica econômica leva à busca de rentabilidades imediatas e do favorecimento do curto prazo ao invés do longo prazo.Essa diferença de expectativa quanto ao resultado dos investimentos, se de longo ou de curto prazo, foi também identificada por Ryon Braga (2011), consultor financeiro da área educacional:

\begin{abstract}
Na maioria dos casos, o custo/benefício de adquirir uma instituição assim não é vantajoso, principalmente se o comprador tiver como sócio fundos de investimento, que precisam sair do investimento em curto período de tempo. O tempo necessário para se recuperar minimamente uma universidade nestas condições é de quatro a seis anos. $\mathrm{O}$ que os investidores financeiros não conseguiram ainda enxergar é que educação, ainda que possa ser um negócio muito lucrativo, não é como os demais setores da economia em que você investe (aporta capital), conserta (reestrutura a empresa) e vende com lucro dois ou três anos depois. Para "consertar" uma universidade em situação difícil leva, pelo menos, quatro a cinco anos. A Estácio é um bom exemplo disso. O GP (atual sócio-gestor da empresa), considerado um investidor com altíssima expertise em gestão, levou três anos para "arrumar" a casa e, levará outros três anos para colher os frutos disto. A lógica de negócios dos investidores financeiros, versus a situação atual das grandes instituições de ensino no Brasil é uma combinação que dificulta muito o fechamento de bons negócios. Há perspectiva e possibilidade de mais de 150 negócios de fusões e aquisições no setor educacional em 2011 e 2012, mas, se a lógica de investimento não for revista, talvez não se concretizem nem um terço disto. Quem não tem visão de longo prazo, de sustentabilidade e perenidade de uma empresa, não deve investir em educação. Se você olha apenas o aumento percentual da geração operacional de caixa a cada trimestre, escolha outro setor para investir.
\end{abstract}

\title{
3.2 Como construir uma empresa de educação de sucesso
}

Em sua obra The Global Education Industry: Lessons from Private Education in Developing Countries, James Tooley (2001) analisa instituições de ensino privadas em diferentes países emergentes e lista uma série de características para a formação de uma instituição de ensino privada de sucesso. O referido autor divide as características de acordo com os seguintes critérios: (i) lucratividade; (ii) eficiência educacional; e (iii) equidade.

Com relação à lucratividade, segundo Tooley (2001, pp. 44-5), para a manutenção e 
crescimento de sua participação no mercado, uma empresa de educação de sucesso deve:

(i) preocupar-se em promover o nome de sua marca, sendo essa prática especialmente importante para as redes de escolas e universidades ${ }^{306}$; (ii) procurar ser inovadora, particularmente em termos de tecnologia, para manter e atrair consumidores; (iii) procurar expandir seus negócios no âmbito local, regional e até internacional e buscar os benefícios de integrações horizontais (pela aquisição de outras instituições), laterais (atuando em novas áreas da educação ou em outros meios como televisão e rádio) e verticais (pela atuação na área de publicações e desenvolvimento de softwares ${ }^{307}$ ); e (iv) utilizar o sistema de franquias em sua expansão, recebendo royalties, ou vendendo materiais pedagógicos ${ }^{308}$.

Ainda com relação à lucratividade, para o financiamento e administração de uma empresa educacional de sucesso, os seguintes pontos devem ser observados, segundo Tooley (2001, p. 45-6): (i) gerenciar cuidadosamente os riscos de não pagamento das

\footnotetext{
${ }^{306}$ As empresas analisadas por Tooley (2001) investem muito no divulgação de suas marcas. Em seu estudo, o autor destacou que essa prática envolve os seguintes aspectos: (i) gastos com publicidade que envolvem em média $10 \%$ do faturamento; (ii) as empresas têm equipes de tempo integral trabalhando com marketing e administração para desenvolver e fortalecer a marca; (iii) uma variedade de métodos e promoções são utilizados para fortalecer a marca; (iv) as empresas podem prosseguir com êxito numa estratégia de marca dupla; (v) pesquisas de marketing independente mostram que a promoção da marca foi bem-sucedida para muitas empresas, apesar de algumas pesquisas da própria empresa mostrarem que a maioria dos clientes ouviu falar dos cursos por meio de indicação boca a boca, em vez de publicidade.

307 Tooley $(2001$, p. 82) destaca que muitas das empresas bem-sucedidas expandiram suas operações por meio de integrações horizontais, adquirindo outras empresas ou instituições, integrações laterais, com a diversificação de suas atividades para outros níveis de educação, ou outros negócios relacionados à educação como recrutamento profissional; outras empresas fizeram integrações verticais, adquirindo empresas de publicação educacional, de desenvolvimento de produtos multimídia. Como exemplos de integração horizontal, Tooley (2001, p. 82-3) citou as instituições brasileiras Objetivo/Unip e COC e Pitágoras, que iniciaram suas atividades como cursos pré-universitários e expandiram suas atividades para outros níveis de ensino, o que ocorreu por meio da aquisição de outras instituições ou aberturas de novas escolas. Como exemplos de integração vertical, Tooley (2001, p. 83) citou o Objetivo, que abriu a universidade Unip, e o COC, que na época estava buscando fazer uma universidade, o que ocorreu depois com o SEB; a Educor da África do Sul, que passou a atuar no ensino secundário e técnico até universidade; e a NIIT da Î́ndia, que passou a oferecer, além dos cursos de informática, oportunidades de entretenimento educacional (edutainment) para crianças e adultos em escolas ou bairros. Na integração lateral, muitas das empresas de educação analisadas por Tooley $(2001$, p. 83) encontraram "sinergia" entre educação e recrutamento profissional, tanto como ferramenta de marketing, como forma de melhorar a experiência educacional oferecida. Tooley $(2001$, p. 84) cita exemplos de empresas de educação que adquiriram agências de recrutamento de profissionais ou o contrário (como a Educor na África do Sul). Com relação às integrações laterais e verticais, Tooley (2001, p. 84) cita COC, Pitágoras e Objetivo/Unip, que atuam em rádio e televisão e outras mídias, inicialmente como uma forma de estender sua atuação em outras mídias educacionais (integração vertical), mas também como uma forma de diversificar o portfólio. O COC, por exemplo, apresentava um sistema combinado de educação e comunicação, com teatro, cinema, TV e rádio, buscando incrementar as atividades culturais dos estudantes. Nas integrações verticais, Tooley $(2001$, p. 85) cita os exemplos do $\mathrm{COC}$ e Objetivo novamente, que possuíam editoras para publicação de livros, apostilas, produtos multimídia, como CD-ROMs, entre outros produtos. Cita também a NIIT que, na época, possuía o maior centro de desenvolvimento de software educacional do mundo, desenvolvendo CD-ROMs e materiais para cursos pela internet.

${ }^{308}$ Tooley (2001, p. 88) afirmou que o sistema de franquias foi uma estratégia importante para a expansão de muitas empresas de educação, como a NIIT, da Índia, que criou um sistema de franquias de centros de computação.
} 
mensalidades, por meio do emprego de uma variedade de técnicas de incentivos e punições; (ii) implantar uma administração de sucesso, com linhas claras de autoridade, papéis claramente definidos, principalmente para os executivos e administradores não executivos, e usando sofisticados sistemas de informação; (iii) garantir que todos os recursos, incluindo espaço, professores e tecnologia, sejam utilizados de forma eficiente, com esforços consideráveis para garantir isso; (iv) empregar tecnologia inovadora para reduzir custos; (v) empregar pesquisadores dedicados a estudar formas mais eficientes de utilização dos recursos existentes; e (vi) ter um capital inicial modesto e financiar sua expansão pela sua autogeração de fluxo de caixa. Tooley (2001, pp. 45-6) destaca também que circunstâncias favoráveis de crédito (como taxas de juros mais baixas, menor exigência de garantias bancárias) tornam interessante tomar empréstimos para investimento e expansão.

Com relação à eficiência, em termos de qualidade educacional, uma empresa educacional de sucesso, para Tooley (2001, p. 46), deve: (i) usar a certificação reconhecida, e ter certificados de formação profissional aprovados pelo órgãos profissionais competentes; (ii) preocupar-se com o controle de qualidade, especialmente para aqueles grupos que desenvolvem suas atividades em redes de ensino ou cadeias de operações; e (iii) procurar empregar tecnologia inovadora para melhorar o processo de aprendizagem.

Com relação à equidade e justiça social, Tooley (2001, p. 47) entende que uma empresa educacional de sucesso, em termos de lucratividade e eficiência educacional, mas que também se preocupe com acesso equitativo, pode: (i) organizar um sistema próprio de financiamento estudantil, que pode ser financiado por meio de doações, mas que deve possuir uma estrutura para ser autofinanciado a médio prazo; (ii) subsidiar algumas vagas para alunos de rendimentos mais baixos; (iii) buscar estabelecer boas relações com o setor público da educação, em parte porque seria politicamente conveniente, mas também porque o governo deve buscar a ajuda do setor privado na melhoria de padrões dentro do setor público; (iv) ter um programa de responsabilidade social, ajudando a comunidade local ou nacional e, ao mesmo tempo, procurando promover a imagem da empresa.

Analisando o caso da Anhanguera, verificamos que ela adota, em geral, todas as prática mencionadas por Tooley (2001) e descritas acima, como veremos no Capítulo 4 da Dissertação.

Ademais, para Tooley (2001, p. 47), é irrelevante para o sucesso de uma empresa ou instituição se ela: (i) recebe doações - o autor destaca que este fato pode inclusive 
diminuir o interesse da companhia em inovar e trabalhar de forma mais eficiente; (ii) é de fins lucrativos ou não lucrativos; (iii) é proprietária ou aluga os imóveis em que exerce suas atividades - o autor destaca que este fato depende de circunstâncias locais.

Muitas das instituições examinadas por Tooley (2001) mostraram preocupação com a manutenção de custos baixos; com o uso eficiente de recursos, como espaço, tecnologia e tempo do professor; e com a busca por inovação. A empresa de ensino de informática e cursos técnicos indiana, NIIT, companhia aberta a que nos referimos no item 2.4.6.2 acima, por exemplo, procura utilizar de forma produtiva todos os seus recursos das $7 \mathrm{~h}$ às 22h. Além disso, a NIIT também reduziu o número de professores qualificados, seus gastos com professores e seu espaço físico - Tooley (2001, p. 69) destaca que, desde o início de suas atividades, a NIIT sempre procurou racionalizar espaço e tempo de contato com os professores. Tooley (2001, p. 72) afirma também que essa empresa efetuou pesquisas para desenvolver métodos de ensino que reduzissem o tempo de contato com os professores e utilizassem de forma mais produtiva o espaço, buscando, por exemplo reduzir o tempo das aulas para a transmissão de um determinado conteúdo. Segundo Tooley (2001, p. 70), essa empresa "desenvolveu um modelo educacional que utiliza 3 tipos de salas - salas de aula, salas de estudo (mind-room) e salas de máquinas (machine room) - que permitiram que um centro com apenas 30 computadores pudesse acomodar até 1.260 estudantes por dia". Outro grupo estudado por Tooley (2001), a Educor, da África do Sul, companhia aberta a que nos referimos no item 2.4.6.2 acima, utiliza salas de aula para o ensino médio de manhã e a mesma sala de aula para outras aulas nos outros períodos para o ensino superior.

No Brasil, Oliveira (2009) descreve uma série de práticas adotadas por empresas educacionais para a redução dos custos no oferecimento da educação. Segundo o autor (2009, p. 744):

Traduzindo, juntam-se classes para atividades de estudo. Como o pagamento de professores é por hora-aula, dependendo do número de classes que são agrupadas, a economia pode ser intensa. Professores de algumas dessas instituições que entrevistei me informaram que elas realizam procedimentos similares de economia. Além dessa de estudos conjuntos na biblioteca, pode-se utilizar de atividades de instrução programada nos laboratórios de informática, contabilizadas como aula na grade curricular, e o engenhoso mecanismo da "aula fictícia". Os professores contratados por hora-aula ganham adicional noturno após as 22 horas. Assim, encerram-se as atividades com os professores nesse horário, ainda que na grade curricular conste mais uma aula. Nesse caso, ou os alunos realizam estas atividades de laboratório de informática e biblioteca, ou simplesmente são dispensados. 


\subsection{A relação entre o aluno consumidor e a instituição fornecedora do serviço educacional}

Nos termos do artigo $2^{\circ}$, do CDC, "consumidor é toda pessoa física ou jurídica que adquire ou utiliza produto ou serviço como destinatário final”,309.

Nos termos do artigo $3^{\circ}$, do $\mathrm{CDC}$, "fornecedor é toda pessoa física ou jurídica, pública ou privada, nacional ou estrangeira, bem como os entes despersonalizados, que desenvolvem atividade de produção, montagem, criação, construção, transformação, importação, exportação, distribuição ou comercialização de produtos ou prestação de serviços".

Nesse sentido, o estudante que se matricula numa instituição de ensino superior assume o papel de um consumidor que contrata um serviço (educação), cujo fornecedor é a instituição $^{310}$.

A instituição atua de forma profissional e organizada, buscando ofertar cursos que atraiam a clientela. Nesse sentido, estão disponíveis no mercado cursos com os mais variados preços ${ }^{311}$ e prazos de duração, com estabelecimentos em diferentes locais, visando

\footnotetext{
309 Nos termos do Parágrafo Único, do artigo $2^{\circ}$ do CDC - "Equipara-se a consumidor a coletividade de pessoas, ainda que indetermináveis, que haja intervindo nas relações de consumo".

310 Winch (1996, p. 100-1) destaca que no mercado em geral há compradores e vendedores, e que os consumidores são facilmente identificáveis. Mas o autor destaca que na educação isso é diferente - não apenas por conta da existência de compradores e usuários do serviço (os pais e as crianças, por exemplo), mas porque não é óbvio quem seja o consumidor da educação. Crianças numa escola não são consumidores como o comprador de um alimento ou de uma massagem. Para Winch, a "educação é algo muito mais complexo que um produto ou um serviço do tipo que são usualmente considerados na teoria econômica. $\mathrm{O}$ cliente está frequentemente numa posição ruim para fazer um julgamento da qualidade do que está recebendo [...], considerando sua satisfação imediata. A experiência mais desconfortável pode ser a mais valiosa para ele do ponto de vista educacional, mas ele pode não se dar conta disso no momento em que recebe a educação, notando isso apenas tempo depois. Além disso, o cliente que paga pelo serviço muito frequentemente não é o usuário do serviço e tem um problema potencial em obter a informação necessária para decidir se o serviço está sendo devidamente ofertado. Tradução livre de: "Education is something much more complex than a product or a service of the kind that is usually considered in economic theory. The client is often in a poor position to make a judgement of the quality of what he is receiving [...], related to his immediate satisfaction. The most uncomfortable experiences may be the most valuable for him from an educational point of view, but he may not realise this until some time later. In addition, the paying client is very often not the user of the service and so has a potencial problem in obtaining the information necessary to deciding whether the service is being properly provided" (WINCH, 1996, p. 101).

${ }^{311}$ Em reportagem publicada na Folha de São Paulo, em 21/06/2010, destaca-se a queda no preço das mensalidades em faculdades particulares. De 1999 a 2009, o valor médio caiu 31\% de R\$ 532 para R\$367, aponta levantamento do Semesp (Sindicato das Entidades Mantenedoras de Estabelecimentos de Ensino Superior no Estado de São Paulo) com 1.084 instituições de todo o País. A reportagem destaca que quem pratica os menores preços em geral são instituições de menor porte, que deixam de investir em pesquisa, laboratório, professores etc. Para se equilibrar, uma instituição deve cobrar mensalidade média de $\mathrm{R} \$ 450$, diz Carlos Monteiro, consultor em ensino superior. A mensalidade da FGV (Fundação Getulio Vargas), uma das instituições mais bem avaliadas do País, é de cerca de R\$ 2.400. Mackenzie e PUC cobram uma mensalidade média de $\mathrm{R} \$ 1.100$. Disponível também para assinantes em:
} 
fácil acesso para os alunos. Para atrair os alunos consumidores ${ }^{312}$, as instituições utilizam diversas estratégias de marketing para promover a imagem da instituição por meio de publicidade profissional.

Com relação à propagandas utilizada pelas instituições de ensino superior para atrair seus consumidores, Sampaio (2000, p. 320) afirma:

Quanto à propaganda especificamente, essa comunicação direta com o consumidor em potencial, realizada de forma profissional e especializada, também é fenômeno novo na área do ensino superior. O que não significa que as escolas superiores jamais tivessem divulgado seus cursos visando à ampliação de sua clientela. Todavia, esses procedimentos não seguiam estratégias definidas, enfim, não eram coisa de profissional. As propagandas eram muito localizadas, com textos diretos, informativos, distribuídos como santinhos de políticos em cursinhos de preparação para o vestibular e escolas de segundo grau, onde se encontra o público preferencial das instituições superiores.

Atualmente, o cenário é outro. De anos para cá, a propaganda dos estabelecimentos privados de ensino superior vem ganhando as ruas, dividindo, conforme o período do ano, com a dos cursinhos pré-vestibulares o espaço dos outdoors da cidade, ocupando páginas de jornais diários e revistas semanais. Com efeito, ante de uma demanda inelástica, a disputa pela clientela acirra-se, aumentando a competição entre as instituições de ensino superior. E a propaganda, dada a sua própria natureza, é uma das manifestações mais expressivas do dinamismo do setor privado voltado ao atendimento da demanda de massa por ensino superior.

O aluno consumidor, dentro de uma estrutura de mercado, tem total liberdade para escolher a instituição que melhor se enquadra nas suas expectativas e que apresenta custo compatível com sua posição social e objetivos profissionais ${ }^{313}$. Sobre os alunos clientes,

Sécca e Leal (2009, p. 31) afirmam:

$<$ http://www1.folha.uol.com.br/fsp/cotidian/ff2106201001.htm>.Acesso em: 30/06/2012.

312 Para Sampaio (2000, p. 348), "na linguagem do mercado, o objetivo das instituições de ensino superior é persuadir os jovens a consumir determinado curso/escola que, invariavelmente, se apresenta como distinto e distintivo. No caso do candidato ao ensino superior, o apelo ao acesso a um tipo de produto valorizado - o diploma - transforma-se em defesa e afirmação da personalidade e vocação individual. Nesse sentido, o consumo por ensino superior é invadido pela sedução, pelos diferentes apelos das identidades juvenis, pelo narcisismo, pela busca do próprio conhecimento, entre outros".

${ }^{313}$ Em pesquisa realizada no ano de 2004, a consultoria Hoper Educacional ouviu 800 estudantes de instituições particulares na cidade de São Paulo e constatou que, no momento da escolha da instituição privada de ensino superior em que estudará, é a localização - e não a qualidade do ensino - o item que o estudante paulistano mais leva em conta. Segundo a pesquisa, 38\% dos estudantes citaram a localização do campus como o fator que mais influenciou sua escolha, seguido da qualidade (28\%), do preço (16\%) e da indicação (16\%). Em outro estudo feito em 2000 pela Hoper Educacional com estudantes da região Sudeste, $72 \%$ deles afirmaram que estavam na universidade para obter um diploma, enquanto apenas $23 \%$ disseram que estavam lá para obter uma boa preparação para o mercado de trabalho ou para expandir seus conhecimentos. Em entrevista concedida à Folha de São Paulo, em 2003, Antonio Carbonari Netto, então vice-presidente do Semesp (Sindicato das Entidades Mantenedoras de Estabelecimentos de Ensino Superior no Estado de São Paulo), um dos sócios fundadores e atual Presidente do Conselho de Administração da Anhanguera, afirmou que "a localização e o preço são mesmo os fatores mais levados em conta, principalmente por estudantes mais pobres". Com base em pesquisas encomendadas pelo Semesp, para os estudantes mais ricos, a qualidade apareceu em primeiro lugar no momento da escolha da instituição de ensino, seguida da localização. Entre os mais pobres, a situação é diferente, com o preço aparecendo como o principal fator, junto com a $\quad$ localização. $\quad$ Disponível em <http://www1.folha.uol.com.br/folha/educacao/ult305u15663.shtml>. Acesso em: 26/06/2009. 
Os compradores ou clientes são os alunos. Estes costumam analisar fatores como localização, preço, portfólio de cursos da IES, qualidade do corpo docente, imagem da IES, instalações, opiniões de colegas, familiares, além de considerarem suas próprias ambições no mercado de trabalho.

Como consumidor de serviços educacionais, o aluno pode ter sua relação com a instituição disciplinada pelo CDC, que prevê, entre os direitos básicos dos consumidores (art. $6^{\circ}, \mathrm{CDC}$ ): (i) "a educação e divulgação sobre o consumo adequado dos produtos e serviços, asseguradas a liberdade de escolha e a igualdade nas contratações” (inciso II); (ii) "a informação adequada e clara sobre os diferentes produtos e serviços, com especificação correta de quantidade, características, composição, qualidade e preço, bem como sobre os riscos que apresentem" (inciso III); e (iii) “a proteção contra a publicidade enganosa e abusiva, métodos comerciais coercitivos ou desleais, bem como contra práticas e cláusulas abusivas ou impostas no fornecimento de produtos e serviços" (inciso IV).

Com relação ao direito à informação adequada sobre o produto e serviço (art. $6^{\circ}$, III, CDC), a LDB em seu artigo 47, Parágrafo $1^{\circ}$, estabelece que as instituições deverão informar aos interessados, "antes de cada período letivo, os programas dos cursos e demais componentes curriculares, sua duração, requisitos, qualificação dos professores, recursos disponíveis e critérios de avaliação, obrigando-se a cumprir as respectivas condições". Sobre a transparência de informações nas instituições de ensino superior, Cunha (2003, p. 59) afirma:

As empresas de ensino superior devem operar em regime de transparência, no que se refere à oferta de sua "mercadoria", informando aos seus consumidores, ao início de cada ano letivo: (i) a qualificação de seu corpo docente, a descrição dos recursos materiais à disposição dos alunos; (ii) o elenco dos cursos reconhecidos e dos que estejam em processo de reconhecimento, assim como o resultado das avaliações realizadas pelo MEC; (iii) o valor dos encargos financeiros a serem assumidos pelos alunos e as normas de reajuste aplicáveis durante o período letivo. As penalidades para as instituições transgressoras são as previstas pelo Código de Defesa do Consumidor, que veda a propaganda enganosa e prevê a possibilidade de intervenção pelo Poder Público.

A atuação do aluno como consumidor que escolhe um determinado produto de acordo com as informações disponíveis no mercado está de acordo com o ambiente regulatório estabelecido no Brasil - fornecimento das informações sobre qualidade dos cursos e instituições na forma de conceitos e rankeamento das instituições para escolha pelo mercado, conforme desenvolvido no Capítulo 2 dessa Dissertação.

A instituição como fornecedora responde, independentemente de culpa, pela 
reparação de quaisquer danos causados aos consumidores por defeitos relacionados à prestação dos serviços, bem como por informações insuficientes ou inadequadas sobre sua fruição e riscos (art. 14, CDC).

Para Ranieri (2005, p. 67):

são considerados defeitos aqueles decorrentes do modo de fornecimento (ensino inadequado ou insuficiente, por exemplo) ou da época em que foram fornecidos (aulas ministradas fora do período regularmente determinado para tanto) (art. 14, I e III). Nesses casos, nota-se que todas as vítimas do evento equiparam-se a consumidores, o que numa hipótese ampliada, significa dizer que os defeitos no oferecimento do ensino alcançariam todos os que estão sujeitos à atuação do profissional malformado (art. 17).

O fornecedor responde também por vícios de qualidade que tornem o serviço impróprio para o consumo ou lhe diminuam o valor, bem como por aqueles "decorrentes da disparidade com as indicações constantes da oferta ou mensagem publicitária” (art. 20, CDC). Nessas condições, o consumidor pode exigir, alternativamente e à sua escolha, "a reexecução dos serviços, sem custo adicional e quando cabível” (art. 20, I, CDC); "a restituição imediata da quantia paga, monetariamente atualizada, sem prejuízo de eventuais perdas e danos" (art. 20, II, CDC); ou "o abatimento proporcional do preço” (art. 20, III, CDC). Sobre essa responsabilidade, Ranieri (2005, p. 68) coloca como exemplo a questão da revalidação dos diplomas emitidos por instituições estrangeiras:

Questão importante neste tema é a da revalidação de diplomas emitidos por instituições estrangeiras, diretamente ou mediante convênio com instituições nacionais, referentes a cursos presenciais e/ou a distância que, geralmente, não têm equivalência com os brasileiros, dependendo por isso de análise de mérito para fins profissionais no País. Esta ressalva, se não for expressa, sujeita o fornecimento à responsabilização.

Para a garantia de seus direitos como consumidor de serviços educacionais, o aluno poderá recorrer aos órgãos de defesa do consumidor, como a Fundação de Proteção e Defesa do Consumidor (PROCON) $)^{314}$ ou ao Poder Judiciário, que decidirá a demanda a partir das regras do CDC.

Além da defesa de interesses individuais, é possível também a propositura de ações coletivas, para a proteção de interesses ou direitos difusos, interesses ou direitos coletivos e interesses ou direitos individuais homogêneos, nos termos do artigo 81, Parágrafo Único do CDC.

\footnotetext{
314 Sobre os procedimentos perante o PROCON/SP, $\quad$ vide $<$ http://www.procon.sp.gov.br/pdf/acs_cadastro_de_reclamacoes_fundamentadas_2009.pdf $>$. Acesso em: $18 / 01 / 2011$.
} 
Sobre as ações possíveis para a proteção do direito à educação, Ranieri destaca (2005, p. 69):

\begin{abstract}
A tutela do direito à educação pela via judicial, em situações de omissão, incapacidade ou negligência do Estado na aferição da qualidade do ensino, também pode ser feita por meio [...] do mandado de segurança individual ou coletivo (art. $5^{\circ}$, LXIX e LXX); o mandado de injunção (Art. $5^{\circ}$, LXXI); a ação popular (Art. $5^{\circ}$, LXXIII); e a ação direta de inconstitucionalidade (Art. 103). Isso sem contar que a utilização do direito de petição (Art. $5^{\circ}$, XXXIV, a) e a regra genérica de inexclusão da apreciação, pelo Judiciário, de qualquer lesão ou ameaça de direito (Art. $5^{\circ}, \mathrm{XXXV}$ ), garantem a possibilidade de interposição de Ações cautelares, ordinárias e penais, reafirmada no âmbito do Código de Defesa do Consumidor, em seu art. 83.
\end{abstract}

Nesse contexto, as empresas de educação são rés em diversos processos movidos por alunos, que tratam de diferentes assuntos, como problemas envolvendo matrículas, expedição de diplomas, inscrição indevida em órgãos de proteção de crédito. No Capítulo 4 desta Dissertação são descritas algumas demandas envolvendo a Anhanguera e seus alunos, que seguem regras do CDC.

Por fim, ressaltamos que a visão do aluno como apenas um consumidor de serviços educacionais é uma visão reducionista. Antes de ser consumidor, o aluno do sistema privado é o titular do direito à educação, envolvido numa relação jurídica em que um prestador privado oferece um serviço público (educação), regulado e regido por normas constitucionais e legais. Nesse sentido, a proteção do aluno, como cidadão e titular do direito à educação, é muito mais ampla do que a prevista no CDC e utilizada para a resolução de muitas demandas envolvendo o aluno do setor privado e a instituição prestadora do serviço de ensino.

\title{
3.4 Motivos para a abertura de capital de uma empresa
}

Segundo André Rocha, colunista do jornal Valor Econômico, as seguintes razões levam os controladores de uma empresa a abrirem seu capital em Bolsa de Valores $^{315}$ :

(i) possibilidade de consolidação - por meio do ingresso no mercado de capitais, empresas levantam recursos para adquirir seus concorrentes e aumentar o grau de concentração no seu setor de atuação, consolidando sua posição no mercado. O referido analista cita a Anhanguera como um exemplo desse tipo de empresa;

315 Fonte: Blog André Rocha, Jornal Valor Econômico, de 08/02/2012. Disponível em: http://www.valor.com.br/valor-investe/o-estrategista/2523578/por-que-algumas-companhias-estao-deixandoo-mercado $>$. Acesso em: 08/12/2012. 
(ii) captação para investimentos - empresas ingressam no mercado de capitais visando a crescer organicamente ${ }^{2}$ es. O mercado acionário serve como fonte de financiamento para investimentos dessa natureza;

(iii) reestruturação financeira - empresas que passaram por dificuldades financeiras podem ingressar no mercado acionário para financiar a sua recuperação;

(iv) precificação do valor da empresa para possível venda futura - segundo o referido colunista, "a listagem é uma das formas mais eficientes para se definir o valor justo de uma empresa. A avaliação de companhias de capital fechado é mais subjetiva. Assim, o controlador traz o empreendimento a mercado tentando maximizar a sua participação";

(v) profissionalização da companhia para perenizá-la - segundo o colunista, "a abertura de capital permite que a organização melhore seus controles e aperfeiçoe sua governança. Assim, algumas companhias vêm a mercado com um discurso de consolidação, mas a principal tarefa é profissionalizar a administração";

(vi) precificação de unidade de negócios - nesse modelo, apenas uma das unidades do negócio da empresa vem ao mercado. A abertura de capital, nesses casos, segundo o colunista, é importante para que essas empresas passem a ser mais bem avaliadas pelos investidores.

Conforme descrição constante no Capítulo 4, nota-se que a abertura de capital da Anhanguera permitiu que a empresa implementasse sua consolidação no mercado, crescimento orgânico e também a profisssionalização de sua administração.

\subsection{Sete virtudes do intuito lucrativo para James Tooley (1999)}

James Tooley (1999), um dos defensores da educação-mercadoria, sujeita ao sistema de mercado ${ }^{316}$, lista sete virtudes do intuito lucrativo:

(i) o desejo de expansão - o intuito lucrativo oferece um incentivo adicional para as empresas assumirem riscos para se expandirem. Investidores são atraídos pela possibilidade de lucro (TOOLEY, 1999, p. 1).

\footnotetext{
316 Tooley (1998, p. 274) entende que não há nada na natureza da educação que a diferencie de outros negócios, impossibilitando-a de ser comercializada no mercado. Nesse sentido, Tooley $(1998,278-9)$ acredita que o sistema de mercado é capaz de fornecer oportunidades educacionais para todos e oportunidades educacionais adequadas para todos, sujeito a algumas demandas de bem-estar social garantidas pelo Estado (com o Estado auxiliando alguns grupos minoritários que não tenham condições financeiras para estar no ambiente de mercado).
} 
(ii) a necessidade de controle de qualidade - o crescimento de uma rede de ensino por meio de aquisições deve ser permeada por um controle da qualidade do ensino do grupo. Segundo Tooley (1999, p. 2), conforme uma marca se torna conhecida, consumidores - pais e crianças - têm que estar tranquilos sobre a qualidade do serviço oferecido. Tooley identificou algumas empresas que adotam controle interno de qualidade como a NIIT, da India, e a brasileira Kroton que também possui um sistema de controle de qualidade para a rede Pitágoras.

(iii) o nome da marca resolve o problema de informação - segundo Tooley (1999, p. 2), a marca e a reputação que a envolvem determinam o comportamento de muitos consumidores que, mesmo sem conhecer a fundo o produto ou seu modo de funcionamento, adquirem um produto de uma marca famosa pois se sentem mais seguros. Algumas marcas tornam-se tão famosas que se confundem com o produto, como "Xerox", ou a graduação na instituição NIIT da Índia, que ficou conseguida como "GNIIT”.

(iv) a necessidade de pesquisa e desenvolvimento - segundo Tooley (1999, p. 3), o sucesso de uma rede de ensino ou uma empresa de educação inspira outras a entrarem no mercado. Tooley $(1999$, p. 3) destaca que a empresa não necessariamente vai querer investir em pesquisa e desenvolvimento, contudo, caso ela não o faça, seus concorrentes certamente o farão, o que a estimulará a também investir para não perder mercado.

(v) recompensas apropriadas para utilização dos professores - para Tooley (1999, p. 4), “o intuito lucrativo pode também assegurar que os professores serão devidamente recompensados e a excelência de ensino disseminada ${ }^{317}$ ". Tooley $(1999$, p. 4) destaca que o número de professores prestigiados e inspiradores de jovens são raros. Nesse sentido, há possibilidades tecnológicas, como o ensino a distância, que permitem que professores de excelência alcancem um número muito maior de estudantes.

(vi) atração de investimento e custo de eficiência - o intuito lucrativo pode ajudar a obter o capital necessário para investimento nas instituições de ensino, porque os investidores serão atraídos pelo possível retorno do investimento ${ }^{318}$.

Segundo Tooley (1999, p. 4), “com o incentivo do lucro, as empresas de educação estão sempre ansiosas para garantir que a inovação tecnológica seja utilizada para manter os custos o mais baixos possível e os padrões altos - caso contrário, alunos serão perdidos para outros competidores. Essa combinação de custo de eficiência e a possibilidade de

\footnotetext{
317 Tradução livre de: "The profit motive, fifth, can also ensure that teachers are properly rewarded and teaching excellence widely disseminated" (TOOLEY, 1999, p. 4).

318 Segundo Tooley (1999, p. 4), "the profit motive can help provide the desperately needed capital for investment in our schools - because investors will be atracted by the returns that might be available".
} 
investimento deixa os padrões elevados para todos ${ }^{319}$ ".

(vii) preocupação com o destino dos alunos - para se distinguir de outras instituições de ensino, uma rede privada pode auxiliar seus formandos a encontrar opções satisfatórias após deixarem sua rede - como um emprego ou a continuidade nos estudos (TOOLEY, 1999, p. 5). As instituições farão então convênios ou outras parcerias com empresas ao seu entorno, contratarão ou serão proprietárias de empresas de recrutamento em que especialistas procurarão posições para os alunos da instituição.

Tooley (1999, p. 5) destaca que as sete virtudes acima descritas são obtidas em decorrência do intuito lucrativo, sem qualquer pretensão de que a empresa seja bem intencionada ou tenha algum espírito filantrópico ou público. São apenas resultados de decisões de negócios calculadas. São decisões que elevam os padrões de qualidade e incrementam as oportunidades, sem qualquer boa intenção.

Analisando o caso da Anhanguera, verificamos que nem todas as virtudes descritas por Tooley (1999) são perseguidas pela empresa, como veremos no Capítulo 4 da Dissertação.

\subsection{Obrigações e deveres no dia a dia de uma companhia aberta listada no Novo Mercado}

No momento em que a mantenedora de uma instituição de ensino superior (ou uma empresa controladora de um grupo de mantenedoras) resolve transformar-se numa empresa, especialmente numa companhia aberta como a Anhanguera, determinadas práticas, bem como regras e deveres previstos em leis, devem ser observados no desenvolvimento da atividade, como:

(i) observar os direitos essenciais dos acionistas previstos no artigo 109 da Lei $n^{\text {o }} 6.404 / 76$ (Lei das S.As.) $)^{320}$, sobretudo os direitos de participação nos lucros e de fiscalização dos negócios sociais;

(ii) realizar assembleias gerais ordinárias e extraordinárias para as deliberações

\footnotetext{
319 Tradução livre de: "with the incentive of profit, educational companies are always anxious to ensure that technological innovation is utilised which can both keep costs as low as possible and keep standards highelse learners will be lost to other competitors. It is this combination of cost-effectiveness and the possibility of investment which can lead to higher standards for all" (TOOLEY, 1999, p. 4).

${ }^{320}$ Art. 109, Lei $6.404 / 76$ - "Nem o estatuto social nem a assembleia-geral poderão privar o acionista dos direitos de: I - participar dos lucros sociais; II - participar do acervo da companhia, em caso de liquidação; III - fiscalizar, na forma prevista nesta Lei, a gestão dos negócios sociais; IV - preferência para a subscrição de ações, partes beneficiárias conversíveis em ações, debêntures conversíveis em ações e bônus de subscrição, observado o disposto nos artigos 171 e 172; V - retirar-se da sociedade nos casos previstos nesta Lei”.
} 
sociais, nos termos dos artigos 121 e seguintes da Lei das S.As., bem como Reuniões do Conselho de Administração, Diretoria e Conselho Fiscal, nos termos dos artigos 138 e seguintes da Lei das S.As., cumprindo formalidades legais para convocação, instalação, deliberação, lavratura de atas em livro de registro, arquivamento em órgãos públicos, publicação em jornais de grande circulação e disponibilização nos sites da CVM, BM\&FBOVESPA e de relações com investidores da companhia dos editais de convocação e as atas de referidas assembleias ou reuniões, bem como de documentos relacionados a esses atos;

(iii) além de realizar e divulgar os atos mencionados no item "ii", obedecer regras de transparência de informação previstas nos artigos 157 , Parágrafo $4^{\text {o321 }}$ da Lei das S.As. e Instruções CVM n ${ }^{\text {os }} 358 / 02^{322}, 480 / 09^{323}$, divulgando amplamente ao público informações periódicas e eventuais, fatos relevantes e avisos aos acionistas contendo informações relevantes ${ }^{324}$ sobre o funcionamento da companhia e demais assuntos de interesses dos acionistas que possam influenciar a cotação dos valores mobiliários da companhia e a decisão de investir ou não na empresa;

(iv) observar padrões internacionais de contabilidade e de divulgação de informações contábeis periódicas, nos termos dos artigos 177, Parágrafo $5^{\text {0325 }}$ e Instrução $\mathrm{CVM} \mathrm{n}^{\circ} 457 / 07^{326}$;

321 Art. 157, § 4 , Lei das S.As. - "Os administradores da companhia aberta são obrigados a comunicar imediatamente à bolsa de valores e a divulgar pela imprensa qualquer deliberação da assembleia-geral ou dos órgãos de administração da companhia, ou fato relevante ocorrido nos seus negócios, que possa influir, de modo ponderável, na decisão dos investidores do mercado de vender ou comprar valores mobiliários emitidos pela companhia".

${ }^{322}$ A Instrução $\mathrm{CVM} \mathrm{n}^{\circ} 358$, de 03/01/2002, dispõe sobre a divulgação e uso de informações sobre ato ou fato relevante relativo às companhias abertas, disciplina a divulgação de informações na negociação de valores mobiliários e na aquisição de lote significativo de ações de emissão de companhia aberta, estabelece vedações e condições para a negociação de ações de companhia aberta na pendência de fato relevante não divulgado ao mercado e revoga outras instruções da CVM sobre esta mesma temática.

${ }^{323}$ A Instrução CVM n ${ }^{\circ} 480$, de 07/12/2009, dispõe sobre o registro de emissores de valores mobiliários admitidos à negociação em mercados regulamentados de valores mobiliários.

${ }^{324}$ Nos termos do art. $2^{\circ}$, da Instrução CVM n ${ }^{\circ} 358 / 02$ - "Considera-se relevante, para os efeitos desta Instrução, qualquer decisão de acionista controlador, deliberação da assembleia geral ou dos órgãos de administração da companhia aberta, ou qualquer outro ato ou fato de caráter político-administrativo, técnico, negocial ou econômico-financeiro ocorrido ou relacionado aos seus negócios que possa influir de modo ponderável: I - na cotação dos valores mobiliários de emissão da companhia aberta ou a eles referenciados; II - na decisão dos investidores de comprar, vender ou manter aqueles valores mobiliários; III - na decisão dos investidores de exercer quaisquer direitos inerentes à condição de titular de valores mobiliários emitidos pela companhia ou a eles referenciados".

325 Art. 177, § $3^{\circ}$ - "As demonstrações financeiras das companhias abertas observarão, ainda, as normas expedidas pela Comissão de Valores Mobiliários e serão obrigatoriamente submetidas a auditoria por auditores independentes nela registrados".

${ }^{326}$ A Instrução CVM n ${ }^{\circ} 457$, de 13/07/2007, dispõe sobre a elaboração e divulgação das demonstrações financeiras consolidadas, com base no padrão contábil internacional emitido pelo International Accounting Standards Board - IASB. 
(v) atentar para a influência nos negócios da companhia de fatores externos como crises financeiras nacionais e internacionais, consequências indesejadas de políticas econômicas, que podem alterar a cotação das ações da companhia, reduzindo seu valor econômico $^{327}$; e

(vi) buscar a satisfação dos interesses dos seus investidores e o cumprimento de metas assumidas perante o mercado para que a empresa transmita confiança e ganhe credibilidade, consolidando sua posição no mercado.

Sobre este aspecto, a Anhanguera assumiu uma série de compromissos com seus investidores nas ofertas públicas de ações que realizou nos últimos anos. Sobre a realização desses compromissos, a Companhia presta contas. Abaixo um exemplo dos compromissos assumidos na oferta de ações realizada em 2010 e a prestação de contas dos administradores da empresa (ANHANGUERA, 2012e):

Em 2011, a Companhia atingiu seus principais objetivos apresentados ao mercado: i) a expansão de seus negócios, investindo na aquisição de aproximadamente 100 mil alunos, antecipando seu plano de expansão original; ii) melhoria substancial em sua plataforma de tecnologia para ensino a distância; iii) investimentos em melhoria e adequações das instituições adquiridas e sede administrativa; e iv) conclusão com sucesso da integração das empresas adquiridas.

Os fortes investimentos realizados para cumprir os compromissos assumidos foram financiados pela emissão de ações de $\mathrm{R} \$ 844.1$ milhões concluída no final de 2010. Foram $\mathrm{R} \$ 886,2$ milhões investidos em aquisições, com mais $\mathrm{R}$ \$ 85,7 milhões em despesas relacionadas às transações e reestruturações das aquisições, além de $\mathrm{R} \$ 191,1$ milhões em investimentos em infraestrutura e tecnologia. Esses investimentos representam mais de $50 \%$ do nosso Patrimônio Líquido e ampliaram de forma substancial o potencial de crescimento e geração de resultados futuros pela Companhia.

A Anhanguera é também uma companhia listada no Novo Mercado da BM\&FBOVESPA. O Novo Mercado é o segmento especial de listagem que apresenta as maiores exigências em termos de melhores práticas de governança corporativa do mercado de capitais brasileiro e, por conta disso, as ações nele listadas, geralmente, apresentam um valor de mercado maior que as demais. A adesão a esse segmento é voluntária, mediante a assinatura de um contrato, por meio do qual a companhia compromete-se a observar as regras constantes no regulamento de listagem do Novo Mercado. Dentre as regras

327 Segundo Winch (1996, p. 77): “o preço da ação não é determinado exclusivamente por julgamentos analíticos: fatores externos, tais como eventos políticos, podem ter um impacto no preço da ação, e pode-se argumentar que há um forte elemento de psicologia das multidões em muitas decisões de compra e venda, baseadas não em informações sobre qualidade e preço, mas sobre a forma como as outras pessoas estão se comportando no mercado". Tradução livre de: "share price is not determined purely by analytical judgements: external factors such as political events may have an impact on share price and it is arguable that there is a strong element of crowd psychology in many decisions to buy and sell, based not upon information about quality and price but upon the way in which other people are behaving in the market" (WINCH, 1996, p. 77). 
constantes nesse regulamento, encontra-se a exigência de que (a) a totalidade do capital social da empresa seja representada apenas por ações ordinárias nominativas (ações com direito de voto); (b) a companhia mantenha $25 \%$ de suas ações em circulação no mercado (free float); (c) o conselho de administração da companhia seja composto por no mínimo 5 membros, dos quais, pelo menos, $20 \%$ sejam membros independentes; (d) as demonstrações financeiras da companhia observem padrões internacionais; e (e) a companhia resolva seus conflitos na Câmara de Arbitragem do Mercado ${ }^{328}$.

Considerando as exigências acima descritas, nota-se que a mantenedora de uma instituição de ensino (ou a empresa controladora de um grupo de mantenedoras) que adote a forma de uma companhia aberta e que também esteja listada no Novo Mercado, como a Anhanguera, deve possuir uma estrutura adequada para cumprir com todos os deveres assumidos e oferecer um serviço (educação) que seja lucrativo, competitivo e que desperte a atenção dos investidores. Assim sendo, essas instituições devem, por exemplo, possuir um setor de relações com investidores e contratar administradores profissionais experientes no trato com o mercado de capitais. Considerando essas exigências e a necessidade de investimentos para isso, além da Anhanguera, existem apenas mais três companhias abertas que atuam no setor educacional no Brasil - Estácio (listada no Novo Mercado), Kroton (também listada no Novo Mercado) e Abril Educação S.A. (listada no Nível 2).

\subsection{As teorias explicativas da empresa}

Uma empresa pode ser entendida de diferentes maneiras - como uma instituição, como um contrato ou como uma organização.

As concepções contratualistas e institucionalistas são as mais recorrentes na doutrina e legislação. A concepção organicista é recente e surge como uma alternativa para lidar com os problemas das outras concepções.

Considerar uma empresa como um contrato implica reconhecer que a atividade deve ser orientada de acordo com o interesse dos sócios e, consequentemente, com o interesse de maximização dos lucros, que se torna o próprio interesse social.

De acordo com a concepção institucionalista, a empresa deve ser vista como uma instituição, com um viés publicístico. Nesse sentido, o interesse social envolve os

\footnotetext{
328 Para sobre o informações Novo Mercado, vide: $<$ http://www.bmfbovespa.com.br/empresas/pages/empresas_governanca-corporativa.asp>. Acesso em $17 / 01 / 2011$.
} 
interesses que circundam a empresa, em especial, o interesse pela própria preservação da empresa.

No ordenamento jurídico brasileiro, prevalece a concepção contratualista, que é reconhecida no artigo 981 do Código Civil, que prevê que "celebram contrato de sociedade as pessoas que reciprocamente se obrigam a contribuir, com bens ou serviços, para o exercício de atividade econômica e a partilha, entre si, dos resultados ${ }^{329}$, Nessa definição, segundo Calixto Salomão Filho (2006, p. 36), encontram-se "todos os traços da doutrina contratualista tradicional: pluralidade de pessoas, concentradas em torno do exercício de uma atividade econômica [...] e a reciprocidade das obrigações entre os sócios, que se obrigam entre si e não com relação à sociedade".

Há também no ordenamento jurídico brasileiro algumas previsões em que se identificam traços da teoria institucionalista, como a regra da função social da empresa, que será desenvolvida no item 3.8 abaixo.

As abordagens contratualista e institucionalista são insuficientes para lidar com alguns problemas envolvendo as empresas.

A identificação do interesse social apenas como o interesse pela maximização do valor de venda das ações (SALOMÃO FILHO, 2006, pp. 29-30), como propõe a teoria contratualista, levou, por exemplo, à busca desenfreada de aumento do valor de venda das ações, com a utilização pelos agentes do mercado dos mais diferentes artifícios, como interpretação permissiva de regras contábeis, maquiagem de balanços, prática de operações fraudulentas, manipulação de preços ou criação de condições artificiais de procura, oferta ou preços de valores mobiliários, omissão de informação relevante por quem estava obrigado a divulgá-la, bem como sua prestação de forma incompleta, falsa ou tendenciosa, manipulando assim o mercado. Tais fenômenos geraram crises no mercado norteamericano, como o caso Enron, Marta Stewart e os escândalos das empresas de auditoria, entre outros.

A identificação do interesse social como o interesse pela autopreservação da empresa desconsidera os outros interesses envolvidos na atividade.

Nesse sentido, analisar a empresa como organização (concepção organicista) implica colocar o valor da organização como o elemento central do contrato social, o qual deverá ordenar de forma coerente os interesses envolvidos na sociedade, com vistas à solução dos conflitos deles decorrentes (SALOMÃO FILHO, 2006, p. 43).

${ }^{329}$ Grifo nosso. 
Inúmeros interesses envolvem a realidade de uma empresa, como os interesses de seus trabalhadores, dos consumidores, dos concorrentes, dos titulares da tutela pelo direito ambiental. No caso de uma empresa que presta serviço educacional, segundo Winch (1996, p. 4), os principais grupos de interesses envolvidos são as pessoas que estão sendo educadas (crianças, jovens e adultos), os responsáveis por aqueles que estão sendo educados (geralmente, os pais), aqueles que ensinam ou atuam no ambiente escolar (professores, servidores, administradores, inspetores etc.), o Estado, os contribuintes e o governo.

Considerando essa pluralidade de interesses, a organização deve criar elementos para que as partes nela envolvidas atuem de forma cooperativa, com a internalização seletiva desses interesses ditos externos (SALOMÃO FILHO, 2006, p. 43).

Todos os interesses envolvidos na organização devem ser considerados para a criação da estrutura necessária à diminuição dos conflitos deles decorrentes. Nesse sentido, se não considerados os interesses dos investidores, a empresa não conseguirá manter-se no mercado. Ao mesmo tempo, se não considerado o interesse público envolvido na atividade, o interesse dos alunos, dos professores e dos demais agentes envolvidos na prestação do serviço educacional pela organização, esta corre o risco de atuar de forma a não observar os princípios da educação e do ensino e os objetivos da educação previstos na Constituição de 1988 e na LDB.

Nesse sentido, o interesse social deve ser identificado ao interesse pela melhor organização possível do feixe de relações envolvidas na sociedade. Nesse sentido, para Salomão Filho (2006, p. 42):

[...] o interesse da empresa não pode ser mais identificado, como no contratualismo, ao interesse dos sócios nem tampouco, como na fase institucionalista mais extremada, à autopreservação. Deve sim ser relacionado à criação de uma organização capaz de estruturar da forma mais eficiente - e aqui a efíciência é a distributiva e não alocativa - as relações jurídicas que envolvem a sociedade.

A teoria organicista, assim, possibilita a proteção dos interesses envolvidos na sociedade e a solução interna de conflitos por meio da criação de regras organizativas internas e externalização daquelas que não podem ser internalizadas, as quais deverão ser acompanhadas por um correto tratamento legislativo (SALOMÃO FILHO, 2006, p. 44).

A ausência de internalização progressiva dos interesses envolvidos na organização pode gerar crises. No setor de educação, as consequências da má compreensão do interesse 
social podem ser assim ainda mais maléficas, uma vez que este setor possui grandes externalidades sociais, como veremos no item 3.13 a seguir.

\subsection{Função Social da Empresa e suas críticas}

De acordo com a legislação brasileira, toda empresa tem uma função social. Nesse sentido, os artigos 116, Parágrafo Único, 117, Parágrafo 1, "a” e 154 da Lei das S.As., estabelecem que:

Art. 116, Parágrafo único - O acionista controlador deve usar o poder com o fim de fazer a companhia realizar o seu objeto e cumprir sua função social, e tem deveres e responsabilidades para com os demais acionistas da empresa, os que nela trabalham e para com a comunidade em que atua, cujos direitos e interesses deve lealmente respeitar e atender.

Art. 117. O acionista controlador responde pelos danos causados por atos praticados com abuso de poder.

$\S 1^{\circ}$ São modalidades de exercício abusivo de poder:

a) orientar a companhia para fim estranho ao objeto social ou lesivo ao interesse nacional, ou levá-la a favorecer outra sociedade, brasileira ou estrangeira, em prejuízo da participação dos acionistas minoritários nos lucros ou no acervo da companhia, ou da economia nacional.

Art. 154. O administrador deve exercer as atribuições que a lei e o estatuto lhe conferem para lograr os fins e no interesse da companhia, satisfeitas as exigências do bem público e da função social da empresa.

A Constituição de 1988 se refere à função social da propriedade, em alguns $\operatorname{dispositivos}^{330}$, em especial no artigo $5^{\circ}$, XXIII, que estabelece que "a propriedade atenderá a sua função social".

Sobre a função social da propriedade, Comparato (1996, p. 41) afirma que o termo "função", numa acepção jurídica mais abstrata, significa uma atividade dirigida a um fim, que comporta da parte do sujeito agente um poder ou competência. Nesse sentido, há funções exercidas no interesse de uma pessoa ou de pessoas determinadas, como o pátrio poder ou a curatela; e funções que devem ser desempenhadas em benefício da coletividade. Nesta última hipótese enquadra-se a função social.

De acordo com essa concepção, uma empresa que oferece um serviço que também é um direito fundamental, que beneficia a coletividade (como é o caso das empresas de educação), teria uma evidente função social.

\footnotetext{
${ }^{330}$ Há referência à função social também nos artigos 170, III; 173, Parágrafo $1^{\circ}$, I; 182, Parágrafo $2^{\circ} ; 184$ e 186 da Constituição de 1988.
} 
Comparato (1996, p. 42) destaca que, na Constituição de 1988, a função social da propriedade é apresentada como imposição do dever positivo de uma adequada utilização dos bens, em proveito da coletividade (nesse sentido, artigo 182, Parágrafos $2^{\circ}$ e $4^{\circ}$ e artigo 186). Para o autor (1996, p. 42), o Estado exerce um papel decisivo e insubstituível na aplicação da regra da função social, uma vez que ele impõe as sanções pelo descumprimento da função social da propriedade.

Com relação aos dispositivos constantes na Lei das S.As., Comparato (1996, p. 44) afirma que:

a lei reconhece que, no exercício da atividade empresarial, há interesses internos e externos, que devem ser respeitados: não só os das pessoas que contribuem diretamente para o funcionamento da empresa, como os capitalistas e os trabalhadores, mas também os interesses da "comunidade" em que ela atua.

No entanto, Comparato (1996, p. 44) questiona a efetividade da função social num sistema capitalista - se no caso de conflito entre o interesse próprio da empresa, como unidade econômica, e o interesse geral da coletividade, o empresário sacrificaria o interesse empresarial em prol do bem comum. Deixaria o empresário de aumentar os preços dos produtos ou serviços de primeira necessidade em prol do bem comum?

As mesmas questões podem ser feitas para uma empresa de educação - numa decisão envolvendo aumento dos lucros ou aumento dos gastos com infraestrutura ou corpo docente, para qual lado apontaria o empresário da educação? Esse ponto é levantado em uma reportagem da Revista Capital Aberto de setembro de $2007^{331}$ :

Já um ponto em que todos convergem refere-se ao potencial conflito ideológico do processo de mercantilização do ensino. A questão é como equilibrar a função social que a educação exerce com a expectativa de retorno financeiro de analistas e investidores e sua inerente pressão por custos. Essa relação não poderia provocar um choque de interesses que colocasse a sociedade civil de um lado e os investidores de outro?

Essas dúvidas, para Comparato (1996, p. 44), deixam claro o alcance limitado, senão nulo, da função social das empresas.

Nesse sentido, Comparato (1996, p. 44) destaca que:

A empresa capitalista - importa reconhecer - não é, em última análise, uma unidade de produção de bens, ou de prestação de serviços, mas sim uma organização produtora de lucros. É esta a chave lógica para a compreensão de sua estrutura e funcionamento. $\mathrm{O}$

331 Disponível em: <http://www.capitalaberto.com.br/ler_artigo.php?pag=2\&sec=4\&i=1561>. Acesso em: $08 / 12 / 2012$. 
objeto da empresa, ou seja, o exercício de uma atividade econômica de produção ou distribuição de bens, ou de prestação de serviços, está sempre subordinado ao objetivo final de apuração e distribuição de lucros.

Nos termos do artigo $2^{\circ}$ da Lei das S.As., "pode ser objeto da companhia qualquer empresa de fim lucrativo, não contrário à lei, à ordem pública e aos bons costumes”. Sobre esse dispositivo, Comparato (1996, p. 45) ressalta que a "companhia não poderá jamais renunciar à sua finalidade lucrativa, mesmo que todos os acionistas renunciem ao seu direito de receber dividendos e sejam movidos pelo mais elevado intuito altruístico, ou pela intenção de participar de alguma campanha pública de auxílio social”.

Da mesma forma, embora a lei estabeleça como dever do administrador exercer suas atribuições tendo em vista a "função social da empresa" (art. 154, caput, Lei das S.As.), nenhum órgão administrativo, no exercício de suas atribuições, está legalmente autorizado a praticar atos gratuitos não razoáveis, em benefício da comunidade em que atua a empresa (art. 154, Parágrafo $4^{0332}$ ). A razoabilidade imposta pelo dispositivo legal, para Comparato (1996, p. 45), deve ser apreciada em função da finalidade lucrativa, que é da essência da sociedade anônima.

Comparato (1996, p. 45) ressalta também que a jurisprudência brasileira já firmou o entendimento de que uma companhia pode ser dissolvida judicialmente em razão do não preenchimento de seu fim social (art. 206, II, b, Lei das S.As.), "quando deixa persistentemente de produzir lucros".

Assim sendo, Comparato (1996, p. 45) concluiu que:

\begin{abstract}
É imperioso reconhecer, por conseguinte, a incongruência em se falar numa função social das empresas. No regime capitalista, o que se espera e exige delas é, apenas, a eficiência lucrativa, admitindo-se que, em busca do lucro, o sistema empresarial como um todo exerça a tarefa necessária de produzir ou distribuir bens e de prestar serviços no espaço de um mercado concorrencial. Mas é uma perigosa ilusão imaginar-se que, no desempenho dessa atividade econômica, o sistema empresarial, livre de todo controle dos Poderes Públicos, suprirá naturalmente as carências sociais e evitará os abusos; em suma, promoverá a justiça social.
\end{abstract}

Uma empresa livre do controle dos Poderes Públicos, ou seja, sem nenhum tipo de exigência legal para buscar fins sociais, não deixaria de lado seu caráter lucrativo (nem diminuiria seus lucros) para buscar outros objetivos, como atender carências sociais. Nesse sentido, uma empresa de educação só atenderia exigências de qualificação do corpo

332 Art. 154, $\S 4^{\circ}$ - "O conselho de administração ou a diretoria podem autorizar a prática de atos gratuitos razoáveis em benefício dos empregados ou da comunidade de que participe a empresa, tendo em vista suas responsabilidades sociais". (grifo nosso) 
docente, infraestrutura, estímulo a criação cultural e o desenvolvimento do espírito científico e do pensamento reflexivo (art. 43, LDB), por exemplo, se obrigada fosse pelas autoridades públicas.

Sobre empresas multinacionais, Comparato (1996, p. 45) afirma que é "incongruente esperar" que tais empresas "trabalhem, naturalmente, em prol do interesse nacional, de cada país", pois elas não colocariam "o bem do Brasil acima do interesse de seu grupo como um todo, e de sacrificar a sua lucratividade global" em benefício do “desenvolvimento econômico e social da nação brasileira”. Nesse sentido, é importante compreender que os investidores estrangeiros de empresas educacionais brasileiras estão interessados no retorno positivo de seus investimentos antes de qualquer outro objetivo social.

Assim sendo, Comparato conclui (1996, p. 46) que a efetividade da função social das empresas depende da atuação do governo, como um piloto que "saiba conduzir a nave, em quaisquer condições, rumo ao porto de destino", que num "Estado Democrático e Social é o estabelecimento de condições de vida dignas para todos, sem preferências ou discriminações".

\subsection{Falhas de mercado}

Na teoria econômica, são descritas algumas falhas de mercado, situações em que a atuação estatal é necessária, pois a utilização de mecanismos de mercado privado gera resultados econômicos indesejados do ponto de vista social ou ineficientes (SAKURAI; TONETO; GREMAUD, 2010, p. 1).

Segundo Fábio Nusdeo (2008, pp. 139-69), as seis falhas principais do mercado são: (a) quanto à mobilidade dos fatores - falha de origem física ou cultural $\frac{333}{3}$; (b) quanto à transparência ou acesso à informação - falha de origem legal ${ }^{334}$; (c) quanto à concentração

\footnotetext{
${ }^{333}$ Nusdeo (2008, p. 139-43) defende que, para o mercado se autorregular, os fatores de produção deveriam apresentar um certo grau de mobilidade, a fim de reagirem a todo momento aos sinais indicativos apresentados pelos preços. Contudo, os fatores de produção apresentam rigidez - física, operacional, institucional e até psicológica, que dificulta ou mesmo impede tal mobilidade. Imagine uma plantação de café: a safra tem seu ciclo independentemente das condições de mercado, sejam favoráveis ou não; quando o ciclo se encerrar, o produto estará disponível. A rigidez também ocorre nos hábitos de consumo - o brasileiro, apesar de enfrentar um aumento no preço do feijão, continuaria consumindo esse alimento em razão do hábito.

${ }^{334}$ Segundo Nusdeo (2008, p. 143-6): para um funcionamento correto do mercado, todos os operadores deveriam ter acesso às informações sobre o mesmo e às características dos produtos nele comercializados. $\mathrm{O}$ sistema de mercado, no entanto, visando benefícios particulares e a curto prazo, tenderia a esconder informações sobre o bem objeto de negociação que pudessem diminuir o preço do produto.
} 
econômica - falha de estrutura ${ }^{335}$; (d) falha analítica - quando os custos de transação são desconsiderados ${ }^{336}$; (e) quanto aos efeitos externos ou externalidades - falha de sinal; e (f) quanto ao suprimento de bens coletivos - falha de incentivo. Para os fins da Dissertação, cabe analisar as externalidades e a falha de suprimento de bens coletivos.

\subsection{A educação como bem coletivo e as falhas de mercado}

Conforme mencionamos no Capítulo 1, a educação pode ser entendida como um bem coletivo.

Considerando "o princípio da racionalidade hedonista, indissociável do utilitarismo e mola mestra do sistema de mercado", Nusdeo (2008, p. 161) entende que o sistema de mercado é falho no suprimento de bens coletivos, também conhecidos, na bibliografia internacional, como bens públicos.

Segundo Nusdeo (2008, pp. 161-2), de acordo com o princípio hedonista, se um indivíduo não pode ser excluído da utilização de um bem, ele também não teria incentivos para colaborar financeiramente com a produção de bens coletivos, pois terceiros que não contribuíram para o bem (free riders) receberiam idêntico benefício ${ }^{337}$.

Nesse sentido, uma economia fundada no mercado tenderia a discriminar fortemente os bens coletivos e a exagerar a produção de bens exclusivos. Por exemplo, teria muitos carros, mas poucas linhas de metrô, muitas fábricas e poucos aparelhos antipoluentes (NUSDEO, 2008, p. 162).

\footnotetext{
335 Outro pressuposto básico do sistema de mercado, segundo Nusdeo (2008, p. 146-52), é a atomização. Atomização aplicada ao mercado significa que, para seu bom funcionamento, ele deve ser composto por um número razoavelmente grande de compradores e vendedores em interação recíproca, não sendo nenhum deles excessivamente grande ou importante. Contudo, em busca de maiores lucros e ganhos de escala, os agentes tenderiam à concentração.

${ }^{336}$ No sistema de mercado, segundo Nusdeo (2008, p. 164-7), o preço de um determinado bem deveria englobar todos os custos de transação envolvidos na sua produção. Transação neste contexto é toda e qualquer operação econômica, assim entendida como a que envolve a circulação de riquezas entre agentes econômicos. Segundo Sztajn (2004, p. 7-31), custos de transação são todos os custos incorridos para realizar uma transação, como custos com estudos para a procura de bens no mercado, análise do preço e qualidade do bem desejado, contratação de mão de obra, preparação, monitoramento, execução de contratos.

337 Segundo Stiglitz (1999, p. 132), “o problema do free rider é apenas um reflexo de um problema de incentivo importante que se coloca no caso de bens públicos. Se o bem vai ser fornecido de qualquer maneira, por que eu deveria pagar? O que eu gostaria de contribuir seria insignificante, e dificilmente mudaria a oferta agregada. Para ter certeza, se todos justificaram da mesma forma, o bem não seria fornecido. Esse é um dos argumentos para o governo fornecer esses bens, porque o governo tem o poder de obrigar as pessoas a contribuir (por meio de impostos)". Tradução livre de: "The free rider problem is just a reflection of an important incentive problem that arises in the case of public goods. If the good is going to be provided anyway, why sould I pay? What I would contribute would be negligible, and hardly alter the aggregate supply. To be sure, if everyone reasoned the same way, the good would not be supplied. That is one of the arguments for government's providing these goods, because government has the power to compel people to contribute (through taxes)" (STIGLITZ, 1999, p. 132).
} 
A deficiente provisão de bens coletivos seria, portanto, uma das distorções do mercado, pois o fato de as necessidades por bens coletivos não serem adequadamente atendidas não significa que as mesmas não existam. Isso gera uma falha de incentivo "para a população manifestar sua preferência, o que implica numa falha de sinal para os supridores desses bens" (NUSDEO, 2008, p. 162).

Nesse sentido, apenas o Estado pode impor aos indivíduos que colaborem para o fornecimento de bens coletivos, o que ele faz por meio da cobrança de tributos - segundo Nusdeo (2008, p. 162):

o Estado desde as mais remotas eras cobrava os seus tributos para fazer face, entre outros fins, às necessidades de caráter coletivo, inclusive a sua própria manutenção. No entanto, com o crescimento da população e seu adensamento nas áreas urbanas, expandiram-se enormemente as necessidades coletivas, antes pura e simplesmente consideradas, tais como a vacinação, o ensino básico, o saneamento, o planejamento urbano, ampliando-se, inclusive, a noção de serviço público tratada pelo Direito Administrativo.

Nusdeo (2008, p. 162-3) também ressalta a ligação entre o conceito de bem coletivo e de externalidade, na modalidade positiva (na forma de geração ou produção de benefícios externos extramercado). Com base nessa ligação, Nusdeo (2008, p. 163) conclui que bem

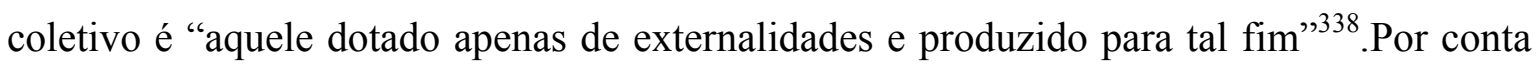
disso, Nusdeo (2008, p. 163) entende que a falha de mercado, no caso dos bens coletivos, é do mesmo tipo da verificada no caso das externalidades, assunto que será desenvolvido abaixo $^{339}$ :

\footnotetext{
338 Stiglitz (1999, p. 136), na mesma linha, afirma: "Externalidades como bens públicos impuros. Bens públicos puros têm a propriedade de que, se um indivíduo compra mais do mesmo, o consumo deste bem por todos os indivíduos aumenta na mesma quantidade. (Os indivíduos podem, é claro, diferir na forma como valorizam o aumento do consumo). Bens privados puros têm a propriedade de que, se um indivíduo compra mais do mesmo, os outros são (pelo menos diretamente) não afetados. Bens para os quais há externalidades no consumo têm a propriedade de que os outros são afetados, mas não necessariamente na mesma quantidade. Externalidades podem, assim, ser vistas como uma forma de bens públicos impuros (ou, talvez melhor dizendo, os bens públicos podem ser vistos como uma forma extrema de externalidades)". Tradução livre de: "Externalities as impure public goods. Pure public goods have the property that if one individual purchases more of it, all individual's consumption of that good increases by the same amount. (Individuals may, of course, differ in how they value the increased consumption). Pure private goods have the property that if one individual purchases more of it, others are (at least directly) unaffected. Goods for which there are externalities in consumption have the property that others are affected, but not necessarily in the same amount. Externalities can thus be viewed as a form of impure public goods (or perhaps better stated, public goods can be viewed as an extreme form of externalities)" (STIGLITZ, 1999, p. 136).

${ }^{339}$ Nusdeo (2008, p. 163) destaca que existem "bens ou serviços que, muito embora exclusivos, geram um tal montante de externalidades positivas a ponto de serem cada vez mais vistos, eles próprios, como bens coletivos. É o caso da vacina: aparentemente trata-se de um bem exclusivo, pois protege a quem foi com ela inoculado. Mas, à medida que uma parcela razoável da população a receba, aumentam as probabilidades de todo o conjunto de habitantes ver-se livre de uma possível epidemia. As altas externalidades fazem a vacina ser encarada muito mais como um bem coletivo do que exclusivo. $\mathrm{O}$ mesmo se aplica a inúmeros outros setores, notadamente os do ensino e do saneamento".
} 
falta de sinal decorrente da ausência de incentivo na manifestação desse tipo de necessidade, a qual ocorre ou deve ocorrer não pelos canais de mercado, mas pelos canais da representação política, mediante a escolha de legisladores e governantes cujos programas contemplem o fornecimento deste ou daquele conjunto de bens coletivos, conforme a preferência dos eleitores.

Assim sendo, o Estado deveria suprir o particular destes bens diretamente ou mediante concessão de serviços públicos, contratação com terceiros, por meio de incentivos à produção, pelo setor privado, de bens dotados de alto coeficiente de externalidades positivas (NUSDEO, 2008, p. 163).

Com isso se conclui que, para os bens coletivos, o sistema de mercado não funciona adequadamente. Nesse caso, o Estado deveria atuar na economia para corrigir as falhas do mercado e perseguir o interesse coletivo e social envolvido na atividade.

\subsection{As externalidades}

Para Rachel Sztajn (2004, p. 7):

Externalidade, termo largamente empregado pelos economistas, ligado a benefícios ou custos nascidos e presos ao exercício de atividade que não são suportados pelo seu exercente, por quem lhes dá causa, mas recaem sobre terceiros externos à sua origem, pessoa, grupos de pessoas ou à sociedade.

De acordo com Calixto Salomão Filho (2008, p. 33), "há externalidade sempre que determinada relação jurídica produz efeitos geralmente não-mensuráveis a sujeitos que não participam daquela determinada relação". Exemplo clássico é a poluição, externalidade (negativa) causada pela produção industrial, que não atinge apenas os produtores ou consumidores diretos dos produtos fabricados (partes da relação econômica), mas também os moradores das áreas próximas à indústria (terceiros).

Na área social, para Salomão Filho (2008, p. 34), “externalidades são benefícios ou malefícios causados pela relação jurídica a grupos sociais menos favorecidos ou à organização da sociedade como um todo".

Externalidade é, assim, "o efeito experimentado por alguém, mas que deriva de ato, fato ou ação de outrem ${ }^{340 "}$ " (SZTAJN, 2004, p 7). Nusdeo (2008, p. 153) destaca que as

\footnotetext{
${ }^{340} \mathrm{Na}$ mesma linha, a definição de Stiglitz (1999, p. 215): "Sempre que um indivíduo ou uma empresa assumirem uma ação que tenha efeito sobre outro indivíduo ou empresa, para os quais estes últimos não pagaram ou cuja ação não foi paga, dizemos que há uma externalidade". Tradução livre de: "Whenever an individual or firm undertakes an action that has an effect on another individual or firm, for which the latter does not pay or is not paid, we say there is an externality" (STIGLITZ, 1999, p. 215).
} 
externalidades correspondem a "custos ou benefícios circulando externamente ao mercado, vale dizer, que se quedam incompensados, pois, para eles, o mercado, por limitações institucionais, não consegue imputar um preço". Dessa maneira, "o nome externalidade ou efeito externo não quer significar fatos ocorridos fora das unidades econômicas, mas sim fatos ou efeitos ocorridos fora do mercado, externos ou paralelos a ele, podendo ser vistos como efeitos parasitas" (NUSDEO, 2008, p. 153).

As externalidades que têm como consequência custos para terceiros são chamadas de negativas, e as que beneficiam terceiros são as positivas (STIGLITZ, 1999, pp. 80-1 ${ }^{341}$ ).

A tendência natural do agente privado quando se depara com uma externalidade negativa é de não incorrer em quaisquer custos para modificar sua forma de produção e deixar que o terceiro (coletividade) sofra com os efeitos danosos e ainda arque com os custos deles decorrentes, salvo ação do poder público impondo sua internalização ${ }^{342}$ (uma vez que o produtor hedonista, pensando em seus custos, tem o impulso de tornar ou manter externo o que não esteja obrigado a internalizar) (NUSDEO, 2008, pp. 156-7). Nusdeo (2008, p. 154) ressalta que as externalidades negativas "não decorrem de uma ação delituosa ou ilegal por parte dos causadores dos custos. Eles exercem-na dentro das regras do jogo do mercado".

Com relação às externalidades positivas, que se apresentam como benefícios para a coletividade, há uma tendência natural dos agentes econômicos, também de acordo com o espírito hedonista do mercado, em lançar para fora os seus custos (externalizá-los) e internalizar os benefícios gerados externamente ao mercado (NUSDEO, 2008, pp. 155-6). Neste último caso, na hipótese em que a atividade produza externalidades sociais positivas, os agentes econômicos tenderiam ainda a buscar uma compensação dos beneficiados pela externalidade positiva produzida, por meio de subsídios do Estado, redução de impostos, entre outras medidas (NUSDEO, 2008, p. 156).

\footnotetext{
341 Segundo Stiglitz (1999, p. 80-1), “Casos em que uma ação individual impuser um custo sobre os outros são chamados de externalidades negativas. Mas nem todas as externalidades são negativas. Existem alguns casos importantes de externalidades positivas, em que ações individuais conferem um benefício aos outros". Tradução livre de: "Instances where one individual's actions impose a cost on others are referred to as negative externalities. But not all externalities are negative. There are some important instances of positive externalities, where one individual 's actions confer a benefit upon others" (STIGLITZ, 1999, p. 80-1).

${ }^{342}$ Segundo Sakurai; Toneto e Gremaud (2010, p. 2), "a principal característica da externalidade negativa está associada ao fato de que a ação de um agente gera consequências indesejadas a outros, mas, mais do que isso, o mecanismo clássico de mercado não consegue precificar adequadamente tais malefícios, pois o agente gerador não assume todos os custos decorrentes de sua ação, diferentemente de um bem tipicamente privado - em alguns casos, o mecanismo de mercado falha porque tais malefícios são difusos e atingem uma coletividade, diminuindo os incentivos individuais em limitar a ação do agente gerador. Seja como for, a ideia é que, na existência de externalidades negativas, a ação governamental pode ser benéfica ao limitar a ação dos indivíduos através da imposição de sanções legais ou de multas, por exemplo".
} 
Para Joseph Stiglitz (1999, pp. 80-1):

\begin{abstract}
Sempre que tais externalidades estiverem presentes, a alocação de recursos pelo mercado não será eficiente. Já que os indivíduos não suportam o custo total das externalidades negativas que eles geram, eles irão se envolver em uma quantidade excessiva de tais atividades, inversamente, uma vez que os indivíduos não gozam de todos os benefícios de atividades geradoras de externalidades positivas, eles irão se envolver muito pouco nelas. Assim, por exemplo, sem algum tipo de intervenção do governo, o grau de poluição seria demasiado elevado ${ }^{343}$.
\end{abstract}

Sobre as atividades que produzem externalidades sociais, Salomão Filho (2008, p. 34) afirma que: "o que importa é a existência de relevância social na atividade, que faz com que ela não possa ser prestada pelos particulares sem efeitos distributivos perversos".

\title{
3.12 As externalidades sociais e a sua incompatibilidade com a lógica econômica
}

Como vimos acima, o agente privado, dentro da lógica econômica, possui outros objetivos no desempenho de sua atividade, que não a produção ou conservação de externalidade sociais positivas (ou o atendimento da função social da empresa, em benefício da coletividade). Segundo o pensamento de Salomão Filho (2008), o prestador privado teria dificuldades em conciliar tais objetivos com as externalidades sociais geradas em determinadas atividades. Para o autor (2008, p. 33):

Toda vez que determinada atividade econômica tiver externalidades sociais, sejam positivas ou negativas (respectivamente, benefícios ou malefícios), o mercado não será um elemento organizador eficiente, pois nesses casos o mercado não é capaz de recompensálas ou compensá-las.

A internalização das externalidades pelo agente privado não seria atrativa, já que as externalidades não geram retorno imediato (e muitas vezes nem mediato) para os recursos investidos pelo empresário. As externalidades sociais positivas, em geral, geram benefícios para a coletividade, os quais não envolvem necessariamente lucros para o agente econômico privado. Um administrador de uma empresa, numa decisão estratégica entre questões que envolvam retorno financeiro para os sócios e externalidades sociais para a coletividade, tenderia a decidir em favor da questão que gere maior lucro para os sócios da

\footnotetext{
${ }^{343}$ Tradução livre de: "Whenever there are such externalities, the resource allocation provided by the market will not be efficient. Since individuals do not bear the full cost of the negative externalities they generate, they will engage in an excessive amount such activities; conversely, since individuals do not enjoy the full benefits of activities generating positive externalities, they will engage in too little of these. Thus, for example, without government intervention of some kind, the level of pollution would be too high" (STIGLITZ, 1999, p. 80-1).
} 
empresa, já que este é seu objetivo principal. De acordo com Salomão Filho (2008, p. 34), setores que apresentam externalidades sociais relevantes não poderiam ser regulados ${ }^{344}$, devendo o Estado prestar diretamente o serviço, uma vez que o prestador privado teria grande dificuldade em aceitar o valor social embutido na atividade. Para o autor (2008, p. 34):

[...] toda vez que estiverem presentes estas externalidades sociais não há possibilidade de participação do particular. É inútil tentar mudar sua natureza através de regimes jurídicos específicos. Não há regime de direito público que consiga mudar - ao menos no que tange às decisões econômicas - a mentalidade individualista dos particulares.

\subsection{As externalidades sociais da educação e a atuação do setor privado}

A educação pode ser vista como uma atividade com relevantes externalidades sociais, tanto positivas quanto negativas. A respeito da educação, Salomão Filho (2008, p. 34) afirma:

Imagine-se o caso clássico da educação. Jamais o que o estudante está disposto ou tem condições de pagar pela escola pode remunerar o imenso benefício social trazido pela educação de cada indivíduo. Até porque esse benefício não é passível de mensuração. Isso responde pelos maus resultados da educação quando sujeita às regras de mercado - ou a escola privada desvirtua o sistema educacional, oferecendo ensino de baixa qualidade e, portanto, deixando de produzir externalidades sociais positivas, ou o preço cobrado pelo ensino geralmente torna-o inacessível à grande maioria, o que também gera grandes externalidade sociais negativas.

Na mesma linha, Nusdeo (2008, p. 156) também classifica a educação como uma atividade produtora de externalidades positivas, dando o seguinte exemplo:

Uma fábrica instalada numa região de baixo nível de instrução da comunidade poderá promover programas de capacitação de recursos humanos. Além de preparar os seus operários para as tarefas a ela necessárias, referida fábrica estará contribuindo para a melhoria do nível geral de conhecimentos daquela cidade, pois os trabalhadores mais preparados poderão se tornar vereadores, coordenadores de programas municipais ou mesmo ir trabalhar em outras fábricas que venham a ali se instalar posteriormente, beneficiando-se, eles e a comunidade, do investimento em instrução realizado pela primeira.

\footnotetext{
${ }^{344}$ Regular, para o Professor Salomão Filho, "engloba toda forma de organização da atividade econômica através do Estado, seja a intervenção através da concessão de serviço público ou o exercício de poder de polícia". A concepção é ampla e justifica-se pelo fato do Estado ordenar ou regular a atividade econômica quando concede ao particular a prestação de serviços públicos e regula sua utilização - impondo preços, quantidade produzida etc., bem como quando edita regras no exercício do poder de polícia administrativo. (SALOMÃO FILHO, 2001, p. 15)
} 
Mas o que diferencia a educação de outros setores econômicos? Por que a educação teria essa restrição - de não poder ser oferecida pelo setor privado - e outras atividades que também produzem externalidades não?

A resposta para esta pergunta pode ser encontrada se observarmos detalhes da doutrina de Salomão Filho (2008). Primeiro, o autor trata da impossibilidade da participação do particular em atividades que produzem externalidades sociais ("benefícios ou malefícios causados pela relação jurídica a grupos sociais menos favorecidos ou à organização da sociedade como um todo" - SALOMÃO FILHO, 2008, p. 34) e não apenas externalidades. E, segundo, o autor ressalta a importância da existência de "relevância social na atividade, que faz com que ela não possa ser prestada pelos particulares sem efeitos distributivos perversos" (SALOMÃO FILHO, 2008, p. 34). Portanto, a ideia por ele desenvolvida não se aplica a qualquer atividade, mas apenas àquelas que preencham essas características - produzam externalidades sociais e tenham relevância social (como educação e saúde, destacadas pelo próprio autor).

A educação, conforme descreveremos abaixo, é uma atividade que produz externalidades sociais positivas e negativas e que apresenta uma evidente relevância social. Além disso, a educação é diferente dos setores econômicos comuns por conta de sua própria natureza. A educação em si é uma externalidade social ${ }^{345}$. É um direito, que deve ser garantido pelo Estado. Nesse sentido, ser alfabetizado e depois progressivamente alcançar os níveis superiores da educação é um direito social e uma externalidade social. O processo educativo envolve não apenas quem oferece (instituição e seus professores) e quem recebe a educação (alunos), mas também a sociedade como um todo (desde a família, a comunidade no entorno da instituição até todos os indivíduos que se relacionam em sociedade).

Nessa linha, Amartya Sen (2000, p.154) destaca a importância da educação como um bem que favorece o indivíduo e a coletividade ao mesmo tempo, afirmando que:

As pessoas que recebem educação obviamente se beneficiam com isso, mas, adicionalmente, uma expansão geral da educação e alfabetização em uma região pode favorecer a mudança social (até mesmo a redução da fecundidade e da

\footnotetext{
${ }^{345} \mathrm{O}$ mesmo raciocínio pode ser empregado para a área da saúde. Em outras atividades, a externalidade é uma consequência da atividade e não gerada pela atividade em si, como a educação e saúde. Numa indústria de automóveis, por exemplo, a produção do carro em si não é uma externalidade social, mas o que decorre dele, como sua aquisição em grande escala, com o consequente impacto no trânsito e na poluição das grandes cidades, diminuindo a qualidade de vida da população (externalidade social negativa, no caso). Além disso, ter um carro não é um direito fundamental, que deve ser garantido pelo Estado, é muito mais uma comodidade para o consumidor individual, com consequências para a sociedade como um todo.
} 
mortalidade), além de ajudar a aumentar o progresso econômico que beneficia também outras pessoas.

Nesse sentido, o próprio aumento do grau de educação da sociedade é uma externalidade social positiva da educação, em razão da sua capacidade de desenvolver a personalidade do indivíduo e sua capacidade crítica, influenciando seu modo de atuar na sociedade, mediante a aquisição de conhecimentos que permitem a emancipação do indivíduo, o que favoreceria a sociedade como um todo. $\mathrm{O}$ oferecimento de uma educação de boa qualidade auxilia o desenvolvimento científico e tecnológico do país e amplia o acesso dos jovens a melhores níveis de emprego e renda, com a consequente diminuição da dependência tecnológica, aumento da renda e diminuição das desigualdades sociais, o que também é uma externalidade social positiva. Ademais, a própria instalação de uma instituição de ensino em determinadas localidades melhora a qualidade de vida da população do seu entorno.

Entretanto, a educação também pode gerar externalidades negativas. No sistema de mercado, caso a qualidade do ensino varie de acordo com o valor da mensalidade, haveria um incremento das desigualdades sociais em função do tipo de mercadoria (educação) que o indivíduo tem condições de obter. Em geral, a falta da educação ou a educação de baixa qualidade é uma externalidade negativa.

A educação como mercadoria, que circula e concorre no mercado, diferencia os alunos, conforme a condição econômica para a escolha do melhor produto:

Os compradores/consumidores adquirem a mercadoria que lhes é possível obter. Embora
ela pareça equivalente a outras mercadorias semelhantes, já que não há distinção formal na
hora do registro curricular profissional, as diferenças qualitativas do processo ensino-
aprendizagem e de capital institucional são reais e definem o ingresso e o exercício da
profissão no mercado de trabalho. A mercadoria adquirida, que possui qualidade inferior,
não permite ao seu proprietário (ao aluno) ingressar e/ou permanecer com eficiência no
mundo do trabalho (OLIVEIRA; DOURADO, 2005, p. 70).

A afirmação de que a educação é diferente de outros bens comercializados no sistema de mercado é também sustentada por Christopher Winch (1996) ${ }^{346}$. Primeiro, porque o Estado tem interesse em controlar certas atividades, como a educação, mesmo

346 James Tooley possui uma obra em que refuta todos os argumentos de Winch (1996). Trata-se do seguinte artigo: TOOLEY, James. The 'neo-liberal' critique of state intervention in education: a reply to Winch. Journal of Philosophy of Education, Oxford, v. 32, n. 2, 1998. Parte dos contra-argumentos de Tooley (1998) estão descritos nas notas de rodapé abaixo. 
quando ele autoriza o setor privado a atuar nelas ${ }^{347}$. Segundo, porque a educação está associada a valores dos indivíduos e da sociedade ${ }^{348}$, e por isso não pode ser considerada um bem puramente comercial, dirigido à busca do lucro ${ }^{349}$. Terceiro, porque a introdução de sistemas de qualidade orientados pelo mercado não tem a mesma eficácia em organizações educacionais ${ }^{350}$. Quarto, porque o conceito de consumidor como utilizado no setor privado não se aplica na área da educação ${ }^{351}$ (WINCH, 1996, p. 16).

Winch (1996, p. 18) destaca também que os resultados da educação não são

${ }^{347}$ Winch (1996, p. 16) destaca que o Estado continua mantendo serviços públicos, ainda que eles estejam sujeitos a disciplinas de mercado, o que demonstra que alguns setores nunca operarão de uma forma totalmente independente do Estado.

${ }^{348}$ Segundo Winch (1996, p. 17), a educação está associada a valores diferentes das relações de mercado. A educação tem valores que envolvem os indivíduos e a sociedade, algumas com orientação religiosa ou preocupação moral. Empresas estão também associadas a valores, mas outro tipo de valores, que envolvem sua maneira de atuar, suas relações com seus empregados e consumidores. Nas instituições de ensino, o relacionamento com os alunos é mais longo, envolvendo várias fases da educação, os valores são mais particulares, as escolas procuram modificar seus alunos, influenciando-os em suas vidas, e não buscam simplesmente influenciá-los a voltar ao estabelecimento e comprar novamente seus produtos e/ou serviços, como fazem outras atividades comerciais (WINCH, 1996, p. 17). Tooley (1998, p. 270) discorda desse argumento afirmando que atividades comerciais também promovem valores e modificam as pessoas, cita livros que podem mudar a vida das pessoas e que são publicados por editoras comerciais, via lojas comerciais.

349 Tooley (1998, p. 269) afirma que Winch (1996) confunde educação com educação escolar e oportunidades educacionais. Para Tooley (1998, p. 269), quando a doutrina neoliberal coloca a educação como uma mercadoria, ela está falando da oferta de oportunidades educacionais e não da educação em si, como um valor intrínseco de desenvolvimento pessoal. Segundo Tooley (1998, p. 269), dentro da categoria proposta pelos neoliberais da educação como mercadoria, entram a educação escolar, lojas de livros, lojas de computadores e atividades que oferecem oportunidades educacionais - o processo educacional envolve também ler livros, assistir à televisão, ir ao cinema, visitar zoológicos, atividades que já estão no setor privado e que não são diferentes de outras atividades comerciais. Winch (1996, p. 13), no entanto, destaca que o termo "educação" envolve uma grande variedade de atividades. Cita o exemplo de um treinamento de curta duração para empregados de uma empresa, prestado em contrapartida do pagamento de um determinado valor. Como a efetividade desse treinamento pode ser medida de acordo com a melhora de determinados indicadores de performance, como a redução de acidentes ou atraso na entrega de mercadorias, esse seria um caso de serviço privado de educação.

${ }^{350}$ Essa questão, para Winch $(1996$, p. 17), envolve o relacionamento de longo prazo que a educação estabelece com o aluno. Para que os benefícios da educação sejam obtidos, não basta ao aluno acompanhar o curso, mas deve também estabelecer uma relação com os professores e com os colegas para que o processo de aprendizagem seja completo. Além disso, o relacionamento de longo prazo dificulta o controle de qualidade porque muitos valores podem ser obtidos fora do tempo previsto numa determinada avaliação. Tooley (1998, p. 271), por outro lado, destaca que várias relações comerciais são de longo prazo, como as negociações envolvendo a compra de uma casa, e que o controle de qualidade também é feito em longo prazo, o que desqualificaria essa diferença da educação para outras mercadorias.

${ }^{351}$ Descobrir quem é o consumidor da educação é uma questão para Winch (1996). Ele ressalta que, para os neoliberais, a resposta é clara - o consumidor é a pessoa que paga pelo bem. No mercado educacional, seriam os pais ou o aluno. Para Winch (1996, p. 17), existem alguns problemas nessa abordagem - primeiro, porque o consumidor poderia ser a criança, mas isso é problemático, porque uma criança pode ainda não ter os valores apropriados para orientar uma organização. Para Tooley (1998, p. 271), isso não é um problema e se aplica a outras relações comerciais, como a compra de uma roupa para uma criança, pois os valores envolvidos são os valores dos pais e não da criança. Winch $(1196$, p. 4), por outro lado, destaca que, se o consumidor não é o usuário do serviço, surge um problema de informação - como saber se o serviço está sendo devidamente prestado? A resposta seria que o Estado controlaria essa qualidade, o que coloca em choque esta posição com a doutrina neoliberal, que entende que o Estado não conseguiria também obter essa informação. 
produtos nem serviços, no sentido em que esses termos são utilizados no mercado. Os resultados da educação não podem ser medidos em termos de produtividade ou lucratividade de uma empresa. Isso porque a educação está relacionada com ganhos de longo prazo de variados tipos. Segundo Winch (1996, p. 18), esses ganhos envolvem valores, assim como benefícios econômicos, diretos ou indiretos, que resultam de um país que tem uma mão de obra bem educada ${ }^{352}$.

A respeito das diferenças entre o tratamento público e privado da educação, nota-se que, com relação à pesquisa e conhecimento científico e tecnológico, o País teria muito a perder caso se sustentasse numa estrutura privada de ensino superior, pois as instituições privadas teriam menor estímulo e recursos para o desempenho dessas atividades em razão dos grandes investimentos necessários e retorno não previsível.

Como contraponto, nas instituições de ensino superior públicas, o tratamento da educação é, a princípio, regido por outra dinâmica. Nestas, o Estado é o mantenedor, os recursos utilizados são públicos e organizados em direção ao interesse coletivo. Não tendo como objetivo fundamental o lucro, as instituições públicas podem investir em atividades que não geram retorno econômico imediato, mas que contribuem para o desenvolvimento de um espírito crítico e investigativo em seus alunos, para o desenvolvimento técnico e científico do País, para a melhora da qualidade de vida da população, bem como para a solução de questões nacionais, relativas a problemas de saúde pública, segurança, economia, transporte, agricultura, entre outros. Além disso, desenvolvem atividades de extensão relacionadas com a comunidade local em que estão inseridas, auxiliando políticas públicas. Nesse sentido, as instituições públicas cumprem com maior efetividade as finalidades da educação superior previstas no artigo 43 da LDB. Sobre as universidades públicas, Ranieri (2000, p. 237) afirma:

A que necessidades sociais responde a universidade pública? Certamente àquelas não filtradas pelo mercado, desvinculadas de critérios de demanda e consumo, uma vez que estes podem ser oferecidos, com sucesso, pela iniciativa privada. Ensino, pesquisa e extensão na universidade pública, portanto, se relacionam, direta ou indiretamente, à promoção da cidadania, tal como expressa nos objetivos fundamentais da República: a construção de uma sociedade livre, justa e solidária; a garantia do desenvolvimento nacional; a redução das desigualdades; a promoção do bem comum $\left(\mathrm{CF}\right.$, artigo $\left.3^{\circ}\right)$.

Não que universidades privadas estejam desobrigadas destes objetivos. Pelo contrário, a

\footnotetext{
352 Segundo Winch (1996, p. 16), "The outcomes of education considered more generally, however, are not use values like this which can be directly measured in terms of the productivity and profitability of a firm. This is because education is concerned with long-term gains of various kinds. These include values, standards of behavior and the maintenance of culture as well as the economic benefits, direct and indirect, that result from a country having a well-educated workforce".
} 
própria Constituição Federal reclama-lhes a participação neste mister (artigo 205), razão pela qual thes confere autonomia (artigo 207). O que diferencia as universidades públicas neste contexto é que desobrigadas, estas, do retorno econômico das atividades, podem atuar numa dimensão mais ampla, de natureza reflexiva e integradora, contribuindo para a solução de problemas sociais e o desenvolvimento do conhecimento em áreas de menor retorno econômico.

As lógicas que orientam os setores público e privado da educação são diferentes.A própria Anhanguera (2012d, p. 117-8) reconhece essa diferença afirmando:

Enquanto as instituições de ensino superior públicas são direcionadas para servir como centros de excelência e pesquisa, com padrões de admissão extremamente competitivos e capacidade de expansão limitada, as instituições de ensino superior privadas voltam sua atenção para as exigências profissionais impostas pelo mercado de trabalho e desenvolvem programas flexíveis para atender às necessidades dos trabalhadores.

Nesse sentido, com relação ao ensino superior, Sampaio (2000, p. 88) afirma:

A lógica que orienta a criação de uma instituição pública ou de um novo curso em estabelecimento já autorizado difere da lógica do setor privado de atendimento da demanda de massa. Em geral, no setor público, critérios de "necessidades sociais", sejam reais ou justificadores de disputas políticas regionais, são acionados para ampliar o leque de cursos ou para criar novos estabelecimentos. No caso das universidades públicas, muitas vezes, seus próprios órgãos dirigentes opõem-se à ampliação de vagas, porque isso implicaria, em geral, o oferecimento de cursos no turno noturno.

Já no setor privado, é a existência de um mercado de ensino superior que preside a abertura de novos estabelecimentos e/ou de novos cursos. Atrair maior número de alunos significa manter o empreendimento e, fundamentalmente, aumentar o lucro dos proprietários dos estabelecimentos privados.

Em vista do acima exposto, verifica-se que a lógica econômica, a busca por resultados, o ambiente empresarial, a forma como a atividade é desempenhada, a transformação da educação em serviço privado, a não atratividade de investimentos que não geram retorno econômico imediato podem afastar a educação, quando oferecida por instituições privadas, de sua concepção de atividade produtora de externalidades sociais positivas.

Verificar a aplicação desses pressupostos ao caso da Anhanguera é o objetivo do Capítulo 4 a seguir. 


\section{CAPÍTULO 4. O CASO DA ANHANGUERA}

Considerando os pressupostos teóricos apresentados nos capítulos antecedentes, o objetivo deste Capítulo é implementar uma análise empírica do caso da Anhanguera, buscando verificar o tratamento dado por esta empresa à educação. Para tanto, este Capítulo foi estruturado de modo a responder às Questões da Análise Empírica, na ordem proposta na Introdução.

Ressaltamos novamente que as informações constantes neste Capítulo foram retiradas de fontes oficiais, a partir de documentos e dados disponíveis para acesso público em sites de órgãos oficiais a respeito da educação superior no Brasil e da Anhanguera, em especial, os sites do Inep (http://www.inep.gov.br), MEC (http://www.mec.gov.br), Sinaes (http://www.sinaes.gov.br), IBGE (http://www.ibge.gov.br), Comissão de Valores Mobiliários - $\quad$ CVM $\quad$ (http://www.cvm.gov.br), $\quad$ BM\&FBOVESPA (http://www.bmfbovespa.com.br), Anhanguera - Comercial (http://www.anhanguera.com), Anhanguera - Relações com Investidores (http://www.anhanguera.com/ri) e Anhanguera Responsabilidade Social (http://rsocial.anhanguera.com). Ademais, incluímos informações sobre processos judiciais e jurisprudência envolvendo a Anhanguera, obtidas nos sites do Supremo Tribunal Federal (http://www.stf.jus.br) e Superior Tribunal de Justiça (http://www.stj.jus.br).

Neste Capítulo, encontram-se as informações mais relevantes obtidas nas fontes acima descritas. No Apêndice A da Dissertação, consta a descrição de toda a documentação pública analisada da Anhanguera.

\subsection{Grupo I - Informações gerais sobre a Anhanguera}

\subsubsection{Questões de 1 a 4}

Neste subitem, procuramos responder às seguintes questões: 
Quadro 4 - Questões da Análise Empírica $n^{\text {os }} 1,2,3$ e 4

\begin{tabular}{|l|l|}
\hline $\mathbf{N}^{\mathbf{0}}$ & \multicolumn{1}{|c|}{ Grupo I - Informações Gerais sobre a Anhanguera } \\
\hline 1. & $\begin{array}{l}\text { Qual é o objeto social da Anhanguera? Quais seus direitos e deveres com relação às IES a ela } \\
\text { subordinadas? Como fica o tratamento da autonomia universitária no relacionamento da Anhanguera } \\
\text { e suas subsidiárias? }\end{array}$ \\
\hline 2. & $\begin{array}{l}\text { Como é a estrutura societária do grupo Anhanguera? Quem detém o controle do grupo? Qual a } \\
\text { posição da Anhanguera dentro do grupo? Quais são as entidades mantenedoras das IES do grupo? } \\
\text { Quantas IES fazem parte do grupo? Quais as formas de organização acadêmica dessas instituições? }\end{array}$ \\
\hline 3. & $\begin{array}{l}\text { Qual a posição da Anhanguera no mercado educacional brasileiro? A quantos alunos seu grupo } \\
\text { atende? Em quais regiões atua? }\end{array}$ \\
\hline 4. & $\begin{array}{l}\text { A Anhanguera é uma empresa atrativa para os investidores? Qual o valor médio de cotação das ações } \\
\text { da Anhanguera? Qual o valor de lucro líquido apurado pela Anhanguera nos últimos anos? }\end{array}$ \\
\hline
\end{tabular}

A Anhanguera (Companhia) é uma sociedade por ações de capital aberto, listada no Novo Mercado da BM\&FBOVESPA, com sede na cidade de Valinhos, estado de São Paulo, controladora do grupo Anhanguera, que atua no setor do ensino superior, ensino profissional, educação continuada, cursos na área jurídica e cursos preparatórios para concursos públicos, nas modalidades presencial e a distância (ANHANGUERA, 2012d, p. 109).

Especificamente com relação ao ensino superior, o grupo Anhanguera oferece aos seus alunos quatro programas acadêmicos: (i) graduação presencial; (ii) graduação a distância; (iii) pós-graduação lato sensu; e (iv) pós-graduação stricto sensu (ANHANGUERA, 2012d, p. 109).

O objeto social da Anhanguera é (i) o desenvolvimento e/ou administração de atividades e/ou instituições nas áreas de educação de nível superior, educação profissional e/ou outras áreas associadas à educação; (ii) a administração de bens e negócios próprios; (iii) a participação, na qualidade de acionista ou quotista, em outras sociedades ou empreendimentos, no Brasil ou no exterior; (iv) o desenvolvimento de cursos na área jurídica e de cursos preparatórios para concursos públicos em geral, sejam preparatórios para concursos públicos jurídicos, ministrados de forma presencial e telepresencial a distância, de cunho intensivo e extensivo, sejam de extensão universitária e de pósgraduação lato sensu, oferecidos ao público consumidor de modo direto, por meio presencial ou por meio de qualquer sistema tecnológico de comunicação de dados diretamente para os consumidores, ou por meio de uma rede de parceiros ou concessão de franquias de unidades de ensino a distância, receptores do sinal televisivo ou de qualquer outro sistema de transmissão de dados; (v) o oferecimento de cursos de aprendizagem, treinamento gerencial e profissional, preparatórios para carreira jurídica, atualização profissional, extensão universitária, especialização e monográficos; (vi) a prestação de serviços de promoção e organização de eventos e cursos; (vii) o desenvolvimento e a 
ampliação do conteúdo dos cursos de pós-graduação oferecidos, bem como o desenvolvimento de novos cursos de pós-graduação lato sensu nas diversas áreas do conhecimento, ministrados de forma telepresencial a distância; (viii) a prestação de serviços relativa a cursos livres, inclusive cursos de idioma e demais atividades correlatas; (ix) a edição de livros e demais atividades correlatas; (x) a gestão de direitos autorais de obras literárias; (xi) a intermediação e representação de venda de jornais, revistas, livros e outras publicações, inclusive com o recebimento de comissões pelas vendas; e (xii) serviços de assessoria, consultoria, orientação e assistência operacional em gestão empresarial, inclusive com relação à concessão de franquias de unidades de ensino a distância $^{353}$. Até 30/09/2010, quando foi aprovada a incorporação pela Anhanguera de sua subsidiária, LFG Business, Edições e Participações Ltda. (LFG), a Anhanguera atuava apenas como uma holding ${ }^{354}$, mas após a incorporação da LFG, a Anhanguera passou a desempenhar também de forma direta as atividades anteriormente desenvolvidas pela LFG, que estão descritas nos itens (iv) a (xii) do seu objeto social acima (ANHANGUERA, 2012d, p. 109).

Em 31 de dezembro de 2011, a Anhanguera era considerada a maior empresa do setor educacional em atividade no Brasil e o segundo maior grupo educacional do mundo em termos de valor de mercado que, naquela data, era de $\mathrm{R} \$ 2,93$ bilhões; e em número de alunos que, naquela data, era de mais de $400 \mathrm{mil}^{355}$, matriculados em 73 campi e em mais de 500 polos (ANHANGUERA, 2012d, p. 109).

O grupo Anhanguera desenvolve suas atividades em campi e polos. Anteriormente, possuía também unidades de formação profisssional operadas no modelo de franquia, mas essa atividade foi interrompida no segundo semestre de $2010^{356}$. Os campi são unidades que oferecem todos os programas acadêmicos da Anhanguera (graduacão presencial, graduacão a distancia, pós-graduacão lato sensu, pós-graduação stricto sensu e educacão continuada), e os polos são unidades operadas pela Anhanguera e por parceiros locais com oferta selecionada dos cursos na metodologia a distância, incluindo graduação, pós-

\footnotetext{
${ }^{353}$ Conforme artigo $3^{\circ}$ do ES da Anhanguera, consolidado na AGE de 31/05/2012 (ANHANGUERA, 2012c)

354 Holding é uma empresa que possui como atividade principal a participação societária majoritária em outras empresas, atuando nelas como sócia controladora. Nesse sentido, quando atuava como holding, a Anhanguera desempenhava apenas as atividades descritas nos itens (i) a (iii) do seu objeto social.

${ }^{355}$ Destes, mais de 160 mil estão em cursos que têm a educação a distância como principal metodologia de ensino (ANHANGUERA, 2012d, p. 112).

${ }^{356}$ As unidades de formação profissional eram operadas por modelo de franquia com oferta selecionada de cursos de ensino profissionalizante com a marca Microlins. Esse segmento foi descontinuado durante o segundo semestre de 2010, com a venda da participação da Anhanguera na Microlins (ANHANGUERA, 2012d, p. 110).
} 
graduação lato sensu e educação continuada (ANHANGUERA, 2012d, p. 110).

Segundo a Anhanguera (2012d, p. 113), seus campi "são tipicamente dimensionados para atender entre 2.000 e 7.000 alunos, após três a cinco anos de existência, quando geralmente atingem a sua maturidade". Em 31/12/2011, o Grupo Anhanguera possuía 73 campi $^{357}$ de ensino superior, em 44 cidades, com um total médio de 250 mil alunos e uma média de 3,5 mil alunos por campus (ANHANGUERA, 2012d, p. 113). Segundo a Companhia (2012d, p. 148), naquela data, dos seus 73 campi, 56 ainda não haviam atingido seu amadurecimento. A tendência, portanto, segundo a própria Companhia (2012d, p. 113), é de crescimento nos próximos anos, quando um número maior de campi atingirá a maturidade.

Os polos são tipicamente dimensionados para atender até 1.000 alunos, após três a cinco anos de existência, quando geralmente atingem sua maturidade (ANHANGUERA 2012d, p. 114). Segundo a Companhia (2012d, p. 114), a infraestrutura dos polos é "menos completa que aquela oferecida pelos Campus", composta por salas de aula com recursos audiovisuais, sala de estudo, laboratório de informática e biblioteca. Em 31/12/2011, a Anhanguera possuía 500 polos, em mais de 450 cidades, em todos os estados brasileiros e no Distrito Federal, com um total de 145 mil alunos e uma média de mais de 291 alunos por polo (ANHANGUERA, 2012d, p. 114). De acordo com informações da Companhia (2012d, p. 115), o número de polos tem crescido de forma expressiva - entre 31/12/2010 e $31 / 12 / 2011$, o número de alunos em polos cresceu $9,1 \%$.

Existem polos próprios e polos em parceria com terceiros. Nos polos em parceria, o parceiro local é responsável pela estrutura física e pelos serviços locais (serviços ao aluno, marketing, equipamentos, instalações). Em contrapartida à prestação desses serviços, os parceiros locais recebem um percentual que varia entre $25 \%$ e $56 \%$ da receita líquida mensal recebida pelo polo, dependendo do tipo de curso por ele oferecido (ANHANGUERA, 2012d, p. 115). Independentemente de ser próprio ou em parceria, no modelo de polos, a Anhanguera é responsável por todas as atividades pedagógicas centrais - desenvolvimento de currículo, materiais impressos, tutoria eletrônica, teleaulas, ambiente virtual de aprendizagem (AVA), contratação de professores locais para as atividades acadêmicas desenvolvidas nos polos, marketing, plataforma de tecnologia da informação e gestão financeiro-administrativa da rede (ANHANGUERA, 2012d, p. 115).

357 Os campi da Anhanguera são implantados geralmente em imóveis alugados, cujos locadores são os antigos proprietários das instituições de ensino superior adquiridas. Conforme análise das Atas das Reuniões do Conselho de Administração da Anhanguera. Vide Apêndice A da Dissertação. 
Abaixo dados sobre a média de alunos matriculados nos campi e nos polos em 2010 e 2011:

Tabela 29 - Média de Alunos Matriculados - 2010 - 2011

\begin{tabular}{c|c|c}
\hline & $\mathbf{4}^{\mathbf{0}}$ Trimestre 2011 & $\mathbf{4}^{\mathbf{0}}$ Trimestre 2010 \\
\hline Média de alunos matriculados & $\mathbf{4 0 0 . 1 0 9}$ & $\mathbf{2 9 2 . 2 4 8}$ \\
Campi & 254.795 & 159.114 \\
Polos & 145.314 & 133.134 \\
\hline
\end{tabular}

Fonte: Anhanguera (2012e)

Dentre os segmentos operacionais em que a empresa atuou nos anos de 2009 e 2011 (campi, polos e unidades de formação profissional), a receita da Anhanguera concentrou-se nos campi (com porcentagens acima de $76 \%$ da receita total):

Tabela 30 - Distribuição da Receita entre os Segmentos Operacionais da Anhanguera -2009 - 2011

\begin{tabular}{c|c|c|c}
\hline $\begin{array}{c}\text { Segmento } \\
\text { Operacional }\end{array}$ & Ano & $\begin{array}{c}\text { Receita do Segmento } \\
\text { Operacional (reais) }\end{array}$ & $\begin{array}{c}\text { Participação na } \\
\text { Receita Total (\%) }\end{array}$ \\
\hline Campi & 2011 & 1.015 .647 & 82,4 \\
& 2010 & 781.296 & 77,8 \\
Polos & 2009 & 695.480 & 76,9 \\
& 2011 & 216.521 & 17,6 \\
& 2010 & 204.909 & 20,4 \\
Formação & 2009 & 162.816 & 18,0 \\
Profissional & 2011 & $\mathrm{~N} / \mathrm{A}$ & $\mathrm{N} / \mathrm{A}$ \\
& 2010 & 17.634 & 1,8 \\
Total Segmentos & 2009 & 46.253 & 5,1 \\
& 2011 & 1.232 .168 & 100 \\
& 2010 & 1.003 .839 & 100 \\
& 2009 & 904.548 & 100 \\
\hline
\end{tabular}

Fonte: Anhanguera (2012d)

A Anhanguera atua nas regiões Sudeste, Sul e Centro-Oeste do Brasil. Em 2010, segundo a Companhia, a Anhanguera contava com market share de, aproximadamente, $5 \%, 2 \%$ e $11 \%$ em cada uma dessas regiões, respectivamente (ANHANGUERA, 2012d, p. 122).

Abaixo a relação de localidades em que o grupo Anhanguera oferece cursos de graduação $^{358}$ :

\footnotetext{
${ }^{358}$ Informações obtidas no site comercial da Anhanguera. A somatória das localidades constantes na tabela dá um total de 48 cidades e 70 campi, informação diferente da constante no Formulário de Referência de 2012, que afirma que o grupo possui 73 campi. Como no Formulário de Referência não há uma listagem de todos os campi e unidades, preferimos utilizar a informação constante no site, que deve estar mais atualizada. Disponível em: <http://www.unianhanguera.edu.br/graduacao/localidades/graduacao_localidades.php>.
} 
Quadro 5 - Unidades Anhanguera

\begin{tabular}{|c|c|c|c|c|c|}
\hline & Região & Estado & Cidade & $\begin{array}{l}\text { Organização } \\
\text { Acadêmica }^{359}\end{array}$ & $\begin{array}{c}\text { Oferece cursos a } \\
\text { distância pela } \\
\text { Universidade } \\
\text { Anhanguera- } \\
\text { Uniderp }^{\mathbf{3 6 0}}\end{array}$ \\
\hline 1. & \multirow[t]{19}{*}{ Sudeste } & $\mathrm{MG}$ & $\begin{array}{l}\text { Belo Horizonte } \\
\text { (3 unidades) }\end{array}$ & Faculdade $^{361}$ & Sim \\
\hline 2. & & RJ & Niterói & Centro Universitário $^{362}$ & $\mathrm{Sim}$ \\
\hline 3. & & $\mathrm{SP}$ & Bauru & Faculdade & $\mathrm{Sim}$ \\
\hline 4. & & $\mathrm{SP}$ & Campinas (4 unidades) & Faculdade & $\mathrm{Sim}$ \\
\hline 5. & & $\mathrm{SP}$ & Guarulhos & Faculdade $^{363}$ & Não \\
\hline 6. & & $\mathrm{SP}$ & Indaiatuba & Faculdade & $\mathrm{Sim}$ \\
\hline 7. & & $\mathrm{SP}$ & Itapecerica da Serra & Faculdade & Sim \\
\hline 8. & & $\mathrm{SP}$ & Jacareí & Faculdade & Sim \\
\hline 9. & & SP & Jundiaí (2 unidades) & Faculdade $^{364}$ & Sim \\
\hline 10. & & $\mathrm{SP}$ & Leme & Centro Universitário & $\mathrm{Sim}$ \\
\hline 11. & & SP & Limeira & Faculdade & Sim \\
\hline 12. & & $\mathrm{SP}$ & Matão & Faculdade & Sim \\
\hline 13. & & SP & Osasco (2 unidades) & $\begin{array}{ll}\text { Faculdade } & \mathrm{e} \\
\text { Universidade }^{365} & \end{array}$ & Sim \\
\hline 14. & & SP & Pindamonhangaba & Universidade $^{366}$ & Sim \\
\hline 15. & & $\mathrm{SP}$ & Piracicaba & Faculdade & Sim \\
\hline 16. & & SP & Pirassununga & Centro Universitário & Sim \\
\hline 17. & & $\mathrm{SP}$ & Ribeirão Preto & Faculdade & $\mathrm{Sim}$ \\
\hline 18. & & SP & Rio Claro & Faculdade & Sim \\
\hline 19. & & SP & Santa Bárbara d'Oeste & Faculdade & Sim \\
\hline
\end{tabular}

Acesso em 03/07/2012.

${ }^{359}$ No site comercial da Anhanguera (http://www.anhanguera.com), nas informações sobre as unidades, em algumas delas ainda se mantinha o nome original da instituição de ensino superior adquirida pela Anhanguera. Pela análise das informações lá presentes, nota-se que as instituições adquiridas passam por um processo de transição para o modelo Anhanguera - quando a marca da instituição adquirida é muito forte, ela permanece e aglutina-se ao nome Anhanguera, como é o caso da Universidade Anhanguera-Uniderp; nos demais casos, após um período de transição, as instituições passam a se denominar apenas Anhanguera. Nas notas de rodapé a seguir, destacamos essas informações.

360 Informações obtidas no site comercial da Anhanguera. Disponível em: $<$ http://www.unianhanguera.edu.br/graduacao/localidades/graduacao_localidades.php $>$. Acesso em 03/07/2012. Analisando as referidas informações, nota-se que as IES que ainda não oferecem cursos a distância pela Universidade Anhanguera-Uniderp são as que passaram a integrar o grupo em tempos mais recentes. Passado o período inicial de transição para o modelo Anhanguera, a tendência é que todas as IES ofereçam cursos a distância por meio da Universidade Anhanguera-Uniderp. Mesmo no período de transição, a Anhanguera não deixa de oferecer, contudo, parte da carga horária dos cursos, por meio de aulas a distância, fato este que tem gerado insatisfação nos alunos que faziam cursos apenas presenciais nas instituições adquiridas, conforme item 4.3.2 a seguir.

${ }^{361}$ Uma das unidades é a Faculdade de Negócios de Belo Horizonte, as outras duas já se denominam Anhanguera.

${ }^{362}$ Trata-se do Centro Universitário Plínio Leite - Unipli.

${ }^{363}$ Trata-se das Faculdades Integradas Torricelli.

${ }^{364}$ Uma das unidades é a Faculdade de Tecnologia Professor Luiz Rosa; a outra já se denomina Anhanguera.

${ }^{365}$ Uma das unidades é a Uniban; a outra já se denomina Anhanguera.

366 Trata-se da Universidade Anhanguera-Uniderp. 
Quadro 5 - Unidades Anhanguera

\begin{tabular}{|c|c|c|c|c|c|}
\hline & Região & Estado & Cidade & $\begin{array}{c}\text { Organização } \\
\text { Acadêmica }\end{array}$ & $\begin{array}{c}\text { Oferece cursos a } \\
\text { distância pela } \\
\text { Universidade } \\
\text { Anhanguera-Uniderp }\end{array}$ \\
\hline 20. & \multirow[t]{11}{*}{ Sudeste } & SP & $\begin{array}{l}\text { Santo André } \\
(2 \text { unidades })\end{array}$ & $\begin{array}{ll}\text { Universidade }^{367} & \mathrm{e} \\
\text { Centro Universitário } & \end{array}$ & Sim \\
\hline 21. & & SP & $\begin{array}{lll}\text { São } & \text { Bernardo } & \text { do } \\
\text { Campo }(3 \text { unidades })\end{array}$ & $\begin{array}{ll}\text { Faculdade }^{368} & \mathrm{e} \\
\text { Universidade }^{369} & \end{array}$ & Não \\
\hline 22. & & SP & São Caetano do Sul & Faculdade & Sim \\
\hline 23. & & SP & São José dos Campos & Faculdade & Sim \\
\hline 24. & & SP & $\begin{array}{l}\text { São Paulo (5 unidades) } \\
\text { Brigadeiro, Campo } \\
\text { Limpo, Maria Cândida, } \\
\text { Morumbi e Pirituba) }\end{array}$ & $\begin{array}{l}\text { Centro Universitário e } \\
\text { Universidade }^{370}\end{array}$ & Sim \\
\hline 25. & & $\mathrm{SP}$ & Sertãozinho & Faculdade & Sim \\
\hline 26. & & SP & Sorocaba (3 unidades) & Faculdade $^{371}$ & Sim \\
\hline 27. & & SP & Sumaré & Faculdade & Sim \\
\hline 28. & & $\mathrm{SP}$ & Taboão da Serra & Faculdade & Sim \\
\hline 29. & & SP & Taubaté (2 unidades) & Faculdade & Sim \\
\hline 30. & & SP & Valinhos & Faculdade & Sim \\
\hline 31. & \multirow{9}{*}{$\begin{array}{l}\text { Centro- } \\
\text { Oeste }\end{array}$} & $\mathrm{DF}$ & Brasília & Faculdade $^{372}$ & Sim \\
\hline 32. & & $\mathrm{DF}$ & Taguatinga (3 unidades) & Faculdade $^{373}$ & Sim \\
\hline 33. & & GO & Anápolis & Faculdade & Sim \\
\hline 34. & & $\mathrm{GO}$ & Goiânia & Faculdade $^{374}$ & Não \\
\hline 35. & & GO & Valparaíso de Goiás & Faculdade & Sim \\
\hline 36. & & MS & $\begin{array}{l}\text { Campo Grande } \\
\text { (2 unidades) }\end{array}$ & Centro Universitário & Não \\
\hline 37. & & MT & Cuiabá (2 unidades) & Faculdade $^{375}$ & Não \\
\hline 38. & & MS & Dourados & Faculdade & Sim \\
\hline 39. & & MT & Rondonópolis & Faculdade & Não \\
\hline
\end{tabular}

${ }^{367}$ Trata-se da Universidade do Grande ABC - UniABC.

${ }^{368}$ Trata-se da Faculdade Anchieta, Faculdade de Tecnologia Anchieta e da Faculdade Anhanguera.

${ }^{369}$ Trata-se da Uniban.

${ }^{370}$ Trata-se da Uniban.

3712 unidades são Imapes e Faculdade Uirapuru; a outra já se denomina Anhanguera.

${ }^{372}$ Trata-se da Faciteb.

3732 unidades são Facnet e Faculdade Santa Terezinha, a outra já se denomina Anhanguera.

374 Trata-se da Faculdade de Goiânia - FAG.

${ }^{375}$ Uma das unidades é a Famat, a outra já se denomina Anhanguera. 
Quadro 5 - Unidades Anhanguera

\begin{tabular}{|c|c|c|c|c|c|}
\hline & Região & Estado & Cidade & $\begin{array}{c}\text { Organização } \\
\text { Acadêmica }\end{array}$ & $\begin{array}{c}\text { Oferece cursos a } \\
\text { distância pela } \\
\text { Universidade } \\
\text { Anhanguera-Uniderp }\end{array}$ \\
\hline 40. & \multirow[t]{9}{*}{ Sul } & PR & $\begin{array}{l}\text { Cascavel (2 unidades - } \\
\text { Avenida e Lago) }\end{array}$ & Faculdade $^{376}$ & Não \\
\hline 41. & & $\mathrm{RS}$ & Caxias do Sul & Faculdade & $\mathrm{Sim}$ \\
\hline 42. & & $\mathrm{RS}$ & Passo Fundo & Faculdade & Sim \\
\hline 43. & & $\mathrm{RS}$ & Pelotas & Faculdade & Sim \\
\hline 44. & & $\mathrm{RS}$ & Porto Alegre & Faculdade & Sim \\
\hline 45. & & $\mathrm{RS}$ & Rio Grande & Faculdade & Sim \\
\hline 46. & & $\mathrm{SC}$ & Jaraguá do Sul & Faculdade & Sim \\
\hline 47. & & $\mathrm{SC}$ & Joinville & Faculdade & Não \\
\hline 48. & & $\mathrm{SC}$ & São José & Faculdade 377 & Não \\
\hline
\end{tabular}

Da relação acima, nota-se que as atividades da Anhanguera concentram-se em estabelecimentos isolados (faculdades), os quais são mantidos, em sua grande maioria, pela subsidiária Anhanguera Educacional Ltda. (Aesa).

O capital social da Anhanguera, em 31/05/2012, era de $\mathrm{R} \$ 1.876 .773 .869,63$, dividido em 145.690.261 ações ordinárias nominativas. Nesta data, o capital social da Anhanguera encontrava-se pulverizado no mercado - com 142.936 .481 (98,109839\%) ações em circulação no mercado (ANHANGUERA, 2012d, p. 481; 510).

Em 31/05/2012, a estrutura societária do grupo Anhanguera era a seguinte (ANHANGUERA, 2012d, p. 168):

${ }^{376}$ Trata-se da Faciap.

${ }^{377}$ Trata-se da Uniban.

${ }^{378}$ Disponível em: <http://www.anhanguera.com/graduacao/localidades/graduacao_localidades.php >. Acesso em: 03/07/2012. 


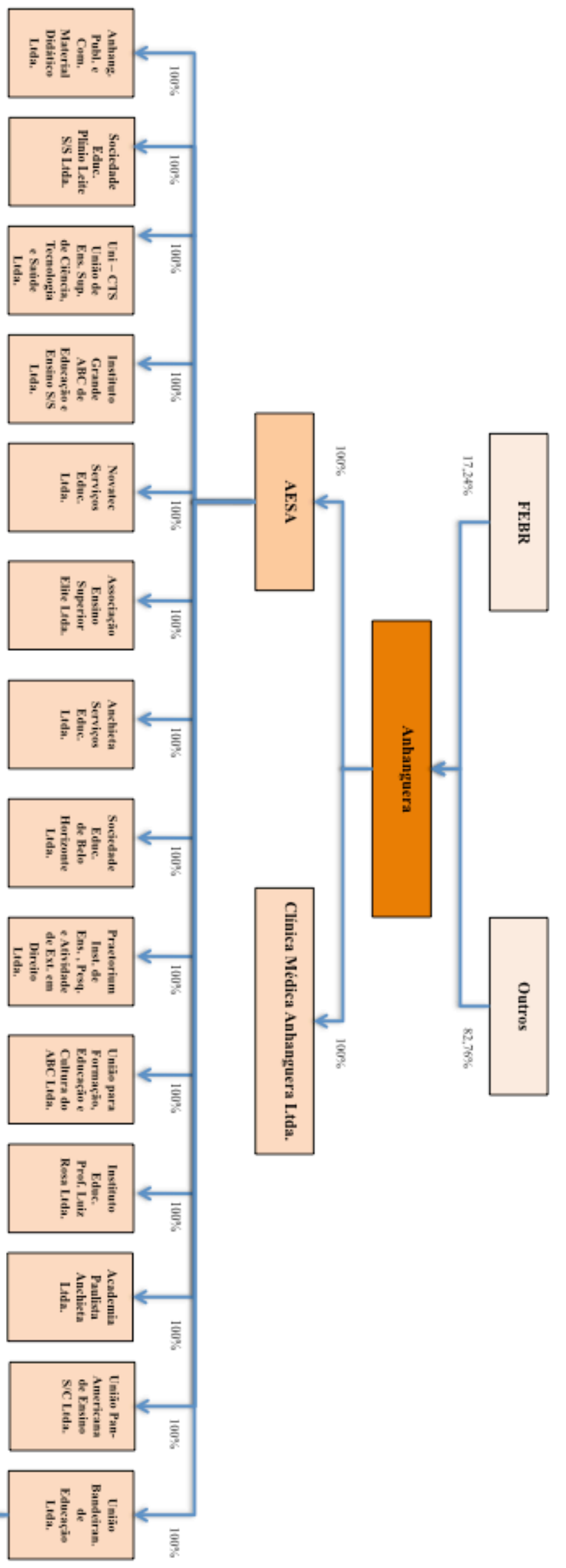


As atividades educacionais da Anhanguera concentram-se na sua subsidiária Aesa, que é a entidade mantenedora da maioria das instituições de ensino superior do grupo. Conforme descrito no histórico da Anhanguera abaixo, a expansão da empresa teve por base a aquisição diretamente pela Anhanguera de mantenedoras de IES e, posteriormente, a aquisição pela Aesa de mantenedoras de IES. Após um período de transição, as IES geralmente passam para a mantença da Aesa, e as entidades mantenedoras são incorporadas a esta.

Abaixo informações sobre as subsidiárias da Anhanguera, as entidades mantenedoras e as IES mantidas, integrantes do grupo:

\section{Quadro 6 - Informações sobre as subsidiárias da Anhanguera, mantenedoras e mantidas 31/12/2011}

\begin{tabular}{|c|c|c|c|}
\hline & $\begin{array}{l}\text { Denominação } \\
\text { Social }\end{array}$ & Sede & $\begin{array}{l}\text { É mantenedora de IES? } \\
\text { Se não, qual o objeto social? }\end{array}$ \\
\hline 1 & $\begin{array}{l}\text { Academia Paulista } \\
\text { Anchieta Ltda. }\end{array}$ & $\begin{array}{lll}\text { São } & \text { Paulo - } \\
\text { SP } & & \\
\end{array}$ & $\begin{array}{l}\text { Sim. É a mantenedora da Universidade Bandeirante de São Paulo } \\
\text { (Uniban). }\end{array}$ \\
\hline 2 & $\begin{array}{l}\text { Anchieta Serviços } \\
\text { Educacionais Ltda. }\end{array}$ & $\begin{array}{l}\text { São Bernardo } \\
\text { do Campo - } \\
\text { SP }\end{array}$ & $\begin{array}{l}\text { Não. } \\
\text { Objeto Social: “A prestação de serviços educacionais no ramo da } \\
\text { Educação Infantil, Ensino Regular de Pré-Escola, Ensino } \\
\text { Fundamental, Ensino Técnico, consistente na manutenção de } \\
\text { instituições e de cursos regulares, incluindo-se atividades de } \\
\text { estudos e pesquisas científicas, tudo de acordo com os currículos } \\
\text { oficiais de ensino sem prejuízo da inclusão de aulas e matérias } \\
\text { complementares, além da promoção de outros cursos livres”. }\end{array}$ \\
\hline 3 & Aesa & Valinhos - SP & $\begin{array}{l}\text { Sim. É a mantenedora de todas as demais IES do grupo } \\
\text { Anhanguera }\end{array}$ \\
\hline 4 & $\begin{array}{l}\text { Anhanguera } \\
\text { Publicações e } \\
\text { Comércio de } \\
\text { Material Didático } \\
\text { Ltda. }\end{array}$ & Valinhos - SP & $\begin{array}{l}\text { Não. } \\
\text { Objeto Social: “(i) Comércio de livros e materiais didáticos em } \\
\text { geral; (ii) desenvolvimento, produção, elaboração, edição, } \\
\text { publicação, distribuição de livros e materiais didáticos em geral; } \\
\text { (iii) o comércio e varejista de mercadoria em geral; e (iv) a } \\
\text { participação em outras sociedades, etc.” }\end{array}$ \\
\hline 5 & $\begin{array}{l}\text { Associação de } \\
\text { Ensino Superior } \\
\text { Elite Ltda. }\end{array}$ & $\begin{array}{l}\text { Guarulhos } \\
\text { SP }\end{array}$ & Sim. É a mantenedora das Faculdades Integradas Torricelli - FIT. \\
\hline 6 & $\begin{array}{l}\text { Sociedade } \\
\text { Educacional Plínio } \\
\text { Leite S/S Ltda. }\end{array}$ & Niterói - RJ & $\begin{array}{l}\text { Sim. É a mantenedora do Centro Universitário Plínio Leite } \\
\text { (Unipli) })^{379}\end{array}$ \\
\hline 7 & $\begin{array}{l}\text { Cesag - Complexo } \\
\text { de Ensino Superior } \\
\text { Anita Garibaldi } \\
\text { Ltda. }\end{array}$ & São José - SC & $\begin{array}{l}\text { Sim. É a mantenedora da Faculdade União Bandeirante } \\
\text { (Faculdade Uniban) })^{380}\end{array}$ \\
\hline
\end{tabular}

\footnotetext{
${ }^{379}$ Segundo o sistema eletrônico de consultas do MEC, esta instituição já é atualmente mantida pela Aesa. Disponível em: <http://emec.mec.gov.br/emec/consultacadastro/detalhamento/d96957f455f6405d14c6542552b0f6eb/NTE1>. Acesso em: 20/09/2012.

${ }^{380}$ Informações extraídas de <http://emec.mec.gov.br/>. Acesso em: 20/09/2012.
} 


\section{Quadro 6 - Informações sobre as subsidiárias da Anhanguera, mantenedoras e mantidas 31/12/2011}

\begin{tabular}{|c|c|c|c|}
\hline & $\begin{array}{l}\text { Denominação } \\
\text { Social }\end{array}$ & Sede & $\begin{array}{c}\text { É mantenedora de IES? } \\
\text { Se não, qual o objeto social? }\end{array}$ \\
\hline 8 & $\begin{array}{l}\text { Clínica Médica } \\
\text { Anhanguera Ltda. }\end{array}$ & Valinhos - SP & $\begin{array}{l}\text { Não. } \\
\text { Objeto social: “(i) o desenvolvimento e/ou administração de } \\
\text { atividades e/ou instituições nas áreas de educação profissional } \\
\text { e/ou outras áreas associadas à educação; (ii) serviços prestados de } \\
\text { consultas e tratamentos odontológicos a pacientes externos; (iii) } \\
\text { serviços prestados de consultas de tratamento médico a pacientes } \\
\text { externos; (iv) serviços de enfermagem; (v) serviços de psicologia } \\
\text { e psicanálise; (vi) serviços de fisioterapia; (vii) serviços de } \\
\text { terapia ocupacional; (viii) atividades de profissionais da nutrição; } \\
\text { (ix) atividade médica ambulatorial restrita a consultas; (x) a } \\
\text { administração de bens e negócios próprios; e (xi) a participação, } \\
\text { na qualidade de acionista ou quotista, em outras sociedades ou } \\
\text { empreendimentos, no Brasil ou no exterior". } \\
\text { De acordo com a Anhanguera (2012d, p. 339), esta empresa } \\
\text { "desenvolve atividades em áreas relacionadas à educação, } \\
\text { incluindo atividades de pesquisas e práticas nas áreas de saúde e } \\
\text { pedagógicas (empresa anteriormente denominada Anhanguera } \\
\text { Educação Profissional Ltda., que teve a razão social e objeto } \\
\text { alterados em 11/01/2011)". }\end{array}$ \\
\hline 9 & $\begin{array}{ll}\text { Instituição } & \\
\text { Educacional } & \\
\text { Professor } & \text { Luiz } \\
\text { Rosa Ltda. } & \\
\end{array}$ & Jundiaí - SP & $\begin{array}{l}\text { Sim. É a mantenedora da Faculdade de Tecnologia Professor } \\
\text { Luiz Rosa }\end{array}$ \\
\hline 10 & $\begin{array}{l}\text { Instituto Grande } \\
\text { ABC de Educação } \\
\text { e Ensino S/S Ltda. } \\
\text { (IGABC) }\end{array}$ & $\begin{array}{l}\text { São Bernardo } \\
\text { do Campo - } \\
\text { SP }\end{array}$ & Sim. É a mantenedora da Faculdade Anchieta ${ }^{381}$ \\
\hline 11 & $\begin{array}{l}\text { Novatec Serviços } \\
\text { Educacionais Ltda. }\end{array}$ & $\begin{array}{l}\text { São Bernardo } \\
\text { do Campo - } \\
\text { SP } \\
\end{array}$ & Sim. É a mantenedora da Faculdade de Tecnologia Anchieta ${ }^{382}$ \\
\hline
\end{tabular}

${ }^{381}$ Segundo o sistema eletrônico de consultas do MEC, esta instituição já é atualmente mantida pela Aesa. em: $<$ http://emec.mec.gov.br/emec/consultacadastro/detalhamento/d96957f455f6405d14c6542552b0f6eb/MTQ3OA>. Acesso em: 20/09/2012.

${ }^{382}$ Segundo o sistema eletrônico de consultas do MEC, esta instituição já é atualmente mantida pela AESA. Disponível em: $<$ http://emec.mec.gov.br/emec/consultacadastro/detalhamento/d96957f455f6405d14c6542552b0f6eb/Mzk5MA>. Acesso em: 20/09/2012. 
Quadro 6 - Informações sobre as subsidiárias da Anhanguera, mantenedoras e mantidas 31/12/2011

\begin{tabular}{|c|c|c|c|}
\hline & Denominação Social & Sede & $\begin{array}{l}\text { É mantenedora de IES? } \\
\text { Se não, qual o objeto social? }\end{array}$ \\
\hline 12 & $\begin{array}{l}\text { Praetorium }- \text { Instituto de } \\
\text { Ensino, Pesquisa e } \\
\text { Atividades de Extensão em } \\
\text { Direito Ltda. }\end{array}$ & $\begin{array}{l}\text { Belo Horizonte - } \\
\text { MG }\end{array}$ & $\begin{array}{l}\text { Não. } \\
\text { Objeto social: “(i) desenvolvimento e adm. de } \\
\text { atividades e instituições nas áreas de educação de } \\
\text { nível superior, educação profissional e outras; (ii) } \\
\text { desenvolvimento e administração de cursos de } \\
\text { nível superior, cursos livres e preparatórios em } \\
\text { geral, ministrados sob a forma presencial, por } \\
\text { correspondência, por transmissão eletrônica de } \\
\text { dados ou por qualquer outro método; (iii) preparo, } \\
\text { aquisição, venda ou licenciamento, a qualquer } \\
\text { título, de conteúdo ligado a educação de nível } \\
\text { superior e preparatórios, bem como a colocação } \\
\text { desse conteudo à disposição de usuários por } \\
\text { quaisquer meios atualmente existentes ou que } \\
\text { venham a ser desenvolvidos; (iv) administração de } \\
\text { bens e negócios próprios; (v) participação em } \\
\text { outras sociedades, nacionais ou estrangeiras, como } \\
\text { acionista ou quotistas; e (vi) locação ou sublocação } \\
\text { de imóveis, bem como locação de espaço em sua } \\
\text { página na internet”. }\end{array}$ \\
\hline 13 & $\begin{array}{l}\text { Sociedade Educacional de } \\
\text { Belo Horizonte Ltda. }\end{array}$ & $\begin{array}{l}\text { Belo Horizonte - } \\
\text { MG }\end{array}$ & $\begin{array}{l}\text { Sim. É a mantenedora da Faculdade de Negócios } \\
\text { de Belo Horizonte. }\end{array}$ \\
\hline 14 & $\begin{array}{l}\text { Unesec - União de Escolas } \\
\text { de Educação Corporativa } \\
\text { Ltda. }\end{array}$ & São José - SC & $\begin{array}{l}\text { Sim. É a mantenedora da Escola Superior de } \\
\text { Educação Corporativa }(\text { Esec) })^{383}\end{array}$ \\
\hline 15 & $\begin{array}{l}\text { União Bandeirante de } \\
\text { Educação Ltda. }\end{array}$ & São Paulo - SP & $\begin{array}{l}\text { Sim. É a mantenedora da Escola Superior de } \\
\text { Educação Corporativa }- \text { Esec e da Faculdade } \\
\text { União Bandeirante }-\mathrm{FUB}^{384}\end{array}$ \\
\hline 16 & $\begin{array}{llr}\text { UNI }- & \text { CTS União } & \text { de } \\
\text { Ensino } & \text { Superior } & \text { de } \\
\text { Ciência, } & \text { Tecnologia } & \text { e } \\
\text { Saúde Ltda. } & \end{array}$ & Brasília - DF & $\begin{array}{l}\text { Sim. É a mantenedora da Faculdade de Ciências e } \\
\text { Tecnologia de Brasília (Faciteb) }\end{array}$ \\
\hline
\end{tabular}

${ }^{383}$ Informação extraída de <http://emec.mec.gov.br/>. Acesso em: 20/09/2012.

384 Segundo o sistema eletrônico de consultas do MEC, estas instituições não são mantidas pela União Bandeirante. Segundo o MEC, a Faculdade União Bandeirante é mantida pela Cesag, e a Esec pela Unesec. Disponível em: <http://emec.mec.gov.br/>. Acesso em: 20/09/2012.

385 Segundo o sistema eletrônico de consultas do MEC, esta instituição já é mantida pela Aesa. Disponível em: $<$ http://emec.mec.gov.br/emec/consultacadastro/detalhamento/d96957f455f6405d14c6542552b0f6eb/NTI5MA>. Acesso em: 20/09/2012. 


\section{Quadro 6 - Informações sobre as subsidiárias da Anhanguera, mantenedoras e mantidas 31/12/2011}

\begin{tabular}{|c|c|c|c|}
\hline & Denominação Social & Sede & $\begin{array}{c}\text { É mantenedora de IES? } \\
\text { Se não, qual o objeto social? }\end{array}$ \\
\hline 17 & $\begin{array}{l}\text { União Pan-Americana de } \\
\text { Ensino S/C Ltda. }\end{array}$ & Cascavel - PR & $\begin{array}{l}\text { Sim. É a mantenedora da Faculdade de Ciências } \\
\text { Aplicadas de Cascavel - Faciap. }\end{array}$ \\
\hline 18 & $\begin{array}{l}\text { União para Formação, } \\
\text { Educação e Cultura do } \\
\text { ABC Ltda. (Unifec) }\end{array}$ & $\begin{array}{l}\text { Santo André - } \\
\text { SP }\end{array}$ & $\begin{array}{l}\text { Sim. É a mantenedora da Universidade do Grande } \\
\text { ABC - UniABC. }\end{array}$ \\
\hline
\end{tabular}

Fonte: Anhanguera $(2012 \mathrm{~d})^{386}$

Em 31/05/2012, a Anhanguera possuía 1.123 acionistas pessoas físicas; 921 acionistas pessoas jurídicas e 519 acionistas investidores institucionais ${ }^{387}$. Desse total, apenas 3 acionistas detinham mais de $5 \%$ do seu capital social - um desses acionistas era o Fundo de Educação Para o Brasil - Fundo de Investimento em Participações (FEBR), fundo de investimento em participações criado, administrado e gerido pelo Pátria Investimentos S.A. (Pátria), que possuía, naquela data, individualmente, a maior participação no capital social da Anhanguera (17,24\%) (ANHANGUERA, 2012d).

Este fundo foi criado com o objetivo de investir inicialmente na Aesa, com autorização para investimento em outras empresas do setor educacional ${ }^{388}$. No passado, o FEBR deteve mais de 50\% do capital social da Anhanguera e, como acionista controlador, foi um dos principais responsáveis pela políticas de expansão da empresa. Após a adesão da Companhia ao Novo Mercado e diluição do seu capital social, o FEBR deixou de deter a maioria do capital social da Anhanguera, mas manteve o controle da empresa e a orientação de seus negócios, por meio da sua participação no Conselho de Administração, conforme descrito no item 4.2.4 abaixo.

\footnotetext{
${ }^{386}$ Nas notas de rodapé acima destacamos informações obtidas no site do sistema eletrônico de consultas do $\operatorname{MEC}(<\mathrm{http}: / /$ emec.mec.gov.br $>$ ) que divergem das informações fornecidas pela Anhanguera.

387 Segundo a CVM, “investidores institucionais são os profissionais da aplicação de poupança de terceiros. Nessa categoria, estão incluídos os fundos mútuos de investimento em ações, as companhias seguradoras, as entidades fechadas de previdência privada - os chamados fundos de pensão, entre outros". Disponível em: $<$ http://www.cvm.gov.br/port/protinv/caderno1(new).asp>. Acesso em: 08/12/2012.

${ }^{388}$ Nos termos da Cláusula 7.1 do Regulamento do FEBR, "o objetivo do Fundo é obter rendimentos para seus Quotistas, por meio de investimentos de longo prazo em valores mobiliários, tais como ações, debêntures, bônus de subscrição e outros valores mobiliários conversíveis e/ou permutáveis em ações, conforme admitido na regulamentação ('Valores Mobiliários'), de emissão da Anhanguera Educacional S.A., sociedade por ações, com sede na Cidade de Itatiba, Estado de São Paulo, na Rua José de Paula Andrade, 210, inscrita no CNPJ/MF sob n. ${ }^{\circ}$ 05.808.792/0001-49 (“AES") e de emissão de outras companhias que atendam aos requisitos descritos no item 7.4. abaixo (as companhias que atendam os requisitos descritos no item 7.4. abaixo e sejam passíveis de investimento pelo Fundo, as 'Companhias Alvo')".
} 
Nos termos do artigo $2^{\circ}$, da Instrução CVM n ${ }^{\circ} 391 / 2003$ (ICVM 391/03), fundos de investimento em participações, como o FEBR, são constituídos sob a forma de condomínio fechado, como uma "comunhão de recursos destinados à aquisição de ações, debêntures, bônus de subscrição, ou outros títulos e valores mobiliários conversíveis ou permutáveis em ações de emissão de companhias, abertas ou fechadas, participando do processo decisório da companhia investida, com efetiva influência na definição de sua política estratégica e na sua gestão, notadamente através da indicação de membros do Conselho de Administração"389. Nesse sentido, o FEBR influencia diretamente na orientação dos negócios da Anhanguera.

A administração do FEBR compete ao seu administrador e gestor, Pátria, que detém, nos termos do artigo 3.2 do Regulamento do $\mathrm{FEBR}^{390}$, poderes para "praticar todos os atos necessários à administração e à gestão do Fundo", inclusive o direito de "ação e o de comparecer e votar em assembleias gerais e/ou especiais das Companhias Investidas ${ }^{391 "}$. Pela administração e gestão do fundo, o Pátria recebe uma remuneração que corresponde a uma taxa de administração e uma taxa de performance ${ }^{392}$.

Nos termos do artigo 1.2 do Regulamento do $\mathrm{FEBR}^{393}$, o fundo tem prazo fixo de duração de oito anos, contados da data de encerramento da sua segunda emissão de quotas ${ }^{394}$, podendo ser prorrogado o prazo por um período de até dois anos, mediante proposta do administrador e aprovação em assembleia geral dos quotistas do fundo.

Abaixo a lista dos maiores acionistas da Anhanguera:

\footnotetext{
${ }^{389}$ O Parágrafo $2^{\circ}$ do artigo $2^{\circ}$ da ICVM 391/03 estabelece que: "a participação do fundo no processo decisório da companhia investida pode ocorrer: I - pela detenção de ações que integrem o respectivo bloco de controle, II pela celebração de acordo de acionistas ou, ainda, III - pela celebração de ajuste de natureza diversa ou adoção de procedimento que assegure ao fundo efetiva influência na definição de sua política estratégica e na sua gestão".

${ }^{390}$ Regulamento do FEBR disponível em: <http://www.cvm.gov.br>. Acesso em: 07/01/2012.

${ }^{391}$ Nos termos do artigo 10 da ICVM 391/03 - "O administrador terá poderes para exercer todos os direitos inerentes aos títulos e valores mobiliários integrantes da carteira do fundo, inclusive o de ação e o de comparecer e votar em assembleias gerais e especiais, podendo delegar para o gestor esses poderes, no todo ou em parte".

392 Informações sobre a taxa de administração e performance encontram-se previstas na Cláusula Quarta do Regulamento do FEBR, disponível em: <http://www.cvm.gov.br>. Acesso em: 07/01/2012.

${ }_{393}$ Regulamento do FEBR disponível em: < http://www.cvm.gov.br>. Acesso em: 07/01/2012.

394 Não conseguimos confirmar se o FEBR já efetuou sua $2^{\mathrm{a}}$ emissão de quotas. No site da CVM (http://www.cvm.gov.br) havia referência a 3 prospectos de distribuição do FEBR divulgados entre os anos de 2006 e 2007, no entanto, o conteúdo dos prospectos não estava disponível para consulta por problemas no link de acesso. Considerando que a $2^{\mathrm{a}}$ emissão tenha se realizado no ano de 2006, os investimentos do FEBR na Anhanguera poderiam se encerrar no ano de 2014, prorrogável até 2016 (estando esta informação sujeita a confirmação). Disponível em: <http://www.cvm.gov.br>. Acesso em: 07/01/2012.
} 
Tabela 31 - Maiores acionistas da Anhanguera em 31/12/2011

\begin{tabular}{lr}
\multicolumn{1}{c}{ Acionista } & \% de Ações Ordinárias \\
\hline FEBR & $17,243135 \%$ \\
Manning \& Napier Advisors ${ }^{395}$ & $5,117385 \%$ \\
FMR LLC & $5,361013 \%$ \\
Outros & $71,086800 \%$ \\
Ações em Tesouraria & $1,191667 \%$ \\
Total & $\mathbf{1 0 0 , 0 0 0 0 0 0 \%}$ \\
\hline
\end{tabular}

Fonte: Anhanguera (2012d)

Abaixo a distribuição do capital social do principal acionista da Anhanguera, o FEBR:

Tabela 32 - Distribuição do capital social do FEBR em 31/12/2011

\begin{tabular}{l|r}
\multicolumn{1}{c|}{ Acionista } & \% de Ações Ordinárias \\
\hline Gabriel Mário Rodrigues & $39,4 \%$ \\
Angela Regina Rodrigues de Paula Freitas $^{398}$ & $12,1 \%$ \\
Carmen Silva Rodrigues Maia $^{399}$ & $12,1 \%$ \\
Gláucia Helena Castelo Branco Rodrigues $^{400}$ & $12,1 \%$ \\
Educational Investments LLP & $12,1 \%$ \\
Carol Fundo de Investimento em Quotas & $5,5 \%$ \\
Fundo de Investimento em Participações & \\
Outros & \\
Total & $6,7 \%$ \\
\hline
\end{tabular}

Fonte: Anhanguera (2012d)

O patrimônio da Anhanguera aumentou progressivamente nos últimos anos. Abaixo dados a esse respeito:

395 A Manning \& Napier Advisors, LLC é uma gestora de fundos privada com sede em Nova Iorque, EUA (ANHANGUERA, 2012d, p. 486).

${ }^{396}$ A FMR LLC é uma gestora de fundos privada com sede em Massachusetts, EUA (ANHANGUERA, 2012d, p. 486).

${ }^{397}$ Gabriel Mário Rodrigues é fundador e presidente da Universidade Anhembi Morumbi.

${ }^{398}$ É filha de Gabriel Mário Rodrigues.

${ }^{399}$ É filha de Gabriel Mário Rodrigues.

${ }^{400}$ É filha de Gabriel Mário Rodrigues.

${ }^{401}$ Esta empresa é detida 99,99\% pelo Highland Investment Fund, um fundo de investimento constituído nas Ilhas Cayman. O quotista do Highland Investment Fund, por sua vez, é o Banco UBS na Suíça, sociedade de capital aberto listada na Swiss Stock Exchange (ANHANGUERA, 2012d, p. 486).

${ }^{402}$ Este fundo é detido $100 \%$ por Olimpio Matarazzo Neto, membro do CA da Anhanguera (ANHANGUERA, 2012d, p. 480). 
Tabela 33 - Evolução Patrimonial da Anhanguera - 2007 - 2011

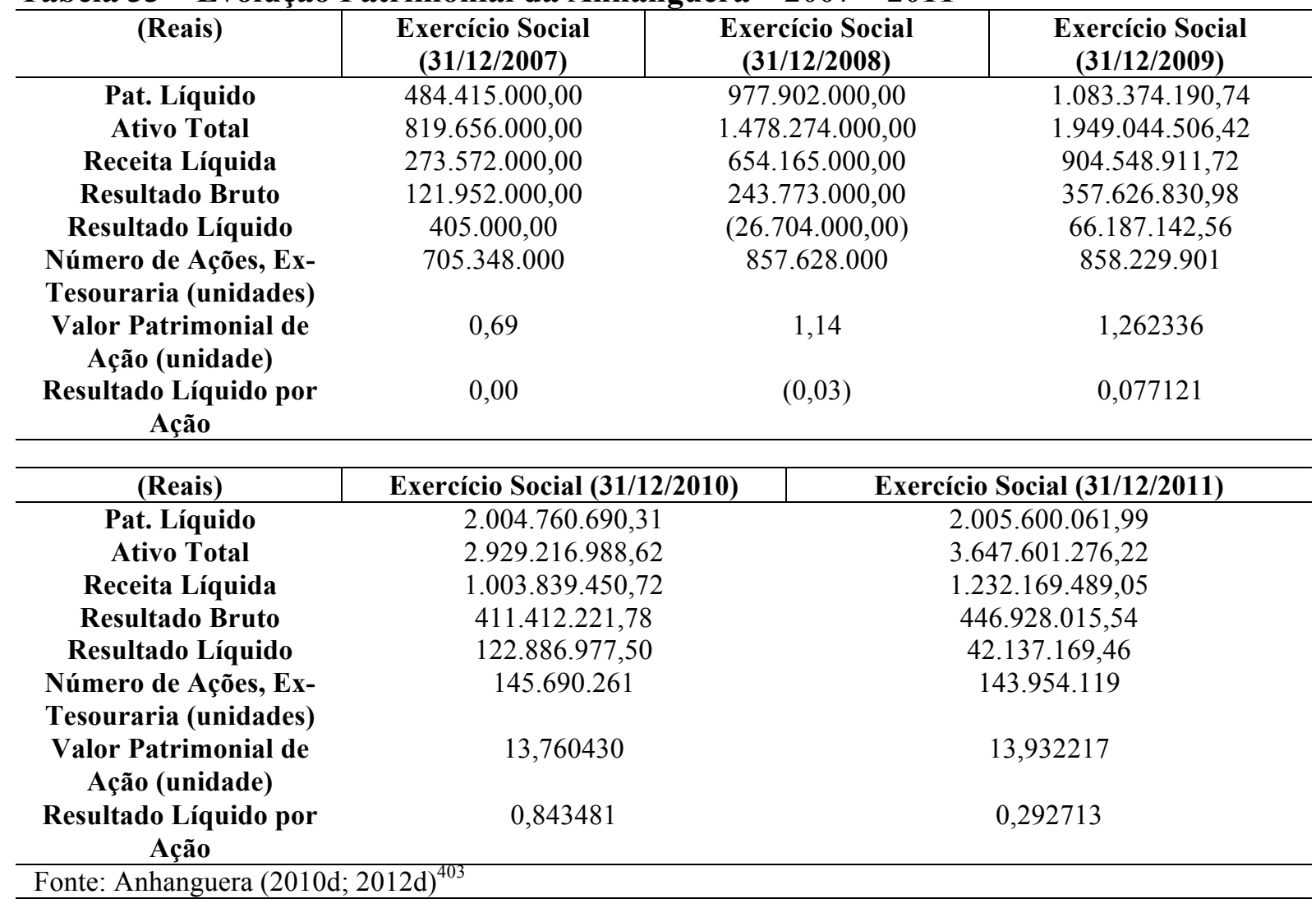

O aumento do patrimônio líquido foi influenciado pelo aumento dos ativos da Anhanguera e de suas receitas, como se vê na tabela acima. O aumento no valor dos ativos e das receitas, por sua vez, está relacionado às inúmeras aquisições feitas pela empresa nos últimos anos. Tais fatos aumentaram consideravelmente o valor patrimonial das ações da Companhia (de $\mathrm{R} \$ 1,262336$, em 2009, para $\mathrm{R} \$ 13,932217$, em 2011), o que torna essa empresa muito atrativa para os investidores.

A Anhanguera negociou na BM\&FBOVESPA, entre março de 2007 e dezembro de 2010, certificados de depósitos de ações, denominados Units, que representavam, cada um, uma ação ordinária $(\mathrm{ON})$ e seis ações preferenciais (PNs) de emissão da Companhia. Em 09/12/2010, a Anhanguera efetuou sua terceira oferta pública de valores mobiliários e passou a negociar apenas ações ordinárias (ONs), listadas no Novo Mercado da BM\&FBOVESPA. Abaixo dados sobre o volume de negociações e as maiores e menores cotações das Units e ONs da Anhanguera entre os anos de 2007 e 2011:

403 Informações de 2007 e 2008 extraídas de Anhanguera (2010d, p. 3) e demais informações extraídas de Anhanguera (2012d, p. 4). 
Tabela 34 - Volume de Negociações, Cotações Valores Mobiliários Anhanguera - 2007 $-2011$

(continua)

\begin{tabular}{|c|c|c|c|c|c|}
\hline \multicolumn{6}{|c|}{ Exercício Social Findo em 31/12/2007 } \\
\hline Trimestre & $\begin{array}{c}\text { Valor } \\
\text { Mobiliário }\end{array}$ & $\begin{array}{c}\text { Entidade } \\
\text { Administrativa }\end{array}$ & $\begin{array}{c}\text { Volume de } \\
\text { Negociações } \\
\text { (R\$ em } \\
\text { milhões) }\end{array}$ & $\begin{array}{l}\text { Valor Maior } \\
\text { Cotação } \\
\text { (R\$/por } \\
\text { unidade) }\end{array}$ & $\begin{array}{c}\text { Valor Menor } \\
\text { Cotação } \\
\text { (R\$/por unidade) }\end{array}$ \\
\hline $31 / 03 / 2007^{404}$ & UNIT & BM\&FBOVESPA & 8,1 & 22,50 & 20,00 \\
\hline $30 / 06 / 2007$ & UNIT & BM\&FBOVESPA & 3,9 & 28,50 & 23,00 \\
\hline $30 / 09 / 2007$ & UNIT & BM\&FBOVESPA & 3,4 & 33,75 & 26,84 \\
\hline $31 / 12 / 2007$ & UNIT & BM\&FBOVESPA & 3,2 & 38,00 & 32,00 \\
\hline \multicolumn{6}{|c|}{ Exercício Social Findo em 31/12/2008 } \\
\hline Trimestre & $\begin{array}{c}\text { Valor } \\
\text { Mobiliário }\end{array}$ & $\begin{array}{c}\text { Entidade } \\
\text { Administrativa }\end{array}$ & $\begin{array}{l}\text { Volume de } \\
\text { Negociações } \\
\text { (R\$) }\end{array}$ & $\begin{array}{l}\text { Valor Maior } \\
\text { Cotação } \\
\text { (R\$/por } \\
\text { unidade) }\end{array}$ & $\begin{array}{l}\text { Valor Menor } \\
\text { Cotação } \\
\text { (R\$/por } \\
\text { unidade) }\end{array}$ \\
\hline $31 / 03 / 2008$ & UNIT & BM\&FBOVESPA & 166.098 .831 & 37,00 & 21,50 \\
\hline $30 / 06 / 2008$ & UNIT & BM\&FBOVESPA & 162.761 .254 & 31,69 & 24,00 \\
\hline $30 / 09 / 2008$ & UNIT & BM\&FBOVESPA & 198.450 .715 & 31,50 & 18,70 \\
\hline $31 / 12 / 2008$ & UNIT & BM\&FBOVESPA & 101.495 .179 & 22,56 & 12,11 \\
\hline \multicolumn{6}{|c|}{ Exercício Social Findo em 31/12/2009 } \\
\hline Trimestre & $\begin{array}{c}\text { Valor } \\
\text { Mobiliário }\end{array}$ & $\begin{array}{c}\text { Entidade } \\
\text { Administrativa }\end{array}$ & $\begin{array}{c}\text { Volume } \\
\text { Negociado (R\$) }\end{array}$ & $\begin{array}{l}\text { Valor Maior } \\
\text { Cotação } \\
\text { (R\$/por } \\
\text { unidade) }\end{array}$ & $\begin{array}{l}\text { Valor Menor } \\
\text { Cotação } \\
\text { (R\$/por } \\
\text { unidade) }\end{array}$ \\
\hline $31 / 03 / 2009$ & UNIT & BM\&FBOVESPA & 168.815 .626 & 12,80 & 9,25 \\
\hline $30 / 06 / 2009$ & UNIT & BM\&FBOVESPA & 133.157 .772 & 20,64 & 11,10 \\
\hline $30 / 09 / 2009$ & UNIT & BM\&FBOVESPA & 117.989 .841 & 23,00 & 17,10 \\
\hline $31 / 12 / 2009$ & UNIT & BM\&FBOVESPA & 377.877 .914 & 26,59 & 20,50 \\
\hline \multicolumn{6}{|c|}{ Exercício Social Findo em 31/12/2010 } \\
\hline Trimestre & $\begin{array}{c}\text { Valor } \\
\text { Mobiliário }\end{array}$ & $\begin{array}{c}\text { Entidade } \\
\text { Administrativa }\end{array}$ & $\begin{array}{c}\text { Volume } \\
\text { Negociado }(\mathbf{R} \$)\end{array}$ & $\begin{array}{c}\text { Valor Maior } \\
\text { Cotação } \\
\text { (R\$/por } \\
\text { unidade) } \\
\end{array}$ & $\begin{array}{l}\text { Valor Menor } \\
\text { Cotação } \\
\text { (R\$/por } \\
\text { unidade) } \\
\end{array}$ \\
\hline $31 / 03 / 2010$ & UNIT & BM\&FBOVESPA & 558.498 .639 & 28,55 & 24,45 \\
\hline $30 / 06 / 2010$ & UNIT & BM\&FBOVESPA & 380.122 .568 & 27,82 & 22,00 \\
\hline $30 / 09 / 2010$ & UNIT & BM\&FBOVESPA & 831.612 .523 & 31,30 & 25,70 \\
\hline $31 / 12 / 2010$ & UNIT & BM\&FBOVESPA & 1.861 .782 .271 & 40,21 & 29,74 \\
\hline
\end{tabular}

404 Primeiro trimestre de 2007 inicia-se em 12/03/2007, em função da Oferta Pública Inicial de Units da Anhanguera. O valor do volume de negociações em 2007, apesar de expresso em milhões de reais, é muito menor que os valores dos demais anos. É possível que tenha havido algum erro na informação divulgada pela empresa na fonte que consultamos. 
Tabela 34 - Volume de Negociações, Cotações Valores Mobiliários Anhanguera - 2007 2011

(conclusão)

\begin{tabular}{c|c|c|c|c|c}
\hline Trimestre & $\begin{array}{c}\text { Valor } \\
\text { Mobiliário }\end{array}$ & $\begin{array}{c}\text { Entidade } \\
\text { Administrativa }\end{array}$ & $\begin{array}{c}\text { Volume } \\
\text { Negociado (R\$) }\end{array}$ & $\begin{array}{c}\text { Valor Maior } \\
\text { Cotação } \\
\text { (R\$/por } \\
\text { unidade) }\end{array}$ & $\begin{array}{c}\text { Valor Menor } \\
\text { Cotação } \\
\text { (R\$/por unidade) }\end{array}$ \\
\hline $31 / 03 / 2011$ & $\begin{array}{c}\text { Ações } \\
\text { Ordinárias } \\
\text { Ações } \\
30 / 06 / 2011\end{array}$ & BM\&FBOVESPA & 1.097 .009 .085 & 42,13 & 34,23 \\
$30 / 09 / 2011$ & $\begin{array}{c}\text { Ordinárias } \\
\text { Ações }\end{array}$ & BM\&FBOVESPA & 1.513 .303 .711 & 40,00 & 32,70 \\
$31 / 12 / 2011$ & $\begin{array}{c}\text { Ordinárias } \\
\text { Ações } \\
\text { Ordinárias }\end{array}$ & BM\&FBOVESPA & 1.303 .169 .387 & 26,75 & 21,90 \\
\hline Fonte: Anhanguera (2010d; 2012d) & & & 265 & 16,10 \\
\hline
\end{tabular}

Abaixo informações consolidadas sobre as negociações dos valores mobiliários da Anhanguera desde a oferta pública inicial (IPO) de 2007:

\begin{tabular}{lr} 
Tabela 35 - Informações consolidadas sobre negociações de valores mobiliários da \\
\multicolumn{2}{c}{ Anhanguera desde IPO } \\
\hline Código de negociação na BM\&FBOVESPA & AEDU3 \\
IPO (2007 - R\$ por Unit) & 18,00 \\
Preço de emissão das ações na 2a oferta pública de 22/04/2008 (R\$ por Unit) & 26,00 \\
Preço de emissão das ações na 3 $3^{\text {a }}$ oferta pública de 09/12/2010 (R por Ação) & 36,70 \\
Cotação em 29/12/2011 (R \$ por Ação) & 20,10 \\
Acumulado desde o IPO & $11,7 \%$ \\
IBOVESPA desde o IPO & $28,6 \%$ \\
Volume Médio Diário em 2011 (R\$ milhões) & 22,4 \\
\hline
\end{tabular}

Fonte: Anhanguera (2007b; 2008e; 2010e; 2012e)

Analisando os dados constantes nas tabelas 34 e 35 acima, nota-se que, no ano de 2007, o valor da cotação das Units da Anhanguera foi sempre superior ao valor do IPO $\mathrm{R} \$ 18,00$ (a menor cotação no ano foi R\$20,00). Nos anos de 2008 e 2009, possivelmente, influenciada pela crise financeira internacional, a cotação das Units da Anhanguera chegou a $\mathrm{R} \$ 12,11$ (em 2008) e $\mathrm{R} \$ 9,25$ (menor valor de cotação em 2009), observado que, no período imediatamente posterior à segunda oferta pública de ações (ocorrida em 22/04/2008), as cotações foram maiores. A partir de 2010, o volume negociado e as cotações apresentaram valores maiores. Em 2010, a menor cotação para as Units da Anhanguera foi de R $\$ 22,00$. No último trimestre de 2010, possivelmente após a terceira oferta pública da Anhanguera, cujo preço por ação foi de $\mathrm{R} \$ 36,70$, a Companhia bateu seu recorde de volume de negociação

405 Dados de 2007 extraídos de Anhanguera (2010d, p. 208) e demais dados extraídos de Anhanguera (2012d, p. 520-521). 
(R \$1,8 bilhão). Em 2011, a maior cotação para as ONs foi de $\mathrm{R} \$ 42,13$ (em março de 2010), e a menor de $\mathrm{R} \$ 16,10$ (em dezembro de 2010), com um volume negociado superior a $\mathrm{R} \$ 1$ bilhão em todos os trimestres.

O lucro líquido da Anhanguera teve a seguinte evolução nos últimos anos:

\begin{tabular}{|c|c|c|c|c|c|}
\hline & \multicolumn{5}{|c|}{ Exercício (valores expressos em R\$) } \\
\hline & 2007 & 2008 & 2009 & 2010 & 2011 \\
\hline $\begin{array}{c}\text { Lucro } \\
\text { Líquido do } \\
\text { Exercício }\end{array}$ & $405.918,04$ & $(26.704 .616,00)$ & $72.859 .255,24$ & $122.887 .977,45$ & $54.485 .224,08$ \\
\hline Dividendos & $3.856,22$ & 0,00 & $459.003,47$ & $1.237 .275,21$ & $400.303,11$ \\
\hline $\mathbf{O N}$ & 459.989 .555 & 492.262 .027 & 450.765 .230 & 145.690 .261 & 143.954 .119 \\
\hline PN & 245.358 .665 & 365.365 .944 & 407.464.671 & - & - \\
\hline Total & 705.348 .220 & 857.627 .971 & 858.229 .901 & 145.690 .261 & 143.954 .119 \\
\hline $\begin{array}{c}\text { Lucro } \\
\text { Líquido/ } \\
\text { Prejuízo } \\
\text { por Ação }\end{array}$ & 0,000575 & $(0,031138)$ & 0,084895 & 0,843488 & 0,292712 \\
\hline $\begin{array}{c}\text { Dividendos } \\
\text { por Ação }\end{array}$ & 0,000005 & - & 0,000535 & 0,008493 & 0,00278077 \\
\hline
\end{tabular}

A Anhanguera tem como política destinar seus resultados da seguinte maneira: do lucro líquido do exercício, após a dedução dos prejuízos acumulados e a provisão para o imposto de renda: (i) $5 \%$ é destinado para a constituição da reserva legal, limitada a $20 \%$ do capital social integralizado da Companhia; (ii) do saldo do lucro líquido do exercício, após a dedução acima descrita e ajustado na forma do art. 202 da Lei das S.As., 1\% é destinado para pagamento de dividendo obrigatório a todos os acionistas. Sempre que o montante do dividendo obrigatório ultrapassar a parcela realizada do lucro líquido do exercício, a administração poderá propor, e a Assembleia Geral aprovar, destinar o excesso à constituição de reserva de lucros a realizar, nos termos do art. 197 da Lei das S.As.; e (iii) a parcela remanescente terá a destinação que a Assembleia Geral decidir, envolvendo inclusive a retenção de lucros, com base em orçamentos de capital (art. 20, ES) (ANHANGUERA, 2012c).

Nos últimos anos, a Companhia adotou a seguinte destinação para seu lucro líquido: 
Tabela 37 - Informações sobre Destinação Lucro Líquido e Distribuição de Dividendos Anhanguera 2007 - 2011

\begin{tabular}{|c|c|c|c|c|}
\hline (Reais) & $\begin{array}{c}\text { Exercício Social } \\
\mathbf{3 1} / \mathbf{1 2} / \mathbf{2 0 0 7} \\
\end{array}$ & \multicolumn{2}{|c|}{$\begin{array}{c}\text { Exercício Social } \\
\mathbf{3 1} / \mathbf{1 2} / \mathbf{2 0 0 8}\end{array}$} & $\begin{array}{c}\text { Exercício Social } \\
31 / 12 / 2009 \\
\end{array}$ \\
\hline Lucro Líquido do Exercício & $405.918,04$ & \multicolumn{2}{|c|}{$(26.704 .616,00)$} & $72.859 .255,24$ \\
\hline Lucro Líquido Ajustado & $385.622,00$ & \multicolumn{2}{|c|}{$(26.704 .616,00)$} & $45.900 .347,00$ \\
\hline $\begin{array}{c}\text { Percentual de Dividendo } \\
\text { distribuído em relação ao lucro } \\
\text { líquido ajustado }\end{array}$ & $1 \%$ & \multicolumn{2}{|c|}{-} & $1 \%$ \\
\hline Reserva Legal & $20.295,90$ & & & $2.415 .807,71$ \\
\hline Dividendos & $3.856,22$ & & & $459.003,47$ \\
\hline Reserva de Retenção de Lucro & $381.765,92$ & & & $45.441 .343,11$ \\
\hline (Reais) & \multicolumn{2}{|c|}{ Exercício Social 31/12/2010 } & \multicolumn{2}{|c|}{ Exercício Social 31/12/2011 } \\
\hline Lucro Líquido do Exercício & \multicolumn{2}{|c|}{$122.887 .977,45$} & \multicolumn{2}{|c|}{$54.485 .224,08$} \\
\hline Lucro Líquido Ajustado & \multicolumn{2}{|c|}{$123.727 .521,36$} & \multicolumn{2}{|c|}{$40.030 .310,99$} \\
\hline $\begin{array}{c}\text { Percentual de Dividendo } \\
\text { distribuído em relação ao lucro } \\
\text { líquido ajustado }\end{array}$ & \multicolumn{2}{|l|}{$1 \%$} & \multicolumn{2}{|c|}{$1 \%$} \\
\hline Reserva Legal & \multicolumn{2}{|c|}{$6.511 .974,81$} & \multicolumn{2}{|c|}{$2.106 .858,47$} \\
\hline Dividendos & \multicolumn{2}{|c|}{$1.237 .275,21$} & \multicolumn{2}{|c|}{$400.303,11$} \\
\hline Reserva de Retenção de Lucro & \multicolumn{2}{|c|}{$122.490 .246,15$} & \multicolumn{2}{|c|}{$51.978 .062,50$} \\
\hline
\end{tabular}

Fonte: Anhanguera (2010d; 2012d; 2008a) ${ }^{406}$

Considerando os dados acima, nota-se que grande parte do lucro apurado pela empresa é retido em conta de Reserva de Retenção de Lucros. A retenção dos lucros é feita com base em orçamentos de capital aprovados nas Assembleias Gerais da Companhia. Abaixo a descrição dos orçamentos de capital da Anhanguera entre os anos de 2008 e 2012:

Tabela 38 - Orçamentos de Capital Anhanguera 2008 - $2012^{407}$

\begin{tabular}{ccccc} 
& $\begin{array}{c}\mathbf{2 0 0 8 / 2 0 0 9} \\
\text { (R\$ em } \\
\text { milhões) }\end{array}$ & $\begin{array}{c}\mathbf{2 0 1 0} \\
\text { (R\$ em } \\
\text { milhões) }\end{array}$ & $\begin{array}{c}\mathbf{2 0 1 1} \\
\text { (R\$ em } \\
\text { milhões) }\end{array}$ & $\begin{array}{c}\text { (co12 } \\
\text { (R\$ em milhões) }\end{array}$ \\
\hline $\begin{array}{c}\text { Fontes } \\
\text { Reserva Legal }\end{array}$ & $\mathbf{5 1 3 , 5}$ & $\mathbf{2 4 8 , 1}$ & $\mathbf{5 9 1 , 2}$ & $\mathbf{1 0 0 , 4}$ \\
Retenção de Lucros & 0,0 & 45,4 & - & - \\
Captação programada & 0,3 & - & 122,5 & 52,0 \\
Captação líquida oferta de & - & $108,6^{408}$ & - & - \\
ações & 479,3 & - & - & - \\
Saldo de caixa 31/12/2007 & 33,9 & - & - & - \\
Geração de caixa próprio & - & - & - &
\end{tabular}

\footnotetext{
${ }^{406}$ Informações dos exercícios de 2007 e 2008 extraídas de Anhanguera (2010d) e demais informações extraídas de Anhanguera (2012d) e Anhanguera (2008b).

${ }^{407}$ Mantivemos nesta tabela todas as colunas constantes em cada um dos orçamentos de capitais analisados. Alguns itens provavelmente referem-se ao mesmo tipo de investimento, como "expansão/manutenção unidades existentes" e "expansão orgânica", mas como a empresa utilizou denominações diferentes nos anos analisados, mantivemos a denominação utilizada pela empresa.

${ }^{408}$ Valor referente ao empréstimo contratado junto a IFC e outras agências multilaterais em 23/12/2009, no valor de $\mathrm{R} \$ 108.607 .680,00$ (ANHANGUERA, 2010b).
} 
Tabela 38 - Orçamentos de Capital Anhanguera 2008 - $2012^{409}$

\begin{tabular}{c|c|c|c|c}
\hline & $\begin{array}{c}\mathbf{2 0 0 8 / 2 0 0 9} \\
\text { (R\$ em } \\
\text { milhões) }\end{array}$ & $\begin{array}{c}\mathbf{2 0 1 0} \\
\text { (R\$ em } \\
\text { milhões) }\end{array}$ & $\begin{array}{c}\mathbf{2 0 1 1} \\
\text { (R\$ em } \\
\text { milhões) }\end{array}$ & $\begin{array}{c}\text { 2012 } \\
\text { (R\$ em milhões) }\end{array}$ \\
\hline $\begin{array}{c}\text { Recursos Próprios } \\
\text { Usos }\end{array}$ & - & 94,0 & 468,7 & 48,4 \\
Tecnologia e Projetos & $\mathbf{5 1 3 , 5}$ & $\mathbf{2 4 8 , 1}$ & $\mathbf{5 9 1 , 2}$ & $\mathbf{1 0 0 , 4}$ \\
Investimentos em Subsidiária & - & 22,5 & 40,1 & 36,7 \\
(Aesa) & - & - & - & 63,7 \\
Manutenção & - & - & - & 26,9 \\
Expansão & - & - & - & - \\
Expansão aquisições & - & 109,3 & 450,0 & - \\
Expansão novas unidades & - & 30,7 & - & - \\
Expansão/manutenção & - & 85,5 & - & - \\
unidades existentes & - & - & 78,2 & - \\
Expansão orgânica & - & - & - & \\
Projetos de Expansão e & 513,5 & - & & \\
Melhoria de Qualidade \\
Outros
\end{tabular}

Analisando os dados acima, nota-se que a maior parte dos recursos retidos pela Companhia foram utilizados na expansão da Anhanguera por meio de aquisições. Além disso, a empresa investiu parte desses recursos no crescimento orgânico (por meio da expansão ou manutenção de unidades existentes), na melhoria da qualidade e em tecnologia e projetos.

Em 31/12/2011, a Anhanguera apresentava um endividamento financeiro composto por empréstimos, financiamentos, debêntures, notas promissórias e arrendamento mercantil no valor de R\$573,5 milhões. Em 31/12/2010, o endividamento era de R \$388 milhões, e em 31/12/2009, de R\$401,4 milhões (ANHANGUERA, 2012d, p. 349).

Segundo a Anhanguera (2012d, p. 14), sua principal fonte de receitas é o recebimento das mensalidades cobradas de seus alunos e, do seu total de custos, aproximadamente $60 \%$ decorrem de despesas com pessoal e $9 \%$ com despesas de aluguel.

\subsubsection{Questão 5}

Neste subitem, procuramos responder à seguinte questão:

${ }^{409}$ Mantivemos nesta tabela todas as colunas constantes em cada um dos orçamentos de capitais analisados. Alguns itens provavelmente referem-se ao mesmo tipo de investimento, como "expansão/manutenção unidades existentes" e "expansão orgânica", mas como a empresa utilizou denominações diferentes nos anos analisados, mantivemos a denominação utilizada pela empresa.

${ }^{410}$ Dados de 2008 e 2009 extraídos de Anhanguera (2008a); dados de 2009 extraídos de Anhanguera (2010b); dados de 2011 extraídos de Anhanguera (2011a) e dados de 2012 extraídos de Anhanguera (2012b). 


\section{Quadro 7 - Questão da Análise Empírica n ${ }^{0} 5$}

\begin{tabular}{|l|l|}
\hline $\mathbf{N}^{\mathbf{0}}$ & \multicolumn{1}{|c|}{ Grupo I - Informações Gerais sobre a Anhanguera } \\
\hline 5. & $\begin{array}{l}\text { Como foi o histórico de formação da Anhanguera? Em qual contexto da história brasileira ela se situa? } \\
\text { Quando a Anhanguera abriu seu capital? Quantas emissões públicas de valores mobiliários efetuou e } \\
\text { qual o volume de recursos arrecadados em cada uma delas? }\end{array}$ \\
\hline
\end{tabular}

A história do grupo Anhanguera começou em 1994, com a fundação das Faculdades Integradas Anhanguera, na cidade de Leme, estado de São Paulo, por um grupo de professores liderado por Antônio Carbonari Netto (atual presidente do Conselho de Administração da Anhanguera) e José Luis Poli. Posteriormente, as atividades foram divididas em quatro instituições de ensino superior, sendo três delas sem fins lucrativos ${ }^{411}$. Ao final de 2002, essas instituições, em conjunto, possuíam uma média de 8.848 alunos matriculados em sete unidades, localizadas em seis cidades no estado de São Paulo (ANHANGUERA, 2012d, p. 90).

Em 2003, as três instituições sem fins lucrativos foram convertidas em instituições com fins lucrativos. Neste mesmo ano, todas as instituições do grupo foram incorporadas numa nova empresa denominada Anhanguera Educacional S.A., antiga denominação da Anhanguera Educacional Ltda. ${ }^{412}$ (Aesa), atual mantenedora da maioria das instituições de ensino superior do grupo. Neste mesmo ano, o

Instituto Superior de Comunicação Publicitária (ISCP), entidade mantenedora da Universidade Anhembi Morumbi, tornou-se acionista da Aesa, mediante a subscrição de novas ações. Esses fatos marcaram o novo rumo que os negócios da companhia iriam tomar. $\mathrm{O}$ ingresso do ISCP trouxe conhecimentos sobre o mercado educacional brasileiro e recursos financeiros que permitiram a abertura de novas unidades em cidades do interior do estado de São Paulo. Ao final de 2005, a rede de ensino já contava com 10 campi (ANHANGUERA, 2012d, p. 90).

Em 2005, o ISCP permutou sua participação acionária na Aesa por quotas do fundo de investimento em participações FEBR, administrado pelo Pátria, que captou e investiu novos

\footnotetext{
411 As três instituições sem fins lucrativos denominavam-se (i) Associação Lemense de Educação e Cultura, entidade mantenedora do Centro Universitário Anhanguera (Leme e Pirassununga), Faculdade Comunitária de Campinas e Faculdades Integradas de Valinhos; (ii) Instituto Jundiaiense de Educação e Cultura, entidade mantenedora da Faculdade Politécnica de Jundiaí; e (iii) Instituto de Ensino Superior Anhanguera, entidade mantenedora da Faculdade Politécnica de Matão. Disponível em: http://www.anhanguera.com/a-instituicao/. Acesso em: 14/01/2013.

412 A Anhanguera Educacional S.A. foi transformada em sociedade limitada, passando a denominar-se Anhanguera Educacional Ltda.
} 
recursos na empresa. Além dos recursos captados, o FEBR obteve uma linha de crédito de US\$12 milhões junto ao IFC. Esses recursos foram contribuídos ao capital social da Aesa em troca de novas ações e utilizados para financiar suas estratégias de aquisição e expansão orgânica. Como resultado dessas operações, o FEBR tornou-se acionista controlador da Aesa, passando a orientar todos os negócios da Companhia (ANHANGUERA, 2012d, p. 90). Nesse contexto, a Anhanguera (na qualidade de contratante) celebrou um contrato de prestação de serviços com o Pátria, por meio do qual, o contratado deveria prestar serviços de consultoria e planejamento financeiro em aquisições para a Anhanguera, recebendo uma comissão sobre o valor das aquisições efetuadas (ANHANGUERA, 2010c) ${ }^{413}$. Ademais, segundo informações da Revista Capital Aberto (2010), o Pátria, por meio do FEBR, aplicou, em 2005, R $\$ 800$ milhões na Anhanguera.

Em 19 de dezembro de 2006, os acionistas da Aesa adquiriram a Anhanguera, sociedade de capital aberto constituída em 2001, sob a denominação de Mehir Holdings S.A. Em 29 de dezembro de 2006, a Anhanguera tornou-se controladora da Aesa e, em 31 de dezembro desse mesmo ano, a rede de ensino passou a contar com 13 unidades operacionais e um alunado médio de 24.527 (ANHANGUERA, 2007b).

Em 08 de março de 2007, a Anhanguera tornou-se a primeira empresa do setor educacional a abrir o capital na América Latina. Com sua oferta pública inicial, captou $\mathrm{R} \$ 360$ milhões no mercado (ANHANGUERA, 2007a; 2007b) ${ }^{414}$. Deste valor, investiu 49\% em potenciais aquisições, $41 \%$ na expansão de unidades existentes e abertura de novas unidades e $10 \%$ para quitação de dívidas de curto prazo (ANHANGUERA, 2010b) ${ }^{415}$. Dentro do processo de expansão, a Anhanguera adquiriu, em 2007, sete mantenedoras de instituições de ensino superior (ANHANGUERA, 2008d) ${ }^{416}$, ampliando sua presença em três regiões do País

\footnotetext{
${ }^{413}$ Este contrato foi rescindido em 30 de outubro de 2009 (ANHANGUERA, 2010c, p. 45).

${ }^{414}$ Nos termos da RCA 08/03/2007 (ANHANGUERA, 2007a) e do Prospecto de 08/03/2007 (ANHANGUERA, 2007b), a oferta primária resultou num aumento de capital de R \$360 milhões (captação bruta), e a oferta secundária resultou em $\mathrm{R} \$ 85.500,00$, pagos aos acionistas da Anhanguera que venderam suas ações na oferta. $\mathrm{O}$ valor da captação líquida para a Companhia, descontadas as comissões, foi de R $\$ 342$ milhões, conforme Prospecto de 08/03/2007 (ANHANGUERA, 2007a).

${ }^{415}$ Conforme item 10 - Comentários dos Diretores, Demonstrações Financeiras da Companhia de 31/12/2009, anexas à AGO de 30/04/2010 (ANHANGUERA, 2010b)..

416 De acordo com o IAN de 31/12/2008, item 09.01 (ANHANGUERA, 2008d), foram adquiridas pela Companhia em 2007: (i) Centro Hispano-Brasileiro, mantenedora da Unibero, localizada na cidade de São Paulo/SP; (ii) União Fênix de Educação e Cultura Ltda., sociedade mantenedora da Faculdade Fênix de Bauru Fafeb e do Instituto Superior de Educação Fênix de Bauru - Isefeb; (iii) Oeste Organização de Ensino Superior e Tecnologia S/C Ltda., mantenedora da Faculdade Integração Zona Oeste - Fizo, localizada na cidade de Osasco/SP; (iv) Sociedade Educacional Noiva do Mar Ltda., mantenedora da Faculdade Atlântico Sul de Pelotas e da Faculdade Atlântico Sul de Rio Grande, ambas localizadas no estado do Rio Grande do Sul; (v) Cesup, mantenedora das instituições de ensino Uniderp - Universidade para o Desenvolvimento do Estado e da Região
} 
- Centro-Oeste, Sul e Sudeste e, além disso, iniciou suas atividades na educação a distância por meio da aquisição de uma rede de 452 polos, com presença em 24 estados e no Distrito Federal $^{417}$. A estreia da Anhanguera na Bolsa de Valores foi muito bem-sucedida ${ }^{418}$, o que atraiu outras empresas do ramo a ingressarem no mercado de capitais, conforme descrito no Capítulo 2 dessa Dissertação.

Em 06 de dezembro de 2007, a Anhanguera celebrou um contrato de empréstimo com o Banco Bradesco, no valor de R\$50 milhões (ANHANGUERA, 2012d, p. 350).

Em 08 de fevereiro de 2008, a Anhanguera emitiu 13 notas promissórias comerciais no valor total de R $\$ 130$ milhões. Segundo a Companhia, “os recursos foram utilizados para financiar aquisições e a expansão das atividades da Companhia, bem como para o pagamento das despesas e comissões relativas à emissão destas notas" (ANHANGUERA, 2012d, p. 529).

Em 22 de abril de 2008, a Anhanguera realizou sua segunda oferta pública primária, que resultou na captação de R\$508 milhões (ANHANGUERA, 2008b, 2008c, 2008e) (19. $^{4}$. Deste valor, $60 \%$ foram investidos em potenciais aquisições, $27 \%$ na quitação de dívidas de curto prazo e $13 \%$ na expansão de unidades existentes e abertura de novas unidades (ANHANGUERA, 2010b) $^{420}$.

Em 29 de abril de 2008, foi aprovada em Assembleia Geral Ordinária uma proposta de orçamento de capital para a retenção de lucros da empresa e investimento desses recursos (R\$513 milhões) em projetos de expansão e melhoria da qualidade (ANHANGUERA, 2008a).

do Pantanal; FAD - Faculdade Dourados; FIP- Faculdades Integradas de Ponta Porã; IESD - Instituto de Educação Superior de Dourados; e Firve - Faculdades Integradas de Rio Verde, localizadas no Centro-Oeste brasileiro; (vi) União da Associação Educacional Sul-Matogrossense Ltda., mantenedora da Unaes; (vii) Instituto Superior Senador Fláquer de Santo André S/S Ltda., mantenedora do Centro Universitário de Santo André UniA.

${ }^{417}$ Referente à aquisição da Cesup, conforme IAN 31/12/2008, item 09.01 (ANHANGUERA, 2008d).

${ }^{418}$ A cotação mínima do papel da Anhanguera, no início das negociações, foi de R $\$ 18,00$. Durante o pregão, o valor chegou a R \$29,99, uma variação de $21,39 \%$, que deu a ela o $3^{\circ}$ lugar de melhor variação em abril de 2007 (YOKOI, 2007, p. 8 e LIPPI, 2008, p. 16). Das 48 companhias que abriram o capital em 2007 no Brasil, 31 se valorizaram menos que o Ibovespa; a Anhanguera, por outro lado, valorizou-se 31,8\% a mais que o Ibovespa, e a rentabilidade das suas ações foi de 86,11\% (GREGÓRIO, 2007, p. 16). Em junho de 2007, a Anhanguera já apresentava um Ebitda de R\$ 15,9 milhões, valor 210,8\% superior ao registrado no primeiro trimestre de 2006 (REVISTA CAPITAL ABERTO, 2007, p. 69). Apenas nos primeiros quatro meses de negociação, as ações da Anhanguera valorizaram 60\% (HESSEL; MARREY, 2007, p. 53

${ }^{419}$ Nos termos das RCAs de 18/04/2008 e 22/04/2008 e do Prospecto de 22/04/2008 (ANHANGUERA, 2008b; 2008c; 2008e), a oferta resultou num aumento de capital social de $\mathrm{R} \$ 442.000 .000,00$ (captação bruta), e o exercício do lote suplementar num aumento de R\$66.300.000,00. O valor da captação líquida, descontadas as comissões e sem considerar o lote suplementar, foi de R\$423,2 milhões, conforme Prospecto de 22/04/2008 (ANHANGUERA, 2008e).

${ }^{420}$ Conforme item 10 - Comentários dos Diretores, Demonstrações Financeiras da Companhia de 31/12/2009, anexas à AGO de 30/04/2010 (ANHANGUERA, 2010b). 
Em 30 de setembro de 2008, a Anhanguera celebrou um contrato de empréstimo com o Banco Santander S.A. no valor principal de R\$50 milhões (ANHANGUERA, 2012d, p. $350)$.

Considerando os recursos em caixa, a Anhanguera adquiriu e abriu novos campi $^{421}$, envolveu-se em novas aquisições de mantenedoras de instituições de ensino superior e, com isso, ampliou seus canais de distribuição, expandindo suas atividades nos estados de São Paulo (quatro aquisições ${ }^{422}$ ), Rio Grande do Sul (duas aquisições ${ }^{423}$ ), Distrito Federal (três aquisições ${ }^{424}$ ), Mato Grosso (duas aquisições ${ }^{425}$ ), Minas Gerais (uma aquisição ${ }^{426}$ ) e Santa Catarina (duas aquisições ${ }^{427}$ ). Em 31 de outubro de 2008, a empresa contava com quase 220

${ }^{421}$ Foram abertos, em 2008, um total de 21 campi, sendo 6 novos e 15 por meio de aquisições, conforme IAN de 31/12/2008, item 09.01 (ANHANGUERA, 2008d).

${ }_{422}$ De acordo com o IAN de 31/12/2008, item 09.01 (ANHANGUERA, 2008d), trata-se da aquisição da (i) Sociedade Educacional Sul Sancaetanense S/S. Ltda., sociedade mantenedora da Faenac - Faculdade Editora Nacional, com sede na cidade de São Caetano do Sul, estado de São Paulo; (ii) Instituto de Ensino de Sertãozinho Ltda., sociedade mantenedora da Fasert - Faculdade de Sertãozinho, com sede na cidade de Sertãozinho, estado de São Paulo; (iii) Pioneira Educacional Ltda., sociedade mantenedora da Faculdade Taboão da Serra, com sede na cidade de Taboão da Serra, estado de São Paulo; e (iv) Sociedade de Ensino Superior Itapecerica da Serra S/S Ltda., mantenedora da Faculdade de Itapecerica da Serra, com sede na cidade de Itapecerica da Serra, estado de São Paulo.

${ }^{423}$ De acordo com o IAN de 31/12/2008, item 09.01 (ANHANGUERA, 2008d), trata-se da aquisição da (i) Sociedade Educacional Caxias do Sul Ltda., sociedade mantenedora da Faculdade Kantum, com sede em Caxias do Sul, estado do Rio Grande do Sul; (ii) Sociedade Educacional Garra Ltda., mantenedora das Faculdades Planalto - Faplan, com sede em Passo Fundo, estado do Rio Grande do Sul.

${ }^{424}$ De acordo com o IAN de 31/12/2008, item 09.01 (ANHANGUERA, 2008d), trata-se da aquisição da (i) SBCEC - Sociedade Brasil Central de Educação e Cultura S/S Ltda., com sede em Taguatinga, Distrito Federal, sociedade mantenedora das instituições de ensino superior denominadas Faculdade de Administração JK Faculdade JK, Faculdade de Ciências Biológicas JK - Faculdade JK, Faculdade de Comunicação Social JK Faculdade JK, Faculdade JK Administração de Valparaíso - Faculdade JK, Faculdade JK Valparaíso Faculdade JK e Faculdade Juscelino Kubitschek - FJK; (ii) Centro de Ensino Unificado de Taguatinga Ltda., sociedade mantenedora da instituição de ensino superior denominada Faculdade Santa Terezinha, com sede em Taguatinga, Distrito Federal; (iii) Sesla - Sociedade Educacional de Ensino Superior do Lago Ltda., sociedade mantenedora da Faculdade de Negócios e Tecnologias da Informação - Facnet, com sede em Taguatinga, Distrito Federal.

${ }^{425}$ De acordo com o IAN de 31/12/2008, item 09.01 (ANHANGUERA, 2008d), trata-se da aquisição do (i) Centro de Ensino Superior se Rondonópolis S/S Ltda., sociedade mantenedora da Facsul - Faculdade do Sul de Mato Grosso, com sede na cidade de Rondonópolis, estado de Mato Grosso; e (ii) Sociedade Educacional Centro América Ltda., sociedade mantenedora da Faculdade Centro América, com sede em Cuiabá, estado de Mato Grosso.

${ }^{426}$ De acordo com o IAN de 31/12/2008, item 09.01 (ANHANGUERA, 2008d), trata-se da aquisição da Sociedade Brasileira de Ensino Superior Ltda., sociedade mantenedora da Fabrai - Faculdade Brasileira de Ciências Exatas, Humanas e Sociais e da Faculdade de Tecnologia Fabrai, com sede na cidade de Belo Horizonte, estado de Minas Gerais.

${ }^{427}$ De acordo com o IAN de 31/12/2008, item 09.01 (ANHANGUERA, 2008d), trata-se da aquisição da (i) Educar - Instituição Educacional S/S Ltda., sociedade mantenedora das instituições de ensino superior denominadas: (a) Instituto de Ensino Superior de Joinville - Iesville, (b) a Faculdade de Tecnologia Iesville Fati, (c) a Faculdade de Tecnologia São Carlos - Fatesc, (d) o Instituto Superior de Educação de Santa Catarina - Isesc, e (e) a Faculdade de Tecnologia de Jaraguá do Sul - Fatej, com sede na cidade de Joinvile, estado de Santa Catarina; e (ii) Intesc - Instituto Tecnológico de Educação Superior e Pesquisa de Santa Catarina Ltda., sociedade mantenedora da instituição de ensino superior denominada Faculdade de Tecnologia Jaraguaense Fateja, com sede na cidade de Jaraguá do Sul, estado de Santa Catarina. 
mil alunos de ensino superior e já oferecia uma gama maior de serviços - por conta da aquisição de instituições que atuavam no ensino profissionalizante e em cursos presenciais e a distância preparatórios para concursos públicos ${ }^{428}$ (ANHANGUERA, 2008d).

Em 2009, a Anhanguera continuou captando recursos no mercado: (i) efetuou três emissões públicas de debêntures, no valor total de R\$290 milhões (ANHANGUERA, $2008 \mathrm{~d})^{429}$; (ii) emitiu mais 10 notas promissórias comerciais no valor total de $\mathrm{R} \$ 10$ milhões (ANHANGUERA, 2012d, p. 351); (iii) celebrou um contrato de financiamento com o IFC, Société de Promotion et de Participation pour la Coopération Économique (Proparco ${ }^{430}$ ) e Deutsche Investitions - Und Entwicklungsgesellschaft Mbh (DEG) no valor total de R\$108,6 milhões (ANHANGUERA, 2009c; 2010b) ${ }^{431}$; e (iv) contratou empréstimos com o Banco Santander S.A. no valor de R\$63 milhões (ANHANGUERA, 2009a; 2009b). Esses recursos, somados à geração própria de fluxo de caixa operacional (principal fonte de recursos da companhia), permitiram à Anhanguera adicionar novos campi à sua rede de ensino, resultando num total de 54 (ANHANGUERA, 2012d, p. 114) ${ }^{432}$.

Em dezembro de 2009, o FEBR, José Luis Poli, Claudia Maria Fontesi Poli, Alex Carbonari, Erik Carbonari e Giulianna Carbonari Meneghello, acionistas da Anhanguera, realizaram uma oferta pública secundária ${ }^{433}$, que resultou na captação bruta de $\mathrm{R} \$ 750$ milhões (ANHANGUERA, 2012d, p. 534). Tendo em vista que essa oferta foi exclusivamente secundária, todos os recursos obtidos foram destinados apenas aos acionistas vendedores, não resultando em recursos para a Companhia. Após a realização da oferta, o FEBR permaneceu como acionista controlador da Anhanguera, detentor de $63,02 \%$ do capital social votante e

\footnotetext{
${ }^{428}$ Dentre as aquisições feitas pela Anhanguera, em 2008, destacam-se (i) a aquisição de $30 \%$ das ações da Escola de Profissões S.A. (nova denominação da Editora Microlins Brasil S.A.), passando a contar com os mais de 500 mil alunos de Ensino Profissionalizante da instituição investida; e (ii) a aquisição de $100 \%$ da LFG Business e Participações Ltda. (LFG), sociedade detentora da Rede LFG e marcas LFG, Prima, Rede Pró e Premier, que possuía na época 70 mil alunos matriculados em 62 cursos oferecidos em sua rede de 322 polos de ensino a distância (ANHANGUERA, 2008d).

${ }^{429}$ De acordo com o IAN 31/12/2008, item 08.01. (ANHANGUERA, 2008d), as emissões públicas de debêntures tiveram as seguintes características: (i) em 12/03/2009, montante emitido de R $\$ 40$ milhões; (ii) em 28/09/2009, montante emitido de R\$50 milhões; (iii) em 28/10/2009, montante emitido de R\$ 190 milhões; e (iv) em 28/10/2009 (outra emissão), montante emitido de $\mathrm{R} \$ 10$ milhões.

${ }^{430}$ Proparco é o braço da Agência Francesa de Desenvolvimento (AFD) para o financiamento do setor privado.

431 Conforme item 10 - Comentários dos Diretores, Demonstrações Financeiras da Companhia de 31/12/2009, anexas à AGO de 30/04/2010 (ANHANGUERA, 2010b) e RCA de 18/12/2009 (ANHANGUERA, 2009c).

${ }^{432}$ Em 18/11/2009, a Aesa adquiriu a totalidade das quotas representativas do capital social do Centro de Ensino Superior de Goiânia Ltda, pelo valor de R\$150.000,00. Em 26/01/2010, esta instituição foi incorporada pela Aesa (ANHANGUERA, 2012d, p. 114). .

433 Oferta Pública Secundária acontece quando são ofertadas ações já existentes, de modo que os recursos não são aportados na empresa, mas direcionados aos acionistas vendedores. Fonte: $<$ http://www.bmfbovespa.com.br/pt-br/mercados/acoes/ofertas-publicas/ofertas-publicas.aspx?idioma=pt-br $>$. Acesso em: 03/07/2012.
} 
24,16\% do capital social total (ANHANGUERA, 2012d, 534).

Ao final do ano de $2009^{434}$, a média de alunos matriculados em cursos da Companhia atingiu 255 mil alunos, dos quais 58\% em seus campi e $42 \%$ em seus polos (ANHANGUERA, 2012d).

Em 10 de junho de 2010, a Anhanguera alienou a totalidade de sua participação no capital social da Microlins, por um valor de R \$33,7 milhões. Em 30 de setembro de 2010, a Anhanguera incorporou sua subsidiária LFG, passando a desempenhar as atividades anteriormente desenvolvidas por esta empresa (ANHANGUERA, 2012d, p. 91).

A partir da segunda metade de 2010, o grupo Anhanguera voltou a realizar uma nova série de aquisições, impulsionadas por uma nova oferta pública de ações que a Companhia viria a efetuar no final de 2010. As aquisições, no entanto, passaram a ser feitas pela Aesa. Entre agosto e dezembro de 2010, a Aesa adquiriu duas mantenedoras de instituições de ensino superior (ANHANGUERA, 2012d) ${ }^{435}$.

Em 29 de outubro de 2010, os acionistas da Anhanguera aprovaram o ingresso da Companhia no Novo Mercado da BM\&FBOVESPA, com a conversão da totalidade das ações representativas de seu capital social em ações ordinárias (com direito à voto) e o compromisso de manter, pelo menos, $25 \%$ de suas ações em circulação no mercado (free float) (ANHANGUERA, 2010a).

Em 09 de dezembro de 2010, a Anhanguera realizou sua terceira oferta pública primária, que resultou na captação bruta total de R\$844,1 milhões (ANHANGUERA, 2012d, p. 91). Desse total, a companhia pretendia investir $84 \%$ na realização de aquisições de empresas do setor de ensino e 16\% na abertura de novas unidades, principalmente nas regiões Sul, Sudeste e Centro-Oeste (regiões nas quais a Anhanguera já possui unidades operacionais)

\footnotetext{
${ }^{434}$ Conforme item 6.5 do Formulário de Referência da Anhanguera de 2012 (ANHANGUERA, 2012d), em 2009, foram também realizadas as seguintes operações: (i) em 30/06/2009, a Companhia alienou a totalidade das quotas que detinha no capital social das seguintes controladas: (a) EM Colégio Universitário de Taboão da Serra Ltda. - EPP; (b) Colégio Universitário Taboão Ensino Fundamental Ltda. - EPP; (c) Colégio Universitário de Taboão da Serra Ltda. - EPP; e (d) Escola de Educação Infantil Universitário Junior Taboão da Serra Ltda, pelo valor total de $\mathrm{R} \$ 3.400 .000,00$; e (ii) em 07/08/2009, a Aesa alineou a totalidade das quotas que detinha no capital social do Colégio Técnico Comercial Senador Fláquer S/S Ltda. O montante pactuado pela operação foi equivalente ao valor total do endividamento do Colégio, de $\mathrm{R} \$ 904.579,35$ na data de assinatura de Compra e Venda, relativo a dívidas com o INSS, sem qualquer pagamento adicional à Aesa.

${ }^{435}$ Conforme itens 6,5 e 8.3 do Formulário de Referência da Anhanguera de 2012 (ANHANGUERA, 2012d), em 20/08/2010, a LFG Business e Participações Ltda. adquiriu a totalidade das quotas representativas do capital social do Centro de Ensino Superior de Mato Grosso Ltda., pelo valor de R \$98.000,00 (em 30/09/2010, a Anhanguera incorporou a LFG Business e Participações Ltda, e em 31/12/2010, o Centro de Ensino Superior de Mato Grosso Ltda. foi incorporado pela Aesa). Em 16/12/2010, a Aesa adquiriu a totalidade das quotas representativas do capital social da Sociedade Educacional Plínio Leite S/S Ltda., sociedade mantenedora do Centro Universitário Plínio Leite (Unipli), pelo valor de R\$56.972.735,25.
} 
(ANHANGUERA, 2010e).

Como resultado das aquisições efetuadas em 2010, a Anhanguera adquiriu mais dois novos campi, ingressou no estado do Rio de Janeiro, fortaleceu sua presença na região Sudeste e encerrou o ano com 56 campi em operação (ANHANGUERA, 2012d, p. 91).

$\mathrm{O}$ ano de 2011 foi mais um ano de intensa expansão da Anhanguera por meio de aquisições. Entre março e setembro de 2011, a Aesa envolveu-se em 12 aquisições de mantenedoras de instituições de ensino superior (ANHANGUERA, 2012d; 2011c) ${ }^{436}$. Dentre essas aquisições, destaca-se a aquisição do grupo Uniban $^{437}$, realizada em 16 de setembro de 2011. Por meio dessa operação, que envolveu mais de $\mathrm{R} \$ 510$ milhões, o grupo Anhanguera ingressou no estado do Paraná e na região metropolitana de Florianópolis e tornou-se o segundo maior grupo educacional do mundo ${ }^{438}$, com mais de 400 mil alunos, dentre os quais

${ }^{436}$ Em 03/03/2011, a Aesa envolveu-se em duas aquisições (i) do Grupo Ibmec Educacional S.A., adquiriu os bens e direitos da Faculdade Uirapuru e do Instituto Manchester Paulista de Ensino Superior, ambos localizados na cidade de Sorocaba/SP, pelo valor de R\$5.069.000,00; e (ii) adquiriu a totalidade das quotas representativas do capital social da Unicts - União de Ensino Superior de Ciência, Tecnologia e Saúde Ltda., sociedade mantenedora da instituição de ensino superior denominada Faculdade de Ciências e Tecnologia de Brasília, pelo montante de $\mathrm{R} \$ 2.200 .000,00$. Em 31/03/2011, a Aesa envolveu-se em duas aquisições: (i) da totalidade das quotas do capital social da Novatec - Novatec Serviços Educacionais Ltda., sociedade mantenedora da instituição de ensino superior denominada Faculdade de Tecnologia Anchieta, pelo montante de $\mathrm{R} \$ 27.833 .000,00$; e (ii) da totalidade das quotas representativas do capital social da IGABC - Instituto Grande ABC de Educação e Ensino S/S Ltda., sociedade mantenedora da instituição de ensino superior denominada Faculdade Anchieta, pelo montante de R\$46.470.000,00. Em 28/04/2011, a Aesa adquiriu a totalidade das quotas do capital social da Associação de Ensino Superior Elite Ltda., sociedade mantenedora da instituição de ensino superior denominada Faculdades Integradas Torricelli - FIT, pelo valor de R $\$ 22.486 .000,00$. Em 17/05/2011, a Aesa envolveu-se em duas aquisições: (i) da totalidade das quotas do capital social da Praetorium, Instituto de Ensino, Pesquisa e Atividade de Extensão em Direito Ltda., pelo montante de R\$48.001.000,00; e (ii) da totalidade das quotas do capital social da Sociedade Educacional de Belo Horizonte Ltda., sociedade mantenedora da instituição de ensino superior denominada Faculdade Metropolitana de Belo Horizonte, pelo montante de R \$4.589.000,00. Em 27/07/2011, a Aesa adquiriu a totalidade das quotas do capital social da Unifec - União para Formação, Educação e Cultura do ABC Ltda., sociedade mantenedora da instituição de ensino superior denominada Universidade do Grande ABC, pelo montante de R\$49.497.000,00. Em 28/07/2011, a Aesa adquiriu a totalidade das quotas do capital social da Instituição Educacional Professor Luiz Rosa Ltda., sociedade mantenedora da instituição de ensino superior denominada Faculdade de Tecnologia Professor Luiz Rosa, pelo montante de R \$2.989.000,00. Em 16/09/2011, a Aesa envolveu-se em três aquisições (i) da totalidade das quotas do capital social da APA - Academia Paulista Anchieta Ltda., sociedade mantenedora da instituição de ensino superior denominada Universidade Bandeirante de São Paulo - Uniban; (ii) da totalidade das quotas do capital social da União Pan-Americana de Ensino S/C Ltda., sociedade mantenedora da instituição de ensino superior denominada Faculdade de Ciências Aplicadas de Cascavel - Faciap; e (iii) da totalidade das quotas do capital social da União Bandeirante de Educação Ltda., sociedade mantenedora das instituições de ensino superior denominadas Escola Superior de Educação Corporativa - Esec e Faculdade União Bandeirante - FUB. $\mathrm{O}$ valor dessas aquisições totalizou $\mathrm{R} \$ 510.561 .000,00$, sendo: (i) $\mathrm{R} \$ 382.561 .000,00$ pela totalidade das quotas de emissão do grupo Uniban; e (ii) $\mathrm{R} \$ 128.000 .000,00$ pela aquisição de três imóveis operacionais (ANHANGUERA, 2012d; 2011c). Sobre estas aquisições vide também as atas das RCAs descritas no Apêndice A da Dissertação.

${ }^{437}$ O Grupo Uniban, em março de 2011, possuía 55,1 mil alunos matriculados em seus 9 campi localizados na região metropolitana de São Paulo, 2 campi localizados em Cascavel - PR e 1 campus localizado em São José SC (ANHANGUERA, 2011c).

${ }^{438}$ Nesta data, a Anhanguera perdia apenas para a americana Apollo Group, proprietária da Universidade de Phoenix. Disponível em: <http://www.estadao.com.br/noticias/vidae,anhanguera-compra-uniban-por-r-510- 
110 mil apenas na Grande São Paulo (ANHANGUERA, 2011c).

Logo após a aquisição do grupo Uniban, em 19 de setembro de 2011, a Anhanguera realizou sua $4^{\mathrm{a}}$ emissão de debêntures, no valor de R $\$ 400$ milhões (ANHANGUERA, 2011b).

Como resultado das aquisições de 2011, a Anhanguera aumentou seu número de alunos em mais de 150 mil, encerrando o ano com um total de 73 campi $^{439}$ e mais de 500 polos em sua rede de ensino ${ }^{440}$ (ANHANGUERA, 2012d).

Com a aquisição da Uniban, os campi do grupo Anhanguera passaram a ter capacidade para atender 700 mil alunos, o que contribui para o objetivo do grupo de alcançar, entre 2014 e 2015, a marca de 1 milhão de alunos - número este que elevaria a participação da empresa no mercado de ensino superior brasileiro para $15 \%{ }^{441}$.

\subsection{Grupo II - Educação como serviço prestado mediante o desempenho de uma atividade empresária}

\subsubsection{Questão 6}

Neste subitem, nosso objetivo é responder à seguinte questão:

\section{Quadro 8 - Questão da Análise Empírica nº 6}

\begin{tabular}{|c|c|}
\hline $\mathbf{N}^{\mathbf{0}}$ & $\begin{array}{c}\text { Grupo II - Educação como serviço prestado mediante o desempenho de uma atividade } \\
\text { empresária }\end{array}$ \\
\hline 6. & $\begin{array}{l}\text { Foram encontradas práticas empresariais que evidenciem o tratamento da prestação de serviços } \\
\text { educacionais como atividade empresária? Quais foram as práticas encontradas? Foi encontrada } \\
\text { preocupação com criação de escala e eficiência para diminuição dos custos envolvidos na atividade e } \\
\text { aumento dos lucros para distribuição aos acionistas? }\end{array}$ \\
\hline
\end{tabular}

A Anhanguera desenvolve claramente uma atividade empresária.

Primeiro porque se trata de uma sociedade por ações de capital aberto, listada no Novo Mercado da BM\&FBOVESPA, que oferece um determinado serviço (educação) mediante remuneração por seus consumidores, visando lucro para distribuição aos acionistas.

milhoes, 773921,0.htm>. Acesso em: 04/07/2012.

${ }^{439}$ A Companhia acredita ainda haver potencial significativo para ampliação do número de campi no Brasil acredita haver 253 cidades no Brasil com população acima de 100 mil habitantes, com potencial para implantação de pelo menos um campus (ANHANGUERA, 2012d, p. 114)

${ }^{440}$ Em 2011, a Companhia adquiriu 19 novos campi, sendo um deles um campus pré-operacional em Brasília. Ademais, encerrou as atividades no campus localizado na cidade de Ponta Porã, encerrando o ano de 2011 com um total de 73 campi e mais de 500 polos em sua rede de ensino (ANHANGUERA, 2012d, p. 91)

441 Fonte: Jornal O Estado de São Paulo, matéria veiculada no dia 17/09/2011. Disponível em: $<$ http://www.estadao.com.br/noticias/vidae,anhanguera-compra-uniban-por-r-510-milhoes,773921,0.htm>.

Acesso em: 04/07/2012. 
Segundo porque, para o oferecimento do seu principal produto (ensino superior de massa, com ganhos de escala), bem como para o atendimento de todas as exigências legais para companhias de capital aberto no Brasil e das práticas de governança corporativa do Novo Mercado, conforme descritas no Capítulo 2 da Dissertação, a Anhanguera estruturou-se na forma de uma empresa de grande porte, com organização, coordenação e profissionalismo.

Considerando que na estrutura da Anhanguera encontramos organização, coordenação, profissionalismo e a prestação de um serviço mediante remuneração, visando lucro para distribuição aos acionistas, todos os elementos essenciais de uma atividade empresária são preenchidos pela empresa.

Além disso, a Anhanguera apresenta outras características e práticas empresariais, que demonstram o desempenho de uma atividade empresária. Nos subitens a seguir e ao longo de todo este Capítulo, vamos descrever essas características e práticas empresariais, destacando ações criadoras de ganhos de escala e eficiência, para diminuição dos custos e aumento dos lucros da empresa.

\subsubsection{Alunos consumidores}

Os alunos da Anhanguera são os consumidores que contratam a prestação de serviços educacionais pelas instituições integrantes do grupo Anhanguera (fornecedores). Muitas demandas envolvendo os alunos e as instituições de ensino integrantes do grupo são resolvidas a partir do Código de Defesa do Consumidor. Em 30 de setembro de 2009, a Anhanguera e suas subsidiárias eram parte (polo passivo) em 1.275 processos cíveis e 1.228 procedimentos referentes a reclamações junto ao PROCON, envolvendo pedidos de indenização por inscrição indevida do nome dos alunos em órgãos de proteção ao crédito, problemas com matrícula, emissão de documentos e outras demandas baseadas no Código de Defesa do Consumidor (ANHANGUERA, 2008d) ${ }^{442}$.

\subsubsection{Busca de eficiência e ganhos de escala}

A Anhanguera desenvolve um modelo operacional eficiente e padronizado, que gera ganhos de escala ${ }^{443}$. A empresa possui um modelo de gestão de multiunidades, que consiste

\footnotetext{
${ }^{442}$ Conforme item 14.03 do IAN de 31/12/2008 (ANHANGUERA, 2008d).

${ }^{443}$ A busca de escala é um dos objetivos da empresa. Segundo o fundador da Anhanguera e atual presidente do
} 
em concentrar na sede da Companhia em Valinhos - SP o desenvolvimento acadêmico, a supervisão das unidades, o treinamento do corpo docente e as funções gerenciais e administrativas, enquanto as unidades, construídas de forma padronizada, oferecem infraestrutura e serviços de apoio aos alunos e são administradas por diretores locais, responsáveis pela supervisão do funcionamento da unidade, do corpo docente, por atingir as metas e controlar a qualidade do ensino. Com essa dinâmica, a Anhanguera reduz sua estrutura administrativa e seu custo de produção. Essa economia lhe confere vantagens competitivas, permitindo-lhe cobrar mensalidades com preços mais baixos que seus concorrentes e assim atrair um número maior de alunos.

A Anhanguera conta com dois tipos de unidades (campi e polos). Cada uma de suas unidades possui uma infraestrutura padrão, considerada necessária e adequada aos cursos oferecidos. Esse modelo operacional multiunidades padronizado possibilita também uma pronta expansão para novos mercados, mediante a replicação do modelo acadêmico, do projeto pedagógico unificado e do treinamento de docentes e funcionários de forma consistente e eficiente, gerando ganhos de escala. Com um projeto pedagógico unificado, a Anhanguera pode adotar a mesma metodologia de ensino e os mesmos livros e materiais didáticos em todas as suas unidades (ANHANGUERA, 2012d, p. 112).

Segundo a Anhanguera (ANHANGUERA, 2010f, p. 24):

o modelo acadêmico utilizado, padronizado, facilita o aprendizado por parte dos alunos. Todos os professores, nos cursos, utilizam um livro-texto, que funciona com um guia para o curso. Esses livros são referência de mercado, são reconhecidos. Há, ainda, livros sobre temas ligados à sustentabilidade, utilizados em todos os cursos. Por meio de acordos com as editoras, a Anhanguera Educacional adquire grandes lotes de todos eles, que podem ser vendidos aos alunos por um preço bem mais acessível. Além disso, a Anhanguera Educacional publica seus próprios livros, geralmente escritos por professores da casa. Esse programa Livro-Texto facilita o aprendizado dos alunos. Além disso, estimula a leitura e combate a pirataria, pela possibilidade de os alunos montarem sua própria biblioteca.

A padronização da metodologia de ensino e a utilização dos mesmos livros e materiais didáticos em todos os cursos é uma prática que pode contrariar o princípio da liberdade de ensino e do pluralismo. Comentários a esse respeito encontram-se no item 4.3.1 abaixo.

CA, Antonio Carbonari Netto: “Quando a gente faz educação superior e pensa em lucro é pra investir em que? Em qualidade mas também em escalabilidade. Se você tem um bom modelo de currículo seja ele de início ou de massa. Você precisa ter escala. O Brasil é muito grande. Nós estamos com 13 - 14\% de universitários ainda e os outros $80 \%$ e tanto? Cadê? Financiamento precisa, elucidá-los das profissões, quer dizer, que tipo de profissão você quer? Que ocupação você precisa fazer? Acho que tem uma grande empreitada aí. Dá pra dobrar ou triplicar o número de alunos nessa década aqui, com muita folga, com muita folga". Áudio disponível em: http://www.abmes.org.br/abmes/video/detalhe/id/39. Acesso em: 01/08/2012. 


\subsubsection{Venda cruzada de cursos}

A Anhanguera tem como um dos seus objetivos explorar potenciais sinergias de venda cruzada de seus produtos. Para tanto, a Companhia divulga entre seus próprios alunos os diversos produtos e serviços que compõem seu portfólio e busca acompanhar todo o ciclo de desenvolvimento profissional do aluno desde a graduação, visando desenvolver relacionamentos de longo prazo (pós-graduação, educação continuada, entre outros).

Por meio dessa estratégia, a Anhanguera busca maximizar o potencial de geração de receita de sua rede e de sua base de alunos e ex-alunos (ANHANGUERA, 2010e, p. 29).

\subsubsection{Obtenção de incentivos fiscais}

Assim como outras grandes empresas, a Anhanguera recebe incentivos fiscais de alguns municípios em que atua, tais como isenções de ISS e IPTU e autorizações para ocupação e uso de determinados imóveis livre de pagamento. Na cidade de Leme - SP, a Anhanguera quando iniciou suas atividades recebeu um prédio da Prefeitura Municipal em comodato $^{444}$ e na cidade de Valinhos - SP troca o valor devido de ISS por bolsas de estudo concedidas à prefeitura em valor equivalente ${ }^{445}$.

Por conta de sua participação no ProUni, a Anhanguera beneficia-se também de isenções fiscais federais de Imposto de Renda da Pessoa Jurídica, Programa de Integração Social, Contribuição para o Financiamento da Seguridade Social e Contribuição Social sobre o Lucro Líquido referentes às receitas de cursos de graduação e graduação tecnológica.

A obtenção de incentivos fiscais contribui para a redução do custo de produção da Anhanguera e, consequentemente, para o aumento dos seus lucros.

\subsubsection{Questão 7}

Neste subitem, procuramos responder à seguinte questão:

\footnotetext{
${ }^{444}$ Segundo Carbonari: "Então 1990, eu protocolei o primeiro pedido de faculdade, na cidade de Leme, estado de São Paulo. Por que Leme? Porque o Prefeito e o Vice-Prefeito me convidaram, vamo pra lá, eu te dou um prédio, sem aluguel, em cessão de comodato e faz a tua faculdade lá. O que eu quero é pra minha cidade". Vídeo disponível em: http://www.youtube.com/watch?v=SP6ThzLM32k. Acesso em: 07/01/2013.

${ }^{445}$ Disponível em: http://www.unianhanguera.edu.br/ri/. Acesso em 17/01/2011.
} 


\section{Quadro 9 - Questão da Análise Empírica nº 7}

\begin{tabular}{|c|c|}
\hline $\mathbf{N}^{\mathbf{0}}$ & $\begin{array}{c}\text { Grupo II - Educação como serviço prestado mediante o desempenho de uma atividade } \\
\text { empresária }\end{array}$ \\
\hline 7. & $\begin{array}{l}\text { Quais as principais fontes de recurso da Anhanguera? Qual foi a destinação dos recursos captados no } \\
\text { mercado pela Anhanguera? Qual porcentagem foi investida em infraestrutura para os alunos e qual } \\
\text { porcentagem foi destinada para o crescimento da empresa por meio de novas aquisições? Com relação } \\
\text { à infraestrutura, quais foram os investimentos feitos? }\end{array}$ \\
\hline
\end{tabular}

As principais fontes de recursos da Anhanguera são: (i) a receita obtida pelo pagamento das mensalidades, taxas pela prestação de serviços acadêmicos de seus alunos ${ }^{446} \mathrm{e}$ vendas de livros do Programa Livro Texto (PLT) e apostilas, que, em 2011, atingiram o valor de R\$1.232.169.489,05 (receita líquida) (ANHANGUERA, 2012d, p. 4); (ii) o capital obtido pelas três ofertas públicas de ações realizadas em 2007, 2008 e 2010, cujo valor total de captação bruta foi de $\mathrm{R} \$ 1,712$ bilhões; (iii) o capital obtido pelas ofertas públicas de debêntures realizadas em 2009 e 2011, com valor total de R\$690 milhões; (iv) o capital obtidos pela emissão de notas promissórias comerciais em 2008 e 2009, no valor total de R \$140 milhões; e (v) o capital obtido por financiamentos e empréstimos, entre eles o contrato de financiamento com IFC, Proparco e DEG, em 2009, no valor total de R \$108,6 milhões; e os contratos de empréstimo com o Banco Santander S.A., nos anos de 2008 e 2009, no valor total de R\$113 milhões.

Conforme mencionamos no item 4.1.2 acima, a Anhanguera fez a seguinte destinação dos recursos captados no mercado nas três ofertas públicas realizadas pela empresa: (i) dos R \$360 milhões captados na oferta pública inicial (08/03/2007), investiu 49\% em potenciais aquisições, $41 \%$ na expansão de unidades existentes e abertura de novas unidades e $10 \%$ para quitação de dívidas de curto prazo (ANHANGUERA, 2010b) ${ }^{447}$; (ii) dos R $\$ 508$ milhões captados na segunda oferta pública (22/04/2008), investiu $60 \%$ em potenciais aquisições, $27 \%$ na quitação de dívidas de curto prazo e $13 \%$ na expansão de unidades existentes e abertura de novas unidades (ANHANGUERA, 2010b) ${ }^{448}$; e (iii) dos $\mathrm{R} \$ 844,1$ milhões captados na na terceira oferta pública primária $(09 / 12 / 2010)$, pretendia investir $84 \%$ para a realização de

\footnotetext{
${ }^{446}$ Além do recebimento de mensalidades decorrentes da venda dos serviços educacionais, a Anhanguera também aufere receita por meio da cobrança de taxas de seus alunos pela prestação de serviços acadêmicos, como impressões de documentos, programas de recuperação acadêmica, provas de segunda chamada, requerimentos de revisão de notas, requerimentos de histórico escolar, venda de material didático, taxas de inscrição no vestibular, entre outras (ANHANGUERA, 2012d, p. 111).

${ }^{447}$ Conforme item 10 - Comentários dos Diretores, Demonstrações Financeiras da Companhia de 31/12/2009, anexas à AGO de 30/04/2010 (ANHANGUERA, 2010b).

${ }^{448}$ Conforme item 10 - Comentários dos Diretores, Demonstrações Financeiras da Companhia de 31/12/2009, anexas à AGO de 30/04/2010 (ANHANGUERA, 2010b).
} 
aquisições de empresas do setor de ensino e 16\% para a abertura de novas unidades, principalmente nas regiões Sul, Sudeste e Centro-Oeste (ANHANGUERA, 2010e, p. 89).

Pelos dados acima, nota-se que a Anhanguera concentrou os recursos captados no mercado na expansão de seus negócios, tendo realizado nos últimos anos inúmeras aquisições de mantenedoras de instituições de ensino superior nas regiões Sudeste, Sul e Centro-Oeste do Brasil, além de ter expandido suas unidades existentes e aberto novas unidades. Segundo informações da Companhia (ANHANGUERA, 2010b; 2010d) ${ }^{449}$, além dos custos envolvidos na efetiva compra e repassados aos antigos proprietários das mantenedoras, a Anhanguera também utiliza recursos para a adequação das novas unidades à estrutura padronizada da Anhanguera, com a construção de salas de aula, laboratórios, bibliotecas e demais infraestrutura. A Companhia efetua alterações na estrutura existente buscando maior produtividade por meio do desenvolvimento de melhorias em tecnologia da informação e processos, no setor administrativo (ANHANGUERA, 2010b; 2010d) ${ }^{450}$.

\subsubsection{Questão 8}

Neste subitem, procuramos responder à seguinte questão:

\section{Quadro 10 - Questão da Análise Empírica n ${ }^{0} 8$}

\begin{tabular}{|l|l|}
\hline $\mathbf{N}^{\mathbf{0}}$ & Grupo II - Educação como serviço prestado mediante o desempenho de uma atividade empresária \\
\hline 8. & $\begin{array}{l}\text { Como é o processo seletivo da Anhanguera? Quais são as formas de publicidade e marketing utilizadas } \\
\text { pela Anhanguera para atrair novos alunos? Essas práticas demonstram características empresariais da } \\
\text { atividade? }\end{array}$ \\
\hline
\end{tabular}

Segundo informações da Companhia (2012d, p. 151), o processo seletivo para os cursos superiores da Anhanguera envolve um exame vestibular com perguntas de múltipla escolha, perguntas de respostas curtas e uma redação, ou pode ser utilizada a nota do Enem (que é exigido para os alunos que buscam as bolsas do ProUni ou o Fies). Após a conclusão do processo de seleção, caso haja vagas remanescentes, uma nova seleção de alunos poderá ser feita.

O processo seletivo da Anhanguera é feito duas vezes por ano para os cursos

\footnotetext{
${ }^{449}$ Conforme item 10 - Comentários dos Diretores, Demonstrações Financeiras da Companhia de 31/12/2009, anexas à AGO de 30/04/2010 (ANHANGUERA, 2010b) e Formulário de Referência da Anhanguera de 2010, item 10.10.a. (ANHANGUERA, 2010d).

${ }^{450}$ Conforme item 10 - Comentários dos Diretores, Demonstrações Financeiras da Companhia de 31/12/2009, anexas à AGO de 30/04/2010 (ANHANGUERA, 2010b) e Formulário de Referência da Anhanguera de 2010, item 10.10.a (ANHANGUERA, 2010d).
} 
presenciais e quatro vezes por ano para os cursos a distância. O processo principal é realizado em janeiro, e os outros tendem a ser menores e podem nem acontecer dependendo da demanda pelo curso (ANHANGUERA, 2012d, p. 151).

Para atrair novos alunos, a Anhanguera investe na divulgação de sua marca e em estratégias de publicidade e marketing.

A marca de uma instituição de ensino superior agrega valor. Nesse sentido, instituições de ensino superior tradicionais, com melhor reputação no mercado, e marcas fortes, geralmente, cobram mensalidades mais caras (SÉCCA; LEAL, 2009, p. 28). Instituições de massa, como a Anhanguera, investem na divulgação de suas marcas, buscando atrair seu público-alvo, e isso lhes dá vantagem sobre outras instituições desconhecidas do grande público (SÉCCA; LEAL 2009, p. 28).

A Anhanguera (2012d, p. 147) afirma:

A Companhia tem como objetivo oferecer Ensino Profissional de qualidade, permitindo que jovens trabalhadores das classes média e baixa realizem seus projetos de vida por meio da melhoria de sua qualificação profissional e perspectivas de sucesso no mercado de trabalho e, consequentemente, crescer e desenvolver o reconhecimento da sua marca e criar valor para seus acionistas.

A Anhanguera investe em publicidade e marketing para divulgar a marca Anhanguera e outras marcas do grupo visando atingir públicos diferentes - por exemplo, usa a marca “Uniderp” em Campo Grande (MS) para atender a um público de classes A e B, a marca "LFG" para a rede de cursos preparatórios para concursos públicos e a marca "Anhanguera" para um público das classes C e D, principalmente (SÉCCA; LEAL 2009, p. 130).

Segundo a Anhanguera (2012d, p. 153), a estratégia de marketing da empresa "tem como objetivo atrair novos alunos, aumentar a retenção de alunos matriculados e consolidar a percepção do valor dos cursos".

Como revela em seus documentos, a Companhia adotou, entre outras, as seguintes campanhas de marketing:

(i) para recrutar novos alunos em potencial - "a Companhia direciona e segmenta seus esforços de marketing em cada localidade de acordo com os resultados de pesquisas de demanda local, buscando identificar as aspirações dos alunos em potencial" (ANHANGUERA, 2012d, p. 154).

Em busca desse objetivo, a Anhanguera veicula anúncios em televisão, outdoors, rádio e jornais. Em 2011, a Anhanguera lançou uma campanha com o tema "Anhanguera, aqui o 
seu esforço ganha força", que segundo a Companhia (2012d, 154) reconhece e valoriza:

[...] a batalha daqueles que buscam na educação superior a transformação de suas vidas, oferecendo benefícios que amenizam as dificuldades. O reconhecimento ao empenho do aluno é um fato inédito no setor e evidencia a proposta da instituição em estimular a população brasileira a superar os obstáculos, investindo na formação superior para que consiga colocar em prática o seu projeto de vida.

Para o vestibular de 2011, a Anhanguera trouxe o seguinte mote: "se você tem uma ambição na cabeça, faça Anhanguera". Segundo a Companhia (2010f, p. 23):

\begin{abstract}
Esse conceito reforça a plataforma de empregabilidade e inclusão social, explorando a relação entre o estudante e o mercado de trabalho e enfatizando atributos como preço, portal de emprego exclusivo para o aluno com mais de 50 mil vagas e a primeira e única instituição de ensino superior do Brasil a conquistar o primeiro lugar em Inovação e Qualidade, segundo pesquisa realizada neste ano pela revista IstoÉ Dinheiro.
\end{abstract}

(ii) para reter os alunos matriculados na instituição -a Anhanguera divulga entre os seus alunos os índices de satisfação do $\mathrm{PAI}^{451}$ e as melhorias implementadas pela empresa. Além disso, oferece aos alunos um Serviço de Atendimento ao Aluno (SAE), para apoio psicopedagógico (ANHANGUERA, 2012d, p. 154).

(iii) para melhorar a percepção do valor da marca - "a Companhia procura melhorar a percepção do valor de sua marca pelos agentes que influenciam o processo de tomada de decisão de alunos em potencial, como empregadores, e por seus clientes internos e externos" (ANHANGUERA, 2012d, p. 154). Para isso, mantém um departamento de relações públicas e implementa campanhas para divulgar sua marca. Além disso, "também divulga a produção acadêmica de seus alunos e do corpo docente a importantes grupos do setor e a autoridades governamentais" (ANHANGUERA, 2012d, p. 154).

A Anhanguera classifica como despesas com marketing as seguintes atividades: (i) publicidade veiculada em redes de televisão, outdoors, rádio, jornais, entre outros veículos; (ii) equipes internas de vendas e marketing; (iii) publicações de artigos de professores e alunos; e (iv) pessoal de apoio ao departamento de marketing, entre outros (ANHANGUERA, 2012d, p. 355).

Em julho de 2012, foi noticiada uma prática de marketing da Anhanguera que causou polêmica. A empresa passou a sortear em suas unidades automóveis e tablets para os alunos que antecipassem o pagamento da mensalidade. Essa prática é considerada ilegal por não

${ }^{451}$ Assunto tratado no item 4.3.4 abaixo. 
observar as regras, nem pagar as taxas necessárias para a realização desse tipo de ação promocional, que é fiscalizada pela Caixa Econômica Federal. Segundo o jornal O Estado de São Paulo ${ }^{452}$ :

\begin{abstract}
Antes de passar pela roleta que dá acesso às salas de aula, o aluno do câmpus da Uniban em Osasco - uma das instituições compradas pelo Grupo Anhanguera no ano passado - passa por um carro zero e pela faixa com a inscrição "Adiante a mensalidade do próximo mês e concorra a 4 carros e 40 tablets". A estratégia de fidelização, no entanto, não está sendo divulgada nem no site da instituição nem das redes sociais porque a ação é ilegal.

"O concurso não precisa de autorização do governo para acontecer, já esse tipo de ação promocional, sim. É para fugir da burocracia e da fiscalização que garantem a lisura do processo que as instituições cometem essas irregularidades", explica Renan Ferraciolli, diretor de fiscalização do Procon-SP. [...]

O tipo de ação realizada pela Anhanguera, explica Ferraciolli, é denominada "operação assemelhada a concurso" e, portanto, necessita de autorização da Caixa Econômica Federal.

É esse o órgão que autoriza esse tipo de sorteio, mediante o encaminhamento de documentação e o pedido de autorização no prazo mínimo de 40 dias antes da data de início da promoção comercial.

Além disso, a entidade promotora deve pagar taxas de fiscalização com valores proporcionais ao custo dos prêmios. Os valores vão de R \$ 27 a R \$ 66 mil. [...]

"Não existe nenhum indicador mais importante do que a satisfação do estudante e, hoje, o aluno começa a ter um olhar mais crítico sobre essas variáveis. Ele não se deixa levar por algumas novidades", explica o consultor Carlos Monteiro. Segundo ele, ações como sorteio de carros podem significar antecipação de caixa, mas são equivocadas ao não valorizar o que o aluno realmente tem direito ao comprar o serviço. "O universitário sabe que, para conseguir um bom emprego e apresentar uma boa performance profissional, ele precisa de competências e habilidades que estão longe desses aspectos de marketing."
\end{abstract}

Entre os anos de 2010 e 2011, a Anhanguera recebeu os seguintes reconhecimentos e premiações relacionados a sua marca e estratégias de marketing ${ }^{453}$ : (i) a marca "Anhanguera" foi eleita, em 2010, como a $29^{\mathrm{a}}$ marca mais valiosa do Brasil pela consultoria Brand Analytics/MillwardBrown, e, em 2011, como a 26 ${ }^{\mathrm{a}}$ marca mais valiosa, tendo sido a primeira e única marca de educação a integrar este ranking (ANHANGUERA, 2012d, p. 147) ${ }^{454}$; (ii) a Anhanguera figurou em $13^{\circ}$ lugar no ranking geral da lista "Melhores e Maiores" de 2010 da Revista Exame; (iii) a Anhanguera conquistou o primeiro lugar no ranking de marketing direto da Associação Brasileira de Marketing Direto (ABEMD), em 2010; (iv) pelo terceiro ano consecutivo, em 2011, a Anhanguera obteve o primeiro lugar, no item "Responsabilidade Social" e, no ano de 2011, também o primeiro lugar no item "Inovação e Qualidade", na

\footnotetext{
452 Disponível em: <http://www.estadao.com.br/noticias/geral,anhanguera-causa-polemica-ao-sortear-carros-etablets, 895613,0.htm>. Acesso em 25/09/2012.

${ }^{453}$ Prêmios que também são divulgados pela empresa e que se tornam estratégia de marketing para a divulgação da marca.

${ }^{454}$ A marca "Anhanguera" foi eleita em 2009 como a 37 marca mais valiosa do Brasil. Em 2010, a Companhia subiu oito colocações, alcançando o $29^{\circ}$ lugar, e, em 2011, alcançou o $26^{\circ}$ lugar. registrando o $11^{\circ}$ maior crescimento entre as 200 marcas que participaram do levantamento no Brasil. (ANHANGUERA, 2012d, p. 147).
} 
publicação "Melhores da Dinheiro", organizado pela Revista IstoÉ Dinheiro, que congrega as 500 melhores empresas do Brasil, no geral e por setor de atividade; (v) em 2011, a Anhanguera foi a primeira empresa de serviços educacionais a participar, pelo segundo ano consecutivo, da lista de empresas/ações que integram o Índice de Sustentabilidade Empresarial (ISE) da BM\&FBOVESPA (ANHANGUERA 2010f; 2011d) ${ }^{455}$; e (vi) segundo a Anhanguera (2010f, p. 63), “como reconhecimento por sua atuação em prol da qualidade de ensino com inclusão social, a Anhanguera Educacional foi convidada a apresentar cases em prestigiosas organizações”, como Harvard Business School Boston, em fevereiro de 2010, e no International Finance Corporation (IFC), em abril de 2010.

\subsubsection{Questões 9 e 10}

Neste subitem, procuramos responder às seguintes questões:

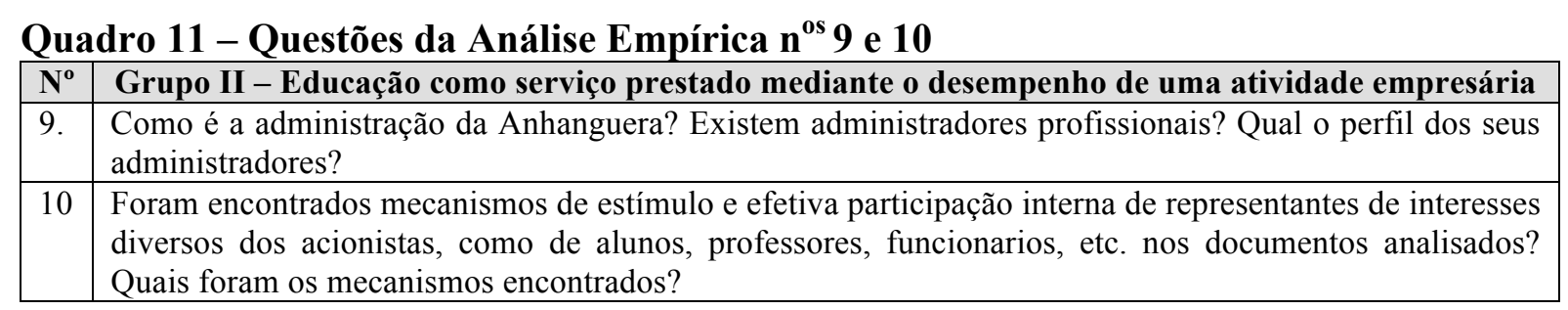

A administração da Anhanguera e a condução de seus negócios, como ocorre em todas as sociedades por ações de capital aberto do Brasil, é exercida por meio de três órgãos: (i) a Assembleia Geral (AG); (ii) o Conselho de Administração (CA); e (iii) a Diretoria. Além disso, a Anhanguera possuía, em 31/12/2011, Conselho Fiscal instalado e os seguintes comitês para assessorar seus órgãos de administração: Comitê Financeiro, Comitê de Remuneração, Comitê de Auditoria e Comitê Educacional ${ }^{456}$.

A AG é composta por todos os acionistas da Companhia, que se reúnem de forma ordinária nos quatro primeiros meses do ano para deliberar sobre as matérias previstas no artigo 132 da Lei das S.As. e de forma extraordinária, nos demais casos. A AG é o órgão

\footnotetext{
${ }^{455}$ Segundo a Anhanguera: “o ISE tem por objetivo refletir o retorno de uma carteria composta por ações de empresas com reconhecido comprometimento com a responsabilidade social e sustentabilidade empresarial, e também atuar como promotor das boas práticas no meio empresarial brasileiro. Trata-se de um expressivo reconhecimento de que a Anhanguera Educacional está no caminho certo, no que diz respeito à inserção da sustentabilidade em suas estratégias e ações" (ANHANGUERA, 2011d)..

${ }^{456}$ Informações sobre competências e modo de funcionamento dos comitês são encontradas no Formulário de Referência da Anhanguera de 2012, item 12.1 (ANHANGUERA, 2012d).
} 
decisório superior das sociedades por ações, e dentre suas atribuições ${ }^{457}$, está a eleição do Conselho de Administração.

As deliberações em AG são tomadas pela maioria dos votos dos presentes, com exceção das matérias previstas no artigo 136 da Lei das S.As. que dependem da aprovação de acionistas representando metade, no mínimo, das ações com direito de voto. Como empresa integrante do Novo Mercado, a Anhanguera possui apenas acionistas detentores de ações ordinárias, todas com direito de voto e, em 31/05/2012, não possuía nenhum acionista detentor de mais de $50 \%$ do seu capital social.

O CA da Anhanguera é composto por no mínimo cinco e, no máximo, nove membros. Conforme exigência do Novo Mercado, 20\% dos membros do CA da Anhanguera são conselheiros independentes ${ }^{458}$. Os conselheiros possuem mandato unificado de dois anos, permitida a reeleição.

Segundo o Estatuto Social da Anhanguera (art. 10), o CA da Companhia deve se reunir, no mínimo, trimestralmente, para examinar e acompanhar os resultados financeiros e operacionais da Companhia e deliberar sobre todos os assuntos de sua competência. Reuniões extraordinárias podem ocorrer sempre que necessário.

O CA da Anhanguera delibera sobre as principais questões envolvendo a condução dos negócios da Anhanguera e de suas subsidiárias ${ }^{459}$, elege a diretoria e orienta seus trabalhos. Analisando as competências do CA da Anhanguera e os documentos analisados, nota-se:

\footnotetext{
${ }^{457}$ Nos termos do art. $7^{\circ}$ do ES da Anhanguera - "Sem prejuízo das demais competências previstas em lei e neste Estatuto Social, compete à Assembleia Geral: (i) alteração do Estatuto Social; (ii) aumento ou redução do capital social, acima do limite do capital autorizado, e aprovação de avaliação de bens destinados à integralização de capital; (iii) emissão de debêntures pela Companhia, ressalvado o disposto no art. $10^{\circ}$, $6^{\circ}$, (iv) do Estatuto Social; (iv) transformação, cisão, incorporação e fusão da Companhia, assim como sua dissolução e liquidação, eleição e destituição de liquidantes e julgamento de suas contas; (v) destinação dos lucros e distribuição dos dividendos; (vi) aprovação de planos de outorga de opção de compra ou subscrição de ações aos seus administradores e empregados, bem como aos administradores e empregados de outras sociedades que sejam controladas direta ou indiretamente pela Companhia; (vii) deliberar sobre a saída do Novo Mercado da BM\&FBOVESPA - Bolsa de Valores, Mercadorias e Futuros; (viii) definição da remuneração global anual dos membros da administração, bem como da participação dos administradores nos lucros e resultados da Companhia, participação esta que não poderá exceder os limites do art. 152 da Lei das Sociedades por Ações, observada a proposta do conselho de administração que deverá estar contida nas Demonstrações Financeiras submetidas à Assembleia Geral Ordinária; (ix) o cancelamento do registro de companhia aberta perante a Comissão de Valores Mobiliários; e a escolha da empresa especializada responsável pela elaboração do laudo de avaliação das ações da Companhia, em caso de cancelamento do registro de companhia aberta e/ou saída do Novo Mercado da BM\&FBOVESPA, conforme previsto no Capítulo VIII deste Estatuto Social, dentre as empresas indicadas pelo Conselho de Administração" (ANHANGUERA, 2012c).

${ }^{458}$ Definição sobre Conselheiro Independente constante também no artigo $9^{\circ}$, Parágrafo $2^{\circ}$ do ES da Anhanguera (ANHANGUERA, 2012c).

${ }^{459}$ Competências do CA previstas no artigo 10, Parágrafo $6^{\circ}$ do ES da Anhanguera (ANHANGUERA, 2012c).
} 
(i) que neste órgão são tomadas as principais decisões quanto aos rumos do negócio da Companhia, como a aprovação de investimentos, abertura de novas unidades, a realização de ofertas públicas, emissões de debêntures, contratação de empréstimos, entre outras;

(ii) que todas as propostas enviadas pelo CA da Anhanguera para deliberação em AG foram aprovadas por unanimidade pelos acionistas da Companhia;

(iii) que o CA da Anhanguera decide todos os assuntos principais quanto ao funcionamento e atuação das subsidiárias do grupo. Previamente, no CA da Anhanguera é definida a orientação de voto da Companhia nas assembleias gerais ou reuniões de sócios das subsidiárias. Dessa maneira, todas as decisões do grupo concentram-se na Anhanguera. Com isso, nota-se que não há autonomia universitária das subsidiárias com relação à mantenedora (Aesa) ou à Anhanguera, pelo menos com relação às principais questões envolvendo o direcionamento dos negócios, pois essas decisões são tomadas pelo CA da Anhanguera, que é a empresa controladora do grupo; e

(iv) considerando suas atribuições, a formação do CA da Anhanguera é de fundamental importância para a definição dos negócios da Companhia e de suas subsidiárias.

A Diretoria da Anhanguera é composta por, no mínimo, três e, no máximo, dez membros, sendo um Diretor Presidente ${ }^{460}$, um Diretor Vice-Presidente Financeiro ${ }^{461}$, um Diretor de Relações com Investidores ${ }^{462}$, e os demais sem designação específica (art. 11, ES) (ANHANGUERA, 2012c).

O Conselho Fiscal da Anhanguera é de funcionamento não permanente, tem poderes e atribuições previstos em lei e somente será instalado a pedido dos acionistas, nos termos do artigo 161 da Lei das S.As. O CF da Anhanguera foi reiteradamente instalado, a pedido de seus acionistas, desde a Assembleia Geral Ordinária de 04/05/2009 ${ }^{463}$.

Analisando a estrutura de administração da Anhanguera, seu Estatuto Social e as atas de $A G$ e reuniões do CA e CF constantes no Apêndice A da Dissertação, nota-se que não há qualquer tipo de representação de interesses diversos dos acionistas nesses órgãos. A Anhanguera não possui nenhum representante de seus funcionários, nem dos seus alunos no CA, nem em qualquer outro órgão. Também não identificamos nenhum mecanismo de

${ }^{460}$ Competências do Diretor Presidente previstas no artigo 13 do ES da Anhanguera (ANHANGUERA, 2012c).

461 Competências do Diretor Vice-Presidente Financeiro previstas no artigo 14 do ES da Anhanguera (ANHANGUERA, 2012c).

${ }^{462}$ Competências do Diretor de Relações com Investidores previstas no artigo 15 do ES da Anhanguera (ANHANGUERA, 2012c).

${ }^{463}$ A esse respeito, vide Apêndice A. 
estímulo para a participação de representantes de outros interesses que não dos sócios na Companhia em seus órgãos decisórios. Com isso, nota-se que a Anhanguera é uma típica empresa que funciona em torno de seus acionistas e para lhes gerar retorno financeiro, mediante a prestação de serviços educacionais.

A esse respeito, ressalta-se que a Anhanguera possui apenas um plano de opção de compra de ações para seus administradores e altos executivos, que permite aos beneficiários a aquisição de ações da Companhia em condições e preços favoráveis. Segundo a Anhanguera $(2012 d)^{464}$ :

\begin{abstract}
Ao possibilitar que os administradores e empregados se tornem acionistas da Companhia, espera-se que estes tenham fortes incentivos para comprometer-se efetivamente com a criação de valor e exerçam suas funções de maneira a integrar-se aos interesses dos acionistas e aos planos de crescimento da Companhia, visando à maximização dos lucros. O Plano de Opção de Compra de Ações estimula os beneficiários, ainda que por meio do comprometimento de seus recursos próprios, a buscar a valorização das ações.

Adicionalmente, o modelo adotado espera ser eficaz como mecanismo de retenção de executivos chave, em face, principalmente, do compartilhamento da valorização das ações da Companhia. [....]

Parte considerável da remuneração total se concentra nos incentivos que visam compartilhar o risco e o resultado da Companhia com seus principais executivos, estando a remuneração baseada em ações diretamente relacionadas a este alinhamento de interesses. [...]

$\mathrm{O}$ beneficiário tem como incentivo o exercício de opções a preços relativamente mais baixos que o valor de mercado das ações da Companhia, fazendo com que atue constantemente em prol da valorização de tais ações.
\end{abstract}

Nesse contexto, dentro de uma estrutura empresarial, a Anhanguera possui administradores profissionais, com experiência no setor educacional e no mercado de capitais. Além disso, como a própria Companhia afirma, "a Anhanguera conta também com a vantagem de ter em seu grupo de acionistas o Pátria, um dos maiores gestores de investimentos em participações do Brasil ${ }^{465}$ ", o que contribui para o desenvolvimento de políticas de gestão e administração profissionais, voltadas ao mercado. Segundo a Revista Capital Aberto (2010), a profissionalização da Anhanguera está muito ligada ao ingresso do Pátria: "quando o fundo chegou, a Anhanguera era uma empresa familiar e seus balanços não eram sequer auditados. Aos poucos, os membros da família foram se afastando da gestão, e ela passou a ser mais profissionalizada".

De acordo com a AGO de 30/04/2012 (ANHANGUERA, 2012b), o Presidente do CA da Anhanguera é Antonio Carbonari Netto, um dos fundadores da Anhanguera e com ampla

\footnotetext{
464 Conforme Formulário de Referência da Anhanguera de 2012, itens 13.4.c , 13.4.d. e 13.4.e. (ANHANGUERA, 2012d)

${ }^{465}$ Disponível em: <http://www.unianhanguera.edu.br/ri/>. Acesso em 17/01/2011.
} 
experiência no setor educacional ${ }^{466}$. Além dele, também compõem o CA sua esposa, três membros ligados ao Pátria e um conselheiro independente (ANHANGUERA, 2012b; 2012d, p. 424-9).

A diretoria da Anhanguera tem perfil profissional - de seis membros, três são administradores profissionais, com experiência no mercado financeiro e de capitais, um possui formação jurídica, uma diretora é especialista na área de educação para cuidar da parte acadêmica da empresa e um membro é ligado ao Pátria (ANHANGUERA, 2012d, p. 424-9).

Observando os membros da administração da Anhanguera, nota-se que o Pátria tem grande influência no CA (possuindo três dos seis membros), o que the permite orientar os negócios da Companhia em conjunto com seus fundadores (totalizando cinco dos seis votos do CA). A diretoria, subordinada ao CA, tem um perfil profissional, com predomínio de profissionais com experiência no mercado financeiro e de capitais.

Por fim, destaca-se que os membros da Diretoria e do CA da Anhanguera recebem remuneração fixa e variável. A remuneração fixa é compatível com os valores pagos por grandes empresas no mercado, e a remuneração variável considera metas operacionais, financeiras e de qualidade anualmente aprovadas pelo CA. Em 31/12/2011, vigoravam os seguintes critérios para as metas:

Tabela 39 - Critérios para remuneração variável da administração

\begin{tabular}{cl}
\hline Indicadores & \multicolumn{1}{c}{ Critérios } \\
\hline $\begin{array}{c}\text { Indicadores de } \\
\text { Qualidade }\end{array}$ & $\begin{array}{l}\text { Avaliação Interna: ISD - Índice de Satisfação Discente } \\
\text { Avaliação Externa: (i) Enade - Exame Nacional de Desempenho de Estudantes; } \\
\text { (ii) CC/CPC - Conceito de Curso; (iii) CI/IGC - Conceito da Instituição. }\end{array}$ \\
Indicadores & Número de Alunos/ Campus: (i) captação; e (ii) rematrícula. \\
Operacionais & Número de Alunos/ Polos: (i) captação; e (ii) rematrícula. \\
Indicadores & Receita Líquida \\
Financeiros & Ebitda \\
& Contas a receber de alunos (dias) \\
& Geração de caixa operacional
\end{tabular}

Fonte: Anhanguera (2012d)

${ }^{466}$ Conforme informações da Anhanguera, a empresa participa "ativamente de políticas públicas relacionadas à educação, por meio de associação e parceria com órgãos corporativos, associações de classe e conselho de educação e desenvolvimento. A atuação é voltada às áreas de educação, saúde e sustentabilidade". Nesse contexto, segundo a Anhanguera, "o presidente da Organização, professor Antonio Carbonari Netto, como representante da Associação Brasileira das Mantenedoras de Estabelecimentos de Ensino Superior (ABMES) e do Sindicato das Entidades Mantenedoras de Estabelecimentos de Ensino Superior no Estado de São Paulo (Semesp), participou de discussões com o Minstério da Educação (MEC) e com o então presidente da República, Luis Inácio Lula da Silva. A área financeira da Anhanguera Educacional também teve um papel de destaque na construção e, depois, na reformulação do Fundo de Financiamento ao Estudante do Ensino Superior (Fies), auxiliando o MEC. Foi a primeira instituição a aderir ao novo Fies, formalizando o primeiro contrato, em Taubaté. Em 2011, há um grupo de trabalho, coordenado pelo MEC, com a finalidade de analisar novas oportunidades no Fies; esse grupo conta a participação ativa da Anhangeura Educacional". (ANHANGUERA, 2011d). 
Segundo a Anhanguera (2012d, p. 22), a forma de remuneração dos seus administradores e executivos volta-se à obtenção de resultados de curto prazo, em detrimento de investimento de longo prazo, nas palavras da Companhia:

Devido ao fato de uma parcela relevante da remuneração dos administradores e executivos da Companhia estar intimamente ligada à geração de resultados e à performance das ações da Companhia, tais administradores e executivos podem vir a conduzir suas atividades com maior foco na geração de resultados no curto prazo, o que poderá não coincidir com os interesses dos demais acionistas da Companhia que tenham uma visão de investimento de longo prazo.

A afirmação da Anhanguera acima coaduna-se com a preocupação exposta no Capítulo 3 de que numa empresa existem situações de conflito de interesses e, caso não haja a internalização de interesses ditos externos (como dos alunos), a empresa será orientada apenas para a decisão que favorece o seu tomador, que gera mais lucros para os acionistas e, no caso exposto acima, que gera uma remuneração maior para o administrador e para o grupo de interesses que ele representa.

\subsubsection{Questão 11}

Neste subitem, procuramos responder à seguinte questão:

\section{Quadro 12 - Questão da Análise Empírica nº 11}

\begin{tabular}{|l|l|}
\hline $\mathbf{N}^{\mathbf{0}}$ & Grupo II - Educação como serviço prestado mediante o desempenho de uma atividade empresária \\
\hline 11 & $\begin{array}{l}\text { Qual o valor médio das mensalidades cobradas pela Anhanguera? Existe um público-alvo? A Companhia } \\
\text { direciona sua atividade para esse público-alvo? }\end{array}$ \\
\hline
\end{tabular}

O público-alvo do grupo Anhanguera são os adultos das classes média e baixa, principalmente aqueles que trabalham durante o dia e estudam à noite e que buscam cursos orientados para o mercado de trabalho e com custo acessível (ANHANGUERA, 2012d). Com a meta de alcançar 1 milhão de alunos no ano de 2015, o grupo Anhanguera tem procurado ampliar seu público-alvo, buscando atingir também: (i) jovens recém-formados no Ensino Médio, para os quais oferece, segundo a Anhanguera (2011d), "mensalidades acessíveis, ensino de qualidade reconhecido pelo Ministério da Educação (MEC) e pelo mercado de trabalho, o Programa do Livro-Texto (PLT), cursos atuais, metodologias de ensino modernas e inovadoras e a flexibilidade da educação a distância"; e (ii) alunos mais maduros (acima da faixa etária escolar), que "decidiram retomar os estudos, mas encontram barreiras para se 
matricular em uma instituição de Ensino Superior, como preço inacessível da mensalidade e falta de tempo para os estudos" (ANHANGUERA, 2011d).

O público-alvo da Anhanguera é um segmento cuja penetração no ensino superior ainda é pequena, mas que se encontra em crescente expansão no Brasil. Nesse contexto, destaca-se o aumento das classes C e D no País ${ }^{467}$ e sua demanda crescente por educação superior, influenciada em parte pelo diferencial de salário que o acesso aos mais elevados níveis de ensino proporciona ${ }^{468}$.

Esse público é considerado promissor pela Anhanguera por conta (i) do crescimento da renda real da população; (ii) dos novos requisitos de qualificação para o mercado de trabalho; (iii) do aumento do grau de escolarização médio da população brasileira; (iv) da crescente oferta de crédito educacional, direto ou na forma de bolsas do ProUni, tanto pelo Governo Federal quanto por instituições financeiras privadas, os quais beneficiam diretamente essa população (ANHANGUERA, 2010e, p. 26) ${ }^{469}$.

Moldando seu produto ao público-alvo, a Anhanguera busca oferecer cursos voltados para o mercado de trabalho e especialmente no período noturno, permitindo que seus estudantes continuem a trabalhar em seus horários regulares. Segundo a Companhia, seus “cursos são elaborados para os jovens inseridos no mercado de trabalho e se destinam a oferecer aos alunos qualificações práticas que satisfaçam suas necessidades profissionais" ${ }^{\natural 70}$. Com isso, de acordo com a Anhanguera (2010e, p. 23), a Companhia busca oferecer as condições necessárias "para que os alunos possam realizar seus projetos de vida, por meio da melhoria de sua qualificação e perspectivas de sucesso profissional”. A Anhanguera aponta como seus principais diferenciais a oferta de cursos com currículos focados no mercado de trabalho, professores com experiência de mercado e estrutura necessária para a formação profissional (ANHANGUERA, 2010f, p. 23).Segundo Carbonari ${ }^{471}$ :

\footnotetext{
467 Para Augusto Vieira, analista da Neo Investimentos, a Anhanguera se destaca por atuar em um nicho promissor e com boas perspectivas de crescimento, que é o do aluno trabalhador (HESSEL; MARREY, 2007, p. 54). Conforme o Relatório "Economia Brasileira em Perspectiva", - junho/julho 2010, em 2010, a classe C já correspondia a mais de 103 milhões de pessoas (com um crescimento entre 2008 e 2010 de 21,5\%) e as classes C e D já superavam a classe $B$ em consumo. Disponível em: $<$ http://www.fazenda.gov.br/portugues/docs/perspectiva-economia-brasileira/edicoes/Economia-Brasileira-EmPerpectiva-Jun-Jul10.pdf $>$. Acesso em17/01/2011.

${ }^{468}$ Dados da Tendência Consultoria apontam que pessoas que concluem o ensino superior ganham em média $100 \%$ a mais do que aquelas que terminam apenas o nível médio. Disponível em: $<$ http://www.hoper.com.br/site2010/noticia-hoper.php?id=91>. Acesso em 17/01/2011.

${ }^{469}$ Vide Prospecto 09/12/2010, p. 26.

${ }^{470}$ Vide $<$ http://www.unianhanguera.edu.br/ri/>. Acesso em 17/01/2011.

${ }^{471}$ Áudio disponível em: http://www.youtube.com/watch?v=SP6ThzLM32k. Acesso em: 07/01/2013.
} 
Qual é a missão da Anhanguera? Porque se eu disser assim a missão é fazer pesquisa para o desenvolvimento do Brasil, eu vou estar de novo prestigiando o pesquisador, o doutor, o PHD, a classe A. Não. A missão da Anhanguera foi definida assim: prover, promover, oferecer cursos superiores de boa qualidade para auxiliar no desenvolvimento, no projeto de vida do aluno. Ponto. Quer dizer, o aluno vem pra Anhanguera pra ser auxiliado no seu projeto de vida, não no meu... Se eu não tenho essa idéia de desenvolver o projeto de vida do aluno, eu provavelmente iria copiar a missão das universidades federais, estaduais, que é formar dirigente, prover o Brasil de alta ciência e tecnologia que eles fazem melhor do que eu.

Após estudos, a Anhanguera concluiu que os jovens trabalhadores das classes média e baixa selecionam sua instituição de ensino superior baseados em uma combinação de três principais fatores: (i) variedade de cursos oferecidos; (ii) localização das unidades; e (iii) preço das mensalidades ${ }^{472}$.

Considerando esses fatores, para ser competitiva no mercado, a Anhanguera procura (i) cobrar mensalidades em geral mais baixas que as de seus concorrentes diretos, com condições de pagamento diferenciadas ${ }^{473}$, sustentadas por um modelo de negócio diferenciado, padronizado e eficiente; (ii) disponibilizar aos seus alunos materiais didáticos gratuitos ou com preços reduzidos ${ }^{474}$; (iii) proporcionar uma redução dos custos de transporte dos alunos, dada a localização estratégica das suas unidades presenciais ou pelos cursos a distância (ANHANGUERA, 2010e, p. 27) - quando abre ou adquire novas unidades, a Anhanguera foca na (iv) seleção de locais convenientes com base em estudos demográficos da sua população-alvo na cidade ou região em questão, considerando variáveis como tamanho do mercado-alvo, ambiente competitivo, taxa de penetração de educação superior, poder de compra dos alunos em potencial e estratificação do nível de renda; e (v) disponibilidade de transporte.

Muitas vezes, a localização privilegiada permite que o aluno pague parte da mensalidade do curso apenas com a economia das despesas de transporte, o que é muito interessante para o público-alvo da Companhia ${ }^{475}$.

\footnotetext{
${ }^{472}$ Vide: $<$ http://www.unianhanguera.edu.br/ri/>. Acesso em 17/01/2011.

${ }^{473}$ A Anhanguera disponibiliza diversas formas de pagamento para seus estudantes, como débito automático em conta-corrente, cartões de crédito, pagamento avulso ou recorrente, financiamentos governamentais ou privados. Para maiores informações a esse respeito, vide: $<\mathrm{http}: / /$ www.creditoparaestudar.com.br/veja_como_funciona.php $>$ $<$ http://www.unianhanguera.edu.br/noticias/estudantes_contam_pagamento_22122010.php $>$. Acesso em: $17 / 01 / 2011$

${ }^{474}$ Nessa política, a Anhanguera possui o Programa do Livro-Texto (PLT).

${ }^{475}$ Segundo Carbonari: "A Anhanguera ela sempre esteve nos bairros, nunca foi uma universidade, uma faculdade de centro, quer dizer, é onde o aluno está, com isso ele economiza uma condução, ele economiza às vezes um almoço, uma janta. Então, nós, sempre pensamos, de uma maneira bem franciscana, em fazer esse tipo de inclusão social". Vídeo disponível em: http://www.youtube.com/watch?v=HV2PDUwDkG0. Acesso em: 07/01/2013.
} 
Os preços das mensalidades variam de acordo com o curso, localização ou com o semestre acadêmico. Os valores das mensalidades dos cursos de graduação e graduação tecnológica para o segundo semestre de 2011 variaram de $\mathrm{R} \$ 199,00^{476}$ a $\mathrm{R} \$ 1.527,00$ (excluídos os cursos de medicina ${ }^{477}$ e odontologia) (ANHANGUERA, 2012d, p. 152). Com esses valores de mensalidade, a Anhanguera consegue atingir um grande número de alunos e, mesmo com uma margem de lucro menor por aluno, obtém ganhos de escala e um lucro total alto.

Nesse nicho de mercado, os principais concorrentes da Anhanguera são outros grandes grupos de ensino superior de massa - como a Unip, Unesa, Uninove, Kroton, além de instituições de pequeno porte em algumas localidades (ANHANGUERA, 2012d, p. 121).

Segundo a Companhia (2012d, p 121-2):

\begin{abstract}
A competição entre as instituições de ensino superior ocorre principalmente através dos seguintes fatores: preço, conveniência e qualidade percebida pelo aluno, sendo esse último afetado pelas avaliações do Ministério da Educação e pela própria experiência educacional dos alunos. A combinação de tais fatores traduz-se na proposição de valor de uma dada instituição de ensino superior, que, de acordo com sua atratividade, é refletida na capacidade de atrair e reter alunos.

Enquanto instituições menores possuem baixa eficiência operacional, devido a sua escala e menor grau de profissionalização, a Anhanguera Educacional possui modelo de negócios altamente padronizado e grande volume de alunos, que se traduzem em ganhos de escala e eficiência operacional. As eficiências auferidas nesse modelo altamente escalável da Companhia são revertidos em uma maior capacidade de investir em sua marca, na promoção de seus cursos, na qualificação docente, na infraestrutura de suas unidades, na sua plataforma tecnológica e na sua equipe de gestão, de modo que a Companhia acredita ter maior capacidade de oferecer cursos de qualidade a preços acessíveis e com maior conveniência do que seus típicos concorrentes.
\end{abstract}

A Anhanguera oferece aos seus alunos as seguintes opções de financiamento dos estudos (i) Fies - no ano de 2011, 35,2 mil alunos foram contemplados com esse tipo de crédito; (ii) ProUni - em 2011, 13\% dos alunos da Anhanguera contaram com bolsas do ProUni, de 50\% a 100\%; (iii) Crédito Universitário Anhanguera (produto desenvolvido pelo Itaú Unibanco) - desenvolvido para os cursos de graduação, permite o refinanciamento de até $100 \%$ das dívidas, a taxas mensais de 3\%, com entrada de $10 \%$ a $50 \%$ e parcelamento em 12 meses; (iii) parceria financeira com o Santander Brasil, para pós-graduação/MBA - permite o financiamento de $100 \%$, com prazo de pagamento em até duas vezes o tempo de duração do

\footnotetext{
476 Este valor de mensalidade foi encontrado no seguinte site: <http://www.vestibulares.br>. Acesso em: $31 / 07 / 2012$.

${ }^{477}$ A mensalidade do curso de medicina, oferecido pela Universidade Anhanguera-Uniderp, era de R $\$ 4.732,51$, em janeiro de 2013. Disponível em: <http://www.escolasmedicas.com.br/mensal.php>. Acesso em: 04/01/2012.
} 
curso, a taxas de 1,95\% ao mês; (iv) financiamento privado Pravaler; (v) bolsas governamentais de âmbito estadual e municipal; (vi) débito programado de mensalidades por meio de cartão de crédito ou conta-corrente; (vii) parcelamento de dívidas, sem juros, por meio de cartão de crédito ou débito em conta-corrente (ANHANGUERA, 2011d).

Abaixo dados sobre o número de bolsas do ProUni obtidas pelos alunos da Anhanguera:

Tabela 40 - Quantidade de bolsas ProUni Anhanguera - 2006 - 2010

\begin{tabular}{cc}
\hline Ano & $\mathbf{N}^{\mathbf{0}}$ de bolsas do ProUni \\
\hline 2006 & 2.289 \\
2008 & 11.960 \\
2009 & 19.140 \\
2010 & 20.887 \\
2011 & 33.869 \\
\hline
\end{tabular}

Fonte: Anhanguera (2010f; 2011d) ${ }^{478}$

Abaixo dados sobre as bolsas de estudos dos alunos da Anhanguera:

Tabela 41 - Volume de bolsas de estudos - 2008-2010

\begin{tabular}{cc}
\hline Ano & R\$ (em milhões) \\
\hline 2008 & 147,09 \\
2009 & 296,05 \\
2010 & 387,65 \\
2011 & 159,70 \\
\hline
\end{tabular}

Fonte: Anhanguera (2010f; 2011d)

Tabela $42-N^{0}$ de bolsistas por valor percentual concedido - 2011

\begin{tabular}{cc}
\hline Percentual da bolsa & $\mathbf{N}^{\mathbf{0}}$ de bolsistas \\
\hline Até $49 \%$ & 24 \\
De $50 \%$ até $99 \%$ & 18.698 \\
$100 \%$ & 15.147 \\
\hline
\end{tabular}

Fonte: Anhanguera (2011d)

A Anhanguera recebe um percentual relevante no número total de bolsas concedidas pelo ProUni nacionalmente $-11 \%$ do total em 2011, conforme dados abaixo:

Tabela 43 - Percentual de bolsas ProUni Anhanguera em relação à quantidade total de bolsas do ProUni - 2008-2010

\begin{tabular}{cc}
\hline Ano & Percentual de Bolsas ProUni Anhanguera \\
\hline 2008 & $5 \%$ \\
2009 & $8 \%$ \\
2010 & $9 \%$ \\
2011 & $11 \%$ \\
\hline
\end{tabular}

Fonte: Anhanguera (2010f; 2011d)

${ }^{478}$ Dado de 2006 disponível em: <www.unianhnaguera.edu.br/ri>. Acesso em 17/01/2011. Demais dados extraídos de Anhanguera (2010f; 2011d).. 


\subsection{Grupo III - Educação como Direito Humano, Bem Público e Serviço Público}

\subsubsection{Questões 12, 13 e 14}

Neste subitem procuramos responder às seguintes questões:

Quadro 13 - Questões da Análise Empírica nos 12, 13 e 14
\begin{tabular}{|l|l|}
\hline $\mathbf{N}^{\mathbf{0}}$ & \multicolumn{1}{c|}{ Grupo III - Educação como direito humano, bem público e serviço público } \\
\hline 12 & $\begin{array}{l}\text { Foi encontrada alguma menção ou preocupação com a observância dos princípios constitucionais da } \\
\text { educação (art. 205) e do ensino (art. 206) pelas IES do grupo nos documentos analisados? Existe alguma } \\
\text { política interna visando à efetivação desses princípios e que também pode ser encarada como uma } \\
\text { externalidade social oriunda da relação instituiçãa-aluno? }\end{array}$ \\
\hline 13 & $\begin{array}{l}\text { Foi encontrada alguma menção ou preocupação com pesquisa, ensino e extensão nos documentos } \\
\text { analisados? Quais as referências encontradas? Estas referências concretizaram-se em práticas de } \\
\text { pesquisa, ensino e extensão pela Anhanguera? Quais foram as práticas encontradas e quais os volumes } \\
\text { investidos? }\end{array}$ \\
\hline 14 & $\begin{array}{l}\text { Como é a metodologia de ensino da Anhanguera? Pode-se dizer que a formação oferecida pela } \\
\text { Anhanguera é principalmente voltada ao mercado de trabalho? }\end{array}$ \\
\hline
\end{tabular}

A Anhanguera oferece cursos em diferentes áreas, como gestão e negócios, direito, educação, engenharia, saúde e tecnologia. Ao todo, segundo a Companhia (2011d), são 155 modalidades de cursos, com 15 licenciaturas, 52 tecnológicos, 47 bacharelados, 41 sequenciais, 12 de ensino a distância e 71 de pós-graduação.

Conforme informamos anteriormente, a Anhanguera possui cinco diferentes programas acadêmicos oferecidos a seus alunos: (i) graduação presencial; (ii) graduação a distância; (iii) pós-graduação lato sensu; (iv) pós-graduação stricto sensu; e (v) educação continuada.

A graduação presencial é oferecida em três graus acadêmicos: (i) cursos de tecnologia (de 2 e 3 anos); (ii) cursos de licenciatura (de 3, 4 e 5 anos); e (iii) cursos de bacharelado (de 4 e 5 anos). Além de aulas presenciais, essa forma de graduação também utiliza teleaulas e o Ambiente Virtual de Aprendizagem (AVA). A Companhia oferece cursos de graduação presencial nas áreas de gestão, saúde, educação, direito, tecnologia e engenharia, que são oferecidos exclusivamente nos campi de ensino superior (ANHANGUERA, 2012d, p. 149).

$\mathrm{Na}$ graduação a distância, a Anhanguera oferece cursos com os mesmos graus acadêmicos da graduação presencial, porém, na metodologia, utiliza principalmente teleaulas e o AVA. Esses cursos utilizam apoio de professores locais e laboratórios em formato presencial. A Companhia oferece cursos de graduação a distância nas áreas de gestão, 
educação e saúde, os quais são oferecidos nos campi e nos polos (ANHANGUERA, 2012d, p. 149).

A pós-graduação lato sensu compreende programas de especialização, inclusive cursos de MBA (Master in Business Administration), normalmente com duração de 12 meses, nas áreas de gestão, direito, saúde e educação, tendo como foco principal a capacitação para o mercado de trabalho. Esses cursos são oferecidos na modalidade presencial e a distância, tanto nos campi como nos polos (ANHANGUERA, 2012d, p. 149).

A pós-graduação stricto sensu consiste em cursos com foco em formação acadêmica e atividades de ensino e pesquisa, preferencialmente, com dedicação dos alunos em período integral. Esses cursos são oferecidos unicamente nos campi (ANHANGUERA, 2012d, p. 149). A pesquisa da Anhanguera estaria concentrada neste programa acadêmico. Informações sobre as atividades de pesquisa da empresa encontram-se abaixo.

A educação continuada consiste em cursos com duração de 1 a 12 meses com foco em desenvolvimento de competências profissionais específicas, voltados principalmente a alunos ou concluintes do ensino superior. Esses cursos são oferecidos em diferentes formatos, combinando aulas presenciais, teleaulas, AVA e materiais impressos. Segundo a Companhia (2012d, p. 150), o principal segmento explorado na área de educação continuada é o de cursos preparatórios para concursos públicos e concursos da Ordem dos Advogados do Brasil (OAB). Nessa modalidade são também oferecidos cursos voltados à gestão e tecnologia. Os cursos de educação continuada são oferecidos nos campi e nos polos.

Conforme descrito acima, nota-se que o ensino da Anhanguera é desenvolvido por meio de quatro principais metodologias: (i) aulas presenciais; (ii) teleaulas; (iii) materiais impressos; e (iv) ambiente virtual de aprendizagem (AVA).

As aulas presenciais são, segundo a Companhia, sua principal metodologia de ensino, principalmente, nos cursos de graduação presencial. As aulas presenciais são também utilizadas, de forma acessória, nos cursos de graduação a distância, de pós-graduação e de educação continuada, que utilizam principalmente a metodologia de educação a distância (teleaulas e atividades no AVA) (ANHANGUERA, 2012d, p. 111).

As teleaulas são palestras produzidas em um estúdio central e transmitidas para salas de aula em todo o Brasil por meio de satélites ou disponibilizadas como vídeo no AVA. Os alunos podem fazer perguntas aos professores por meio de chats. Segundo a Companhia (ANHANGUERA, 2012d, p. 112): 
o material produzido nesse formato é transmitido simultaneamente para diversas salas de aula em todo o Brasil, criando grande efeito de escala e diluindo de forma substancial os custos de produção. Potencialmente, uma aula produzida pode ser transmitida ao vivo para as mais de 570 unidades da Companhia, além da potencial distribuição posterior por meio do Ambiente Virtual de Aprendizagem na internet. Tal efeito de escala possibilita a contratação de professores e palestrantes altamente diferenciados, líderes em seus campos de atuação, a um custo relativamente baixo quando considerado o número de alunos utilizando o conteúdo. (grifo nosso)

Ao todo, segundo informação da Companhia (2011d), em 2011, foram transmitidas cerca de 2.600 aulas por mês, em 30 estúdios.

Dos 400 mil alunos da Anhanguera, mais de 160 mil estão em cursos que têm as teleaulas como sua principal metodologia (ANHANGUERA, 2012d, p. 112).

O grupo Anhanguera utiliza materiais impressos no formato de livros ou de textos como forma de apoio em seus cursos. Segundo a Companhia, a grande maioria dos materiais impressos são conteúdos próprios, desenvolvidos internamente ou com direitos autorais licenciados junto a grandes editoras. A principal ação da Anhanguera nesse campo é o Programa Livro-Texto (PLT), por meio do qual a Anhanguera oferece aos seus alunos "livrostexto personalizados a preços até $80 \%$ menores do que os praticados em livrarias”. Este programa foi implementado em 2005 e já compreende, segundo a Companhia, mais de 1,5 milhão de livros distribuídos em 2011 (ANHANGUERA, 2012d, p. 112). Assim sendo, a Anhanguera acredita possuir "a maior escala do Brasil em termos de distribuição de conteúdo impresso em uma rede própria de formação profissional" (ANHANGUERA, 2012d, p. 112). Abaixo dados sobre o PLT:

Tabela 44 - Informações sobre o PLT Anhanguera - 2005 - 2011

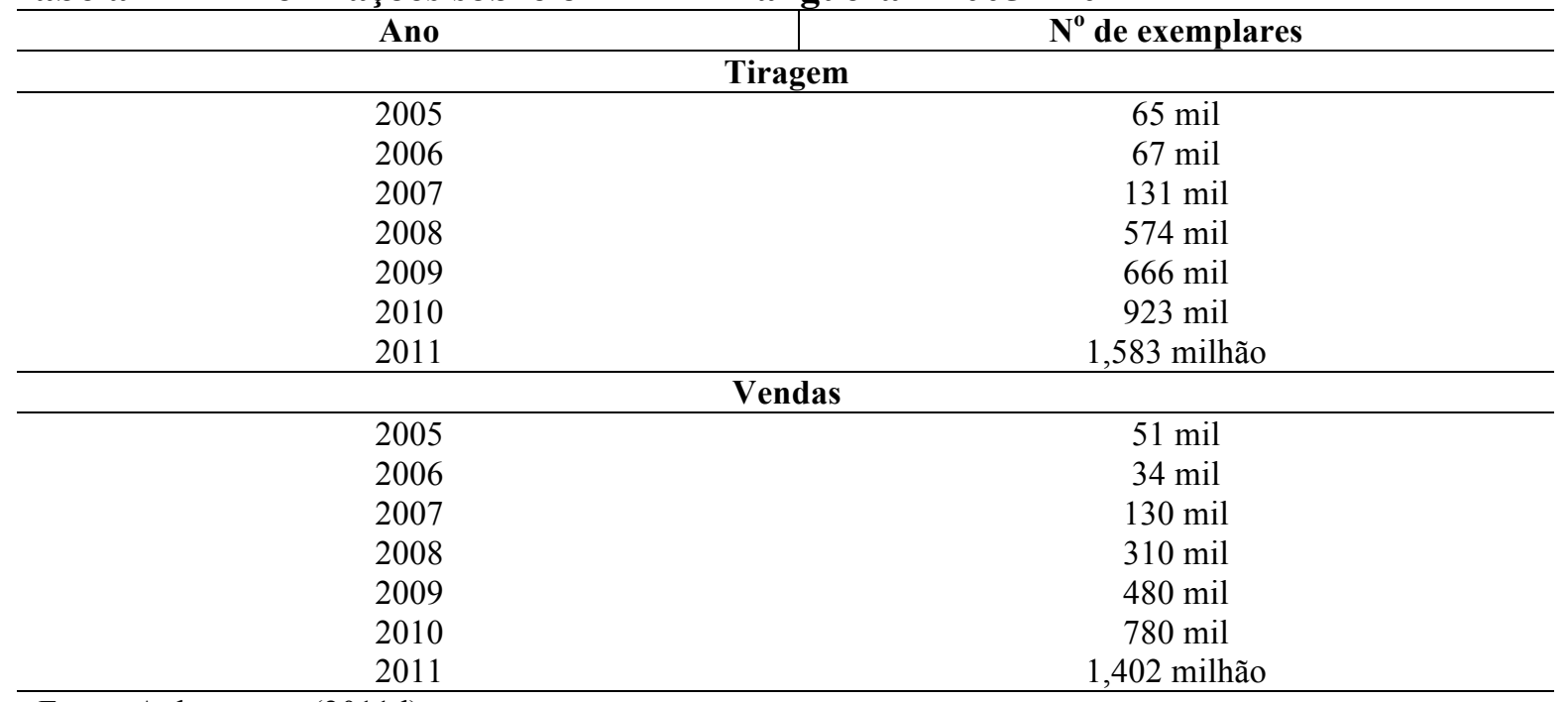

Fonte: Anhanguera (2011d) 
Segundo a Anhanguera (2012d, p. 112):

\begin{abstract}
A escala obtida pela Companhia na produção e distribuição de conteúdo impresso traz grandes ganhos de custo tanto na produção e aquisição de conteúdo, como na impressão, possibilitando a oferta de material de alta qualidade a custos bastante acessíveis aos alunos. Nos cursos de Graduação, são oferecidos materiais didáticos gratuitamente ou, quando cobrado, a um custo até $80 \%$ inferior ao preço normal de varejo de livros similares. Dado que na maioria das instituições de ensino superior os alunos precisam comprar seus livros independentemente, pagando preços substancialmente mais altos, a oferta de livros didáticos gratuitos, ou com preços extremamente acessíveis, representa um diferencial competitivo importante na atração de alunos. (grifo nosso)
\end{abstract}

Segundo a Companhia (ANHANGUERA, 2012d, p. 112), "por meio da utilização de materiais unificados em todas as unidades de ensino, é possível garantir a consistência do conteúdo ministrado em todo o Brasil”. Com essa metodologia, a Companhia consegue padronizar seu ensino, mas ao mesmo tempo, diminui a autonomia didática dos seus professores (liberdade de ensino), os valores de diversidade e pluralidade na educação e a autonomia universitária.

O AVA é uma ferramenta de apoio em todos os cursos. O ambiente virtual consiste em páginas restritas na Internet, nas quais cada aluno pode acessar conteúdos didáticos, tutoria eletrônica, chats, além de serviços acadêmicos e financeiros. Estão disponíveis textos indicados pelos docentes ${ }^{479}$, exercícios, atividades interativas e vídeos, bem como uma ferramenta de pesquisa denominada "Webquest" (ANHANGUERA, 2012d, p. 112).

A Companhia (2012d, p. 113) acredita que:

[...] o uso do Ambiente Virtual de Aprendizagem como ambiente para atividades acadêmicas e distribuição de conteúdo deverá ter um papel crescente entre as metodologias utilizadas, substituindo gradualmente atividades presenciais e materiais impressos. A crescente utilização do Ambiente Virtual de Aprendizagem como metodologia tem como objetivo capacitar os alunos no aprendizado em ambiente digital, uma competência cada vez mais importante no mercado de trabalho, além de representar uma oportunidade importante de redução de custos operacionais dos cursos. (grifo nosso)

Nota-se que das quatro metodologias de ensino utilizadas pela Anhanguera, três delas (teleaulas, materiais impressos e AVA) buscam redução de custos, padronização e criação de escala na forma de produção e distribuição do produto oferecido (mediante a distribuição em

\footnotetext{
${ }^{479}$ De acordo com a Anhanguera, todos os cursos oferecidos (presenciais ou a distância) contam com uma biblioteca virtual. Segundo a Companhia, "é uma ferramenta que facilita o acesso à informação científica e cultural, além de levar comodidade aos alunos e eliminar barreiras de espaço e tempo, promovendo a difusão intelectual e a troca de informações. Na biblioteca virtual, é possível acessar bases de dados, e-books, periódicos de acesso livre, teses, monografias, artigos e links de órgãos institucionais" (ANHANGUERA, 2010f, p. 25).
} 
larga escala de conteúdo didático produzido no âmbito da empresa - aulas, AVA, livros e outros materiais didáticos). Trata-se de práticas empresarias que se voltam mais à ampliação do lucro da empresa do que ao aumento da qualidade da educação e do ensino oferecidos pelas IES integrantes do grupo. As próprias declarações da Companhia denotam o intuito de disseminar o AVA, considerando a possibilidade de redução de custos operacionais que essa metodologia proporciona, e não benefícios de qualidade de ensino para os alunos da Anhanguera.

Nesse contexto, destaca-se que a Anhanguera possui uma Universidade Corporativa (Uniag) desde 2009, cujo objetivo, segundo a empresa (2010f, p. 34), é:

[...] capacitar os diretores, coordenadores de cursos, professores e funcionários técnicoadministrativos para um bom desempenho de suas atividades, visando ao atendimento adequado das necessidades institucionais e dos estudantes da Anhanguera Educacional. Também busca formar gestores, em todos os níveis de hierarquia, para atender ao processo de expansão da Instituição. Com essa capacitação, os participantes entendem melhor os objetivos, os valores e as metas da Anhanguera Educacional e, ao mesmo tempo munem-se de ferramentas de gestão para poder acompanhar as suas diretrizes.

Em maio de 2010, a Uniag realizou a primeira semana de aulas do curso de pósgraduação lato sensu em Gestão Universitária. Participaram 61 professores, entre diretores de unidades e coordenadores de curso. As disciplinas e atividades do curso foram organizadas em torno de cinco competências: acadêmica/pedagógica, estratégica, política/relacional, financeira e mercadológica. Segundo a Anhanguera (2010f, p. 34), após passar por essa especialização, o coordenador de curso pode exercer a função de multiplicador, levando o conteúdo do curso aos demais coordenadores de sua regional. Analisando as competências oferecidas por este curso, nota-se que a Anhanguera considera como conhecimentos relevantes para um coordenador de curso, além de conhecimentos acadêmicos e pedagógicos, habilidades típicas de um administrador de empresas, tais como conhecimentos estratégicos sobre o negócio, políticos e relacionais, financeiros e de mercado.

Com relação às aulas presenciais, o debate sobre custo, escala e formação envolve o perfil dos docentes da Anhanguera, tema desenvolvido abaixo.

Considerando o público-alvo da Anhanguera, a formação oferecida pelas IES integrantes do grupo volta-se ao mercado de trabalho, em especial para cargos que exigem formação técnica e profissionalizante. Isso também pode ser evidenciado pelo posicionamento profissional de seus alunos. No ano de 2010, os cargos ocupados pelos formandos do grupo Anhanguera era o seguinte: 
Tabela 45 - Nível hierárquico do formando Anhanguera - 2010

\begin{tabular}{c|c}
\hline Cargo & Percentual \\
\hline Diretoria & $2 \%$ \\
Chefia & $5 \%$ \\
Gerência & $5 \%$ \\
Supervisão & $12 \%$ \\
Estagiário & $15 \%$ \\
Profissional com ensino médio/profissionalizante & $28 \%$ \\
Assistência & $33 \%$ \\
\hline
\end{tabular}

Fonte: Anhanguera (2010f)

Das informações acima, é possível concluir que os formandos da Anhanguera ocupam, na sua maioria (61\%), cargos de assistência e cargos voltados para profissionais com ensino médio/profissionalizante. Uma parcela (15\%) consegue estágio durante o curso e cargos de supervisão (12\%). Apenas 5\% ocupam gerência, mesma porcentagem (5\%) ocupa chefia e apenas $2 \%$ ocupam cargos de diretoria.

Os alunos da Anhanguera atuam principalmente no setor privado. Abaixo dados sobre os setores de atuação dos formandos em 2010:

Tabela 46 - Setor de atuação do formando Anhanguera - 2010

\begin{tabular}{c|c}
\hline Setor & Percentual \\
\hline Empresa privada & $81 \%$ \\
Empresa pública & $15 \%$ \\
Terceiro Setor & $4 \%$ \\
\hline
\end{tabular}

Fonte: Anhanguera (2010f)

As faixas salariais dos formandos no ano de 2010 foram as seguintes:

Tabela 47 - Faixa salarial do formando Anhanguera - 2010

\begin{tabular}{|c|c|}
\hline Faixa Salarial & Percentual \\
\hline Até R\$ 500,00 & $2 \%$ \\
\hline De $R \$ 500,00$ a $R \$ 1.000,00$ & $21 \%$ \\
\hline De $R \$ 1.000,00$ a $R \$ 1.500,00$ & $17 \%$ \\
\hline De $R \$ 1.500,00$ a $R \$ 2.000,00$ & $9 \%$ \\
\hline De $R \$ 2.000,00$ a $R \$ 2.500,00$ & $5 \%$ \\
\hline De $R \$ 2.500,00$ a $R \$ 3.000,00$ & $3 \%$ \\
\hline De $R \$ 3.000,00$ a $R \$ 3.500,00$ & $2 \%$ \\
\hline Acima de $\mathrm{R} \$ 3.500,00$ & $4 \%$ \\
\hline Sem resposta & $37 \%$ \\
\hline
\end{tabular}

Fonte: Anhanguera (2010f)

Os dados acima informam que 38\% dos formandos da Anhanguera ganhavam, em 2010 , entre $\mathrm{R} \$ 500,00$ e $\mathrm{R} \$ 1.500,00$. Essa pesquisa confirma o perfil do público-alvo da empresa. 
Para medir a satisfação de seus alunos em termos financeiros e profissionais, foi feita a seguinte pesquisa interna pela Anhanguera:

Tabela 48 - Pesquisa de satisfação dos alunos da Anhanguera

\begin{tabular}{lr}
\hline \multicolumn{2}{c}{ Pelo fato de você ter ingressado na Anhanguera, sua situação financeira: } \\
\hline Melhorou & $24,4 \%$ \\
Permaneceu a mesma & $65,2 \%$ \\
Piorou & $10,4 \%$ \\
\hline \multicolumn{1}{c}{ Pelo fato de você ter ingressado na Anhanguera, sua situação profissional: } \\
\hline Melhorou \\
Permaneceu a mesma & $50,8 \%$ \\
Piorou & $47,2 \%$ \\
\hline Fonte- Anhanguera (2010f) & $2,1 \%$ \\
\hline
\end{tabular}

Fonte: Anhanguera (2010f)

Dos mais de 50\% que afirmaram que a vida profissional melhorou, $40 \%$ disseram ter ganhado conhecimento, experiência e informação; $22,4 \%$ conseguiram emprego por causa da faculdade; $13 \%$ conseguiram mais oportunidades e $12 \%$ afirmaram que as portas do mercado se abriram (ANHANGUERA, 2010f, p. 31).

Dos que afirmaram que a situação financeira melhorou, 30,7\% tiveram aumento de salário; $16,8 \%$ conseguiram um bom emprego ou um emprego melhor; 14,4\% adquiriram maior valor no mercado, entre outros motivos (ANHANGUERA, 2010f, p. 31).

Entre os alunos que afirmaram que a situação financeira piorou, o motivo mais citado para a piora foram os custos da faculdade (ANHANGUERA, 2010f, p. 31).

Passamos agora a tratar das informações sobre pesquisa e extensão na Anhanguera.

Em 20/01/1998, foi celebrado um contrato com a Fundação Manoel de Barros (que possui no seu Conselho Curador e Conselho Fiscal membros da administração da Anhanguera) e o Centro de Ensino Superior de Campo Grande S/S Ltda. (Cesup incorporado pela Aesa) para a doação de recursos financeiros, correspondentes a até $6 \%$ da receita bruta do Cesup "para atividades de apoio prestadas nas áreas de pesquisa, extensão e artes, bolsas de estudos para acadêmicos, bolsas de ensino para docentes, bolsas de capacitação de recursos humanos, bolsas de pesquisa, concessão de crédito educativo institucional, promoção e realização de cursos de readaptação acadêmica em períodos especiais, além de outras atividades". No exercício de 2011, esses recursos foram de R\$301.784,61 (ANHANGUERA, 2012d, p. 488).

Segundo a Anhanguera (2011d), ao longo de 2011, foram oferecidas 30 bolsas de pósgraduação e mestrado no âmbito da Fundação Nacional de Desenvolvimento do Ensino Superior Particular (Funadesp), criada em 1998 para, de acordo com a Companhia, "auxiliar 
as instituições na busca continuada de qualidade e relevância em atividades nas áreas de ensino, pesquisa, extensão, gestão acadêmica e desenvolvimento institucional, científico, tecnológico e lato sensu". No ano de 2011, 57 professores receberam ajuda de custo para participar de eventos científicos (em 2010, foram 81). A Anhanguera possui também um Programa Permanente de Capacitação Docente - especialização em Metodologia e Didática do Ensino Superior, oferecido a todos os docentes gratuitamente, que teve 523 inscritos em 2010, os quais prosseguiram os estudos em 2011, com o encerramento de disciplinas e a conclusão dos trabalhos.

As IES do grupo Anhanguera concedem também bolsas de iniciação científica. Para tanto, a Aesa mantém o Instituto de Pesquisas Aplicadas e Desenvolvimento Educacional (Ipade), que possui o Programa de Iniciação Científica (PIC). O objetivo do PIC é incentivar a produção científica dos alunos. O Ipade coordena programas e projetos de pesquisas aplicadas e de iniciação científica, além de supervisionar a produção científica e intelectual (tanto de alunos como de professores), para fins de publicação em revistas internas ou externas. Abaixo dados sobre os projetos de iniciação científica da Anhanguera entre os anos de 2008 e 2011:

\begin{tabular}{c|c|c|ccc} 
Tabela $49-\begin{array}{c}\text { Informações } \\
-\mathbf{2 0 0 8}-\mathbf{2 0 1 1}\end{array}$ & sobre bolsas & de iniciação & científica & Anhanguera \\
\hline & $\mathbf{2 0 0 8}$ & $\mathbf{2 0 0 9}$ & $\mathbf{2 0 1 0}$ & $\mathbf{2 0 1 1}$ \\
\hline Projetos aprovados & 202 & 194 & 313 & 607 \\
Alunos bolsistas PIC & 103 & 121 & 221 & 312 \\
Alunos voluntários & 99 & 142 & 295 & 589 \\
Total de alunos & 202 & 286 & 516 & 901 \\
Alunos com outras bolsas & - & 108 & 223 & Não disponível \\
Projetos inscritos no Congresso & - & 53 & 136 & 273 \\
Nacional de Iniciação Científica & & & & \\
(Conic) & - & 31 & 46 & 54 \\
Unidades com PIC & & & & \\
\hline
\end{tabular}

Fonte: Anhanguera (2010f; 2011d)

Considerando o total de alunos da Anhanguera (400 mil em 31/12/2011), o número de projetos de iniciação científica aprovados é ínfimo, correspondendo a apenas $0,15175 \%$ do total de alunos.

Com relação à extensão, a Anhanguera envolve-se em inúmeras ações, que também são consideradas ações de responsabilidade social.

Segundo a Anhanguera (2010f, p. 43), em 2010, foram criados o Instituto de Ação

${ }^{480}$ Informações sobre o ano de 2008 extraídas de Anhanguera (2010f, p. 30). Demais informações extraídas de Anhanguera (2011d). 
Social e Extensão Comunitária (Iasec) e o Programa de Extensão Comunitária (PEC). O Iasec é o elo entre a Anhanguera e as comunidades. Os objetivos do PEC são: (i) "promover a aprendizagem dos alunos da Anhanguera Educacional com base na experiência. Isso significa ter o aluno de Direito atuando como advogado, o aluno de Pedagogia atuando como professor etc."; e (ii) "colaborar para a promoção de melhor qualidade de vida nas comunidades do entorno da Organização".

De acordo com a Anhanguera (2010f, p. 43), o PEC atua em três eixos: "projetos e programas de responsabilidade social com a comunidade externa; prestação de serviços à comunidade externa, por meio dos laboratórios de graduação e pós-graduação; e eventos acadêmicos complementares".

A Anhanguera investe em atividades de responsabilidade social, que são um dos itens avaliados pelo Sinaes. Em 2011, suas atividades de responsabilidade social atenderam mais de 1,5 milhão de pessoas, em mais de 1.000 projetos, com o prêmio de primeiro lugar entre as empresas do setor de serviços no ranking de responsabilidade social e ambiental divulgado pela revista IstoÉ Dinheiro (ANHANGUERA, 2012d, p. 163). Em 2010, foram conduzidos 842 projetos de responsabilidade social, com 1.035 .798 pessoas beneficiadas, nos quais atuaram 29.959 professores e 150.644 alunos (ANHANGUERA, 2010f, p. 16). Em 2009, foram 796 projetos e 805.784 pessoas beneficiadas (ANHANGUERA, 2010f, p. 16). Abaixo um quadro resumo dos projetos de responsabilidade social da Anhanguera ${ }^{481}$ :

\section{Quadro 14 - Projetos de responsabilidade social da Anhanguera 2010 e 2011}

\begin{tabular}{|c|c|c|c|c|}
\hline Área & Projeto & Público atendido & $\begin{array}{c}\mathrm{N}^{0} \text { de } \\
\text { pessoas } \\
\text { atendidas } \\
\text { em } 2010\end{array}$ & $\begin{array}{c}\mathrm{N}^{0} \text { de pessoas } \\
\text { atendidas em } 2011\end{array}$ \\
\hline Educação & $\begin{array}{c}\text { Biblioteca Aberta Zilda } \\
\text { Arns }\end{array}$ & $\begin{array}{c}\text { Alunos de ensino } \\
\text { fundamental e médio das } \\
\text { escolas públicas }\end{array}$ & 6.370 & 7.378 \\
\hline Educação & $\begin{array}{c}\text { Apoio pedagógico a } \\
\text { alunos e professores do } \\
\text { ensino básico e EJA, nas } \\
\text { ações: reforço escolar, } \\
\text { alfabetização de jovens e } \\
\text { adultos e educação } \\
\text { ambiental }\end{array}$ & $\begin{array}{c}\text { Alunos de ensino } \\
\text { fundamental, médio e } \\
\text { EJA das escolas públicas }\end{array}$ & 47.912 & $\begin{array}{c}\text { EJA - 3.271 } \\
\text { Apoio pedagógico - } \\
106.942\end{array}$ \\
\hline Educação & Brinquedoteca & Crianças de 3 a 12 anos & 5.844 & 6.769 \\
\hline Educação & $\begin{array}{l}\text { Faculdade Aberta da } 3^{\mathrm{a}} \\
\text { Idade }\end{array}$ & $\begin{array}{l}\text { Cidadãos com mais de } \\
45 \text { anos }\end{array}$ & 4.615 & 5.346 \\
\hline
\end{tabular}

${ }^{481}$ Segundo a Companhia (2012d, p. 164), a Anhanguera também faz contribuições e doações para organizações filantrópicas das localidades em que opera. 
Quadro 14 - Projetos de responsabilidade social da Anhanguera 2010 e 2011

\begin{tabular}{|c|c|c|c|c|}
\hline Área & Projeto & Público atendido & $\begin{array}{c}\mathbf{N}^{0} \text { de } \\
\text { pessoas } \\
\text { atendidas } \\
\text { em } 2010\end{array}$ & $\begin{array}{l}\mathrm{N}^{0} \text { de pessoas } \\
\text { atendidas em } 2011\end{array}$ \\
\hline $\begin{array}{l}\text { Educação } \\
\text { Profissional }\end{array}$ & $\begin{array}{l}\text { Qualificação profissional } \\
\text { de jovens e adultos das } \\
\text { comunidades - } \\
\text { capacitação para o } \\
\text { primeiro emprego, } \\
\text { inclusão digital e } \\
\text { atividades profissionais }\end{array}$ & $\begin{array}{l}\text { Jovens e adultos em } \\
\text { busca do primeiro } \\
\text { emprego ou de } \\
\text { recolocação profissional }\end{array}$ & 76.636 & 88.768 \\
\hline $\begin{array}{l}\text { Direitos } \\
\text { Humanos } \\
\end{array}$ & Assistência jurídica & Pessoas da comunidade & 48.256 & 55.895 \\
\hline $\begin{array}{l}\text { Esporte, Lazer } \\
\text { e Cultura }\end{array}$ & Atividades esportivas & $\begin{array}{l}\text { Alunos de graduação da } \\
\text { Anhanguera, crianças e } \\
\text { jovens das comunidades }\end{array}$ & 66.653 & 77.204 \\
\hline Saúde & Atividades de saúde & Pessoas da comunidade & 352.834 & 141.188 \\
\hline Saúde Animal & Hospital veterinário & $\begin{array}{l}\text { Animais de pequeno, } \\
\text { médio e grande porte }\end{array}$ & 85.771 & $\begin{array}{c}\text { Atendimentos nos } \\
\text { cursos de Medicina } \\
\text { Veterinária: } 20.698 \\
\text { Exames realizados: } \\
19.062 \\
\end{array}$ \\
\hline $\begin{array}{l}\text { Assistência } \\
\text { Social }\end{array}$ & Campanhas assistenciais & $\begin{array}{l}\text { Instituições filantrópicas } \\
\text { do entorno das unidades }\end{array}$ & 198.557 & 229.989 \\
\hline Interdisciplinar & $\begin{array}{c}\text { Dia Nacional do Ensino } \\
\text { Responsável }\end{array}$ & Comunidades do entorno & 142.350 & $\begin{array}{l}360.000 \\
\text { (durante a semana de } \\
\text { realização do evento) }\end{array}$ \\
\hline \multicolumn{3}{|c|}{ Total de Pessoas Beneficiadas } & 1.035 .798 & 1,48 milhão \\
\hline
\end{tabular}

Fonte: Anhanguera (2010f; 2011d; 2012d)

Segundo a Anhanguera (2010f, p. 16), a estratégia de desenvolvimento sustentável da instituição fundamenta-se nas seguintes premissas: (i) "inclusão social”; (ii) "qualidade de ensino"; (iii) "capacidade do aluno de estudar e aprender por si mesmo (autodesenvolvimento)"; (iv) "formação ética do aluno para sua atuação profissional e conscientização sobre o papel de sua profisssão na sociedade"; (v) "promoção da cidadania e da importância do meio ambiente".

Segundo a Companhia (2010f, p. 16), a Anhanguera possui um Comitê de Responsabilidade Social, "que avalia o desempenho da Empresa diante dos indicadores de sustentabilidade nacional e internacionalmente reconhecidos; coordena o Inventário de Emissões; e recomenda a revisão ou readequação de políticas, estratégias e ações nos planos de atuação ambiental e social e de relacionamento com os públicos de interesse, com foco em diálogo, engajamento e comprometimento".

Segundo a Companhia (2010f, p. 11): 
Fundada em 1994, desde o início a Anhanguera Educacional vem ampliando a oferta de cursos, com foco em sua política de inclusão social. Do lado técnico, a Instituição trabalha para manter um modelo acadêmico com ênfase na formação e na cidadania das pessoas. Todos os cursos ministrados trazem, no seu currículo, uma disciplina de Responsabilidade Social e Meio Ambiente. Para que os alunos tenham consciência de cidadania, de protagonismo social e de cuidados com o meio ambiente e possam agir em prol de uma causa, de um empreendimento sustentável.

Da mesma forma, os currículos também contemplam disciplinas que dão suporte ao ingresso no mercado de trabalho e ao desenvolvimento pessoal e profissional, diante da constatação de que o mundo, atualmente, exige muito mais do que conhecimento. A ideia é desenvolver competências e ampliar a autonomia intelectual dos alunos.

Das informações acima, nota-se que a Anhanguera trata extensão universitária como ações de "responsabilidade social". O termo "responsabilidade social" é muito mais utilizado no ramo empresarial do que na área educacional, apesar de ações de "responsabilidade social" também serem avaliadas pelo Sinaes. A Anhanguera deve utilizar essa prática também como estratégia de marketing, melhorando a imagem da empresa junto ao mercado.

$\mathrm{Na}$ área de estudos e pesquisas sobre sustentabilidade no campo social, a Anhanguera Educacional atua no Observatório do Programa de Extensão Comunitária, numa parceria com a Universidade de São Paulo (USP) de Ribeirão Preto (SP). O Observatório, denominado Observatório de Educação, Sustentabilidade e Responsabilidade Social, "materializa-se em um grupo de pesquisa formado por doutores, mestres e alunos de iniciação científica da Anhanguera Educacional e da USP de Ribeirão Preto". Pela Anhanguera, compunham a equipe do Observatório quatro professores do Iasec, sete diretores de unidade, 16 professores orientadores e 74 alunos de iniciação científica, sendo 25 bolsistas e 49 voluntários (ANHANGUERA, 2010f, p. 47).

De acordo com a Anhanguera (2010f, p. 47), os principais objetivos do Observatório são: (i) "elaborar projetos para identificar demandas e necessidades de serviços educacionais, por meio de pesquisas em meio às comunidades do entorno das unidades da Anhanguera Educacional"; e (ii) "mapear e padronizar processos e desenvolver indicadores de resultados que determinem a relevância, a qualidade e a eficácia dos programas institucionais de responsabilidade socioambiental para comunidade e para a Anhanguera".

A Anhanguera (2010f, p. 47) espera, por meio da sua atuação no Observatório:

(i) "obter maior visibilidade para as unidades, por intermédio da divulgação de resultados na mídia, e revistas especializadas e congressos científicos"; (ii) "desenvolver projetos de extensão comunitária que fortaleçam as estratégias das unidades e atendam às demandas das comunidades"; (iii) "agregar valor à avaliação do MEC"; (iv) "obter validação dos processos e da metodologia dos projetos pela Universidade de São Paulo (USP), o que permite a ampliação 
dos atendimentos e facilita parcerias".

Os dados acima evidenciam as atividades da Anhanguera nas áreas de ensino, pesquisa e extensão. Dentre as três atividades, fica claro que o foco da empresa é o ensino, sobretudo ensino voltado para formação técnica, profissionalizante. Considerando que (i) as atividades da empresa concentram-se em faculdades, que não precisam cumprir com a indissociabilidade entre ensino, pesquisa e extensão; e (ii) atividades de pesquisa requerem investimentos altos e com retorno não previsível, que a empresa não tem interesse em assumir e que também prejudicariam sua posição no mercado, já que é uma empresa direcionada a um público-alvo que não tem condições de arcar com mensalidades em valor alto, a Anhanguera investe pouco em pesquisa, e sua pesquisa tem pouca relevância no cenário nacional (conforme dados abaixo). Com relação à extensão, nota-se também que a Anhanguera atua em projetos nesse âmbito, os quais também denomina de ações de responsabilidade social.

A respeito dos princípios da educação (art. 205, CF/88) do ensino (art. 206, CF/88), nota-se que:

(i) com relação aos objetivos da educação - o pleno desenvolvimento da pessoa, seu preparo para o exercício da cidadania e sua qualificação para o trabalho (art. 205, CF/88) - o foco da empresa é a qualificação para o trabalho e o desenvolvimento profissional de seus alunos. Ações para o desenvolvimento da cidadania são também mencionadas em alguns documentos, mas em geral reduzidas a disciplinas ou atividades de extensão relacionadas com responsabilidade social e meio ambiente;

(ii) com relação à igualdade - refletida nos princípios da igualdade de condições de acesso e permanência (art. 206, I, CF/88) e da garantia de padrão de qualidade (art. 206, VII, CF/88) - a Anhanguera lida com o primeiro princípio como uma forma de atrair e manter seus alunos. Para tanto, oferece diferentes formas de pagamento das mensalidades, bolsas de estudo e financiamentos. Nesse contexto, é uma das principais instituições parceiras do ProUni e do Fies. Com relação à garantia de padrão de qualidade, a Anhanguera, considerando as avaliações do MEC, não está bem colocada entre as IES do Brasil, mantendose, em geral, no nível mínimo necessário para a aprovação, atendendo às exigências mínimas para a manutenção dos cursos em funcionamento, possuindo cursos com avaliações negativas e sujeitos a sanções;

(iii) com relação à liberdade - refletida nos princípios da liberdade de aprender e ensinar (art. 206, II, CF/88), da coexistência de instituições públicas e privadas, do pluralismo 
(art. 206, III, CF/88) e da gestão democrática do ensino (art. 206, VI, CF/88) - a Anhanguera não apresenta grande margem para liberdade de ensino e pluralismo, pois possui metodologia de ensino e materiais didáticos padronizados para toda a rede. Sobre a coexistência de instituições públicas e privadas e pluralismo, a Anhanguera representa um nicho do mercado voltado ao ensino de massa, ocupando, portanto, uma posição diferente das instituições públicas ou instituições de elite, que não são suas concorrentes diretas. Sobre a gestão democrática do ensino, repetimos aqui nossa crítica feita no Capítulo 1 à restrição desse princípio às instituições públicas. Não encontramos nenhuma informação sobre gestão democrática do ensino nas IES integrantes do grupo Anhanguera e ainda verificamos que não há nenhum representante de interesses diversos dos acionistas nas instâncias decisórias da Anhanguera;

(iv) com relação aos profissionais da educação - tutelados pelos princípios da valorização dos profissionais (art. 206, V, CF/88) e do piso salarial profissional nacional (art. 206, VIII, CF/88) - considerando que 60\% do total de custos da Anhanguera decorre de despesas com pessoal (ANHANGUERA, 2012d, p. 14), a empresa tem como política reduzir os custos com seus professores. Nesse sentido, após a aquisição de mantenedoras de IES, muitos docentes das IES adquiridas, geralmente os que possuem maior titulação e maiores salários, são demitidos pela Anhanguera para a contratação de docentes com menor titulação e menores salários, assunto que será desenvolvido no item 4.3.2 abaixo.

Abaixo dados extraídos do Ranking Universitário Folha (RUF) divulgado pelo jornal Folha de São Paulo, com base em metodologias utilizadas em rankings internacionais ${ }^{482}$, que listou as melhores universidades brasileiras, de acordo com critérios de ensino, pesquisa, inovação e avaliação do mercado. Apresentamos o resultado final do RUF, que combina todos os critérios, listando as dez melhores universidades brasileiras e as universidades do grupo Anhanguera (Anhanguera-Uniderp, Uniabc e Uniban):

${ }^{482}$ Para criar o RUF, a Folha definiu uma metodologia baseada em rankings internacionais, como o ranking global THE (Times Higher Education), o QS (Quacquarelli Symonds) e a ARWU (ranking de Xangai), adaptada ao contexto brasileiro. Foram avaliadas 191 universidades. Os indicadores de reputação no mercado de trabalho e de qualidade de ensino foram desenvolvidos a partir de entrevistas feitas pelo Datafolha com pesquisadores e com executivos de Recursos Humanos. Fonte: <http://ruf.folha.uol.com.br/metodologia/>. Acesso em: 20/12/2012. 
Tabela 50 - Ranking Universitário Folha - RUF - 2012

\begin{tabular}{|c|c|c|c|c|c|c|c|c|}
\hline & Universidade & UF & $\begin{array}{l}\text { Cat. } \\
\text { Adm. }\end{array}$ & $\begin{array}{l}\text { Qualidade } \\
\text { de Ensino }\end{array}$ & $\begin{array}{c}\text { Qualidade } \\
\text { de } \\
\text { Pesquisa } \\
\end{array}$ & $\begin{array}{c}\text { Avaliação } \\
\text { do } \\
\text { Mercado }\end{array}$ & $\begin{array}{c}\text { Indicador } \\
\text { de } \\
\text { Inovação }\end{array}$ & $\begin{array}{l}\text { Nota } \\
\text { Total }\end{array}$ \\
\hline $1^{\mathrm{a}}$ & $\begin{array}{l}\text { Universidade de } \\
\text { São Paulo } \\
\text { (USP) }\end{array}$ & SP & $\begin{array}{l}\text { Pública } \\
\text { Est. }\end{array}$ & 19,68 & 54,38 & 19,78 & 4,95 & 98,78 \\
\hline $2^{a}$ & $\begin{array}{l}\text { Universidade } \\
\text { Fed. de Minas } \\
\text { Gerais (UFMG) }\end{array}$ & MG & $\begin{array}{l}\text { Pública } \\
\text { Federal }\end{array}$ & 16,21 & 52,55 & 18,1 & 4,89 & 91,76 \\
\hline $3^{a}$ & $\begin{array}{l}\text { Universidade } \\
\text { Fed. do Rio de } \\
\text { Janeiro (UFRJ) }\end{array}$ & RJ & $\begin{array}{l}\text { Pública } \\
\text { Federal }\end{array}$ & 16,27 & 53,03 & 16,85 & 4,84 & 91 \\
\hline $4^{a}$ & $\begin{array}{l}\text { Universidade } \\
\text { Fed. do Rio } \\
\text { Grd. do Sul } \\
\text { (UFRGS) }\end{array}$ & $\mathrm{RS}$ & $\begin{array}{l}\text { Pública } \\
\text { Federal }\end{array}$ & 15,17 & 52,57 & 16,2 & 4,79 & 88,73 \\
\hline $5^{a}$ & $\begin{array}{l}\text { Universidade } \\
\text { Est. de } \\
\text { Campinas } \\
\text { (Unicamp) }\end{array}$ & SP & $\begin{array}{l}\text { Pública } \\
\text { Est. }\end{array}$ & 18,24 & 53,87 & 9,17 & 5 & 86,73 \\
\hline $6^{\mathrm{a}}$ & $\begin{array}{l}\text { Universidade } \\
\text { Est. Pta. Júlio } \\
\text { de Mesquita } \\
\text { Filho (Unesp) }\end{array}$ & SP & $\begin{array}{l}\text { Pública } \\
\text { Est. }\end{array}$ & 12,87 & 52,4 & 14,02 & 4,68 & 83,97 \\
\hline $7^{a}$ & $\begin{array}{c}\text { Universidade } \\
\text { Fed. do Paraná } \\
\text { (UFPR) }\end{array}$ & PR & $\begin{array}{l}\text { Pública } \\
\text { Federal }\end{array}$ & 7,06 & 50,03 & 18,06 & 4,74 & 79,88 \\
\hline $8^{a}$ & $\begin{array}{l}\text { Universidade de } \\
\text { Brasília (UnB) }\end{array}$ & DF & $\begin{array}{l}\text { Pública } \\
\text { Federal }\end{array}$ & 9,7 & 50,03 & 18,06 & 4,74 & 79,88 \\
\hline $9^{a}$ & $\begin{array}{l}\text { Universidade } \\
\text { Fed. de Santa } \\
\text { Catarina } \\
\text { (UFSC) }\end{array}$ & $\mathrm{SC}$ & $\begin{array}{l}\text { Pública } \\
\text { Federal }\end{array}$ & 8,78 & 51,47 & 13,06 & 4,63 & 77,95 \\
\hline 10 & $\begin{array}{l}\text { Universidade } \\
\text { Fed. de } \\
\text { Pernambuco } \\
\text { (UFPE) }\end{array}$ & PE & $\begin{array}{l}\text { Pública } \\
\text { Federal }\end{array}$ & 8,05 & 48,92 & 15,69 & 4,47 & 77,13 \\
\hline 123 & $\begin{array}{l}\text { Universidade } \\
\text { Anhanguera- } \\
\text { Uniderp }\end{array}$ & MS & Privada & 0 & 15,56 & 6,89 & 0 & 22,45 \\
\hline 137 & $\begin{array}{l}\text { Universidade } \\
\text { Bandeirante } \\
\text { de São Paulo } \\
\text { (Uniban) }\end{array}$ & SP & Privada & 0 & 14,92 & 1,94 & 1,76 & 18,62 \\
\hline 177 & $\begin{array}{c}\text { Universidade } \\
\text { do Grande } \\
\text { ABC } \\
\text { (UniABC) }\end{array}$ & SP & Privada & 0 & 5,96 & 0,69 & 0 & 6,65 \\
\hline
\end{tabular}

${ }^{483}$ Disponível em: <http://ruf.folha.uol.com.br/rankings/rankingdeuniversidades/>. Acesso em: 20/12/2012. 
Pelos dados acima, nota-se que as universidades do grupo Anhanguera foram mal avaliadas (nota zero) no critério ensino (que é o foco da Anhanguera) e também no critério inovação (nota zero para Anhanguera-Uniderp e UniABC e 1,76 para Uniban). As notas em pesquisa foram baixas, e a avaliação pelo mercado também não foi muito positiva. Se considerarmos apenas a avaliação pelo mercado, as universidades da Anhanguera melhoram sua posição no ranking:

\section{Tabela 51 - Ranking Universitário Folha - RUF - Avaliação Mercado - 2012}

\begin{tabular}{|c|c|c|c|c|}
\hline & Universidade & UF & $\begin{array}{c}\text { Categoria } \\
\text { Administrativa }\end{array}$ & $\begin{array}{l}\text { Avaliação do } \\
\text { mercado }\end{array}$ \\
\hline $1^{\mathrm{a}}$ & Universidade de São Paulo (USP) & SP & Pública Estadual & 19,78 \\
\hline $2^{a}$ & $\begin{array}{l}\text { Universidade Fed. de Minas Gerais } \\
\text { (UFMG) }\end{array}$ & MG & Pública Federal & 18,1 \\
\hline $3^{\mathrm{a}}$ & Universidade Fed. do Paraná (UFPR) & PR & Pública Federal & 18,06 \\
\hline $4^{\mathrm{a}}$ & $\begin{array}{l}\text { Pontifícia Universidade Católica de } \\
\text { Minas Gerais (PUC Minas) }\end{array}$ & MG & Privada & 17,8 \\
\hline $5^{\mathrm{a}}$ & Universidade Fed. da Bahia (UFBA) & BA & Pública Federal & 17,66 \\
\hline $6^{\mathrm{a}}$ & $\begin{array}{c}\text { Pontifícia Universidade Católica de São } \\
\text { Paulo (PUC-SP) }\end{array}$ & SP & Privada & 17,05 \\
\hline $7^{\mathrm{a}}$ & $\begin{array}{c}\text { Pontifícia Universidade Católica do Rio } \\
\text { Grande do Sul (PUC-RS) }\end{array}$ & RS & Privada & 16,88 \\
\hline $8^{a}$ & $\begin{array}{c}\text { Universidade Federal do Rio de Janeiro } \\
\text { (UFRJ) }\end{array}$ & RJ & Pública Federal & 16,85 \\
\hline $9^{a}$ & Universidade Paulista (UNIP) & SP & Privada & 16,38 \\
\hline 10 & $\begin{array}{l}\text { Universidade Fed. do Rio Grande do Sul } \\
\text { (UFRGS) }\end{array}$ & RS & Pública Federal & 16,2 \\
\hline 60 & Universidade Anhanguera-Uniderp & MS & Privada & 6,89 \\
\hline 116 & $\begin{array}{c}\text { Universidade Bandeirante de São Paulo } \\
\text { (Uniban) }\end{array}$ & SP & Privada & 1,94 \\
\hline 138 & Universidade do Grande $\mathrm{ABC}$ (UniABC) & SP & Privada & 0,69 \\
\hline
\end{tabular}

Considerando um ranking elaborado pelo portal iG com base nas notas do IGC de 2011 e um universo de 2.136 IES do país, ${ }^{485}$ as universidades do grupo Anhanguera ocuparam as seguintes posições: (i) Universidade Anhanguera-Uniderp foi a $724^{\mathrm{a}}$ colocada; (ii) UniABC foi a $777^{\text {a }}$ colocada; e (iii) a UNIBAN foi a $1.384^{\text {a }}$ colocada. Neste ranking, a melhor IES do grupo Anhanguera foi a Faculdade Anhanguera de Itapecerica da Serra com a $177^{\text {a }}$ posição.

\footnotetext{
${ }^{484}$ Disponível em: $<$ http://ruf.folha.uol.com.br/rankings/pelaavaliacaodomercado/>. Acesso em: 20/12/2012.

485 Disponível em: <http://ultimosegundo.ig.com.br/educacao/2012-12-10/consulte-o-ranking-das-instituicoesde-ensino-superior-de-2011.html > . Acesso em: 14/01/2013.
} 


\subsubsection{Questão 15}

Neste subitem procuramos responder à seguinte questão:

\section{Quadro 15 - Questão da Análise Empírica nº 15}

\begin{tabular}{|l|l|}
\hline $\mathbf{N}^{\mathbf{0}}$ & \multicolumn{1}{|c|}{ Grupo III - Educação como direito humano, bem público e serviço público } \\
\hline 15. & $\begin{array}{l}\text { Como foram as últimas avaliações da qualidade do ensino oferecido pela Anhanguera? Existem } \\
\text { formas de avaliação de qualidade feitas pela própria empresa? Há um caráter empresarial no } \\
\text { controle de qualidade da empresa? }\end{array}$ \\
\hline
\end{tabular}

Até 31/12/2011, a Anhanguera havia credenciado 20 faculdades e um centro universitário e autorizado aproximadamente 600 novos cursos (ANHANGUERA, 2012d, p. $124)^{486}$. Segundo informações da Companhia (2012d, p. 150), ao longo de 2011, a Anhanguera obteve altas notas em todas as visitas de autorização de curso do MEC às suas unidades - "todas as autorizações de cursos submetidas no ano foram concedidas com uma nota média de 3,7 , de uma escala de 1 a 5 pontos".

As avaliações das instituições de ensino superior do grupo Anhanguera, nos últimos anos, ficaram com conceitos entre 2-3 no IGC. Algumas das instituições do grupo, como a Uniban São Paulo, ficam nos últimos lugares dos rankings elaborados a partir do IGC. No ano de 2011, a Uniban foi considerada reprovada com o conceito 2 e perdeu sua autonomia universitária até nova avaliação - com isso seus exames vestibulares ficaram suspensos, bem como o ingresso de novos alunos em todos os cursos ${ }^{487}$.

Abaixo informações sobre as últimas avaliações das IES integrantes do grupo Anhanguera e sobre processos administrativos com o MEC para o saneamento de deficiências de avaliação e penalidades:

\footnotetext{
${ }^{486}$ Este número não corresponde ao total de IES do grupo Anhanguera, pois aqui não estão computadas as IES que a Anhanguera adquiriu já credenciadas e com cursos já autorizados.

${ }^{487}$ Esse processo ainda está em andamento. Para informações vide: <http://emec.mec.gov.br/emec/consultacadastro/detalhamento/d96957f455f6405d14c6542552b0f6eb/NDU3>. Acesso em: 08/12/2012.
} 


\section{Quadro 16 - Informações sobre as avaliações das IES integrantes do grupo Anhanguera 2012}

(continua)

\begin{tabular}{|c|c|c|c|c|c|}
\hline Mantenedora & IES & $\begin{array}{c}\text { CI }- \\
\text { Conceito } \\
\text { Institucional }\end{array}$ & IGC & $\begin{array}{c}\text { IGC } \\
\text { Contínuo }\end{array}$ & $\begin{array}{c}\text { Já foi objeto de processo } \\
\text { administrativo com o MEC } \\
\text { por conta de deficiências } \\
\text { de avaliaçãa }{ }^{488} \text { ? }\end{array}$ \\
\hline $\begin{array}{l}\text { Academia } \\
\text { Paulista } \\
\text { Anchieta Ltda. }\end{array}$ & $\begin{array}{l}\text { Universidade } \\
\text { Bandeirante de São } \\
\text { Paulo (Uniban) }\end{array}$ & $\begin{array}{c}3 \\
(2009)\end{array}$ & $\begin{array}{c}2 \\
(2010)\end{array}$ & $\begin{array}{l}1.8300 \\
(2010)\end{array}$ & $\operatorname{Sim}^{489}$ \\
\hline $\begin{array}{l}\text { Associação de } \\
\text { Ensino } \\
\text { Superior Elite } \\
\text { Ltda. }\end{array}$ & $\begin{array}{l}\text { Faculdades } \\
\text { Integradas } \\
\text { Torricelli (FIT) }\end{array}$ & $\begin{array}{c}3 \\
(2009)\end{array}$ & $\begin{array}{c}2 \\
(2010)\end{array}$ & $\begin{array}{l}1.8700 \\
(2010)\end{array}$ & Não \\
\hline $\begin{array}{l}\text { Cesag - } \\
\text { Complexo de - } \\
\text { Ensino } \\
\text { Superior Anita } \\
\text { Garibaldi Ltda. }\end{array}$ & $\begin{array}{l}\text { Faculdade União } \\
\text { Bandeirante } \\
\text { (Faculdade } \\
\text { Uniban) }\end{array}$ & $\begin{array}{c}4 \\
(2010)\end{array}$ & $\begin{array}{c}3 \\
(2010)\end{array}$ & $\begin{array}{l}1.9600 \\
(2010)\end{array}$ & Não \\
\hline $\begin{array}{l}\text { Instituição } \\
\text { Educacional } \\
\text { Professor Luiz } \\
\text { Rosa Ltda. }\end{array}$ & $\begin{array}{lr}\text { Faculdade } & \text { de } \\
\text { Tecnologia } & \\
\text { Professor } & \text { Luiz } \\
\text { Rosa (Fatec } & \text { Prof. } \\
\text { Luiz Rosa) } & \end{array}$ & $\begin{array}{c}4 \\
(2008)\end{array}$ & $\begin{array}{c}3 \\
(2010)\end{array}$ & $\begin{array}{l}2.2800 \\
(2010)\end{array}$ & Não \\
\hline $\begin{array}{l}\text { Sociedade } \\
\text { Educacional de } \\
\text { Belo Horizonte } \\
\text { Ltda. }\end{array}$ & $\begin{array}{l}\text { Faculdade } r \text { de } \\
\text { Negócios de Belo } \\
\text { Horizonte }\end{array}$ & -X- & $\begin{array}{c}3 \\
(2010)\end{array}$ & $\begin{array}{l}2.0200 \\
(2010)\end{array}$ & Não \\
\hline $\begin{array}{ll}\text { Unesec } & - \\
\text { União } & \text { de } \\
\text { Escolas } & \text { de } \\
\text { Educação } & \\
\text { Corporativa } & \\
\text { Ltda. } & \end{array}$ & $\begin{array}{l}\text { Escola Superior de } \\
\text { Educação } \\
\text { Corporativa - Esec }\end{array}$ & $-x-$ & $-x-$ & $-x-$ & Não \\
\hline $\begin{array}{l}\text { União Pan- } \\
\text { Americana de } \\
\text { Ensino Ltda. }\end{array}$ & $\begin{array}{lr}\text { Faculdade } & \text { de } \\
\text { Ciências } & \text { Aplicadas } \\
\text { de } & \text { Cascavel } \\
\text { (Faciap) } & \\
\end{array}$ & $\begin{array}{c}4 \\
(2011)\end{array}$ & $\begin{array}{c}2 \\
(2010)\end{array}$ & $\begin{array}{l}1.6700 \\
(2010)\end{array}$ & Não \\
\hline $\begin{array}{lr}\text { União } & \text { para } \\
\text { Formação, } & \\
\text { Educação } & \mathrm{e} \\
\text { Cultura } & \text { do } \\
\text { ABC } & \text { Ltda. } \\
\text { (Unifec) } & \end{array}$ & $\begin{array}{l}\text { Universidade do } \\
\text { Grande ABC } \\
\text { UniABC }\end{array}$ & $\begin{array}{c}4 \\
(2009)\end{array}$ & $\begin{array}{c}3 \\
(2010)\end{array}$ & $\begin{array}{l}2.0000 \\
(2010)\end{array}$ & $\operatorname{Sim}^{490}$ \\
\hline
\end{tabular}

${ }^{488}$ Analisamos aqui processos administrativos com o MEC tanto com relação à avaliação de cursos como da instituição a partir do sistema eletrônico de consultas do MEC (http://emec.mec.gov.br/).

$489 \quad$ Disponível em: <http://emec.mec.gov.br/emec/consultacadastro/detalhamento/d96957f455f6405d14c6542552b0f6eb/NDU3>. Acesso em: 08/12/2012.

$490 \quad$ Disponível em: <http://emec.mec.gov.br/emec/consultacadastro/detalhamento/d96957f455f6405d14c6542552b0f6eb/MjE1>. Acesso em: 08/12/2012. 


\section{Quadro 16 - Informações sobre as avaliações das IES integrantes do grupo Anhanguera 2012}

(continua)

\begin{tabular}{|c|c|c|c|c|c|}
\hline Mantenedora & IES & $\begin{array}{c}\text { CI - } \\
\text { Conceito } \\
\text { Institucional }\end{array}$ & IGC & $\begin{array}{c}\text { IGC } \\
\text { Contínuo }\end{array}$ & $\begin{array}{c}\text { Já foi objeto de processo } \\
\text { administrativo com o MEC } \\
\text { por conta de deficiências } \\
\text { de avaliação? }\end{array}$ \\
\hline \multirow[t]{11}{*}{ Aesa } & $\begin{array}{l}\text { Centro } \\
\text { Universitário } \\
\text { Anhanguera (Unia) }\end{array}$ & $\begin{array}{c}3 \\
(2009)\end{array}$ & $\begin{array}{c}3 \\
(2010)\end{array}$ & $\begin{array}{l}2.0600 \\
(2010)\end{array}$ & $\operatorname{Sim}^{491}$ \\
\hline & $\begin{array}{l}\text { Centro } \\
\text { Universitário } \\
\text { Anhanguera } \\
\text { (Unifian) }\end{array}$ & $\begin{array}{c}3 \\
(2009)\end{array}$ & $\begin{array}{c}3 \\
(2010)\end{array}$ & $\begin{array}{l}2.6500 \\
(2010)\end{array}$ & Não \\
\hline & $\begin{array}{l}\text { Centro } \\
\text { Universitário } \\
\text { Anhanguera de } \\
\text { Campo Grande }\end{array}$ & $\begin{array}{c}3 \\
(2009)\end{array}$ & $\begin{array}{c}3 \\
(2010)\end{array}$ & $\begin{array}{l}2.4000 \\
(2010)\end{array}$ & Não \\
\hline & $\begin{array}{l}\text { Centro } \\
\text { Universitário } \\
\text { Anhanguera de São } \\
\text { Paulo }\end{array}$ & $\begin{array}{c}3 \\
(2009)\end{array}$ & $\begin{array}{c}3 \\
(2010)\end{array}$ & $\begin{array}{l}2.2700 \\
(2010)\end{array}$ & Não \\
\hline & $\begin{array}{ll}\text { Centro } & \\
\text { Universitário } & \\
\text { Plínio } \quad \text { Leite } \\
\text { (Unipli) }\end{array}$ & $\begin{array}{c}3 \\
(2009)\end{array}$ & $\begin{array}{c}3 \\
(2010)\end{array}$ & $\begin{array}{l}2.1600 \\
(2010)\end{array}$ & $\mathrm{Sim}^{492}$ \\
\hline & $\begin{array}{l}\text { Faculdade } \\
\text { Anchieta (IGABC) }\end{array}$ & $\begin{array}{c}3 \\
(2009) \\
\end{array}$ & $\begin{array}{c}3 \\
(2010) \\
\end{array}$ & $\begin{array}{l}2.1600 \\
(2010) \\
\end{array}$ & Não \\
\hline & $\begin{array}{l}\text { Faculdade } \\
\text { Anhanguera de } \\
\text { Jundiaí }\end{array}$ & $\begin{array}{c}4 \\
(2009)\end{array}$ & $\begin{array}{c}3 \\
(2010)\end{array}$ & $\begin{array}{l}2.0000 \\
(2010)\end{array}$ & Não \\
\hline & $\begin{array}{l}\text { Faculdade } \\
\text { Anhanguera de } \\
\text { Anápolis (FAAA) }\end{array}$ & $\begin{array}{c}3 \\
(2011)\end{array}$ & $\begin{array}{c}2 \\
(2010)\end{array}$ & $\begin{array}{l}1.8900 \\
(2010)\end{array}$ & $\mathrm{Sim}^{493}$ \\
\hline & $\begin{array}{l}\text { Faculdade } \\
\text { Anhanguera de } \\
\text { Bauru }\end{array}$ & $\begin{array}{c}3 \\
(2010)\end{array}$ & $\begin{array}{c}3 \\
(2010)\end{array}$ & $\begin{array}{l}2.6200 \\
(2010)\end{array}$ & Não \\
\hline & $\begin{array}{l}\text { Faculdade } \\
\text { Anhanguera de } \\
\text { Belo Horizonte }\end{array}$ & -x- & $\begin{array}{c}3 \\
(2010)\end{array}$ & $\begin{array}{l}2.2700 \\
(2010)\end{array}$ & Não \\
\hline & $\begin{array}{ll}\text { Faculdade } & \\
\text { Anhanguera } & \text { de } \\
\text { Brasília (FAB) } & \\
\end{array}$ & $\begin{array}{c}3 \\
(2010)\end{array}$ & $\begin{array}{c}3 \\
(2010)\end{array}$ & $\begin{array}{l}2.0100 \\
(2010)\end{array}$ & $\mathrm{Sim}^{494}$ \\
\hline
\end{tabular}

491

Disponível em:

$<$ http://emec.mec.gov.br/emec/consultacadastro/detalhamento/d96957f455f6405d14c6542552b0f6eb/MjQy>. Acesso em: 08/12/2012.

$492 \quad$ Disponível em: <http:/emec.mec.gov.br/emec/consultacadastro/detalhamento/d96957f455f6405d14c6542552b0f6eb/NTE1>. Acesso em: 08/12/2012.

$493 \quad$ Disponível em: $\quad<$ http://emec.mec.gov.br/emec/consultacadastro/detalhamento/d96957f455f6405d14c6542552b0f6eb/NTU1MA>. Acesso em: 08/12/2012.

$494 \quad$ Disponível em: $\quad<$ http://emec.mec.gov.br/emec/consultacadastro/detalhamento/d96957f455f6405d14c6542552b0f6eb/MTE3Mw>. Acesso em: 08/12/2012. 


\section{Quadro 16 - Informações sobre as avaliações das IES integrantes do grupo Anhanguera 2012}

\begin{tabular}{|c|c|c|c|c|c|}
\hline Mantenedora & IES & $\begin{array}{c}\text { CI - } \\
\text { Conceito } \\
\text { Institucional }\end{array}$ & IGC & $\begin{array}{c}\text { IGC } \\
\text { Contínuo }\end{array}$ & $\begin{array}{c}\text { Já foi objeto de processo } \\
\text { administrativo com o MEC } \\
\text { por conta de deficiências } \\
\text { de avaliação? }\end{array}$ \\
\hline \multirow[t]{13}{*}{ Aesa } & $\begin{array}{l}\text { Faculdade } \\
\text { Anhanguera de } \\
\text { Campinas } \\
\end{array}$ & $\begin{array}{c}3 \\
(2011)\end{array}$ & $\begin{array}{c}2 \\
(2010)\end{array}$ & $\begin{array}{l}1.7900 \\
(2010)\end{array}$ & $\mathrm{Sim}^{495}$ \\
\hline & $\begin{array}{l}\text { Faculdade } \\
\text { Anhanguera de } \\
\text { Caxias do Sul } \\
\text { (FACS) }\end{array}$ & $-\mathrm{X}-$ & $-\mathrm{x}-$ & $-\mathrm{X}-$ & Não \\
\hline & $\begin{array}{l}\text { Faculdade } \\
\text { Anhanguera de } \\
\text { Cuiabá (FAC) } \\
\end{array}$ & $-x-$ & $-x-$ & $-x-$ & Não \\
\hline & $\begin{array}{l}\text { Faculdade } \\
\text { Anhanguera de } \\
\text { Dourados (FAD) } \\
\end{array}$ & $\begin{array}{c}3 \\
(2011)\end{array}$ & $\begin{array}{c}2 \\
(2010)\end{array}$ & $\begin{array}{l}1.7600 \\
(2010)\end{array}$ & Não \\
\hline & $\begin{array}{l}\text { Faculdade } \\
\text { Anhanguera de } \\
\text { Indaiatuba } \\
\end{array}$ & $-\mathrm{X}-$ & $\begin{array}{c}3 \\
(2010)\end{array}$ & $\begin{array}{l}2.5900 \\
(2010)\end{array}$ & Não \\
\hline & $\begin{array}{l}\text { Faculdade } \\
\text { Anhanguera de } \\
\text { Itapecerica da Serra }\end{array}$ & $-\mathrm{X}-$ & $\mathrm{SC}$ & $\mathrm{SC}$ & Não \\
\hline & $\begin{array}{l}\text { Faculdade } \\
\text { Anhanguera de } \\
\text { Jacareí } \\
\end{array}$ & $\begin{array}{c}3 \\
(2010)\end{array}$ & $\begin{array}{c}3 \\
(2010)\end{array}$ & $\begin{array}{l}2.8600 \\
(2010)\end{array}$ & Não \\
\hline & $\begin{array}{l}\text { Faculdade } \\
\text { Anhanguera de } \\
\text { Joinville }\end{array}$ & $\begin{array}{c}3 \\
(2010)\end{array}$ & $\begin{array}{c}3 \\
(2010)\end{array}$ & $\begin{array}{l}2.0000 \\
(2010)\end{array}$ & Não \\
\hline & $\begin{array}{l}\text { Faculdade } \\
\text { Anhanguera de } \\
\text { Limeira } \\
\end{array}$ & $-\mathrm{X}-$ & $\begin{array}{c}3 \\
(2010)\end{array}$ & $\begin{array}{l}2.0700 \\
(2010)\end{array}$ & Não \\
\hline & $\begin{array}{l}\text { Faculdade } \\
\text { Anhanguera de } \\
\text { Matão }\end{array}$ & $\begin{array}{c}3 \\
(2010)\end{array}$ & $\begin{array}{c}3 \\
(2010)\end{array}$ & $\begin{array}{l}2.3700 \\
(2010)\end{array}$ & Não \\
\hline & $\begin{array}{l}\text { Faculdade } \\
\text { Anhanguera } \\
\text { Osasco (Fizo) }\end{array}$ & $\begin{array}{c}3 \\
(2009)\end{array}$ & $\begin{array}{c}2 \\
(2010)\end{array}$ & $\begin{array}{l}1.7900 \\
(2010)\end{array}$ & Não \\
\hline & $\begin{array}{l}\text { Faculdade } \\
\text { Anhanguera de } \\
\text { Passo Fundo }\end{array}$ & $\begin{array}{c}3 \\
(2011)\end{array}$ & $\begin{array}{c}3 \\
(2010)\end{array}$ & $\begin{array}{l}2.5000 \\
(2010)\end{array}$ & Não \\
\hline & $\begin{array}{l}\text { Faculdade } \\
\text { Anhanguera de } \\
\text { Pelotas }\end{array}$ & $\begin{array}{c}3 \\
(2009)\end{array}$ & $\begin{array}{c}3 \\
(2010)\end{array}$ & $\begin{array}{l}2.4800 \\
(2010)\end{array}$ & Não \\
\hline
\end{tabular}

495 


\section{Quadro 16 - Informações sobre as avaliações das IES integrantes do grupo Anhanguera 2012}

(continua)

\begin{tabular}{|c|c|c|c|c|c|}
\hline Mantenedora & IES & $\begin{array}{c}\text { CI - } \\
\text { Conceito } \\
\text { Institucional }\end{array}$ & IGC & $\begin{array}{c}\text { IGC } \\
\text { Contínuo }\end{array}$ & $\begin{array}{l}\text { Já foi objeto de processo } \\
\text { administrativo com o MEC } \\
\text { por conta de deficiências } \\
\text { de avaliação? }\end{array}$ \\
\hline \multirow[t]{12}{*}{ Aesa } & $\begin{array}{l}\text { Faculdade } \\
\text { Anhanguera de } \\
\text { Porto Alegre (Fapa) }\end{array}$ & $\begin{array}{c}4 \\
(2011)\end{array}$ & $-\mathrm{X}-$ & $-\mathrm{X}-$ & Não \\
\hline & $\begin{array}{l}\text { Faculdade } \\
\text { Anhanguera de } \\
\text { Ribeirão Preto } \\
\end{array}$ & $-\mathrm{X}-$ & $-\mathrm{x}-$ & $-\mathrm{x}-$ & Não \\
\hline & $\begin{array}{l}\text { Faculdade } \\
\text { Anhanguera de Rio } \\
\text { Claro }\end{array}$ & $\begin{array}{c}5 \\
(2006)\end{array}$ & $\begin{array}{c}3 \\
(2010)\end{array}$ & $\begin{array}{l}2.5700 \\
(2010)\end{array}$ & Não \\
\hline & $\begin{array}{l}\text { Faculdade } \\
\text { Anhanguera de } \\
\text { Rondonópolis } \\
\text { (FAR) }\end{array}$ & $\begin{array}{c}4 \\
(2009)\end{array}$ & $\begin{array}{c}3 \\
(2010)\end{array}$ & $\begin{array}{l}2.0500 \\
(2010)\end{array}$ & Não \\
\hline & $\begin{array}{l}\text { Faculdade } \\
\text { Anhanguera de } \\
\text { Santa Bárbara } \\
\end{array}$ & $-\mathrm{X}-$ & $\begin{array}{c}3 \\
(2010)\end{array}$ & $\begin{array}{l}2.2300 \\
(2010)\end{array}$ & Não \\
\hline & $\begin{array}{l}\text { Faculdade } \\
\text { Anhanguera de São } \\
\text { Caetano (FASC) }\end{array}$ & $\begin{array}{c}4 \\
(2010)\end{array}$ & $\begin{array}{c}3 \\
(2010)\end{array}$ & $\begin{array}{l}2.4100 \\
(2010)\end{array}$ & $\operatorname{Sim}^{496}$ \\
\hline & $\begin{array}{l}\text { Faculdade } \\
\text { Anhanguera de São } \\
\text { José }\end{array}$ & $-\mathrm{X}-$ & $\begin{array}{c}2 \\
(2010)\end{array}$ & $\begin{array}{l}1.7800 \\
(2010)\end{array}$ & Não \\
\hline & $\begin{array}{l}\text { Faculdade } \\
\text { Anhanguera de } \\
\text { Sertãozinho (Fasert) }\end{array}$ & $\begin{array}{c}3 \\
(2010)\end{array}$ & $\begin{array}{c}3 \\
(2010)\end{array}$ & $\begin{array}{l}2.4600 \\
(2010)\end{array}$ & Não \\
\hline & $\begin{array}{l}\text { Faculdade } \\
\text { Anhanguera de } \\
\text { Sorocaba (FSO) }\end{array}$ & $\begin{array}{c}4 \\
(2006)\end{array}$ & $\begin{array}{c}\mathrm{SC} \\
(2010)\end{array}$ & $\begin{array}{c}\text { SC } \\
(2010)\end{array}$ & Não \\
\hline & $\begin{array}{l}\text { Faculdade } \\
\text { Anhanguera de } \\
\text { Sumaré } \\
\text { (FacSumaré) } \\
\end{array}$ & $\begin{array}{c}4 \\
(2009)\end{array}$ & $-\mathrm{X}-$ & $-\mathrm{X}-$ & Não \\
\hline & $\begin{array}{l}l \text { Faculdade } \\
\text { Anhanguera } \\
\text { Taboão da Serra } \\
\text { (FATS) }\end{array}$ & $\begin{array}{c}3 \\
(2009)\end{array}$ & $\begin{array}{c}3 \\
(2010)\end{array}$ & $\begin{array}{l}2.0700 \\
(2010)\end{array}$ & Não \\
\hline & $\begin{array}{l}\text { Faculdade } \\
\text { Anhanguera de } \\
\text { Taubaté }\end{array}$ & $-\mathrm{X}-$ & $\begin{array}{c}3 \\
(2010)\end{array}$ & $\begin{array}{l}2.3100 \\
(2010)\end{array}$ & Não \\
\hline
\end{tabular}




\section{Quadro 16 - Informações sobre as avaliações das IES integrantes do grupo Anhanguera 2012}

\begin{tabular}{|c|c|c|c|c|c|}
\hline Mantenedora & IES & $\begin{array}{c}\text { CI - } \\
\text { Conceito } \\
\text { Institucional }\end{array}$ & IGC & $\begin{array}{c}\text { IGC } \\
\text { Contínuo }\end{array}$ & $\begin{array}{c}\text { Já foi objeto de processo } \\
\text { administrativo com o MEC } \\
\text { por conta de deficiências } \\
\text { de avaliação? }\end{array}$ \\
\hline \multirow[t]{13}{*}{ Aesa } & $\begin{array}{l}\text { Faculdade } \\
\text { Anhanguera de } \\
\text { Valinhos } \\
\end{array}$ & $\begin{array}{c}3 \\
(2010)\end{array}$ & $\begin{array}{c}3 \\
(2010)\end{array}$ & $\begin{array}{l}2.1000 \\
(2010)\end{array}$ & Não \\
\hline & $\begin{array}{l}\text { Faculdade } \\
\text { Anhanguera de } \\
\text { Valparaíso (FAV) }\end{array}$ & $\begin{array}{c}3 \\
(2011)\end{array}$ & $\begin{array}{c}2 \\
(2010)\end{array}$ & $\begin{array}{l}1.6500 \\
(2010)\end{array}$ & Não \\
\hline & $\begin{array}{l}\text { Faculdade } \\
\text { Anhanguera do Rio } \\
\text { Grande }\end{array}$ & $\begin{array}{c}4 \\
(2011)\end{array}$ & $\begin{array}{c}3 \\
(2010)\end{array}$ & $\begin{array}{l}2.1300 \\
(2010)\end{array}$ & Não \\
\hline & $\begin{array}{l}\text { Faculdade } \\
\text { Anhanguera de } \\
\text { Jaraguá do Sul } \\
\text { (Fateja) }\end{array}$ & $\begin{array}{c}3 \\
(2010)\end{array}$ & $\begin{array}{c}3 \\
(2010)\end{array}$ & $\begin{array}{l}2.0400 \\
(2010)\end{array}$ & Não \\
\hline & $\begin{array}{lr}\text { Faculdade } & \text { de } \\
\text { Ciências } & \text { e } \\
\text { Tecnologia de } & \\
\text { Brasília (Faciteb) } & \end{array}$ & $-\mathrm{X}-$ & $\begin{array}{c}\mathrm{SC} \\
(2010)\end{array}$ & $\begin{array}{c}\mathrm{SC} \\
(2010)\end{array}$ & Não \\
\hline & $\begin{array}{ll}\text { Faculdade } & \text { de } \\
\text { Goiânia (FAG) } & \\
\end{array}$ & $\begin{array}{c}5 \\
(2008) \\
\end{array}$ & $-\mathrm{X}-$ & $-\mathrm{x}-$ & Não \\
\hline & $\begin{array}{l}\text { Faculdade de Mato } \\
\text { Grosso (Famat) }\end{array}$ & $\begin{array}{c}4 \\
(2009) \\
\end{array}$ & $-\mathrm{X}-$ & $-\mathrm{X}-$ & Não \\
\hline & $\begin{array}{lr}\text { Faculdade } & \text { de } \\
\text { Negócios } & \mathrm{e} \\
\text { Tecnologias } & \mathrm{da} \\
\text { Informação } & \\
\text { (Facnet) } & \end{array}$ & $-\mathrm{x}-$ & $\begin{array}{c}2 \\
(2010)\end{array}$ & $\begin{array}{l}1.8700 \\
(2010)\end{array}$ & Não \\
\hline & $\begin{array}{ll}\text { Faculdade } & \text { de } \\
\text { Tecnologia } & \\
\text { Anchieta (FTA) } & \\
\end{array}$ & $\begin{array}{c}3 \\
(2010)\end{array}$ & $\begin{array}{c}3 \\
(2010)\end{array}$ & $\begin{array}{l}2.0400 \\
(2010)\end{array}$ & Não \\
\hline & $\begin{array}{l}\text { Faculdade Santa } \\
\text { Terezinha (Fast) }\end{array}$ & $\begin{array}{c}3 \\
(2010) \\
\end{array}$ & $\begin{array}{c}3 \\
(2010) \\
\end{array}$ & $\begin{array}{l}1.9500 \\
(2010) \\
\end{array}$ & Não \\
\hline & $\begin{array}{l}\text { Faculdades } \\
\text { Integradas de Rio } \\
\text { Verde (Firve) }\end{array}$ & $\begin{array}{c}3 \\
(2010)\end{array}$ & $\begin{array}{c}\mathrm{SC} \\
(2010)\end{array}$ & $\begin{array}{c}\mathrm{SC} \\
(2010)\end{array}$ & Não \\
\hline & $\begin{array}{l}\text { Faculdade Uirapuru } \\
\text { (FAU) }\end{array}$ & $\begin{array}{c}3 \\
(2008) \\
\end{array}$ & $\begin{array}{c}3 \\
(2010) \\
\end{array}$ & $\begin{array}{l}2.2700 \\
(2010) \\
\end{array}$ & Não \\
\hline & $\begin{array}{l}\text { Universidade } \\
\text { Anhanguera } \\
\text { Uniderp }\end{array}$ & $\begin{array}{c}3 \\
(2009)\end{array}$ & $\begin{array}{c}3 \\
(2010)\end{array}$ & $\begin{array}{l}2.2800 \\
(2010)\end{array}$ & $\mathrm{Sim}^{497}$ \\
\hline
\end{tabular}

Fonte: MEC; Anhanguera (2012d)

$\mathrm{Na}$ documentação pública analisada, verificamos uma preocupação interna com a qualidade, analisada a partir dos insumos. Nesse sentido, a Anhanguera (2008a) ${ }^{498}$ afirmou: 
Os gastos para melhoria de qualidade devem ser focados em melhoria da infraestrutura de laboratórios e administrativo, aquisição de máquinas, equipamentos, móveis e utensílios, projetos de tecnologia e reposição e aumento do acervo de livros das bibliotecas das unidades da companhia.

Ademais, a administração da Anhanguera tem uma visão diferente do que seja qualidade. De acordo com a documentação analisada, a "missão da Anhanguera Educacional é proporcionar aos seus alunos ensino de qualidade para que eles possam desenvolver seus projetos de vida de crescimento e ascensão profissional" (ANHANGUERA, 2012d, p. 150).

Segundo a Anhanguera (2010f, p. 22):

Internamente, a Empresa avalia, constantemente, a necessidade de melhorar os controles e processos para manter uma boa prestação de serviços, com menor custo. Por conta disso, começou a ser implantado, em 2010, um Centro de Serviços Compartilhados, com o objetivo de que sejam implementadas, gradativamente, alterações nos processos de back office (retaguarda), para que se tenha, crescentemente, processos mais eficientes.

Segundo Antonio Carbonari Netto ${ }^{499}$, fundador e presidente do CA da Anhanguera:

os administradores me ensinaram que qualidade é aquele conjunto de características que um produto ou um serviço tem que satisfaz duas coisas: o interesse e a satisfação do usuário. Então, se eu faço um currículo eu tenho que pensar o aluno tem interesse e vai ficar satisfeito? Tem interesse, porque ele quer o que, uma profissão. O meu currículo tem que satisfazer os ditames da profíssão que ele tá procurando. Não é? E da mesma forma a satisfação, ele tem que sentir bem, tem que ter infraestrutura, tem que ter multi emails, boas aulas, boa metodologia de ensino... Então, quando você fala que o nosso cliente, o nosso aluno, tem que ter essas duas variáveis - satisfação e interesses - atendidos, o nosso projeto de curso tem qualidade. Agora essa qualidade aqui pode ser diferente de outra acolá. Não é isso? Eu duvido que algum curso europeu hoje tenha qualidade. Atende as necessidades de empregabilidade dos aluno lá? Tem aluno se formando e tendo emprego na Europa com 28\% de desemprego? O nosso tem muito mais qualidade com $6 \%$ de desemprego. Então, qualidade é uma questão também político geográfica. Agora, impor goela abaixo qualidade do século passado para novo modelo de qualidade, pra mim ver, pra mim, é hipocrisia. Hipocrisia naquele sentido que é... todos querem que seja imitado, que ele é o bom da bola e ele não é não... O número de titulares, titulados, numa instituição, o número de doutores, de mestres é importante? Claro que é importante mas não é fundamental para a qualidade. Professor em tempo integral não é fundamental para qualidade. Tô falando do aluno que vem buscar no seu curso noturno o seu diploma pra fazer um upgrade na vida. Não estou falando do filho diurno, do jovem que tem condições materiais melhores, que vai ser um pesquisador mais tarde, não estou falando dele, esse é o pico da curva, é aquele aluno nível A, tempo integral, que alguém paga a escola pra ele. Estou falando da grande massa de jovens trabalhadores, que nós atendemos. Esse aluno se ele gostasse de pesquisa ele aprovaria uma assembleia geral na minha instituição e na de vocês e no carnê estaria assim: mensalidade de ensino tanto, mensalidade pró pesquisa nacional mais tanto, mensalidade pra aprimorar professor mais tanto. Ele paga isso? Ele quer pagar o professor já feito. Ele quer pagar... O governo que cuide da pesquisa, como política pública e dê dinheiro pra isso. Eu não posso tirar da mensalidade de um jovem trabalhador projetos de pesquisa, qualificação docente, extensão universitária

${ }^{499}$ Vídeo disponível em: <http://www.abmes.org.br/abmes/video/detalhe/id/39>. Acesso em: 02/08/2012. 
caríssima. Eu não posso fazer isso. Eu tenho que cobrar dele, aquilo que ele está disposto a pagar.

Pelas palavras de Carbonari nota-se que a empresa está preocupada com o interesse e satisfação dos seus alunos, dentro de uma relação custo-benefício. $\mathrm{O}$ aluno tem o benefício condizente com o valor da mensalidade que paga. Portanto, se paga um valor baixo de mensalidade, não terá pesquisa, nem corpo docente qualificado nem extensão universitária cara.

A Anhanguera monitora semestralmente a qualidade do seu ensino e a satisfação dos seus alunos por meio do Programa de Avaliação Interna (PAI) e da Pesquisa de Importância e Satisfação dos alunos ${ }^{500}$.

O PAI é um programa executado pelas IES do grupo desde 1997 que busca medir a satisfação dos alunos. Segundo a Anhanguera (2010f, p. 26), "esse sistema de avaliação visa criar uma base de dados sólida e confiável, com diagnósticos e reflexões que geram indicadores para apoiar discussões sobre os resultados do programa. Além disso, a avaliação é uma importante ferramenta de aperfeiçoamento de gestão, pois fornece subsídios para adotar melhorias internas. O resultado da avaliação é expresso pelo Índice de Satisfação Discente (ISD), que corresponde à opinião dos alunos representada estatisticamente.

Segundo a Companhia (2012d, p. 151), no segundo semestre de 2011, 84.280 alunos dos campi da Anhanguera responderam à pesquisa do PAI, e o índice de satisfação discente correspondeu a $82 \%$ para o quesito acadêmico, $77 \%$ para infraestrutura e $73 \%$ para atendimento.

Além disso, para medir o desenvolvimento acadêmico dos alunos durante o curso, a Anhanguera utiliza o IDD (Indicador de Diferença dentre os Desempenhos Observado e Esperado), fornecido pelo MEC. Para o ciclo concluído em 2009, a Anhanguera Educacional obteve uma nota média de 3,2 (ANHANGUERA, 2010f, p. 30)".

Com relação ao Enade, a Anhanguera (2010f, p. 30) afirma: “O resultado do Enade serve para verificar o esforço interno de qualidade de ensino e inclusão social, sendo usado também nos boletins divulgados para acionistas e em venda de ações”.

Nota-se um caráter empresarial no controle de qualidade da Anhanguera, na medida em que ele leva em consideração o nível de satisfação de seus consumidores com o produto oferecido e sempre considera os custos envolvidos em qualquer aprimoramento de qualidade,

${ }^{500}$ Fonte: $<$ http://www.unianhanguera.edu.br/ri/>. Acesso em 17/01/2011. 
atendendo assim ao mínimo exigido pelo MEC para que as IES continuem em funcionamento.

\subsubsection{Questão 16}

Neste subitem procuramos responder à seguinte questão:

\section{Quadro 17 - Questão da Análise Empírica nº 16}

\begin{tabular}{|l|l|}
\hline $\mathbf{N}^{\mathbf{0}}$ & \multicolumn{1}{|c|}{ Grupo III - Educação como direito humano, bem público e serviço público } \\
\hline 16. & $\begin{array}{l}\text { Qual o perfil dos professores da Anhanguera? Qual o regime de trabalho desses professores? Qual a } \\
\text { porcentagem de mestres e doutores? Qual a porcentagem de professores em dedicação integral? }\end{array}$ \\
\hline
\end{tabular}

O grupo Anhanguera possuía, em 31/11/2012, aproximadamente 9 mil docentes, os quais, segundo a Companhia (2012d, p. 111), são em sua maioria profissionais de mercado, que atuam como docentes em tempo parcial.

O perfil docente da Anhanguera é coerente com a proposta do grupo, que é oferecer uma formação voltada ao mercado de trabalho. Nesse sentido, privilegiam-se docentes ligados ao mercado, que atuam em regime de tempo parcial ou hora-aula, em detrimento de docentes em dedicação integral.

Abaixo dados sobre o número de empregados da Anhanguera, entre eles os docentes, nos diferentes estados de atuação entre os anos de 2009 e 2011:

Tabela 52 - Número de Empregados Anhanguera - 2009 - 2011

\begin{tabular}{c|ccc|c}
\hline Estado & Data Base & Administrativo & Docente & Total \\
\hline DF & $31 / 12 / 2009$ & 213 & 486 & 699 \\
& $31 / 12 / 2010$ & 212 & 395 & 607 \\
& $31 / 12 / 2011$ & 214 & 213 & 427 \\
\hline GO & $31 / 12 / 2009$ & 227 & 285 & 512 \\
& $31 / 12 / 2010$ & 309 & 366 & 675 \\
& $31 / 12 / 2011$ & 243 & 259 & 502 \\
\hline MG & $31 / 12 / 2009$ & 55 & 132 & 187 \\
& $31 / 12 / 2010$ & 77 & 120 & 197 \\
& $31 / 12 / 2011$ & 154 & 154 & 308 \\
\hline MS & $31 / 12 / 2009$ & 939 & 2.010 & 2.949 \\
& $31 / 12 / 2010$ & 1.232 & 2.533 & 3.765 \\
\hline MT & $31 / 12 / 2011$ & 1.259 & 2.604 & 152 \\
& $31 / 12 / 2009$ & 62 & 90 & 156 \\
& $31 / 12 / 2010$ & 67 & 89 & 150 \\
\hline PR & $31 / 12 / 2011$ & 81 & 69 & 175 \\
\hline RJ & $31 / 12 / 2011$ & 47 & 128 & 487 \\
\hline RS & $31 / 12 / 2011$ & 238 & 249 & 450 \\
& $31 / 12 / 2009$ & 173 & 277 & 646 \\
\end{tabular}


Tabela 52 - Número de Empregados Anhanguera - 2009 - 2011

\begin{tabular}{|c|c|c|c|c|}
\hline Estado & Data Base & Administrativo & Docente & Total \\
\hline \multirow[t]{3}{*}{ SC } & $31 / 12 / 2009$ & 133 & 222 & 355 \\
\hline & $31 / 12 / 2010$ & 126 & 203 & 329 \\
\hline & $31 / 12 / 2011$ & 144 & 223 & 367 \\
\hline \multirow[t]{3}{*}{ SP } & $31 / 12 / 2009$ & 2.874 & 3.448 & 6.322 \\
\hline & $31 / 12 / 2010$ & 2.978 & 3.810 & 6.788 \\
\hline & $31 / 12 / 2011$ & 4.676 & 4.713 & 9.389 \\
\hline \multirow[t]{3}{*}{ Total } & $31 / 12 / 2009$ & 4.676 & 6.950 & 11.626 \\
\hline & $31 / 12 / 2010$ & 5.266 & 7.897 & 13.163 \\
\hline & $31 / 12 / 2011$ & 7.270 & 8.849 & 16.119 \\
\hline
\end{tabular}

Fonte: Anhanguera (2012d)

Abaixo o índice de rotatividade dos empregados da Anhanguera entre os anos de 2009 e 2011:

Tabela 53 - Índice de rotatividade docentes/administrativo Anhanguera - 2009-2011

\begin{tabular}{l|c|c|c}
\hline \multicolumn{1}{c}{ Categoria } & $\mathbf{3 1} / \mathbf{1 2} / \mathbf{2 0 0 9}$ & $\mathbf{3 1} / \mathbf{1 2 / 2 0 1 0}$ & $\mathbf{3 1 / 1 2 / 2 0 1 1}$ \\
\hline Docentes & $2,79 \%$ & $3,12 \%$ & $4,65 \%$ \\
Administrativo & $5,02 \%$ & $3,85 \%$ & $4,19 \%$ \\
\hline Fonte: Anhanguera (2012d) & &
\end{tabular}

Os dados acima evidenciam que, apesar das inúmeras aquisições feitas pela empresa entre os anos de 2009 a 2011, o número de docentes cresceu proporcionalmente pouco enquanto o número de alunos médio passou de 255 mil, em 31/12/2009, para $400 \mathrm{mil}$ em 31/12/2011 (crescimento de 56,86\%), o número de docentes passou de 6.950 para 8.849 , no mesmo período (crescimento de 27,32\%). Apesar disso, a Anhanguera (2012d, p. 474) entende ter havido um crescimento expressivo no número de seus colaboradores, sugerindo que esse número tende a diminuir nos próximos anos.

Abaixo dados sobre as reclamações trabalhistas ajuizadas contra a Companhia e suas subsidiárias:

Tabela 54 - Reclamações Trabalhistas contra Anhanguera - 2009 - 2011

\begin{tabular}{ccc}
\hline Data Base & $\begin{array}{c}\mathbf{N}^{\mathbf{0}} \text { de Reclamações } \\
\text { Trabalhistas }\end{array}$ & $\begin{array}{c}\text { Contingência Estimada } \\
\text { (R\$ Milhões) }\end{array}$ \\
\hline $31 / 12 / 2009$ & 506 & 16,8 \\
$31 / 12 / 2010$ & 599 & 20,5 \\
$31 / 12 / 2011$ & 1.171 & 125,3 \\
\hline
\end{tabular}

Fonte: Anhanguera (2012d)

A tabela acima revela que, entre os anos de 2010 e 2011, houve um grande 
crescimento no número de reclamações trabalhistas contra o grupo Anhanguera. O número de reclamações quase dobrou, no período de um ano, e o valor de contingência multiplicou-se por seis. Esse crescimento pode estar conectado com as inúmeras operações de aquisição envolvendo a empresa ocorridas durante o ano de 2011, as quais implicaram demissões em massa, conforme abaixo descrito.

Interessante notar que, nesses processos de aquisição, a empresa adquirente, em geral, compra a estrutura física, adquire os alunos, mas o corpo docente e os demais funcionários não fazem parte do negócio.

Em seus vários processos de aquisição, a Anhanguera adapta a estrutura dos cursos das instituições adquiridas ao seu modelo empresarial, o que inclui adaptação da infraestrutura e metodologia (com a oferta de aulas a distância, AVA, PLT e demais metodologias acima descritas) e procura ganhar escala com a diminuição do número de funcionários e docentes das instituições adquiridas.

Segundo o Presidente do CA da Companhia, Antonio Carbonari Netto, a Anhanguera, após a implementação de sua infraestrutura padronizada, tem a seguinte razão de produtividade: 4 funcionários para cada 2 mil alunos ${ }^{501}$.

Segundo a Anhanguera (2012d, p. 149):

A Companhia pretende perseguir significativos ganhos de eficiência operacional nos próximos anos. Esses ganhos devem derivar principalmente de redução no custo operacional dos Câmpus adquiridos em 2007, 2009, 2010 e 2011, que operam em nível significativamente abaixo do padrão observado nos Câmpus orgânicos, e de diluição de despesas administrativas, resultante da sinergia entre as aquisições feitas no final de 2008, 2010 e 2011, ainda em integração, e ganhos de escala resultantes do crescimento esperado da operação da empresa. Adicionalmente, a Companhia também acredita que a crescente utilização de tecnologias de Ensino a Distância com escala e melhoria no mix de cursos nas unidades, com a crescente oferta cruzada de novos produtos nas unidades existentes, pode melhorar também a receita média por unidade e rentabilidade do modelo de negócios.

Com relação aos docentes, após uma série de aquisições na região metropolitana de

\footnotetext{
501 Em seminário realizado na ABMES, Carbonari afirmou: "Se você tem um centro de serviços compartilhados, você com certeza economizará funcionários. Faço eu hoje, tem feito a Estácio e outras instituições que estão trabalhando nesta área, estão aceitando a modernidade empregatícia através de centros de serviços compartilhados. Não há duplicação mais de funcionários. Evidentemente, a primeira vez quando eu comecei a faculdade eu tinha 30 funcionários na secretaria. Hoje, eu tenho 4 funcionários a cada 2 mil alunos. Opa, já tem uma razão de produtividade. 4 funcionários a cada 2 mil. Se uma faculdade tem 2 mil alunos e tiver mais que 4 funcionários, eu vou em cima do diretor. Porque a produtividade caiu. Então, hoje nós conseguimos aquilatar a relação de produtividade, pessoas, funções, tarefas (...) Aluno não tem com quem falar, tem, tem a máquina, fala com o computador, entra no CRM etc. e fala. Então, a racionalidade administrativa gera diminuição de pessoas". Áudio disponível em: $<$ http://www.abmes.org.br/abmes/video/detalhe/id/39>. Acesso em: 01/08/2012.
} 
São Paulo (principalmente, Uniban, UniABC e Senador Fláquer), a mídia divulgou que a Anhanguera efetuou demissões em massa no final do ano de 2011, que, segundo o Sinpro-SP (Sindicato dos docentes), teriam sido o maior corte numa instituição de ensino em, ao menos, $20 \operatorname{anos}^{502}$.

Segundo o Jornal Valor Econômico ${ }^{503}$ :

A Anhanguera Educacional demitiu cerca de 1,5 mil professores neste fim de ano, segundo a Federação dos Professores do Estado de São Paulo (Fepesp), entidade que reúne 24 sindicatos da categoria. Esse volume representa cerca de $34 \%$ do corpo docente das faculdades da Anhanguera.

Ainda de acordo com a Fepesp, a maior concentração das demissões foi no Grande ABC paulista, onde o percentual de demissões em relação ao total de professores sobe para $40 \%$. A entidade reuniu informações de 13 sindicatos de professores de São Paulo e não contabiliza as demissões de professores com menos de um ano de emprego, uma vez que esses profissionais realizam suas homologações junto à própria Anhanguera, conforme determina a legislação trabalhista. Com isso, o número de demitidos pode ser maior se for levado em consideração os professores com menos de um ano de trabalho, de acordo com a Fepesp.

Segundo o Sinpro-SP, boa parte dos demitidos são mestres e doutores, que possuem salários mais altos. Para substituí-los, a Anhanguera contrataria docentes com titulação mais baixa e por salários menores ${ }^{504}$. Para 2012, a Anhanguera efetuaria outra mudança: os mestres e doutores que permanecessem na empresa teriam sua carga horária reduzida, para a diminição do salário ${ }^{505}$. A esse respeito, destaca-se que a LDB estabelece a porcentagem de mestres e doutores para universidades e centros universitários (1/3), mas não estabelece um número mínimo de horas-aula.

Ainda segundo o Jornal Valor Econômico:

A Anhanguera Educacional esclareceu, por meio de nota, que o "desligamento de profissionais do corpo docente aconteceu em função do planejamento de carga horária deste semestre e faz parte de um movimento natural das instituições de ensino a cada encerramento de ciclo (semestre). A Anhanguera também reitera que realizou um grande ciclo de aquisições em 2011, com 12 instituições adquiridas, e que a atualização do corpo docente é necessária para adaptar os currículos das novas unidades ao padrão de qualidade dos cursos da Anhanguera. Neste ajuste, a Anhanguera reduziu o número de professores temporários, mas também fará

\footnotetext{
${ }^{502}$ De acordo com o Sinpro-SP, dos 790 professores do quadro da Uniban, 380 deles foram demitidos."Demitir até $10 \%$ do quadro de professores pode ser aceitável, mas $50 \%$ é demissão em massa". Fontes: $<$ http://www1.folha.uol.com.br/fsp/cotidiano/16182-anhanguera-demite-680-professores.shtml > $<$ http://www.estadao.com.br/noticias/impresso,anhanguera--demite-680-professores-,814116,0.htm>. Acesso em 02/08/2012.

${ }^{503}$ Reportagem de 06/02/2012.

${ }^{504}$ Segundo professores, um mestre da Uniban ganha R\$ 38 por hora. A Anhanguera pagararia R\$ 26 aos novatos. Fonte: <http://www1.folha.uol.com.br/fsp/cotidiano/16182-anhanguera-demite-680-professores.shtml $>$. Acesso em 02/08/2012.

505 Fonte: <http://www1.folha.uol.com.br/fsp/cotidiano/16182-anhanguera-demite-680-professores.shtml >. Acesso em 02/08/2012.
} 
contratações de outros em regime integral."

A Anhanguera informou ainda que para "fortalecer a sua atuação na área de pesquisa científica, a Anhanguera criará, a partir de 2012, Núcleos de Pesquisa em oito grandes áreas do conhecimento, compostos por professores doutores e mestres com atuação em regime integral e foco na produção científica e na orientação de Trabalhos de Iniciação Científica dos alunos."

A demissão em massa de docentes e as alterações nas metodologias de ensino, em conjunto com outros problemas envolvendo a administração das instituições e infraestrutura dos cursos, geraram diversos protestos de alunos em várias instituições adquiridas pelo grupo. Dentre as reclamações dos alunos, além da substituição de aulas presenciais por aulas a distância e demissão de professores com mestrado e doutorado, está a superlotação de salas de aula, em que cursos diferentes são reunidos para a mesma aula, com a diminuição da carga horária, aumento abusivo de mensalidade e mudanças na grade curricular sem aviso prévio ${ }^{506}$.

Um desses protestos ocorreu no antigo campus da Uniban, na Rua Maria Cândida em São Paulo. Nesse protesto, ocorrido em 23 de abril de 2012, os alunos mostraram sua insatisfação pela implantação de $20 \%$ do curso em atividades on-line $e^{507}$.

Conforme noticiado pelo jornal O Estado de São Paulo ${ }^{508}$ :

[...] câmpus de Maria Cândida fica praticamente vazio nas noites de sexta-feira. O dia é separado para alunos fazerem exercícios no Ambiente Virtual de Aprendizagem (AVA), site em que os estudantes têm acesso a videoaulas, apostilas e exercícios e devem discutir os assuntos em fóruns e chats.

Essa prática está de acordo com a legislação, que autoriza as instituições de ensino a oferecerem até $20 \%$ da carga horária das graduações em módulos semipresenciais, com avaliações presenciais. Mas não é desejada pelos alunos que compraram um curso presencial e não a distância.

Segundo o jornal, "os estudantes da Anhanguera reclamam da qualidade das atividades, de problemas para acessar o material e da falta de acompanhamento de professores e tutores" ${ }^{\prime 509}$.

A vice-presidente da UNE em São Paulo, Laís Gouveia, entendeu que essa

\footnotetext{
${ }^{506}$ Fontes: <http://www.dgabc.com.br/News/5945822/s-bernardo-estudantes-da-anhanguera-protestam.aspx >. e $<$ http://www.estadao.com.br/noticias/impresso,alunos-da-anhanguera-reclamam-de-falta-deaula,864233,0.htm>. Acesso em 02/08/2012.

507 Fonte: <http://www.estadao.com.br/noticias/vidae,protesto-contra-anhanguera-reune-estudantes-na-zonanorte-de-sp,864531,0.htm\#bb-md-noticia-tabs-2>. Acesso em: 02/08/2012.

508 Fonte: <http://www.estadao.com.br/noticias/vidae,protesto-contra-anhanguera-reune-estudantes-na-zonanorte-de-sp,864531,0.htm\#bb-md-noticia-tabs-2>. Acesso em: 02/08/2012.

509 Fonte: <http://www.estadao.com.br/noticias/vidae,protesto-contra-anhanguera-reune-estudantes-na-zonanorte-de-sp,864531,0.htm\#bb-md-noticia-tabs-2>. Acesso em: 02/08/2012.
} 
manifestação cumpriu o papel de denunciar o descaso com o qual a rede Anhanguera vem tratando os estudantes. Segundo Laís Gouveia: “a maior preocupação deles (Anhanguera) não é prezar por sua excelência, mas sim por suas ações que estão na bolsa. O protesto surge para dar um basta na concepção mercadológica que rege hoje o ensino privado",510.

Em resposta aos protesto, a Anhanguera afirmou que "todas as instituições de ensino que integram o grupo atendem às exigências da legislação educacional e dos instrumentos de avaliação do MEC” e que "os alunos não estão dispensados de permanecer na instituição às sextas-feiras", mas sim que são orientados a fazer atividades complementares, como “elaboração do trabalho de conclusão de curso, ou realização de um estudo de caso que, conforme o tema, pode ser realizado em sala de aula ou em outros locais do câmpus" ${ }^{, 511}$.

Protestos por motivos semelhantes ocorreram também em março de 2012, em Campo Grande - MS ${ }^{512}$ e São Bernardo do Campo - SP (cerca de 500 alunos, segundo informações da mídia) $)^{513}$; e em maio de 2012, em Osasco - SP (ao menos 150 alunos) ${ }^{514}$.

A Anhanguera reconhece como um fator de risco em sua atividade as dificuldades que enfrenta para abrir, integrar e gerenciar com eficiência um número cada vez maior de unidades. Nas palavras da Companhia (2012d, p. 15):

\begin{abstract}
A Companhia pode enfrentar riscos significativos no processo de integração das operações de unidades adquiridas às operações das unidades existentes, tais como a incapacidade de administrar um número maior de funcionários dispersos geograficamente e criar e implementar controles, procedimentos e políticas uniformes com eficiência, além de incorrer em custos de integração elevados. A Companhia pode não ser capaz de integrar o corpo docente e os funcionários com experiência profissional e culturas corporativas diferentes, e seu relacionamento com os funcionários, atuais e os novos, inclusive professores, pode ser prejudicado. A Companhia não pode garantir que conseguirá administrar com eficiência um número cada vez maior de unidades e integrá-las totalmente em sua estrutura centralizada sem comprometer sua lucratividade, não podendo garantir, ainda, que obterá o benefício desejado em cada potencial aquisição. Se a Companhia não for capaz de administrar seu crescimento com eficiência, seu negócio poderá ser prejudicado significativamente.

A estratégia de expansão seletiva da Companhia, inclui a expansão por meio da abertura de novas unidades e aquisição de outras instituições de ensino e sua integração à sua rede. Os planos de expansão da Companhia criarão desafios significativos em termos de manutenção da consistência de sua qualidade e cultura de ensino e da garantia de que sua marca não será prejudicada em decorrência de qualquer queda, real ou percebida, de sua qualidade de ensino.
\end{abstract}

510 Disponível em: <http://www.une.org.br/2012/04/educacao-merece-respeito-estudantes-protestam-contra-ogrupo-anhanguera/>. Acesso em: 25/09/2012.

511 Fonte: <http://www.estadao.com.br/noticias/impresso,instituicao-diz-que-alunos-nao-estao-dispensados-as6s-,864242,0.htm>. Acesso em: 02/08/2012.

512 Fonte: <http://www.campograndenews.com.br/cidades/capital/academicos-de-arquitetura-e-urbanismo-dauniderp-organizam-protesto $>$. Acesso em: 02/08/2012.

513 Fonte: <http://www.dgabc.com.br/News/5945822/s-bernardo-estudantes-da-anhanguera-protestam.aspx $>$. Acesso em: 02/08/2012.

${ }^{514}$ Fonte: $\quad<$ http://noticias.r7.com/educacao/noticias/alunos-da-faculdade-anhanguera-fazem-protesto-contrabaixo-nivel-de-ensino-20120507.html>. Acesso em: 02/08/2012. 
Caso a Companhia não seja capaz de manter seus padrões de qualidade atuais e de beneficiarse de ganhos de escala, a Companhia pode perder sua participação de mercado e ter seus resultados financeiros adversamente afetados.

\subsubsection{Questão 17}

Neste subitem procuramos responder à seguinte questão:

\section{Quadro 18 - Questão da Análise Empírica nº 17}

\begin{tabular}{|l|l|}
\hline $\mathbf{N}^{\mathbf{0}}$ & \multicolumn{1}{|c|}{ Grupo III - Educação como direito humano, bem público e serviço público } \\
\hline 17. & $\begin{array}{l}\text { Qual a relação entre alunos ingressantes/concluintes da Anhanguera? Qual a taxa de evasão da } \\
\text { Anhanguera? }\end{array}$ \\
\hline
\end{tabular}

Abaixo a descrição do fluxo de alunos da Anhanguera durante o ano de 2011:

Tabela 55 - Fluxo alunos Anhanguera 2010 - 2011

\begin{tabular}{|c|c|c|c|c|}
\hline Alunos (mil) & $\begin{array}{c}\mathbf{3}^{\mathbf{0}} \\
\text { Trimestre } \\
\mathbf{2 0 1 0}\end{array}$ & $\begin{array}{c}4^{0} \\
\text { Trimestre } \\
2010\end{array}$ & $\begin{array}{c}\mathbf{3}^{\mathbf{0}} \\
\text { Trimestre } \\
2011\end{array}$ & $\begin{array}{c}4^{0} \\
\text { Trimestre } \\
2011\end{array}$ \\
\hline Saldo Inicial de Ensino Superior & 236,4 & 230,1 & 281,7 & 292,5 \\
\hline Campi & 162,9 & 161,0 & 199,9 & 209,7 \\
\hline Polos & 73,5 & 69,1 & 81,8 & 82,7 \\
\hline (+) Aquisições & - & - & 9,7 & 47,7 \\
\hline Campi & - & - & 8,1 & 47,7 \\
\hline Polos & - & - & 1,6 & - \\
\hline (-) Formandos & $(24,8)$ & - & $(23,1)$ & $(2,9)$ \\
\hline Campi & $(11,8)$ & - & $(12,6)$ & - \\
\hline Polos & $(13,1)$ & - & $(10,5)$ & $(2,9)$ \\
\hline Base Renovável & 211,6 & 230,1 & 268,3 & 337,2 \\
\hline Campi & 151,2 & 161,0 & 195,4 & 257,4 \\
\hline Polos & 60,4 & 69,1 & 72,9 & 79,8 \\
\hline Renovados & 193,3 & 225,6 & 247,4 & 332,0 \\
\hline Campi & 140,9 & 159,1 & 183,2 & 254,8 \\
\hline Polos & 52,4 & 66,5 & 64,2 & 77,2 \\
\hline$(+)$ Entrantes & 36,8 & - & 45,0 & - \\
\hline Campi & 20,1 & - & 26,5 & - \\
\hline Polos & 16,7 & - & 18,5 & - \\
\hline Total Ensino Superior & 230,1 & 225,6 & 292,3 & 332,0 \\
\hline Campi & 161,0 & 159,1 & 209,7 & 254,8 \\
\hline Polos & 69,1 & 66,5 & 82,7 & 77,2 \\
\hline (+) Cursos Livres & 70,9 & 66,7 & 66,0 & 68,1 \\
\hline Campi & - & - & - & - \\
\hline Polos & 70,9 & 66,7 & 66,0 & 68,1 \\
\hline Total Geral & 301,0 & 292,2 & 358,3 & 400,1 \\
\hline Campi & 161,0 & 159,1 & 209,7 & 254,8 \\
\hline Polos & 140,0 & 133,1 & 148,7 & 145,3 \\
\hline
\end{tabular}

Fonte: Anhanguera (2012e)

Com relação aos cursos a distância, a média de evasão dos alunos matriculados na Anhanguera Educacional, em 2011, gira em torno de 13\% a 14\%, enquanto o índice 
internacional é de 50\% (ANHANGUERA, 2011d). Segundo a Anhanguera (2011d), "esse desempenho é resultado do modelo adotado pela Instituição, que prevê dois dias de presença do aluno em sala de aula. Na comparação com o ano anterior (2010), houve crescimento de 11,8\% no número de matrículas em EAD, que passou de 51 mil para 57 mil estudantes".

A Anhanguera acredita que os principais motivos de evasão de seus alunos são: (i) financeiros - como desemprego e impossibilidade de pagar as mensalidades; (ii) dificuldades em conciliar trabalho e estudo; e (iii) acadêmicos - que incluem perda de interesse em um curso específico ou reprovação continuada (ANHANGUERA, 2012d, p. 152).

Para lidar com esses problemas e diminuir a taxa de evasão de seus alunos, a Companhia está "desenvolvendo ações e iniciativas para aumentar os níveis de satisfação, aumentar a permanência e estimular o retorno aos estudos dos alunos desistentes"(ANHANGUERA, 2012d, p. 152).

Com relação às questões financeiras, a Anhanguera oferece as diferentes formas de financiamento de estudos descritas no item 4.2.5 acima e implementa políticas de parcelamento da dívida de alunos para facilitar a cobrança de valores em atraso e, assim, reduzir a evasão (ANHANGUERA, 2012d, p. 152).

\subsubsection{Questão 18}

Neste subitem procuramos responder à seguinte questão:

\section{Quadro 19 - Questão da Análise Empírica nº 18}

\begin{tabular}{|l|l|}
\hline $\mathbf{N}^{\mathbf{0}}$ & \multicolumn{1}{|c|}{ Grupo III - Educação como direito humano, bem público e serviço público } \\
\hline 18. & $\begin{array}{l}\text { Em quantos processos judiciais a Anhanguera é ré? Quais os principais pedidos envolvidos nesses } \\
\text { processos? Quais as principais demandas propostas pelos alunos? Quantos processos coletivos } \\
\text { existem contra a Anhanguera? Como é a jurisprudência dos tribunais superiores sobre a } \\
\text { Anhanguera? }\end{array}$
\end{tabular}

Abaixo uma breve descrição dos processos judiciais e administrativos revelantes, e que não estão em sigilo, em que a Anhanguera e suas subsidiárias são rés, em andamento na data de entrega do Relatório de Referência de 2012 e informados neste mesmo relatório (ANHANGUERA, 2012d) ${ }^{515}$, além de informações sobre a jurisprudência dos tribunais

\footnotetext{
${ }^{515}$ No Relatório de Referência são informados processos judiciais, administrativos ou arbitrais em que o emissor ou suas controladas sejam parte, discriminando entre trabalhistas, tributários, cíveis e outros: (i) que não estejam sob sigilo, e (ii) que sejam relevantes para os negócios do emissor ou de suas controladas relevantes e não sigilosos. Os critérios de relevância adotados pela Anhanguera para a seleção dos processos foram os seguintes:
} 
superiores (STF e STJ) a respeito de demandas envolvendo a Anhanguera.

Ressaltamos que, para uma análise mais aprofundada das demandas aqui descritas, com a verificação dos principais argumentos das partes e do conteúdo das decisões, seria necessário o acesso aos autos de cada um dos processos e procedimentos, o que não foi implementado nesta pesquisa. Esse acesso depende da disponibilização de cópia das petições, sentenças e demais documentos nos órgãos competentes, o que geralmente apenas é possível mediante o pedido no próprio órgão, que disponibiliza o documento em cópia física (com exceção dos órgãos que já possuem tais documentos digitalizados e para acesso público em seus sites).

\subsubsection{Matéria tributária}

Existem dois procedimentos administrativos com a Receita Federal do Brasil (Processo $\mathrm{n}^{\mathrm{o}}$ 13839.000613/2008-00 / MPF $\mathrm{n}^{\mathrm{o}}$ 0812400/00543/05 e Processo $\mathrm{n}^{\mathrm{o}}$ 13839.000612/2008-57 / MPF $\mathrm{n}^{\mathrm{o}}$ 0812400/00543/05) que questionam a dedutibilidade de IRPJ, CSLL, Programa de Integração Social e Contribuição para o Financiamento da Seguridade Social de doações feitas à Fundação Nacional de Desenvolvimento do Ensino Superior Particular (Funadesp) nos anos de 2003, 2004 e 2005, além de diferenças apuradas por verificações mensais nos recolhimentos desses impostos e contribuições entre julho de 2003 e outubro de 2007. O valor envolvido nessas demandas era de R \$13 milhões, em 31/12/2011 (ANHANGUERA, 2012d, pp. 29-30).

Há um Procedimento Investigatório Criminal ( $\mathrm{n}^{\circ}$ 2008.61.05.0122903), em que são partes administradores da Anhanguera para apuração de eventual prática dos crimes previstos nos artigos 168-A (apropriação indébita previdenciária) e 337-A (sonegação de contribuição previdenciária) do Código Penal. O procedimento está suspenso até a apuração de autos de infração que tramitam perante a Receita Federal de Jundiaí (ANHANGUERA, 2012d, p. 81).

Há um Inquérito Policial (nº 9-887/2004) em trâmite na Delegacia da Polícia Federal de Campinas desde setembro de 2004, no qual são partes antigos sócios e administradores da

(i) valores envolvidos referentes às contingências cuja chance de perda pela Companhia, suas subsidiárias ou controladas, foi considerada pelos advogados responsáveis como provável ou possível, que envolvam valores acima de R\$ 1.000.000,00; (ii) sem prejuízo do disposto no item acima, todas as contingências que a administração da Companhia entende relevantes para a decisão de investimento de seus acionistas e do mercado em geral, especialmente as ações de natureza tributária, previdenciária, regulatória e propriedade intelectual, independentemente do prognóstico de perda da ação definido pelo advogado responsável e dos valores envolvidos. 
Anhanguera para apurar a prática de crime contra a ordem tributária em virtude da comercialização irregular de cotas em IES constituídas sob a forma de associações sem fins lucrativos, bem como indícios de retirada disfarçada de lucros. Em dezembro de 2010, os autos foram apensados ao Procedimento Investigatório $\mathrm{n}^{\mathrm{o}}$ 2008.61.05.0122903 (ANHANGUERA, 2012d, p. 82).

Segundo informações da Companhia (2010d, pp. 18-21), a Aesa teve sua imunidade, entre os anos de 2002 e 2003, suspensa pela Receita Federal. As razões para a suspensão da imunidade, segundo a Anhanguera (2010d, pp. 18-21), foram as seguintes: “(i) transformação de associação sem fins lucrativos para sociedade com fins lucrativos em julho de 2003"; (ii) "falta de autenticação dos livros diários no exercício de 2003"; (iii) "suposta remuneração indireta dos dirigentes"; (iv) "ausência de tributação sobre outras receitas não operacionais quando tributadas pelo lucro presumido, bem como de receitas oriundas de prestação de serviços". De acordo com a Anhanguera (2010d, p. 18), a empresa "optou por recolher os débitos à vista com os benefícios do Refis 4". Os débitos referentes à suspensão da imunidade alcançaram R $\$ 13,2$ milhões em 20/12/2007 $7^{516}$.

Há onze execuções fiscais em face da Uniban, promovidas pela Prefeitura Municipal de São Paulo - SP e de São Bernardo do Campo - SP, referentes à cobrança de ISS não pagos entre os anos de 2003 a 2006, com valor de R\$112 milhões, em 31/12/2011. Conforme previsão em contrato, a responsabilidade pelo pagamento de eventual condenação é dos antigos proprietários da Uniban, e não da Anhanguera (ANHANGUERA, 2012d).

Há cinco execuções fiscais em face da Uniban promovidas pela Prefeitura Municipal de São Paulo, referentes à cobrança de multa de obras no valor de $\mathrm{R} \$ 9,8$ milhões, em 31/12/2011 (ANHANGUERA, 2012d).

Dentre os processos e procedimentos administrativos tributários analisados acima,

\footnotetext{
${ }^{516}$ Segundo informações da Anhanguera, "existiam quatro inquéritos policiais para apuração de eventual prática, por parte da Companhia e de seus principais executivos de crimes contra a ordem tributária e econômica. Tais inquéritos policiais investigavam a suposta comercialização irregular de cotas em Institutos de Ensino Superior, e a suposta prática de sonegação fiscal por eventual distribuição disfarçada de lucros por meio da remuneração que a Companhia pagou aos seus administradores sócios no período anterior a 2003, quando as subsidiárias da Companhia, entidades mantenedoras, eram associações sem fins lucrativos e gozavam de benefícios fiscais. Três inquéritos policiais foram instaurados em 2004. Dois deles já foram arquivados, e o remanescente encontra-se em fase de oitiva de testemunhas. Nenhum dos três inquéritos gerou qualquer denúncia oficial por parte da promotoria. O quarto inquérito policial foi distribuído em 2008 e está suspenso aguardando deliberações quanto a dois processos administrativos que tramitam perante a Receita Federal. Inicialmente eram oito processos administrativos; contudo, a Companhia aderiu ao Refis proposto pela Lei 11.941/09, o que gerou a extinção de seis processos, vindo a discussão administrativa a se concentrar tão somente nos dois processos administrativos remanescentes. A apuração de irregularidades nesses Inquéritos Policiais pode ensejar a cobrança de tributos eventualmente devidos pela Companhia em decorrência desses eventuais ilícitos (ANHANGUERA, 2010d, p. 29).
} 
chamam atenção aqueles referentes à suspensão da imunidade tributária. Como vimos neste Capítulo, o grupo Anhanguera iniciou suas atividades por meio de IES sem fins lucrativos. Por meio das informações constantes neste item, nota-se que referidas IES foram alvo de investigações e pagaram débitos referentes a práticas adotadas durante este período que não seriam condizentes com a natureza de IES sem fins lucrativos.

\subsubsection{Matéria Cível}

O Ministério Público do Estado de São Paulo ingressou em junho de 2004 com uma Ação Civil Pública em face da Unifec (União para Formação, Educação e Cultura do ABC Ltda.), visando a apuração de propaganda enganosa, com relação à veiculação de propaganda aos interessados no processo seletivo de 1995, que informava que a Universidade possuía uma série de laboratórios e condições estruturais que não correspondiam à realidade. Em $2^{\mathrm{a}}$ Instância, a Companhia teve êxito, mas ainda aguarda o julgamento de Recurso Especial interposto pelo MP (ANHANGUERA, 2012d, p. 46).

A Fundação Universitária Vida Cristã (Funvic) ingressou em novembro de 2007 com uma Ação Civil Pública em face da Aesa, objetivando cancelar os processos seletivos agendados para 02 de dezembro de 2007 em todo o País, ou subsidiariamente, o cancelamento nas cidades de Pindamonhangaba, Americana, Bauru, Guaratinguetá, Osasco, São José dos Campos, São Paulo, Sumaré e para a Faculdade Politécnica de Taubaté, sob a alegação de que os cursos oferecidos não haviam sido aprovados pelo Ministério da Educação. O processo ainda está pendente de julgamento em $1^{\circ}$ grau (ANHANGUERA, 2012d, p. 48).

Em março de 2009, o Ministério Público Federal ingressou com uma Ação Civil Pública (Processo $n^{0}$ 2009.61.00.007828-5) em face da Uniban, questionando o percentual de docentes mestres e doutores da instituição. Esta ação ainda está pendente de julgamento em $1^{\circ}$ grau (ANHANGUERA, 2012d, p. 70).

O Ministério Público Federal ingressou com nove Ações Civis Públicas, em diferentes Varas Federais, em face da Aesa (Processos $n^{\text {os }}$ 2007.61.00.025387-6, 2008.61.05.003234-3, 2008.61.26.000351-7, 200872.01.000266-7, 2006.61.08.007239-5, 2006.61.15.000174-8) para a proibição de cobrança de quaisquer valores para a emissão e registro de diplomas, com a devolução em dobro dos valores pagos pelos discentes com essa finalidade nos últimos cinco anos. Na maioria dessas ações, o MPF teve êxito em $1^{\text {a }}$ instância. Como resultado dessas ações, a Anhaguera deixou de cobrar taxa de expedição de diploma (ANHANGUERA, 
2012d).

O Ministério Público Federal ingressou com três Ações Civis Públicas (Processos $n^{\text {os }}$ 2008.61.00.007998-4, 002087-30.2011.403.6108 e 0001764.04.2011.403.6115) em face da Aesa questionando valores praticados pela empresa para cobrança de atividades puramente administrativas ou complementares, como a emissão de históricos escolares, documentos e aplicação de trabalhos para a compensação de faltas. O processo foi extinto sem julgamento de mérito. O MPF recorreu da decisão e aguarda o julgamento do recurso (ANHANGUERA, 2012d).

O Ministério Público Federal ingressou, em junho de 2009, com uma Ação Civil Pública (Processo n ${ }^{0}$ 2009.61.00.013545-1) contra a Aesa alegando que a Companhia oferece alguns cursos sem autorização do Ministério da Educação, "valendo-se de atos autorizativos concedidos às instituições de ensino superior mantidas por outras entidades mantenedoras". Alega que, embora tais entidades pertençam ao grupo econômico da Anhanguera, a oferta desses cursos dependeria de atos administrativos que confirmassem a transferência da mantença dessas instituições. Alegou ainda que a oferta de tais cursos sem a efetiva transferência induz a erro os alunos/consumidores e configura propaganda enganosa. Por fim, alegou irregularidade da expressão "presencial-interativa". Referido processo foi distribuído por dependência à Ação Civil Pública n ${ }^{\circ}$ 2007.61.21.005014-3 ${ }^{517}$ (ANHANGUERA, 2012d, pp. 50-1).

Em outubro de 2009, o Ministério Público do Estado do Mato Grosso ingressou com uma Ação Civil Pública (Processo $n^{\circ}$ 761/2009) em face da Aesa para cumprimento da oferta de mensalidade entre $\mathrm{R} \$ 350,00$ e $\mathrm{R} \$ 450,00$, divulgada em anúncios publicitários e em reunião da direção da instituição com o corpo discente, e devolução dos valores já cobrados. A ação foi julgada improcedente, o MP recorreu e aguarda o julgamento do recurso (ANHANGUERA, 2012d, p. 77).

\footnotetext{
${ }^{517}$ Nesse processo foi deferida medida liminar favorável ao autor para determinar que a Anhanguera: (i) se abstenha de praticar publicidade que associe o seu nome à prestação de serviço de educação superior mantido por instituição cuja transferência de mantença ainda não tenha ocorrido; (ii) remova dos polos de Pindamonhangaba e Sumaré qualquer referência às "Faculdades Anhanguera" e "Faculdade Interativa de Pindamonhangaba"; (iii) informe ostensivamente, nas dependê ncias de todos os polos de apoio presencial de ensino a distâ ncia, que tais polos não oferecem ensino presencial e que os diplomas serão emitidos pela Universidade para o Desenvolvimento do Estado e da Região do Pantanal; (iv) se abstenha de utilizar em qualquer publicação a expressão "presencial-interativa" para se referir a cursos de ensino a distância; (v) suspenda a oferta de cursos de Administração de Serviço Social prestados a distância pela Universidade para o Desenvolvimento do Estado e da Região do Pantanal; (vi) publique, sob pena de multa diária de R\$ $50.000,00$, em jornais de grande circulação contrapropaganda informando que não é a mantenedora dos cursos presenciais oferecidos, que os cursos a distância são mantidos pela Universidade para o Desenvolvimento do Estado e da Região do Pantanal e que esta expedirá os diplomas" (ANHANGUERA, 2012d, pp. 50-1).
} 
A Defensoria Pública do Estado do Rio de Janeiro ingressou em fevereiro de 2011 com uma Ação Civil Pública em face da Sociedade Educacional Plínio Leite (Unipli) visando a anulação da transferência do curso de Direito da Unipli do bairro de Camboinhas (Niterói RJ) para o centro de Niterói - RJ. Este processo encontrava-se em fase de instrução em 31/12/2011 (ANHANGUERA, 2012d, p. 47).

O Ministério Público do Estado de Santa Catarina ingressou com uma Ação Civil Pública (Processo $n^{\circ}$ 008.11.005281-9) contra a Aesa em março de 2011 para discutir cláusulas insertas nos contratos de prestação de serviços educacionais, como por exemplo, a exigência de cheques pré-datados ou notas promissórias como forma de garantia dos contratos. Esse processo está pendente de julgamento em $1^{\circ}$ grau (ANHANGUERA, 2012d, p. 58).

Há uma Ação de Indenização (Processo n ${ }^{0}$ 583.00.1999.112476-1) proposta por 38 alunos em face da Uniban, que discute a impossibilidade do exercício da profissão pela falta de requisitos legais da Companhia para o oferecimento do curso de farmácia. Em $1^{\mathrm{a}}$ instância os alunos obtiveram êxito com relação ao pedido de dano moral. As partes recorreram e aguarda-se julgamento do recurso (ANHANGUERA, 2012d, p. 61).

Há uma Ação de Indenização (Processo $n^{0}$ 064.08.016137-9/001) proposta por 36 alunos em face da União de Escolas de Educação Corporativa (Unesec) visando indenização por perdas e danos pela interrupção do curso durante seu andamento. Foi concedida liminar determinando que a Companhia deve arcar com os custos para a conclusão do curso pelos alunos em instituição diversa. De acordo com disposição contratual, a responsabilidade por essa demanda é dos antigos sócios da Unesec e não da Anhanguera (ANHANGUERA, 2012d, p. 62).

Em dezembro de 2003, o Ministério Público do Estado de São Paulo ingressou com uma Ação Civil Pública (Processo n ${ }^{\circ}$ 583.00.2003.164829-6) em face da Uniban pleiteando o reembolso dos alunos pelo cancelamento de matrícula. A Ação foi julgada procedente, e a Uniban recorreu. Recurso aguardando julgamento (ANHANGUERA, 2012d, p. 68).

Em agosto de 2003, o Ministério Público do Estado de São Paulo ingressou com Ação Civil Pública (Processo $\mathrm{n}^{\circ}$ 583.00.2003.105054-9) em face da Uniban pleiteando o cancelamento da multa pelo atraso no pagamento das mensalidades previstas no Contrato de Prestação de Serviços Educacionais, de 9\% sobre o valor da parcela inadimplida, bem como a devolução dos valores cobrados. A sentença foi favorável ao MP, a Companhia recorreu e o STJ manteve a decisão de $1^{\mathrm{a}}$ instância. $\mathrm{O}$ contrato foi alterado e, de acordo com disposição 
contratual, a responsabilidade por essa demanda é dos antigos sócios da Uniban (ANHANGUERA, 2012d, p. 69).

Em novembro de 1999, o Ministério Público do Estado de Mato Grosso do Sul ingressou com uma Ação Civil Pública (Processo $n^{0}$ 001.99.035634-9) em face da Aesa visando à devolução dos valores pagos pelos alunos que cancelaram suas matrículas em 1995, antes de receberem os serviços educacionais oferecidos pela Companhia. A Ação foi julgada procedente, com a condenação da Companhia a pagar multa de aproximadamente R\$ 1.600,00 por descumprimento de cada obrigação e por aluno. O MP recorreu da decisão e aguarda julgamento do recurso. De acordo com disposição contratual, a responsabilidade por essa demanda é dos antigos sócios da Cesup e não da Anhanguera (ANHANGUERA, 2012d, p. 63).

O Ministério Público do Estado do Mato Grosso do Sul ingressou em setembro de 2010 com uma Ação Civil Pública em face da Aesa (sucessora da Cesup) para a execução da sentença prolatada nos autos da Ação Civil Pública $n^{0}$ 001.96.027.644-7, que reconheceu: (a) a existência de cláusulas abusivas nos contratos de prestação de serviços educacionais firmados em 1996: $6^{\text {a }}$ (pagamento da semestralidade para quem vai cursar apenas uma ou mais disciplinas) e $8^{\mathrm{a}}$ (retenção do valor integral da $1^{\mathrm{a}}$ parcela, em caso de desistência); (b) determinou a exclusão de cláusula com estipulação de cobrança em favor de diretórios acadêmicos; (c) devolução simples dos valores indevidamente pagos; (d) determinou a mudança da data do vencimento do dia $1^{\circ}$ para o dia 10 de cada mês; e (e) multa de R\$ $1.000,00$ por aluno e por obrigação não cumprida. O contrato de prestação de serviços educacionais foi adequado, exceto com relação à data de vencimento das mensalidades, que passou para o $5^{\circ}$ dia útil. A ação de cumprimento está em trâmite para a habilitação dos alunos que estudaram entre 1996 e 2009, para provarem valores indevidamente pagos ou retidos, para serem ressarcidos e comprovarem a adequação do Contrato de Prestação de Serviços à decisão judicial. De acordo com disposição contratual, a responsabilidade por essa demanda é dos antigos sócios da Cesup e não da Anhanguera. (ANHANGUERA, 2012d, p. 64)

Analisando as demandas em matéria cível acima, nota-se que a maioria delas envolve Ações Civis Públicas movidas pelos Ministérios Públicos Federal e Estadual visando proteger interesses diversos dos alunos das IES integrantes do grupo. 


\subsubsection{Matéria Trabalhista}

Há uma Ação Civil Coletiva Trabalhista (Processo nº 00066500.25.2006.5.10.0005) movida pelo Ministério Público do Trabalho em face da Aesa (sucessora por incorporação da Sesla - Sociedade de Ensino Superior do Lago Ltda.), para o reconhecimento da existência de grupo econômico envolvendo a Sesla e a condenação da Sesla ao pagamento dos direitos trabalhistas devidos aos empregados demitidos. A sentença em $1^{\circ}$ grau foi procedente, e o processo encontrava-se em fase de execução em 31/12/2012. Por disposição contratual, a responsabilidade por essa demanda é dos antigos sócios da Sesla e não da Anhanguera (ANHANGUERA, 2012d, p. 29).

\subsubsection{Jurisprudência}

Efetuamos pesquisa de jurisprudência sobre a Anhanguera no Supremo Tribunal Federal e no Superior Tribunal de Justiça de São Paulo, no dia 02 de outubro de 2012.

Os critérios de busca para a pesquisa foram: (i) os termos "anhanguera" e "educacional”; e (ii) todos os tipos de decisão (súmulas, acórdãos, decisões monocráticas e informativos de jurisprudência).

Os resultados da pesquisa foram os seguintes:

(i) no STF localizamos apenas 1 decisão monocrática ${ }^{518}$ que tratava da matrícula em estabelecimento público de ensino superior, da esposa de um militar transferido ex-officio da Cidade de Manaus - AM para Brasília, que cursava Direito na Universidade do Amazonas (pública), mas cujo ingresso primário havia se dado por meio do Centro Universitário Anhanguera de Leme - SP. O STF decidiu pela matrícula da aluna, considerando apenas sua matrícula anterior (em instituição pública) e não o ingresso primário (em instituição privada).

(ii) no STJ localizamos 25 decisões monocráticas. Dessas (a) 7 tratavam de pedidos de indenização por conta da inscrição indevida de alunos em cadastros de restrição de crédito $^{519}$; (b) 16 tratavam de questões processuais diversas ${ }^{520}$, como agravos por conta de

\footnotetext{
518 Trata-se da Rcl nº 3651, Relator Min. Carlos Britto, publicada em 16/09/2005.

519 São elas: (i) AREsp n ${ }^{\circ}$ 226355; (ii) AREsp n ${ }^{\circ}$ 030567, Relatora Min. Maria Isabel Gallotti, publicada em 06/09/2012; (iii) AREsp no 018346, Relator Min. Paulo de Tarso Sanseverino, publicada em 30/08/2012; (iv) AREsp n ${ }^{\circ}$ 198032, Relator Min. Raul Araújo, publicada em 06/08/2012; (v) AgRg no AREsp n 031363, Relator Min. Massami Uyeda, publicada em 24/02/2012; (vi) AREsp $n^{\circ} 088468$, Relator Min. Marco Buzzi, publicada em 16/12/2011; e (vii) AREsp n ${ }^{\circ}$ 017966, Relator Min. Raul Araújo, publicada em 30/06/2011.
} 
decisões denegatórias de seguimento de Recurso Especial e de pedidos de liminar e conflitos de competência entre a Justiça Estadual e Federal para julgar demandas envolvendo ensino superior $^{521}$; e (c) duas ${ }^{522}$ tratavam de transferência de servidor público ex-officio e o direito de matrícula em instituição de ensino superior ${ }^{523}$.

Das informações acima, nota-se que um número pequeno de demandas envolvendo a Anhanguera alcançou o STF e o STJ. Isso decorre, provavelmente, do crescimento recente do grupo, ocorrido principalmente a partir do ano de 2007, e da demora do judiciário brasileiro para que as demandas alcancem e sejam julgadas pelo STF e STJ.

${ }^{520}$ São elas: (i) AREsp n ${ }^{\circ}$ 206960, Relator Min. Massami Uyeda, publicada em 27/08/2012; (ii) Rcl n ${ }^{\circ} 009167$, Relator Min. Raul Araújo, publicada em 06/08/2012; (iii) Rcl n ${ }^{0} 009374$, Relator Min. Ari Pargendler, publicada em 02/08/2012; (iv) AREsp n 031363, Relator Min. Massami Uyeda, publicada em 31/08/2011; (v) Rcl n 006007, Relator Min. Luis Felipe Salomão, publicada em 02/08/2011; (vi) AREsp n ${ }^{\circ}$ 016729, Relator Min. Massami Uyeda, publicada em 01/08/2011; (vii) $\mathrm{Ag} \mathrm{n}{ }^{0}$ 824612, Relator Min. Mauro Campbell Marques, publicada em 03/09/2009; (viii) $\mathrm{Ag} \mathrm{n}^{\circ}$ 824612, Relator Min. João Otávio de Noronha, publicada em 11/10/2007; (ix) Ag n 824612, Relator Min. João Otávio de Noronha, publicada em 09/05/2007; (x) Ag n ${ }^{\circ}$ 824612, Relator Min. João Otávio de Noronha, publicada em 18/04/2007; (xi) Ag n ${ }^{\circ}$ 824612, Relator Min. João Otávio de Noronha, publicada em 02/03/2007; (xii) $\mathrm{Ag} \mathrm{n}^{0}$ 824612, Relator Min. João Otávio de Noronha, publicada em 01/02/2007; (xiii) MS n ${ }^{0}$ 010125, Relator Min. Luiz Fux, publicada em 26/11/2004; (xiv) CC n ${ }^{\circ} 120518$, Relator Min. Herman Benjamin, publicada em 10/04/2012; (xv) CC n ${ }^{0} 118554$, Relator Min. Teori Albino Zavascki, publicada em 25/08/2011; e (xvi) CC n ${ }^{\circ} 110725$, Relator Min. Benedito Gonçalves, publicada em 18/06/2010.

521 A jurisprudência do STJ nessa matéria tem caminhado no seguinte sentido: CONFLITO DE COMPETÊNCIA. INSTITUIÇÃO PRIVADA DE ENSINO SUPERIOR. MATRÍCULA. COMPETÊNCIA DA JUSTIÇA ESTADUAL COMUM. 1. Hipótese em que a Justiça Federal e a Justiça Estadual discutem a competência para processamento e julgamento de Ação Ordinária, na qual se objetiva a matrícula em instituição privada de ensino superior. 2. A partir do julgamento do Conflito de Competência 35.972/SP, a Primeira Seção decidiu que o critério definidor da competência da Justiça Federal é, em regra, ratione personae, isto é, leva em consideração a natureza das pessoas envolvidas na relação processual. 3. "Ações de conhecimento, cautelares ou quaisquer outras de rito especial que não o mandado de segurança - a competência será federal quando a ação indicar no polo passivo a União Federal ou quaisquer de suas autarquias (art. 109, I, da Constituição da República); será de competência estadual, entretanto, quando o ajuizamento voltar-se contra entidade estadual, municipal ou contra instituição particular de ensino." (REsp n ${ }^{\circ}$ 373.904/RS, Rel. Ministro Castro Meira, Segunda Turma, DJ de 09.05.2005). 4. Conflito de Competência conhecido para declarar a competência do Juízo de Direito da $1^{\text {a }}$ Vara de Itaperuna - RJ, o suscitado (CC 58.880/RJ, Rel. Ministro Herman Benjamin, Primeira Seção, DJU 1\%/10/2007).

${ }_{522}$ São elas: (i) AREsp n ${ }^{\circ} 216004$, Relator Min. Arnaldo Esteves Lima, publicada em 24/09/2012; e (ii) REsp n ${ }^{\circ}$ 624432, Relatora Min. Denise Arruda, publicada em 04/08/2004.

${ }^{523}$ A posição do STJ é diferente da exposta pelo STF nesse assunto. O STJ entende que a instituição apenas deve ser congênere à instituição anterior, se houver instituição com essas características na cidade para a qual o servidor foi transferido. Nesse sentido: "ADMINISTRATIVO. AGRAVO REGIMENTAL. RECURSO ESPECIAL. ENSINO SUPERIOR. MATRÍCULA COMPULSÓRIA. TRANSFERÊNCIA EX OFFICIO. DEPENDENTE DE MILITAR. VIOLAÇÃO. PRINCÍPIO DA IGUALDADE. MATÉRIA DE ÍNDOLE CONSTITUCIONAL. IMPOSSIBILIDADE. APRECIAÇÃO VIA ELEITA DO ESPECIAL. I - Esta Colenda Corte vem admitindo a matrícula compulsória em instituições públicas de ensino superior àqueles transferidos no interesse da Administração Pública, bem como a seus dependentes, independentemente do fato de serem egressos de instituições privadas de ensino - entendimento do art. $1^{\circ}$, da Lei $n^{\circ} 9.536 / 97$. II - A interpretação acerca de violação ao Princípio da Igualdade propugnado pela Constituição Federal, como também a artigos isolados da Lei Maior é reservada ao Supremo Tribunal Federal, sendo defeso a esta Corte Superior sua análise ainda que para fins de prequestionamento. III - Agravo regimental a que se nega provimento." (AGRESP ${ }^{\circ}$ 542940/PR, $1^{\text {a }}$ Turma, Rel. Min.Francisco Falcão, DJU de 03.11.03, p. 277). 


\section{CONCLUSÃO}

Após o desenvolvimento do tema proposto para esta Dissertação nos quatro capítulos antecedentes, apresentamos aqui a conclusão da pesquisa. A presente Conclusão foi estruturada com base nos objetivos da Dissertação e nos resultados apurados em cada um dos seus capítulos, com destaque para as conclusões relacionadas ao objetivo principal da Dissertação de analisar a compatibilidade entre a lógica econômica e o ensino superior a partir do estudo do caso da Anhanguera.

Com relação à análise da educação como direito humano, bem público e serviço público, desenvolvida principalmente no Capítulo 1, concluímos que:

(i) o direito à educação, tradicionalmente concebido como um direito de segunda dimensão, por apresentar características de direitos de primeira dimensão (dada sua conexão com a liberdade) e de terceira dimensão (dada sua conexão com o desenvolvimento); e também por ser um direito essencial para a efetivação de direitos de outras dimensões, pode ser considerado um direito multidimensional e instrumental. Essa abordagem valoriza a interdependência e a indivisibilidade dos direitos humanos e o entendimento de que a divisão dos direitos em dimensões deve ser utilizada apenas como uma técnica para a compreensão desses direitos;

(ii) a partir da característica de indivisibilidade, o direito à educação deve ser concebido como um direito à educação ao longo da vida. Nesse sentido, o direito à educação não pode ser fracionado, nem deve ser restringido à educação básica e obrigatória. $\mathrm{O}$ direito à educação inclui necessariamente o direito à educação superior, como prevê a Constituição de 1988, que não faz qualquer distinção com relação ao nível de ensino em seu artigo $6^{\circ}$. No entanto, por não ser obrigatório, o acesso ao ensino superior não é compulsório, ou seja, o Estado não pode impor ao indivíduo o acesso e permanência nesse nível de ensino, sujeito a sanções (como pode fazer na educação básica), pois o acesso está condicionado à escolha do indivíduo e ao preenchimento pelo postulante das condições necessárias para o acesso comprovação da capacidade individual, conforme o princípio da meritocracia previsto no artigo 208, V da Constituição de 1988. Mediante a decisão do indivíduo e uma vez preenchida a exigência de mérito, o acesso e a permanência no ensino superior devem ser garantidos pelo Estado;

(iii) todos os dispositivos constantes na Constituição e da LDB com relação à educação, ao ensino e atividades correlatas fazem parte do conteúdo normativo do direito à 
educação e são de observância obrigatória por todos os agentes envolvidos no processo educativo - Estado, instituições públicas e privadas de ensino, estudantes, pais e responsáveis. Concluímos que qualquer violação desses dispositivos representa violação do direito à educação e que as instituições privadas de ensino - considerando a eficácia horizontal dos direitos humanos - devem observar todos os preceitos constitucionais e legais, como parte do conteúdo normativo do direito à educação;

(iv) são características das universidades brasileiras: (a) a autonomia universitária; e (b) a indissociabilidade entre ensino, pesquisa e extensão. A autonomia universitária se dá em face do Estado e não significa independência, pois o Estado, ao mesmo tempo em que outorga a autonomia, autoriza e avalia o funcionamento da instituição, podendo, no caso de uma avaliação negativa, suspender temporariamente as prerrogativas de autonomia (art. 46, Parágrafo $\left.1^{\circ}, \mathrm{LDB}\right)$. A autonomia universitária envolve (a) a autonomia didático-científica; (b) a autonomia administrativa; e (c) a autonomia de gestão financeira e patrimonial. A previsão de autonomia universitária na Constituição de 1988 incentivou as IES privadas a adotar a forma de universidade, sobretudo pela possibilidade de criar e extinguir cursos na sede da instituição e de remanejar o número de vagas que os cursos oferecem. Por outro lado, a manutenção da previsão de indissociabilidade entre ensino, pesquisa e extensão desestimulou muitas IES privadas a adotar a forma de universidade por conta dos investimentos necessários ao desenvolvimento de pesquisa e extensão. Nesse sentido, o setor privado do ensino superior brasileiro adotou preferencialmente a forma de estabelecimentos isolados que não observam o modelo universitário;

(v) o fato da Constituição estabelecer que o ensino é livre à iniciativa privada não significa que ele possa ser organizado com a liberdade de iniciativa que caracteriza o exercício de atividades econômicas comuns. A exigência de cumprimento de normas constitucionais e infraconstitucionais para a sua oferta e a sua submissão à físcalização e avaliação pelo Poder Público tornam a liberdade de iniciativa na educação mais restrita que nas atividades econômicas comuns;

(vi) a concepção de educação como bem público encontra respaldo em autores como Gerald Grace (1989) e Fábio Nusdeo (2008) e foi contemplada em diversos documentos internacionais. Essa classificação ressalta o caráter coletivo e o interesse público que envolvem a educação, bem como os benefícios que ela deve proporcionar a todos, independentemente da condição financeira para pagamento pelo serviço, destacando que a educação não deve ser tratada como qualquer outro bem negociável no mercado, pois não se 
rege pela lógica do mercado;

(vii) a educação quando oferecida pelo Estado é considerada serviço público. Quando prestada por particulares, é questão jurídica controversa. A definição da educação como serviço público, mesmo quando oferecida por particulares, encontra respaldo em autores como Celso Antonio Bandeira de Mello (2011), Maria Sylvia Zanella Di Pietro (2006), Eros Grau (2010) e em decisões do Supremo Tribunal Federal (STF, ADI 1.266/BA, ADI 1.007/PE). Essa classificação realça o interesse público envolvido na atividade, a sua relevância social, como direito fundamental, bem como a necessidade de constante atuação do Estado para garantia deste direito para todos.

Com relação à análise da evolução histórica e jurídica da educação superior no Brasil a partir da Constituição de 1988, desenvolvida principalmente no Capítulo 2, concluímos que:

(viii) apesar dos debates internacionais sobre a atuação do Estado no ensino superior e as controvérsias sobre a classificação da educação como um serviço privado no âmbito do GATS, o ensino superior passou a ser oferecido no Brasil por empresas, que possuem investidores estrangeiros, inclusive grupos de educação de outros países. Esse movimento ganhou impulso no período pós LDB e se intensificou nos anos 2000, considerando o mercado educacional promissor que se formou no País. Houve então o ingresso de grupos de educação de projeção internacional no mercado brasileiro, como as americanas Apollo Group e Laureate International Universities e a inglesa Pearson, e a atuação de investidores profissionais no setor. Esses fatores contribuíram para a entrada de empresas de educação na BM\&FBOVESPA, movimento iniciado pela Anhanguera em 2007 e seguido pelas empresas Estácio, Kroton, SEB e Abril Educação, e para uma onda de fusões e aquisições envolvendo empresas do setor;

(ix) nesse contexto, a partir da década de 1990, foram aprovadas emendas constitucionais e alterações legislativas que impulsionaram o crescimento do setor privado no ensino superior do Brasil;

(x) a principal lei foi a LDB, e as principais regras nela constantes que estimularam esse movimento foram: a quebra do modelo universitário, a criação de novas formas de organização acadêmica, a atribuição de autonomia universitária aos centros universitários, a substituição dos exames vestibulares pelo processo seletivo, a ampliação dos cursos que compõem o ensino superior e o incentivo ao desenvolvimento do ensino a distância. Essas medidas conferiram maior flexibilidade para a atuação do setor privado como a previsão envolvendo os centros universitários que possuem autonomia universitária, 
mas não precisam observar a indissociabilidade entre ensino, pesquisa e extensão; e as regras sobre os processos seletivos que podem ser realizados em diferentes épocas do ano e em formatos variados - e permitiram a redução dos custos operacionais das IES privadas, atendendo a interesses do setor privado;

(xi) os Decretos $\mathrm{n}^{\text {os }} 2.207 / 97$ e 2.306/97 autorizaram que as entidades mantenedoras de IES assumissem a forma de sociedades mercantis (hoje sociedades empresárias), e permitiram o desenvolvimento do setor privado com fins lucrativos no Brasil;

(xii) o Fundef $\left(E C n^{\circ} 14 / 96\right)$ e, posteriormente, o Fundeb (EC n 53 de 2006) permitiram a transferência de recursos para a educação, o que contribuiu para um avanço na universalização do ensino fundamental. Também contribuíram para esse avanço a Lei do Bolsa Escola (Lei $n^{o}$ 10.219/01) e o PNE (Lei n ${ }^{o}$ 10.172/01). A quase universalização do ensino fundamental e o crescimento do ensino médio impulsionaram o crescimento do ensino superior;

(xiii) a Lei $n^{\circ} 9.131 / 95$ e toda a regulamentação posterior em matéria de avaliação do ensino superior permitiram a criação de um Sistema Nacional de Avaliação da Educação Superior (Sinaes), com avaliações periódicas de cursos e instituições e aplicação de sanções. O sistema de avaliação é importante, principalmente para o controle pelo Estado da qualidade do ensino oferecido pelas IES brasileiras. O sistema apresenta falhas ao privilegiar uma regulação pelo mercado e deve ser aprimorado pelo Estado considerando que, segundo a lógica econômica, em decisões que envolvem custos e redução de lucros, bem como a produção de externalidades, empresas apenas alteram suas práticas mediante determinação legal;

(xiv) o Fies (Lei $\left.n^{\circ} 10.260 / 01\right)$ e o ProUni (Lei $\left.n^{\circ} 11.096 / 05\right)$ enfrentaram o problema do acesso ao ensino superior privado em razão do valor das mensalidades e auxiliaram IES privadas a lidar com a evasão de alunos e a preencher vagas que anteriormente ficavam ociosas. Com isso, os referidos programas estimularam o crescimento do setor privado e permitiram o acesso a esse nível de ensino por novas parcelas da população. A abrangência desses programas ainda é pequena e pode ser ampliada pelo Estado, com a alteração dos requisitos exigidos dos seus beneficiários. Por outro lado, esses programas podem ser também utilizados pelo Estado para incrementar a qualidade do sistema mediante a inclusão de requisitos adicionais de qualidade para as IES que fazem parte dos programas;

(xv) o setor privado do ensino superior predomina em número de matrículas, instituições e vagas. A maioria das instituições privadas é organizada na forma de faculdades. 
A maioria das matrículas privadas está nas universidades, com um grande crescimento no número de alunos matriculados em faculdades nos últimos anos. O sistema privado de ensino superior apresenta vagas ociosas e um processo seletivo com relação candidato/vaga muito baixa, o que torna sem efeito o princípio da meritocracia em muitas instituições. No setor privado, predominam docentes horistas e em regime de tempo parcial, com a formação de mestrado e especialização. Além disso, o setor privado do ensino superior brasileiro é muito diversificado com instituições de elite, de nicho, de massa e de pequeno porte.

Com relação à análise da educação como um serviço prestado mediante o desempenho de uma atividade empresária, desenvolvida principalmente no Capítulo 3, concluímos que:

(xvi) no ordenamento brasileiro, a educação pode ser oferecida mediante o exercício de uma atividade empresária. Nesse sentido, a instituição de ensino pode constituir-se como uma empresa (profissional, organizada), que oferece educação (serviço/mercadoria) a um determinado mercado consumidor, mediante remuneração, visando lucro para distribuição aos seus sócios. No entanto, a educação apresenta características que a diferenciam de outros bens comercializados no mercado.

(xvii) a mantenedora de uma instituição de ensino (ou a empresa controladora de um grupo de mantenedoras) que adote a forma de uma companhia aberta e que também esteja listada no Novo Mercado da BM\&FBOVESPA, como a Anhanguera, deve possuir uma estrutura adequada para cumprir com todos os deveres por ela assumidos e oferecer um serviço (educação) que seja lucrativo, competitivo e que desperte a atenção dos investidores;

(xviii) no Brasil predomina a concepção contratualista da empresa, como um contrato orientado de acordo com os interesses dos sócios. A teoria organicista mencionada por Calixto Salomão Filho (2006) possibilitaria a proteção dos demais interesses envolvidos na empresa, mediante a criação de regras organizativas internas para a solução de conflitos e a criação de regras externas para lidar com questões que não são devidamente internalizadas, por meio de tratamento legislativo;

(ixx) Fábio Konder Comparato (1996) questiona a efetividade da função social da empresa num sistema capitalista, questionando a possibilidade de um empresário sacrificar o interesse empresarial em prol do bem comum e destacando a impossibilidade de uma companhia renunciar à sua finalidade lucrativa. Nesse sentido, uma empresa livre do controle dos Poderes Públicos, ou seja, sem nenhum tipo de exigência legal para buscar fins sociais, não deixaria de lado seu caráter lucrativo (nem diminuiria seus lucros) para buscar outros objetivos, como suprir carências sociais; 
(xx) para a provisão de bens públicos (ou coletivos), como a educação, a atuação do sistema de mercado não é suficiente, sendo necessária a intervenção do Estado para a persecução do interesse público envolvido na atividade;

(xxi) a internalização de externalidades geradas em determinadas atividades pelo agente privado não é atrativa, porque gera custos e retorno não previsível para os investimentos. Um administrador de empresas, numa decisão estratégica entre questões que envolvam retorno financeiro para os sócios e externalidades sociais para a coletividade, tenderia a decidir em favor da alternativa que gere maior lucro para os sócios da empresa, já que este é seu objetivo principal. De acordo com Salomão Filho (2008, p. 34), setores que apresentam externalidades sociais relevantes não poderiam ser regulados, devendo o Estado prestar diretamente o serviço, uma vez que o prestador privado teria grande dificuldade em aceitar o valor social embutido na atividade;

(xxii) a educação é um setor diferente dos setores econômicos comuns. Além da restrição da liberdade de iniciativa acima mencionada e o fato de a educação ser um direito fundamental de todos e dever do Estado, a educação é capaz de gerar externalidades sociais, tanto positivas quanto negativas, e o sistema de mercado, livre do controle e fiscalização do Estado, não é eficaz em lidar com esse tipo de atividade;

(xxiii) pelo estudo do caso da Anhanguera, verificamos que as lógicas que orientam os setores público e privado de massa com fins lucrativos da educação são diferentes. IES públicas atuam como centros de excelência de ensino, pesquisa e inovação, possuem corpo docente mais qualificado e em regime de dedicação integral principalmente. O grupo Anhanguera, que presta ensino superior de massa, oferece formação voltada para o mercado de trabalho, com cursos flexíveis, de duração variada, principalmente no período noturno, com a utilização de metodologias de ensino a distância, corpo docente menos qualificado e, em sua maior parte, em regime de tempo parcial ou horista, pesquisa com pouca relevância, com avaliações de qualidade com notas mínimas e alguns cursos reprovados, visando redução de custos no oferecimento do produto e maximização dos lucros.

A análise do caso da Anhanguera, implementada no Capítulo 4 da Dissertação, permitiu a comprovação, por meio de informações de fontes oficiais, de uma série de pressupostos teóricos apresentados nos Capítulos antecedentes, cujas principais conclusões foram acima destacadas. Além das respostas das Questões da Análise Empírica apresentadas no Capítulo 4, concluímos que:

(xxiv) a Anhanguera é uma empresa de grande porte do setor educacional brasileiro, 
constituída sob a forma de uma sociedade por ações de capital aberto, listada no Novo Mercado da BM\&FBOVESPA, cuja formação e expansão foi planejada por um fundo de investimento em participações administrado pelo Pátria, em conjunto com os fundadores do grupo. A Anhanguera é uma empresa atrativa para os investidores, que apresentou nos últimos anos um grande crescimento, tanto em número de alunos como em volume de ativos e patrimônio líquido, resultado de sua política de expansão, financiada, principalmente, pelos recursos captados no mercado pela empresa;

(xxv) a Anhanguera desempenha uma atividade empresária, cujo objetivo final é a prestação de serviços educacionais (que inclui a venda de todos os produtos constantes em seu portfólio) pelas IES integrantes do grupo para seu público-alvo. A Anhanguera trata a educação, portanto, como um serviço a ser oferecido aos seus alunos consumidores, moldando-a ao seu público-alvo. Para tanto, oferece cursos voltados para o mercado de trabalho, geralmente com baixa qualidade, mensalidades com valores reduzidos, unidades em locais de fácil acesso, utilizando diferentes técnicas de marketing para atingir o maior número possível de alunos e com isso obter lucros em escala;

(xxvi) dentro de uma estrutura empresarial, a Anhanguera procura reduzir custos e criar escala no oferecimento de seu produto, de forma a proporcionar o maior retorno econômico possível aos seus acionistas. Possui um modelo operacional e metodologias de ensino padronizados, com grande utilização de tecnologias de ensino a distância, técnicas que geram escala no modo de produção (como o AVA e o PLT) e razão de produtividade na parte administrativa (4 funcionários para cada 2 mil alunos). Após a aquisição de uma nova IES, a Anhanguera procura alterar a infraestrutura, a metodologia de ensino, a estrutura docente e a parte administrativa da IES adquirida, de modo a adequá-la ao seu padrão. Essas adaptações geram efeitos econômicos positivos para a empresa, como ganhos em eficiência e escala e a redução do custo operacional, mas geram efeitos sociais negativos pela queda da qualidade sentida pelos alunos das IES adquiridas, que realizaram diversos protestos a esse respeito nos últimos anos;

(xxvii) a administração da Anhanguera é profissional, com predomínio de membros com experiência no mercado financeiro e de capitais (e não na área educacional), e é estruturada de modo a atender aos interesses de seus acionistas. Não há representação de interesses diversos dos acionistas nos órgãos decisórios, nem foi identificado nenhum mecanismo de estímulo à participação desses interesses diversos em tais órgãos;

(xxviii) as atividades da Anhanguera concentram-se em estabelecimentos isolados, 
que não precisam observar a indissociabilidade entre ensino, pesquisa e extensão. $O$ foco da empresa é o ensino, principalmente formação técnica e profissionalizante, e o perfil docente é também de profissionais do mercado, com predomínio de docentes em regime de tempo parcial. Atividades de pesquisa e extensão foram identificadas nos documentos analisados. Ambas foram tratadas como ações de responsabilidade social e utilizadas como estratégias de marketing da empresa. Além disso, a pesquisa apresentou dados de pouca relevância tanto no interior da empresa como no cenário nacional;

(xxix) a Anhanguera não atende adequadamente aos princípios da educação (art. 205, CF/88) e do ensino (art. 206, CF/88). Com relação aos objetivos de pleno desenvolvimento da pessoa, seu preparo para o exercício da cidadania e sua qualificação para o trabalho (art. 205, $\mathrm{CF} / 88$ ) -- o foco da empresa é a qualificação para o trabalho. Ações para o desenvolvimento da cidadania são mencionadas em alguns documentos, mas em geral reduzidas a disciplinas ou atividades de extensão relacionadas com responsabilidade social e meio ambiente. Com relação aos princípios da igualdade de condições de acesso e permanência (art. 206, I, CF/88) e da garantia de padrão de qualidade (art. 206, VII, CF/88) - a Anhanguera lida com o primeiro princípio como uma forma de atrair e manter seus alunos, oferecendo diferentes formas de pagamento das mensalidades, bolsas de estudo e financiamentos. Nesse contexto, a Anhanguera é uma das principais instituições parceiras do ProUni e do Fies. Com relação à garantia de padrão de qualidade, a Anhanguera, considerando as avaliações do MEC e o ranking RUF, não está bem colocada entre as IES do Brasil. Com relação aos princípios da liberdade de aprender e ensinar (art. 206, II, CF/88) e do pluralismo (art. 206, III, CF/88) - a Anhanguera não apresenta grande margem para liberdade de ensino e pluralismo, pois possui metodologia de ensino e materiais didáticos padronizados para toda a rede. Com relação ao princípio da valorização dos profissionais (art. 206, V, CF/88) a Anhanguera procura reduzir os custos com seus professores. Nesse sentido, após a aquisição de mantenedoras de IES, muitos docentes das IES adquiridas, geralmente os que possuem maior titulação e maiores salários, são demitidos pela Anhanguera para a contratação de docentes com menor titulação e menores salários;

(xxx) as avaliações de qualidade dos cursos e das instituições integrantes do grupo Anhanguera revelaram um ensino de baixa qualidade. As IES, em geral, cumprem apenas os requisitos mínimos para a aprovação nas avaliações, possuindo, em alguns casos, cursos e instituições sujeitos a sanções e penalidades por conta de avaliações negativas.

Considerando todas as conclusões acima e a análise do caso da Anhanguera, 
concluímos, por fim, que a educação quando sujeita à lógica econômica transforma-se numa mercadoria, que será oferecida dentro de uma estrutura empresarial, visando redução de custos e maximização dos lucros para distribuição aos acionistas. No caso da Anhanguera, que se volta para o atendimento das classes média e baixa da população, é oferecido um ensino superior de massa para formação técnica, de baixa qualidade, com valores reduzidos de mensalidade. Nesse contexto, a Anhanguera oferece uma educação limitada, que não atende ao conteúdo normativo do direito à educação. 


\section{REFERÊNCIAS BIBLIOGRÁFICAS}

ABMES - ASSOCIAÇÃO BRASILEIRA DE MANTENEDORAS DE ENSINO SUPERIOR.. Lucro e qualidade acadêmica são compatíveis na Educação Superior? (IV). 08 nov. 2011. Vídeo disponível em: http://www.abmes.org.br/abmes/video/detalhe/id/39. Acesso em: 02/08/2012.

ABREU, Paula Santos de. A educação superior no Brasil e a proposta de liberalização do GATS. Universitas Relações Internacionais, Brasília, v. 6, n. 2, p. 89-108, jul./dez. 2008.

ABRIL EDUCAÇÃO. Informe Publicitário. [s/d] Disponível em: http://www.abrileducacao.com.br/doc/anunVEJA_AbrilEducacao.pdf. Acesso em: $14 / 01 / 2013$.

AGÊNCIA BRASIL. Mais de $60 \%$ dos alunos do ensino superior no País estudam à noite. O Estado de São Paulo, São Paulo, 07 nov. 2011. Disponível em: http://www.estadao.com.br/noticias/vidae,mais-de-60-dos-alunos-do-ensino-superior-no-paisestudam-a-noite,795683,0.htm. Acesso em: 08/12/2012.

AKITA, Eric. Qualidade da educação no Brasil ainda é baixa, aponta Unesco. O Estado de São Paulo, São Paulo, 19 jan. 2010. Disponível em: http://www.estadao.com.br/noticias/suplementos,qualidade-da-educacao-no-brasil-ainda-ebaixa-aponta-unesco,498175,0.shtm. Acesso em: 14/12/2010.

ALMEIDA, Edson P. Panorama do ensino. RAE/FGV, São Paulo, v. 8, n. 1, jan./fev. 2009. Disponível em: http://rae.fgv.br/sites/rae.fgv.br/files/artigos/5419.pdf. Acesso em: 04/01/2012.

AMAZONAS, Lorena. Anhanguera demite 680 professores. O Estado de São Paulo, São Paulo, 22 dez. 2011. Disponível em: http://www.estadao.com.br/noticias/impresso, anhanguera--demite-680-professores,814116,0.htm. Acesso em: 02/08/2012.

ANHANGUERA EDUCACIONAL PARTICIPAÇÕES S.A. Ata da Assembleia Geral Extraordinária realizada em 29 de outubro de 2010, às 10h. Valinhos: 2010a. Disponível em: http://www.cvm.gov.br. Acesso em: 30/06/2012.

. Ata da Assembleia Geral Extraordinária realizada em 31 de maio de 2012. Valinhos: 2012a. Disponível em: http://www.cvm.gov.br. Acesso em: 30/06/2012.

Atas das Assembleias Gerais Ordinária e Extraordinária realizadas em 29 de abril de 2008. Valinhos: 2008a. Disponível em: http://www.cvm.gov.br. Acesso em: $30 / 06 / 2012$. 
. Ata da Assembleia Geral Ordinária realizada em 30 de abril de 2010. Valinhos: 2010b. Disponível em: http://www.cvm.gov.br. Acesso em: 30/06/2012.

. Ata da Assembleia Geral Ordinária realizada em 29 de abril de 2011. Valinhos: 2011a. Disponível em: http://www.cvm.gov.br. Acesso em: 30/06/2012.

Ata da Assembleia Geral Ordinária realizada em 30 de abril de 2012. Valinhos: 2012b. Disponível em: http://www.cvm.gov.br. Acesso em: 30/06/2012.

- Ata da Reunião do Conselho de Administração realizada em 08 de março de 2007. Valinhos: 2007a. Disponível em: http://www.cvm.gov.br. Acesso em: 30/06/2012.

- Ata da Reunião do Conselho de Administração realizada em 18 de abril de 2008. Valinhos: 2008b. Disponível em: http://www.cvm.gov.br. Acesso em: 30/06/2012.

- Ata da Reunião do Conselho de Administração realizada em 22 de abril de 2008. Valinhos: 2008c. Disponível em: http://www.cvm.gov.br. Acesso em: 30/06/2012.

- Ata da Reunião do Conselho de Administração realizada em 30 de janeiro de 2009. Valinhos: 2009a. Disponível em: http://www.cvm.gov.br. Acesso em: 30/06/2012.

. Ata da Reunião do Conselho de Administração realizada em 18 de setembro de 2009. Valinhos: 2009b. Disponível em: http://www.cvm.gov.br. Acesso em: 30/06/2012.

. Ata da Reunião do Conselho de Administração realizada em 18 de dezembro de 2009. Valinhos: 2009c. Disponível em: http://www.cvm.gov.br. Acesso em: 30/06/2012.

- Ata da Reunião do Conselho de Administração realizada em 19 de setembro de 2011. Valinhos: 2011b. Disponível em: http://www.cvm.gov.br. Acesso em: 30/06/2012.

Estatuto Social consolidado na AGE de 31 de maio de 2012. Valinhos: 2012c. Disponível em: Disponível em: http://www.cvm.gov.br. Acesso em: 30/06/2012.

Fato Relevante publicado em 18/09/2011. Valinhos: 2011c. Disponível em: http://www.cvm.gov.br. Acesso em: 30/06/2012.

Formulário de Informações Anuais - IAN de 31/12/2008. Valinhos: 2008d. Disponível em: http://www.cvm.gov.br. Acesso em: 30/06/2012.

Formulário de Informações Trimestrais - ITR de 30/09/2010. Valinhos: 2010c. Disponível em: http://www.cvm.gov.br. Acesso em: 30/06/2012. 
Formulário de Referência de 2010. Valinhos: 2010d. Disponível em: http://www.cvm.gov.br. Acesso em: 11/09/2012.

Formulário de Referência de 2012. Valinhos: 2012d. Disponível em: $\overline{\mathrm{http}: / / \mathrm{w} w w . a n h a n g u e r a . c o m / r i . ~ A c e s s o ~ e m: ~ 11 / 09 / 2012 . ~}$

Prospecto Definitivo de Distribuição Pública Primária de Certificados de Depósitos de Ações (“Units") de 22/04/2008. Valinhos: 2008e. Disponível em: http://www.cvm.gov.br. Acesso em: 30/06/2012.

- Prospecto Definitivo de Distribuição Pública Primária e Secundária de Certificados de Depósitos de Ações (“Units”) de 08/03/2007. Valinhos: 2007b. Disponível em: http://www.cvm.gov.br. Acesso em: 11/09/2012.

. Prospecto Definitivo de Oferta Pública de Distribuição Primária de Ações Ordinárias de Emissão de 09/12/2010. Valinhos: 2010e. Disponível em: http://www.cvm.gov.br. Acesso em: 30/06/2012.

. Relatório Financeiro do $\mathbf{4}^{\mathbf{0}}$ Trimestre de 2011. Valinhos: 2012e. Disponível em: http://www.anhanguera.com/ri. Acesso em: 11/09/2012.

Relatório de Responsabilidade Social de 2010. Valinhos: 2010f. Disponível em: http://www.mzweb.com.br/anhanguera2011/web/arquivos/AE_RelatorioResponsabilidadeSoc ial2010_FINAL.pdf. Acesso em: 02/10/2012.

Relatório de Responsabilidade Social de 2011. Valinhos: 2011d. Disponível em: http://rsocial.anhanguera.com. Acesso em: 30/06/2012.

ASCARELLI, Tulio. A atividade do empresário. Tradução Erasmo Valladão A. e N. França. RDM, São Paulo: Malheiros, n. 109, p. 183-189, jan.-mar. 1998.

BALMANT, Ocimara. Anhanguera causa polêmica ao sortear carros e tablets. O Estado de São Paulo, São Paulo, 04 jul. 2012. Disponível em: http://www.estadao.com.br/noticias/geral,anhanguera-causa-polemica-ao-sortear-carros-etablets, 895613,0.htm. Acesso em 25/09/2012.

BANCO MUNDIAL. La enseñanza superior: las lecciones derivadas de la experiência. (Development in practice) Washington D.C., 1995. Disponível em: http://wwwwds.worldbank.org/servlet/main?menuPK $=64187510$ \&pagePK $=64193027 \& \mathrm{piPK}=64187937$ $\&$ theSitePK=523679\&entityID=000090341_20050614161209. Acesso em: 17/01/2011.

Financing education in developing countries: an exploration of police option. 
Washington $\quad$ D.C., $1986 . \quad$ Disponível em: http://wwwwds.worldbank.org/external/default/WDSContentServer/IW3P/IB/2000/07/07/000178830_98 101901365053/Rendered/PDF/multi_page.pdf. Acesso em: 17/10/2012.

BARREYRO, Gladys Beatriz. Mapa do ensino superior privado. Brasília: Instituto Nacional de Estudos e Pesquisas Educacionais Anísio Teixeira, 2008. Disponível em: http://each.uspnet.usp.br/gladysb/Mapa\%20do\%20ensino\%20superior\%20privado.pdf.

Acesso em: 05/06/2012.

BARROS, Sérgio Resende de. Direitos humanos: paradoxo da civilização. Belo Horizonte: Del Rey, 2003.

BITTAR, Eduardo C. B. O Direito na pós-modernidade (e reflexões frankfurtianas). 2 ed. Rio de Janeiro: Forense Universitária, 2009.

. A escola como espaço de emancipação dos sujeitos. In: ZENAIDE, Maria de Nazaré Tavares et. al. (org.). Direitos humanos: capacitação de educadores. João Pessoa: Editora Universitária/UFPB, 2008. Disponível em: http://portal.mec.gov.br/index.php?option=com_docman\&task=doc_download\&gid=2187\&It emid=.Acesso em 18/01/2013.

BOBBIO, Norberto. A era dos direitos. Rio de Janeiro: Campus, 1992.

BONAVIDES, Paulo. Curso de Direito constitucional. 19. ed. São Paulo: Malheiros, 2006.

BRAGA, Ryon. As classes C e D chegam ao ensino superior. Hoper Educação, jan. 2010. Disponível em: http://www.hoper.com.br/artigo-hoper.php?id=8. Acesso em 22/06/2010.

. Negócios no setor da educação privada. Hoper Educação, jan. 2011. Disponível em: http://www.hoper.com.br/artigo-hoper.php?id=43. Acesso em: 25/09/2012.

BRASIL. Plano diretor de reforma do aparelho do Estado brasileiro. Brasília, 1995. Disponível em: http://www.bresserpereira.org.br/Documents/MARE/PlanoDiretor/planodiretor.pdf. Acesso em:17/07/2012.

CALDERÓN, Adolfo Ignácio. Extensão Universitária: revisitando conceitos e práticas institucionais. In: ; SANTOS, Sonia R. Mendes; SARMENTO, Dirléia Fanfa. Extensão universitária: uma questão em aberto. São Paulo: Xamã, 2011.

CANOTILHO, José J. Gomes. Direito constitucional e teoria da Constituição. 4. ed. Coimbra: Almedina, 2000. 
CARDOZO, Elverson. Acadêmicos de Arquitetura e Urbanismo da Uniderp organizam protesto. Campo Grande News, Campo Grande, 26 mar. 2012. Disponível em: http://www.campograndenews.com.br/cidades/capital/academicos-de-arquitetura-eurbanismo-da-uniderp-organizam-protesto. Acesso em: 02/08/2012.

CARVALHO, José Murilo. Cidadania no Brasil: o longo caminho. 12. ed. Rio de Janeiro: Civilização Brasileira, 2009.

COMPARATO, Fábio Konder. Estado, empresa e função social. In: Revista dos Tribunais, São Paulo, ano 85, v. 732, out. 1996, p. 38-46.

CONFENEN - Confederação Nacional dos Estabelecimentos de Ensino. Ação Direta de Inconstitucionalidade no 3330: Petição inicial. Brasília: Supremo Tribunal Federal, 2004. Disponível em: http://redir.stf.jus.br/estfvisualizadorpub/jsp/consultarprocessoeletronico/ConsultarProcessoEl etronico.jsf? seqobjetoincidente=2251887. Acesso em: 30/06/2012.

CONFERÊNCIA MUNDIAL SOBRE O ENSINO SUPERIOR, 2., 2009, Paris. Comunicado. Paris: Unesco, 2009. Disponível em: http://aplicweb.feevale.br/site/files/documentos/pdf/31442.pdf. Acesso em: 17/01/2011.

CONFERÊNCIA REGIONAL DE EDUCAÇÃO SUPERIOR NA AMÉRICA LATINA E NO CARIBE - CRES, 2008, Cartagena de Índias, Colômbia. Declaração. Cartagena de Índias: Unesco/ Iesalc, 2008 Disponível em: www.iesalc.unesco.org.ve/dmdocuments/declaracaocres_portugues.pdf. Acesso em 30/06/12.

CUNHA, Luiz A. O ensino superior no octênio FHC. Educação \& Sociedade, Campinas, v. 24, n. 82, p. 37-61, abr. 2003. Disponível em: http://www.cedes.unicamp.br. Acesso em: $17 / 07 / 2012$.

DELORS, Jacques (Org.). Educação: um tesouro a descobrir. Relatório para a Unesco da Comissão Internacional sobre Educação para o Século XXI. Brasília: Unesco, 2010. Disponível em: http://unesdoc.unesco.org/images/0010/001095/109590por.pdf. Acesso em: 03/12/2012.

DEODORO, Juliana. Protesto contra Anhanguera reúne estudantes na zona norte de SP. O Estado de São Paulo, São Paulo, 23 abr. 2012. Disponível em: http://www.estadao.com.br/noticias/vidae,protesto-contra-anhanguera-reune-estudantes-nazona-norte-de-sp,864531,0.htm\#bb-md-noticia-tabs-2. Acesso em: 02/08/2012.

DINIZ, Maria Helena. Curso de Direito civil brasileiro. 18. ed. São Paulo: Saraiva. 2002. v. 1: Teoria geral do Direito civil.

DI PIETRO, Maria Sylvia Zanella. Direito administrativo. 19. ed. São Paulo: Atlas, 2006. 
DIRR, Peter J. Distance education: policy considerations for the year 2000. In: MOORE, Michael. Contemporary issues in American distance education. Oxford and New York: Pergamon Press, 1990.

DOURADO, Luiz Fernandes; OLIVEIRA, João Ferreira; CATANI, Afrânio Mendes. Transformações recentes e debates atuais no campo da educação superior no Brasil. In: DOURADO, Luiz Fernandes; OLIVEIRA, João Ferreira; CATANI, Afrânio Mendes (org.). Políticas e gestão da educação superior: transformações recentes e debates atuais. São Paulo: Xamã, 2003, p. 17-31.

EXAME.COM. Fundo Advent compra parte da Kroton por R\$ 280 milhões. Exame.com, 25 jun. 2009. Disponível em: http://exame.abril.com.br/negocios/empresas/noticias/fundoadvent-compra-parte-kroton-r-280-milhoes-479807. Acesso em: 14/01/2013.

Itaú compra participação na Ideal Invest. Exame.com, 05 jun. 2012. Disponível em: http://exame.abril.com.br/negocios/noticias/itau-compra-participacao-na-ideal-invest. Acesso em: 26/03/2012.

FERNANDES, Ivanildo. Mantenedoras educacionais privadas: histórico, organização e situação jurídica. Documentos de Trabalho do Observatório Universitário, Rio de Janeiro, n. 67, jun. 2007. Disponível em: http://www.observatoriouniversitario.org.br/documentos_de_trabalho/documentos_de_trabalh o_67.pdf. Acesso em: 19/07/2012.

FERREIRA, Manoel Gonçalves Filho. Direitos humanos fundamentais. 11. ed. São Paulo: Saraiva, 2009.

FOLHA DE SÃo PAULO. Avanços com o ProUni. Folha de São Paulo, São Paulo, 04 mai. 2011. Editoriais. Disponível em: http://www1.folha.uol.com.br/fsp/opiniao/fz0405201102.htm. Acesso em: 25/09/2012.

. Faculdade do Rio aprova semi-analfabeto. Folha de São Paulo, São Paulo,10 dez 2001. Disponível em: http://www1.folha.uol.com.br/folha/educacao/ult305u7470.shtml. Acesso em: 25/09/2012.

Ranking Universitário Folha: metodologia. Folha de São Paulo, São Paulo, [s/d]. Disponível em: http://ruf.folha.uol.com.br/metodologia/. Acesso em: 20/12/2012.

. Ranking Universitário Folha: ranking geral de universidades. Folha de São Paulo, São Paulo, [s/d]. Disponível em: http://ruf.folha.uol.com.br/rankings/rankingdeuniversidades/. Acesso em: 20/12/2012. 
Ranking Universitário Folha: ranking pela avaliação do mercado. Folha de São Paulo, São Paulo, [s/d]. http://ruf.folha.uol.com.br/rankings/pelaavaliacaodomercado/. Acesso em: 20/12/2012.

FRAUCHES, Celso. Erros e acertos da avaliação educacional no Brasil: seminário atinge seus objetivos. Educação superior comentada: políticas, diretrizes, legislação e normas do ensino superior, ano 2, n. 48, mar. 2012. Disponível em: http://www.abmes.org.br/abmes/noticias/detalhe/id/483/. Acesso em: 25/09/2012.

GALLO, Ricardo. Cai valor de mensalidade em faculdade particular. Folha de São Paulo, São Paulo, 21 jun. 2010. http://www1.folha.uol.com.br/fsp/cotidian/ff2106201001.htm. Acesso em: 25/09/2012.

GARCIA, Maurício. Três grandes tendências para o ensino superior privado no Brasil. Revista Ensino Superior, n. 77, fev. 2005, p. 41-43. Disponível em: http://www.mgar.com.br/mgPdf/2005_03_EnsSuperior.pdf. Acesso em: 27/07/2012.

GOIS, Antônio. Universitário escolhe escola pela localização. Folha de São Paulo, São Paulo, 22 jun. 2004. Disponível em: http://www1.folha.uol.com.br/folha/educacao/ult305u15663.shtml. Acesso em: 26/06/2009.

GORGULHO, Vinícius. A consolidação do mercado. Revista Ensino Superior, Disponível em: http://revistaensinosuperior.uol.com.br/textos.asp?codigo=11892. Acesso em: $30 / 06 / 2012$.

GRACE, Gerald. Education: commodity or public good? British Journal of Educational Studies, v. 37, n. 3, The privatisation of education, aug., 1989, p. 207-221. Disponível em: http://www.jstor.org/stable/3121278. Acesso em: 03/12/2012.

GRAU, Eros Roberto. A ordem econômica na Constituição de 1988. 12 ed. São Paulo: Malheiros, 2007.

A ordem econômica na Constituição de 1988. 14. ed. São Paulo: Malheiros, 2010.

GREGÓRIO, Danilo. A peneira começou a funcionar. Revista Capital Aberto, São Paulo, ano 5, n. 51, p. 12-6, nov. 2007. Disponível para assinantes em: http://www.capitalaberto.com.br/ler_artigo.php?pag=2\&sec $=4 \& \mathrm{i}=1631 \& \mathrm{btxt}=\mathrm{A} \% 20$ peneira $\% 20$ come $\%$ E7ou\%20a\%20funcionar. Acesso em: 05/06/2012.

HADDAD, Fernando. Parecer $\mathbf{n}^{0}$ 218/2006 da Câmara de Educação Superior, aprovado pelo Ministro da Educação, Fernando Haddad. 13 set. 2006. Disponível em: http://www2.mec.gov.br/sapiens/portarias/res2006_218.html. Acesso em: 17/07/2012.

HESSEL, Camila Guimarães; MARREY, Fabio. Investindo em educação. Revista Capital 
Aberto, São Paulo, ano 5, n. 49, p. 52-6, set. 2007. Disponível para assinantes em: $\mathrm{http}: / / \mathrm{www}$. capitalaberto.com.br/ler_artigo.php?pag $=2 \& \mathrm{sec}=4 \& \mathrm{i}=1561 \& \mathrm{btxt}=$ investindo $\% 20$ em\%20educa\%E7\%E3o. Acesso em: 05/06/2012.

HOPER. Análise setorial do ensino superior privado. Coordenação Ryon Braga. Foz do Iguaçu: Hoper Estudos de Mercado, 2011. Disponível em: http://www.hoper.com.br/analisesetorial/Analises\%20Setoriais/Análise\%20Setorial\%20Ensin o\%20Superior\%202011\%20-\%20censo\%202009\%20-

$\% 206 . \% 20 A S \% 20 E M P R E S A S \% 20 L I S T A D A S \% 20 N A \% 20 B M \& F B O V E S P A . p d f . \quad$ Acesso em: $14 / 01 / 2013$.

IBGE. Estatísticas do século XX. Rio de Janeiro: Instituto Brasileiro de Geografia e Estatística, 2006. Disponível em: http://www.ibge.gov.br/seculoxx/seculoxx.pdf. Acesso em: $13 / 06 / 2010$.

Síntese de indicadores sociais: uma análise das condições de vida da população brasileira 2007. Rio de Janeiro: Instituto Brasileiro de Geografia e Estatística, 2007. Disponível

em: http://www.ibge.gov.br/home/estatistica/populacao/condicaodevida/indicadoresminimos/sinte seindicsociais2007/indic_sociais2007.pdf. Acesso em: 14/12/2010.

Síntese de indicadores sociais: uma análise das condições de vida da população brasileira 2008. Rio de Janeiro: Instituto Brasileiro de Geografia e Estatística, 2008. Disponível em: http://biblioteca.ibge.gov.br/visualizacao/monografias/GEBIS\%20$\% 20 \mathrm{RJ} /$ sintese_indic/indic_sociais2008.pdf. Acesso em: 13/06/2010.

Síntese de indicadores sociais: uma análise das condições de vida da população brasileira 2009. Rio de Janeiro: Instituto Brasileiro de Geografia e Estatística, 2009. Disponível em: http://biblioteca.ibge.gov.br/visualizacao/monografias/GEBIS\%20$\% 20 \mathrm{RJ} /$ sintese_indic/indic_sociais2009.pdf. Acesso em: 13/06/2010.

Síntese de indicadores sociais: uma análise das condições de vida da população brasileira 2010. Rio de Janeiro: Instituto Brasileiro de Geografia e Estatística, 2010. Disponível

em: http://www.ibge.gov.br/home/estatistica/populacao/condicaodevida/indicadoresminimos/sinte seindicsociais2010/SIS_2010.pdf. Acesso em: 27/07/2012.

IG SÃO PAULO. Consulte o ranking das instituições de ensino superior de 2011. Último Segundo, São Paulo, 10 dez. 2001. Disponível em: http://ultimosegundo.ig.com.br/educacao/2012-12-10/consulte-o-ranking-das-instituicoes-deensino-superior-de-2011.html. Acesso em: 14/01/2013.

INEP. Cadastro nacional de docentes da educação superior 2005. Brasília: Instituto Nacional de Estudos e Pesquisas Educacionais Anísio Teixeira, 2005. Disponível em: http://download.inep.gov.br/download/superior/2004/censosuperior/Resumo_Tecnico_Cadast ro_Docentes2005_1.pdf. Acesso em: 08/12/2012. 
Censo da educação superior 2003: resumo técnico. Brasília: Instituto Nacional de Estudos e Pesquisas Educacionais Anísio Teixeira, 2003. Disponível em: http://download.inep.gov.br/download/superior/censo/2004/resumo_tecnico_050105.pdf. Acesso em: 29/04/2011.

Censo da educação superior 2008: resultados das principais variáveis. Brasília: Instituto Nacional de Estudos e Pesquisas Educacionais Anísio Teixeira, 2009. Disponível em:

http://portal.inep.gov.br/c/journal/view_article_content?groupId=10157\&articleId=12126\&ve rsion=1.0. Acesso em: 29/04/2011.

Censo da educação superior 2009: resumo técnico. Brasília: Instituto Nacional de

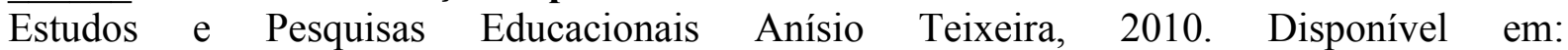
http://download.inep.gov.br/download/superior/censo/2009/resumo_tecnico2009.pdf. Acesso em: 29/04/2011.

Censo da educação superior 2010: resumo técnico. Brasília: Instituto Nacional de

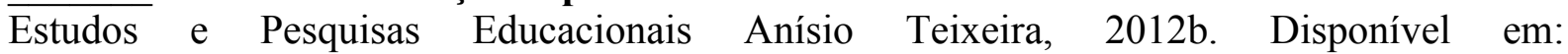
http://download.inep.gov.br/educacao_superior/censo_superior/resumo_tecnico/resumo_tecni co_censo_educacao_superior_2010.pdf. Acesso em: 20/06/2012.

Censo escolar da educação básica 2011: resumo técnico. Brasília: Instituto Nacional de Estudos e Pesquisas Educacionais Anísio Teixeira, 2012a. Disponível em: http://download.inep.gov.br/educacao_basica/censo_escolar/resumos_tecnicos/resumo_tecnic o_censo_educacao_basica_2011.pdf. Ācesso em: 25/07/2012.

Evolução da educação superior: graduação de 1980/1998. Disponível em: http://portal.inep.gov.br/web/censo-da-educacao-superior/evolucao-1980-a-2007. Acesso em: $08 / 12 / 2012$.

. Sinaes - Sistema Nacional de Avaliação da Educação Superior: da concepção à regulamentação. 2. ed. Brasília : Instituto Nacional de Estudos e Pesquisas Educacionais Anísio Teixeira, 2004. Disponível em: http://www.publicacoes.inep.gov.br/arquivos/\%7BB4E0C6B4-314B-4F70-9671E33A4BA67C42\%7D_Sinaes_da_concep\%C3\%A7\%C3\%A3o_\%C3\%A0_regulamenta $\% \mathrm{C} 3$ $\%$ A7\%C3\%A3o.pdf. Acesso em: 23/07/2012.

INTERNATIONAL CONFERENCE ON EDUCATION, 48th, 2008, Geneva, Switzerland. Final Report. Paris: Unesco, 2009. Disponível em: http://www.ibe.unesco.org/fileadmin/user_upload/Policy_Dialogue/48th_ICE/ICE_FINAL_R EPORT_eng.pdf. Acesso em: 03/12/2012.

IWASSO, Simone; MANDELLI, Mariana. Unip dá brinde a aluno que fará Enade. O Estado 
de São Paulo, São Paulo, 07 nov. 2009. Disponível em: http://www.estadao.com.br/noticias/impresso, unip-da-brinde-a-aluno-que-faraenade,462577,0.htm. Acesso em: 25/09/2012.

JUSTEN, Marçal Filho. Curso de Direito administrativo. 2. ed. São Paulo: Saraiva, 2006.

LEHER, Roberto. Expansão privada do ensino superior e heteronomia cultural: um difícil início de século. In: DOURADO, Luiz Fernandes; OLIVEIRA, João Ferreira; CATANI, Afrânio Mendes (org.). Políticas e gestão da educação superior: transformações recentes e debates atuais. São Paulo: Xamã, 2003, p. 81-96.

LIPPI, Roberta. Bem na foto. Revista Capital Aberto. São Paulo: ano 5, n. 57, p.14-7, maio 2008.

http://www.capitalaberto.com.br/ler_artigo.php?pag=2\&sec $=4 \& \mathrm{i}=1901 \& b \mathrm{btx}=\mathrm{bem} \% 20 \mathrm{na} \% 2$ 0foto. Acesso em 05/06/12.

LORDELO, Carlos. Alunos da Anhanguera reclamam de falta de aula. O Estado de São Paulo, São Paulo, 23 abr. 2012. Disponível em: http://www.estadao.com.br/noticias/impresso, alunos-da-anhanguera-reclamam-de-falta-deaula,864233,0.htm. Acesso em 02/08/2012.

MALISKA, Marcos Augusto. O direito à educação e a Constituição. Porto Alegre: Sergio Antonio Fabris Editor, 2001.

MARSHALL, Thomas H. Cidadania, classe social e status. Tradução Meton P. Gadelha. Rio de Janeiro: Zahar, 1967.

MARTINS, Ângela. S. Bernardo: estudantes da Anhanguera protestam. Diário do Grande ABC, 8 mar. 2012. Disponível em: http://www.dgabc.com.br/News/5945822/s-bernardoestudantes-da-anhanguera-protestam.aspx. Acesso em 02/08/2012.

MATOS, Núbia. Enquanto o censo não vem. Revista Ensino Superior. Disponível em: http://revistaensinosuperior.uol.com.br/textos.asp?codigo=12816. Acesso em: 25/09/2012.

MEC. Avaliação: Qualidade da Educação Superior. s/d. Disponível em: http://portal.mec.gov.br/index.php?option=com_docman\&task=doc_download\&gid=4316. Acesso em: 04/01/2013

- Lista de membros da Câmara de Educação Superior. Disponível em: http://portal.mec.gov.br/index.php?option=com_content\&view $=$ article\&id $=14305 \% 3$ Acnecomposicao\&catid=323\%3Aorgaos-vinculados\&Itemid=754. Acesso em: 16/05/2012.

MEDAUAR, Odete. Direito administrativo moderno. 10. ed. São Paulo: Revista dos Tribunais, 2006. 
MEIRELLES, Hely Lopes. Direito administrativo brasileiro. 32. ed. São Paulo: Malheiros, 2006.

MELLO, Celso A. B. Conteúdo jurídico do princípio da igualdade. 3. ed. São Paulo: Malheiros, 2003.

Curso de Direito administrativo. 28. ed. São Paulo: Malheiros, 2011.

MIRANDA, Jorge. Manual de Direito constitucional. 3. ed. Coimbra: Coimbra Editora, 2000. Tomo IV.

MORAES, Alexandre. Direitos humanos fundamentais. São Paulo: Saraiva, 1997.

MORETTI, Denise Martins. A responsabilidade internacional do Estado brasileiro por violações do direito à educação a partir do sistema global de proteção dos direitos humanos. Revista Digital de Direito Público, Ribeirão Preto, v. 1, n. 1, 2012, p. 30-59. Disponível em: www.direitorp.usp.br/periodicos.

A discriminação econômica no ensino superior brasileiro: uma abordagem a partir da Convenção da Unesco contra a discriminação no ensino. In: RANIERI, Nina Beatriz Stocco (Org.). Direito à educação: igualdade e discriminação no ensino. São Paulo: Editora da Universidade de São Paulo, 2010, p. 107-127.

MUTO, Silvio. Solução privada. Revista Capital Aberto. São Paulo, ano 6, n. 69, p. 20-3, maio 2009. Disponível para assinantes em: http://www.capitalaberto.com.br/ler_artigo.php?pag $=2 \& \mathrm{sec}=4 \& \mathrm{i}=2486 \& b \mathrm{btxt}=\mathrm{solu} \% \mathrm{E} 7 \% \mathrm{E} 3 \mathrm{o}$ $\% 20$ privada. Acesso em: 05/06/201 $\overline{2}$.

NINNI, Karina; CRUZ; Renato. Anhanguera compra Uniban por R\$ 510 milhões. O Estado de São Paulo, São Paulo, 17 set. 2011. Disponível em: http://www.estadao.com.br/noticias/vidae, anhanguera-compra-uniban-por-r-510milhoes, 773921,0.htm. Acesso em: 04/07/2012.

NUSDEO, Fábio. Curso de Economia: introdução ao Direito econômico. 5. ed. São Paulo: Revista dos Tribunais, 2008.

O ESTADO DE SÃO PAULO. Instituição diz que alunos 'não estão dispensados' às 6as. O Estado de São Paulo, São Paulo, 23 abr. 2012. Disponível em: http://www.estadao.com.br/noticias/impresso, instituicao-diz-que-alunos-nao-estaodispensados-as-6s-,864242,0.htm. Acesso em: 02/08/2012.

. Retrocesso no ensino superior. O Estado de São Paulo, São Paulo, 12 jul. 2001. 
Disponível em: http://www.estadao.com.br/noticias/impresso,retrocesso-no-ensinosuperior,743708,0.htm. Acesso em: 25/09/2012.

OLIVEIRA, João Ferreira; DOURADO, Luiz Fernandes. Educação superior: o público e o privado na produção do trabalho e da vida acadêmica. In: ADRIÃO, Theresa; PERONI, Vera (Org.). O público e o privado na educação: interfaces entre Estado e sociedade. São Paulo: Xamã, 2005, p. 57-80.

OLIVEIRA, Romualdo Portela. A transformação da educação em mercadoria no Brasil. Educação \& Sociedade, Campinas, v. 30, n. 108, p. 739-760, out. 2009. Disponível em: http://www.cedes.unicamp.br. Acesso em 13/06/2010.

Estado e política educacional no Brasil: desafios do século XXI. 120f. Tese (Livredocência) - Faculdade de Educação, Universidade de São Paulo, São Paulo, 2006.

Educação pública e privada na Constituição Federal de 1988. In ADRIÃO, Theresa; PERONI, Vera (Org.). O público e o privado na educação: interfaces entre Estado e sociedade. São Paulo: Xamã, 2005, p. 155-166.

PARTIDO DEMOCRATAS. Arguição de descumprimento de preceito fundamental $\mathbf{n}^{\mathbf{0}}$ 186: Petição inicial. Brasília, Supremo Tribunal Federal, 2009. Disponível em: http://redir.stf.jus.br/estfvisualizadorpub/jsp/consultarprocessoeletronico/ConsultarProcessoEl etronico.jsf?seqobjetoincidente=2691269. Acesso em: 08/05/2012.

Ação Direta de Inconstitucionalidade no 3314: Petição inicial. Brasília: Supremo Tribunal Federal, 2004. Disponível em: http://redir.stf.jus.br/estfvisualizadorpub/jsp/consultarprocessoeletronico/ConsultarProcessoEl etronico.jsf?seqobjetoincidente=2248290. Acesso em: 08/05/2012.

PASIN, Rodrigo. Bodas de ouro. Revista Capital Aberto, São Paulo, ano 4, n. 44, p. 60-1, abr. 2007. Disponível para assinantes em: http://www.capitalaberto.com.br/ler_artigo.php?pag $=2 \& \mathrm{sec}=3 \& \mathrm{i}=165 \& \mathrm{btxt}=$ bodas $\% 20 \mathrm{de} \% 2$ 0ouro. Acesso em: 05/06/2012.

PNUD - PROGRAMA DAS NAÇÕES UNIDAS PARA O DESENVOLVIMENTO. Os objetivos de desenvolvimento do milênio: 8 objetivos para 2015. Disponível em: http://www.pnud.org.br/odm/. Acesso em: 14/12/2010.

PEREZ-LUÑO, Antonio Enrique. Derechos humanos, estado de derecho y constitución. 8.ed. Madrid: Tecnos, 2002.

Los derechos fundamentales. 7. ed. Madrid: Editorial Tecnos, 1998.

PIOVESAN, Flávia. Direitos humanos e o Direito constitucional internacional. 7. ed. São 
Paulo, Saraiva, 2006.

Temas de direitos humanos. 2. ed. São Paulo: Max Limonad, 2003.

RAMOS, André de Carvalho. Teoria geral dos direitos humanos na ordem internacional. Rio de Janeiro: Renovar, 2005.

RANIERI, Nina Beatriz. Educação superior, Direito e Estado, na Lei de Diretrizes e Bases. São Paulo: Edusp, 2000.

. O Estado democrático de direito e o sentido da exigência de preparo da pessoa para 0 exercício da cidadania, pela via da educação. Tese (Livre-docência) -. Faculdade de Direito, Universidade de São Paulo, São Paulo, 2009.

Autonomia universitária: as universidades públicas e a Constituição Federal de 1988. São Paulo: Editora da Universidade de São Paulo, 1994.

Direitos humanos e comércio internacional: a tutela do direito à educação nas negociações internacionais. In: YARSHELL, Flávio Luiz; MORAES, Mauricio Zanoide. Estudos em homenagem à Professora Ada Pellegrini Grinover. São Paulo: DPJ Editora, 2005, p. 58-70.

REDE RECORD. Alunos da Faculdade Anhanguera fazem protesto contra baixo nível de ensino. R7 Notícias, 07 mai. 2012. Disponível em: http://noticias.r7.com/educacao/noticias/alunos-da-faculdade-anhanguera-fazem-protestocontra-baixo-nivel-de-ensino-20120507.html. Acesso em: 02/08/2012.

REVISTA CAPITAL ABERTO. Bom começo. São Paulo, ano 4, n. 46, p. 68-70, jun. 2007. Disponível para assinantes em: http://www.capitalaberto.com.br/ler_artigo.php?pag $=2 \& \mathrm{sec}=23 \& \mathrm{i}=1409 \& \mathrm{btxt}=\mathrm{bom} \% 20 \mathrm{com}$ e\%E7o. Acesso em: 05/06/2012.

Private Equity Coletânea de Casos. São Paulo, ano 3, dez. 2010. Disponível para assinantes em: http://www.capitalaberto.com.br/ler_artigo.php?pag=3\&sec=34\&i=3656. Acesso em: 05/06/2012.

ROCHA, André. Por que algumas companhias estão deixando o mercado? Jornal Valor Econômico, 08 fev. 2012. Disponível em: http://www.valor.com.br/valor-investe/oestrategista/2523578/por-que-algumas-companhias-estao-deixando-o-mercado. Acesso em: $08 / 12 / 2012$.

SAKURAI, Sergio Naruhiko; TONETO, Rudinei Júnior; GREMAUD, Amaury Patrick. Emenda Constitucional no 29/2000: influência sobre a execução orçamentária dos estados e municípios brasileiros em saúde. In: BLIACHERIENE, Ana Carla; SANTOS, José Sebastião. 
Direito à vida e à saúde: impactos orçamentário e judicial. São Paulo: Atlas, 2010.

SALOMÃO FILHO, Calixto. O novo Direito societário. 3. ed. São Paulo: Ed. Malheiros, 2006.

Regulação da atividade econômica: princípios e fundamentos jurídicos. São Paulo: Ed. Malheiros, 2001.

Regulação da atividade econômica: princípios e fundamentos jurídicos. 2. ed. São Paulo: Ed. Malheiros, 2008.

SAMPAIO, Helena. Ensino superior no Brasil: o setor privado. São Paulo: Hucitec; Fapesp, 2000.

. Evolução do ensino superior brasileiro, 1808-1990. São Paulo: Núcleo de Pesquisas sobre Ensino Superior, 1991. (Documento de Trabalho Nupes 8/91)

SANTOS, Boaventura de Souza (Org.). Reconhecer para libertar os caminhos do cosmopolitismo multicultural. Rio de Janeiro: Civilização Brasileira, 2003.

Cortez, 2000.

Pela mão de Alice: o social e o político na pós-modernidade. 7. ed. São Paulo:

SARLET, Ingo. A eficácia dos direitos fundamentais. 9 ed. Porto Alegre: Livraria do Advogado, 2008.

SCHREIBER, Mariana. Educação atrai investidor estrangeiro. Folha de São Paulo, São Paulo, 17 ago. 2010. Disponível em: http://www1.folha.uol.com.br/fsp/mercado/me1708201013.htm. Acesso em: 05/06/2012.

SÉCCA, Rodrigo Ximenes; LEAL, Rodrigo Mendes. Análise do setor de ensino superior privado no Brasil. BNDES Setorial, n. 30, p. 103-156, set. 2009. Disponível em: http://www.bndes.gov.br/SiteBNDES/export/sites/default/bndes_pt/Galerias/Arquivos/conhec imento/bnset/set3003.pdf. Acesso em: 30/05/2012.

SENADO FEDERAL. Projeto de Lei do senado no 220 de 2010. Disponível em: http://www.senado.gov.br/atividade/materia/detalhes.asp?p_cod_mate=97871. Acesso em: 25/09/2012.

SEN, Amartya. Desenvolvimento como liberdade. Tradução Laura Teixeira Motta. São Paulo: Companhia das Letras, 2000.

SIFUENTES, Mônica. O acesso ao ensino fundamental no Brasil: um direito ao 
desenvolvimento. Rio de Janeiro: América Jurídica, 2001.

SILVA, José Afonso. Curso de Direito constitucional positivo. 33. ed. São Paulo: Malheiros, 2011.

SILVA, Marcos Wanderley. Princípios constitucionais afetos à educação. São Paulo: SRS, 2009.

SINAES. Indicadores sobre a educação superior. Disponível em http://sinaes.inep.gov.br:8080/sinaes/. Acesso em 13/06/2010.

STF. Apresentação do MEC sobre ações afirmativas no STF. Disponível em: http://www.stf.jus.br/portal/cms/verTexto.asp?servico=processoAudienciaPublicaAcaoAfirm ativa._Acesso em: 14/12/2010.

Ação Direta de Inconstitucionalidade 1.007-7/PE. Relator Ministro Eros Grau. Diário Oficial da União. Brasília, DF, 24 fev. 2006.

Ação Direta de Inconstitucionalidade 1.266/5/BA. Relator Ministro Eros Grau. Diário Oficial da União. Brasília, DF, 23 set. 2005.

Arguição de Descumprimento de Preceito Fundamental $\mathbf{n}^{\mathbf{0}}$ 186: voto do Ministro Relator Ricardo Lewandowski. Brasília: Supremo Tribunal Federal, 2012. Disponível em: http://www.stf.jus.br/arquivo/cms/noticiaNoticiaStf/anexo/ADPF186RL.pdf. Acesso em: 08/05/2012.

STIGLITZ, Joseph E. Globalização: como dar certo. Tradução Pedro Maia Soares. São Paulo: Companhia das Letras, 2007.

Economics of the public sector. 3rd. ed. New York: Norton, 1999.

SZTAJN, Rachel. Externalidades e custos de transação: a redistribuição de direitos no Novo Código Civil. RDM, v. 43, n.133, p.7-31, jan./mar. 2004.

TAKAHASHI, Fábio. Cresce evasão em universidade paga de SP. Folha de São Paulo, São Paulo, 21 jun. 2011. Disponível em: http://www1.folha.uol.com.br/fsp/cotidian/ff2106201115.htm. Acesso em: 25/09/2012.

; GOMES, Patrícia. Anhanguera demite 680 professores. Folha de São Paulo, São Paulo, 21 dez. 2011. Disponível em: http://www1.folha.uol.com.br/fsp/cotidiano/16182anhanguera-demite-680-professores.shtml. Acesso em 02/08/2012.

TOOLEY, James. The 'neo-liberal' critique of state intervention in education: a reply to Winch. Journal of Philosophy of Education, Oxford, v. 32, n. 2, 1998. 
Should the private sector profit from education? The seven virtues of highly effective markets. Educational Notes, London: Libertarian Alliance, n. 31, 1999.

The Global Education Industry: Lessons from Private Education in Developing Countries. 2nd. ed. London: Institute of Economic Affairs; Washington, DC: In association with the International Finance Corp., 2001.

UNESCO. Declaración mundial sobre la educación superior en el siglo XXI: visión y acción. Paris: Unesco, $1998 . \quad$ Disponível em: http://www.unesco.org/education/educprog/wche/declaration_spa.htm\#declaracion. Acesso em: 13/06/2010.

Global Education Digest 2011: comparing education statistics across the world. Canada: Unesco, 2011. Disponível em: http://www.uis.unesco.org/Education/Documents/ged2011-en.pdf. Acesso em: 31/07/2012.

Higher education in a globalized society. Paris: Unesco, 2004. Disponível em: http://unesdoc.unesco.org/images/0013/001362/136247e.pdf. Acesso em 17/01/2011.

Relatório de monitoramento de educação para todos Brasil 2008: educação para todos em 2015 - alcançaremos a meta? Brasília: Unesco, 2008. Disponível em: http://unesdoc.unesco.org/images/0015/001592/159294por.pdf. Acesso em 14/12/2010.

- Relatório de monitoramento global de educação para todos 2010: relatório conciso - alcançar os marginalizados. Paris: Unesco, 2010. Impresso no Brasil. Disponível em: http://unesdoc.unesco.org/images/0018/001865/186525por.pdf. Acesso em: $14 / 12 / 2010$.

UNE - UNIÃO NACIONAL DOS ESTUDANTES. Educação merece respeito: estudantes protestam contra o Grupo Anhanguera. Disponível em: http://www.une.org.br/2012/04/educacao-merece-respeito-estudantes-protestam-contra-ogrupo-anhanguera/. Acesso em: 25/09/2012.

VALOR ECONÔMICO. Ensino chega a R\$ 2,4 bi em aquisições. Valor Econômico, 09 jan. 2012. Disponível para assinantes em: http://www.valor.com.br/empresas/1176138/ensinochega-r-24-bi-em-aquisicoes. Acesso em: 30/06/2012.

WINCH, Christopher. Quality and education. Oxford: Blackwell Publishers/The Journal of the Philosophy of Education Society of Great Britain, 1996.

YOKOI, Yuki. Universidades e escolas preparam-se para desembarcar na bolsa. Revista Capital Aberto, São Paulo, ano 4, n. 47, p. 8-9, jul. 2007. Disponível em: 
http://www.capitalaberto.com.br/ler_artigo.php?pag=2\&sec $=17 \& \mathrm{i}=1434 \& b t \mathrm{xt}=$ Universidades $\% 20 \mathrm{e} \% 20$ escolas\%20preparam-se \%20para\%20desembarcar\%20na\%20bolsa. Acesso em: $05 / 06 / 12$.

YOUTUBE. Analfabeto é aprovado no vestibular da Universidade Estácio de Sá. Vídeo disponível em: http://www.youtube.com/watch?v=A2ykCr9jg5Q. Acesso em: 25/09/2012.

. Entrevista Antonio Carbonari Netto - Revista Uniban \# 178. Vídeo disponível em: http://www.youtube.com/watch?v=HV2PDUwDkG0. Acesso em: 07/01/2013.

Entrevista com prof. Antônio Carbonari Netto, da Anhanguera Educacional Completo. Vídeo disponível em: http:/www.youtube.com/watch?v=SP6ThzLM32k. Acesso em: 07/01/2013.

Padeiro e doméstica analfabetos são aprovados no vestibular da Gama Filho.

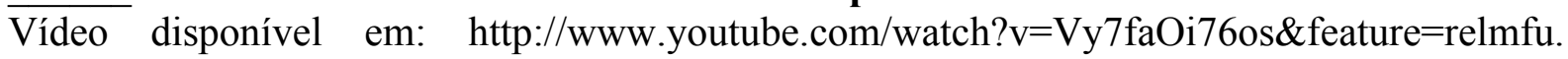
Acesso em: 25/09/2012.

ZAGO, Nadir. Pré-vestibular popular e trabalho docente: caracterização social e mobilização. Revista Contemporânea de Educação, Rio de Janeiro, v. 4, n. 8, ago./dez. 2009. Disponível em: http://www.educacao.ufrj.br/contemporanea-numeros-n8.html. Acesso em 13/06/2010. 


\section{APÊNDICE A - Documentação analisada da Anhanguera}

\section{Quadro de Documentação Analisada da Anhanguera}

\begin{tabular}{|c|c|c|c|}
\hline & Data & Tipo & Ordem do Dia/ Conteúdo \\
\hline 1. & $30 / 04 / 2003$ & $\mathrm{AGO}$ & $\begin{array}{l}\text { (i) aprovar o Balanço Patrimonial e as demais DFs da Companhia referentes } \\
\text { ao exercício social encerrado em } 31 / 12 / 2002 \text {; (ii) deliberar sobre a } \\
\text { destinação dos resultados do exercício; (iii) ratificar a dispensa da eleição } \\
\text { dos membros do CA em virtude de permanecerem os atuais no pleno } \\
\text { exercício de seu mandato regular de } 3 \text { anos; (iv) estipular remuneração } \\
\text { anual global dos Diretores e membros do CA; e (v) eleger os membros do } \\
\text { CF e respectiva remuneração, sendo o caso. }\end{array}$ \\
\hline 2. & $30 / 04 / 2004$ & AGOE & $\begin{array}{l}\text { Em AGO: (i) aprovar o Balanço Patrimonial e as demais DFs da Companhia } \\
\text { referentes ao exercício social encerrado em } 31 / 12 / 2003 \text {; (ii) deliberar sobre } \\
\text { a destinação dos resultados do exercício; (iii) deliberar sobre a eleição dos } \\
\text { membros do CA e diretores; (iv) estipular remuneração anual global dos } \\
\text { Diretores e membros do CA; e (v) eleger os membros do CF e respectiva } \\
\text { remuneração, sendo o caso. Em AGE: deliberar sobre a alteração do } \\
\text { endereço da sede da Companhia. }\end{array}$ \\
\hline 3. & $29 / 04 / 2005$ & $\mathrm{AGO}$ & $\begin{array}{l}\text { (i) aprovar o Balanço Patrimonial e as demais DFs da Companhia referentes } \\
\text { ao exercício social encerrado em 31/12/2004; (ii) deliberar sobre a } \\
\text { destinação dos resultados do exercício; (iii) estipular remuneração anual } \\
\text { global dos Diretores e membros do CA; e (iv) eleger os membros do CF e } \\
\text { respectiva remuneração, sendo o caso. }\end{array}$ \\
\hline 4. & $28 / 04 / 2006$ & $\mathrm{AGO}$ & $\begin{array}{l}\text { (i) aprovar o Balanço Patrimonial e as demais DFs da Companhia referentes } \\
\text { ao exercício social encerrado em 31/12/2005; (ii) deliberar sobre a } \\
\text { destinação dos resultados do exercício; (iii) estipular remuneração anual } \\
\text { global dos Diretores e membros do CA; e (iv) eleger os membros do CF e } \\
\text { respectiva remuneração, sendo o caso. }\end{array}$ \\
\hline 5. & $05 / 12 / 2006$ & $\mathrm{AGE}$ & $\begin{array}{l}\text { (i) retificar a redação dos arts. } 5^{\circ}, 6^{\circ}, 8^{\circ}, 26,27 \text { e } 28 \text { do ES da Companhia } \\
\text { consolidado na ata das AGOE realizadas em 30/04/2004; e (ii) ratificação } \\
\text { das demais deliberações tomadas nessas assembléias e dos demais } \\
\text { dispositivos do ES. }\end{array}$ \\
\hline 6. & $19 / 12 / 2006$ & AGE & $\begin{array}{l}\text { (i) alterar a sede social; (ii) alterar o objeto social; (iii) reformular e } \\
\text { consolidar o ES; (iv) aceitar as cartas de renúncias apresentadas pelos atuais } \\
\text { conselheiros e eleger os novos membros do CA. }\end{array}$ \\
\hline 7. & $\begin{array}{l}\text { 29/12/2006, } \\
\text { às } 11 \mathrm{~h}\end{array}$ & AGE & $\begin{array}{l}\text { (i) autorização para que a Administração proceda à adesão da Companhia } \\
\text { ao Regulamento de Listagem Nível } 2 \text { da Bolsa de Valores de São Paulo; e } \\
\text { (ii) aumento do capital social da Companhia. }\end{array}$ \\
\hline 8. & $\begin{array}{l}29 / 12 / 2006 \\
\text { às } 16 \mathrm{~h}\end{array}$ & AGE & (i) aumentar o capital social da Companhia. \\
\hline 9. & $12 / 01 / 2007$ & AGE & $\begin{array}{l}\text { (i) alteração da denominação social da Companhia; (ii) aprovação de } \\
\text { contrato de opção de compra de ações; (iii) re-ratificação da AGE de } \\
\text { 19/12/2006. }\end{array}$ \\
\hline 10. & $\begin{array}{c}06 / 02 / 2007 \\
\text { às } 17 \mathrm{~h}\end{array}$ & AGEsp & (i) conversão de 51.225.177 PN no mesmo número de ONs. \\
\hline 11. & $\begin{array}{l}06 / 02 / 2007 \\
\text { às } 20 \mathrm{~h}\end{array}$ & $\mathrm{AGE}$ & (i) conversão de 51.225.177 PN no mesmo número de ONs. \\
\hline 12. & $07 / 02 / 2007$ & AGE & $\begin{array}{l}\text { (i) reformulação do ES; (ii) aceitação de carta de renúncia apresentada por } \\
\text { Ricardo Leonel Scavazza ao cargo de Vice-Presidente do CA e atribuição } \\
\text { dessa função a outro membro do CA; e (iii) eleição dos membros do CA. }\end{array}$ \\
\hline 13. & $\begin{array}{l}12 / 02 / 2007 \\
\text { às } 17 \mathrm{~h}\end{array}$ & AGE & $\begin{array}{l}\text { (i) conversão de ONs em PNs da Companhia; (ii) desdobramento de ações; } \\
\text { (iii) alteração do art. } 5^{\circ} \text { (capital social) do ES. }\end{array}$ \\
\hline 14. & $\begin{array}{l}12 / 02 / 2007 \\
\text { às } 20 \mathrm{~h}\end{array}$ & AGEsp & $\begin{array}{l}\text { (i) conversão de } 894.217 \text { ON detidas por Erik Carbonari no mesmo número } \\
\text { de PNs, conforme AGE realizada pela Companhia nesta data }\end{array}$ \\
\hline
\end{tabular}




\begin{tabular}{|c|c|c|c|}
\hline & Data & Tipo & Ordem do Dia/ Conteúdo \\
\hline 15. & $16 / 02 / 2007$ & AGE & (i) re-ratificação do texto da Ata da AGE de 12/02/2007. \\
\hline 16. & $\begin{array}{c}07 / 03 / 2007 \\
\text { às } 8 \mathrm{~h}\end{array}$ & AGO & $\begin{array}{l}\text { (i) aprovar o relatório da administração, Balanço Patrimonial e as demais } \\
\text { DFs da Companhia referentes ao exercício social encerrado em } 31 / 12 / 2006 \text {, } \\
\text { incluindo o parecer dos auditores independentes; (ii) deliberar sobre a } \\
\text { destinação do lucro líquido do exercício; (iii) deliberar sobre a mudança do } \\
\text { jornal do local da sede da Companhia no qual são publicados os atos } \\
\text { societários e demais documentos da mesma. }\end{array}$ \\
\hline 17. & $\begin{array}{c}07 / 03 / 2007 \\
18 \mathrm{~h}\end{array}$ & AGE & $\begin{array}{l}\text { Renúncia dos acionistas ao recebimento dos dividendos deliberados na } \\
\text { AGO conforme faculta o parágrafo } 4^{\circ} \text { do art. } 124 \text { da Lei } 6.404 / 76 \text {. }\end{array}$ \\
\hline 18. & $01 / 08 / 2007$ & AGE & $\begin{array}{l}\text { (i) ratificar a nomeação da KPMG Auditores Independentes, para a } \\
\text { avaliação do patrimônio líquido contábil da Yanchep Participações S.A. e } \\
\text { elaboração do respectivo laudo do patrimônio líquido contábil da Yanchep; } \\
\text { (ii) examinar e deliberar sobre o Laudo de Avaliação; (iii) examinar e } \\
\text { deliberar sobre o Protocolo e Justificação de Incorporação da Yanchep pela } \\
\text { Companhia; (iv) examinar e deliberar sobre a incorporação da totalidade do } \\
\text { patrimônio da Yanchep na Companhia, sem aumento de capital da } \\
\text { Companhia, com a conseqüente extinção da Yanchep; e (v) autorizar os } \\
\text { administradores da Companhia a praticarem todos os atos e a tomarem } \\
\text { todas as providências necessárias à implementação dessa operação. }\end{array}$ \\
\hline 19. & $29 / 04 / 2008$ & AGOE & $\begin{array}{l}\text { Em AGO: (i) tomar as contas dos administradores, deliberar sobre as DFs } \\
\text { da Companhia, Balanço Patrimonial e Relatório dos Auditores } \\
\text { Independentes, referentes ao exercício social encerrado em 31/12/2007; (ii) } \\
\text { eleger os membros do CA; (iii) fixar o limite de valor da remuneração anual } \\
\text { global dos membros do CA e da Diretoria para o exercício social de 2008; e } \\
\text { (iv) deliberar sobre a proposta de destinação do lucro líquido do exercício e } \\
\text { distribuição de dividendos.Em AGE: (i) ratificar a aquisição (a) do Instituto } \\
\text { de Ensino Superior Senador Fláquer de Santo André Ltda., sociedade } \\
\text { mantenedora do Centro Universitário de Santo André - UniA ("UniA”); (b) } \\
\text { Centro de Ensino Superior de Campo Grande S/A Ltda. (“CESUP”); e (c) } \\
\text { União da Associação Educacional Sul-Matogrossense S/S Ltda. } \\
\text { ("UNAES"), em atendimento ao disposto no art. } 256 \text { da Lei } 6.404 / 76 \text {; e (ii) } \\
\text { homologar o aumento do capital social da Companhia, dentro do limite do } \\
\text { seu capital autorizado, no montante de R\$178.226,80, mediante a emissão } \\
\text { de } 515.940 \text { PNs e } 85.990 \text { ONs, representativas de } 85.990 \text { Units, conforme } \\
\text { aprovado em RCA da Companhia, realizada em 11/04/2008. }\end{array}$ \\
\hline 20. & $05 / 09 / 2008$ & AGE & 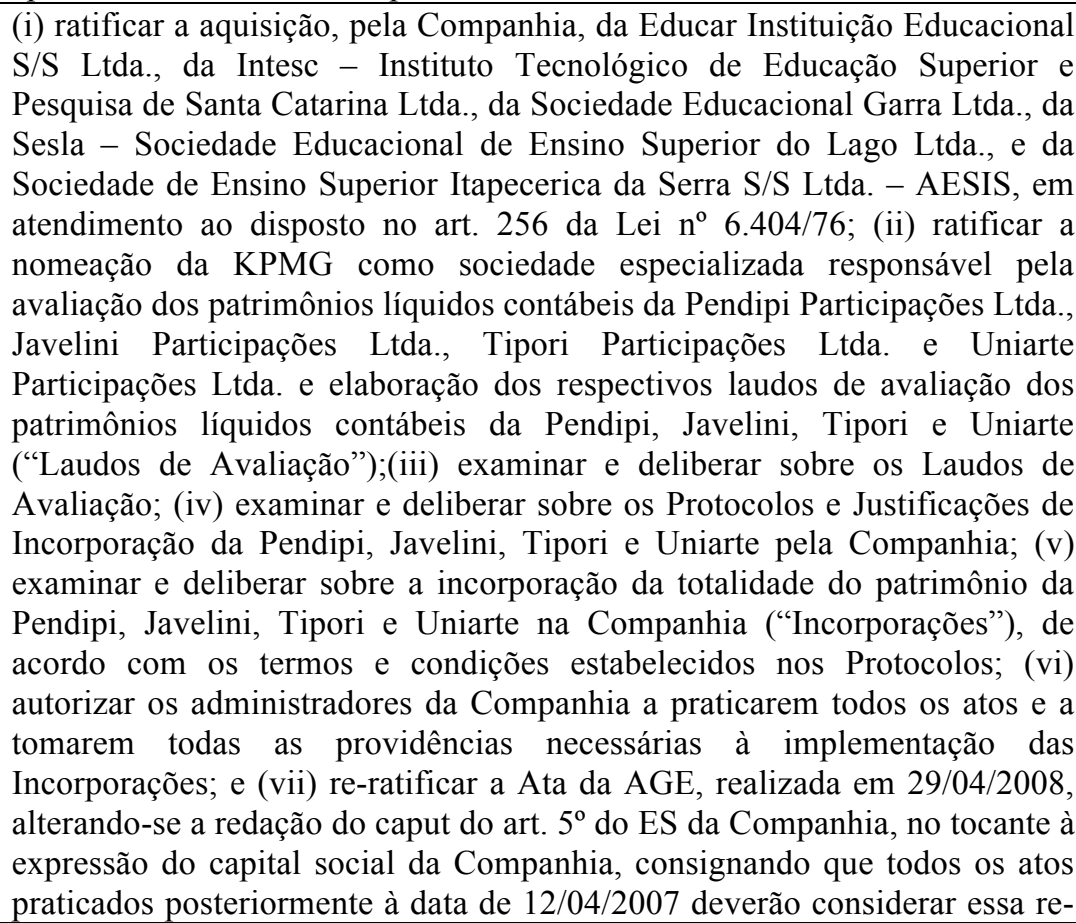 \\
\hline
\end{tabular}




\begin{tabular}{|c|c|c|c|}
\hline & Data & Tipo & Ordem do Dia/ Conteúdo \\
\hline & & & ratificação do capital social da Companhia. \\
\hline 21. & $\begin{array}{c}04 / 05 / 2009 \\
\text { às } 10 h 30\end{array}$ & $\mathrm{AGO}$ & $\begin{array}{l}\text { Em AGO: (i) tomar as contas dos administradores, deliberar sobre as DFs } \\
\text { da Companhia, Balanço Patrimonial e Relatório dos Auditores } \\
\text { Independentes, referentes ao exercício social encerrado em } 31 / 12 / 2008 \text {; (ii) } \\
\text { eleger os membros do CA; (iii) fixar o limite de valor da remuneração anual } \\
\text { global dos membros do CA e da Diretoria para o exercício social de 2009; } \\
\text { (iv) deliberar sobre a proposta de destinação do lucro líquido do exercício e } \\
\text { distribuição de dividendos; e (v) apreciar a proposta de instalação do CF em } \\
\text { caráter não permanente para atuar no exercício de } 2009 \text { e fixar sua } \\
\text { remuneração. }\end{array}$ \\
\hline 22. & $\begin{array}{c}04 / 05 / 2009 \\
10 \mathrm{~h}\end{array}$ & AGE & $\begin{array}{l}\text { (i) ratificar a aquisição, pela Companhia, da (a) Sociedade Educacional } \\
\text { Caxias do Sul Ltda. ("Kantum"), (b) Sociedade Educacional Centro } \\
\text { América Ltda. ("Facam"), (c) Centro de Ensino Superior de Rondonópolis } \\
\text { S/S Ltda. ("Cesur"), (d) Sociedade Brasileira de Ensino Superior Ltda. } \\
\text { ("Fabrai"), (e) SBCEC - Sociedade Brasil Central de Educação e Cultura } \\
\text { S/S Ltda. ("SBCEC"), (f) SOESC - Sociedade Educacional Sul } \\
\text { Sancaetanense S.S. Ltda. ("SOESC"), (g) Centro de Ensino Unificado de } \\
\text { Taguatinga Ltda. ("Fast"), (h) Pioneira Educacional Ltda. ("Pioneira"), (i) } \\
\text { Instituição de Ensino de Sertãozinho Ltda. ("Fasert"), (j) Editora Microlins } \\
\text { Ltda, antiga razão social da Escola de Profissões S.A. ("Microlins"), (l) } \\
\text { LFG Business e Participações Ltda. ("LFG"), (m) Colégio Universitário de } \\
\text { Taboão da Serra Ltda. - EPP ("Colégio I"), (n) Colégio Universitário } \\
\text { Taboão Ensino Fundamental Ltda. - EPP ("Colégio II"), (o) Cursinho } \\
\text { Universitário Taboão da Serra Sociedade Simples Ltda. ("Cursinho"), (p) } \\
\text { EM Colégio Universitário de Taboão da Serra Ltda. - EPP ("EM Colégio"), } \\
\text { e (q) Escola de Educação Infantil Universitário Junior Taboão da Serra } \\
\text { Ltda. ("Escola"), em atendimento ao disposto no art. 256 da Lei n" } \\
\text { 6.404/76; (ii) Deliberar acerca da proposta de alteração do art. 5 do ES em } \\
\text { função do aumento de capital deliberado em RCA realizada em 10/10/2008, } \\
\text { e retificado e homologado em RCA realizada em 03/03/2009; (iii) Deliberar } \\
\text { acerca da proposta de alteração dos art. 10, 11 e 17 do ES, tendo por } \\
\text { objetivo (a) estabelecer controles adicionais para eventual realização de } \\
\text { operações com instrumentos derivativos (Art. 10), e (b) aumentar o número } \\
\text { de Diretores e a forma de representação da Companhia (Arts. 11 e 17); e } \\
\text { (iv) Examinar e deliberar sobre a Proposta da Administração para conversão } \\
\text { de até } 45.000 .000 \text { de ONs de emissão da Companhia em PNs, na proporção } \\
\text { de uma PN para cada uma ON, sob os termos e nas condições constantes da } \\
\text { referida proposta. }\end{array}$ \\
\hline 23. & $03 / 09 / 2009$ & AGE & $\begin{array}{l}\text { (i) Deliberar acerca da emissão de debêntures não conversíveis em ações } \\
\text { com garantia real no valor de até R } \$ 50.000 .000,00 \text { pela Companhia, nos } \\
\text { termos do art. } 52 \text { e seguintes da Lei } 6.404 / 76 \text { e demais disposições legais } \\
\text { pertinentes; (ii) Deliberar acerca da delegação ao CA da Companhia da } \\
\text { competência para alterar, se necessário, as matérias de que trata a segunda } \\
\text { parte do parágrafo } 1^{\circ} \text { do art. } 59 \text { da Lei n. }{ }^{\circ} 6.404 / 76 \text {; (iii) Deliberar acerca da } \\
\text { autorização à Diretoria da Companhia para tomar todas as providências no } \\
\text { sentido de promover o registro da Emissão perante a Comissão de Valores } \\
\text { Mobiliários - CVM e demais órgãos competentes, bem como para lavrar a } \\
\text { escritura de emissão, celebrar o contrato de garantia, assinar toda e qualquer } \\
\text { documentação correlata à Emissão, contratar agência(s) de rating, } \\
\text { instituições financeiras autorizadas a operar no mercado de capitais para } \\
\text { efetuar a colocação das Debêntures, bem como contratar agente fiduciário, } \\
\text { banco centralizador e banco mandatário e escriturador, fixando-lhes os } \\
\text { respectivos honorários; (iv) Ratificar todos os atos relativos à Emissão, que } \\
\text { tenham sido praticados pela Diretoria anteriormente à data da AG; e (c) } \\
\text { Deliberar acerca da eleição de membros do CF. }\end{array}$ \\
\hline 24. & $25 / 11 / 2009$ & $\mathrm{AGE}$ & $\begin{array}{l}\text { (i) Deliberar acerca da alteração do caput do Art. } 5^{\circ} \text { do ES da Companhia } \\
\text { em função: (a) do aumento de capital deliberado em RCA realizada em } \\
\text { 26/06/2009, e (b) da conversão voluntária de ONs em PNs da Companhia, }\end{array}$ \\
\hline
\end{tabular}




\begin{tabular}{|c|c|c|c|}
\hline & Data & Tipo & Ordem do Dia/ Conteúdo \\
\hline & & & $\begin{array}{l}\text { no âmbito da proposta aprovada na AGE realizada em } 04 / 05 / 2009 \text {; e (ii) } \\
\text { Examinar e deliberar sobre proposta para conversão de até } 164.688 .000 \\
\text { ONs de emissão da Companhia em PNs, na proporção de uma PN para cada } \\
\text { uma ON, sob os termos e nas condições constantes da referida proposta. }\end{array}$ \\
\hline 25. & $\begin{array}{c}30 / 04 / 2010 \\
\text { às } 10 h 30\end{array}$ & AGO & $\begin{array}{l}\text { (i) tomar as contas dos administradores, deliberar sobre as DFs da } \\
\text { Companhia, Balanço Patrimonial e Relatório dos Auditores Independentes, } \\
\text { referentes ao exercício social encerrado em } 31 / 12 / 2009 \text {; (ii) deliberar sobre } \\
\text { a proposta de destinação do lucro líquido do exercício e distribuição de } \\
\text { dividendos; (iii) eleição dos membros do CA; (iv) instalação do CF da } \\
\text { Companhia, eleição de seus membros e fixação do valor da sua } \\
\text { remuneração global anual; (v) fixação do limite de valor da remuneração } \\
\text { anual global dos administradores da Companhia para o exercício social de } \\
2010 \text {. }\end{array}$ \\
\hline 26. & $30 / 04 / 2010$ & $\mathrm{AGE}$ & $\begin{array}{l}\text { (i) deliberação sobre a proposta de alteração do caput do Art. } 5^{\circ} \text { do ES da } \\
\text { Companhia em função da conversão voluntária de ONs em PNs da } \\
\text { Companhia, no âmbito da proposta aprovada na AGE realizada em } \\
\text { 25/11/2009; (ii) deliberação acerca da proposta de alteração do Art. } 10, \S 6^{\circ} \text {, } \\
\text { inciso (i), bem como da inclusão do inciso (xiii) no } \S 6^{\circ} \text { do Art. } 10 \text { do ES da } \\
\text { Companhia; (iii) deliberação acerca da aprovação, pela Companhia, de } \\
\text { plano de opção de compra de ações. }\end{array}$ \\
\hline 27. & $06 / 09 / 2010$ & $\mathrm{AGE}$ & $\begin{array}{l}\text { (i) alteração dos seguintes Arts. da Companhia: } \S 4^{\circ} \text { do Art. } 5^{\circ} \text { do ES; } \\
\text { Parágrafo Único do Art. } 7^{\circ} \text { do ES; } \S 6^{\circ} \text { e seus incisos do Art. } 10^{\circ} \text { do ES, } \\
\text { bem como a inclusão dos incisos (xv) a (xxvi) para a ampliação do rol de } \\
\text { matérias sujeitas à aprovação do CA da Companhia; do } \S 7^{\circ} \text { e } \S 8^{\circ} \text { do Art. } \\
10^{\circ} \text { do ES; } \S 5^{\circ} \text { e do caput do Art. } 11 \text { do ES; Art. } 13 \text { e seus incisos do ES } \\
\text { para alterar as atribuições do administrador; alteração do Art. } 14 \text { e seus } \\
\text { incisos do ES, para alterar as atribuições do administrador; Exclusão do Art. } \\
15 \text {, renumerando os demais arts. do ES; } \S 1^{\circ} \text { e do caput do Art. } 16 \text { do ES; do } \\
\text { Art. } 19 \text { do ES; em razão da renumeração, a alteração dos arts.: Inciso (i) do } \\
\text { Art. } 23 ; \S 9^{\circ} \S 10^{\circ} \text { e } \S 12^{\circ} \text { e caput do Art. } 24 \text {; Arts. } 25 \text {, } 29,30 \text {, parágrafo } \\
\text { único do Art. } 31 \text {, inciso II do Art. } 32 \text {; e Art. } 40 \text {; e (ii) deliberar acerca da } \\
\text { renumeração e consolidação do ES. }\end{array}$ \\
\hline 28. & $30 / 09 / 2010$ & AGE & $\begin{array}{l}\text { (i) examinar e deliberar sobre o Protocolo e Justificação de Incorporação da } \\
\text { LFG Business, Edições e Participações Ltda. pela Anhanguera Educacional } \\
\text { Participações S.A.;(ii) ratificar a nomeação da KPMG,, como sociedade } \\
\text { especializada responsável pela avaliação do patrimônio líquido da LFG } \\
\text { Business, Edições e Participações Ltda., pelo seu valor patrimonial contábil, } \\
\text { bem como pela elaboração do respectivo laudo de avaliação ("Laudo de } \\
\text { Avaliação");(iii) examinar e deliberar sobre o Laudo de Avaliação;(iv) } \\
\text { examinar e deliberar sobre a proposta de incorporação, pela Companhia, da } \\
\text { LFG Business, Edições e Participações Ltda. ("LFG”) ("Incorporação"), } \\
\text { com a consequente extinção da LFG;(v) em razão da Incorporação, } \\
\text { deliberar sobre a alteração do Art. } 3^{o} \text { do ES da Companhia, referente ao seu } \\
\text { objeto social, para incluir as seguintes atividades ora desenvolvidas pela } \\
\text { LFG, que são complementares às atividades atualmente desenvolvidas pela } \\
\text { Companhia: (a) o desenvolvimento de cursos na área jurídica e de cursos } \\
\text { preparatórios para concursos públicos em geral, sejam preparatórios para } \\
\text { concursos públicos jurídicos, ministrados de forma presencial e } \\
\text { telepresencial à distância, de cunho intensivo e extensivo, sejam de extensão } \\
\text { universitária e de pós-graduação lato sensu, oferecido ao público } \\
\text { consumidor de modo direto, por meio presencial ou por meio de qualquer } \\
\text { sistema tecnológico de comunicação de dados diretamente para os } \\
\text { consumidores, ou por meio de uma rede de parceiros, receptores do sinal } \\
\text { televisivo ou de qualquer outro sistema de transmissão de dados; (b) o } \\
\text { oferecimento de cursos de aprendizagem, treinamento gerencial e } \\
\text { profissional, preparatórios para carreira jurídica, atualização profissional, } \\
\text { extensão universitária, especialização e monográficos; (c) a prestação de } \\
\text { serviços de promoção e organização de eventos e cursos; (d) o }\end{array}$ \\
\hline
\end{tabular}




\begin{tabular}{|c|c|c|c|}
\hline & Data & Tipo & Ordem do Dia/ Conteúdo \\
\hline & & & $\begin{array}{l}\text { desenvolvimento e a ampliação do conteúdo dos cursos de pós-graduação } \\
\text { oferecidos, bem como o desenvolvimento de novos cursos de pós-graduação } \\
\text { lato sensu nas diversas áreas do conhecimento, ministrados de forma } \\
\text { telepresencial à distância; (e) a edição de livros e demais atividades } \\
\text { correlatas; (f) serviços de assessoria, consultoria, orientação e assistência } \\
\text { operacional em gestão empresarial; e (vi) autorizar os administradores da } \\
\text { Companhia a praticarem todos os atos e a tomarem todas as providências } \\
\text { necessárias à implementação e formalização da Incorporação. }\end{array}$ \\
\hline 29. & $\begin{array}{c}29 / 10 / 2010, \\
\text { às } 10 \mathrm{~h}\end{array}$ & AGE & $\begin{array}{l}\text { (i) o ingresso da Companhia no segmento especial de governança } \\
\text { corporativa da BM\&FBOVESPA, denominado Novo Mercado; (ii) caso } \\
\text { aprovada a deliberação constante do item (i) acima, a conversão da } \\
\text { totalidade das PNs de emissão da Companhia em ONs, na razão de } 1 \text { PN } \\
\text { para } 1 \text { ON e, consequentemente, a extinção das Units representativas de } \\
\text { ações de emissão da Companhia; (iii) o grupamento de ONs de emissão da } \\
\text { Companhia, na razão de } 7 \text { ações para } 1 \text { nova ação, de forma a manter a } \\
\text { continuidade das negociações de ações de emissão da Companhia em bolsa } \\
\text { de valores; (iv) uma vez aprovadas as deliberações dos itens anteriores, a } \\
\text { reforma do ES da Companhia, com o objetivo de adaptá-lo às } \\
\text { determinações do Regulamento do Novo Mercado da BM\&FBOVESPA; e } \\
\text { (v) tendo em vista a migração da Companhia para o segmento de listagem } \\
\text { do Novo Mercado da BM\&FBOVESPA, ratificar a eleição dos atuais } \\
\text { membros do CA da Companhia e estender os seus respectivos mandatos até } \\
\text { a data de realização da AGO que aprovar as DFs da Companhia relativas ao } \\
\text { exercício social findo em } 31 / 12 / 2012 \text {. }\end{array}$ \\
\hline 30. & $\begin{array}{c}29 / 10 / 2010, \\
\text { às } 12 \mathrm{~h}\end{array}$ & AGEsp & $\begin{array}{l}\text { Em decorrência do ingresso da Companhia no segmento especial de } \\
\text { governança corporativa da BM\&FBOVESPA, denominado Novo Mercado, } \\
\text { ratificar a deliberação que aprovar a conversão da totalidade das PNs de } \\
\text { emissão da Companhia em ONs, na razão de } 1 \text { PN para } 1 \text { ON e, } \\
\text { consequentemente, da extinção das Units representativas de ações de } \\
\text { emissão da Companhia. }\end{array}$ \\
\hline 31. & $29 / 04 / 2011$ & $\mathrm{AGO}$ & $\begin{array}{l}\text { (i) tomar as contas dos administradores, examinar, discutir e deliberar } \\
\text { acerca das DFs da Companhia, referentes ao exercício findo em 31/12/ } \\
2010 \text {, acompanhadas do Parecer dos Auditores Independentes da } \\
\text { Companhia; (ii) deliberação sobre a proposta de destinação do lucro líquido } \\
\text { do exercício e distribuição de dividendos; (iii) substituição dos Srs. Otavio } \\
\text { Lopes Castello Branco Neto, Antonio Carlos de Freitas Valle e Angela } \\
\text { Regina Rodrigues de Paula Freitas como membros do CA da Companhia e } \\
\text { consequente eleição de seus substitutos, conforme proposta da } \\
\text { administração; (iv) fixação do limite de valor da remuneração global anual } \\
\text { dos administradores da Companhia para o exercício social de 2011; e (v) } \\
\text { instalação do CF da Companhia, eleição de seus membros e fixação do } \\
\text { valor da sua remuneração global anual. }\end{array}$ \\
\hline 32. & $11 / 05 / 2011$ & AGE & $\begin{array}{l}\text { Alteração do caput do Art. } 5^{\circ} \text { do ES da Companhia, em função dos } \\
\text { aumentos de capital aprovados dentro do capital autorizado por deliberações } \\
\text { tomadas em RCAs realizadas em } 09 / 12 / 2010 \text { às } 19 \mathrm{~h} \text { e } 20 / 12 / 2010 \text { às } 18 \mathrm{~h} \text {. }\end{array}$ \\
\hline 33. & $08 / 07 / 2011$ & $\mathrm{AGE}$ & $\begin{array}{l}\text { (i) alteração do ES da Companhia, para contemplar as seguintes matérias:(a) } \\
\text { alterar o número do endereço no qual se localiza a sede da Companhia } \\
\text { constante do art. } 2^{\circ} \text { do ES, em função de renumeração realizada pela } \\
\text { Prefeitura de Valinhos, (b) alteração do art. } 3^{\circ} \text { do ES da Companhia, o qual } \\
\text { trata do objeto social da Companhia, incluindo outras atividades a serem } \\
\text { realizadas pela Companhia; (c) atribuição de poderes do CA para autorizar a } \\
\text { amortização, resgate ou recompra de ações da própria Companhia para } \\
\text { manutenção em tesouraria ou cancelamento, bem como deliberar sobre a } \\
\text { eventual alienação das ações porventura em tesouraria, mediante a inclusão } \\
\text { de novo inciso ao art. } 10 \text {, parágrafo } 60 \text {, do ES da Companhia; e (d) alterar a } \\
\text { nomenclatura do cargo de Diretor Superintendente para Diretor Presidente, } \\
\text { refletindo tal alteração nos arts. } 11 \text { e } 13 \text { do ES da Companhia; e (ii) } \\
\text { alteração do jornal nos quais a Companhia realiza suas publicações, nos }\end{array}$ \\
\hline
\end{tabular}




\begin{tabular}{|c|c|c|c|}
\hline & Data & Tipo & Ordem do Dia/ Conteúdo \\
\hline & & & $\begin{array}{l}\text { termos do art. } 289 \text { da Lei das Sociedades por Ações, substituindo o jornal } \\
\text { "Valor Econômico" pelo jornal "Folha de São Paulo". }\end{array}$ \\
\hline 34. & $30 / 04 / 2012$ & $\mathrm{AGO}$ & $\begin{array}{l}\text { (i) tomar as contas dos administradores, examinar, discutir e deliberar } \\
\text { acerca das DFs da Companhia, referentes ao exercício findo em } 31 / 12 / \\
2011 \text {, acompanhadas do Parecer dos Auditores Independentes da } \\
\text { Companhia; (ii) deliberação sobre as propostas de orçamento de capital, } \\
\text { destinação do lucro líquido do exercício e distribuição de dividendos; (iii) } \\
\text { substituição do Marco Antonio Gregori como membro do CA da } \\
\text { Companhia e conseqüente eleição de seu substituto, conforme proposta da } \\
\text { administração; (iv) fixação do limite de valor da remuneração global anual } \\
\text { dos administradores da Companhia para o exercício social de 2012, bem } \\
\text { como ratificação do montante global da remuneração paga aos } \\
\text { administradores da Companhia no exercício social de } 2011 \text {; e (v) instalação } \\
\text { do CF da Companhia, eleição de seus membros e fixação do valor da sua } \\
\text { remuneração global anual. }\end{array}$ \\
\hline 35. & $31 / 05 / 2012$ & $\begin{array}{c}\text { Estatuto } \\
\text { Social }\end{array}$ & Estatuto Social consolidado. \\
\hline 36. & $18 / 09 / 2011$ & $\begin{array}{c}\text { Fato } \\
\text { Relevante }\end{array}$ & Informações sobre a aquisição do grupo Uniban pelo grupo Anhanguera. \\
\hline 37. & $30 / 04 / 2003$ & RCA & $\begin{array}{l}\text { (i) deliberar sobre a renúncia dos Diretores Pércio Freire Rodrigues de } \\
\text { Souza, José de Menezes Berenger Neto e Heinz Jorg Gruber; (ii) designar o } \\
\text { novo Diretor de Relação com Investidores; (iii) deliberar sobre a eleição de } \\
\text { novos membros da Diretoria, bem como fixar seus respectivos mandatos; e } \\
\text { (iv) ratear a remuneração global aprovada pela AGE realizada na presente } \\
\text { data. }\end{array}$ \\
\hline 38. & $26 / 04 / 2004$ & $\mathrm{RCA}$ & $\begin{array}{l}\text { (i) aprovar o Relatório da Administração e as DFs da Companhia, referentes } \\
\text { ao exercício social encerrado em } 31 / 12 / 2003 \text {; e (ii) convocar as AGOE dos } \\
\text { acionistas da Companhia para o dia } 30 / 04 / 2004 \text {. }\end{array}$ \\
\hline 39. & $20 / 04 / 2005$ & RCA & $\begin{array}{l}\text { Deliberar sobre o desligamento dos Diretores Fernão Carlos Botelho } \\
\text { Bracher e Antonio Beltran Martinez. }\end{array}$ \\
\hline 40. & $28 / 04 / 2006$ & RCA & $\begin{array}{l}\text { (i) deliberar sobre a eleição dos membros da Diretoria da Companhia; e (ii) } \\
\text { ratear a remuneração anual global aprovada pela AGO da Companhia } \\
\text { realizada nesta data. }\end{array}$ \\
\hline 41. & $19 / 12 / 2006$ & $\mathrm{RCA}$ & $\begin{array}{l}\text { Aceitação das cartas de renúncia apresentadas pelos atuais Diretores e } \\
\text { eleição dos novos membros da Diretoria da Companhia. }\end{array}$ \\
\hline 42. & $29 / 01 / 2007$ & $\mathrm{RCA}$ & $\begin{array}{l}\text { (i) aprovação do Programa de Global Depositary Receipts ("Programa de } \\
\text { GDRs") da Companhia, nos termos das isenções de registro previstas da } \\
\text { Regra 144A e no Regulamento S, do Securities Act editado pela Securities } \\
\text { and Exchange Commission ("SEC"). }\end{array}$ \\
\hline 43. & $07 / 02 / 2007$ & $\mathrm{RCA}$ & $\begin{array}{l}\text { (i) aceitação da carta de renúncia apresentada pelo Diretor Marcos Lima } \\
\text { Verde Guimarães Jr.; e (ii) atribuição de funções aos Diretores da } \\
\text { Companhia. }\end{array}$ \\
\hline 44. & $15 / 02 / 2007$ & $\mathrm{RCA}$ & $\begin{array}{l}\text { (i) autorização para realização de Distribuição Pública Primária de } \\
\text { Certificado de Depósito de Ações (Units) de emissão da Companhia, a ser } \\
\text { realizada no Brasil, em mercado de balcão de não organizado, com esforços } \\
\text { de venda no exterior, em conformidade com o disposto nas isenções de } \\
\text { registro previstas na Rule 144A e na Regulation S, do Securities Act de } \\
1933 \text { dos EUA;(ii) autorização para aumento de capital dentro do limite do } \\
\text { capital autorizado, mediante emissão de Units representativas de } 1 \text { ON e } 6 \\
\text { PNs;(iii) autorização para emissão e alienação de } 24.750 .000 \text { ONs e } \\
148.500 .000 \text { PNs, representadas por } 24.750 .000 \text { Units. Desse total, serão } \\
20.000 .000 \text { novas ONs e } 120.000 .000 \text { novas PNs, totalizando } 20.000 .000 \\
\text { Units emitidas pela Companhia ("Distribuição Primária"); e } 4.750 .000 \text { ONs } \\
\text { e } 28.500 .000 \text { PNs, representadas por } 4.750 .000 \text { PNs, de titularidade dos } \\
\text { acionistas vendedores a serem alienadas "Distribuição Secundária"). A } \\
\text { quantidade total de Units inicialmente ofertada poderá ser acrescida em até } \\
15 \% \text { das Units inicialmente ofertadas, conforme Opção de Units de Lote } \\
\text { Suplementar, para atender eventual excesso de demanda. Sem prejuízo da }\end{array}$ \\
\hline
\end{tabular}




\begin{tabular}{|c|c|c|c|}
\hline & Data & Tipo & Ordem do Dia/ Conteúdo \\
\hline & & & $\begin{array}{l}\text { Opção de Units de Lote Suplementar, a quantidade de Units inicialmente } \\
\text { oferta poderá, a critério da Companhia e dos Acionistas Vendedores, ser } \\
\text { aumentada em até } 20 \% \text { do total de Units inicialmente ofertadas, conforme } \\
\text { dispõe o art. 14, Par. } 2^{\circ} \text { da ICVM } 400 \text {. As Units também poderão ser } \\
\text { emitidas na forma de Global Depositary Shares (GDS), representadas por } \\
\text { Global Depositary Receipts (GDR);(iii) adesão da Companhia às regras e ao } \\
\text { Regulamento do Nível } 2 \text { da Bovespa e a respectiva listagem de suas ações } \\
\text { no Nível } 2 \text { da Bovespa. }\end{array}$ \\
\hline 45 . & $08 / 03 / 2007$ & RCA & $\begin{array}{l}\text { Deliberar sobre: (i) aprovação do aumento de capital da Companhia, dentro } \\
\text { do limite de capital autorizado, no âmbito da oferta pública primária de } \\
\text { certificados de depósito de ações ("Units") realizada no Brasil e com } \\
\text { esforços de venda no exterior; (ii) fixação do preço de emissão das Units } \\
\text { objeto do aumento de capital social e respectiva justificativa; (iii) exclusão } \\
\text { do direito de preferência dos acionistas da Companhia na subscrição das } \\
\text { novas ações; (iv) determinação da forma de subscrição e integralização das } \\
\text { ações a serem emitidas; (v) aprovação do Prospecto Definitivo utilizado na } \\
\text { distribuição pública primária; e (vi) destinação dos recursos a serem } \\
\text { auferidos pela Companhia em decorrência do aumento de capital. }\end{array}$ \\
\hline 46. & $09 / 03 / 2007$ & RCA & $\begin{array}{l}\text { Deliberar sobre: (i) a verificação do número de ações subscritas no aumento } \\
\text { de capital social realizado em } 15 / 02 / 2007 \text {, no contexto da oferta pública de } \\
\text { distribuição de certificados de depósitos de ações ("Units"), representado } \\
\text { cada um por } 6 \text { PNs e } 1 \text { ON de emissão da Companhia. }\end{array}$ \\
\hline 47. & $\begin{array}{l}\text { 09/03/2007, } \\
\text { às } 10 \mathrm{~h}\end{array}$ & RCA & $\begin{array}{l}\text { Deliberar sobre: (i) a aprovação da aquisição da União Fênix de Educação e } \\
\text { Cultura Ltda.; e (ii) ratificar todos os atos realizados pela Diretoria para } \\
\text { aquisição da Yanchep Participações S.A. }\end{array}$ \\
\hline 48. & $09 / 04 / 2007$ & RCA & $\begin{array}{l}\text { Deliberação acerca da indicação da Companhia como garantidora no que } \\
\text { tange à aquisição, pela sua subsidiária Anhanguera Educacional S/A, das } \\
\text { quotas da empresa OESTE - Organização de Ensino Superior e Tecnologia } \\
\text { S/C Ltda., mantenedora da Instituição de Ensino Superior denominada } \\
\text { Faculdade Integração Zona Oeste, com sede na cidade de Osasco - SP. }\end{array}$ \\
\hline 49. & $12 / 04 / 2007$ & RCA & $\begin{array}{l}\text { Aprovar o aumento do capital da Companhia, dentro do limite do capital } \\
\text { autorizado, em vista do exercício de opção de compra de ações por } \\
\text { executivo da Companhia. }\end{array}$ \\
\hline 50. & $06 / 06 / 2007$ & $\mathrm{RCA}$ & $\begin{array}{l}\text { Ratificar a assinatura pela Companhia, na qualidade de fiadora, do Contrato } \\
\text { de Locação para Fins Não Residenciais, do imóvel localizado na Estrada do } \\
\text { Campo Limpo, 288, Bairro da Capelinha, Cidade de São Paulo - SP. }\end{array}$ \\
\hline 51. & $16 / 07 / 2007$ & RCA & $\begin{array}{l}\text { (i) examinar, aprovar e recomendar à AGE da Companhia a ratificação da } \\
\text { nomeação da KPMG Auditores Independentes ("KPMG"), como sociedade } \\
\text { especializada responsável pela avaliação do patrimônio líquido contábil da } \\
\text { Yanchep Participações S.A., e elaboração do respectivo laudo do } \\
\text { patrimônio líquido contábil da Yanchep;(ii) examinar, aprovar e } \\
\text { recomendar à AGE da Companhia a aprovação do Laudo de Avaliação;(iii) } \\
\text { examinar, aprovar e recomendar à AGE a aprovação do Protocolo e } \\
\text { Justificação de Incorporação da Yanchep pela Companhia; e (iv) examinar, } \\
\text { aprovar e recomendar à AGE a aprovação da incorporação da totalidade do } \\
\text { patrimônio da Yanchep na Companhia, de acordo com os termos e } \\
\text { condições estabelecidos no Protocolo, sem aumento do capital da } \\
\text { Companhia, e com a conseqüente extinção da Yanchep. }\end{array}$ \\
\hline 52. & $28 / 08 / 2007$ & RCA & $\begin{array}{l}\text { Deliberar acerca da indicação da Companhia como fiadora no Contrato de } \\
\text { Locação para Fins Não Residenciais, do imóvel sito à Avenida Raimundo } \\
\text { Pereira de Magalhães, } n^{\circ} \text {. 3.305, Bairro Pirituba, CEP 02938-970, Cidade de } \\
\text { São Paulo - SP. }\end{array}$ \\
\hline 53. & $27 / 09 / 2007$ & RCA & Aprovar a parceria comercial com o Banco Santander S.A. \\
\hline 54. & $28 / 09 / 2007$ & RCA & $\begin{array}{l}\text { (i) Deliberar acerca da aquisição das sociedades que fazem parte da } \\
\text { operação da Uniderp; e } \\
\text { (ii) Deliberar acerca da aquisição da União da Associação Educacional Sul- } \\
\text { Matogrossense Ltda., com sede na cidade de Campo Grande - MS. }\end{array}$ \\
\hline 55. & $02 / 10 / 2007$ & RCA & Deliberar acerca da indicação da Companhia como fiadora no Contrato de \\
\hline
\end{tabular}




\begin{tabular}{|c|c|c|c|}
\hline & Data & Tipo & Ordem do Dia/ Conteúdo \\
\hline & & & $\begin{array}{l}\text { Locação para Fins Não Residenciais firmado em 19/12/2006 entre Ribeito } \\
\text { Daher Empreendimentos Imobiliários Ltda., na qualidade de locadora e } \\
\text { Anhanguera Educacional S.A., na qualidade de locatária, tendo como objeto } \\
\text { a locação de imóveis localizados na cidade de Jacareí. }\end{array}$ \\
\hline 56. & $05 / 12 / 2007$ & RCA & $\begin{array}{l}\text { Aprovar a contratação de mútuo, pela Companhia, com o Banco Bradesco } \\
\text { S/A, no valor de } \mathrm{R} \$ 50.000 .000,00 \text {. }\end{array}$ \\
\hline 57. & $10 / 12 / 2007$ & RCA & 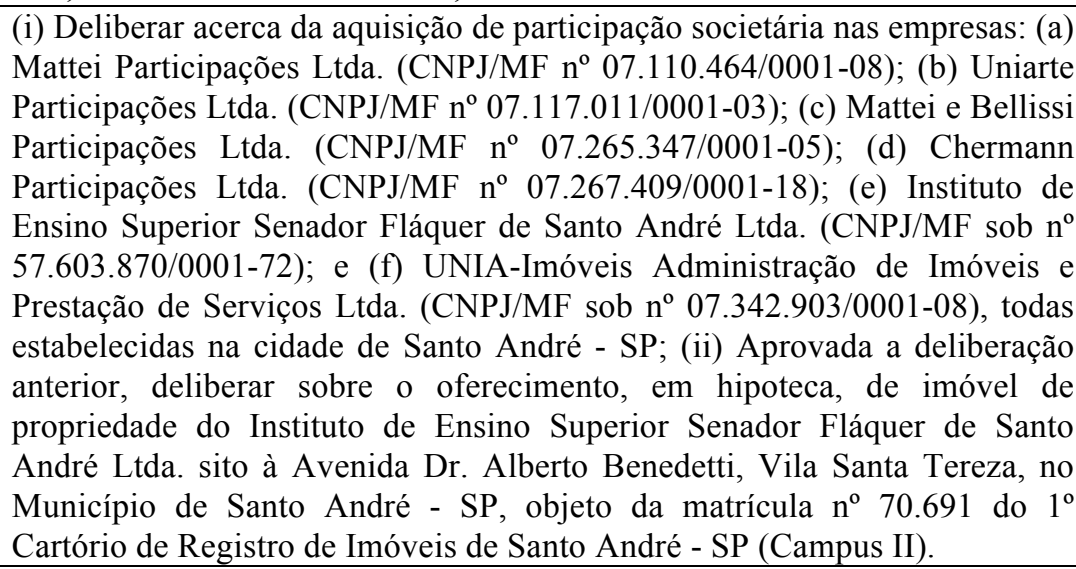 \\
\hline 58. & $19 / 12 / 2007$ & $\mathrm{RCA}$ & $\begin{array}{l}\text { Aprovar a assinatura, como garantidora, de uma Carta de Fiança com o } \\
\text { Banco Bradesco S/A, conforme previsão do Instrumento Particular de } \\
\text { Cessão e Transferência de Quotas e Outras Avenças, datado de } 10 / 12 / 2007 \text {, } \\
\text { contrato que tem por objeto a aquisição das seguintes sociedades } \\
\text { estabelecidas na cidade de Santo André - SP: (a) Mattei Participações Ltda. } \\
\left(\mathrm{CNPJ} / \mathrm{MF} \mathrm{n}^{\mathrm{o}} 07.110 .464 / 0001-08\right) \text {; (b) Uniarte Participações Ltda. } \\
\left(\mathrm{CNPJ} / \mathrm{MF} \mathrm{n}^{\circ} 07.117 .011 / 0001-03\right) \text {; (c) Mattei e Bellissi Participações Ltda. } \\
\left(\mathrm{CNPJ} / \mathrm{MF} \mathrm{n}^{\circ} 07.265 .347 / 0001-05\right) \text {; (d) Chermann Participações Ltda. } \\
\left(\mathrm{CNPJ} / \mathrm{MF} \mathrm{n}^{\mathrm{o}} \text { 07.267.409/0001-18); (e) Instituto de Ensino Superior }\right. \\
\text { Senador Fláquer de Santo André Ltda. (CNPJ/MF sob } \mathrm{n}^{\circ} 57.603 .870 / 0001- \\
72) \text {; e (f) UNIA-Imóveis Administração de Imóveis e Prestação de Serviços } \\
\left.\text { Ltda. (CNPJ/MF sob n }{ }^{\circ} 07.342 .903 / 0001-08\right) \text {. }\end{array}$ \\
\hline 59. & $28 / 12 / 2007$ & RCA & $\begin{array}{l}\text { Aprovar a emissão de notas promissórias comerciais ("NPs") pela } \\
\text { Companhia, mediante oferta pública, nos seguintes termos e condições: (a) } \\
\text { Montante Total da Emissão: R } \$ 130.000 .000,00 \text { ("Montante Total da } \\
\text { Emissão"); (b) Quantidade Total: Emissão de } 13 \mathrm{NPs} \text {, em série única; (c) } \\
\text { Valor Nominal Unitário: R } \$ 10.000 .000,00 \text { ("Valor Nominal Unitário"); (d) } \\
\text { Regime de colocação: Garantia Firme, prestada pelo Coordenador Líder, } \\
\text { garantindo o Montante Total da Emissão; (e) Preço de Subscrição: Valor } \\
\text { Nominal Unitário; (f) Garantia: Cessão fiduciária ("Garantias"): (f.1) dos } \\
\text { direitos creditórios de titularidade da Companhia e/ou de suas controladas, } \\
\text { oriundos da prestação de serviços educacionais aos alunos das entidades de } \\
\text { ensino mantidas pela Companhia, respeitado o limite de 50\% dos } \\
\text { Recebíveis, ou o valor mínimo mensal de R\$ } 22.500 .000,00 \text {; e (f.ii) dos } \\
\text { direitos de crédito que a Companhia tem ou venha a possuir no futuro em } \\
\text { face dos pagamentos dos Recebíveis, limitados a } 50 \% \text { (cinqüenta por cento) } \\
\text { desses pagamentos (g) Destinação dos Recursos: Os recursos captados por } \\
\text { meio da distribuição pública das NPs deverão ser utilizados pela Emissora } \\
\text { para financiar aquisições e a expansão de suas atividades, bem como para o } \\
\text { pagamento das despesas e comissões relativas à emissão das NPs; (h) } \\
\text { Público Alvo: As NPs serão destinadas, única e exclusivamente, a } \\
\text { investidores qualificados; (i) Remuneração: pagamento de juros } \\
\text { remuneratórios incidentes sobre seu Valor Nominal Unitário e determinados } \\
\text { com base na taxa média diária dos depósitos interfinanceiros de um dia, } \\
\text { CDI "over extra grupo", capitalizada de uma sobretaxa de 0,45\% expressa } \\
\text { na forma percentual ao ano, base 252 dias, calculada e divulgada } \\
\text { diariamente pela CETIP no informativo diário, disponível em sua página na } \\
\text { Internet (http://www.cetip.com.br) ("Taxa DI"), calculados "pro rata }\end{array}$ \\
\hline
\end{tabular}




\begin{tabular}{|c|c|c|c|}
\hline & Data & Tipo & Ordem do Dia/ Conteúdo \\
\hline & & & $\begin{array}{l}\text { temporis", desde a Data de Emissão, até o vencimento da respectiva Nota } \\
\text { Promissória, (j) Vencimento: O prazo de vencimento das NPs será de } 180 \\
\text { dias, a contar da Data de Emissão ("Data de Vencimento"); (1) Encargos } \\
\text { Moratórios: Caso a Companhia deixe de efetuar o pagamento de qualquer } \\
\text { quantia devida aos titulares das NPs, os débitos em atraso ficarão sujeitos a } \\
\text { (1.1) multa moratória convencional, irredutível e de natureza não } \\
\text { compensatória de } 2 \% \text { sobre o valor devido e não pago; e (1.2) juros de mora } \\
\text { não compensatórios calculados desde a data do inadimplemento até a data } \\
\text { do efetivo pagamento, à taxa de } 1 \% \text { ao mês, sobre o montante devido e não } \\
\text { pago. (m) Coordenador-Líder: Banco Santander S.A.; Agente de Notas: } \\
\text { Banco Santander S.A. (n) Banco Mandatário:Banco Santander S.A.; (o) } \\
\text { Agente de Garantias: Banco Santander S.A.; (p) Local de Pagamento: Os } \\
\text { pagamentos referentes às NPs serão realizadas em conformidade com os } \\
\text { procedimentos da CETIP, para as NPs registradas no NOTA ou, para os } \\
\text { titulares das NPs que não estiverem vinculadas ao referido sistema, na sede } \\
\text { da Emissora. }\end{array}$ \\
\hline 60. & $13 / 02 / 2008$ & RCA & $\begin{array}{l}\text { Deliberar acerca da aquisição da Sociedade Educacional Garra Ltda., } \\
\text { sociedade empresária limitada, mantenedora da instituição de ensino } \\
\text { superior denominada Faculdades Planalto - FAPLAN, com sede na Rua } \\
\text { Paissandu, 1200, Centro, na Cidade de Passo Fundo-RS. }\end{array}$ \\
\hline 61. & $20 / 02 / 2008$ & $\mathrm{RCA}$ & $\begin{array}{l}\text { (i) Deliberar acerca da aquisição da SESLA - Sociedade Educacional de } \\
\text { Ensino Superior do Lago Ltda., sociedade mantenedora da instituição de } \\
\text { ensino superior denominada Faculdade de Negócios e Tecnologias da } \\
\text { Informação - FACNET, com sede no Município de Brasília, Distrito } \\
\text { Federal, na QD 01, Rua 210, 40, Salões Comerciais n }{ }^{\circ} \text {. } 2.031 \text { a } 2.037 \text { - } \\
\text { parte, Bairro Águas Claras; e(ii) Deliberar acerca da alteração da forma de } \\
\text { representação da Companhia especificamente para a assinatura do contrato } \\
\text { de aquisição de quotas, da alteração do contrato social e demais documentos } \\
\text { relacionados à aquisição da SESLA - Sociedade Educacional de Ensino } \\
\text { Superior do Lago Ltda. pela Companhia. }\end{array}$ \\
\hline 62. & $25 / 02 / 2008$ & RCA & $\begin{array}{l}\text { (i) Deliberar acerca da aquisição das seguintes sociedades:(I) EDUCAR - } \\
\text { Instituição Educacional S/S Ltda., sociedade simples limitada com sede } \\
\text { social na Rua Presidente Campos Salles, n. 850, na Cidade de Joinvile - } \\
\text { SC, inscrita no CNPJ sob o n. }{ }^{\circ} \text { 03.218.232/0001-09, mantenedora das } \\
\text { instituições de ensino superior denominadas: (a) Instituto de Ensino } \\
\text { Superior de Joinville - IESVILLE, (b) a Faculdade de Tecnologia Iesville - } \\
\text { FATI, (c) a Faculdade de Tecnologia São Carlos - FATESC, (d) o Instituto } \\
\text { Superior de Educação de Santa Catarina - ISESC, e (e) a Faculdade de } \\
\text { Tecnologia de Jaraguá do Sul - FATEJ; e(II) INTESC - Instituto } \\
\text { Tecnológico de Educação Superior e Pesquisa de Santa Catarina Ltda., } \\
\text { sociedade empresária limitada com sede social na Rua Major Julio Ferreira, } \\
\text { n}^{\text {o. }} 459 \text {, na Cidade de Jaraguá do Sul - SC, inscrita no CNPJ sob o n. } \\
\text { 06.191.120/0001-08, mantenedora da instituição de ensino superior } \\
\text { denominada Faculdade de Tecnologia Jaraguaense - FATEJA; e (ii) } \\
\text { Deliberar acerca da alteração da forma de representação da Companhia } \\
\text { especificamente para a assinatura do "Instrumento Particular de Compra e } \\
\text { Venda de Quotas e Outras Avenças", das alterações dos contratos sociais e } \\
\text { demais documentos relacionados à aquisição das sociedades EDUCAR - } \\
\text { Instituição Educacional S/S Ltda. e INTESC - Instituto Tecnológico de } \\
\text { Educação Superior e Pesquisa de Santa Catarina Ltda., pela Companhia. }\end{array}$ \\
\hline 63. & $10 / 03 / 2008$ & $\mathrm{RCA}$ & $\begin{array}{l}\text { (i) Revisão e Aprovação do Relatório da Administração e das contas da } \\
\text { Diretoria; (ii) Apreciação das DFs e Parecer dos Auditores Independentes } \\
\text { da Companhia, relativos ao exercício social findo em } 31 / 12 / 2007 \text {; (iii) } \\
\text { Apreciação da destinação do lucrolíquido da Companhia; e (iv) Aprovação } \\
\text { da convocação da AGO da Companhia. }\end{array}$ \\
\hline 64. & $09 / 04 / 2008$ & $\mathrm{RCA}$ & $\begin{array}{l}\text { (i) Deliberar sobre a emissão de até } 17.000 .000 \text { de certificados de depósitos } \\
\text { de ações, representativos cada um de } 1 \mathrm{ON} \text { e } 6 \text { PNs, nominativas, escriturais, } \\
\text { sem valor nominal, de emissão da Anhanguera Educacional Participações }\end{array}$ \\
\hline
\end{tabular}




\begin{tabular}{|c|c|c|c|}
\hline & Data & Tipo & Ordem do Dia/ Conteúdo \\
\hline & & & $\begin{array}{l}\text { S.A., no âmbito de uma oferta pública de distribuição primária de Units } \\
\text { ("Oferta"); (ii) Deliberar sobre a autorização para o aumento de capital da } \\
\text { Companhia dentro do limite do capital autorizado; (iii) Deliberar sobre a } \\
\text { concessão de autorização para os membros da diretoria da Companhia } \\
\text { adotarem todas as providências e praticar todos os atos necessários à } \\
\text { realização da Oferta; e (iv) Deliberar sobre a ratificação dos atos já } \\
\text { praticados pelos membros da diretoria da Companhia no contexto da Oferta. }\end{array}$ \\
\hline 65. & $\begin{array}{l}11 / 04 / 2008, \\
\text { às } 9 \mathrm{~h}\end{array}$ & RCA & $\begin{array}{l}\text { Aprovar o aumento do capital da Companhia, dentro do limite do capital } \\
\text { autorizado, em vista do exercício de opção de compra de ações por } \\
\text { executivo da Companhia. }\end{array}$ \\
\hline 66. & $\begin{array}{c}11 / 04 / 2008, \\
\text { às } 10 \mathrm{~h}\end{array}$ & RCA & Re-ratificar a ata da RCA da Companhia, realizada em 11/04/2008, às 09h. \\
\hline 67. & $\begin{array}{l}22 / 04 / 2008, \\
\text { às } 18 \mathrm{~h}\end{array}$ & RCA & $\begin{array}{l}\text { Deliberar sobre (1) o aumento do capital social da Companhia, dentro do } \\
\text { limite do capital autorizado; e (2) a fixação do preço por Unit. }\end{array}$ \\
\hline 68. & $\begin{array}{c}22 / 04 / 2008, \\
\text { às } 20 \mathrm{~h}\end{array}$ & $\mathrm{RCA}$ & Re-ratificação da Ata da RCA realizada em 22/04/2008, às $19 \mathrm{~h}$. \\
\hline 69. & $23 / 04 / 2008$ & RCA & $\begin{array}{l}\text { Deliberar sobre a verificação do número de certificados de depósitos de } \\
\text { ações, representativos cada um de } 1 \text { ON e } 6 \text { PNs ("Units") subscritos no } \\
\text { aumento de capital social conforme aprovado em RCAs da Companhia } \\
\text { realizadas em } 09 \text { e 22/04/2008, no contexto da oferta pública primária de } \\
\text { Units de emissão da Companhia. }\end{array}$ \\
\hline 70. & $\begin{array}{l}\text { 28/04/2008, } \\
\text { às } 9 \mathrm{~h}\end{array}$ & RCA & $\begin{array}{l}\text { Deliberar sobre a homologação do número de certificados de depósitos de } \\
\text { ações, representativos cada um de } 1 \text { ON e } 6 \text { PNs ("Units") subscritos no } \\
\text { aumento de capital social conforme aprovado em RCAs da Companhia } \\
\text { realizadas em } 09 \text { e 22/04/2008, no contexto da oferta pública primária de } \\
\text { Units de emissão da Companhia. }\end{array}$ \\
\hline 71. & $\begin{array}{l}\text { 28/04/2008, } \\
\text { às } 9 \text { h30 }\end{array}$ & RCA & $\begin{array}{l}\text { Aprovar o aumento do capital social da Companhia, dentro do limite do } \\
\text { capital autorizado, em vista do exercício de opção de compra de ações por } \\
\text { executivo da Companhia. }\end{array}$ \\
\hline 72. & $\begin{array}{l}28 / 04 / 2008, \\
\text { às } 18 \mathrm{~h}\end{array}$ & RCA & $\begin{array}{l}\text { Deliberar sobre: (i) o aumento do capital social da Companhia e a } \\
\text { quantidade de Units a serem emitidas no contexto da oferta pública de } \\
\text { certificados de depósitos de ações, representativos cada um de } 1 \text { ON e } 6 \\
\text { PNs, nominativas, escriturais, sem valor nominal ("Units"), em razão do } \\
\text { exercício integral da opção de ações do lote suplementar concedida ao } \\
\text { Banco de Investimentos Credit Suisse (Brasil) S.A., nos termos do Contrato } \\
\text { de Coordenação, Subscrição e Colocação de Certificados de Depósitos de } \\
\text { Ações de Emissão da Anhanguera Educacional Participações S.A. } \\
\text { ("Contrato de Distribuição") e conforme previsto no art. } 24 \text { da Instrução } \\
\text { CVM n }{ }^{\circ} 400 / 2003 \text {; (ii) a fixação do preço de emissão das Units objeto do } \\
\text { aumento de capital referido no item (i) e respectiva justificativa; e (iii) a } \\
\text { verificação da subscrição das Units emitidas no aumento de capital referido } \\
\text { no item (i) acima. }\end{array}$ \\
\hline 73. & $05 / 05 / 2008$ & RCA & $\begin{array}{l}\text { Deliberar sobre a homologação do número de certificados de depósitos de } \\
\text { ações, representativos cada um de } 1 \text { ON e } 6 \text { PNs ("Units") subscritos no } \\
\text { aumento de capital social conforme aprovado em RCA da Companhia } \\
\text { realizada em 28/04/2008, no âmbito da oferta pública de Units da } \\
\text { Companhia ("Oferta") em razão do exercício integral da opção de ações do } \\
\text { lote suplementar concedida ao Banco de Investimentos Credit Suisse } \\
\text { (Brasil) S.A., nos termos do Contrato de Coordenação, Subscrição e } \\
\text { Colocação de Certificados de Depósitos de Ações de Emissão da } \\
\text { Anhanguera Educacional Participações S.A. ("Contrato de Distribuição") e } \\
\text { conforme previsto no art. } 24 \text { da ICVM 400/2003. }\end{array}$ \\
\hline 74. & $\begin{array}{l}\text { 27/05/2008, } \\
\text { às } 9 \mathrm{~h}\end{array}$ & RCA & $\begin{array}{l}\text { Deliberar acerca da aquisição da Sociedade Educacional Sul Sancaetanense } \\
\text { S/S. Ltda., sociedade mantenedora da FAENAC - Faculdade Editora } \\
\text { Nacional, com sede na cidade de São Caetano do Sul - SP. }\end{array}$ \\
\hline 75. & $\begin{array}{l}\text { 27/05/2008, } \\
\text { às } 9 \text { h30 }\end{array}$ & RCA & $\begin{array}{l}\text { Deliberar acerca da aquisição da Sociedade Brasileira de Ensino Superior } \\
\text { Ltda., sociedade mantenedora da FABRAI - Faculdade Brasileira de } \\
\text { Ciências Exatas, Humanas e Sociais e da Faculdade de Tecnologia }\end{array}$ \\
\hline
\end{tabular}




\begin{tabular}{|c|c|c|c|}
\hline & Data & Tipo & Ordem do Dia/ Conteúdo \\
\hline & & & FABRAI, com sede na cidade de Belo Horizonte - MG. \\
\hline 76. & $16 / 06 / 2008$ & RCA & $\begin{array}{l}\text { (i) Deliberar a ratificação da assinatura do Instrumento Particular de Cessão } \\
\text { de Créditos e Outras Avenças firmado pela Companhia e Casa dos } \\
\text { Parafusos Ltda., Geraldo Eudóxio Cândido de Lima, Edelmo José de } \\
\text { Azevedo, Eduardo Afonso de Medeiros Parente e Loreno Antônio Sôster, } \\
\text { na data de 02/04/2008; e (ii) Deliberar acerca da ratificação da renegociação } \\
\text { do preço, realizada em 15/10/2007, referente à aquisição das sociedades: } \\
\text { Centro de Ensino Superior de Campo Grande S/S Ltda., Editora Uniderp } \\
\text { Ltda., Farmácia Escola Uniderp Ltda. - EPP e INEPES - Instituto de } \\
\text { Pesquisas de Interesse e Opinião Pública Ltda. }\end{array}$ \\
\hline 77. & $07 / 07 / 2008$ & RCA & $\begin{array}{l}\text { (i) Deliberar acerca da aquisição do Centro de Ensino Superior de } \\
\text { Rondonópolis S/S Ltda., sociedade mantenedora da FACSUL - Faculdade } \\
\text { do Sul de Mato Grosso, com sede na cidade de Rondonópolis - MT; (ii) } \\
\text { Deliberar acerca da alteração da forma de representação da Companhia } \\
\text { especificamente para a assinatura do contrato de aquisição de quotas, da } \\
\text { alteração do contrato social e demais documentos relacionados à aquisição } \\
\text { do Centro de Ensino Superior de Rondonópolis S/S Ltda. }\end{array}$ \\
\hline 78. & $31 / 07 / 2008$ & RCA & 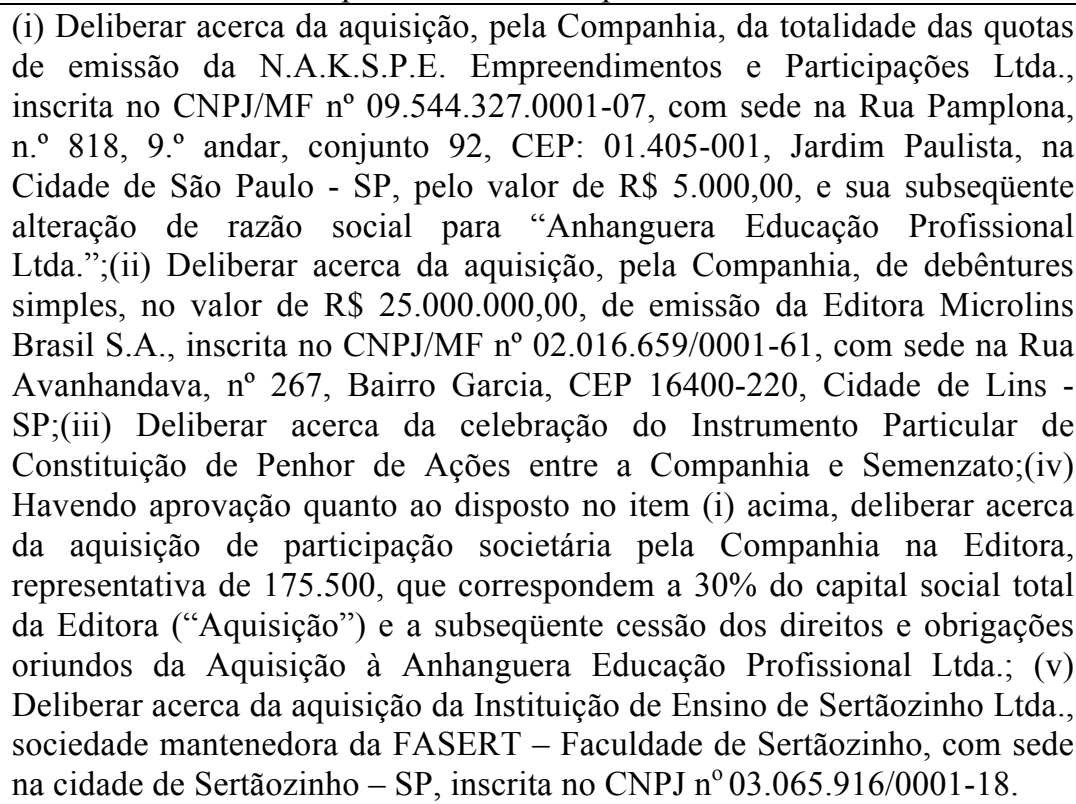 \\
\hline 79. & $12 / 08 / 2008$ & RCA & $\begin{array}{l}\text { Deliberar acerca da aprovação e ratificação das alterações nas condições } \\
\text { financeiras relativas à emissão de notas promissórias comerciais ("NPs") } \\
\text { pela Companhia mediante oferta pública, aprovada em RCA de } 28 / 12 / 2007 \text {. }\end{array}$ \\
\hline 80. & $15 / 08 / 2008$ & RCA & $\begin{array}{l}\text { (1) deliberar acerca da ratificação da renegociação do preço, realizada em } \\
\text { 15/10/2007, referente à aquisição das seguintes sociedades: Centro de } \\
\text { Ensino Superior de Campo Grande S/S Ltda, Editora Uniderp Ltda., } \\
\text { Farmácia Escola Uniderp Ltda.-EPP e INEPES - Instituto de Pesquisas de } \\
\text { Interesse e Opinião Pública Ltda.; (2) examinar, aprovar e recomendar à } \\
\text { AGE da Companhia a ratificação da nomeação da KPMG Auditores } \\
\text { Independentes, ("KPMG”), sociedade especializada responsável pela } \\
\text { avaliação dos patrimônios líquidos contábeis da Pendipi Participações Ltda., } \\
\text { sociedade empresária limitada com sede na Rua Coronel Abílio Soares no } \\
\text { 163, sala 03, Centro, CEP 09020-260, no Município de Santo André - SP, } \\
\text { inscrita no CNPJ/MF sob n' 07.110.464/0001-08, ("Pendipi”), Javelini } \\
\text { Participações Ltda., sociedade empresária limitada com sede na Rua } \\
\text { Coronel Abílio Soares no 163, sala 05, Centro, CEP 09020-260, no } \\
\text { Município de Santo André - SP, inscrita no CNPJ/MF sob no } \\
\text { 07.265.347/0001-05, (“Javelini”), Tipori Participações Ltda., sociedade } \\
\text { empresária limitada com sede na Rua Coronel Abílio Soares n } 163 \text {, sala 02, } \\
\text { Centro, CEP 09020-260, no Município de Santo André - SP, inscrita no } \\
\text { CNPJ/MF sob no 07.267.409/0001-18, (“Tipori”); e Uniarte Participações }\end{array}$ \\
\hline
\end{tabular}




\begin{tabular}{|c|c|c|c|}
\hline & Data & Tipo & Ordem do Dia/ Conteúdo \\
\hline & & & 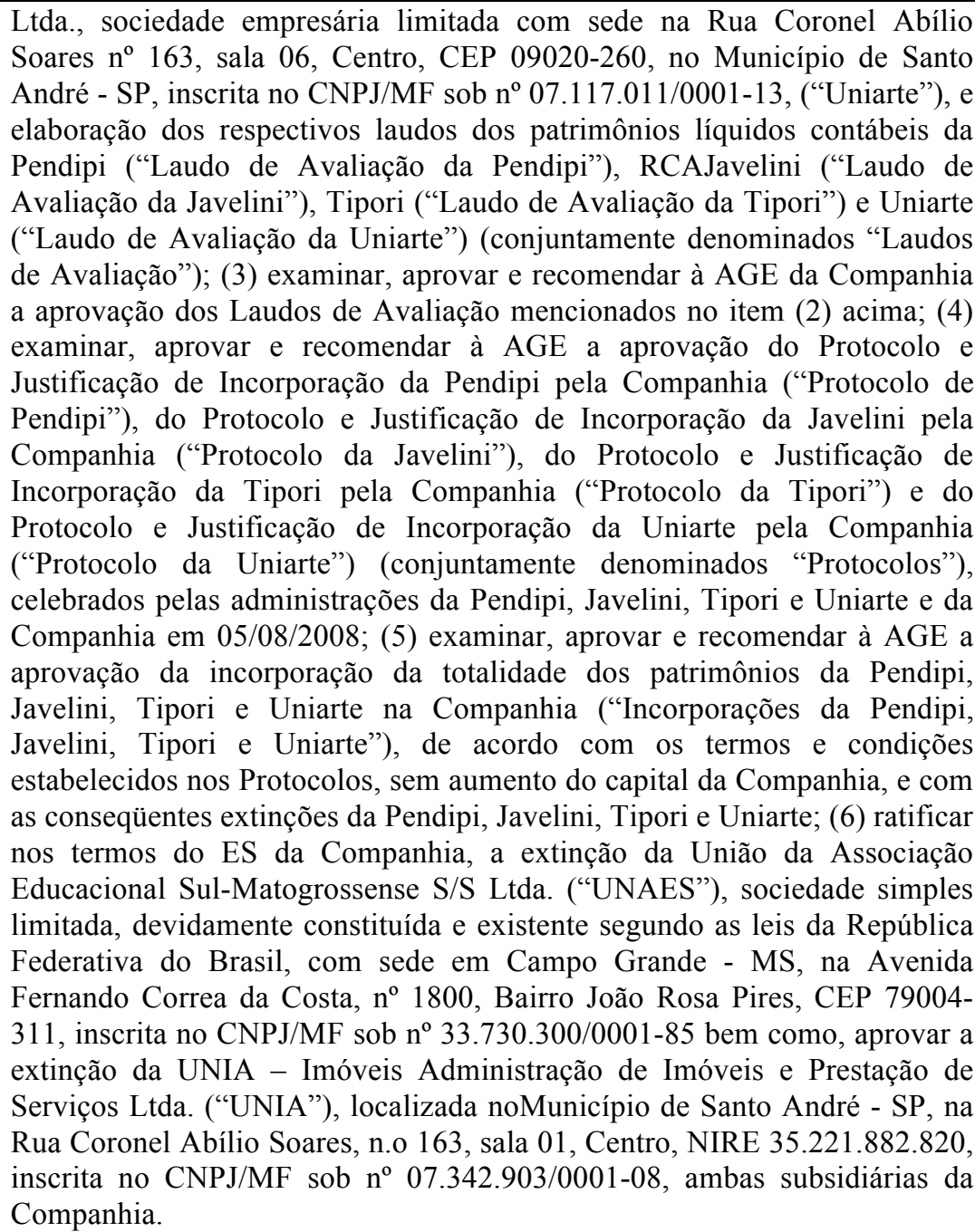 \\
\hline 81. & $29 / 08 / 2008$ & $\mathrm{RCA}$ & $\begin{array}{l}\text { (i) Deliberar acerca da aquisição da SBCEC - Sociedade Brasil Central de } \\
\text { Educação e Cultura S/S Ltda., com sede em Taguatinga - DF, sociedade } \\
\text { mantenedora das instituições de ensino superior denominadas Faculdade de } \\
\text { Administração JK - Faculdade JK, Faculdade de Ciências Biológicas JK - } \\
\text { Faculdade JK, Faculdade de Comunicação Social JK - Faculdade JK, } \\
\text { Faculdade JK Administração de Valparaíso - Faculdade JK, Faculdade JK } \\
\text { Valparaíso - Faculdade JK e Faculdade Juscelino Kubitschek - FJK. }\end{array}$ \\
\hline 82. & $12 / 09 / 2008$ & RCA & $\begin{array}{l}\text { (i) Deliberar acerca da aquisição do Centro de Ensino Unificado de } \\
\text { Taguatinga Ltda., com sede em Taguatinga - DF, sociedade mantenedora da } \\
\text { instituição de ensino superior denominada Faculdade Santa Terezinha; (ii) } \\
\text { Deliberar acerca da alteração da forma de representação da Companhia } \\
\text { especificamente para a assinatura do contrato de aquisição de quotas, da } \\
\text { alteração do contrato social e demais documentos relacionados à aquisição } \\
\text { do Centro de Ensino Unificado de Taguatinga Ltda. }\end{array}$ \\
\hline 83. & $19 / 09 / 2008$ & $\mathrm{RCA}$ & $\begin{array}{l}\text { (i) Deliberar acerca da aquisição das seguintes sociedades: (I) Pioneira } \\
\text { Educacional Ltda., sociedade simples limitada com sede na Rodovia Regis } \\
\text { Bittencourt, n. }{ }^{\circ} \text { 199, Centro, CEP 06768-000, no Município de Taboão da } \\
\text { Serra - SP, inscrita no CNPJ/MF sob o n. }{ }^{\circ} 59.050 .526 / 0001-29 \text {, } \\
\text { mantenedora da instituição de ensino superior denominada Faculdade } \\
\text { Taboão da Serra; (II) Cursinho Universitário Taboão daSerra S/S Ltdal., } \\
\text { sociedade simples limitada com sede na Rua João Slaviero, n. }{ }^{\circ} \text { 65, Jardim } \\
\text { da Glória, CEP 06763-470, no Município de Taboão da Serra - SP, inscrita } \\
\text { no CNPJ/MF sob o n. }{ }^{\circ} \text { 07.460.993/0001-23; (III) EM Colégio Universitário } \\
\text { de Taboão da Serra Ltda.-EPP, sociedade simples limitada com sede na }\end{array}$ \\
\hline
\end{tabular}




\begin{tabular}{|c|c|c|c|}
\hline & Data & Tipo & Ordem do Dia/ Conteúdo \\
\hline & & & 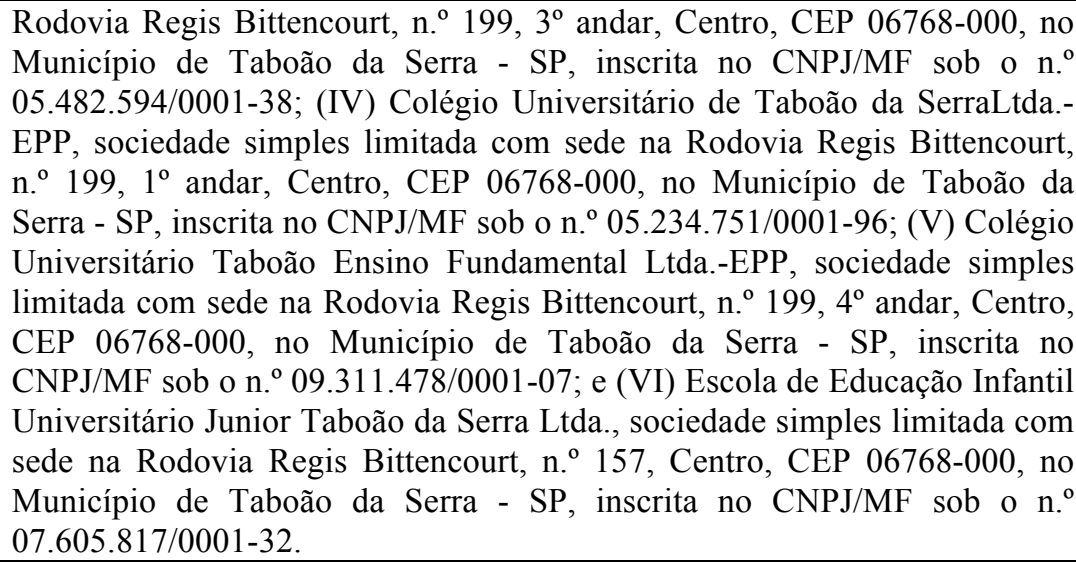 \\
\hline 84. & $30 / 09 / 2008$ & $\mathrm{RCA}$ & $\begin{array}{l}\text { Aprovar contratação de empréstimo junto ao Banco Santander S/A., pela } \\
\text { Companhia, nos seguintes termos e condições: (a) Montante Total do } \\
\text { Empréstimo: R\$50.000.000,00; (b) Garantia: Cessão Fiduciária dos direitos } \\
\text { creditórios de titularidade da Companhia e/ou de suas controladas, oriundos } \\
\text { da prestação de serviços educacionais aos alunos das entidades de ensino } \\
\text { mantidas pela Companhia, respeitado o limite de R\$ 8.000.000,00. } \\
\text { Entidades controladas (i) Anhanguera Educacional S.A.; (ii) Centro } \\
\text { Hispano Brasileiro de Cultura S.A.; (iii) Sociedade Brasileira de Ensino } \\
\text { Superior Ltda.; (iv) SESLA - Sociedade Educacional de Ensino Superior do } \\
\text { Lago Ltda.; (v) Centro de Ensino Superior de Campo Grande Ltda. - } \\
\text { CESUP; (vi) Instituição de Ensino de Sertãozinho Ltda.; (vii) Instituto de } \\
\text { Ensino Superior Senador Fláquer de Santo André Ltda.; (viii) Intesc - } \\
\text { Instituto Tecnológico de Educação Superior e Pesquisa de Santa Catarina } \\
\text { Ltda.; (ix) Educar - Instituto Educacional S/S Ltda.; (x) Sociedade Brasil } \\
\text { Central de Educação e Cultura S/S Ltda.; (xi) Sociedade Educacional } \\
\text { Sulsancaetanense S/S Ltda.; (xii) Sociedade Educacional Garra Ltda.; e } \\
\text { (xiii) Centro de Ensino Superior de Rondonópolis S/S Ltda.; (c) Destinação } \\
\text { dos Recursos: Os recursos deverão ser utilizados pela Companhia para } \\
\text { recomposição de capital de giro, a fim de financiar aquisições e a expansão } \\
\text { de suas atividades. }\end{array}$ \\
\hline 85. & $03 / 10 / 2008$ & $\mathrm{RCA}$ & $\begin{array}{l}\text { Deliberar acerca (i) da aquisição, por si ou por qualquer outra sociedade do } \\
\text { grupo, da LFG Business e Participações Ltda., sociedade empresária } \\
\text { limitada com sede na Rua Bela Cintra, 1149, 10o andar, conjunto 102, } \\
\text { Consolação, CEP 01415-001, na Cidade de São Paulo - SP, inscrita no } \\
\text { CNPJ/MF sob o n }{ }^{\circ} \text { 09.343.389/0001-42; e (ii) da outorga de fiança, pela } \\
\text { Companhia, em garantia dos pagamentos decorrentes desta aquisição. }\end{array}$ \\
\hline 86. & $10 / 10 / 2008$ & $\mathrm{RCA}$ & $\begin{array}{l}\text { Aprovar o aumento de capital social da Companhia, dentro do limite do } \\
\text { capital autorizado, conforme autoriza o Art. } 5^{\circ}, \S 7^{\circ} \text {, do ES da Companhia, } \\
\text { de acordo com os seguintes termos e condições: (i) valor total do aumento } \\
\text { de capital social: o capital social será aumentado de R\$ } 992.289 .628,93 \text { para } \\
\text { R } \$ 1.058 .865 .790,84 \text {, totalizando, portanto, um aumento de R\$ } \\
66.576 .161,91 \text {; (ii) quantidade de ações a serem emitidas: emissão para } \\
\text { subscrição privada de } 14.043 .568 \text { novas ONs e } 10.633 .855 \text { novas PNs, } \\
\text { nominativas e sem valor nominal, com os mesmos direitos e obrigações das } \\
\text { ONs e PNs já existentes; (iii) preço de emissão por ação: o preço de emissão } \\
\text { por ação será de R\$ 2,6978571429 por ON ou por PN, determinado com } \\
\text { base na média ponderada por volume de negociação das cotações dos } \\
\text { Certificados de Depósitos de Ações ("Units") da Companhia, apuradas nos } \\
\text { pregões da Bolsa de Valores de São Paulo ("BVSP") entre os dias } \\
29 / 09 / 2008 \text { e } 03 / 10 / 2008 \text {, de acordo com o sistema de informações } \\
\text { financeiras da empresa Bloomberg L.P. Este preço por ON e PN equivale a } \\
\text { um preço de R\$ } 18,885 \text { por Unit; (iv) direito de preferência: os acionistas } \\
\text { detentores das ONs e PNs da Companhia na última data de negociação antes } \\
\text { da publicação do aviso aos acionistas informando acerca do aumento de }\end{array}$ \\
\hline
\end{tabular}




\begin{tabular}{|c|c|c|c|}
\hline & Data & Tipo & Ordem do Dia/ Conteúdo \\
\hline & & & $\begin{array}{l}\text { capital ora deliberado, terão o direito de preferência na subscrição do } \\
\text { aumento de capital social sobre a mesma classe de ações que forem } \\
\text { detentores, ficando estabelecido que os acionistas detentores de Units da } \\
\text { Companhia deverão observar a preservação da proporção das Units por eles } \\
\text { atualmente detidas. O direito de preferência deverá ser exercido no prazo de } \\
30 \text { dias a contar da data da publicação do aviso aos acionistas que tiver por } \\
\text { objeto o aumento de capital ora deliberado; (v) negociação ex-direitos: as } \\
\text { ações adquiridas a partir do dia da data de publicação do aviso aos } \\
\text { acionistas, inclusive, não farão jus ao direito de preferência na subscrição } \\
\text { do aumento de capital social e, a partir de tal data, inclusive, as ações de } \\
\text { emissão da Companhia serão negociadas ex-subscrição; (vi) dividendos: as } \\
\text { ações emitidas após a aprovação e a homologação do respectivo aumento de } \\
\text { capital social farão jus ao recebimento de dividendos integrais relativos ao } \\
\text { exercício social encerrado em } 31 / 12 / 2008 \text {; (vii) forma de integralização: a } \\
\text { integralização das ações subscritas deverá ser à vista, em moeda corrente } \\
\text { nacional, no ato da subscrição, que deverá ocorrer dentro do mesmo prazo } \\
\text { de } 30 \text { dias para o exercício do direito de preferência indicado no item (iv) } \\
\text { acima; (viii) procedimento de sobras de ações não subscritas: após o } \\
\text { término do prazo para o exercício do direito de preferência, os acionistas } \\
\text { que manifestarem interesse na reserva de sobras no boletim de subscrição } \\
\text { terão o prazo de } 5 \text { dias contados da data de apuração de sobras a ser } \\
\text { informada pelo Banco Itaú S.A. para a subscrição das sobras das ações não } \\
\text { subscritas, ficando estabelecido que os acionistas que forem detentores de } \\
\text { Units deverão respeitar a preservação da proporção das Units por eles } \\
\text { atualmente detidas, sendo certo que caso o procedimento de rateio de sobras } \\
\text { não seja concluído no primeiro rateio de sobras, o eventual saldo será } \\
\text { vendido na BVSP, em benefício da Companhia, conforme dispõe o Art. } \\
171, \S 7^{\circ} \text {, ,a", da Lei n } 6.404 / 76 \text {. }\end{array}$ \\
\hline 87. & $20 / 10 / 2008$ & RCA & $\begin{array}{l}\text { Aprovar a extinção de suas subsidiárias, as sociedades, Instituto de Ensino } \\
\text { Superior "Senador Fláquer" de Santo André Ltda., inscrita no CNPJ/MF } \\
\text { sob o } \mathrm{n}^{\circ} 57.603 .870 / 0001-72 \text {, INTESC - Instituto Tecnológico de Educação } \\
\text { Superior e Pesquisa de Santa Catarina Ltda., inscrita no CNPJ/MF sob o n } \\
\text { 06.191.121/0001-08, Educar Instituição Educacional S/S Ltda., inscrita no } \\
\text { CNPJ/MF sob o no 03.218.232/0001-09, SESLA - Sociedade Educacional } \\
\text { de Ensino Superior do Lago Ltda., inscrita no CNPJ/MF sob o n } \\
\text { 02.914.383/0001-39, Sociedade Educacional Garra Ltda., inscrita no } \\
\text { CNPJ/MF sob o no 92.647.189/0001-27, Editora Uniderp Ltda., inscrita no } \\
\text { CNPJ/MF sob o no 05.009.368/0001-34 e INEPES - Instituto de Pesquisas } \\
\text { de Interesse e Opinião Pública Ltda., inscrita no CNPJ/MF sob o n } \\
07.559 .332 / 0001-50 \text {. }\end{array}$ \\
\hline 88. & $12 / 11 / 2008$ & RCA & $\begin{array}{l}\text { Deliberar acerca da aquisição da (i) Sociedade Educacional Caxias do Sul } \\
\text { Ltda., com sede em Caxias do Sul, sociedade mantenedora da instituição de } \\
\text { ensino superior denominada Faculdade Kantum e (ii) Sociedade } \\
\text { Educacional Centro América Ltda., com sede em Cuiabá, sociedade } \\
\text { mantenedora da instituição de ensino superior denominada Faculdade } \\
\text { Centro América. }\end{array}$ \\
\hline 89. & $04 / 12 / 2008$ & RCA & $\begin{array}{l}\text { Deliberar a ratificação acerca da indicação da Companhia como fiadora da } \\
\text { Sociedade Educacional Garra Ltda. no } 1^{\circ} \text { Termo Aditivo ao Contrato de } \\
\text { Locação Para Fins Não Residenciais, do imóvel sito à Rua Paissandu, n'. } \\
\text { 1200, bairro Centro, CEP 99010-101, cidade de Passo Fundo - RS. }\end{array}$ \\
\hline 90. & $22 / 12 / 2008$ & RCA & $\begin{array}{l}\text { (i) Deliberar acerca da assinatura do Instrumento Particular de Contrato de } \\
\text { Mútuo a ser celebrado entre a Companhia e sua coligada Escola de } \\
\text { Profissões S/A., no valor total de } \mathrm{R} \$ 4.500 .000,00 \text {; } \\
\text { (ii) Deliberar acerca da incorporação, e a conseqüente extinção de suas } \\
\text { subsidiárias: Sociedade Educacional Caxias do Sul Ltda., Sociedade } \\
\text { EducacionalCentro América Ltda., Centro de Ensino Superior de } \\
\text { Rondonópolis S/A Ltda., Sociedade Brasileira de Ensino Superior Ltda., } \\
\text { SBCEC - Sociedade Brasil Central de Educação e Cultura S/S Ltda., }\end{array}$ \\
\hline
\end{tabular}




\begin{tabular}{|c|c|c|c|}
\hline & Data & Tipo & Ordem do Dia/ Conteúdo \\
\hline & & & $\begin{array}{l}\text { SOESC - Sociedade Educacional Sul Sancaetanense S/S. Ltda., Centro de } \\
\text { Ensino Unificado de Taguatinga Ltda., Pioneira Educacional Ltda., } \\
\text { Instituição de Ensino de Sertãozinho Ltda., J.L.P.S.P.E. Empreendimentos e } \\
\text { Participações Ltda. e Anhanguera Educação Profissional Ltda. Exceto pela } \\
\text { J.L.P.S.P.E. Empreendimentos e Participações Ltd. que será incorporada } \\
\text { LFG Business e Participações Ltda., com sede na Rua Bela Cintra, n } 1149 \text {, } \\
10^{\circ} \text { andar, conjunto 102, Consolação, CEP 01415-001, na Cidade e Estado } \\
\text { de São Paulo, inscrita no CNPJ/MF sob o n } \text { n }^{\circ} \text { 09.343.389/0001-42, e pela } \\
\text { Anhanguera Educação Profissional Ltda., que será incorporada pela Escola } \\
\text { de Profissões S/A., com sede na Rua Dr. Alceu de campos Rodrigues no 46, } \\
9^{\circ} \text { andar, sala 97, Itaim-Bibi, na Cidade de São Paulo - SP, inscrita no } \\
\text { CNPJ/MF sob o n }{ }^{\circ} \text { 02.016.659/0001-61, as empresas acima serão } \\
\text { incorporadas pela empresa Anhanguera Educacional S/A "AESA", } \\
\text { sociedade por ações, devidamente constituída e existente segundo as leis da } \\
\text { República Federativa do Brasil, com sede na Cidade de Valinhos - SP, na } \\
\text { Alameda Maria Tereza, n }{ }^{\circ} \text { 2000, sala 01, Bairro Dois Córregos, inscrita no } \\
\text { CNPJ/MF sob o n }{ }^{\circ} 05.808 .792 / 0001-49 \text {. }\end{array}$ \\
\hline 91. & $30 / 01 / 2009$ & RCA & $\begin{array}{l}\text { Aprovar contratação de empréstimo junto ao Banco Santander S/A., pela } \\
\text { Companhia, nos seguintes termos e condições: (a) Montante Total do } \\
\text { Empréstimo: R\$ } 13.000 .000,00 \text {, juros remuneratórios determinados com } \\
\text { base na taxa média diária dos depósitos interfinanceiros de um dia, CDI", } \\
\text { calculada e divulgada diariamente pela CETIP no informativo diário, } \\
\text { disponível na pagina na Internet (www.cetip.com.br) ("Taxa DI"); (b) } \\
\text { Garantia: Cessão Fiduciária dos direitos creditórios de titularidade de suas } \\
\text { subsidiarias, limitados ao valor do empréstimo; (c) Destinação dos } \\
\text { Recursos: Os recursos deverão ser utilizados pela Companhia para } \\
\text { recomposição de capital de giro, a fim de financiar aquisições e a expansão } \\
\text { de suas atividades. }\end{array}$ \\
\hline 92. & $18 / 02 / 2009$ & RCA & $\begin{array}{l}\text { (1) Aprovar a Emissão Pública de Debêntures Simples ("Emissão" e } \\
\text { "Debêntures", respectivamente) pela Companhia, mediante oferta pública, a } \\
\text { serem subscritas e integralizadas na data de emissão ("Data de Emissão") } \\
\text { nos seguintes termos e condições: } \\
\text { (a) Montante Total da Emissão: até R\$ 40.000.000,00; (b) Número de } \\
\text { Séries: a Emissão será realizada em série única; (c) Quantidade de } \\
\text { Debêntures: serão emitidas } 4.000 \text { Debêntures; (d) Valor Nominal Unitário: } \\
\text { as Debêntures terão valor nominal unitário de R\$10.000,00 na data de sua } \\
\text { respectiva subscrição e integralização ("Valor Nominal Unitário"); (e) } \\
\text { Coordenador da Emissão: Banco Itaú BBA S.A.; (f) Espécie: da espécie } \\
\text { quirografária, observado o disposto na legislação vigente; (g) Prazo e } \\
\text { Vencimento: 18 meses contados da Data da Emissão ("Data do } \\
\text { Vencimento"); (h) Amortização do Principal: na Data do Vencimento da } \\
\text { Emissão; (i) Remuneração: equivalente a taxa média diária de juros dos DI } \\
\text { - Depósitos Interfinanceiros de um dia, "over extra grupo", expressa na } \\
\text { forma percentual ao ano, base } 252 \text { dias úteis, calculada e divulgada } \\
\text { diariamente pela CETIP S.A. - Balcão Organizado de Ativos e Derivativos } \\
\text { ("CETIP”) no informativo diário, disponibilizado em sua página na Internet } \\
\text { (http://www.cetip.com.br) ("Taxa DI"), acrescido de uma sobretaxa de } \\
\text { 3,50\% a.a., calculados de forma exponencial e cumulativa "pro rata } \\
\text { temporis", por dias úteis corridos, desde a Data de Emissão, até o } \\
\text { vencimento das respectivas Debêntures; (j) Destinação dos Recursos: os } \\
\text { recursos serão destinados a expansão das atividades da Companhia; (k) } \\
\text { Pagamento de Juros: trimestralmente; (l) Garantias: aval da sua subsidiária, } \\
\text { Anhanguera Educacional S.A. (“Avalista"), inscrita no CNPJ/MF n } \\
\text { 05.808.792/0001-49; (m) Forma de Colocação: as Debêntures serão objeto } \\
\text { de distribuição pública com intermediação de instituição integrante do } \\
\text { sistema de distribuição, sob o regime de garantia firme e esforços restritos } \\
\text { de colocação, com base no disposto no item "Esforços Restritos" abaixo; (n) } \\
\text { Subscrição e Integralização: a subscrição e integralização das Debêntures }\end{array}$ \\
\hline
\end{tabular}




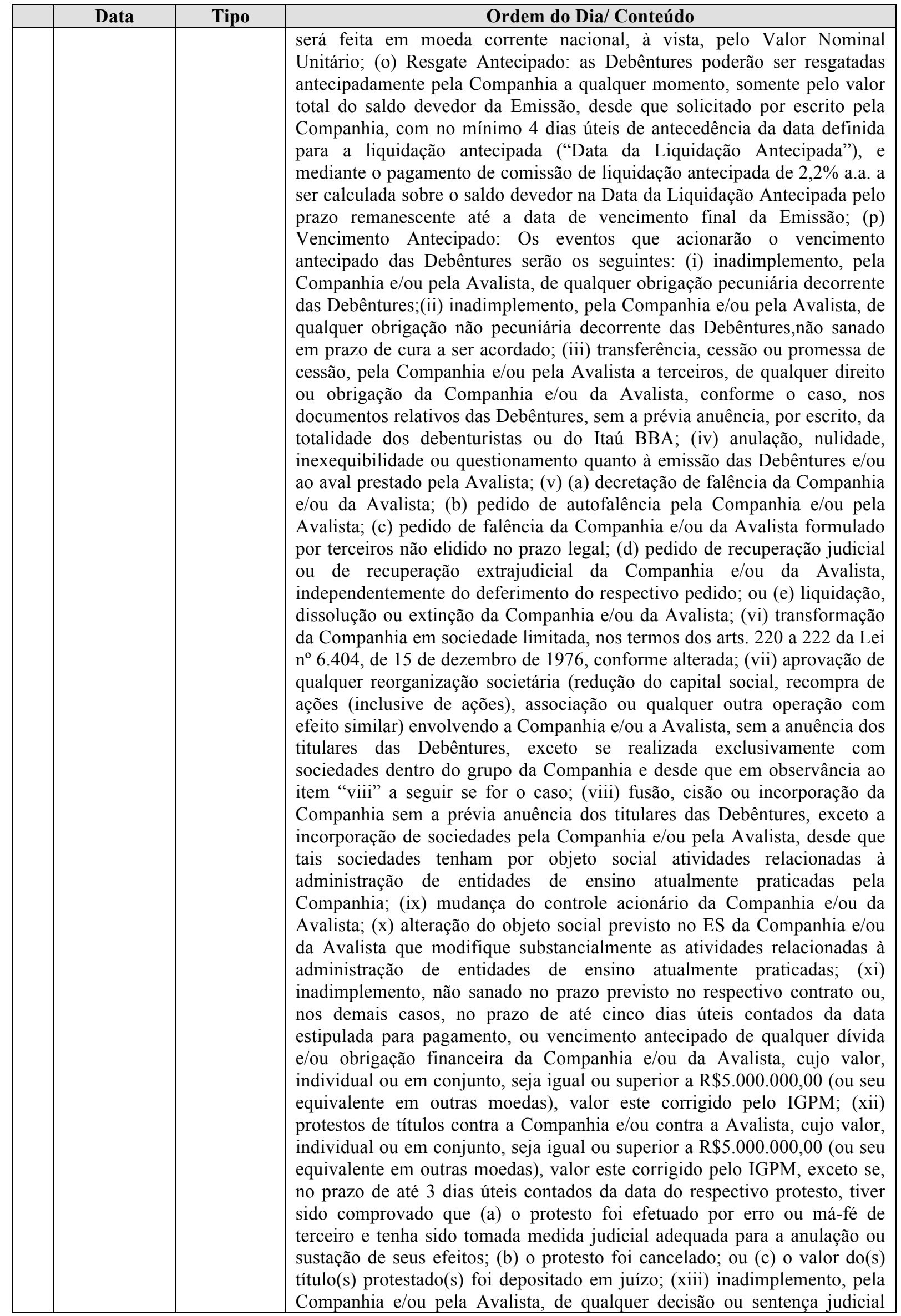




\begin{tabular}{|c|c|c|c|}
\hline & Data & Tipo & Ordem do Dia/ Conteúdo \\
\hline & & & 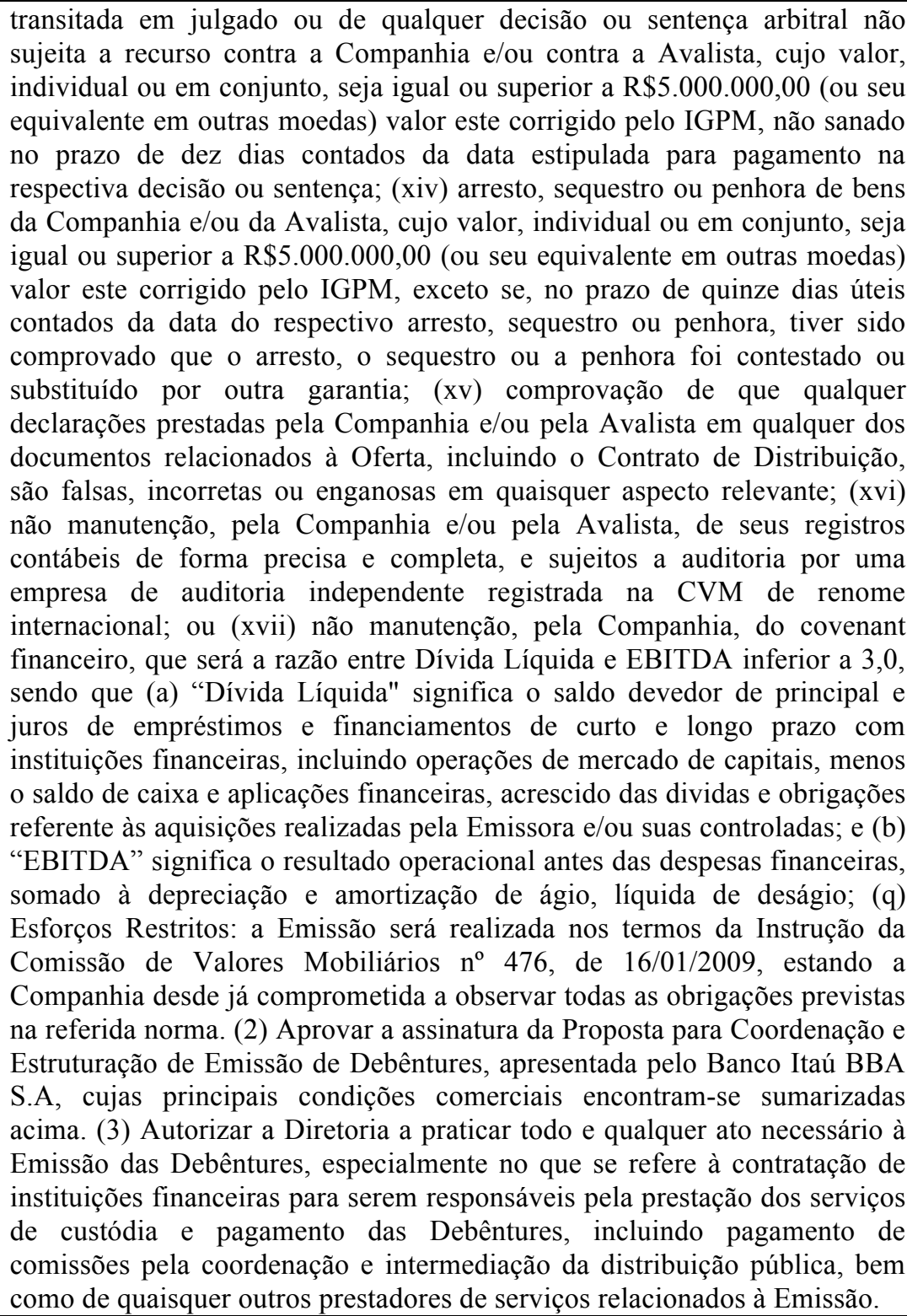 \\
\hline 93. & $20 / 02 / 2009$ & RCA & $\begin{array}{l}\text { Retificar os itens }(\mathrm{c}),(\mathrm{d}),(\mathrm{m}) \text { e }(\mathrm{q}) \text { dos termos referentes à Emissão Pública } \\
\text { de Debêntures Simples da Companhia, deliberados em Ata de RCA da } \\
\text { Companhia em 18/02/2009. }\end{array}$ \\
\hline 94. & $03 / 03 / 2009$ & RCA & $\begin{array}{l}\text { (i) re-ratificação da Ata da RCA da Companhia, realizada em } 10 / 102008 \text {, no } \\
\text { tocante à expressão do capital social da Companhia, consignando que todos } \\
\text { os atos praticados posteriormente à data de } 10 / 10 / 2008 \text { deverão considerar } \\
\text { essa re-ratificação do capital social da Companhia; (ii) cancelamento de } \\
1.407 .086 \text { ONs e } 8.442 .516 \mathrm{PNs} \text {, equivalentes a } 1.407 .086 \text { Units, não } \\
\text { subscritas no âmbito do aumento de capital social aprovado em RCA } \\
\text { realizada em } 10 / 10 / 2008 \text {; e (iii) retificação e homologação do aumento de } \\
\text { capital social aprovado em RCA realizada em } 10 / 10 / 2008 \text {. }\end{array}$ \\
\hline 95. & $31 / 03 / 2009$ & RCA & $\begin{array}{l}\text { (i) Revisão e Aprovação do Relatório da Administração; (ii) Apreciação das } \\
\text { DFs e Parecer dos Auditores Independentes da Companhia, relativos ao } \\
\text { exercício social findo em 31/12/2008; (iii) apreciação da proposta de } \\
\text { destinação do lucro líquido da Companhia; e (iv) Aprovação da convocação } \\
\text { da AGO da Companhia. }\end{array}$ \\
\hline 96. & $17 / 04 / 2009$ & RCA & $\begin{array}{l}\text { (i) apreciar proposta de alteração dos Arts. } 10,11 \text { e } 17 \text { do ES, tendo por } \\
\text { objetivo (a) estabelecer controles adicionais para eventual realização de } \\
\text { operações com instrumentos derivativos (Art. 10), e (b) aumentar o número }\end{array}$ \\
\hline
\end{tabular}




\begin{tabular}{|c|c|c|c|}
\hline & Data & Tipo & Ordem do Dia/ Conteúdo \\
\hline & & & $\begin{array}{l}\text { de Diretores e a forma de representação da Companhia (Art. } 11 \text { e 17); (ii) } \\
\text { deliberar acerca da conversão de até } 45.000 .000 \text { de ONs em até } 45.000 .000 \\
\text { de PNs da Companhia; e (iii) deliberar sobre a convocação de AGE nos } \\
\text { termos do ES da Companhia, visando submeter à aprovação dos acionistas } \\
\text { da Companhia as matérias aqui referidas que são de sua competência. }\end{array}$ \\
\hline 97. & 08/05/2009 & RCA & $\begin{array}{l}\text { (i) Aceitação da carta de renúncia apresentada pelo Sr. Ricardo Leonel } \\
\text { Scavazza em relação, tão somente, ao cargo de Diretor de Relação com } \\
\text { Investidores da Companhia; (ii) Deliberação acerca da eleição dos membros } \\
\text { da Diretoria da Companhia; e (iii) Apreciação dos resultados da Companhia } \\
\text { referentes ao } 1^{\circ} \text { trimestre de } 2009 \text {. }\end{array}$ \\
\hline 98. & $05 / 06 / 2009$ & RCA & $\begin{array}{l}\text { Aprovar a renovação da contratação de empréstimo junto ao Banco } \\
\text { Santander S/A., pela Companhia, nos seguintes termos e condições: (a) } \\
\text { Montante Total do Empréstimo: R\$ } 13.000 .000,00 \text {, jurosremuneratórios } \\
\text { determinados com base na taxa média diária dos depósitos interfinanceiros } \\
\text { de um dia, CDI", calculada e divulgada diariamente pela CETIP no } \\
\text { informativo diário, disponível na pagina na Internet (www.cetip.com.br) } \\
\text { ("Taxa DI"); (b) Garantia: Cessão Fiduciária dos direitos creditórios de } \\
\text { titularidade de suas subsidiarias, limitados ao valor do empréstimo; (c) } \\
\text { Destinação dos Recursos: Os recursos deverão ser utilizados pela } \\
\text { Companhia para recomposição de capital de giro, a fim de financiar } \\
\text { aquisições e a expansão de suas atividades. }\end{array}$ \\
\hline 99. & $\begin{array}{c}\text { 26/06/2009, } \\
\text { às } 10 \mathrm{~h}\end{array}$ & RCA & 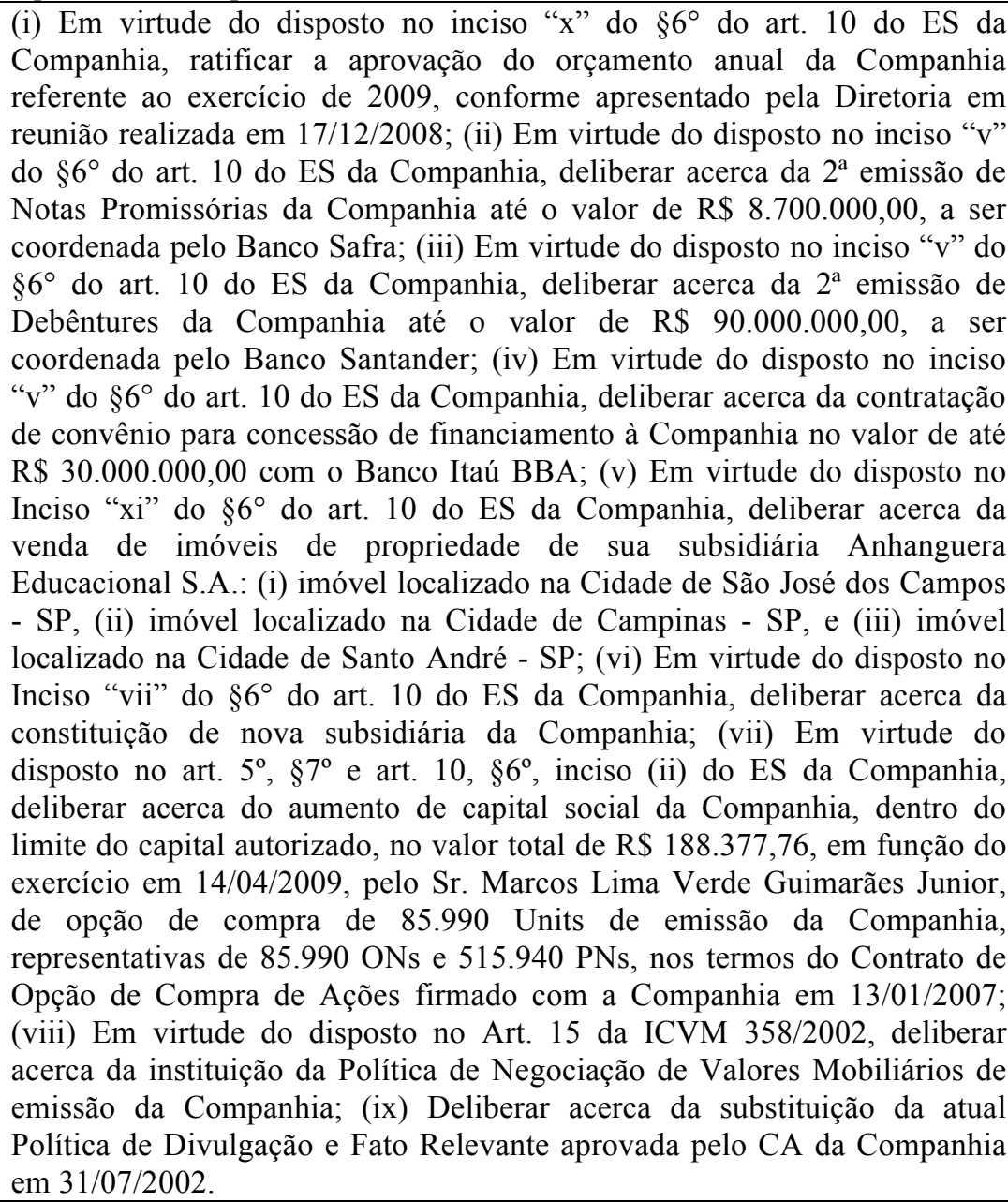 \\
\hline 100 & $\begin{array}{c}\text { 26/06/2009, } \\
\text { às } 11 \mathrm{~h}\end{array}$ & RCA & $\begin{array}{l}\text { Deliberar acerca da assinatura, pela Companhia, do Termo Aditivo ao } \\
\text { Instrumento Particular de Compra e Venda da Unidade Instituto Senador } \\
\text { Fláquer. }\end{array}$ \\
\hline 101 & $08 / 07 / 2009$ & RCA & $\begin{array}{l}\text { Deliberação acerca da alienação, pela Companhia, da totalidade das quotas } \\
\text { representativas do capital social das seguintes sociedades: (i) EM Colégio }\end{array}$ \\
\hline
\end{tabular}




\begin{tabular}{|c|c|c|c|}
\hline & Data & Tipo & Ordem do Dia/ Conteúdo \\
\hline & & & $\begin{array}{l}\text { Universitário de Taboão da Serra Ltda. - EPP; (ii) Colégio Universitário de } \\
\text { Taboão da Serra Ltda. - EPP; (iii) Colégio Universitário Taboão Ensino } \\
\text { Fundamental Ltda. - EPP; e (iv) Escola de Educação Infantil Universitário } \\
\text { Júnior de Taboão da Serra Ltda. }\end{array}$ \\
\hline 102 & $07 / 08 / 2009$ & $\mathrm{RCA}$ & 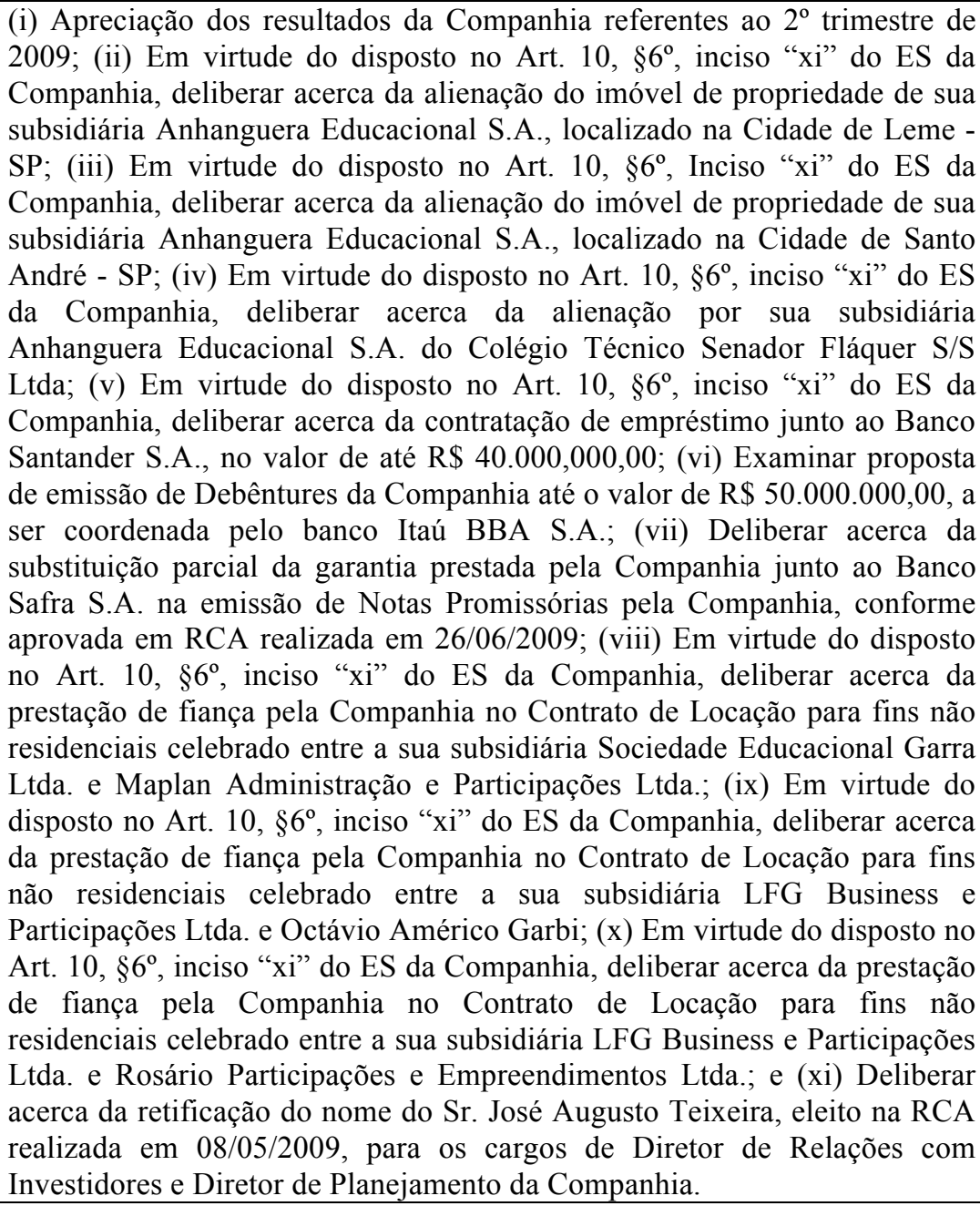 \\
\hline 103 & $28 / 08 / 2009$ & $\mathrm{RCA}$ & $\begin{array}{l}\text { (i) Em virtude do disposto no Art. } 10, \S 6^{\circ} \text {, inciso "xi” do ES da Companhia, } \\
\text { deliberar acerca da alienação do imóvel de propriedade de sua subsidiária } \\
\text { Anhanguera Educacional S.A., localizado na Cidade de Taboão da Serra - } \\
\text { SP; (ii) Em virtude do disposto no Art. } 10, \S 6^{\circ} \text {, inciso "xi" do ES da } \\
\text { Companhia, deliberar acerca das prestações de fianças pela Companhia, em } \\
\text { favor de sua subsidiária, Anhanguera Educacional S.A., nos Contratos de } \\
\text { Locação para fins não residenciais, dos imóveis localizados em (a) Taboão } \\
\text { da Serra - SP, (b) Campinas - SP e (c) São José dos Campos - SP. }\end{array}$ \\
\hline 104 & $\begin{array}{c}11 / 09 / 2009 \\
\text { às } 15 \mathrm{~h}\end{array}$ & $\mathrm{RCA}$ & $\begin{array}{l}\text { (i) Em virtude do disposto no Art. } 10, \S 6^{\circ} \text {, inciso "iv" do ES da Companhia, } \\
\text { deliberar acerca da } 3^{\mathrm{a}} \text { Emissão de Debêntures pela Companhia no valor de } \\
\text { até R } \$ 200.000 .000,00 \text { a ser coordenada pelo Itaú BBA S.A; (ii) Deliberar } \\
\text { acerca da delegação de poderes à Diretoria da Companhia para praticar } \\
\text { todos os atos necessários para a efetivação da } 3^{\mathrm{a}} \text { emissão de debêntures pela } \\
\text { Companhia; e(iii) Nos termos do art. } 59, \S 1^{\circ} \text {, da Lei no } 6.404 / 76 \text {, conforme } \\
\text { alterada, deliberar acerca da retificação de certos termos e condições da } 2^{\circ} \\
\text { Emissão de Debêntures Simples da Companhia, aprovados na AGE } \\
\text { realizada em 03/09/2009, sendo eles: (a) retificação das cláusulas de } \\
\text { vencimento antecipado "ii", "iv", "viii" e "xvii"; (b) inclusão das cláusulas } \\
\text { de vencimento antecipado item "xviii" e "xix"; e (c) alteração do prazo } \\
\text { mínimo de comunicação pela Companhia aos debenturistas para oferta de } \\
\text { resgate antecipado. }\end{array}$ \\
\hline
\end{tabular}




\begin{tabular}{|c|c|c|c|}
\hline & Data & Tipo & Ordem do Dia/ Conteúdo \\
\hline 105 & $18 / 09 / 2009$ & $\mathrm{RCA}$ & $\begin{array}{l}\text { (i) Em virtude do disposto no Art. } 10, \S 6^{\circ} \text {, inciso "xi" do ES da Companhia, } \\
\text { deliberar acerca da contratação de empréstimo junto ao Banco Santander } \\
\text { S.A., no valor de até R } \$ 50.000,000,00 \text {; (ii) Em virtude do disposto no Art. } \\
10, \S 6^{\circ} \text {, inciso "xi" do ES da Companhia, deliberar acerca da renovação da } \\
\text { conta garantida junto ao Banco Santander S.A., no valor de até R } \$ \\
8.000,000,00 \text {; (iii) Em virtude do disposto no Art. } 10, \S 6^{\circ} \text {, inciso "xi" do ES } \\
\text { da Companhia, deliberar acerca da prestação garantia através de concessão } \\
\text { de aval pela Companhia, em favor de sua subsidiária, Anhanguera } \\
\text { Educacional S.A., no contrato de conta garantida a ser firmado junto ao } \\
\text { Banco do Brasil S.A., no valor de até R } \$ 7.000,000,00 \text {; e (iv) Em virtude do } \\
\text { disposto no Art. } 10, \S 6^{\circ} \text {, inciso "xi" do ES da Companhia, deliberar acerca } \\
\text { da prestação de fiança pela Companhia, em favor de sua subsidiária, } \\
\text { Anhanguera Educacional S.A. em contratos de locação para fins não } \\
\text { residenciais. }\end{array}$ \\
\hline 106 & $25 / 09 / 2009$ & $\mathrm{RCA}$ & 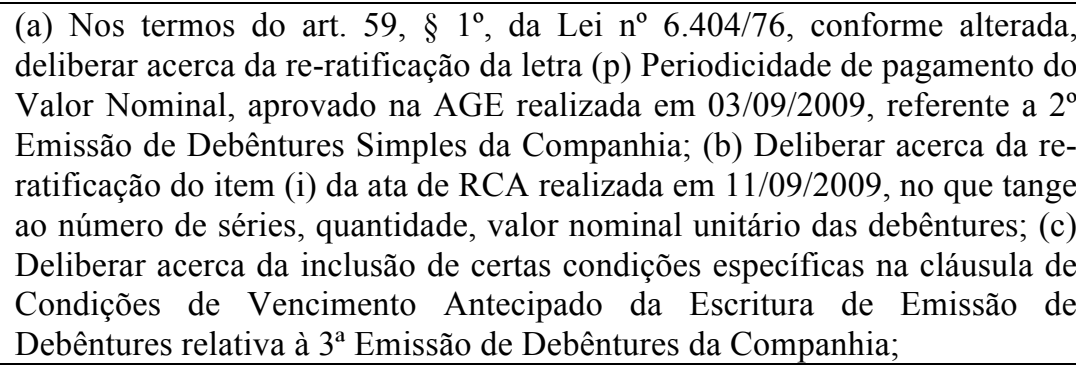 \\
\hline 107 & $\begin{array}{l}\text { 09/10/2009, } \\
\text { às } 10 \mathrm{~h}\end{array}$ & $\mathrm{RCA}$ & $\begin{array}{l}\text { (i) Deliberar acerca da re-ratificação da relação dos imóveis conforme item } \\
\text { (ix) da ata de RCA realizada em } 07 / 08 / 2009 \text {, que aprovou a prestação de } \\
\text { fiança pela Companhia, em favor de sua subsidiária, LFG Business e } \\
\text { Participações Ltda.; (ii) Deliberar acerca da retificação do item (a) da ata de } \\
\text { RCA realizada em } 25 / 09 / 2009 \text {, que constou como referência a letra (q) ao } \\
\text { invés da letra (p); e (iii) Apreciar os resultados da Companhia referentes a } \\
\text { agosto de } 2009 \text { e acumulado dos } 8 \text { primeiros meses do ano. }\end{array}$ \\
\hline 108 & $\begin{array}{l}\text { 09/10/2009, } \\
\text { às } 11 \mathrm{~h}\end{array}$ & $\mathrm{RCA}$ & $\begin{array}{l}\text { (i) Deliberar acerca da implantação do Código de Ética pela Companhia; (ii) } \\
\text { Deliberar acerca da instauração pela Companhia dos seguintes Comitês: (a) } \\
\text { Comitê de Auditoria; (b) Comitê de Remuneração; e (c) Comitê Financeiro. }\end{array}$ \\
\hline 109 & $19 / 10 / 2009$ & $\mathrm{RCA}$ & $\begin{array}{l}\text { Deliberar acerca da homologação do capital social da Companhia e sua } \\
\text { divisão em ONs e PNs em razão da proposta de conversão de até } \\
45.000 .000,00 \text { de ONs de emissão da Companhia em PNs, aprovada na } \\
\text { AGE da Companhia em 04/05/2009. }\end{array}$ \\
\hline 110 & $\begin{array}{l}\text { 20/10/2009, } \\
\text { às } 12 \mathrm{~h}\end{array}$ & $\mathrm{RCA}$ & $\begin{array}{l}\text { (i) Deliberar acerca do resultado do procedimento de coleta de intenção } \\
\text { junto aos investidores;(ii) Deliberar acerca da ratificação dos atos já } \\
\text { praticados pela Diretoria necessários à consecução da já mencionada } \\
\text { Emissão. }\end{array}$ \\
\hline 111 & $06 / 11 / 2009$ & $\mathrm{RCA}$ & $\begin{array}{l}\text { (i) Deliberar acerca da liberação parcial do penhor de ações constituído em } \\
\text { favor da Companhia; e (ii) Deliberar acerca da alteração na composição da } \\
\text { Diretoria da Companhia, nos termos do Art. 10, parágrafo } 6^{\circ} \text {, (vi) do ES. }\end{array}$ \\
\hline 112 & $24 / 11 / 2009$ & $\mathrm{RCA}$ & $\begin{array}{l}\text { (i) Deliberar acerca da celebração de contratos e documentos relativos à } \\
\text { Oferta Pública Secundária de Units de Emissão da Companhia } \\
\text { ("Oferta");(ii) Outorgar poderes à Diretoria da Companhia para a } \\
\text { celebração de contratos e documentos da Oferta; e(iii) Deliberar sobre a } \\
\text { ratificação dos atos já praticados pelos membros da Diretoria da Companhia } \\
\text { no contexto da Oferta. }\end{array}$ \\
\hline 113 & $18 / 12 / 2009$ & $\mathrm{RCA}$ & $\begin{array}{l}\text { (i) Em virtude do disposto no Art. } 10, \$ 6^{\circ} \text {, inciso "xi” do ES da Companhia, } \\
\text { deliberar acerca da prestação de garantia pela Companhia, mediante a } \\
\text { cessão fiduciária de Certificado de Depósito Bancário de emissão do Itaú } \\
\text { BBA no valor total de até R } \$ 72.000 .000,00 \text {, oriunda das obrigações } \\
\text { assumidas pela sua subsidiária, Anhanguera Educacional S.A., conforme } \\
\text { termo aditivo ao contrato de convênio para concessão de financiamento } \\
\text { (Vendor Eletrônico Itaú BBA) datado de } 17 / 06 / 2009 \text { entre a Anhanguera }\end{array}$ \\
\hline
\end{tabular}




\begin{tabular}{|c|c|c|c|}
\hline & Data & Tipo & Ordem do Dia/ Conteúdo \\
\hline & & & $\begin{array}{l}\text { Educacional S.A e o banco Itaú BBA; e(ii) Em virtude do disposto no inciso } \\
\text { "xi" do } \S 6^{\circ} \text { do art. } 10 \text { do ES da Companhia, deliberar acerca da contratação } \\
\text { de financiamento no valor de até R } \$ 115.000 .000,00 \text { junto ao International } \\
\text { Finance Corporation (IFC), Société de Promotion et de Participation pour la } \\
\text { Coopération Économique e DEG - Deutsche Investitions - UND } \\
\text { Entwicklungsgesellschaft MBH. }\end{array}$ \\
\hline 114 & $\begin{array}{l}12 / 03 / 2010, \\
\text { às } 8 \mathrm{~h} 30 .\end{array}$ & RCA & $\begin{array}{l}\text { Deliberar acerca da alteração da denominação do cargo de Diretor de } \\
\text { Planejamento, nos termos do Art. } 11 \text { do ES. }\end{array}$ \\
\hline 115 & $\begin{array}{c}\text { 12/03/2010 } \\
\text { às } 9 \mathrm{~h}\end{array}$ & RCA & $\begin{array}{l}\text { (i) revisão e aprovação do Relatório da Administração sobre os negócios } \\
\text { sociais e os principais fatos administrativos, bem como as contas da } \\
\text { Diretoria, referentes ao exercício social findo em } 31 / 12 / 2009 \text {; (ii) } \\
\text { apreciação das DFs e Parecer dos Auditores Independentes da Companhia, } \\
\text { relativos ao exercício social findo em } 31 / 12 / 2009 \text {; (iii) apreciação da } \\
\text { proposta de destinação do lucro líquido da Companhia, referente ao } \\
\text { exercício social findo em } 31 / 12 / 2009 \text {, incluindo a proposta de orçamento de } \\
\text { capital; (iv) deliberação acerca da proposta de alteração do caput do Art. } 5^{\circ} \\
\text { do ES da Companhia em função da conversão voluntária de ONs em PNs da } \\
\text { Companhia, no âmbito da proposta aprovada na AGE realizada em } \\
25 / 11 / 2009 ; \text { (v) deliberação acerca da proposta de alteração do Art. } 10 \text {, } \S 6^{\circ} \text {, } \\
\text { inciso (i), bem como da inclusão do inciso (xiii) no } \S 6^{\circ} \text { do Art. } 10 \text { do ES da } \\
\text { Companhia; e (vi) deliberação acerca da convocação da AGO e AGE da } \\
\text { Companhia. }\end{array}$ \\
\hline 116 & $\begin{array}{c}\text { 07/05/2010 } \\
\text { às 9h30 }\end{array}$ & RCA & $\begin{array}{l}\text { (i) Em atendimento ao disposto no art. } 10^{\circ}, \S 6^{\circ} \text {, inciso (vii) do ES da } \\
\text { Companhia, aprovar a abertura de nova filial da Sociedade no município de } \\
\text { São Paulo - SP;(ii) Em virtude do disposto no art. } 5^{\circ} \text { e art. } 10, \S 6^{\circ} \text {, inciso (ii) } \\
\text { do ES da Companhia, deliberar acerca do aumento do capital social da } \\
\text { Companhia, dentro do limite de capital autorizado, em função do exercício } \\
\text { do Sr. Marcos Lima Verde Guimarães Junior, de opção de compra de } \\
85.990 \text { Units de emissão da Companhia, representativas de } 85.990 \text { ONs e } \\
515.940 \text { PNs, nos termos do Contrato de Opção de Compra de Ações } \\
\text { firmado com a Companhia em } 13 / 01 / 2007 \text {; e(iii) Apreciação dos resultados } \\
\text { da Companhia referentes ao } 1^{\circ} \text { trimestre de } 2010 \text {. }\end{array}$ \\
\hline 117 & $\begin{array}{c}07 / 05 / 2010 \\
\text { às } 10 \mathrm{~h}\end{array}$ & RCA & $\begin{array}{l}\text { (i) Em atendimento ao disposto no art. } 10^{\circ}, \S 6^{\circ} \text {, incisos (viii) e (xi) do ES } \\
\text { da Companhia, deliberar acerca da prestação de garantia, em favor de sua } \\
\text { subsidiária, Anhanguera Educacional S.A., no aumento de limite para } \\
\text { contratação de fiança bancária, mantida junto ao Banco Bradesco S.A., de } \\
\mathrm{R} \$ 18.000 .000,00 \text { para R } \$ 20.000 .000,00 \text {; (ii) Em atendimento ao disposto } \\
\text { no art. } 10^{\circ}, \S 6^{\circ} \text {, incisos (viii) e (xi) do ES da Companhia, deliberar acerca } \\
\text { da prestação de garantia, em favor de sua subsidiária, Anhanguera } \\
\text { Educacional S.A., no aumento de limite para contratação de fiança bancária, } \\
\text { mantida junto ao Banco Santander S.A., de } \mathrm{R} \$ 12.880 .715,04 \text { para R } \$ \\
30.000 .000,00 \text {; e(iii) Em atendimento ao disposto no art. } 10^{\circ}, \S 6^{\circ} \text {, incisos } \\
\text { (viii) e (xi) do ES da Companhia, deliberar acerca da prestação de garantia } \\
\text { pela Companhia, no valor de até R } \$ 1.500 .000,00 \text {, equivalente } 30 \% \text { das } \\
\text { obrigações assumidas por sua subsidiaria, Escola de Profissões S.A., na } \\
\text { operação de capital de giro que envolve o valor total de até R } \$ \\
\text { 5.000.000,00, e que será realizada junto ao Banco Santander S.A. }\end{array}$ \\
\hline 118 & $\begin{array}{c}07 / 05 / 2010 \\
\text { às } 10 \mathrm{~h} 30\end{array}$ & RCA & $\begin{array}{l}\text { Em atendimento ao disposto no Art. } 10, \S 6^{\circ} \text {, inciso (xiii) do ES da } \\
\text { Companhia, ratificar o Regimento Interno do Comitê de Auditoria da } \\
\text { Companhia e eleger os seus membros. }\end{array}$ \\
\hline 119 & $09 / 06 / 2010$ & RCA & $\begin{array}{l}\text { Em virtude do disposto no Art. } 10, \text { Par. } 6^{\circ} \text {, inciso "xi" do ES da Companhia, } \\
\text { deliberar acerca da alienação da totalidade das ações detidas diretamente } \\
\text { por sua subsidiária integral, Anhanguera Educação Profissional Ltda., na } \\
\text { Escola de Profissões. }\end{array}$ \\
\hline 120 & $\begin{array}{c}01 / 07 / 2010 \\
\text { às } 9 \text { h30. }\end{array}$ & $\mathrm{RCA}$ & $\begin{array}{l}\text { (i) Em virtude da renúncia do Sr. Marcos Lima Verde Guimaraes Junior ao } \\
\text { cargo de Diretor Financeiro e Membro do Comitê de Auditoria, deliberar } \\
\text { acerca da eleição de seu substituto, em atendimento ao disposto no art. } 10^{\circ} \text {, } \\
\text { Par. } 6^{\circ} \text {, inciso (vi) do ES da Companhia;(ii) Deliberação acerca da eleição }\end{array}$ \\
\hline
\end{tabular}




\begin{tabular}{|c|c|c|c|}
\hline & Data & Tipo & Ordem do Dia/ Conteúdo \\
\hline & & & $\begin{array}{l}\text { de membro da Diretoria da Companhia;(iii) Deliberar acerca da proposta de } \\
\text { incorporação da subsidiaria LFG Business, Edições e Participações Ltda. } \\
\text { pela Companhia. }\end{array}$ \\
\hline 121 & $\begin{array}{l}01 / 07 / 2010 \\
\text { às } 10 \mathrm{~h}\end{array}$ & RCA & $\begin{array}{l}\text { (i) Criação do } 1^{\text {o }} \text { Programa de Outorga de Certificados de Depósito de } \\
\text { Ações ("Units") da Companhia, no contexto do Plano de Opção de Compra } \\
\text { de Ações aprovado na AGE da Companhia realizada em 30/04/2010 } \\
\text { ("Plano"), com a eleição dos respectivos beneficiários e definição do } \\
\text { numero de Units que poderão ser adquiridas por cada um deles;(ii) } \\
\text { Definição do preço de exercício das opções e as condições de seu } \\
\text { pagamento;(iii) Definição dos prazos e condições de exercício das } \\
\text { opções;(iv) Autorização para a Diretoria efetuar as outorgas de opção de } \\
\text { compra de ações aos beneficiários. }\end{array}$ \\
\hline 122 & $\begin{array}{l}01 / 07 / 2010 \\
\text { às } 12 \mathrm{~h}\end{array}$ & RCA & $\begin{array}{l}\text { Em atendimento ao disposto no art. } 10^{\circ} \text {, Par. } 6^{\circ} \text {, inciso (xi) do ES da } \\
\text { Companhia, deliberar acerca:(a) de aquisição pela Companhia de imóvel } \\
\text { situado em Cuiabá - MT; e(b) alienação de imóveis pela Companhia e pela } \\
\text { sua subsidiária Anhanguera Educacional S.A. em favor do Fundo de } \\
\text { Investimento Imobiliário Anhanguera Educacional. }\end{array}$ \\
\hline 123 & $\begin{array}{l}13 / 08 / 2010 \\
\text { às } 9 \mathrm{~h}\end{array}$ & $\mathrm{RCA}$ & $\begin{array}{l}\text { (i) Apreciação dos resultados da Companhia referentes ao } 2^{\circ} \text { trimestre de } \\
2010 \text {; e(ii) Em atendimento ao Art. } 10^{\circ} \text {, parágrafo } 6^{\circ} \text {, inciso (viii) do ES da } \\
\text { Companhia, deliberar acerca da ratificação da assinatura do } 3^{\circ} \text { Termo } \\
\text { Aditivo ao Contrato de Locação para Fins não Residenciais, celebrado entre } \\
\text { a Companhia (Locadora) e Anhanguera Educacional S/A. (Locatária), em } \\
\text { razão da aquisição pela Companhia, do imóvel objeto da matrícula } n^{\circ} .1 .277 \\
\text { do Cartório de Registro de Imóveis de Valinhos/SP, que já era objeto de } \\
\text { locação pela Anhanguera Educacional S/A. }\end{array}$ \\
\hline 124 & $\begin{array}{l}13 / 08 / 2010 \\
\text { às } 10 h 30\end{array}$ & RCA & $\begin{array}{l}\text { Deliberar sobre a proposta de instauração do Comitê Educacional da } \\
\text { Companhia. }\end{array}$ \\
\hline 125 & $\begin{array}{l}14 / 09 / 2010 \\
\text { às } 10 \mathrm{~h}\end{array}$ & RCA & $\begin{array}{l}\text { (i) aprovar a abertura de filiais;(ii) examinar, aprovar e recomendar à AGE } \\
\text { da Companhia a aprovação do Protocolo e Justificação de Incorporação da } \\
\text { LFG Business, Edições e Participações Ltda. pela Anhanguera Educacional } \\
\text { Participações S.A.;(iii) examinar, aprovar e recomendar à AGE da } \\
\text { Companhia a ratificação da nomeação dos avaliadores contratados para a } \\
\text { avaliação do patrimônio líquido da LFG Business, Edições e Participações } \\
\text { Ltda. ("LFG") a ser vertido para a Companhia, bem como para a elaboração } \\
\text { do respectivo Laudo de Avaliação ("Laudo de Avaliação");(iv) examinar, } \\
\text { aprovar e recomendar à AGE da Companhia a aprovação do Laudo de } \\
\text { Avaliação;(v) examinar, aprovar e recomendar à AGE da Companhia è RS } \\
\text { da LFG a aprovação da incorporação da LFG pela Companhia } \\
\text { ("Incorporação"), com a consequente extinção da LFG;(vi) aprovar a } \\
\text { convocação da AGE da Companhia, para deliberar sobre a } \\
\text { Incorporação;(vii) em razão da Incorporação, examinar, aprovar e } \\
\text { recomendar à AGE da Companhia a alteração do Art. 30 do ES da } \\
\text { Companhia, referente ao seu objeto social, para incluir as atividades } \\
\text { desenvolvidas pela LFG;(viii) autorizar a divulgação de Fato Relevante para } \\
\text { tratar da Incorporação, nos termos da ICVM 319/99. }\end{array}$ \\
\hline 126 & $15 / 09 / 2010$ & RCA & $\begin{array}{l}\text { (i) aceitação da carta de renúncia apresentada pelo Sr. Ricardo Leonel } \\
\text { Scavazza ao cargo de Diretor Vice-Presidente Operacional; e (ii) eleição de } \\
\text { novos membros para Diretoria da Companhia. }\end{array}$ \\
\hline 127 & $13 / 10 / 2010$ & RCA & $\begin{array}{l}\text { (i) deliberar e recomendar à AGE da Companhia o seu ingresso no } \\
\text { segmento especial de governança corporativa da BM\&FBOVESPA S.A., } \\
\text { denominado Novo Mercado;(ii) em decorrência da deliberação constante do } \\
\text { item (i) acima, deliberar e recomendar à AGE da Companhia a aprovação } \\
\text { da conversão da totalidade das PNs de emissão da Companhia em ONs, na } \\
\text { razão de } 1 \text { PN para } 1 \text { ON e, consequentemente, da extinção das Units } \\
\text { representativas de ações de emissão da Companhia;(iii) deliberar e } \\
\text { recomendar à AGE da Companhia a aprovação do grupamento de Ons de } \\
\text { emissão da Companhia, na razão de } 7 \text { ações para } 1 \text { nova ação, de forma a } \\
\text { manter a continuidade das negociações das ações de emissão da Companhia }\end{array}$ \\
\hline
\end{tabular}




\begin{tabular}{|c|c|c|c|}
\hline & Data & Tipo & Ordem do Dia/ Conteúdo \\
\hline & & & $\begin{array}{l}\text { em bolsa de valores;(iv) uma vez aprovadas as deliberações constantes dos } \\
\text { itens (i) a (iii) anteriores, deliberar e recomendar à AGE da Companhia a } \\
\text { aprovação da reforma do ES da Companhia, com o objetivo de adaptá-lo às } \\
\text { determinações do Regulamento do Novo Mercado da BM\&FBOVESPA;(v) } \\
\text { aprovar a convocação de AGE da Companhia para deliberar sobre as } \\
\text { matérias constantes dos itens acima e de AGEsp, esta para os fins do Art. } \\
136 \text { da Lei n } \text { n }^{\circ} \text {. } 404 / 76 \text {, conforme alterada;(vi) caso aprovadas as matérias } \\
\text { acima, deliberar sobre a emissão pela Companhia de, inicialmente, até } \\
20.000 .000 \text { de ONs, nominativas, escriturais e sem valor nominal, no } \\
\text { âmbito de uma oferta pública de distribuição primária de ONs da } \\
\text { Companhia; e(vii) autorizar a Diretoria da Companhia a tomar todas as } \\
\text { providências necessárias com vistas à implementação e conclusão do } \\
\text { processo de ingresso da Companhia no segmento de Novo Mercado da } \\
\text { BM\&F/BOVESPA, de acordo com as deliberações constantes desta } \\
\text { reunião, assim como adotar todas as providências e praticar todos os atos } \\
\text { necessários à realização da referida oferta pública de distribuição primária } \\
\text { de Ons de emissão da Companhia. }\end{array}$ \\
\hline 128 & $01 / 12 / 2010$ & RCA & $\begin{array}{l}\text { (i) Em atendimento ao disposto no art. } 10^{\circ}, \S 6^{\circ} \text {, inciso (xii) do ES da } \\
\text { Companhia, deliberar acerca da aquisição de participação societária na } \\
\text { Sociedade Educacional Plínio Leite S/S Ltda., sociedade mantenedora da } \\
\text { instituição de ensino superior denominada Centro Universitário Plínio Leite, } \\
\text { pela subsidiária da Companhia Anhanguera Educacional Ltda.; (ii) Em } \\
\text { atendimento ao disposto no art. } 10, \S 6^{\circ} \text {, incisos (xxvi), deliberar acerca da } \\
\text { prestação de garantia pela Companhia com relação à aquisição da } \\
\text { participação societária na Sociedade Educacional Plínio Leite S/S Ltda.pela } \\
\text { subsidiária da Companhia Anhanguera Educacional Ltda.; (iii) Em } \\
\text { atendimento ao disposto no art. } 10^{\circ}, \S 6^{\circ} \text {, inciso (x) do ES da Companhia, } \\
\text { deliberar quanto à alteração excepcional na forma de representação da } \\
\text { Companhia e da subsidiária Anhanguera Educacional Ltda. especificamente } \\
\text { para a assinatura do Instrumento Particular de Compra e Venda de Quotas e } \\
\text { Outras Avenças, a ser celebrado com a Sociedade Educacional Plínio Leite } \\
\text { S/S Ltda., da alteração do contrato social e demais documentos relacionados } \\
\text { à aquisição da Sociedade Educacional Plínio Leite S/S Ltda.; (iv) Em } \\
\text { atendimento ao disposto no art. } 10^{\circ} \text {, } \S 6^{\circ} \text {, inciso (xv) do ES da Companhia, } \\
\text { deliberar acerca do voto a ser proferido pela Companhia em RS da } \\
\text { subsidiária da Companhia Anhanguera Educacional Ltda., com relação à } \\
\text { aquisição de participação societária na Sociedade Educacional Plínio Leite } \\
\text { S/S Ltda. }\end{array}$ \\
\hline 129 & $\begin{array}{l}09 / 12 / 2010 \\
\text { às } 19 \mathrm{~h}\end{array}$ & RCA & $\begin{array}{l}\text { Deliberar sobre: (i) a retificação de parte da deliberação constante do item } \\
\text { "vi" das Deliberações da Ata de RCA da Companhia realizada em } \\
\text { 13/10/2010, e a ratificação das demais deliberações tomadas no mesmo } \\
\text { item; (ii) a aprovação do aumento do capital social da Companhia mediante } \\
\text { emissão de ONs, todas nominativas, escriturais e sem valor nominal, de } \\
\text { emissão da Companhia ("Ações"), mediante distribuição pública, dentro do } \\
\text { limite do capital autorizado, com a exclusão do direito de preferência dos } \\
\text { atuais acionistas da Companhia na subscrição, nos termos do art. 172, inciso } \\
\text { I da Lei no } 6.404 / 76 \text {; (iii) a fixação do preço de emissão das Ações e a } \\
\text { justificativa do critério de fixação do preço; (iv) a aprovação da concessão } \\
\text { de opção de distribuição de lote suplementar de ações, nos termos do art. } 24 \\
\text { da ICVM 400/03; (v) a forma de integralização e colocação das Ações; (vi) } \\
\text { a aprovação do Prospecto Definitivo e do Offering Memorandum relativos à } \\
\text { distribuição pública referida no item (ii) acima; e (vii) a autorização para a } \\
\text { Diretoria praticar todos e quaisquer atos necessários, bem como assinar todo } \\
\text { e qualquer contrato e/ou documento relacionados à consecução do aumento } \\
\text { de capital mediante distribuição pública referido no item (ii) acima. }\end{array}$ \\
\hline 130 & $\begin{array}{l}09 / 12 / 2010 \\
\text { às } 20 \mathrm{~h}\end{array}$ & RCA & $\begin{array}{l}\text { Verificar a subscrição da totalidade de } 20.000 .000 \text { de ONs, todas } \\
\text { nominativas, escriturais e sem valor nominal, ao preço de emissão de } \\
\mathrm{R} \$ 36,70 \text { por ação, totalizando } \mathrm{R} \$ 734.000 .000,00 \text {, emitidas em razão do }\end{array}$ \\
\hline
\end{tabular}




\begin{tabular}{|c|c|c|c|}
\hline & Data & Tipo & Ordem do Dia/ Conteúdo \\
\hline & & & $\begin{array}{l}\text { aumento do capital social da Companhia, deliberado em reunião deste CA } \\
\text { realizada nesta data, no âmbito da oferta pública de distribuição primária de } \\
\text { ações de emissão da Companhia. }\end{array}$ \\
\hline 131 & $\begin{array}{c}\text { 20/12/2010, } \\
\text { às } 18 \mathrm{~h}\end{array}$ & RCA & $\begin{array}{l}\text { Deliberar sobre o aumento de capital da Companhia, dentro do limite do seu } \\
\text { capital autorizado, no contexto da oferta pública de distribuição de ONs de } \\
\text { emissão da Companhia, mediante a emissão de novas ONs em decorrência } \\
\text { do exercício da opção outorgada ao Banco Merrill Lynch de Investimentos } \\
\text { S.A., na qualidade de Agente Estabilizador S.A. ("BofA Merrill Lynch"), } \\
\text { para a distribuição de um lote suplementar de ONs, nominativas, escriturais, } \\
\text { sem valor nominal, nas mesmas condições da Oferta. }\end{array}$ \\
\hline 132 & $\begin{array}{c}\text { 20/12/2010 } \\
\text { às } 19 \mathrm{~h}\end{array}$ & RCA & $\begin{array}{l}\text { (i) Verificar a subscrição da totalidade de } 3.000 .000 \text { de ONs, todas } \\
\text { nominativas, escriturais e sem valor nominal, ao preço de emissão de } \\
\mathrm{R} \$ 36,70 \text { por ação, totalizando } \mathrm{R} \$ 110.100 .000,00 \text {, emitidas em razão do } \\
\text { aumento do capital social da Companhia, deliberado em reunião deste CA } \\
\text { realizada nesta data, no âmbito da oferta pública de distribuição primária de } \\
\text { ações de emissão da Companhia. }\end{array}$ \\
\hline 133 & $07 / 02 / 2011$ & RCA & $\begin{array}{l}\text { (i) Em atendimento ao disposto no art. 10o, §6o, inciso (ix) do ES da } \\
\text { Companhia, deliberar acerca da venda de imóveis situados na cidade de } \\
\text { Osasco - SP, de propriedade da sua subsidiaria Anhanguera Educacional } \\
\text { Ltda., na qualidade de vendedora;(ii) Em atendimento ao disposto no art. } \\
\text { 10o, §6o, inciso (ix) do ES da Companhia, deliberar acerca da locação de } \\
\text { imóveis para fins não Residenciais, pela sua subsidiaria, Anhanguera } \\
\text { Educacional Ltda., na qualidade de locadora;(iii) Em atendimento ao } \\
\text { disposto no art. 10o, §6o, inciso (xii) do ES da Companhia, deliberar acerca } \\
\text { da outorga de garantia (fiança) pela Companhia, em favor de sua } \\
\text { subsidiária, Anhanguera Educacional Ltda., nas obrigações do Contrato de } \\
\text { Locação para fins não Residenciais, conforme item (ii) acima;(iv) Em } \\
\text { atendimento ao disposto no art. 10o, §6o, incisos (xv) do ES da Companhia, } \\
\text { deliberar acerca da ratificação do voto proferido pela Companhia em RS da } \\
\text { sua subsidiária Anhanguera Educacional Ltda., realizada em 07/02/2011 às } \\
\text { 9h; e(v) Deliberar por autorizar os membros da Diretoria da Companhia e } \\
\text { de sua subsidiária, Anhanguera Educacional Ltda., assinarem todos e } \\
\text { quaisquer contratos e demais documentos e a praticarem todos e quaisquer } \\
\text { atos necessários à efetivação das operações imobiliárias supramencionadas, } \\
\text { incluindo, mas não se limitando, tomarem todas as providências necessárias } \\
\text { junto aos respectivos cartórios de imóveis, e demais órgãos públicos, para } \\
\text { efetivarem as transferências dos respectivos imóveis, registros, averbações, } \\
\text { e demais atualizações cadastrais. }\end{array}$ \\
\hline 134 & $15 / 02 / 2011$ & $\mathrm{RCA}$ & $\begin{array}{l}\text { (i) Em atendimento ao disposto no art. } 100, \S 60 \text {, inciso (ix) do ES da } \\
\text { Companhia, deliberar acerca da aquisição por si, ou por sua subsidiária, } \\
\text { Anhanguera Educacional Ltda., de imóveis situados na cidade de Sorocaba - } \\
\text { SP; (ii) Em atendimento ao disposto no art. } 100 \text {, } \$ 60 \text {, inciso (ix) do ES da } \\
\text { Companhia, deliberar acerca da locação de imóveis para fins não } \\
\text { Residenciais, por si ou por sua subsidiaria, Anhanguera Educacional Ltda., } \\
\text { na qualidade de locadora ("Locação dos Imóveis"); (iii) Em atendimento ao } \\
\text { disposto no art. 10o, §6o, inciso (xii) do ES da Companhia, deliberar acerca } \\
\text { da outorga de garantia por si, ou por sua subsidiária, Anhanguera } \\
\text { Educacional Ltda., com relação às obrigações assumidas por conta: (a) da } \\
\text { Aquisição dos Imóveis mencionados no item (i), e (b) da Locação dos } \\
\text { Imóveis, mencionada no item (ii) acima;(iv) Em atendimento ao disposto no } \\
\text { art. } 100, \S 60 \text {, inciso (viii) do ES da Companhia, deliberar acerca da abertura } \\
\text { de filial por sua subsidiária Anhanguera Educacional Ltda.;(v) Em } \\
\text { atendimento ao disposto no art. } 100, \S 60 \text {, incisos (xv) do ES da Companhia, } \\
\text { deliberar acerca da ratificação do voto proferido pela Companhia em RS da } \\
\text { sua subsidiária Anhanguera Educacional Ltda., realizada em } 15 / 02 / 2011 \text { às } \\
9 \text { h; e(vi) Deliberar por autorizar os membros da Diretoria da Companhia e } \\
\text { de sua subsidiária, Anhanguera Educacional Ltda., assinarem todos e } \\
\text { quaisquer contratos e demais documentos e a praticarem todos e quaisquer }\end{array}$ \\
\hline
\end{tabular}




\begin{tabular}{|c|c|c|c|}
\hline & Data & Tipo & Ordem do Dia/ Conteúdo \\
\hline & & & $\begin{array}{l}\text { atos necessários à efetivação das operações imobiliárias supramencionadas, } \\
\text { incluindo, mas não se limitando, tomarem todas as providências necessárias } \\
\text { junto aos respectivos cartórios de imóveis, e demais órgãos públicos, para } \\
\text { efetivarem as transferências dos respectivos imóveis, registros, averbações, } \\
\text { e demais atualizações cadastrais. }\end{array}$ \\
\hline 135 & $\begin{array}{l}\text { 22/02/2011, } \\
\text { às } 9 \mathrm{~h}\end{array}$ & $\mathrm{RCA}$ & $\begin{array}{l}\text { (i) Em atendimento ao disposto no art. 10o, §6o, inciso (xii) do ES da } \\
\text { Companhia, deliberar acerca da aquisição de participação societária na } \\
\text { União de Ensino Superior de Ciência, Tecnologia e Saúde Ltda., sociedade } \\
\text { mantenedora da instituição de ensino superior denominada Faculdade de } \\
\text { Ciências e Tecnologia de Brasília, por si ou por sua subsidiária, Anhanguera } \\
\text { Educacional Ltda.;(ii) Caso seja aprovado o item (i) acima, em atendimento } \\
\text { ao disposto no art. 10o, §6o, inciso (xii) do ES da Companhia, deliberar } \\
\text { acerca da locação de imóveis para fins não residenciais por sua subsidiária, } \\
\text { União de Ensino Superior de Ciência, Tecnologia e Saúde Ltda., na } \\
\text { qualidade de Locatária;(iii) Caso seja aprovado o item (i) acima, em } \\
\text { atendimento ao disposto no art. 10o, §6o, inciso (xxvi) do ES da } \\
\text { Companhia, deliberar acerca da prestação de garantia por si ou por sua } \\
\text { subsidiária, Anhanguera Educacional Ltda., conforme aplicável, com } \\
\text { relação à: (a) aquisição da participação societária na União de Ensino } \\
\text { Superior de Ciência, Tecnologia e Saúde Ltda., e (b) prestação de fiança no } \\
\text { Contrato de Locação para fins não Residenciais ("Contrato de Locação"), a } \\
\text { ser firmado pela subsidiária, União de Ensino Superior de Ciência, } \\
\text { Tecnologia e Saúde Ltda., na qualidade de Locatária;(iv) Em atendimento } \\
\text { ao disposto no art. 10o, §6o, inciso (viii) do ES da Companhia, deliberar } \\
\text { acerca da abertura de filiais por si, ou por sua subsidiária Anhanguera } \\
\text { Educacional Ltda.; e(v) Em atendimento ao disposto no art. 10", §6o, } \\
\text { incisos (xv) do ES da Companhia, deliberar acerca do voto a ser proferido } \\
\text { pela Companhia em reunião de sócio da subsidiária Anhanguera } \\
\text { Educacional Ltda., com relação à aquisição de participação societária na } \\
\text { União de Ensino Superior de Ciência, Tecnologia e Saúde Ltda., bem como } \\
\text { na assinatura do Contrato de Locação e todos e quaisquer contratos e } \\
\text { documentos relacionados à aquisição. }\end{array}$ \\
\hline 136 & $\begin{array}{l}22 / 02 / 2011 \\
\text { às } 10 \mathrm{~h}\end{array}$ & $\mathrm{RCA}$ & $\begin{array}{l}\text { (i) Em atendimento ao disposto no art. 10o, §6o, inciso (xii) do ES da } \\
\text { Companhia, deliberar acerca da aquisição ("Aquisição") de determinados } \\
\text { ativos, consubstanciados em bens e direitos ("Bens e Direitos") do Grupo } \\
\text { IBMEC Educacional S.A. ("IBMEC"), por si ou por sua subsidiária, } \\
\text { Anhanguera Educacional Ltda.; (ii) Em atendimento ao disposto no art. 10o, } \\
\text { §6o, inciso (xii) do ES da Companhia, deliberar pela assinatura do Contrato } \\
\text { de Locação para fins não Residenciais ("Contrato de Locação") a ser } \\
\text { celebrado por sua subsidiária, Anhanguera Educacional Ltda., na qualidade } \\
\text { de Locatária, ou assinatura de eventual instrumento de cessão de contratos } \\
\text { de locação já existentes, na qualidade de cessionária ("Cessão da } \\
\text { Locação"); (iii) Caso seja aprovado os itens (i) e (ii) acima, em atendimento } \\
\text { ao disposto no art. 10o, §6o, inciso (xxvi), deliberar acerca da prestação de } \\
\text { garantia pela Companhia, com relação às obrigações assumidas por sua } \\
\text { subsidiária, Anhanguera Educacional Ltda. relativas: (a) à Aquisição dos } \\
\text { Bens e Direitos, e (b) ao Contrato de Locação, a ser firmado pela } \\
\text { subsidiária, Anhanguera Educacional Ltda., na qualidade de "Locatária" ou } \\
\text { à Cessão da Locação; (iv) Em atendimento ao disposto no art. 10o, §6o, } \\
\text { incisos (viii) do ES da Companhia, deliberar acerca da abertura de filiais } \\
\text { por sua subsidiária Anhanguera Educacional Ltda.; e (v) Em atendimento ao } \\
\text { disposto no art. 10, §6o, incisos (xv) do ES da Companhia, deliberar acerca } \\
\text { do voto a ser proferido pela Companhia em reunião de sócio da subsidiária } \\
\text { Anhanguera Educacional Ltda., com relação à Aquisição dos Bens e } \\
\text { Direitos, bem como no tocante à assinatura de todos e quaisquer contratos e } \\
\text { documentos relacionados à Aquisição. }\end{array}$ \\
\hline 137 & $\begin{array}{l}25 / 03 / 2011 \\
\text { às } 9 \mathrm{~h}\end{array}$ & RCA & $\begin{array}{l}\text { (i) deliberar pela abertura, retificação, alteração e encerramento de } \\
\text { endereços de filiais daCompanhia e/ou de suas subsidiarias;(ii) ratificar a }\end{array}$ \\
\hline
\end{tabular}




\begin{tabular}{|c|c|c|c|}
\hline & Data & Tipo & Ordem do Dia/ Conteúdo \\
\hline & & & $\begin{array}{l}\text { assinatura do Instrumento Particular de Quitação referente à Venda e } \\
\text { Compra de Bem Imóvel (Unidade FAC 3, localizada na cidade de Campinas } \\
\text { - SP, na Estrada Campinas-Mogi Mirim, no município e Comarca de } \\
\text { Campinas - SP);(iii) deliberar pela assinatura de Termo Aditivo ao } \\
\text { Instrumento Particular de Compra e Venda de Quotas e Outras avenças da } \\
\text { Oeste Organização de Ensino Superior e Tecnologia Limitada ("FIZO");(iv) } \\
\text { deliberar pela aceitação da carta de renúncia apresentada pelo Sr. Oseas } \\
\text { Rodolph Cancela dos Santos Junior;(v) deliberar pela eleição de Membros } \\
\text { do Comitê de Auditoria; e(vi) deliberar acerca do voto a ser proferido pelos } \\
\text { representantes da Companhia em reuniões de sócios de suas subsidiárias } \\
\text { com relação às deliberações tomadas acerca dos itens (i), (ii), (iii) e (iv) } \\
\text { acima. }\end{array}$ \\
\hline 138 & $\begin{array}{c}\text { 25/03/2011, } \\
\text { às } 9 \text { h30 }\end{array}$ & RCA & $\begin{array}{l}\text { (i) revisão e aprovação do Relatório da Administração sobre os negócios } \\
\text { sociais e os principais fatos administrativos, bem como as contas da } \\
\text { Diretoria, referentes ao exercício social findo em } 31 / 12 / 2010 \text {;(ii) apreciação } \\
\text { das DFs acompanhadas do Relatório dos Auditores Independentes da } \\
\text { Companhia, relativos ao exercício social findo em } 31 / 12 / 2010 \text {;(iii) } \\
\text { apreciação da proposta de destinação do lucro líquido da Companhia, } \\
\text { referente ao exercício social findo em } 31 / 12 / 2010 \text {, incluindo a proposta de } \\
\text { orçamento de capital;(iv) deliberação acerca da proposta de alteração (a) do } \\
\text { Art. 2o do ES da Companhia, para o fim específico de consolidar as atuais } \\
\text { filiais da Companhia; e (b) do Art. 5o do ES da Companhia, para o fim } \\
\text { específico de refletir os aumentos de capital aprovados dentro do capital } \\
\text { autorizado por deliberações tomadas nas RCAs da Companhia em } \\
\text { 09/12/2010 e } 20 / 12 / 2010 ;(\text { v) analise e deliberação acerca do estudo técnico } \\
\text { de impostos diferidos;(vi) deliberação acerca de voto a ser proferido em RS } \\
\text { das suas subsidiárias, Anhanguera Educacional Ltda., Anhanguera } \\
\text { Educação Profissional Ltda., Anhanguera Publicações e Com. de Material } \\
\text { Didático Ltda., Sociedade Educacional Plínio Leite S/S Ltda., e União de } \\
\text { Ensino Superior de Ciência, Tecnologia e Saúde Ltda., com relação às } \\
\text { contas de mencionadas referentes ao exercício social encerrado em } \\
31 / 12 / 2010 \text {, inclusive as DFs e o relatórios dos auditores independentes, } \\
\text { especificamente da sua subsidiária Anhanguera Educacional Ltda.; e(vii) } \\
\text { deliberação acerca da convocação da AGO e AGE da Companhia. }\end{array}$ \\
\hline 139 & $\begin{array}{c}\text { 25/03/2011, } \\
\text { às } 10 \mathrm{~h}\end{array}$ & RCA & $\begin{array}{l}\text { (i) Em atendimento ao disposto no art. 10o, §6o, inciso (xii) do ES da } \\
\text { Companhia, deliberar acerca da aquisição de participação societária, por si } \\
\text { ou por sua subsidiária Anhanguera Educacional Ltda. (“Anhanguera } \\
\text { Ltda."), da totalidade das quotas representativas do capital social das } \\
\text { sociedades: (a) Instituto Grande ABC de Educação e Ensino S/S Ltda. } \\
\text { ("IGABC"), e (b) Novatec Serviços Educacionais Ltda. ("Novatec");(ii) } \\
\text { Caso seja aprovado o item (i) acima, em atendimento ao disposto no art. } \\
\text { 10o, §6o, inciso e (xii) do ES da Companhia, deliberar acerca das } \\
\text { assinaturas dos Contratos de Locação para Fins não Residenciais (Contrato } \\
\text { de Locação) e eventuais aditamentos aos respectivos Contratos a serem } \\
\text { firmados por si, ou por suas subsidiárias adquiridas, IGABC e Novatec, } \\
\text { ambas na qualidade de Locatárias;(iii) Caso seja aprovado o item (i) acima, } \\
\text { em atendimento ao disposto no art. 10, §6o, inciso (xxvi) do ES da } \\
\text { Companhia, deliberar acerca da prestação de garantia por si ou por sua } \\
\text { subsidiária, Anhanguera, conforme aplicável, com relação à: (a) aquisições } \\
\text { da participação societária nas sociedades IGABC e Novatec, e (b) prestação } \\
\text { de fiança nos Contratos de Locação, a serem firmado pelas subsidiárias, } \\
\text { IGABC e Novatec, ambas na qualidade de Locatárias; e(iv) Em } \\
\text { atendimento ao disposto no art. 10o, §6o, inciso (viii) do ES da Companhia, } \\
\text { deliberar acerca da abertura de filiais por si, ou por sua subsidiária } \\
\text { Anhanguera Ltda., conforme aplicável;(v) Em atendimento ao disposto no } \\
\text { art. } 10 o \text { o, §6o, inciso (xv) do ES da Companhia, deliberar acerca do voto a } \\
\text { ser proferido pela Companhia em RS da Anhanguera Ltda., subsidiária da } \\
\text { Companhia, com relação (a) à aquisição de participação societária nas }\end{array}$ \\
\hline
\end{tabular}




\begin{tabular}{|c|c|c|c|}
\hline & Data & Tipo & Ordem do Dia/ Conteúdo \\
\hline & & & $\begin{array}{l}\text { sociedades IGABC e Novatec, (b) à assinatura dos Contratos de Locação e } \\
\text { de todos e quaisquer contratos e documentos relacionados à aquisição, seja } \\
\text { como parte ou como garantidora e, ainda, (c) à aprovação da transferência } \\
\text { das mantenças da Faculdade Anchieta - IGABC e da Faculdade de } \\
\text { Tecnologia Anchieta, atualmente mantidas pela IGABC e pela Novatec, } \\
\text { para a subsidiária Anhanguera Ltda., englobando a autorização para } \\
\text { assinatura de quaisquer documentos necessários para que referidas } \\
\text { transferências sejam realizadas junto ao Ministério da Educação, inclusive } \\
\text { de instrumentos de cessão das respectivas mantenças entre a IGABC e a } \\
\text { Novatec, na qualidade de cedentes, e a Anhanguera Ltda., na qualidade de } \\
\text { cessionária. }\end{array}$ \\
\hline 140 & $\begin{array}{c}25 / 03 / 2011 \\
\text { às } 10 h 30\end{array}$ & RCA & $\begin{array}{l}\text { (i) Criação do } 2^{\circ} \text { Programa de Outorga de Certificados de Depósitos de } \\
\text { Ações da Anhanguera Educacional Participações S.A., no contexto do Plano } \\
\text { de Opção de Compra de Ações aprovado na AGE da Companhia realizada } \\
\text { em } 30 / 04 / 2010 \text {, com a eleição dos respectivos beneficiários e definição do } \\
\text { número de Ações que poderão ser adquiridas por cada um deles;(ii) } \\
\text { Definição do preço de exercício das opções e as condições de seu } \\
\text { pagamento;(iii) Definição dos prazos e condições de exercício das } \\
\text { opções;(iv) Autorização para a Diretoria Estatutária efetuar as outorgas de } \\
\text { opção de compra de Ações aos beneficiários. }\end{array}$ \\
\hline 141 & $12 / 05 / 2011$ & $\mathrm{RCA}$ & $\begin{array}{l}\text { (i) apresentação e deliberação acerca das informações financeiras trimestrais } \\
\text { e resultados da Companhia correspondentes ao período de três meses } \\
\text { encerrado em } 31 / 03 / 2011 \text {;(ii) deliberação acerca da aceitação da carta de } \\
\text { renúncia do Sr. Antonio Carbonari Netto ao cargo de Diretor Presidente da } \\
\text { Companhia;(iii) deliberação acerca da alteração na denominação do cargo } \\
\text { do Sr. Alexandre Silveira Dias, passando de Diretor Superintendente para } \\
\text { Diretor Presidente e Diretor Superintendente;(iv) deliberação acerca de (a) } \\
\text { re-ratificação do endereço de filiais da Companhia e (b) abertura de filiais } \\
\text { da Companhia e/ou de suas subsidiárias; e(v) apresentação do Relatório de } \\
\text { Responsabilidade Social da Companhia relativo ao ano de } 2010 \text {. }\end{array}$ \\
\hline 142 & $17 / 05 / 2011$ & RCA & $\begin{array}{l}\text { (i) Em atendimento ao disposto no art. } 10 \text {, Parágrado } 6^{\circ} \text {, incisco (xii) do ES } \\
\text { da Companhia, deliberar acerca da aquisição de participação societária, pela } \\
\text { Companhia ou por sua subsisidária Anhanguera Educacional Ltda. } \\
\text { ("Subsidiária"), da totalidade das quotas representativas do capital social da: } \\
\text { (a) Sociedade Educacional de Belo Horizonte Ltda., sociedade limitada, } \\
\text { com sede na Cidade de Belo Horizonte - MG, na Rua Uberaba, 295, Barro } \\
\text { Preto, inscrita no CNPJ sob o no. 03.393.655/0001-05 ("SBH”); e (b) } \\
\text { Praetorium Instituto de Ensino, Pesquisa e Atividade de Extensão em } \\
\text { Direito Ltda., sociedade limitada, com sede na Cidade de Belo Horizonte - } \\
\text { MG, na Rua Alvarenga Peixoto, 1427, Santo Agostinho, inscrita no CNPJ } \\
\text { sob o no. 00.647.911/0001-05 ("Praetorium"); (ii) Caso seja aprovado o } \\
\text { item (i) acima, em atendimento ao disposto no art. 10o, §6o, inciso e (xii) } \\
\text { do ES da Companhia, deliberar acerca das assinaturas dos Contratos de } \\
\text { Locação para fins comerciais e eventuais aditamentos e/ou instrumentos de } \\
\text { sublocação aos mencionados contratos ("Contratos de Locação") } \\
\text { necessários para conduzir as atividades das Sociedade, a serem firmados } \\
\text { pela Companhia, pela Subsidiária ou por suas suas subsidiárias adquiridas, } \\
\text { SBH e Praetorium, em qualquer caso na qualidade de locatária e/ou } \\
\text { sublocatária; (iii) Caso seja aprovado o item (i) acima, em atendimento ao } \\
\text { disposto no art. 10, §6o, inciso (xxvi) do ES da Companhia, deliberar acerca } \\
\text { da prestação de garantia, pela Companhia ou pela Subsidiária, Aconforme } \\
\text { aplicável, com relação à: (a) aquisições das participações societárias das } \\
\text { Sociedades, e (b) prestação de fiança nos Contratos de Locação, a serem } \\
\text { firmados e/ou em quaisquer outros contratos de financiamento e/ou } \\
\text { empréstimo dos quais SBH e Praetorium figurem como devedora; e(iv) Em } \\
\text { atendimento ao disposto no art. 10o, §6o, inciso (viii) do ES da Companhia, } \\
\text { deliberar acerca da abertura de filiais pela Companhia ou pela Subsidiária, } \\
\text { conforme aplicável;(v) Em atendimento ao disposto no art. 10o, §6o, inciso }\end{array}$ \\
\hline
\end{tabular}




\begin{tabular}{|c|c|c|c|}
\hline & Data & Tipo & Ordem do Dia/ Conteúdo \\
\hline & & & $\begin{array}{l}\text { (xv) do ES da Companhia, deliberar acerca do voto a ser proferido pela } \\
\text { Companhia em RS da Subsidiária, com relação (a) à aquisição de } \\
\text { participações societárias das Sociedades, (b) à assinatura dos Contratos de } \\
\text { Locação e de todos e quaisquer contratos e documentos relacionados à } \\
\text { aquisição das Sociedades, seja como parte ou como garantidora e, ainda, (c) } \\
\text { à aprovação da transferência da mantença da Faculdade Metropolitana de } \\
\text { Belo Horizonte (Escola Superior de Negócios), atualmente mantida pela } \\
\text { SBH, para a Subsidiária, englobando a autorização para assinatura de } \\
\text { quaisquer documentos necessários para que referida transferência seja } \\
\text { realizada junto ao Ministério da Educação, inclusive de instrumento de } \\
\text { cessão da respectiva mantença entre SBH, na qualidade de cedente, e a } \\
\text { Subsidiária, na qualidade de cessionária. }\end{array}$ \\
\hline 143 & $25 / 05 / 2011$ & $\mathrm{RCA}$ & $\begin{array}{l}\text { (i) Deliberação acerca da re-ratificação da ata de RCA da Compahia } \\
\text { realizada em } 15 / 02 / 2011,11 \mathrm{~h} \text {, com relação à aprovação de compra de } \\
\text { imóvel localizado na cidade de Sorocaba, em função da alteração de } \\
\text { determinadas condições comerciais para a compra. }\end{array}$ \\
\hline 144 & $08 / 06 / 2011$ & $\mathrm{RCA}$ & $\begin{array}{l}\text { (i) Criação do } 3^{0} \text { Programa de Outorga de Ações da Anhanguera } \\
\text { Educacional Participações S.A., no contexto do Plano de Opção de Compra } \\
\text { de Ações aprovado na AGE da Companhia realizada em 30/04/2010, com a } \\
\text { eleição dos respectivos beneficiários e definição do número de Ações que } \\
\text { poderão ser adquiridas por cada um deles;(ii) Definição do preço de } \\
\text { exercício das opções e as condições de seu pagamento;(iii) Definição dos } \\
\text { prazos e condições de exercício das opções;(iv) Autorização para a } \\
\text { Diretoria efetuar as outorgas de opção de compra de ações aos beneficiários. }\end{array}$ \\
\hline 145 & $17 / 06 / 2011$ & $\mathrm{RCA}$ & $\begin{array}{l}\text { (i) Em atendimento ao disposto no art. } 10^{\circ} \text {, Parágrafo } 6^{\circ} \text {, inciso (xiv) do ES } \\
\text { da Companhia, deliberar acerca da reeleição do Sr. Jorge Michel Lepeitier } \\
\text { ao cargo de Presidente do Comitê de Auditoria da Companhia;(ii) Deliberar } \\
\text { acerca da alteração do número do endereço da sede social da Companhia e } \\
\text { respectivamente de suas subsidiárias localizadas em Valinhos, em função de } \\
\text { renumeração notificada pela prefeitura da referida cidade; e(iii) Em } \\
\text { atendimento ao disposto no art. } 10^{\circ} \text {, Parágrafo } 6^{\circ} \text {, inciso (viii) do ES da } \\
\text { Companhia, deliberar acerca da abertura, encerramento e modificações em } \\
\text { filiais da Companhia e de suas subsidiárias. }\end{array}$ \\
\hline 146 & $29 / 06 / 2011$ & $\mathrm{RCA}$ & $\begin{array}{l}\text { (i) Em atendimento ao disposto no art. } 10^{\circ}, \S 6^{\circ} \text {, inciso (xii) do ES da } \\
\text { Companhia, deliberar acerca da assinatura do Instrumento Particular de } \\
\text { Promessa de Venda e Compra de Imóveis, cujo objeto é a venda de imóveis } \\
\text { situados na cidade de Campinas - SP, de propriedade da Companhia;(ii) } \\
\text { Caso seja aprovado o item (i) acima, em atendimento ao disposto no art. } \\
\text { 10o, §6o, inciso (xii) do ES da Companhia, deliberar acerca da assinatura } \\
\text { do Instrumento Particular de Contrato de Locação Atípica de Imóveis e } \\
\text { Outras Avenças, a ser firmado pela Companhia e/ou sua subsidiária, } \\
\text { Anhanguera Educacional Ltda., na condição de Locatária, dos imóveis } \\
\text { localizados na Cidade de Campinas - SP;(iii) Em atendimento ao disposto } \\
\text { no art. } 10^{\circ} \text {, §6 }{ }^{\circ} \text {, inciso (xii) do ES da Companhia, deliberar acerca da } \\
\text { assinatura do Instrumento Particular de Promessa de Venda e Compra de } \\
\text { Imóvel, cujo objeto é a venda de imóvel situado na cidade de Cuiabá, } \\
\text { Estado do Mato Grosso, de propriedade da Companhia;(iv) Caso seja } \\
\text { aprovado o item (iii) acima, em atendimento ao disposto no art. 10o, §6o, } \\
\text { inciso (xii) do ES da Companhia, deliberar acerca da assinatura do } \\
\text { Instrumento Particular de Contrato de Locação Atípica de Imóvel e Outras } \\
\text { Avenças, a ser firmado pela Companhia e/ou sua subsidiária, Anhanguera } \\
\text { Educacional Ltda., na condição de Locatária, do imóvel localizado na } \\
\text { Cidade de Cuiabá, Estado do Mato Grosso;(v) Caso sejam aprovados os } \\
\text { itens (ii) e (iv) acima, em atendimento ao disposto no art. } 10^{\circ} \text {, §6 } 6^{\circ} \text {, inciso } \\
\text { (xxvi) do ES da Companhia, deliberar acerca da outorga de garantia pela } \\
\text { Companhia ou por sua subsidiária, Anhanguera Educacional Ltda., com } \\
\text { relação às obrigações a serem assumidas nos Contratos de Locação de } \\
\text { Campinas e Cuiabá(vi) Em atendimento ao disposto no art. } 10^{\circ} \text {, §6 } 6^{\circ} \text {, inciso }\end{array}$ \\
\hline
\end{tabular}




\begin{tabular}{|c|c|c|c|}
\hline & Data & Tipo & Ordem do Dia/ Conteúdo \\
\hline & & & $\begin{array}{l}\text { (xv) do ES da Companhia, deliberar acerca do voto a ser proferido pela } \\
\text { Companhia em RS da subsidiária da Companhia Anhanguera Educacional } \\
\text { Ltda., com relação às assinaturas dos Contratos de Locação de Campinas e } \\
\text { Cuiabá, prestações de garantias em favor da Companhia, bem como de } \\
\text { todos e quaisquer contratos e/ou documentos relacionados às referidas } \\
\text { operações imobiliárias; e(vii) Deliberar por autorizar os membros da } \\
\text { Diretoria da Companhia e de sua subsidiária Anhanguera Educacional } \\
\text { Ltda., a assinarem quaisquer documentos e a praticarem todos e quaisquer } \\
\text { atos necessários à efetivação das operações imobiliárias supramencionadas, } \\
\text { incluindo, mas não se limitando, o Instrumento Particular de Compromisso } \\
\text { de Pagamento de Prêmio de Locação e Outras Avenças (tanto de Campinas } \\
\text { quanto de Cuiabá), contrato de conta vinculada (escrow), contratação de } \\
\text { fiança bancária e seguros exigidos, tomarem todas as providências } \\
\text { necessárias junto aos respectivos cartórios de imóveis, e demais órgãos } \\
\text { públicos, para efetivarem as transferências dos respectivos imóveis, } \\
\text { registros, averbações, e demais atualizações cadastrais. }\end{array}$ \\
\hline 147 & $20 / 07 / 2011$ & $\mathrm{RCA}$ & $\begin{array}{l}\text { (i) Deliberar acerca do 1o Programa de Recompra de Ações de emissão da } \\
\text { Companhia. }\end{array}$ \\
\hline 148 & $27 / 07 / 2011$ & $\mathrm{RCA}$ & 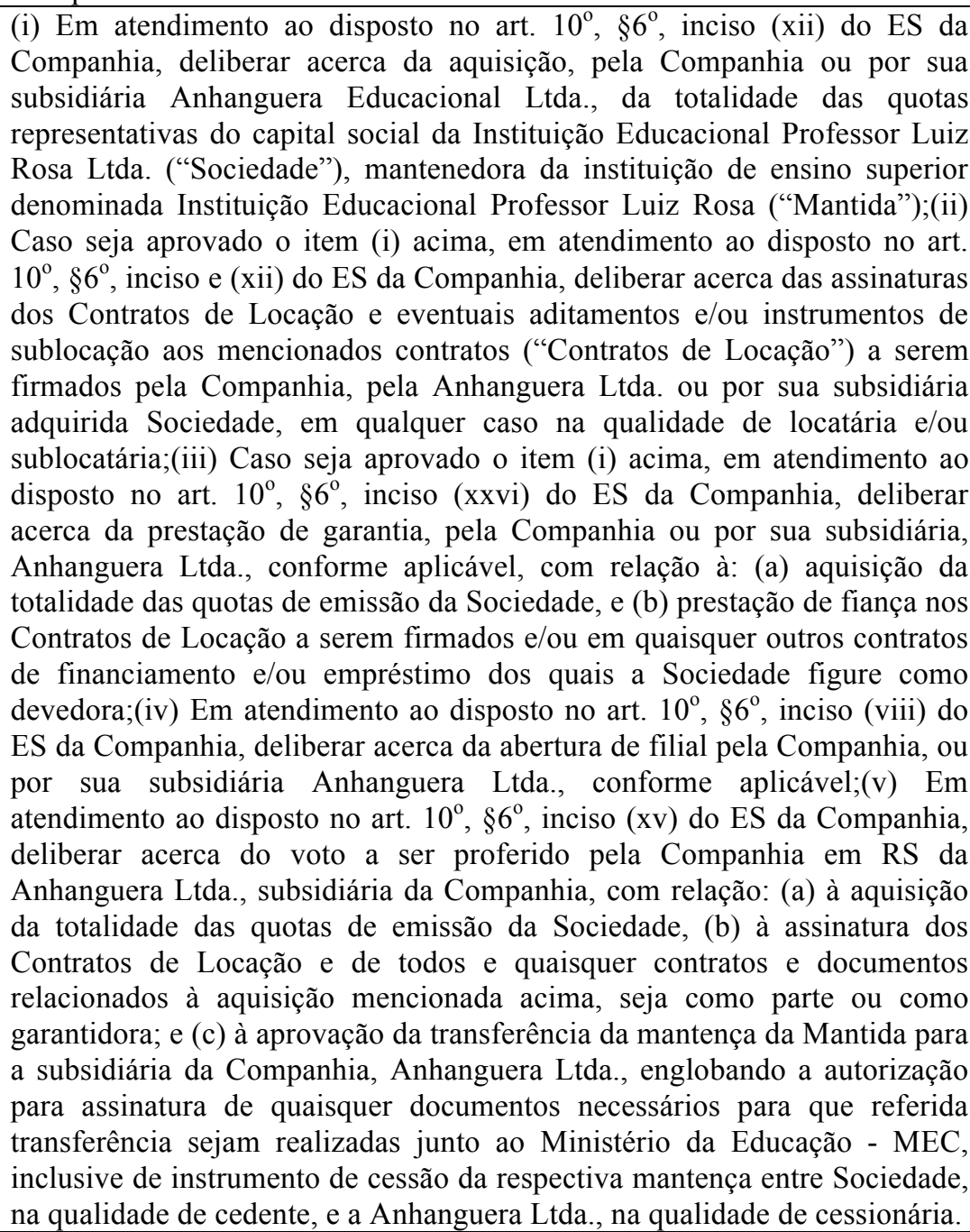 \\
\hline 149 & $28 / 07 / 2011$ & $\mathrm{RCA}$ & $\begin{array}{l}\text { (i) Deliberar acerca do encerramento de filiais da Companhia e/ou de suas } \\
\text { subsidiarias;(ii) Deliberar acerca da inclusão de novas instituições } \\
\text { financeiras para atuarem como intermediadoras do lo Programa de } \\
\text { Recompra de Acões da Companhia. }\end{array}$ \\
\hline 150 & $12 / 08 / 2011$ & RCA & $\begin{array}{l}\text { (i) Apresentar e deliberar acerca da aprovação das informações trimestrais } \\
\text { (ITRs) da Companhia referentes ao período encerrado em } 30 / 06 / 2011 \text {;(ii) }\end{array}$ \\
\hline
\end{tabular}




\begin{tabular}{|c|c|c|c|}
\hline & Data & Tipo & Ordem do Dia/ Conteúdo \\
\hline & & & $\begin{array}{l}\text { Deliberar acerca da locação de imóvel localizado na cidade de Belo } \\
\text { Horizonte - MG, pela subsidiária Anhanguera Educacional Ltda., com } \\
\text { prestação de fiança pela Companhia;(iii) Deliberar acerca da prestação de } \\
\text { fiança pela Companhia em garantia à locação referida no item (iii) acima; } \\
\text { e(iv) Deliberar acerca de voto favorável a ser proferido em RS da } \\
\text { subsidiária Anhanguera Educacional Ltda. com relação à locação referida } \\
\text { acima. }\end{array}$ \\
\hline 151 & $05 / 09 / 2011$ & $\mathrm{RCA}$ & $\begin{array}{l}\text { (i) Deliberar acerca da assinatura pela Companhia do Primeiro Termo } \\
\text { Aditivo ao Instrumento Particular de Compra e Venda de Quotas, } \\
\text { Compromisso de Subscrição de Ações e Outras Avenças, originalmente } \\
\text { celebrado em } 06 / 10 / 2008 \text { entre J.L.P.S.P.E. Empreendimentos e } \\
\text { Participações Ltda., na qualidade de Compradora, e Luiz Flávio Gomes e } \\
\text { Julio Cesar Gomes. }\end{array}$ \\
\hline 152 & $15 / 09 / 2011$ & RCA & 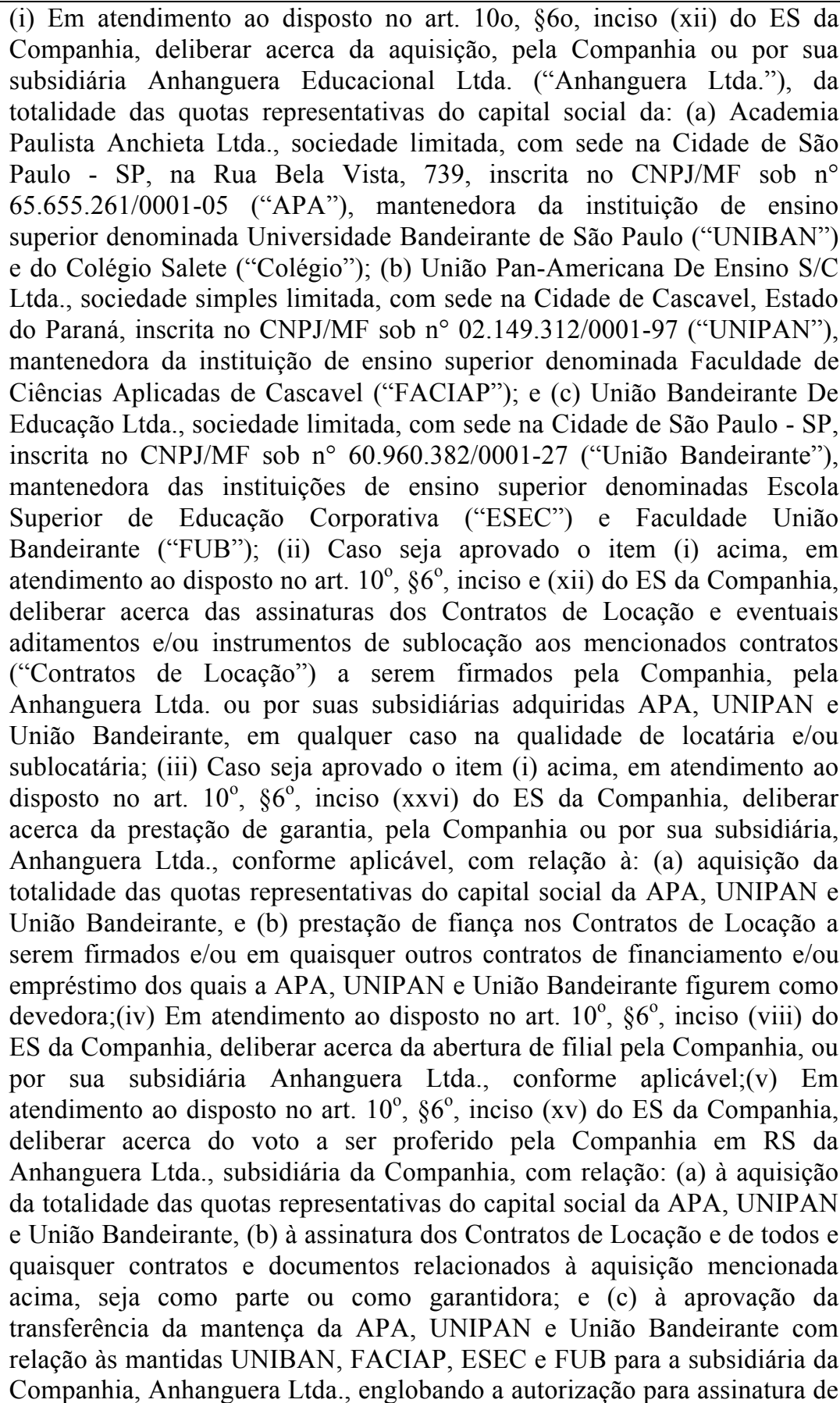 \\
\hline
\end{tabular}




\begin{tabular}{|c|c|c|c|}
\hline & Data & Tipo & Ordem do Dia/ Conteúdo \\
\hline & & & $\begin{array}{l}\text { quaisquer documentos necessários para que referida transferência sejam } \\
\text { realizadas junto ao Ministério da Educação - MEC, inclusive de instrumento } \\
\text { de cessão da respectiva mantença entre APA, UNIPAN e União } \\
\text { Bandeirante, cada uma na qualidade de cedente, e a Anhanguera Ltda., na } \\
\text { qualidade de cessionária. }\end{array}$ \\
\hline 153 & $19 / 09 / 2011$ & $\mathrm{RCA}$ & 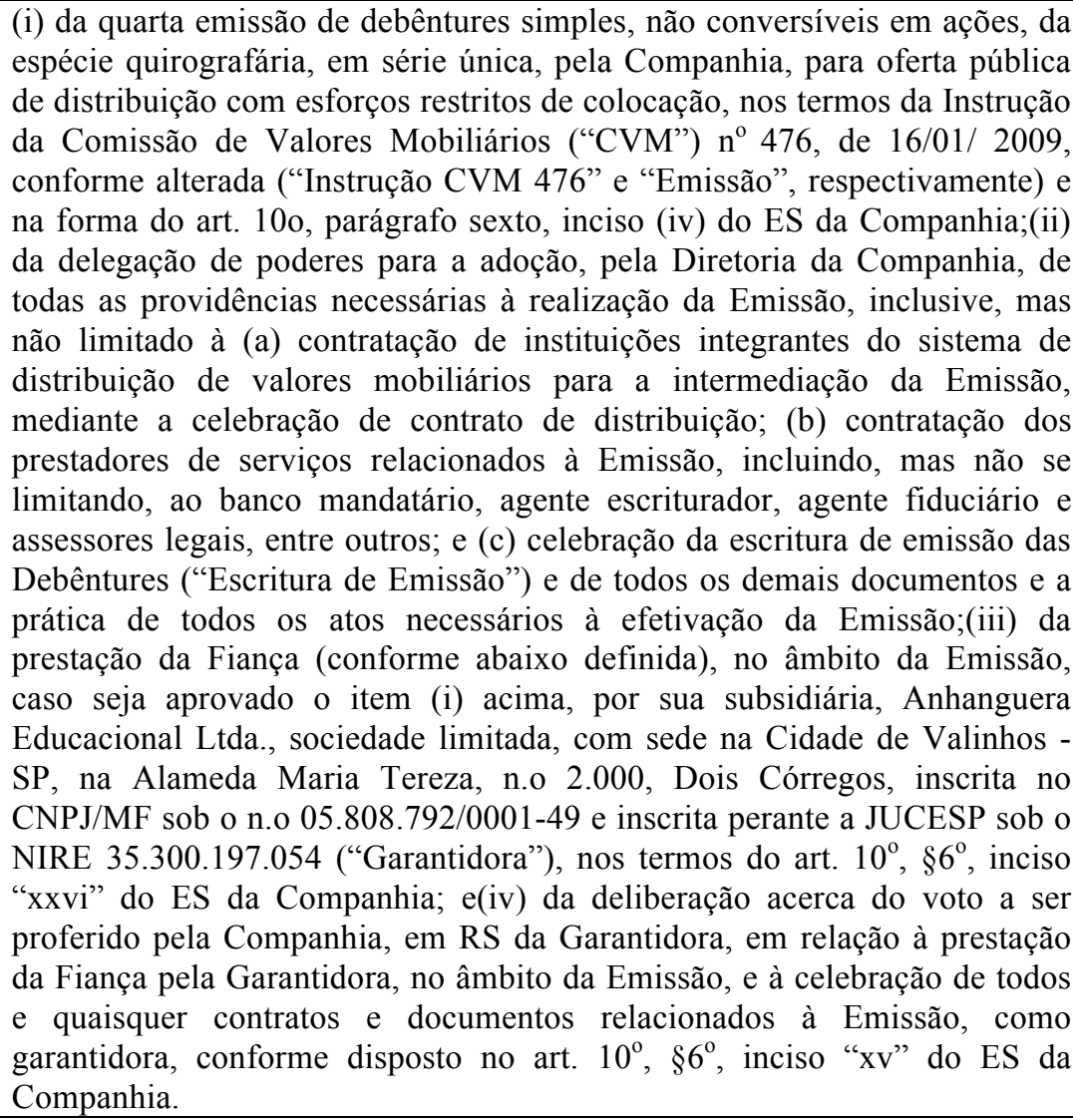 \\
\hline 154 & $05 / 10 / 2011$ & $\mathrm{RCA}$ & $\begin{array}{l}\text { (i) Cancelamento do 2o Programa de Outorga de Ações da Companhia;(ii) } \\
\text { Renumeração do 3o Programa de Outorga de Ações, em função do } \\
\text { cancelamento do 2o Programa de Outorga da Companhia; e(iii) Autorização } \\
\text { para a Diretoria da Companhia tomar todas as medidas necessárias para } \\
\text { cancelar o 2o Programa de Outorga e renumerar o 3o Programa de Outorga, } \\
\text { caso seja aprovado os itens (i) e (ii) acima. }\end{array}$ \\
\hline 155 & $\begin{array}{l}\text { 07/10/2011, } \\
\text { às } 10 \mathrm{~h}\end{array}$ & $\mathrm{RCA}$ & $\begin{array}{l}\text { (i) Deliberar acerca da abertura, encerramento e modificações em filiais da } \\
\text { Companhia e de suas subsidiárias; (ii) Deliberar acerca da aceitação da } \\
\text { renúncia do Sr. Alessandro Tomazela do cargo de membro do Comitê de } \\
\text { Auditoria da Companhia e eleger seu substituto;(iii) Deliberar acerca da } \\
\text { doação, pela subsidiária da Companhia, Anhanguera Educacional Ltda., em } \\
\text { favor da Prefeitura Municipal de São José dos Campos/SP, de uma faixa de } \\
\text { terras do imóvel objeto da matrícula no. 199.096 do 1o Cartório de Registro } \\
\text { de Imóveis de São José dos Campos/SP; (iv) Deliberar acerca de voto } \\
\text { favorável a ser proferido em RS da subsidiária Anhanguera Educacional } \\
\text { Ltda. com relação às matérias deliberadas e que forem aplicáveis à referida } \\
\text { subsidiária. }\end{array}$ \\
\hline 156 & $\begin{array}{l}07 / 10 / 2011 \\
\text { às } 11 \mathrm{~h}\end{array}$ & $\mathrm{RCA}$ & $\begin{array}{l}\text { (i) Criação do 3o Programa de Outorga de Ações da Anhanguera } \\
\text { Educacional Participações S.A., no contexto do Plano de Opção de Compra } \\
\text { de Ações aprovado na AGE da Companhia realizada em 30/04/2010, com a } \\
\text { eleição dos respectivos beneficiários e definição do número de Ações que } \\
\text { poderão ser adquiridas por cada um deles;(ii) Definição do preço de } \\
\text { exercício das opções e as condições de seu pagamento;(iii) Definição dos } \\
\text { prazos e condições de exercício das opções;(iv) Autorização para a } \\
\text { Diretoria efetuar as outorgas de opção de compra de ações aos beneficiários. }\end{array}$ \\
\hline
\end{tabular}




\begin{tabular}{|c|c|c|c|}
\hline & Data & Tipo & Ordem do Dia/ Conteúdo \\
\hline 157 & $24 / 10 / 2011$ & $\mathrm{RCA}$ & $\begin{array}{l}\text { Apreciar e deliberar a respeito da proposta da administração de resgate } \\
\text { antecipado compulsório das debêntures da 1a série da 3a Emissão Pública } \\
\text { de Debêntures Simples, Não Conversíveis em Ações, da Espécie } \\
\text { Quirografária com Garantia Fidejussória da Companhia. }\end{array}$ \\
\hline 158 & $31 / 10 / 2011$ & $\mathrm{RCA}$ & $\begin{array}{l}\text { (i) Deliberar acerca da aceitação da carta de renúncia apresentada pelo Sr. } \\
\text { Alexandre Silveira Dias ao cargo de Diretor Presidente da Companhia e } \\
\text { demais cargos exercidos nas subsidiárias da Companhia e eleição de seu } \\
\text { substituto; (ii) Deliberar acerca da aceitação da carta de renúncia } \\
\text { apresentada pelo Sr. Ricardo Leonel Scavazza ao cargo de Diretor Vice } \\
\text { Presidente Financeiro da Companhia e de suas subsidiárias e eleição de seu } \\
\text { substituto; (iii) Deliberar acerca da abertura, encerramento e mudança de } \\
\text { filiais da Companhia e/ou de suas subsidiárias; (iv) Deliberar acerca da } \\
\text { ratificação de voto favorável proferido em RS de suas subsidiárias para } \\
\text { aumento de capital decorrente de integralização de adiantamentos para } \\
\text { futuro aumento de capital (AFACs); (v) Deliberar acerca de voto a ser } \\
\text { proferido em RS de suas subsidiárias em função das aprovações ora } \\
\text { tratadas. }\end{array}$ \\
\hline 159 & $11 / 11 / 2011$ & $\mathrm{RCA}$ & $\begin{array}{l}\text { (i) Apresentação e deliberação dos resultados e informações financeiras } \\
\text { trimestrais (ITR) do trimestre encerrado em 30/09/2011. }\end{array}$ \\
\hline 160 & $\begin{array}{c}12 / 03 / 2010 \\
\text { às } 11 \mathrm{~h}\end{array}$ & $\mathrm{RCF}$ & $\begin{array}{l}\text { Acompanhar a RCA de } 12 / 03 / 2010 \text {, examinar as DFs, Relatório da } \\
\text { Administração, proposta de orçamento de capital, destinação do lucro } \\
\text { líquido relativo ao exercício social findo em } 31 / 12 / 2009 \text { e emitir o Parecer } \\
\text { do CF a esse respeito. }\end{array}$ \\
\hline 161 & $\begin{array}{c}\text { 14/09/2010, } \\
\text { às } 11 \mathrm{~h}\end{array}$ & $\mathrm{RCF}$ & $\begin{array}{l}\text { Opinar sobre a Proposta da Administração da Incorporação pela Companhia } \\
\text { da sua Controlada LFG Business, Edições Participações Ltda. nos termos } \\
\text { do Protocolo e Justificação de Incorporação. }\end{array}$ \\
\hline 162 & $25 / 03 / 2011$ & $\mathrm{RCF}$ & $\begin{array}{l}\text { Aprovação do Parecer do Conselho Fiscal que examinou o Relatório da } \\
\text { Administração, as DFs referentes ao exercício social encerrado em } \\
\text { 31/12/2010, o Orçamento de Capital para o exercício de } 2011 \text { e a Proposta } \\
\text { de Destinação do Resultado. }\end{array}$ \\
\hline 163 & $08 / 03 / 2007$ & Prospecto & $\begin{array}{l}\text { Prospecto Definitivo de Distribuição Pública Primária e Secundária de } \\
\text { Certificados de Depósitos de Ações ("Units") de 08/03/2007. } \\
\text { Conteúdo: informações sobre a oferta (preços, prazos, destinação dos } \\
\text { recursos, instituições participantes) e sobre a Companhia (estimativas e } \\
\text { declarações futuras, informações financeiras e operacionais, pontos fortes, } \\
\text { estratégias, fatores de risco, estrutura societária e capital social) }\end{array}$ \\
\hline 164 & $22 / 04 / 2008$ & Prospecto & $\begin{array}{l}\text { Prospecto Definitivo de Distribuição Pública Primária de Certificados de } \\
\text { Depósitos de Ações ("Units") de } 22 / 04 / 2008 \text {. } \\
\text { Conteúdo: informações sobre a oferta (preços, prazos, destinação dos } \\
\text { recursos, instituições participantes) e sobre a Companhia (estimativas e } \\
\text { declarações futuras, informações financeiras e operacionais, pontos fortes, } \\
\text { estratégias, fatores de risco, estrutura societária e capital social) }\end{array}$ \\
\hline 165 & $08 / 12 / 2009$ & Prospecto & $\begin{array}{l}\text { Prospecto Definitivo de Oferta Pública de Distribuição Secundária de } \\
\text { Certificados de Depósitos de Ações ("Units") de 08/12/2009. } \\
\text { Conteúdo: informações sobre a oferta (preços, prazos, destinação dos } \\
\text { recursos, instituições participantes) e sobre a Companhia (estimativas e } \\
\text { declarações futuras, informações financeiras e operacionais, pontos fortes, } \\
\text { estratégias, fatores de risco, estrutura societária e capital social) }\end{array}$ \\
\hline 166 & $09 / 12 / 2010$ & Prospecto & $\begin{array}{l}\text { Prospecto Definitivo de Oferta Pública de Distribuição Primária de Ações } \\
\text { Ordinárias de Emissão de } 09 / 12 / 2010 \text {. } \\
\text { Conteúdo: informações sobre a oferta (preços, prazos, destinação dos } \\
\text { recursos, instituições participantes) e sobre a Companhia (estimativas e } \\
\text { declarações futuras, informações financeiras e operacionais, pontos fortes, } \\
\text { estratégias, fatores de risco, estrutura societária e capital social) }\end{array}$ \\
\hline 167 & $01 / 07 / 2010$ & $\begin{array}{l}\text { Formulário } \\
\text { de } \\
\text { Referencia }\end{array}$ & $\begin{array}{l}\text { Formulário de Referência de } 2010 \text {. } \\
\text { Conteúdo: informações consolidadas sobre: (i) a situação econômico- } \\
\text { financeira daCompanhia (data-base de } 31 / 12 / 2009 \text { e informações sobre os } \\
\text { três últimos exercícios sociais); (ii) os valores mobiliários emitidos pela }\end{array}$ \\
\hline
\end{tabular}




\begin{tabular}{|c|c|c|c|}
\hline & Data & Tipo & Ordem do Dia/ Conteúdo \\
\hline & & & $\begin{array}{l}\text { Companhia e negociados no mercado; (iii) o histórico da Companhia; (iv) } \\
\text { as atividades da Companhia e de suas subsidiárias e os fatores de risco } \\
\text { envolvidos nas atividades; (v) o grupo econômico de que a Companhia faz } \\
\text { parte; (vi) projeções sobre os negócios da Companhia; (vii) assembléias } \\
\text { gerais, reuniões dos órgãos de administração e informações sobre os } \\
\text { membros da administração da Companhia; (viii) recursos humanos; (ix) } \\
\text { dados sobre os acionistas da Companhia; (x) o capital social da Companhia } \\
\text { e seu controle; e (xi) processos judiciais envolvendo a Companhia. }\end{array}$ \\
\hline 168 & 2011 & $\begin{array}{l}\text { Formulário } \\
\text { de } \\
\text { Referência }\end{array}$ & $\begin{array}{l}\text { Informações consolidadas sobre: (i) a situação econômico-financeira } \\
\text { daCompanhia (data-base de } 31 / 12 / 2010 \text { e informações sobre os três últimos } \\
\text { exercícios sociais); (ii) os valores mobiliários emitidos pela Companhia e } \\
\text { negociados no mercado; (iii) o histórico da Companhia; (iv) as atividades da } \\
\text { Companhia e de suas subsidiárias e os fatores de risco envolvidos nas } \\
\text { atividades; (v) o grupo econômico de que a Companhia faz parte; (vi) } \\
\text { projeções sobre os negócios da Companhia; (vii) assembléias gerais, } \\
\text { reuniões dos órgãos de administração e informações sobre os membros da } \\
\text { administração da Companhia; (viii) recursos humanos; (ix) dados sobre os } \\
\text { acionistas da Companhia; (x) o capital social da Companhia e seu controle; } \\
\text { e (xi) processos judiciais envolvendo a Companhia. }\end{array}$ \\
\hline 169 & 2012 & $\begin{array}{l}\text { Formulário } \\
\text { de } \\
\text { Referência }\end{array}$ & $\begin{array}{l}\text { Informações consolidadas sobre: (i) a situação econômico-financeira } \\
\text { daCompanhia (data-base de } 31 / 12 / 2011 \text { e informações sobre os três últimos } \\
\text { exercícios sociais); (ii) os valores mobiliários emitidos pela Companhia e } \\
\text { negociados no mercado; (iii) o histórico da Companhia; (iv) as atividades da } \\
\text { Companhia e de suas subsidiárias e os fatores de risco envolvidos nas } \\
\text { atividades; (v) o grupo econômico de que a Companhia faz parte; (vi) } \\
\text { projeções sobre os negócios da Companhia; (vii) assembléias gerais, } \\
\text { reuniões dos órgãos de administração e informações sobre os membros da } \\
\text { administração da Companhia; (viii) recursos humanos; (ix) dados sobre os } \\
\text { acionistas da Companhia; (x) o capital social da Companhia e seu controle; } \\
\text { e (xi) processos judiciais envolvendo a Companhia. }\end{array}$ \\
\hline 170 & $31 / 12 / 2008$ & IAN & $\begin{array}{l}\text { Informações consolidadas sobre: (i) os valores mobiliários emitidos pela } \\
\text { Companhia e negociados no mercado; (i) o histórico da Companhia; (iii) as } \\
\text { atividades da Companhia e de suas subsidiárias e os fatores de risco } \\
\text { envolvidos nas atividades; (iv) o grupo econômico de que a Companhia faz } \\
\text { parte; (v) projeções sobre os negócios da Companhia; (vi) assembléias } \\
\text { gerais, reuniões dos órgãos de administração e informações sobre os } \\
\text { membros da administração da Companhia; (vii) recursos humanos; (viii) } \\
\text { dados sobre os acionistas da Companhia; (ix) o capital social da Companhia } \\
\text { e seu controle; (x) o ES e Acordo de Acionistas; e (xi) processos judiciais } \\
\text { envolvendo a Companhia. }\end{array}$ \\
\hline 171 & $30 / 09 / 2010$ & ITR & $\begin{array}{l}\text { Informações consolidadas sobre a situação econômico-financeira } \\
\text { daCompanhia no } 3^{\circ} \text { trimestre de } 2010 \text {, notas explicativas dos } \\
\text { administradores, comentários sobre o desempenho no trimestre, projeções } \\
\text { empresariais e relatório dos auditores independentes. }\end{array}$ \\
\hline 172 & $31 / 03 / 2012$ & $\begin{array}{c}\text { Relatório } \\
\text { Financeiro }\end{array}$ & $\begin{array}{l}\text { Formulário Financeiro do } 4^{\circ} \text { Trimestre de } 2011 \text {. } \\
\text { Conteúdo: informações sobre a situação econômico-financeira } \\
\text { daCompanhia no } 4^{\circ} \text { trimestre de } 2011 \text {, contendo mensagem da } \\
\text { administração para o mercado, destaques financeiros do período, } \\
\text { desempenho econômico-financeiro da empresa, dados sobre contas a } \\
\text { receber, fluxo de caixa, endividamento e mercado de capitais. }\end{array}$ \\
\hline 173 & 2010 & $\begin{array}{l}\text { Relatório } \\
\text { de Resp. } \\
\text { Social }\end{array}$ & $\begin{array}{l}\text { Informações sobre a empresa (missão, visão, valores, perfil, governança } \\
\text { corporativa, estratégia, perspectivas, ética, transparência, visão de negócios, } \\
\text { gestão de riscos, gestão de imagem, reputação e desempenho econômico- } \\
\text { financeiro) e ações de responsabilidade social (projetos, desempenho } \\
\text { ambiental). }\end{array}$ \\
\hline 174 & 2011 & $\begin{array}{l}\text { Relatório } \\
\text { de Resp. } \\
\text { Social }\end{array}$ & $\begin{array}{l}\text { Informações sobre a empresa (missão, visão, valores, perfil, governança } \\
\text { corporativa, estratégia, perspectivas, ética, transparência, visão de negócios, } \\
\text { gestão de riscos, gestão de imagem, reputação e desempenho econômico- }\end{array}$ \\
\hline
\end{tabular}




\begin{tabular}{|l|l|l|l|}
\hline & Data & Tipo & \multicolumn{1}{c|}{ Ordem do Dia/ Conteúdo } \\
\hline & & $\begin{array}{l}\text { financeiro) e ações de responsabilidade social (projetos, desempenho } \\
\text { ambiental). }\end{array}$ \\
\hline
\end{tabular}

Fonte: CVM; Anhanguera; MZWEB ${ }^{524}$

${ }^{524}$ Todas as atas de AG, RCA e RCF, o ES, o Fato Relevante, o IAN, o ITR, o Formulário de Referência de 2010 e os Prospectos foram extraídos do site da CVM (http://www.cvm.gov.br). O Relatório de Responsabilidade Social de 2010 foi extraído do site MZWEB (http://www.mzweb.com.br/anhanguera2011/web/arquivos/AE_RelatorioResponsabilidadeSocial2010_FINAL.p df). O Relatório de Responsabilidade Social de 2011 foi extraído do site da Anhanguera - Responsabilidade Social (http://rsocial.anhanguera.com). O Relatório Financeiro do $4^{\circ}$ Trimestre de 2011 e o Relatório de Referência de 2012 foram extraídos do site da Anhanguera - Relações com Investidores (http://www.anhanguera.com/ri). 


\title{
APÊNDICE B - Dispositivos que tratam direta ou indiretamente do direito à educação na Constituição e na ADCT
}

\author{
As referências ao direito à educação encontram-se grifadas nos dispositivos abaixo.
}

\section{Quadro de Dispositivos que tratam direta ou indiretamente do direito à educação na Constituição e na ADCT}

\begin{tabular}{|c|c|}
\hline \multicolumn{2}{|r|}{$\begin{array}{lc}\text { CF/88 } \\
\end{array}$} \\
\hline 1. & $\begin{array}{l}\text { Art. } 5^{\circ} \text {. Todos são iguais perante a lei, sem distinção de qualquer natureza, garantindo-se aos } \\
\text { brasileiros e aos estrangeiros residentes no País a inviolabilidade do direito à vida, à liberdade, à } \\
\text { igualdade, à segurança e à propriedade, nos termos seguintes: } \\
\text { IV - é livre a manifestação do pensamento, sendo vedado o anonimato; } \\
\text { IX - é livre a expressão da atividade intelectual, artística, científica e de comunicação, } \\
\text { independentemente de censura ou licença; } \\
\text { XIII - é livre o exercício de qualquer trabalho, ofício ou profissão, atendidas as qualificações } \\
\text { profissionais que a lei estabelecer; } \\
\text { XIV - é assegurado a todos o acesso à informação e resguardado o sigilo da fonte, quando } \\
\text { necessário ao exercício profissional; } \\
\text { XXXIII - todos têm direito a receber dos órgãos públicos informações de seu interesse particular, } \\
\text { ou de interesse coletivo ou geral, que serão prestadas no prazo da lei, sob pena de responsabilidade, } \\
\text { ressalvadas aquelas cujo sigilo seja imprescindível à segurança da sociedade e do Estado; } \\
\text { LXIII - o preso será informado de seus direitos, entre os quais o de permanecer calado, sendo-lhe } \\
\text { assegurada a assistência da família e de advogado; } \\
\text { LXXIII - qualquer cidadão é parte legítima para propor ação popular que vise a anular ato lesivo ao } \\
\text { patrimônio público ou de entidade de que o Estado participe, à moralidade administrativa, ao meio } \\
\text { ambiente e ao patrimônio histórico e cultural, ficando o autor, salvo comprovada má-fé, isento de } \\
\text { custas judiciais e do ônus da sucumbência; } \\
\text { XXIX - a lei assegurará aos autores de inventos industriais privilégio temporário para sua } \\
\text { utilização, bem como proteção às criações industriais, à propriedade das marcas, aos nomes de } \\
\text { empresas e a outros signos distintivos, tendo em vista o interesse social e o desenvolvimento } \\
\text { tecnológico e econômico do País; }\end{array}$ \\
\hline 2. & $\begin{array}{l}\text { Art. } 6^{\circ} \text {. São direitos sociais a educação, a saúde, a alimentação, o trabalho, a moradia, o lazer, a } \\
\text { segurança, a previdência social, a proteção à maternidade e à infância, a assistência aos } \\
\text { desamparados, na forma desta Constituição. (Redação dada pela Emenda Constitucional } n^{\circ} 64 \text {, de } \\
\text { 2010) }\end{array}$ \\
\hline 3. & $\begin{array}{l}\text { Art. } 7^{\circ} \text {. São direitos dos trabalhadores urbanos e rurais, além de outros que visem à melhoria de sua } \\
\text { condição social: } \\
\text { IV - salário mínimo , fixado em lei, nacionalmente unificado, capaz de atender a suas necessidades } \\
\text { vitais básicas e às de sua família com moradia, alimentação, educação, saúde, lazer, vestuário, } \\
\text { higiene, transporte e previdência social, com reajustes periódicos que lhe preservem o poder } \\
\text { aquisitivo, sendo vedada sua vinculação para qualquer fim; } \\
\text { XXV - assistência gratuita aos filhos e dependentes desde o nascimento até } 5 \text { (cinco) anos de idade } \\
\text { em creches e pré-escolas; (Redação dada pela Emenda Constitucional no } 53 \text {, de 2006) }\end{array}$ \\
\hline 4 & $\begin{array}{l}\text { Art. 21. Compete à União: } \\
\text { XXIII - explorar os serviços e instalações nucleares de qualquer natureza e exercer monopólio } \\
\text { estatal sobre a pesquisa, a lavra, o enriquecimento e reprocessamento, a industrialização e o } \\
\text { comércio de minérios nucleares e seus derivados, atendidos os seguintes princípios e condições: } \\
\text { b) sob regime de permissão, são autorizadas a comercialização e a utilização de radioisótopos para } \\
\text { a pesquisa e usos médicos, agrícolas e industriais; (Redação dada pela Emenda Constitucional n } \\
\text { 49, de } 2006 \text { ) }\end{array}$ \\
\hline & \\
\hline
\end{tabular}




\begin{tabular}{|c|c|}
\hline 6. & $\begin{array}{l}\text { Art. 23. É competência comum da União, dos Estados, do Distrito Federal e dos Municípios: } \\
\text { III - proteger os documentos, as obras e outros bens de valor histórico, artístico e cultural, os } \\
\text { monumentos, as paisagens naturais notáveis e os sítios arqueológicos; } \\
\text { V - proporcionar os meios de acesso à cultura, à educação e à ciência; } \\
\text { XI - registrar, acompanhar e fiscalizar as concessões de direitos de pesquisa e exploração de } \\
\text { recursos hídricos e minerais em seus territórios; } \\
\text { XII - estabelecer e implantar política de educação para a segurança do trânsito. }\end{array}$ \\
\hline 7. & $\begin{array}{l}\text { Art. 24. Compete à União, aos Estados e ao Distrito Federal legislar concorrentemente sobre: } \\
\text { IX - educação, cultura, ensino e desporto; }\end{array}$ \\
\hline 8. & $\begin{array}{l}\text { Art. 30. Compete aos Municípios: } \\
\text { VI - manter, com a cooperação técnica e financeira da União e do Estado, programas de educação } \\
\text { infantil e de ensino fundamental; (Redação dada pela Emenda Constitucional no } 53 \text {, de 2006) } \\
\text { IX - promover a proteção do patrimônio histórico-cultural local, observada a legislação e a ação } \\
\text { fiscalizadora federal e estadual. }\end{array}$ \\
\hline 9. & $\begin{array}{l}\text { Art. 34. A União não intervirá nos Estados nem no Distrito Federal, exceto para: } \\
\text { VII - assegurar a observância dos seguintes princípios constitucionais: } \\
\text { e) aplicação do mínimo exigido da receita resultante de impostos estaduais, compreendida a } \\
\text { proveniente de transferências, na manutenção e desenvolvimento do ensino e nas ações e serviços } \\
\text { públicos de saúde. (Redação dada pela Emenda Constitucional no } 29 \text {, de 2000) }\end{array}$ \\
\hline 10 . & $\begin{array}{l}\text { Art. 35. O Estado não intervirá em seus Municípios, nem a União nos Municípios localizados em } \\
\text { Território Federal, exceto quando: } \\
\text { III - não tiver sido aplicado o mínimo exigido da receita municipal na manutenção e } \\
\text { desenvolvimento do ensino e nas ações e serviços públicos de saúde; (Redação dada pela Emenda } \\
\text { Constitucional no } 29 \text {, de 2000) }\end{array}$ \\
\hline 11. & 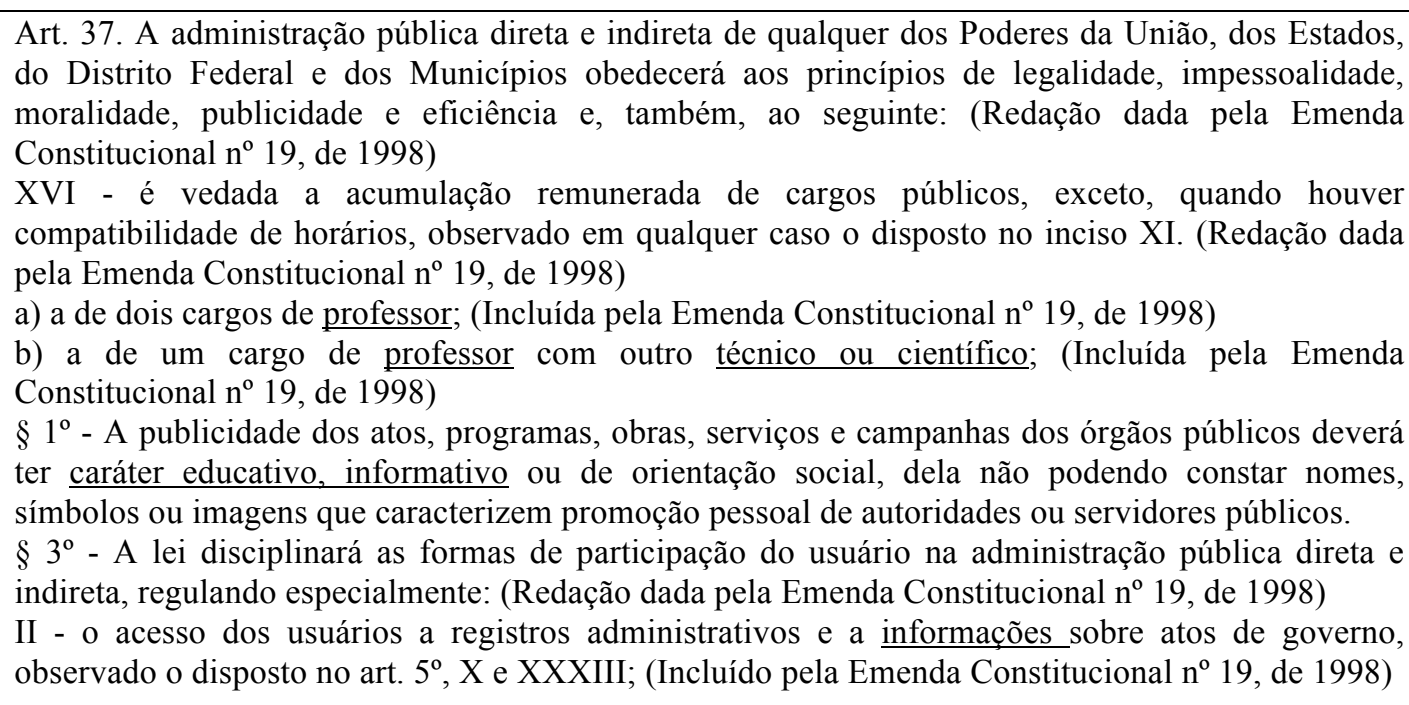 \\
\hline 12 . & $\begin{array}{l}\text { Art. 39. A União, os Estados, o Distrito Federal e os Municípios instituirão conselho de política de } \\
\text { administração e remuneração de pessoal, integrado por servidores designados pelos respectivos } \\
\text { Poderes. (Redação dada pela Emenda Constitucional no } 19 \text {, de 1998) } \\
\S 2^{\circ} \text { - A União, os Estados e o Distrito Federal manterão escolas de governo para a formação e o } \\
\text { aperfeiçoamento dos servidores públicos, constituindo-se a participação nos cursos um dos } \\
\text { requisitos para a promoção na carreira, facultada, para isso, a celebração de convênios ou contratos } \\
\text { entre os entes federados. (Redação dada pela Emenda Constitucional no } 19 \text {, de 1998) }\end{array}$ \\
\hline 13. & $\begin{array}{l}\text { Art. 40. A } \\
\text { Município }\end{array}$ \\
\hline
\end{tabular}




\begin{tabular}{|c|c|}
\hline & $\begin{array}{l}\text { contributivo e solidário, mediante contribuição do respectivo ente público, dos servidores ativos e } \\
\text { inativos e dos pensionistas, observados critérios que preservem o equilíbrio financeiro e atuarial e o } \\
\text { disposto neste artigo. (Redação dada pela Emenda Constitucional no } 41,19.12 .2003 \text { ) } \\
\S 5^{\circ} \text { - Os requisitos de idade e de tempo de contribuição serão reduzidos em cinco anos, em relação } \\
\text { ao disposto no } \S 1^{\circ} \text {, III, "a", para o professor que comprove exclusivamente tempo de efetivo } \\
\text { exercício das funções de magistério na educação infantil e no ensino fundamental e médio. } \\
\left.\text { (Redação dada pela Emenda Constitucional } n^{\circ} 20 \text {, de } 15 / 12 / 98\right)\end{array}$ \\
\hline 14. & $\begin{array}{l}\text { Art. 93. Lei complementar, de iniciativa do Supremo Tribunal Federal, disporá sobre o Estatuto da } \\
\text { Magistratura, observados os seguintes princípios: } \\
\text { IV - previsão de cursos oficiais de preparação, aperfeiçoamento e promoção de magistrados, } \\
\text { constituindo etapa obrigatória do processo de vitaliciamento a participação em curso oficial ou } \\
\text { reconhecido por escola nacional de formação e aperfeiçoamento de magistrados; (Redação dada } \\
\text { pela Emenda Constitucional no } n^{\circ} \text {, de 2004) }\end{array}$ \\
\hline 15. & 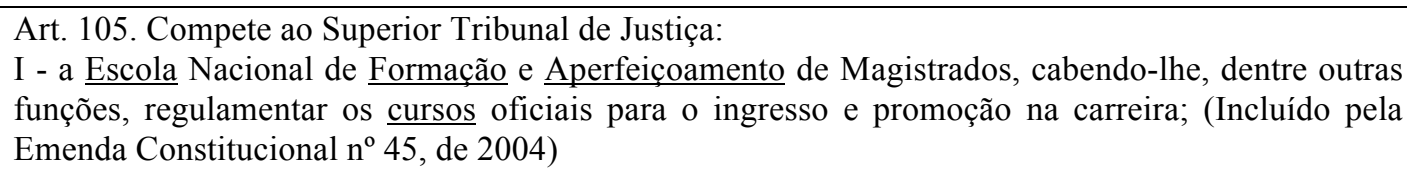 \\
\hline 16. & $\begin{array}{l}\text { Art. 111-A. O Tribunal Superior do Trabalho compor-se-á de vinte e sete Ministros, escolhidos } \\
\text { dentre brasileiros com mais de trinta e cinco e menos de sessenta e cinco anos, nomeados pelo } \\
\text { Presidente da República após aprovação pela maioria absoluta do Senado Federal, sendo: (Incluído } \\
\text { pela Emenda Constitucional no } 45 \text {, de } 2004 \text { ) } \\
\text { I - a Escola Nacional de Formação e Aperfeiçoamento de Magistrados do Trabalho, cabendo-lhe, } \\
\text { dentre outras funções, regulamentar os cursos oficiais para o ingresso e promoção na carreira; } \\
\text { (Incluído pela Emenda Constitucional n }{ }^{\circ} \underline{45 \text {, de } 2004 \text { ) }}\end{array}$ \\
\hline 17. & $\begin{array}{l}\text { Art. 150. Sem prejuízo de outras garantias asseguradas ao contribuinte, é vedado à União, aos } \\
\text { Estados, ao Distrito Federal e aos Municípios: } \\
\text { VI - instituir impostos sobre: } \\
\text { c) patrimônio, renda ou serviços dos partidos políticos, inclusive suas fundações, das entidades } \\
\text { sindicais dos trabalhadores, das instituições de educação e de assistência social, sem fins lucrativos, } \\
\text { atendidos os requisitos da lei; }\end{array}$ \\
\hline 18. & $\begin{array}{l}\text { Art. 167. São vedados: } \\
\text { IV - a vinculação de receita de impostos a órgão, fundo ou despesa, ressalvadas a repartição do } \\
\text { produto da arrecadação dos impostos a que se referem os arts. } 158 \text { e } 159 \text {, a destinação de recursos } \\
\text { para as ações e serviços públicos de saúde, para manutenção e desenvolvimento do ensino e para } \\
\text { realização de atividades da administração tributária, como determinado, respectivamente, pelos } \\
\text { arts. } 198, \S 2^{\circ}, 212 \text { e } 37 \text {, XXII, e a prestação de garantias às operações de crédito por antecipação } \\
\text { de receita, previstas no art. } 165, \S 8^{\circ} \text {, bem como o disposto no } \S 4^{\circ} \text { deste artigo; (Redação dada pela } \\
\text { Emenda Constitucional } n^{\circ} 42 \text {, de } 19.12 .2003 \text { ) }\end{array}$ \\
\hline 19. & $\begin{array}{l}\text { Art. 187. A política agrícola será planejada e executada na forma da lei, com a participação efetiva } \\
\text { do setor de produção, envolvendo produtores e trabalhadores rurais, bem como dos setores de } \\
\text { comercialização, de armazenamento e de transportes, levando em conta, especialmente: } \\
\text { III - o incentivo à pesquisa e à tecnologia; } \\
\text { IV - a assistência técnica e extensão rural; }\end{array}$ \\
\hline 20. & $\begin{array}{l}\text { Art. 199. A assistência à saúde é livre à iniciativa privada. } \\
\S 4^{\mathrm{o}} \text { - A lei disporá sobre as condições e os requisitos que facilitem a remoção de órgãos, tecidos e } \\
\text { substâncias humanas para fins de transplante, pesquisa e tratamento, bem como a coleta, } \\
\text { processamento e transfusão de sangue e seus derivados, sendo vedado todo tipo de comercialização. }\end{array}$ \\
\hline 21. & $\begin{array}{l}\text { recursos humanos na área de saúde; } \\
\text { a de atuação o desenvolvimento científico e tecnológico; }\end{array}$ \\
\hline
\end{tabular}




\begin{tabular}{|c|c|}
\hline 22. & $\begin{array}{l}\text { Art. 201. A previdência social será organizada sob a forma de regime geral, de caráter contributivo } \\
\text { e de filiação obrigatória, observados critérios que preservem o equilíbrio financeiro e atuarial, e } \\
\text { atenderá, nos termos da lei, a: (Redação dada pela Emenda Constitucional n }{ }^{\circ} 20 \text {, de 1998) } \\
\S 8^{\circ} \text { - Os requisitos a que se refere o inciso I do parágrafo anterior serão reduzidos em cinco anos, } \\
\text { para o professor que comprove exclusivamente tempo de efetivo exercício das funções de } \\
\text { magistério na educação infantil e no ensino fundamental e médio. (Redação dada pela Emenda } \\
\text { Constitucional no } \mathrm{n}^{\circ} 20 \text {, de 1998) }\end{array}$ \\
\hline 23. & $\begin{array}{l}\text { Art. 205. A educação, direito de todos e dever do Estado e da família, será promovida e incentivada } \\
\text { com a colaboração da sociedade, visando ao pleno desenvolvimento da pessoa, seu preparo para o } \\
\text { exercício da cidadania e sua qualificação para o trabalho. }\end{array}$ \\
\hline 24. & 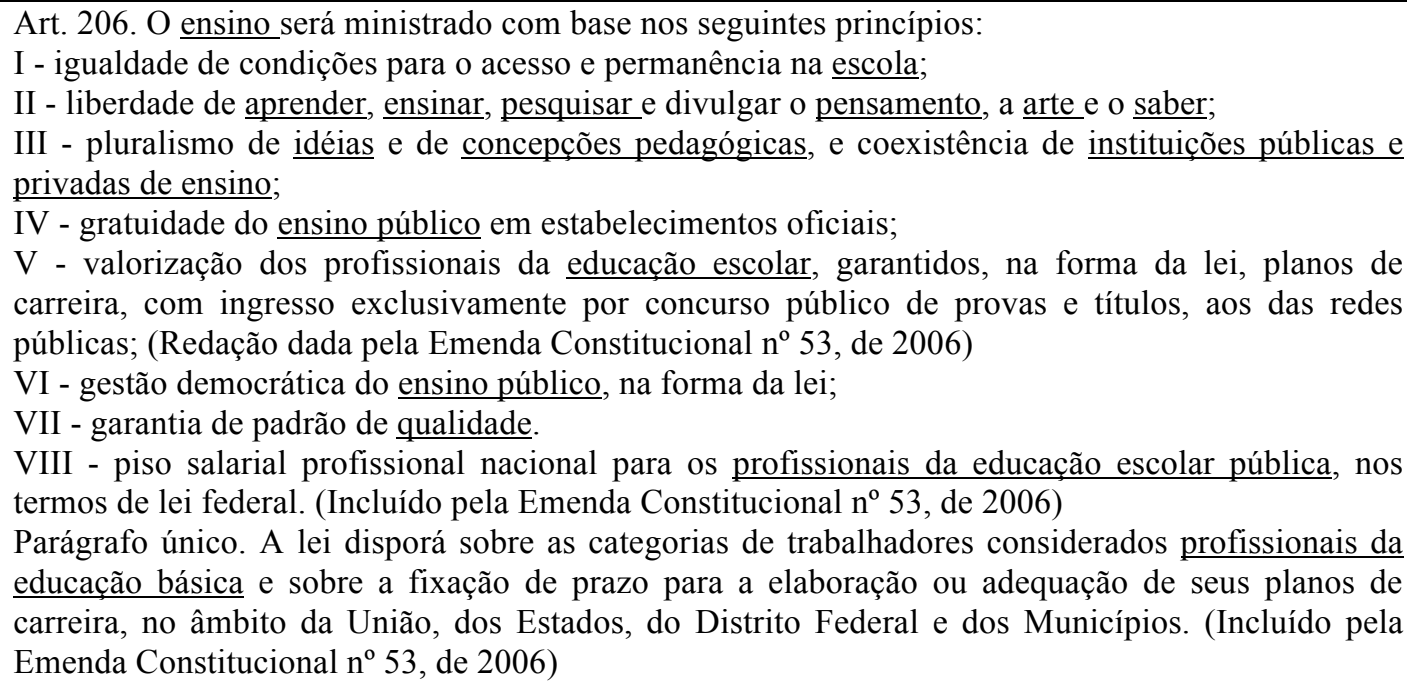 \\
\hline 25 & $\begin{array}{l}\text { Art. 207. As universidades gozam de autonomia didático-científica, administrativa e de gestão } \\
\text { financeira e patrimonial, e obedecerão ao princípio de indissociabilidade entre ensino, pesquisa e } \\
\text { extensão. } \\
\S 1^{\circ} \text { - É facultado às universidades admitir professores, técnicos e cientistas estrangeiros, na forma } \\
\text { da lei. (Incluído pela Emenda Constitucional } n^{\circ} 11 \text {, de } 1996 \text { ) } \\
\S 2^{\circ} \text { - O disposto neste artigo aplica-se às instituições de pesquisa científica e tecnológica. (Incluído } \\
\text { pela Emenda Constitucional } n^{\circ} 11 \text {, de } 1996 \text { ) }\end{array}$ \\
\hline 26. & $\begin{array}{l}\text { Art. 208. O dever do Estado com a educação será efetivado mediante a garantia de: } \\
\text { I - educação básica obrigatória e gratuita dos } 4 \text { (quatro) aos } 17 \text { (dezessete) anos de idade, } \\
\text { assegurada inclusive sua oferta gratuita para todos os que a ela não tiveram acesso na idade própria; } \\
\text { (Redação dada pela Emenda Constitucional } n^{\circ} 59 \text {, de } 2009 \text { ) } \\
\text { II - progressiva universalização do ensino médio gratuito; (Redação dada pela Emenda } \\
\text { Constitucional n } n^{\circ} 14 \text {, de 1996) } \\
\text { III - atendimento educacional especializado aos portadores de deficiência, preferencialmente na } \\
\text { rede regular de ensino; } \\
\text { IV - educação infantil, em creche e pré-escola, às crianças até } 5 \text { (cinco) anos de idade; (Redação } \\
\text { dada pela Emenda Constitucional no } 53 \text {, de } 2006 \text { ) } \\
\text { V - acesso aos níveis mais elevados do ensino, da pesquisa e da criação artística, segundo a } \\
\text { capacidade de cada um; } \\
\text { VI - oferta de ensino noturno regular, adequado às condições do educando; } \\
\text { VII - atendimento ao educando, em todas as etapas da educação básica, por meio de programas } \\
\text { suplementares de material didático-escolar, transporte, alimentação e assistência à saúde. (Redação } \\
\text { dada pela Emenda Constitucional no } 59 \text {, de } 2009 \text { ) } \\
\S 1^{\circ}-\text { O acesso ao ensino obrigatório e gratuito é direito público subjetivo. } \\
\S 2^{\circ} \text { - O não-oferecimento do ensino obrigatório pelo Poder Público, ou sua oferta irregular, } \\
\text { importa responsabilidade da autoridade competente. }\end{array}$ \\
\hline
\end{tabular}




\begin{tabular}{|c|c|}
\hline & $\begin{array}{l}\S 3^{\circ} \text { - Compete ao Poder Público recensear os educandos no ensino fundamental, fazer-lhes a } \\
\text { chamada e zelar, junto aos pais ou responsáveis, pela freqüência à escola. }\end{array}$ \\
\hline 27. & $\begin{array}{l}\text { Art. } 209 . \mathrm{O} \text { ensino é livre à iniciativa privada, atendidas as seguintes condições: } \\
\text { I - cumprimento das normas gerais da educação nacional; } \\
\text { II - autorização e avaliação de qualidade pelo Poder Público. }\end{array}$ \\
\hline 28. & $\begin{array}{l}\text { Art. 210. Serão fixados conteúdos mínimos para o ensino fundamental, de maneira a assegurar } \\
\text { formação básica comum e respeito aos valores culturais e artísticos, nacionais e regionais. } \\
\S 1^{\circ}-\mathrm{O} \text { ensino religioso, de matrícula facultativa, constituirá disciplina dos horários normais das } \\
\text { escolas públicas de ensino fundamental. } \\
\S 2^{\circ}-\mathrm{O} \text { ensino fundamental regular será ministrado em língua portuguesa, assegurada às } \\
\text { comunidades indígenas também a utilização de suas línguas maternas e processos próprios de } \\
\text { aprendizagem. }\end{array}$ \\
\hline 29. & 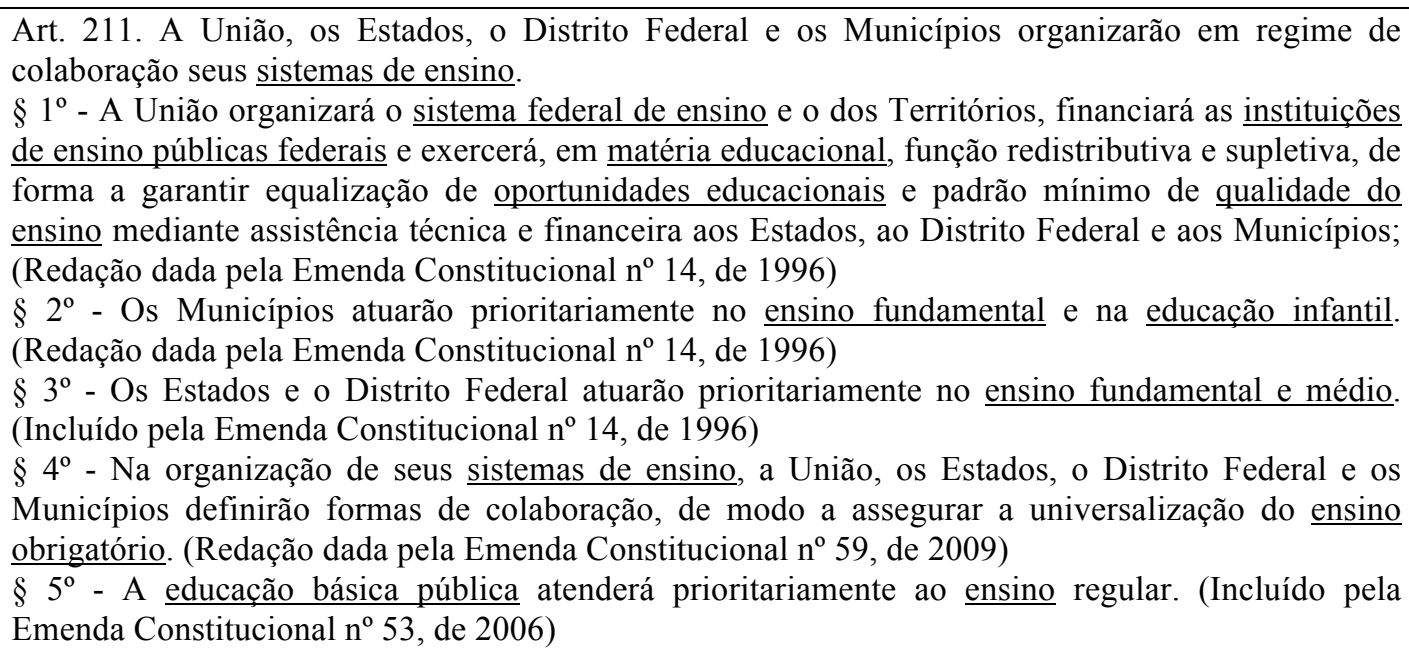 \\
\hline 30. & 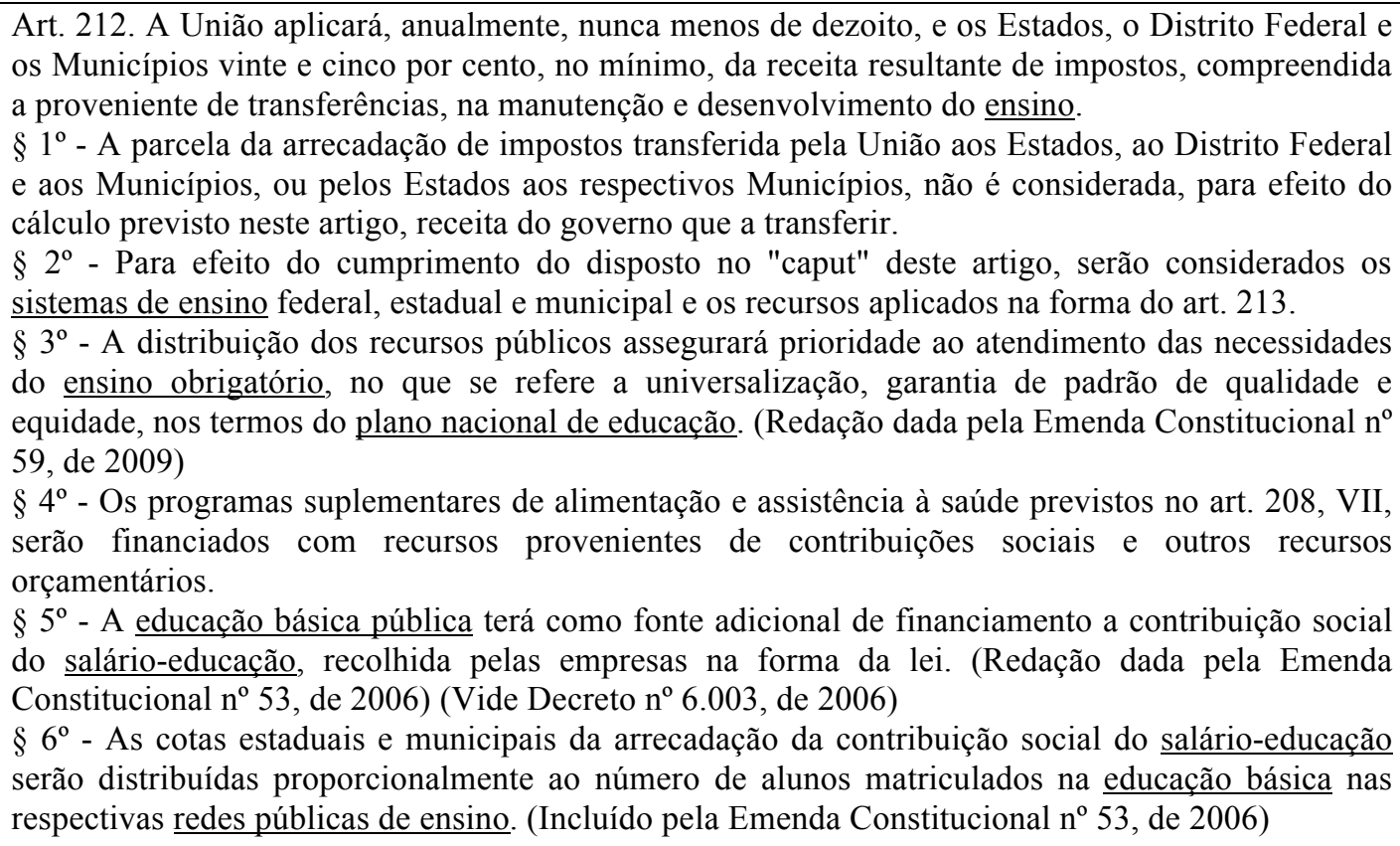 \\
\hline 31. & $\begin{array}{l}\text { Art. 213. Os recursos públicos serão destinados às escolas públicas, podendo ser dirigidos a escolas } \\
\text { comunitárias, confessionais ou filantrópicas, definidas em lei, que: } \\
\text { I - comprovem finalidade não-lucrativa e apliquem seus excedentes financeiros em educação; } \\
\text { II - assegurem a destinação de seu patrimônio a outra escola comunitária, filantrópica ou }\end{array}$ \\
\hline
\end{tabular}




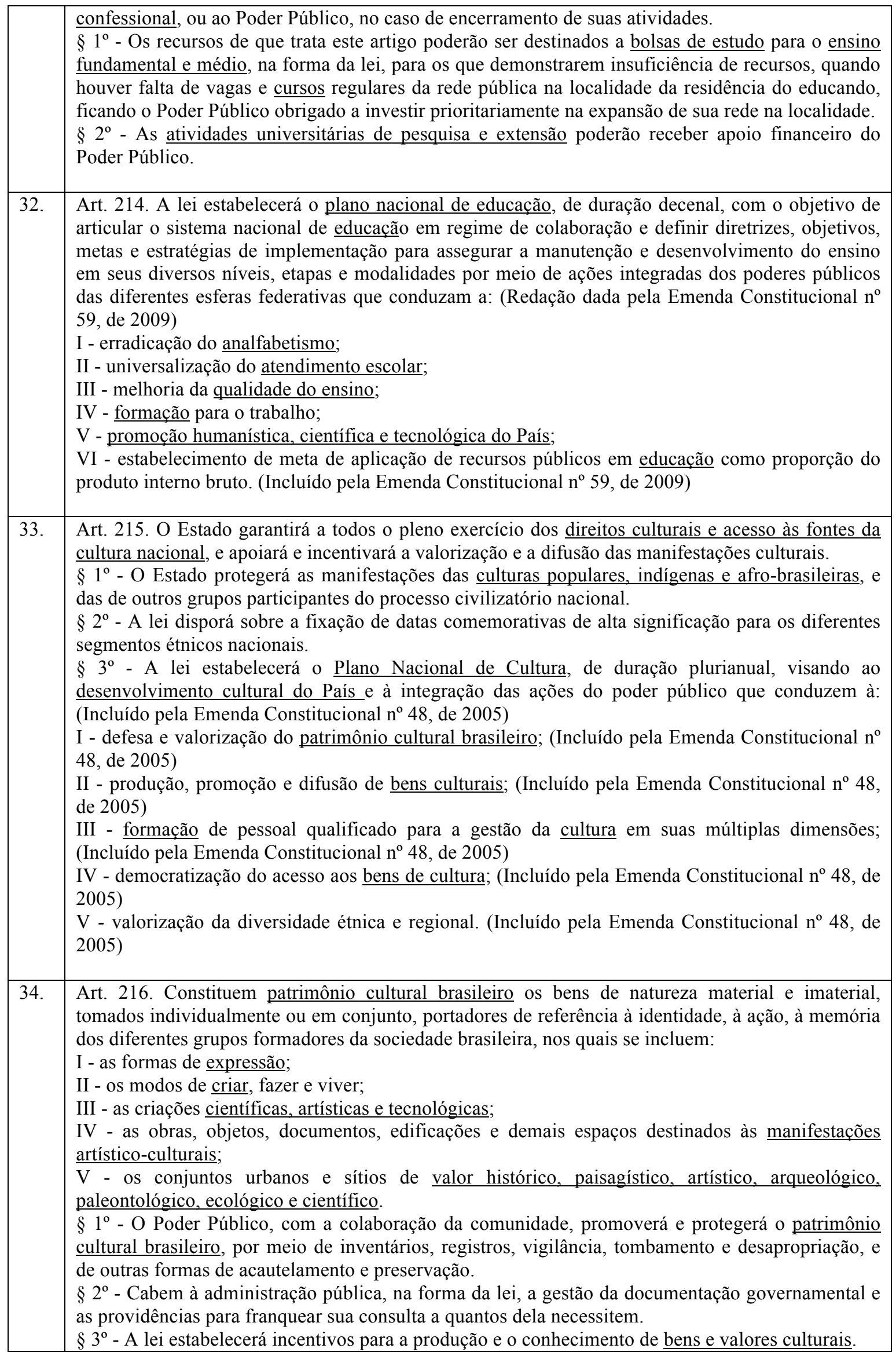




\begin{tabular}{|c|c|}
\hline & $\begin{array}{l}\S 4^{\circ} \text { - Os danos e ameaças ao patrimônio cultural serão punidos, na forma da lei. } \\
\S 5^{\circ} \text { - Ficam tombados todos os documentos e os sítios detentores de reminiscências históricas dos } \\
\text { antigos quilombos. } \\
\S 6^{\circ} \text { - É facultado aos Estados e ao Distrito Federal vincular a fundo estadual de fomento à cultura } \\
\text { até cinco décimos por cento de sua receita tributária líquida, para o financiamento de programas e } \\
\text { projetos culturais, vedada a aplicação desses recursos no pagamento de: (Incluído pela Emenda } \\
\text { Constitucional no 42, de } 19.12 .2003 \text { ) } \\
\text { I - despesas com pessoal e encargos sociais; (Incluído pela Emenda Constitucional no } 42 \text {, de } \\
19.12 .2003 \text { ) } \\
\text { II - serviço da dívida; (Incluído pela Emenda Constitucional no 42, de } 19.12 .2003 \text { ) } \\
\text { III - qualquer outra despesa corrente não vinculada diretamente aos investimentos ou ações } \\
\text { apoiados. (Incluído pela Emenda Constitucional } n^{\circ} 42 \text {, de } 19.12 .2003 \text { ) }\end{array}$ \\
\hline 35. & $\begin{array}{l}\text { Art. 217. É dever do Estado fomentar práticas desportivas formais e não-formais, como direito de } \\
\text { cada um, observados: } \\
\text { II - a destinação de recursos públicos para a promoção prioritária do desporto educacional e, em } \\
\text { casos específicos, para a do desporto de alto rendimento; }\end{array}$ \\
\hline 36. & $\begin{array}{l}\text { Art. 218. O Estado promoverá e incentivará o desenvolvimento científico, a pesquisa e a } \\
\text { capacitação tecnológicas. } \\
\S 1^{\circ} \text { - A pesquisa científica básica receberá tratamento prioritário do Estado, tendo em vista o bem } \\
\text { público e o progresso das ciências. } \\
\S 2^{\circ} \text { - A pesquisa tecnológica voltar-se-á preponderantemente para a solução dos problemas } \\
\text { brasileiros e para o desenvolvimento do sistema produtivo nacional e regional. } \\
\S 3^{\circ} \text { - O Estado apoiará a formação de recursos humanos nas áreas de ciência, pesquisa e } \\
\text { tecnologia, e concederá aos que delas se ocupem meios e condições especiais de trabalho. } \\
\S 4^{\circ} \text { - A lei apoiará e estimulará as empresas que invistam em pesquisa, criação de tecnologia } \\
\text { adequada ao País, formação e aperfeiçoamento de seus recursos humanos e que pratiquem sistemas } \\
\text { de remuneração que assegurem ao empregado, desvinculada do salário, participação nos ganhos } \\
\text { econômicos resultantes da produtividade de seu trabalho. } \\
\S 5^{\circ} \text { - É facultado aos Estados e ao Distrito Federal vincular parcela de sua receita orçamentária a } \\
\text { entidades públicas de fomento ao ensino e à pesquisa científica e tecnológica. }\end{array}$ \\
\hline 37. & $\begin{array}{l}\text { Art. 219. O mercado interno integra o patrimônio nacional e será incentivado de modo a viabilizar } \\
\text { o desenvolvimento cultural e sócio-econômico, o bem-estar da população e a autonomia } \\
\text { tecnológica do País, nos termos de lei federal. }\end{array}$ \\
\hline 38. & $\begin{array}{l}\text { Art. 220. A manifestação do pensamento, a criação, a expressão e a informação, sob qualquer } \\
\text { forma, processo ou veículo não sofrerão qualquer restrição, observado o disposto nesta } \\
\text { Constituição. }\end{array}$ \\
\hline 39. & $\begin{array}{l}\text { Art. 221. A produção e a programação das emissoras de rádio e televisão atenderão aos seguintes } \\
\text { princípios: } \\
\text { I - preferência a finalidades educativas, artísticas, culturais e informativas; } \\
\text { II - promoção da cultura nacional e regional e estímulo à produção independente que objetive sua } \\
\text { divulgação; } \\
\text { III - regionalização da produção cultural, artística e jornalística, conforme percentuais estabelecidos } \\
\text { em lei; }\end{array}$ \\
\hline 40. & $\begin{array}{l}\text { Art. 225. Todos têm direito ao meio ambiente ecologicamente equilibrado, bem de uso comum do } \\
\text { povo e essencial à sadia qualidade de vida, impondo-se ao Poder Público e à coletividade o dever } \\
\text { de defendê-lo e preservá- lo para as presentes e futuras gerações. } \\
\S 1^{\circ} \text { - Para assegurar a efetividade desse direito, incumbe ao Poder Público: } \\
\text { II - preservar a diversidade e a integridade do patrimônio genético do País e fiscalizar as entidades } \\
\text { dedicadas à pesquisa e manipulação de material genético; } \\
\text { VI - promover a educação ambiental em todos os níveis de ensino e a conscientização pública para } \\
\text { a preservação do meio ambiente; }\end{array}$ \\
\hline
\end{tabular}




\begin{tabular}{|c|c|}
\hline 41. & $\begin{array}{l}\text { Art. 226. A família, base da sociedade, tem especial proteção do Estado. } \\
\S 7^{\circ} \text { - Fundado nos princípios da dignidade da pessoa humana e da paternidade responsável, o } \\
\text { planejamento familiar é livre decisão do casal, competindo ao Estado propiciar recursos } \\
\text { educacionais e científicos para o exercício desse direito, vedada qualquer forma coercitiva por parte } \\
\text { de instituições oficiais ou privadas. }\end{array}$ \\
\hline 42. & $\begin{array}{l}\text { Art. 227. É dever da família, da sociedade e do Estado assegurar à criança, ao adolescente e ao } \\
\text { jovem, com absoluta prioridade, o direito à vida, à saúde, à alimentação, à educação, ao lazer, à } \\
\text { profissionalização, à cultura, à dignidade, ao respeito, à liberdade e à convivência familiar e } \\
\text { comunitária, além de colocá-los a salvo de toda forma de negligência, discriminação, exploração, } \\
\text { violência, crueldade e opressão. (Redação dada Pela Emenda Constitucional no } 65 \text {, de 2010) } \\
\S 3^{\circ} \text { - O direito a proteção especial abrangerá os seguintes aspectos: } \\
\text { III - garantia de acesso do trabalhador adolescente e jovem à escola; (Redação dada Pela Emenda } \\
\text { Constitucional } n^{\circ} 65 \text {, de } 2010 \text { ) }\end{array}$ \\
\hline 43. & $\begin{array}{l}\text { Art. 229. Os pais têm o dever de assistir, criar e educar os filhos menores, e os filhos maiores têm o } \\
\text { dever de ajudar e amparar os pais na velhice, carência ou enfermidade. }\end{array}$ \\
\hline 44. & $\begin{array}{l}\text { Art. 242. O princípio do art. 206, IV, não se aplica às instituições educacionais oficiais criadas por } \\
\text { lei estadual ou municipal e existentes na data da promulgação desta Constituição, que não sejam } \\
\text { total ou preponderantemente mantidas com recursos públicos. } \\
\S 1^{\circ} \text { - O ensino da História do Brasil levará em conta as contribuições das diferentes culturas e } \\
\text { etnias para a formação do povo brasileiro. } \\
\S 2^{\circ} \text { - O Colégio Pedro II, localizado na cidade do Rio de Janeiro, será mantido na órbita federal. }\end{array}$ \\
\hline 45. & $\begin{array}{l}\text { Art. 240. Ficam ressalvadas do disposto no art. } 195 \text { as atuais contribuições compulsórias dos } \\
\text { empregadores sobre a folha de salários, destinadas às entidades privadas de serviço social e de } \\
\text { formação profissional vinculadas ao sistema sindical. }\end{array}$ \\
\hline \multicolumn{2}{|r|}{ ADCT } \\
\hline 46. & $\begin{array}{l}\text { Art. 19. Os servidores públicos civis da União, dos Estados, do Distrito Federal e dos Municípios, } \\
\text { da administração direta, autárquica e das fundações públicas, em exercício na data da promulgação } \\
\text { da Constituição, há pelo menos cinco anos continuados, e que não tenham sido admitidos na forma } \\
\text { regulada no art. } 37 \text {, da Constituição, são considerados estáveis no serviço público. } \\
\S 3^{\circ} \text { - O disposto neste artigo não se aplica aos professores de nível superior, nos termos da lei. }\end{array}$ \\
\hline 47. & $\begin{array}{l}\text { Art. 29. Enquanto não aprovadas as leis complementares relativas ao Ministério Público e à } \\
\text { Advocacia-Geral da União, o Ministério Público Federal, a Procuradoria-Geral da Fazenda } \\
\text { Nacional, as Consultorias Jurídicas dos Ministérios, as Procuradorias e Departamentos Jurídicos de } \\
\text { autarquias federais com representação própria e os membros das Procuradorias das Universidades } \\
\text { fundacionais públicas continuarão a exercer suas atividades na área das respectivas atribuições. }\end{array}$ \\
\hline 48. & $\begin{array}{l}\text { Art. 53. Ao ex-combatente que tenha efetivamente participado de operações bélicas durante a } \\
\text { Segunda Guerra Mundial, nos termos da Lei } \mathrm{n}^{0} 5.315 \text {, de } 12 \text { de setembro de 1967, serão } \\
\text { assegurados os seguintes direitos: } \\
\text { IV - assistência médica, hospitalar e educacional gratuita, extensiva aos dependentes; }\end{array}$ \\
\hline 49. & $\begin{array}{l}\text { Art. 60. Até o } 14^{\circ} \text { (décimo quarto) ano a partir da promulgação desta Emenda Constitucional, os } \\
\text { Estados, o Distrito Federal e os Municípios destinarão parte dos recursos a que se refere o caput do } \\
\text { art. } 212 \text { da Constituição Federal à manutenção e desenvolvimento da educação básica e à } \\
\text { remuneração condigna dos trabalhadores da educação, respeitadas as seguintes disposições: } \\
\text { (Redação dada pela Emenda Constitucional } n^{\circ} 53 \text {, de } 2006 \text { ). } \\
\text { I - a distribuição dos recursos e de responsabilidades entre o Distrito Federal, os Estados e seus } \\
\text { Municípios é assegurada mediante a criação, no âmbito de cada Estado e do Distrito Federal, de um } \\
\text { Fundo de Manutenção e Desenvolvimento da Educação Básica e de Valorização dos Profissionais } \\
\text { da Educação - FUNDEB, de natureza contábil; (Incluído pela Emenda Constitucional no } 53 \text {, de } \\
\text { 2006). } \\
\text { II - os Fundos referidos no inciso I do caput deste artigo serão constituídos por } 20 \% \text { (vinte por }\end{array}$ \\
\hline
\end{tabular}


cento) dos recursos a que se referem os incisos I, II e III do art. 155; o inciso II do caput do art. 157; os incisos II, III e IV do caput do art. 158; e as alíneas a e b do inciso I e o inciso II do caput do art. 159, todos da Constituição Federal, e distribuídos entre cada Estado e seus Municípios, proporcionalmente ao número de alunos das diversas etapas e modalidades da educação básica presencial, matriculados nas respectivas redes, nos respectivos âmbitos de atuação prioritária estabelecidos nos $\S \S 2^{\circ}$ e $3^{\circ}$ do art. 211 da Constituição Federal; (Incluído pela Emenda Constitucional $\mathrm{n}^{\mathrm{0}} 53$, de 2006).

III - observadas as garantias estabelecidas nos incisos I, II, III e IV do caput do art. 208 da Constituição Federal e as metas de universalização da educação básica estabelecidas no Plano Nacional de Educação, a lei disporá sobre: (Incluído pela Emenda Constitucional no 53, de 2006).

a) a organização dos Fundos, a distribuição proporcional de seus recursos, as diferenças e as ponderações quanto ao valor anual por aluno entre etapas e modalidades da educação básica e tipos de estabelecimento de ensino; (Incluído pela Emenda Constitucional n ${ }^{\circ}$ 53, de 2006).

b) a forma de cálculo do valor anual mínimo por aluno; (Incluído pela Emenda Constitucional $\mathrm{n}^{\mathrm{o}}$ 53, de 2006).

c) os percentuais máximos de apropriação dos recursos dos Fundos pelas diversas etapas e modalidades da educação básica, observados os arts. 208 e 214 da Constituição Federal, bem como as metas do Plano Nacional de Educação; (Incluído pela Emenda Constitucional n 53, de 2006).

d) a fiscalização e o controle dos Fundos; (Incluído pela Emenda Constitucional no 53, de 2006).

e) prazo para fixar, em lei específica, piso salarial profissional nacional para os profissionais do magistério público da educação básica; (Incluído pela Emenda Constitucional n n 53, de 2006).

IV - os recursos recebidos à conta dos Fundos instituídos nos termos do inciso I do caput deste artigo serão aplicados pelos Estados e Municípios exclusivamente nos respectivos âmbitos de atuação prioritária, conforme estabelecido nos $\S \S 2^{\circ}$ e $3^{\circ}$ do art. 211 da Constituição Federal; (Incluído pela Emenda Constitucional no 53 , de 2006).

V - a União complementará os recursos dos Fundos a que se refere o inciso II do caput deste artigo sempre que, no Distrito Federal e em cada Estado, o valor por aluno não alcançar o mínimo definido nacionalmente, fixado em observância ao disposto no inciso VII do caput deste artigo, vedada a utilização dos recursos a que se refere o $\S 5^{\circ}$ do art. 212 da Constituição Federal; (Incluído pela Emenda Constitucional $\mathrm{n}^{\circ} 53$, de 2006).

VI - até $10 \%$ (dez por cento) da complementação da União prevista no inciso V do caput deste artigo poderá ser distribuída para os Fundos por meio de programas direcionados para a melhoria da qualidade da educação, na forma da lei a que se refere o inciso III do caput deste artigo; (Incluído pela Emenda Constitucional no 53, de 2006).

VII - a complementação da União de que trata o inciso V do caput deste artigo será de, no mínimo: (Incluído pela Emenda Constitucional $\mathrm{n}^{\circ}$ 53, de 2006).

a) R \$ 2.000.000.000,00 (dois bilhões de reais), no primeiro ano de vigência dos Fundos; (Incluído pela Emenda Constitucional $\mathrm{n}^{\circ}$ 53, de 2006).

b) R \$ 3.000.000.000,00 (três bilhões de reais), no segundo ano de vigência dos Fundos; (Incluído pela Emenda Constitucional no 53 , de 2006).

c) $\mathrm{R} \$ 4.500 .000 .000,00$ (quatro bilhões e quinhentos milhões de reais), no terceiro ano de vigência dos Fundos; (Incluído pela Emenda Constitucional n ${ }^{\circ} 53$, de 2006).

d) $10 \%$ (dez por cento) do total dos recursos a que se refere o inciso II do caput deste artigo, a partir do quarto ano de vigência dos Fundos; (Incluído pela Emenda Constitucional $n^{\circ}$ 53, de 2006).

VIII - a vinculação de recursos à manutenção e desenvolvimento do ensino estabelecida no art. 212 da Constituição Federal suportará, no máximo, 30\% (trinta por cento) da complementação da União, considerando-se para os fins deste inciso os valores previstos no inciso VII do caput deste artigo; (Incluído pela Emenda Constitucional no 53 , de 2006).

IX - os valores a que se referem as alíneas a, b, e c do inciso (Incluído pela Emenda Constitucional $\mathrm{n}^{\mathrm{o}} 53$, de 2006).

VII do caput deste artigo serão atualizados, anualmente, a partir da promulgação desta Emenda Constitucional, de forma a preservar, em caráter permanente, o valor real da complementação da União; (Incluído pela Emenda Constitucional no 53 , de 2006).

X - aplica-se à complementação da União o disposto no art. 160 da Constituição Federal; (Incluído pela Emenda Constitucional no 53 , de 2006).

XI - o não-cumprimento do disposto nos incisos V e VII do caput deste artigo importará crime de responsabilidade da autoridade competente; (Incluído pela Emenda Constitucional $n^{\circ} 53$, de 2006).

XII - proporção não inferior a $60 \%$ (sessenta por cento) de cada Fundo referido no inciso I do caput deste artigo será destinada ao pagamento dos profissionais do magistério da educação básica em 


\begin{tabular}{|c|c|}
\hline & 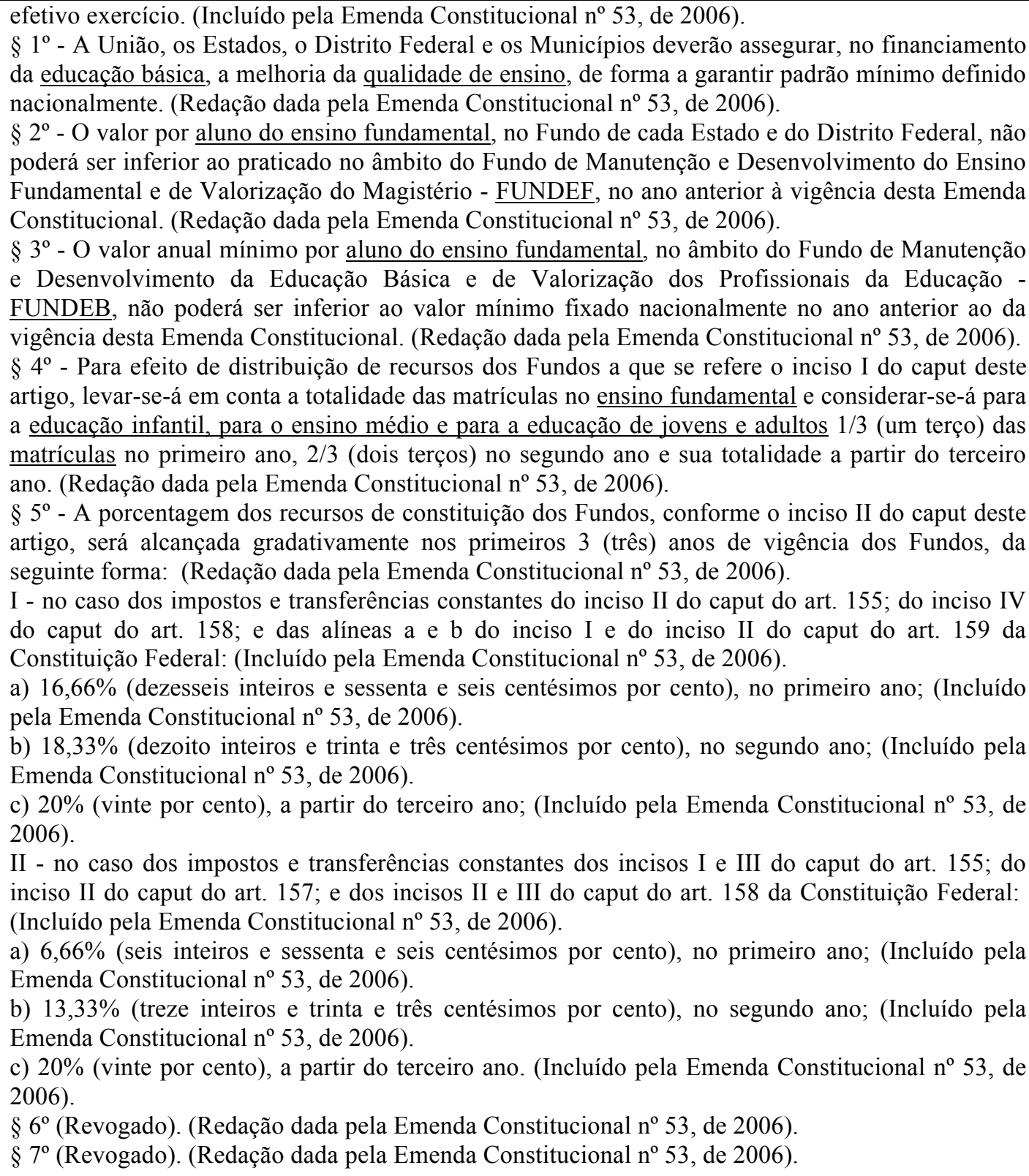 \\
\hline 50 & $\begin{array}{l}\text { Art. 61. As entidades educacionais a que se refere o art. } 213 \text {, bem como as fundações de ensino e } \\
\text { pesquisa cuja criação tenha sido autorizada por lei, que preencham os requisitos dos incisos I e II } \\
\text { do referido artigo e que, nos últimos três anos, tenham recebido recursos públicos, poderão } \\
\text { continuar a recebê-los, salvo disposição legal em contrário. }\end{array}$ \\
\hline 51. & $\begin{array}{l}\text { Art. 62. A lei criará o Serviço Nacional de Aprendizagem Rural (SENAR) nos moldes da legislação } \\
\text { relativa ao Serviço Nacional de Aprendizagem Industrial (SENAI) e ao Serviço Nacional de } \\
\text { Aprendizagem do Comércio (SENAC), sem prejuízo das atribuições dos órgãos públicos que atuam } \\
\text { na área. }\end{array}$ \\
\hline 52. & $\begin{array}{l}\text { Art. 64. A Imprensa Nacional e demais gráficas da União, dos Estados, do Distrito Federal e dos } \\
\text { Municípios, da administração direta ou indireta, inclusive fundações instituídas e mantidas pelo } \\
\text { Poder Público, promoverão edição popular do texto integral da Constituição, que será posta à } \\
\text { disposição das escolas e dos cartórios, dos sindicatos, dos quartéis, das igrejas e de outras } \\
\text { instituições representativas da comunidade, gratuitamente, de modo que cada cidadão brasileiro } \\
\text { possa receber do Estado um exemplar da Constituição do Brasil. }\end{array}$ \\
\hline
\end{tabular}




\begin{tabular}{|c|c|}
\hline 53. & $\begin{array}{l}\text { Art. } 71 \text {. É instituído, nos exercícios financeiros de } 1994 \text { e } 1995 \text {, bem assim nos períodos de } \\
01 / 01 / 1996 \text { a 30/06/97 e 01/07/97 a 31/12/1999, o Fundo Social de Emergência, com o objetivo de } \\
\text { saneamento financeiro da Fazenda Pública Federal e de estabilização econômica, cujos recurso } \\
\text { serão aplicados prioritariamente no custeio das ações dos sistemas de saúde e educação, incluindo a } \\
\text { complementação de recursos de que trata o } \S 3^{\circ} \text { do art. } 60 \text { do Ato das Disposições Constitucionai } \\
\text { Transitórias, benefícios previdenciários e auxílios assistenciais de prestação continuada, inclusive } \\
\text { liquidação de passivo previdenciário, e despesas orçamentárias associadas a programas de relevante } \\
\text { interesse econômico e social.(Redação dada pela Emenda Constitucional n }{ }^{\circ} 17 \text {, de 1997) }\end{array}$ \\
\hline 54. & $\begin{array}{l}\text { Art. } 76 \text {. É desvinculado de órgão, fundo ou despesa, até } 31 \text { de dezembro de } 2011,20 \% \text { (vinte po } \\
\text { cento) da arrecadação da União de impostos, contribuições sociais e de intervenção no domíni } \\
\text { econômico, já instituídos ou que vierem a ser criados até a referida data, seus adicionais } \\
\text { respectivos acréscimos legais. (Redação dada pela Emenda Constitucional no } 56 \text {, de } 2007 \text { ) } \\
\S 2^{\circ} \text { - Excetua-se da desvinculação de que trata o caput deste artigo a arrecadação da contribuiçãa } \\
\text { social do salário-educação a que se refere o art. } 212, \S 5^{\circ} \text {, da Constituição.(Incluído pela Emenda } \\
\text { Constitucional no } 27 \text {, de } 2000 \text { ) } \\
\S 3^{\circ} \text { - Para efeito do cálculo dos recursos para manutenção e desenvolvimento do ensino de que } \\
\text { trata o art. } 212 \text { da Constituição, o percentual referido no caput deste artigo será de } 12,5 \% \text { (doze } \\
\text { inteiros e cinco décimos por cento) no exercício de } 2009,5 \% \text { (cinco por cento) no exercício de } \\
2010 \text {, e nulo no exercício de } 2011 \text {. (Incluído pela Emenda Constitucional no } 59 \text {, de } 2009 \text { ) }\end{array}$ \\
\hline 55. & $\begin{array}{l}\text { Art. 79. É instituído, para vigorar até o ano de } 2010 \text {, no âmbito do Poder Executivo Federal, c } \\
\text { Fundo de Combate e Erradicação da Pobreza, a ser regulado por lei complementar com o objetivo } \\
\text { de viabilizar a todos os brasileiros acesso a níveis dignos de subsistência, cujos recursos serão } \\
\text { aplicados em ações suplementares de nutrição, habitação, educação, saúde, reforço de renda } \\
\text { familiar e outros programas de relevante interesse social voltados para melhoria da qualidade de } \\
\text { vida. (Incluído pela Emenda Constitucional n }{ }^{\circ} 31 \text {, de } 2000 \text { ) }\end{array}$ \\
\hline
\end{tabular}

Fonte: CF/88 e ADCT 


\section{APÊNDICE C - Lista de normas aplicáveis à educação superior vigentes em 05/05/2012}

Quadro de normas aplicáveis à educação superior vigentes em 05/05/2012

\begin{tabular}{|c|c|}
\hline Ato normativo & Descrição \\
\hline $\begin{array}{l}\text { Lei } n^{\circ} 12.244, \text { de } 24 \\
\text { de maio de } 2010\end{array}$ & Dispõe sobre a universalização das bibliotecas nas instituições de ensino do País. \\
\hline $\begin{array}{l}\text { Lei } \mathrm{n}^{\mathrm{o}} 12.089 \text {, de } 11 \\
\text { de novembro de } \\
2009\end{array}$ & $\begin{array}{l}\text { Proíbe que uma mesma pessoa ocupe } 2 \text { (duas) vagas simultaneamente em } \\
\text { instituições públicas de ensino superior. }\end{array}$ \\
\hline $\begin{array}{l}\text { Lei } n^{\circ} 9.640 \text {, de } 25 \\
\text { de maio de } 2009\end{array}$ & $\begin{array}{l}\text { Dispõe sobre o número de Cargos de Direção e Funções Gratificadas das } \\
\text { Instituições Federais de Ensino Superior, dos Centros Federais de Educação } \\
\text { Tecnológica, das Escolas Agrotécnicas Federais, das Escolas Técnicas Federais, } \\
\text { das Instituições Federais de Ensino Militar, e dá outras providências. }\end{array}$ \\
\hline $\begin{array}{l}\text { Lei } \mathrm{n}^{\mathrm{o}} 11.788, \text { de } 25 \\
\text { de setembro de } \\
2008\end{array}$ & $\begin{array}{l}\text { Dispõe sobre o estágio de estudantes; altera a redação do art. } 428 \text { da Consolidação } \\
\text { das Leis do Trabalho - CLT, aprovada pelo Decreto-Lei } \mathrm{n}^{\circ} 5.452 \text {, de } 1^{\circ} \text { de maio de } \\
\text { 1943, e a Lei } \mathrm{n}^{\circ} \text { 9.394, de } 20 \text { de dezembro de } 1996 \text {; revoga as Leis } \mathrm{n}^{\text {os }} 6.494 \text {, de } 7 \\
\text { de dezembro de } 1977 \text {, e } 8.859 \text {, de } 23 \text { de março de } 1994 \text {, o parágrafo único do art. } \\
82 \text { da Lei }{ }^{\circ} 9.394 \text {, de } 20 \text { de dezembro de } 1996 \text {, e o art. } 6^{\circ} \text { da Medida Provisória } \mathrm{n}^{\circ} \\
\text { 2.164-41, de } 24 \text { de agosto de } 2001 \text {; e dá outras providências. }\end{array}$ \\
\hline $\begin{array}{l}\text { Lei } n^{\circ} 11.487 \text {, de } 15 \\
\text { de junho de } 2007\end{array}$ & $\begin{array}{l}\text { Altera a Lei } \mathrm{n}^{\circ} 11.196 \text {, de } 21 \text { de novembro de } 2005 \text {, para incluir novo incentivo à } \\
\text { inovação tecnológica e modificar as regras relativas à amortização acelerada para } \\
\text { investimentos vinculados a pesquisa e ao desenvolvimento. }\end{array}$ \\
\hline $\begin{array}{l}\text { Lei } \mathrm{n}^{\mathrm{o}} 11.180 \text {, de } 23 \\
\text { de setembro de } \\
2005\end{array}$ & $\begin{array}{l}\text { Institui o Projeto Escola de Fábrica, autoriza a concessão de bolsas de permanência } \\
\text { a estudantes beneficiários do Programa Universidade para Todos - PROUN, } \\
\text { institui o Programa de Educação Tutorial - PET, altera a Lei no 5.537, de } 21 \text { de } \\
\text { novembro de } 1968 \text {, e a Consolidação das Leis do Trabalho - CLT, aprovada pelo } \\
\text { Decreto-Lei no 5.452, de 1o de maio de 1943, e dá outras providências. }\end{array}$ \\
\hline $\begin{array}{l}\text { Lei n }{ }^{\circ} 11.096, \text { de } 13 \\
\text { de janeiro de } 2005\end{array}$ & $\begin{array}{l}\text { Institui o Programa Universidade para Todos - PROUNI, regula a atuação de } \\
\text { entidades beneficentes de assistência social no ensino superior }\end{array}$ \\
\hline $\begin{array}{l}\text { Lei } n^{\circ} 10.870, \text { de } 19 \\
\text { de maio de } 2004\end{array}$ & $\begin{array}{l}\text { Institui a Taxa de Avaliação in loco das instituições de educação superior e dos } \\
\text { cursos de graduação e dá outras providências. }\end{array}$ \\
\hline $\begin{array}{l}\text { Lei n }{ }^{\circ} 10.861, \text { de } 14 \\
\text { de abril de } 2004\end{array}$ & Institui o Sistema Nacional de Avaliação da Educação Superior - SINAES \\
\hline $\begin{array}{l}\text { Lei } n^{\circ} 10.436, \text { de } 24 \\
\text { de abril de } 2002\end{array}$ & Dispõe sobre a Língua Brasileira de Sinais - Libras \\
\hline $\begin{array}{l}\text { Lei } n^{\circ} 10.260 \text {, de } 12 \\
\text { de julho de } 2001\end{array}$ & Fundo de Financiamento ao estudante do Ensino $\mathrm{Su}$ \\
\hline $\begin{array}{l}\text { Lei n }{ }^{\circ} 10.172 \text {, de } 9 \\
\text { de janeiro de } 2001\end{array}$ & Aprova o Plano Nacional de Educação \\
\hline $\begin{array}{l}\text { Lei } n^{\circ} 9.795, \text { de } 27 \\
\text { de abril de } 1999\end{array}$ & Política Nacional de Educação Ambiental \\
\hline $\begin{array}{l}\text { Lei } n^{\circ} 9.394 \text {, de } 20 \\
\text { de dezembro de } \\
1996\end{array}$ & Estabelece as diretrizes e bases da educação nacional \\
\hline $\begin{array}{l}\text { Lei } \mathrm{n}^{\circ} 9.131 \text {, de } 24 \\
\text { de novembro de } \\
1995\end{array}$ & $\begin{array}{l}\text { Altera dispositivos da Lei } \mathrm{n}^{\circ} 4.024 \text {, de } 20 \text { de dezembro de } 1961 \text {, e dá outras } \\
\text { providências. }\end{array}$ \\
\hline $\begin{array}{l}\text { Lei } n^{\circ} 9.192 \text {, de } 21 \\
\text { de dezembro de } \\
1995\end{array}$ & Regulamenta o processo de escolha dos dirigentes universitários \\
\hline $\begin{array}{l}\text { Lei } n^{\circ} 8.958 \text {, de } 20 \\
\text { de dezembro de } \\
1994\end{array}$ & $\begin{array}{l}\text { Dispõe sobre as relações entre as instituições federais de ensino superior e de } \\
\text { pesquisa científica e tecnológica e as fundações de apoio }\end{array}$ \\
\hline $\begin{array}{l}\text { Lei } n^{\circ} 8.405 \text {, de } 9 \\
\text { de janeiro de } 1992\end{array}$ & $\begin{array}{l}\text { Autoriza o Poder Executivo a instituir como fundação pública a Coordenação de } \\
\text { Aperfeiçoamento de Pessoal de Nível Superior (Capes) e dá outras providências. }\end{array}$ \\
\hline
\end{tabular}




\begin{tabular}{|c|c|}
\hline Ato normativo & Descrição \\
\hline $\begin{array}{l}\text { Lei } \mathrm{n}^{\circ} 7.395 \text {, de } 31 \\
\text { de outubro de } 1985\end{array}$ & Dispõe sobre os órgãos de representação dos estudantes de nível superior \\
\hline $\begin{array}{l}\text { Lei } n^{0} 7.165 \text {, de } 14 \\
\text { de dezembro de } \\
1983\end{array}$ & $\begin{array}{l}\text { Dispõe sobre a fixação e alteração do número de vagas nos cursos superiores de } \\
\text { graduação }\end{array}$ \\
\hline $\begin{array}{l}\text { Lei } \mathrm{n}^{\circ} 7.088, \text { de } 23 \\
\text { de março de } 1983\end{array}$ & Estabelece normas para a expedição de documentos escolares \\
\hline $\begin{array}{l}\text { Lei } \mathrm{n}^{\circ} 6.932 \text {, de } 7 \\
\text { de julho de } 1981\end{array}$ & Dispõe sobre as atividades do médico residente \\
\hline $\begin{array}{l}\text { Lei } \mathrm{n}^{0} 6.503 \text {, de } 13 \\
\text { de dezembro de } \\
1977\end{array}$ & Dispõe sobre a Educação Física, em todos os graus e ramos do ensino \\
\hline $\begin{array}{l}\text { Lei } \mathrm{n}^{\circ} 6.202 \text {, de } 17 \\
\text { de abril de } 1975\end{array}$ & Atribui à estudante em estado de gestação o regime de exercícios domiciliares \\
\hline $\begin{array}{lll}\text { Decreto-lei } & & \mathrm{n}^{\mathrm{o}} \\
1.044, \text { de } 21 & \text { de } \\
\text { outubro de } 1969 & \end{array}$ & $\begin{array}{l}\text { Dispõe sôbre tratamento excepcional para os alunos portadores das afecções que } \\
\text { indica }\end{array}$ \\
\hline $\begin{array}{l}\text { Lei } n^{\circ} 5.540 \text {, de } 28 \\
\text { de novembro de } \\
1968\end{array}$ & Nomeação de Reitores e Vice-Reitores de universidades \\
\hline $\begin{array}{l}\text { Lei } \mathrm{n}^{\circ} 4.881-\mathrm{A} \text {, de } \\
6 \text { de dezembro de } \\
1965\end{array}$ & Dispõe sôbre o Estatuto do Magistério Superior \\
\hline $\begin{array}{l}\text { Lei } \mathrm{n}^{\circ} 4.024 \text {, de } 20 \\
\text { de dezembro de } \\
1961\end{array}$ & Conselho Nacional de Educação \\
\hline $\begin{array}{l}\text { Decreto } \mathrm{n}^{\mathrm{o}} 7.423 \\
\text { de } 31 \text { de dezembro } \\
\text { de } 2010\end{array}$ & $\begin{array}{l}\text { Regulamenta a Lei } \mathrm{n}^{\circ} 8.958 \text {, de } 20 \text { de dezembro de } 1994 \text {, que dispõe sobre as } \\
\text { relações entre as instituições federais de ensino superior e de pesquisa científica e } \\
\text { tecnológica e as fundações de apoio, e revoga o Decreto } \mathrm{n}^{\circ} 5.205 \text {, de } 14 \text { de } \\
\text { setembro de } 2004 \text {. }\end{array}$ \\
\hline $\begin{array}{l}\text { Decreto } \mathrm{n}^{\mathrm{o}} 7.233, \\
\text { de } 19 \text { de julho de } \\
2010\end{array}$ & $\begin{array}{l}\text { Dispõe sobre procedimentos orçamentários e financeiros relacionados à autonomia } \\
\text { universitária, e dá outras providências. }\end{array}$ \\
\hline $\begin{array}{l}\text { Decreto } n^{\circ} 6.755 \\
\text { de } 29 \text { de janeiro de } \\
2009\end{array}$ & $\begin{array}{l}\text { Institui a Política Nacional de Formação de Profissionais do Magistério da } \\
\text { Educação Básica, disciplina a atuação da Coordenação de Aperfeiçoamento de } \\
\text { Pessoal de Nível Superior -CAPES no fomento a programas de formação inicial e } \\
\text { continuada, e dá outras providências. }\end{array}$ \\
\hline $\begin{array}{l}\text { Decreto } \mathrm{n}^{\mathrm{o}} 6.495 \\
\text { de } 30 \text { de junho de } \\
2008\end{array}$ & Institui o Programa de Extensão Universitária - PROEXT. \\
\hline $\begin{array}{l}\text { Decreto } \mathrm{n}^{\mathrm{o}} 6.096, \\
\text { de } 24 \text { de abril de } \\
2007\end{array}$ & $\begin{array}{l}\text { Institui o Programa de Apoio a Planos de Reestruturação e Expansão das } \\
\text { Universidades Federais - REUNI. }\end{array}$ \\
\hline $\begin{array}{l}\text { Decreto } \mathrm{n}^{\mathrm{o}} 5.801, \\
\text { de } 8 \text { de junho de } \\
2006\end{array}$ & Dispõe sobre a Escola de Altos Estudos, e dá outras providências. \\
\hline $\begin{array}{l}\text { Decreto } \mathrm{n}^{\mathrm{o}} 5.800, \\
\text { de } 8 \text { de junho de } \\
2006\end{array}$ & Dispõe sobre o Sistema Universidade Aberta do Brasil - UAB. \\
\hline $\begin{array}{l}\text { Decreto } \mathrm{n}^{\mathrm{o}} 5.786, \\
\text { de } 24 \text { de maio de } \\
2006\end{array}$ & Dispõe sobre os centros universitários e dá outras providências. \\
\hline $\begin{array}{l}\text { Decreto } \mathrm{n}^{\mathrm{o}} 5.773, \\
\text { de } 9 \text { de maio de } \\
2006\end{array}$ & $\begin{array}{l}\text { Dispõe sobre o exercício das funções de regulação, supervisão e avaliação de } \\
\text { instituições de educação superior e cursos superiores de graduação e seqüenciais no } \\
\text { sistema federal de ensino }\end{array}$ \\
\hline $\begin{array}{l}\text { Decreto } \mathrm{n}^{\mathrm{o}} 5626 \text {, } \\
\text { de } 22 \text { de dezembro }\end{array}$ & $\begin{array}{l}\text { Regulamenta a Lei no } 10.436 \text {, de } 24 \text { de abril de } 2002 \text {, que dispõe sobre a Língua } \\
\text { Brasileira de Sinais - Libras, e o art. } 18 \text { da Lei no } 10.098 \text {, de } 19 \text { de dezembro de }\end{array}$ \\
\hline
\end{tabular}




\begin{tabular}{|c|c|}
\hline Ato normativo & Descrição \\
\hline de 2005 & 2000. \\
\hline $\begin{array}{l}\text { Decreto } \mathrm{n}^{\mathrm{o}} 5.493 \\
\text { de } 18 \text { de julho de } \\
2005 \text {. }\end{array}$ & Regulamenta o disposto na Lei no 11.096 , de 13 de janeiro de 2005. \\
\hline $\begin{array}{l}\text { Súmula Vinculante } \\
\mathrm{n}^{\mathbf{0}} 12\end{array}$ & $\begin{array}{l}\text { A cobrança de taxa de matrícula nas universidades públicas viola o disposto no art. } \\
206, \mathrm{IV} \text {, da Constituição Federal. }\end{array}$ \\
\hline 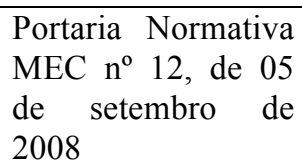 & Institui o Índice Geral de Cursos da Instituição de Educação Superior (IGC). \\
\hline 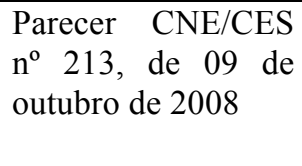 & $\begin{array}{l}\text { Dispõe sobre carga horária mínima e procedimentos relativos à integralização e } \\
\text { duração dos cursos de graduação em Biomedicina, Ciências Biológicas, Educação } \\
\text { Física, Enfermagem, Farmácia, Fisioterapia, Fonoaudiologia, Nutrição e Terapia } \\
\text { Ocupacional, bacharelados, na modalidade presencial. }\end{array}$ \\
\hline 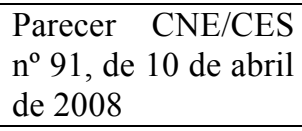 & $\begin{array}{l}\text { Consulta sobre cobrança de taxas pela emissão de diploma de graduação feita por } \\
\text { Instituição de Ensino Superior. }\end{array}$ \\
\hline $\begin{array}{l}\text { Parecer CNE/CES } \\
\mathrm{n}^{\mathbf{o}} 66 \text {, de } 13 \text { de } \\
\text { março de } 2008\end{array}$ & $\begin{array}{l}\text { Diretrizes para credenciamento de novas Instituições de Educação Superior e de } \\
\text { credenciamento institucional para a oferta de cursos superiores na modalidade à } \\
\text { distância e normas processuais para o trâmite do(s) projeto(s) de curso(s) } \\
\text { protocolado(s) em conjunto. }\end{array}$ \\
\hline $\begin{array}{l}\text { Parecer CNE/CES } \\
\mathrm{n}^{\mathbf{0}} 101, \text { de } 19 \text { de } \\
\text { abril de } 2007\end{array}$ & $\begin{array}{l}\text { Consulta sobre a oferta de disciplinas isoladas pelas instituições de ensino superior } \\
\text { e a normatização do art. } 50 \text { da LDB. }\end{array}$ \\
\hline $\begin{array}{l}\text { Parecer CNE/CES } \\
n^{\circ} 224, \text { de } 20 \text { de } \\
\text { setembro de } 2006\end{array}$ & $\begin{array}{l}\text { Abono de faltas a estudantes que se ausentem regularmente dos horários de aulas } \\
\text { devido a convicções religiosas. }\end{array}$ \\
\hline $\begin{array}{l}\text { Parecer CNE/CES } \\
\mathrm{n}^{\mathbf{0}} 218 \text {, de } 10 \text { de } \\
\text { agosto de } 2006\end{array}$ & $\begin{array}{l}\text { Consulta sobre a possibilidade de credenciamento de Faculdades Integradas, } \\
\text { Escolas Superiores e Institutos Superiores de Educação, ante o disposto no art. 12, } \\
\text { inciso I, do Decreto } \mathrm{n}^{\mathrm{0}} 5.773 \text {, de } 9 \text { de maio de } 2006 \text {. }\end{array}$ \\
\hline $\begin{array}{l}\text { Parecer CNE/CES } \\
n^{\mathbf{0}} 282 \text {, de } 04 \text { de } \\
\text { setembro de } 2002\end{array}$ & Análise de Estatutos de Universidades e de Regimentos de IES não universitárias. \\
\hline $\begin{array}{l}\text { Parecer } \mathrm{CNE} / \mathrm{CP} \mathrm{n}^{\circ} \\
2, \text { de } 19 \text { de fevereiro } \\
\text { de } 2002\end{array}$ & $\begin{array}{l}\text { Institui a duração e a carga horária dos cursos de licenciatura, de graduação plena, } \\
\text { de formação de professores da Educação Básica em nível superior. }\end{array}$ \\
\hline $\begin{array}{l}\text { Edital n }{ }^{\circ} 1, \text { de } 22 \text { de } \\
\text { janeiro de } 2009\end{array}$ & $\begin{array}{l}\text { Regulamenta os procedimentos do "regime de migração de sistemas", necessário ao } \\
\text { cumprimento da decisão proferida pelo Supremo Tribunal Federal na ADIN } \\
2501 / \mathrm{DF} \text {, definindo a forma com que as instituições e cursos privados que se } \\
\text { achavam sob o poder regulatório do sistema estadual de ensino de Minas Gerais } \\
\text { serão submetidos ao regramento federal, observando-se as disposições do Sistema } \\
\text { Nacional de Avaliação da Educação Superior - SINAES. }\end{array}$ \\
\hline $\begin{array}{l}\text { Instrução } \\
\text { Normativa } \\
\begin{array}{l}\text { SRF } \\
\text { no }\end{array} \\
\text { outubro de } 2004 \text { de }\end{array}$ & $\begin{array}{l}\text { Dispõe sobre a isenção do imposto de renda e de contribuições aplicável às } \\
\text { instituições que aderirem ao Programa Universidade para Todos. }\end{array}$ \\
\hline $\begin{array}{l}\text { Portaria } \mathrm{n}^{\mathrm{o}} 1.264 \\
\text { de } 17 \text { de outubro de } \\
2008\end{array}$ & $\begin{array}{l}\text { Instrumento de Avaliação Externa de Instituições de Educação Superior do Sistema } \\
\text { Nacional de Avaliação da Educação Superior - SINAES }\end{array}$ \\
\hline $\begin{array}{l}\text { Portaria } \mathrm{n}^{\mathrm{o}} 681 \text {, de } \\
01 \text { de agosto de } \\
2007\end{array}$ & $\begin{array}{l}\text { Convocação para regulação dos cursos superiores de graduação em Medicina } \\
\text { veterinária. }\end{array}$ \\
\hline $\begin{array}{l}\text { Portaria } n^{\circ} 546, \text { de } \\
31 \text { de maio de } 2007\end{array}$ & $\begin{array}{l}\text { Prorrogação do prazo previsto no } \S 5^{\circ} \text { do art. } 4^{\circ} \text { da Portaria } n^{\circ} 147 \text {, de } 2 \text { de } \\
\text { fevereiro de } 2007\end{array}$ \\
\hline $\begin{array}{l}\text { Portaria } \mathrm{n}^{\circ} 147 \text {, de } \\
02 \text { de fevereiro de }\end{array}$ & $\begin{array}{l}\text { Dispõe sobre a complementação da instrução dos pedidos de autorização de cursos } \\
\text { de graduação em Direito e Medicina, para os fins do disposto no art. } 31, \S 1^{\circ} \text { do }\end{array}$ \\
\hline
\end{tabular}




\begin{tabular}{|c|c|}
\hline Ato normativo & Descrição \\
\hline 2007 & Decreto $^{\circ} 5.773$, de 9 de maio de 2006. \\
\hline $\begin{array}{l}\text { Portaria } \mathrm{n}^{\mathrm{o}} 1.309 \text {, } \\
\text { de } 14 \text { de julho de } \\
2006\end{array}$ & $\begin{array}{l}\text { Renova o reconhecimento dos cursos de graduação das instituições de educação } \\
\text { superior que obtiveram o seu reconhecimento ou renovação de reconhecimento } \\
\text { somente para fins de expedição de diplomas, exclusivamente pelo não atendimento } \\
\text { ao que dispunha o art. } 20 \text { do Decreto } \mathrm{n}^{\circ} 3.860 / 2001 \text {. }\end{array}$ \\
\hline $\begin{array}{l}\text { Portaria } \mathrm{n}^{\mathrm{o}} 1.027 \\
\text { de } 15 \text { de maio de } \\
2006\end{array}$ & $\begin{array}{l}\text { Dispõe sobre banco de avaliadores do Sistema Nacional de Avaliação da Educação } \\
\text { Superior - SINAES, a Comissão Técnica de Acompanhamento da Avaliação - } \\
\text { CTAA. }\end{array}$ \\
\hline $\begin{array}{l}\text { Portaria } n^{\circ} 2413 \text { de } \\
07 \text { de julho de } 2005\end{array}$ & $\begin{array}{l}\text { Dispõe sobre a renovação de reconhecimento de cursos de graduação e de } \\
\text { tecnologia. }\end{array}$ \\
\hline $\begin{array}{l}\text { Portaria } \mathrm{n}^{\mathrm{o}} 328 \text { de } \\
01 \text { de fevereiro de } \\
2005\end{array}$ & $\begin{array}{l}\text { Dispõe sobre o Cadastro de Cursos de Pós-Graduação Lato Sensu e define as } \\
\text { disposições para sua operacionalização. }\end{array}$ \\
\hline $\begin{array}{l}\text { Portaria } \mathrm{n}^{\circ} 4363 \text { de } \\
29 \text { de dezembro de } \\
2004\end{array}$ & $\begin{array}{l}\text { Dispõe sobre a autorização e reconhecimento de cursos seqüenciais da educação } \\
\text { superior. }\end{array}$ \\
\hline $\begin{array}{l}\text { Portaria } \mathrm{n}^{\circ} 4361 \text { de } \\
29 \text { de dezembro de } \\
2004\end{array}$ & $\begin{array}{l}\text { Dispõe que os processos de credenciamento e recredenciamento de instituições de } \\
\text { educação superior (IES), credenciamento para oferta de cursos de pós-graduação } \\
\text { lato sensu, credenciamento e recredenciamento de instituições de educação superior } \\
\text { para oferta de cursos superiores a distância, de autorização, reconhecimento e } \\
\text { renovação de reconhecimento de cursos superiores, bem como de transferência de } \\
\text { mantença, aumento e remanejamento de vagas de cursos reconhecidos, desativação } \\
\text { de cursos, descredenciamento de instituições, Plano de Desenvolvimento } \\
\text { Institucional (PDI), aditamento de PDI, além de outros processos afins, deverão ser } \\
\text { protocolizados por meio do Sistema de Acompanhamento de Processos das } \\
\text { Instituições de Ensino Superior - SAPIEnS/MEC. }\end{array}$ \\
\hline $\begin{array}{l}\text { Portaria } n^{\circ} 4059 \text { de } \\
10 \text { de dezembro de } \\
2004\end{array}$ & $\begin{array}{l}\text { Autoriza a inclusão de disciplinas não presenciais em cursos superiores } \\
\text { reconhecidos. }\end{array}$ \\
\hline $\begin{array}{l}\text { Portaria } \mathrm{n}^{\mathrm{o}} 2051 \text { de } \\
09 \text { de julho de } 2004\end{array}$ & $\begin{array}{l}\text { Regulamenta os procedimentos de avaliação do Sistema Nacional de Avaliação da } \\
\text { Educação Superior (SINAES), instituído na Lei no } 10.861 \text {, de } 14 \text { de abril de } 2004 \text {. }\end{array}$ \\
\hline $\begin{array}{l}\text { Portaria } \mathrm{n}^{\mathrm{o}} 1180 \text { de } \\
06 \text { de maio de } 2004\end{array}$ & $\begin{array}{l}\text { Comissão Especial de Acompanhamento e Verificação dos cursos de pós- } \\
\text { graduação lato sensu. }\end{array}$ \\
\hline $\begin{array}{l}\text { Portaria } \\
\text { Interministerial } \mathrm{n}^{\mathrm{o}} \\
865 \text { de } 15 \text { de } \\
\text { setembro de } 2009\end{array}$ & $\begin{array}{l}\text { Aprova o Projeto Piloto de Revalidação de diploma de médico expedido por } \\
\text { universidades estrangeiras e disponibilizar exame de avaliação com base em matriz } \\
\text { referencial de correspondência curricular, com a finalidade de subsidiar os } \\
\text { procedimentos de revalidação conduzidos por universidades públicas. }\end{array}$ \\
\hline $\begin{array}{l}\text { Portaria Normativa } \\
\mathrm{n}^{\mathbf{0}} 10 \text { de } 02 \text { de julho } \\
\text { de } 2009\end{array}$ & Fixa critérios para dispensa de avaliação in loco e dá outras providências. \\
\hline $\begin{array}{l}\text { Portaria Normativa } \\
\mathrm{n}^{\mathbf{0}} 7 \text { de } 22 \text { de junho } \\
\text { de } 2009\end{array}$ & $\begin{array}{l}\text { Dispõe sobre o mestrado profissional no âmbito da Fundação Coordenação de } \\
\text { Aperfeiçoamento de Pessoal de Nível Superior - CAPES. }\end{array}$ \\
\hline $\begin{array}{l}\text { Portaria } \\
\text { Normativan } 19 \text { de } \\
20 \text { de novembro de } \\
2008\end{array}$ & $\begin{array}{l}\text { Dispõe sobre procedimentos de manutenção de bolsas do Programa Universidade } \\
\text { para Todos - ProUni pelas instituições de ensino superior participantes do } \\
\text { programa. }\end{array}$ \\
\hline $\begin{array}{l}\text { Portaria } \\
\text { Normativan }{ }^{\circ} 12 \text { de } \\
05 \text { de Setembro de } \\
2008\end{array}$ & o Índice Geral de Cursos da Instituição de Educação Superior (IGC). \\
\hline $\begin{array}{l}\text { Portaria } \\
\text { Normativan }{ }^{\circ} \quad 4 \text { de } \\
05 \text { de agosto de } \\
2008\end{array}$ & $\begin{array}{l}\text { Regulamenta a aplicação do conceito preliminar de cursos superiores - CPC, para } \\
\text { fins dos processos de renovação de reconhecimento respectivos, no âmbito do ciclo } \\
\text { avaliativo do SINAES instaurado pela Portaria Normativa } n^{\circ} 1 \text {, de } 2007 \text {. }\end{array}$ \\
\hline Portaria & nico de fluxo de trabalho e gerer \\
\hline
\end{tabular}




\begin{tabular}{|c|c|}
\hline Ato normativo & Descrição \\
\hline $\begin{array}{l}\text { Normativan }^{\circ} 40 \text { de } \\
12 \text { de dezembro de } \\
2007\end{array}$ & $\begin{array}{l}\text { informações relativas aos processos de regulação, avaliação e supervisão da } \\
\text { educação superior no sistema federal de educação, e o Cadastro e-MEC de } \\
\text { Instituições e Cursos Superiores e consolida disposições sobre indicadores de } \\
\text { qualidade, banco de avaliadores (Basis) e o Exame Nacional de Desempenho de } \\
\text { Estudantes (ENADE) e outras disposições. }\end{array}$ \\
\hline $\begin{array}{l}\text { Portaria } \\
\text { Normativan } 33 \text { de } \\
14 \text { de agosto de } \\
2007\end{array}$ & $\begin{array}{l}\text { Prorrogar os prazos fixados pela Portaria Normativa } \mathrm{n}^{\circ} 1 \text {, de } 10 \text { de janeiro de } \\
2007 \text {. }\end{array}$ \\
\hline $\begin{array}{l}\text { Portaria } \\
\text { Normativan }^{\mathrm{o}} \quad 6 \quad \text { de } \\
03 \text { de abril de } 2007\end{array}$ & $\begin{array}{l}\text { Alterar os prazos para requerimento de avaliação de cursos, fixados no art. } 2^{\circ} \text { da } \\
\text { Portaria Normativa } \mathrm{n}^{\circ} 01 \text {, de } 10 \text { de janeiro de } 2007\end{array}$ \\
\hline $\begin{array}{l}\text { Resolução } \\
\text { CNE/CES } \mathrm{n}^{\mathrm{o}} 3 \text { de } \\
14 \text { de outubro de } \\
2010\end{array}$ & $\begin{array}{l}\text { Regulamenta o Art. } 52 \text { da Lei } \mathrm{n}^{\circ} \text { 9.394, de } 20 \text { de dezembro de } 1996 \text {, e dispõe sobre } \\
\text { normas e procedimentos para credenciamento e recredenciamento de universidades } \\
\text { do Sistema Federal de Ensino. }\end{array}$ \\
\hline $\begin{array}{l}\text { Resolução } \\
\text { CNE/CES n }{ }^{\circ} 2 \text { de } \\
17 \text { de junho de } \\
2010\end{array}$ & $\begin{array}{l}\text { Institui as Diretrizes Curriculares Nacionais do curso de graduação em Arquitetura } \\
\text { e Urbanismo, alterando dispositivos da Resolução CNE/CES n }{ }^{\circ} 6 / 2006 \text {. }\end{array}$ \\
\hline $\begin{array}{l}\text { Resolução } \\
\text { CNE/CES } \mathrm{n}^{\mathrm{o}} 1 \mathrm{de} \\
20 \text { de janeiro de } \\
2010\end{array}$ & $\begin{array}{l}\text { Dispõe sobre normas e procedimentos para credenciamento e recredenciamento de } \\
\text { Centros Universitários. }\end{array}$ \\
\hline $\begin{array}{l}\text { Resolução } \\
\text { CNE/CES no } 4 \text { de } \\
06 \text { de abril de } 2009\end{array}$ & $\begin{array}{l}\text { Dispõe sobre carga horária mínima e procedimentos relativos à integralização e } \\
\text { duração dos cursos de graduação em Biomedicina, Ciências Biológicas, Educação } \\
\text { Física, Enfermagem, Farmácia, Fisioterapia, Fonoaudiologia, Nutrição e Terapia } \\
\text { Ocupacional, bacharelados, na modalidade presencial. }\end{array}$ \\
\hline $\begin{array}{l}\text { Resolução } \\
\text { CNE/CES n } 2 \text { de } \\
29 \text { de janeiro de } \\
2009\end{array}$ & $\begin{array}{l}\text { Alteração da Resolução CNE/CES n }{ }^{\circ} 1 \text {, de } 1^{\circ} \text { de fevereiro de } 2005 \text {, que estabelece } \\
\text { normas para o apostilamento, no diploma do curso de Pedagogia, do direito ao } \\
\text { exercício do magistério nos anos iniciais do Ensino Fundamental, modificada pela } \\
\text { Resolução CNE/CES n }{ }^{\circ} 8 \text {, de } 29 \text { de março de } 2006 \text {. }\end{array}$ \\
\hline $\begin{array}{l}\text { Resolução } \\
\text { CNE/CES } n^{0} 1 \text { de } \\
16 \text { de janeiro de } \\
2009\end{array}$ & $\begin{array}{l}\text { Aprova as Diretrizes Curriculares Nacionais do Curso de Graduação em Artes } \\
\text { Visuais e dá outras providências. }\end{array}$ \\
\hline $\begin{array}{l}\text { Resolução } \\
\text { CNE/CES n } 8 \text { de } \\
28 \text { de novembro de } \\
2008\end{array}$ & $\begin{array}{l}\text { Institui as Diretrizes Curriculares Nacionais do curso de Estatística, de graduação } \\
\text { plena, em nível superior, e dá outras providências. }\end{array}$ \\
\hline $\begin{array}{l}\text { Resolução } \\
\text { CNE/CES no } 7 \text { de } \\
28 \text { de novembro de } \\
2008\end{array}$ & $\begin{array}{l}\text { Dispõe sobre a utilização de denominações e siglas por Instituições de Educação } \\
\text { Superior. }\end{array}$ \\
\hline $\begin{array}{l}\text { Resolução } \\
\text { CNE/CES n } 5 \text { de } \\
25 \text { de setembro de } \\
2008\end{array}$ & $\begin{array}{l}\text { Estabelece normas para o credenciamento especial de Instituições não Educacionais } \\
\text { para oferta de cursos de especialização. }\end{array}$ \\
\hline $\begin{array}{l}\text { Resolução } \\
\text { CNE/CES n } 4 \text { de } \\
06 \text { de agosto de } \\
2008\end{array}$ & $\begin{array}{l}\text { Institui as Diretrizes Curriculares Nacionais do curso de graduação em } \\
\text { Meteorologia, bacharelado, e dá outras providências. }\end{array}$ \\
\hline $\begin{array}{l}\text { Resolução } \\
\text { CNE/CES n } 2 \text { de } \\
26 \text { de junho de } \\
2008\end{array}$ & $\begin{array}{l}\text { Alteração da Resolução CNE/CES n }{ }^{\circ} 9 \text {, de } 4 \text { de outubro de } 2007 \text {, que estabelece } \\
\text { normas para o apostilamento, em diplomas de cursos de graduação em Pedagogia, } \\
\text { do direito ao exercício do magistério da Educação Infantil. }\end{array}$ \\
\hline
\end{tabular}




\begin{tabular}{|c|c|}
\hline Ato normativo & Descrição \\
\hline $\begin{array}{l}\text { Resolução } \\
\text { CNE/CES no } 1 \text { de } \\
22 \text { de abril de } 2008\end{array}$ & $\begin{array}{l}\text { Dispõe sobre o registro de diplomas de cursos de pósgraduação stricto sensu } \\
\text { (mestrado e doutorado) expedidos por instituições não detentoras de prerrogativas } \\
\text { de autonomia universitária. }\end{array}$ \\
\hline $\begin{array}{l}\text { Resolução } \\
\text { CNE/CES no } 12 \text { de } \\
13 \text { de dezembro de } \\
2007\end{array}$ & Dispõe sobre o registro de diplomas expedidos por instituições não-universitárias. \\
\hline $\begin{array}{l}\text { Resolução } \\
\text { CNE/CES n } 8 \text { de } \\
04 \text { de outubro de } \\
2007\end{array}$ & $\begin{array}{l}\text { Altera o art. } 4^{\circ} \text { e revoga o art. } 10 \text { da Resolução } \mathrm{CNE} / \mathrm{CES} \mathrm{n}^{\circ} 1 / 2002 \text {, que estabelece } \\
\text { normas para a revalidação de diplomas de graduação expedidos por } \\
\text { estabelecimentos estrangeiros de ensino superior. }\end{array}$ \\
\hline $\begin{array}{l}\text { Resolução } \\
\text { CNE/CES n } 9 \text { de } \\
04 \text { de outubro de } \\
2007\end{array}$ & $\begin{array}{l}\text { Estabelece normas para o apostilamento, em diplomas de cursos de graduação em } \\
\text { Pedagogia, do direito ao exercício do magistério da Educação Infantil. }\end{array}$ \\
\hline $\begin{array}{l}\text { Resolução } \\
\text { CNE/CES n } 7 \text { de } \\
04 \text { de outubro de } \\
2007\end{array}$ & $\begin{array}{l}\text { Altera o } \S 3^{\circ} \text { do art. } 10 \text { da Resolução CNE/CES n }{ }^{\circ} 7 / 2004 \text {, que institui as Diretrizes } \\
\text { Curriculares Nacionais para os cursos de graduação em Educação Física, em nível } \\
\text { superior de graduação plena. }\end{array}$ \\
\hline $\begin{array}{l}\text { Resolução } \\
\text { CNE/CES no } 4 \text { de } \\
13 \text { de julho de } 2007\end{array}$ & $\begin{array}{l}\text { Institui as Diretrizes Curriculares Nacionais do Curso de Graduação em Ciências } \\
\text { Econômicas, bacharelado, e dá outras providências. }\end{array}$ \\
\hline $\begin{array}{l}\text { Resolução } \\
\text { CNE/CES no } 3 \text { de } \\
02 \text { de julho de } 2007\end{array}$ & $\begin{array}{l}\text { Dispõe sobre procedimentos a serem adotados quanto ao conceito de hora-aula, e } \\
\text { dá outras providências. }\end{array}$ \\
\hline $\begin{array}{l}\text { Resolução } \\
\text { CNE/CES n } 2 \text { de } \\
18 \text { de junho de } \\
2007\end{array}$ & $\begin{array}{l}\text { Dispõe sobre carga horária mínima e procedimentos relativos à integralização e } \\
\text { duração dos cursos de graduação, bacharelados, na modalidade presencial. }\end{array}$ \\
\hline $\begin{array}{l}\text { Resolução } \\
\text { CNE/CES n } 1 \text { de } \\
08 \text { de junho de } \\
2007\end{array}$ & $\begin{array}{l}\text { Estabelece normas para o funcionamento de cursos de pós-graduação lato sensu, } \\
\text { em nível de especialização. }\end{array}$ \\
\hline $\begin{array}{l}\text { Resolução } \\
\text { CNE/CES n } 12 \text { de } \\
18 \text { de julho de } 2006\end{array}$ & $\begin{array}{l}\text { Altera o prazo previsto no art. } 3^{\circ} \text { da Resolução CNE/CES } n^{\circ} 2 \text {, de } 9 \text { de junho de } \\
2005 \text {, que dispõe sobre os cursos de pós-graduação stricto sensu oferecidos no } \\
\text { Brasil por instituições estrangeiras, diretamente ou mediante convênio com } \\
\text { instituições nacionais. }\end{array}$ \\
\hline $\begin{array}{l}\text { Resolução } \\
\text { CNE/CES n } 11 \text { de } \\
10 \text { de julho de } 2006\end{array}$ & $\begin{array}{l}\text { Revogação de atos normativos no âmbito da Câmara de Educação Superior do } \\
\text { CNE: - Resolução CNE/CES no } 10 \text {, de } 11 \text { de março de } 2002 \ldots\end{array}$ \\
\hline $\begin{array}{l}\text { Resolução } \\
\text { CNE/CES n } 8 \text { de } \\
29 \text { de março de } \\
2006\end{array}$ & $\begin{array}{l}\text { Altera a Resolução CNE/CES } \mathrm{n}^{\circ} 1 \text {, de } 1^{\circ} \text { de fevereiro de } 2005 \text {, que estabelece } \\
\text { normas para o apostilamento, no diploma do curso de Pedagogia, do direito ao } \\
\text { exercício do magistério nos anos iniciais do Ensino Fundamental. }\end{array}$ \\
\hline $\begin{array}{l}\text { Resolução } \\
\text { CNE/CES no } 4 \text { de } \\
02 \text { de fevereiro de } \\
2006\end{array}$ & $\begin{array}{l}\text { Aprova as Diretrizes Curriculares Nacionais para o curso de graduação em } \\
\text { Zootecnia e dá outras providências }\end{array}$ \\
\hline $\begin{array}{l}\text { Resolução } \\
\text { CNE/CES no } 5 \text { de } \\
02 \text { de fevereiro de } \\
2006\end{array}$ & $\begin{array}{l}\text { Institui as Diretrizes Curriculares para o curso de graduação em Engenharia de } \\
\text { Pesca e dá outras providências. }\end{array}$ \\
\hline $\begin{array}{l}\text { Resolução } \\
\text { CNE/CES } n^{\circ} 1 \text { de } \\
02 \text { de fevereiro de } \\
2006\end{array}$ & $\begin{array}{l}\text { Institui as Diretrizes Curriculares Nacionais para o curso de graduação em } \\
\text { Engenharia Agronômica ou Agronomia e dá outras providências. }\end{array}$ \\
\hline
\end{tabular}




\begin{tabular}{|c|c|}
\hline Ato normativo & Descrição \\
\hline $\begin{array}{l}\text { Resolução } \\
\text { CNE/CES n } 2 \text { de } \\
02 \text { de fevereiro de } \\
2006\end{array}$ & $\begin{array}{l}\text { Institui as Diretrizes Curriculares Nacionais para o curso de graduação em } \\
\text { Engenharia Agrícola e dá outras providências. }\end{array}$ \\
\hline $\begin{array}{l}\text { Resolução } \\
\text { CNE/CES n } 3 \text { de } \\
02 \text { de fevereiro de } \\
2006\end{array}$ & $\begin{array}{l}\text { Institui as Diretrizes Curriculares Nacionais para o curso de graduação em } \\
\text { Engenharia Florestal e dá outras providências. }\end{array}$ \\
\hline $\begin{array}{l}\text { Resolução } \\
\text { CNE/CES n } 2 \text { de } \\
09 \text { de junho de } \\
2005\end{array}$ & $\begin{array}{l}\text { Altera a Resolução CNE/CES } n^{\circ} 2 \text {, de } 3 \text { de abril de } 2001 \text {, que dispõe sobre os } \\
\text { cursos de pós-graduação stricto sensu oferecidos no Brasil por instituições } \\
\text { estrangeiras, diretamente ou mediante convênio com instituições nacionais. }\end{array}$ \\
\hline $\begin{array}{l}\text { Resolução } \\
\text { CNE/CES no } 24 \text { de } \\
18 \text { de dezembro de } \\
2002\end{array}$ & $\begin{array}{l}\text { Altera a redação do parágrafo } 4^{\circ} \text { do artigo } 1^{\circ} \text { e o artigo } 2^{\circ} \text {, da Resolução CNE/CES } \\
1 / 2001 \text {, que estabelece normas para o funcionamento de cursos de pós-graduação. }\end{array}$ \\
\hline $\begin{array}{l}\text { Resolução } \\
\text { CNE/CES } n^{\circ} 1 \text { de } \\
28 \text { de janeiro de } \\
2002\end{array}$ & $\begin{array}{l}\text { Estabelece normas para a revalidação de diplomas de graduação expedidos por } \\
\text { estabelecimetos estrangeiros de ensino superior. }\end{array}$ \\
\hline $\begin{array}{l}\text { Resolução } \\
\text { CNE/CES no } 1 \text { de } \\
03 \text { de abril de } 2001 \\
\end{array}$ & ção. \\
\hline $\begin{array}{l}\text { Resolução CNE/CP } \\
n^{\circ} 1 \text { de } 15 \text { de maio } \\
\text { de } 2006\end{array}$ & $\begin{array}{l}\text { Institui Diretrizes Curriculares Nacionais para o Curso de Graduação em } \\
\text { Pedagogia, licenciatura. }\end{array}$ \\
\hline $\begin{array}{l}\text { Resolução } \mathrm{CNE} / \mathrm{CP} \\
\mathrm{n}^{\mathrm{o}} 1 \mathrm{de} 17 \mathrm{de} \\
\text { novembro de } 2005\end{array}$ & $\begin{array}{l}\text { Altera a Resolução CNE/CP } n^{\circ} 1 / 2002 \text {, que institui Diretrizes Curriculares } \\
\text { Nacionais para a Formação de Professores da Educação Básica, em nível superior, } \\
\text { curso de Licenciatura de graduação plena. }\end{array}$ \\
\hline $\begin{array}{l}\text { Resolução CNE/CP } \\
n^{\circ} 2 \text { de } 27 \text { de agosto } \\
\text { de } 2004\end{array}$ & $\begin{array}{l}\text { Adia o prazo previsto no art. } 15 \text { da Resolução CNE/CP 1/2002, que institui } \\
\text { Diretrizes Curriculares Nacionais para a Formação de Professores da Educação } \\
\text { Básica, em nível superior, curso de licenciatura, de graduação plena. }\end{array}$ \\
\hline $\begin{array}{l}\text { Resolução } \mathrm{CNE} / \mathrm{CP} \\
\mathrm{n}^{\mathbf{0}} \quad 3 \text { de } 18 \text { de } \\
\text { dezembro de } 2002\end{array}$ & $\begin{array}{l}\text { Institui as Diretrizes Curriculares Nacionais Gerais para a organização e o } \\
\text { funcionamento dos cursos superiores de tecnologia. }\end{array}$ \\
\hline $\begin{array}{l}\text { Resolução } \mathrm{CNE} / \mathrm{CP} \\
\mathrm{n}^{\mathrm{o}} 1 \text { de } 18 \text { de } \\
\text { fevereiro de } 2002\end{array}$ & $\begin{array}{l}\text { Institui Diretrizes Curriculares Nacionais para a Formação de Professores da } \\
\text { Educação Básica, em nível superior, curso de licenciatura, de graduação plena. }\end{array}$ \\
\hline $\begin{array}{l}\text { Resolução } \mathrm{CNE} / \mathrm{CP} \\
\mathrm{n}^{\mathbf{0}} \quad 1 \text { de } 30 \text { de } \\
\text { setembro de } 1999\end{array}$ & $\begin{array}{l}\text { Dispõe sobre os Institutos Superiores de Educação, considerados os Art. } 62 \text { e } 63 \text { da } \\
\text { Lei } 9.394 / 96 \text { e o Art. } 9^{\circ}, \S 2^{\circ} \text {, alíneas "c" e "h" da Lei 4.024/61, com a redação dada } \\
\text { pela Lei } 9.131 / 95 \text {. }\end{array}$ \\
\hline $\begin{array}{l}\text { Resolução CNS no } \\
350 \text { de } 09 \text { de junho }\end{array}$ & $\begin{array}{l}\text { Entendimento sobre a homologação da abertura de cursos na área da saúde pelo } \\
\text { Ministério da Educação com a não objeção do Ministério da Saúde. }\end{array}$ \\
\hline & Educação Profissional e Te \\
\hline $\begin{array}{l}\text { Lei } \mathrm{n}^{\mathrm{o}} 11.892 \text {, de } 29 \\
\text { de dezembro de } \\
2008\end{array}$ & $\begin{array}{l}\text { Institui a Rede Federal de Educação Profissional, Científica e Tecnológica, cria os } \\
\text { Institutos Federais de Educação, Ciência e Tecnologia, e dá outras providências. }\end{array}$ \\
\hline $\begin{array}{l}\text { Lei }{ }^{\circ} 11.741 \text {, de } 16 \\
\text { de julho de } 2008\end{array}$ & $\begin{array}{l}\text { Altera dispositivos da Lei } \mathrm{n}^{0} 9.394 \text {, de } 20 \text { de dezembro de } 1996 \text {, que estabelece as } \\
\text { diretrizes e bases da educação nacional, para redimensionar, institucionalizar e } \\
\text { integrar as ações da educação profissional técnica de nível médio, da educação de } \\
\text { jovens e adultos e da educação profissional e tecnológica. }\end{array}$ \\
\hline $\begin{array}{l}\text { Lei } n^{\circ} 11.534 \text {, de } 25 \\
\text { de outubro de } 2007\end{array}$ & $\begin{array}{l}\text { Dispõe sobre a criação de Escolas Técnicas e Agrotécnicas Federais e dá outras } \\
\text { providências. }\end{array}$ \\
\hline Lei $n^{\circ} 8.731$, de 16 & Transforma as Escolas Agrotécnicas Federais em autarquias e dá outras \\
\hline
\end{tabular}




\begin{tabular}{|c|c|}
\hline Ato normativo & Descrição \\
\hline $\begin{array}{l}\text { de novembro de } \\
1993\end{array}$ & providências. \\
\hline $\begin{array}{l}\text { Decreto } \mathrm{n}^{\mathrm{o}} 6.986 \\
\text { de } 20 \text { de outubro de } \\
2009\end{array}$ & $\begin{array}{l}\text { Regulamenta os arts. } 11,12 \text { e } 13 \text { da Lei } \text { n }^{\circ} 11.892 \text {, de } 29 \text { de dezembro de } 2008 \text {, que } \\
\text { institui a Rede Federal de Educação Profissional, Científica e Tecnológica e cria os } \\
\text { Institutos Federais de Educação, Ciência e Tecnologia, para disciplinar o processo } \\
\text { de escolha de dirigentes no âmbito destes Institutos. }\end{array}$ \\
\hline $\begin{array}{l}\text { Decreto } \mathrm{n}^{\mathrm{o}} 6.302 \\
\text { de } 12 \text { de dezembro } \\
\text { de } 2007\end{array}$ & Institui o Programa Brasil Profissionalizado. \\
\hline $\begin{array}{l}\text { Decreto } \mathrm{n}^{\mathrm{o}} 6.095 \\
\text { de } 24 \text { de abril de } \\
2007\end{array}$ & $\begin{array}{l}\text { Estabelece diretrizes para o processo de integração de instituições federais de } \\
\text { educação tecnológica, para fins de constituição dos Institutos Federais de } \\
\text { Educação, Ciência e Tecnologia - IFET, no âmbito da Rede Federal de Educação } \\
\text { Tecnológica. }\end{array}$ \\
\hline $\begin{array}{l}\text { Decreto } \mathrm{n}^{\mathrm{o}} 5.224 \\
\text { de } 01 \text { de outubro de } \\
2004\end{array}$ & $\begin{array}{l}\text { Dispõe sobre a organização dos Centros Federais de Educação Tecnológica e dá } \\
\text { outras providências }\end{array}$ \\
\hline
\end{tabular}

Fonte: MEC - normas de ensino superior (http://meclegis.mec.gov.br/) 